\title{
GEOLOGY OF THE ANSIL CU-ZN MASSIVE SULFIDE DEPOSIT,
}

ROUYN-NORANDA, QUEBEC, CANADA

by

Alan George Galley, B.Sc., M.Sc.

1

Thesis submitted to

the Faculty of Graduate Studies and Research

in partial fullfilment of

the requirements for the degree of

Doctor of Philosophy

Department of Earth Sciences

Carleton University

Ottawa, Ontario

August, 1994

Copyright

1994, Alan George Galley 
National Library of Canada

Acquisitions and Bibliographic Services Branch

395 Wellington Street Ottawa, Ontario K1A ON4
Bibliothèque nationale

du Canada

Direction des acquisitions et

des services bibliographiques

395, rue Wellington

Ottawa (Ontario)

Your file Votre reference

Our file Notre réference

THE AUTHOR HAS GRANTED AN IRREVOCABLE NON-EXCLUSIVE LICENCE ALLOWING THE NATIONAL LIBRARY OF CANADA TO REPRODUCE, LOAN, DISTRIBUTE OR SELL COPIES OF HIS/HER THESIS BY ANY MEANS AND IN ANY FORM OR FORMAT, MAKING THIS THESIS AVAILABLE TO INTERESTED PERSONS.
L'AUTEUR A ACCORDE UNE LICENCE IRREVOCABLE ET NON EXCLUSIVE PERMETTANT A LA BIBLIOTHEQUE NATIONALE DU CANADA DE REPRODUIRE, PRETER, DISTRIBUER OU VENDRE DES COPIES DE SA THESE DE QUELQUE MANIERE ET SOUS QUELQUE FORME QUE CE SOIT POUR METTRE DES EXEMPLAIRES DE CETTE THESE A LA DISPOSITION DES PERSONNE INTERESSEES.
THE AUTHOR RETAINS OWNERSHIP OF THE COPYRIGHT IN HIS/HER THESIS. NEITHER THE THESIS NOR SUBSTANTIAL EXTRACTS FROM IT MAY BE PRINTED OR OTHERWISE REPRODUCED WITHOUT HIS/HER PERMISSION.
L'AUTEUR CONSERVE LA PROPRIETE DU DROIT D'AUTEUR QUI PROTEGE SA THESE. NI LA THESE NI DES EXTRAITS SUBSTANTIELS DE CELLECI NE DOIVENT ETRE IMPRIMES OU AUTREMENT REPRODUITS SANS SON AUTORISATION. 
Name Alan Geosge Galley

Dissertation Abstracts International is arranged by broad, general subject categories. Please select the one subject which most nearly describes the content of your dissertation. Enter the corresponding four-digit code in the spaces provided.

\section{Subject Categories}

\section{THE HUMANITIES AND SOCIAL SCIENCES}

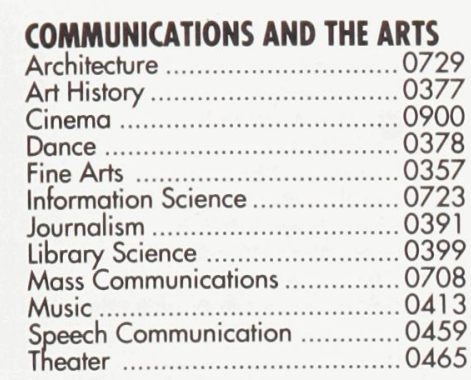

\section{EDUCATION}

General .............................. 0515

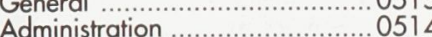

Adult and Continuing ......................0516

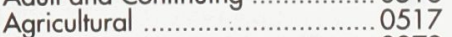

Art .......................................... 0273

Bilingual and Multicultural .......... 0282

Business .........il....................... 0275

Community College .................... 02727

Early Childhood .......................0518

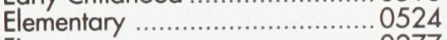

Finance ................................ 0277

Guidance and Counseling .......... 0680

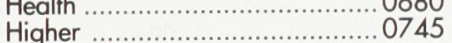

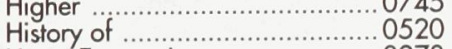

Home Economics ........................ 0278

Industrial ................................. 0521

Mathematics ............................ 0522

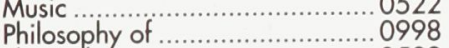

Physical ................................... 0523

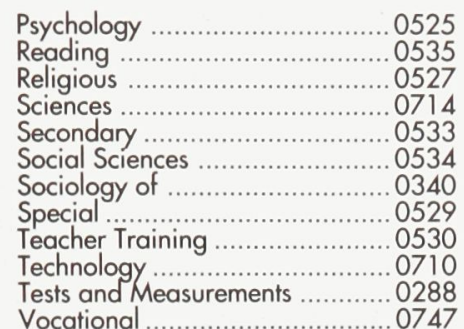

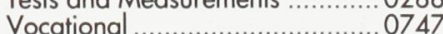

\section{LANGUAGE, LITERATURE AND LINGUISTICS}

Language

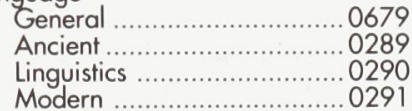

(1)

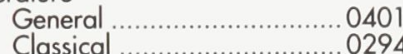

Classical ............................. 0294

Comparative ...................... 0295
Medieval

Modern ................................0298

African ..............0316

American …........ 0591

Asian .......................................... 0305

Canadian (English) ................. 0352

Canadian (French) .............. 035

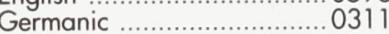

Latin American ...................... 0312

Middle Eastern ...................... 0315

Romance ....................... 0313
PHILOSOPHY, RELIGION AND

\section{THEOLOGY}

Philosophy

Religion

General ................................0318

Biblical Studies ……….........0321

Clergy ………......................0319

... 0320

Theology ……............................... 0469

SOCIAL SCIENCES

American Studies

Anthropology

Archaeology ….................. 0324

Cultural ……................. 0326

Business Administration

General

Accounting

Banking .....

Management

Marketing ......

Canadian Studies

Economics

General ....................... 0501

Agricultural .........................0503

Commerce-Business …….........0505

Finance ….......................... 0508

History …............................. 0509

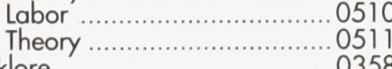

Folklore …............................0358

Geography $\ldots \ldots \ldots \ldots \ldots \ldots \ldots \ldots \ldots \ldots \ldots . . .036$
Gerontology

History

General

.0578

\section{THE SCIENCES AND ENGINEERING}

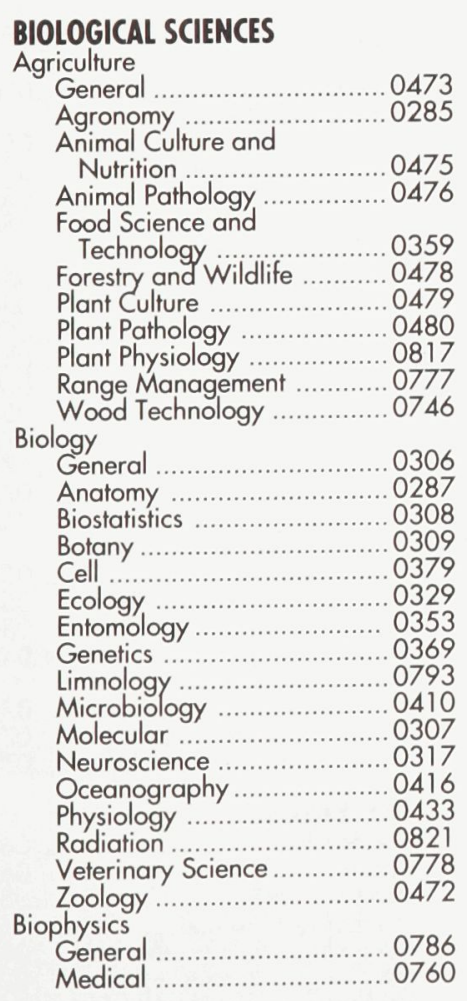

EARTH SCIENCES

Biogeochemistry

\begin{tabular}{|c|c|}
\hline 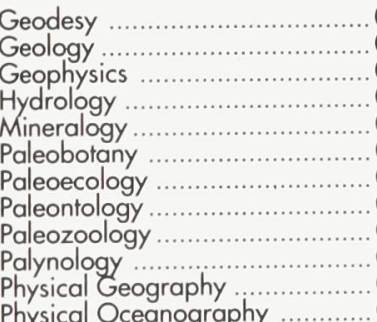 & $\begin{array}{l}0370 \\
0372 \\
0373 \\
0388 \\
0411 \\
0345 \\
0426 \\
0418 \\
0985 \\
0427 \\
0368 \\
0415\end{array}$ \\
\hline
\end{tabular}

\section{HEALTH AND ENVIRONMENTAL}

\section{SCIENCES}

Environmental Sciences .............0768

Health Sciences

General

Audiology.

Chemotherapy

Dentistry.

Hospital Managemen

Human Development

Immunology

Medicine and Surgery

Mental Health

Nursing

Nutrition

Obstetrics and Gynecology ...0380

Occupational Health and

Therapy

Ophthalmology

Pathology

Pharmacology

Pharmacy ............

Public Health

Radiology

Recreation

057

0382

0573

0574

0575
Speech Pathology ............... 0460

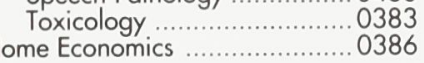

\section{PHYSICAL SCIENCES}

Pure Sciences

Chemistry

General ........

Agricultura

Biochemistry

Inorganic

Nuclear

Organic

Pharmaceutical

Physical

Radiation

Mathematics

Physics

General

Acoustics

Astronomy and

Astrophysics...........

Atmosph

Electronics and Electricity

Elementary Particles and

High Energy

Fluid and Plasmo

Molecular

Nuclear

Optics.

Solid State

Statistics
Applied Sciences

Computer Science
Applied Mechanics
Ancient

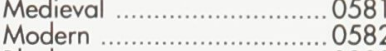

Black

African

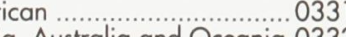

alia and Oceania 0332

Canadian ......................... 0334

European .................................. 0335

Latin American .......................... 0336

Middle Eastern .................... 0333

History of Science ...................... 0585

Law

Political Science

General

International Law and

Relations.

Public Administration...........0616

Recreation

Social Work

Sociology

General .............................0626

Criminology and Penology ....0627

Demography ...................... 0938

Ethnic and Racial Studies .....0631

Individual and Family

Studies

0628

Industrial and Labor

Relations

Public and S....................... 0629

Social Structure and

Development ..............

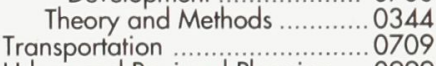

Urban and Regional Planning .... 0999

Women's Studies ..................... 0453
Engineering

General ........................... 0537

Aerospace ...................... 0538

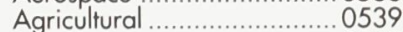

Automotive ............................... 0540

Biomedical ....................... 0541

Chemical .......................... 0542

Electronics and Electrical ..... 0544

Heat and Thermodynamics ... 0348

Hydraulic ..................... 0545

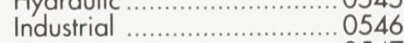

Marine ........................... 0547

Matranica......... 0548

Metallurgy ….......................... 0743

Mining .....................055

Nuclear

Packaging

Petroleum

Sanitary and Munici.............. 0765

Sanitary and Municipal .......055

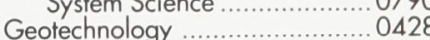

Operations Research ................... 0796

Plastics Technology .................. 0795

PSYCHOLOGY

General

Behavioral

Clinical

Developmental

Experimental

Industrial

Personality

Physiological

Psychobiology

Psychometrics

0346

Social

0621 
Nom

Dissertation Abstracts International est organisé en catégories de sujets. Veuillez s.v.p. choisir le sujet qui décrit le mieux votre thèse et inscrivez le code numérique approprié dans l'espace réservé ci-dessous.

\section{Catégories par sujets}

\section{HUMANITÉS ET SCIENCES SOCIALES}

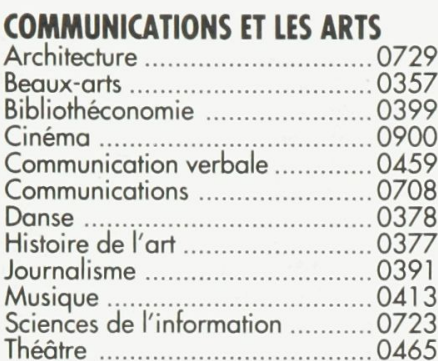

\section{ÉDUCATION}

\section{Généralités}

Art

Colleges communautaires

Commerce 0688

Economie domestique ..................0278

Education sanitaire ................... 0680

Enseignement agricole.....

Enseignement bilingue et

mulficulturel

0517

Enseignement industriel ................052

Enseignement primaire. .............. 0524

Enseignement professionnel ....... 0747

Enseignement religieux .............. 0527

Enseignement secondaire .......... 0533

Enseignement spécial ............... 0529

Ęnseignement supérieur ................. 0745

Evaluation ............................. 0288

Finances ............................ 0277

Histoire de l'éducation ................ 0520

Langues et littérature
Administration

Éducation permanente ................... 0516

Éducation préscolaire .................... 0518

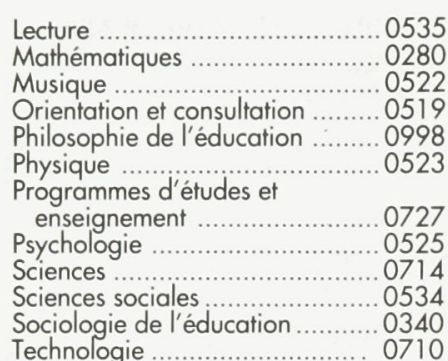

\section{LANGUE, LITTÉRATURE ET}

LINGUISTIQUE

Langues

Généralités ...................... 0679
Anciennes ..................... 0289
Linguistique .................. 0290
Modernes

Modernes

Littérature

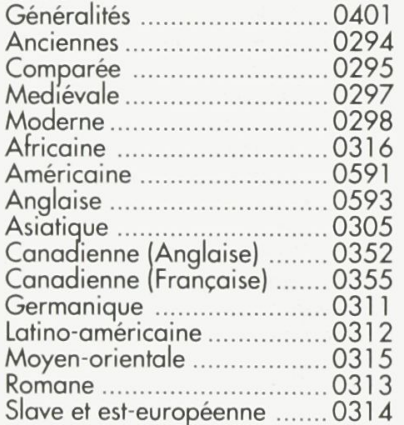

\section{SCIENCES ET INGÉNIERIE}

\section{SCIENCES BIOLOGIQUES}

\section{Agriculture}

Alimentation et technologie

alimentaire ................... 0359

Culture

Elevage et alimentation ..........0475

Exploitation des péturages ....0777

Pathologie animale ............... 0476

Pathologie végétale ................. 0480

Physiologie vegétale ................0817

Sylviculture et faune ................ 0478

Biologie

0746

Generalites ...................... 028

Biologie (Statistiques) ............. 0308

Biologie moléculaire ............. 0307

Botanique .......................... 0309
Cellule

Ecologie . 0329

Entomologie ..................... 0353

Génétique ............................ 0369

Limnologie .................................... 049

Microbiologie .......................0410

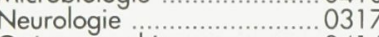

Physiologie ..................... 0433

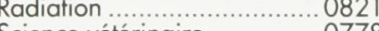

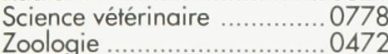

Biophysique

Généralités ...................... 0786

SCIENCES DE LA TERRE
Généralités

ogie

Océanographie ....................0416

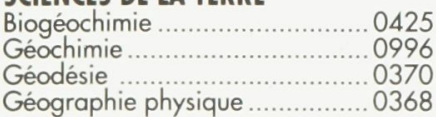

\section{PHILOSOPHIE, RELIGION ET}

THEOLOGIE

Philosophi

Religion

Généralités

Clergé

Etudes bibliques

Histoire des religions

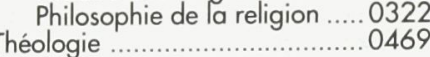

\section{SCIENCES SOCIALES}

Anthropologie

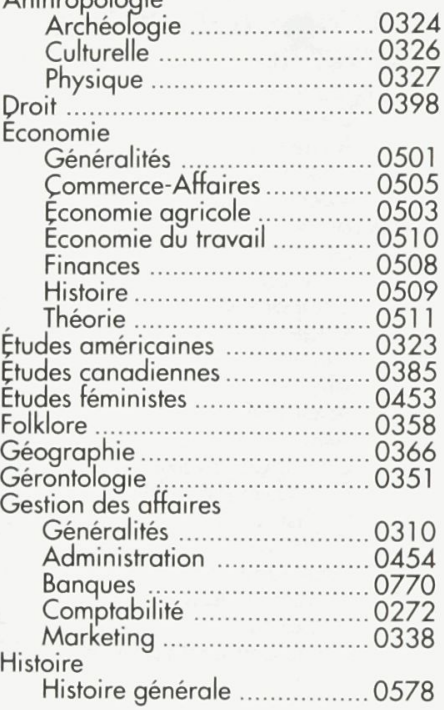

0324

0326
0327

0398

0501

0505

0510

0508

(1)

0323

0385
0453

0453
0358

0366

0310

0454

0272

0338

Histoire générale

0578

\section{SCIENCES PHYSIQUES}

Géophysique

Hydrologie

Minéralogie ....................... 041

Océanographie physique ..........0415

Paléobotanique ........................ 0345

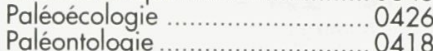

Paléozoologie ................................ 0985

Palynologie

SCIENCES DE LA SANTÉ ET DE

\section{L'ENVIRONNEMENT}

Economie domestique ............... 038

Sciences de l'environnement ...... 0768

Sciences de la santé

Généralités

Administration des hipitaux..... 0566

Alimentation et nutrition ..... 0570

Audiologie

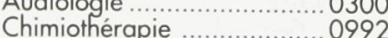

Développement humain ..........0758

Enseignement .................... 0350

Immunologie ..................... 0982

..0575

Medecine du travail et $\quad 0354$

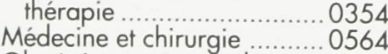

Obstétrique et gynécologie...0380

Ophtalmologie ..................... 038

Orthophonie ...................... 0460

Pathologie ..........................0571

Pharmacie ...................... 0572

Pharmacologie .......................... 0419

Radiologie ........................0574

Santé mentale

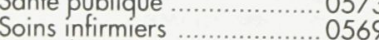

Toxicologie ....
Dentisterie ............................ 0567

Physiothérapie ............................ 0382

\section{Sciences Pures}

Chimie

Genéralités

Biochimie..

Chimie agricole...

Chimie analytique

Chimie nucléaire

Chimie organique

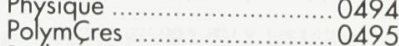

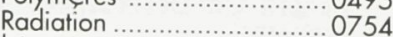

Mathématiques

Physique

Genéralités

Acoustique

Astronomie et

astrophysique

Electronique et électricité

Fluides et plasma

Météorologie

Optique

Particules (Physique

nucléaire

Physique atomique

Physique moléculaire

Physique nucléaire

Radiation

Statistiques

Technologie

Informatique

Ingénierie

$$
\begin{aligned}
& \text { Généralités } \\
& \text { Agricole }
\end{aligned}
$$

Automobile

0383
Chimie minérale

Physique de l'état solide

Sciences Appliqués Et
0485

487

0749

0486

38

494
495
754
405

405

0605

0986

0606

0607

0608

0752

0798

0748

0611

0609

0610

0756
0463

098

0537

0539

0540

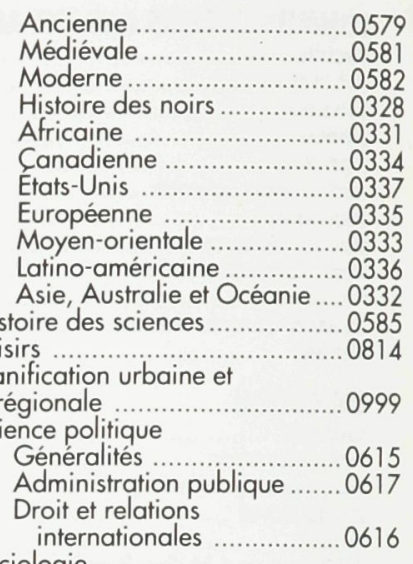

Sociologie
Généralités .......................0626

Généralités .......................0626

Criminologie et

établissements

pénitentiaires ...................0627

Demographie .......................... 0938

Etudes de l' individu et

de la famille.

Études des relations

interethniques et

des relations raciales ........0631

Structure et développement

social

Théorie et méthodes............... 0344

Travail et relations

industrielles

..............0629

Travail social

Biomédicale

Chaleur et ther

modynamique

Conditionnement

(Emballage)

Genie aérospatia

Génie chimique

Génie civil

Génie électronique et

électrique.

Génie industriel

Génie mécanique

Génie nuclégire

Ingénierie des systämes

Mecanique navale

Métallurgie

Science des matériaux

Technique du pétrole

Technique minière

Techniques sanitaires et

municipales

Technologie hydraulique

Mécanique appliquée

Géotechnologie

Matières plastiques

(Technologie)

Textiles et tissus (Technologie) .... 0794

\section{PSYCHOLOGIE}

Généralités

Personnalité .

Psychobiologie

Psychologie clinique 


\section{Carleton University \\ Memorandum}

Date:

To:

MICROMEDIA

From: Sneja Mouelhi

Re:

Please make a note that Appendix $1 V_{8} V$

can be viewed on a diskette available only at carleton University Library. 


\section{ABSTRACT}

The Ansil Cu-Zn volcanic-hosted massive sulfide (VHMS) deposit is located approximately $14 \mathrm{~km} \mathrm{NNW}$ of Rouyn-Noranda, Quebec, within the Blake River Group of the Archean Southern Abitibi greenstone belt. The deposit is the second-lowest within the Central Mine Sequence, a series of bimodal rhyolite-andesite formations that infill the Noranda Cauldron, host to 14 VHMS deposits. The deposit consists of a single massive sulfide lens situated at the contact between rhyolite of the Northwest formation and overlying andesite of the Rusty Ridge formation. The footwall rhyolite is a fissure-fed, lobe-hyaloclastite flow with a vertical facies change from densely packed flow lobes to lobe-breccia to hyaloclastite-lobe-breccia. The rhyolite flow forms a ridge up to $500 \mathrm{~m}$ high which was inundated by the andesite flows. There is a facies change within the andesite near its contact with the massive sulfide lens from massive flows near the base of the formation to pillowed flows with accompanying flow breccia and hyaloclastite. The orebody is hosted within a unit of quartz-phyric, finely layered, felsic volcaniclastic (Cranston tuff) that infills an east-west trending graben formed on the upper surface of the rhyolite flow. At the east end of the graben the Cranston tuff is interlayered with a thin unit of dacite flows.

The deposit lies within an extensive zone of discordant $\mathrm{Na}$ depletion that extends from $400 \mathrm{~m}$ below the deposit at the contact of the synvolcanic Flavrian intrusive complex to over $400 \mathrm{~m}$ above the deposit. This alteration zone is contolled by a fault system that served as a focus for hydrothermal fluid upflow from the beginning of cauldron formation until the end of the first cauldron cycle. Within the $\mathrm{Na}$ depletion zone there are three distinct alteration facies associated with the orebody. Early hydrothermal activity is defined by hydrothermal explosion breccias that formed along the base of the east-west trending graben walls. They were infilled with finely banded quartz-albite-sphalerite-pyrite, and the wallrock altered to sericite-quartz, with finely disseminated sphalerite and pyrite-pyrrhotite. The graben was then infilled with the Cranston tuff, which was selectively altered and 
mineralized by the $\mathrm{Zn}$-rich fluid, particularly along the contact of the unit with the graben walls. The development of northerly trending faults was accompanied by the upflow of $\mathrm{Cu}$ rich fluid that selectively chloritized the footwall rhyolite below the graben floor, and formed a morphologically complex pyrrhotite-chalcopyrite-rich vein stockwork. The hydrothermal mineral assemblage progressively replaced the Cranson tuff in the centre of the graben, overprinting previously deposited sphalerite-mineralized tuff. The hydrothermal minerals also selectively replaced andesitic flow breccia and hyaloclastite with massive pyrrhotite-chalcopyrite along the rhyolite-andesite contact. The replaced Cranston tuff forms the layered eastern half of the orebody, whereas the steep-sided dome at the west end is a product of andesite flow replacement. This hydrothermal stage was also responsible for the continued replacement of interflow hyaloclastite for up to $400 \mathrm{~m}$ above the orebody. The third stage of hydrothermal activity resulted in the formation of calcsilicate alteration assemblages, and then a footwall magnetite vein stockwork and replacement of sections of the massive sulfide orebody by massive magnetite

The Ansil deposit is the product of shallow, subseafloor replacement, with the primary permeability of the host rocks controlling the morphology of the orebody and associated vein stockworks. It began to form in shallow water (200 to $300 \mathrm{~m}$ ) on the graben floor, and continued to evolve during infilling of the graben by felsic mass flows, and burial of the footwall rhyolite by andesitic flows. Late-stage development of the orebody took place under a $500 \mathrm{~m}$ thickness of volcanic flows at an unknown water depth. Three compositionally distinct fluid phases were responsible for the development of the Ansil system: a Si-Zn-K-rich fluid responsible for the hydrothermal brecciation of the graben floor and sphalerite precipitation within the quartz-phyric mass flow, a higher temperature $\mathrm{Fe}-\mathrm{Cu}-\mathrm{Au}-\mathrm{Ag}$-rich fluid formed extensive footwall and hangingwall, chlorite-rich alteration zones and formed the pyrrhotite-chalcopyrite-rich vein stockwork and massive sulfide lens, and finally a $\mathrm{Ca}-\mathrm{Fe}-\mathrm{CO}_{2}$-rich fluid that formed calc-silicate alteration assemblages, then partially replaced the massive sulfide lens with massive magnetite. 


\section{ACKNOWLEDGEMENTS}

I would like to thank Metall Mining Inc. (formerly Minnova Inc.), in particular Dr. Gerald Riverin, for permission to study the Ansil deposit, providing access to their data base on the Ansil area, and for their financial assistance for chemical analyses. The mine staff and miners were always helpful and supportive, in particular Bernard Salmon (chief geologist), Rémi Asselin and Mario Gagnon, and Michel LaBrie of the exploration staff. It was my pleasure to be associated with them for these past few years.

My special graditude to Dr. Ian Jonasson for pestering me to do a doctoral degree, introducing me to the Ansil deposit, spending a considerable amount of time underground with me, and for his considerable intellectual and logistical support.

Many thanks to Drs. Dave Watkinson and Harold Gibson for their advice both in the field and in the laboratory, and for the hours they spent editing the manuscript. Their comments have improved the thesis considerably. This study also benefited from discussions with Doreen Ames, Mark Hannington, Dave Huston, Bruce Gemmel, Jim Franklin and last Arne Bjørlykke, who taught me not to be trapped by traditional thinking.

I would also like to thank Richard Lancaster, Dave Garson and Richard Burke at the Geological Survey of Canada for their logistical support. This includes the preparation of an endless number of polished slabs and photographing them, managing polished thin sectionpreparation and extracting me from computer problems. Some of the diagrams were drafted by Dawn Russell, and the 1:150 scale maps were entered into AUTOCAD by Beth Hillary, and sections into Corel by Dawn Russell. Final map preparation was by Mario Hudon at the Geological Survey of Canada. All three are thanked for their patience and perserverance. Peter Jones (Carleton University) and Gordon Pringle (GSC) are thanked for SEM and microprobe analyses.

I would like to thank the Geological Survey of Canada, in particular Dr. Murray Duke, for allowing me to complete this project as part of my ongoing research responsibilities.

To my family, whose support and understanding made this project as painless as possible. 
I dedicate this work to my parents, who never lost faith in me 


\section{TABLE OF CONTENTS}

Acceptance Page

page

Abstract

Acknowledgements

Table of contents

List of tables

List of figures

\section{CHAPTER 1. INTRODUCTION}

1.1 Purpose of study

1.2 Location

1.3 History

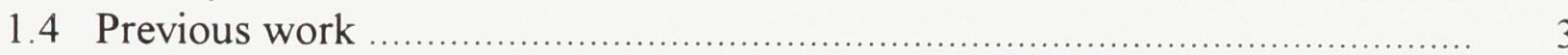

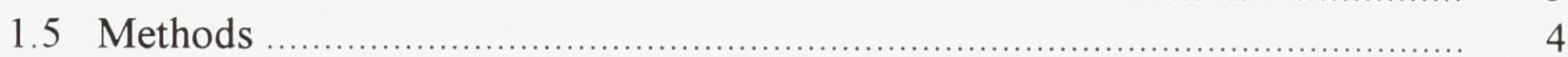

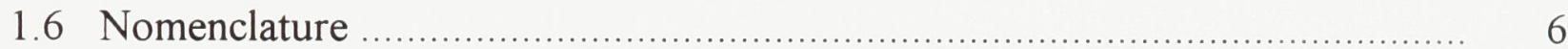

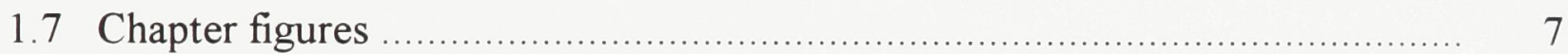

\section{CHAPTER 2. GENERAL GEOLOGY}

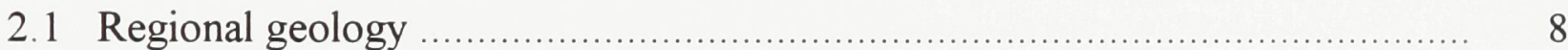

2.1.1 Blake River Group ............................................................ 10

2.1.2 Noranda Volcanic Complex .................................................... 11

2.1.3 Distribution of massive sulfide deposits ......................................... 13

2.1.4 Alteration of the Central Mine Sequence ......................................... 15

2.2 Structure and metamorphism .......................................................... 16

2.2.1 Structure and metamorphism of the Ansil area ............................. 18

Metamorphism ............................................................ 18

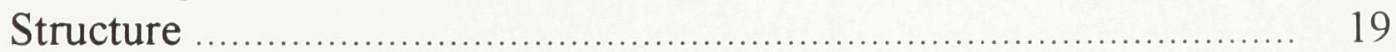

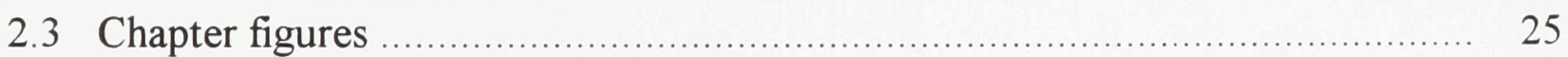

\section{CHAPTER 3. GEOLOGICAL SETTING OF THE ANSIL DEPOSIT}

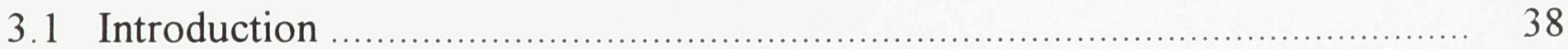

3.2 Northwest formation ................................................................. 39

3.2.1. North Flow stratigraphy ...................................................... 40

3.2.2 Rhyolite facies distribution in the vicinity of the Ansil deposit .............. 43

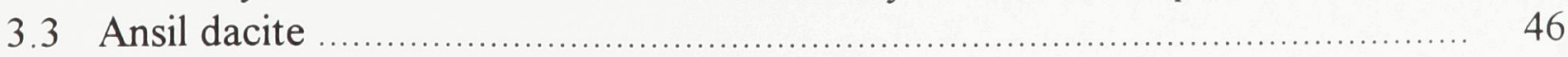




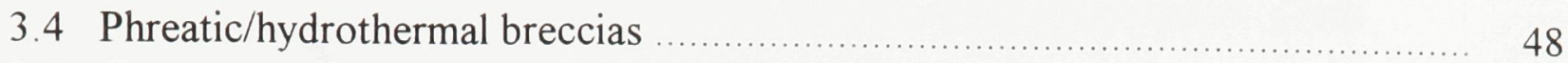

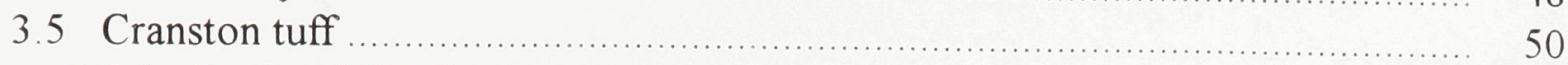

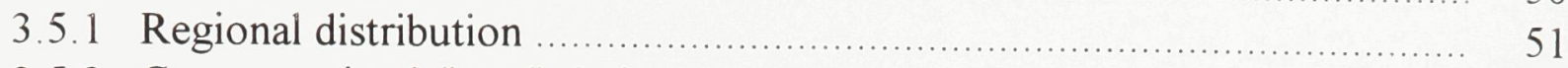

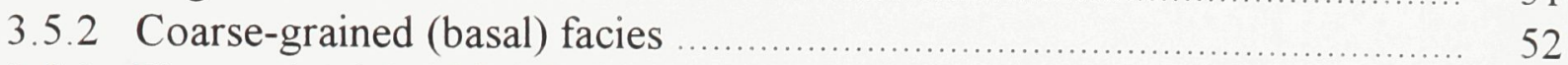

3.5.3 Fine-grained (middle) facies ...................................................... 53

3.5.4 Laminated (upper) facies ........................................................... 54

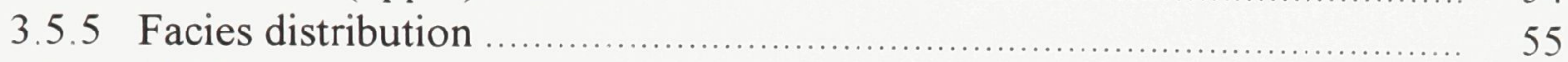

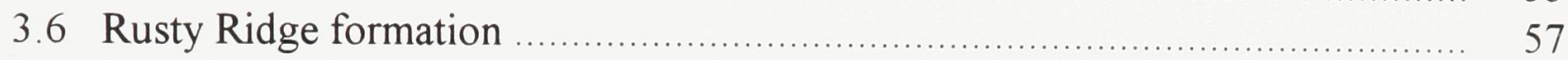

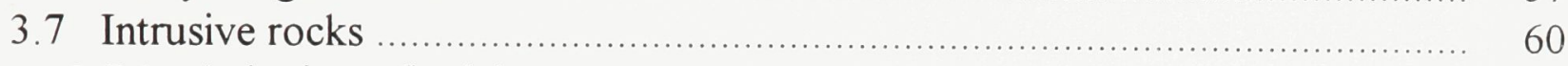

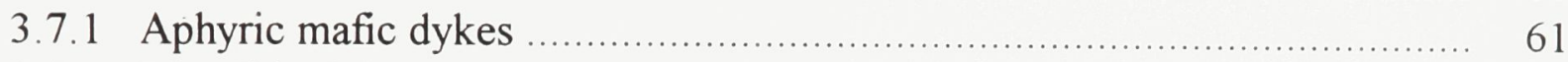

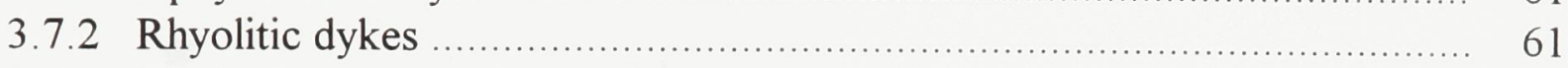

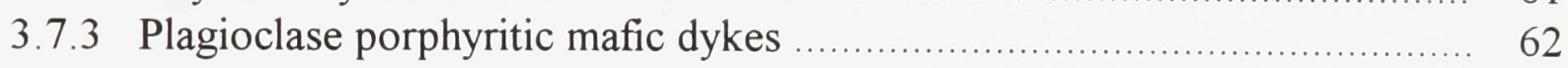

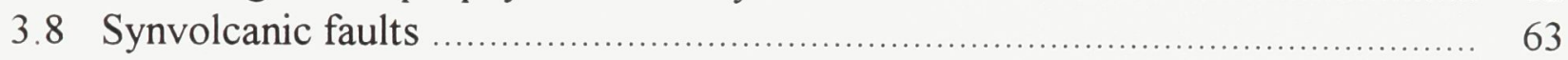

3.9 Summary of the depositional environment of the Ansil deposit .................... 66

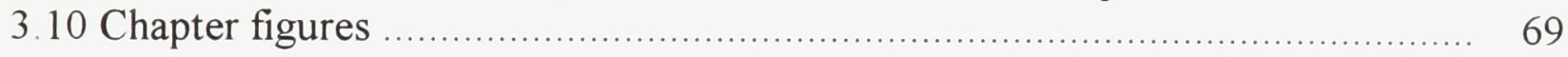

\section{CHAPTER 4. ANSIL OREBODY AND ASSOCIATED MINERALIZATION}

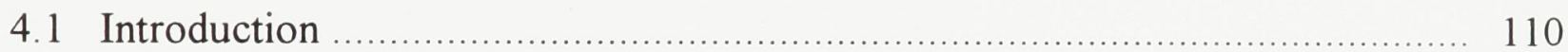

4.2 Footwall sulfide vein stockwork ..................................................... 112

4.2.1 Zn-rich footwall vein stockwork .............................................. 112

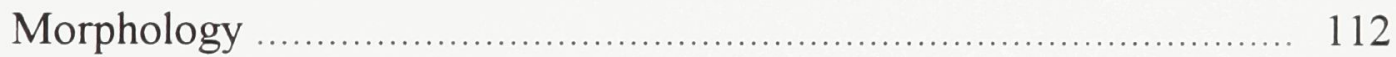

Internal morphology and composition ...................................... 113

4.2.2 $\mathrm{Cu}$-rich footwall vein stockwork ................................................ 116

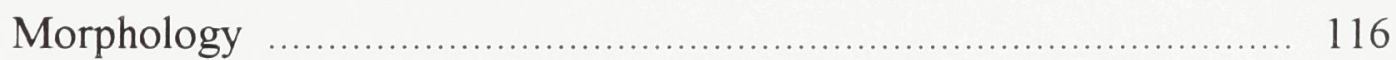

Internal morphology and composition ................................... 117

4.3 Stratiform massive sulfide lens .......................................................... 122

4.3.1 Morphology and composition ................................................. 122

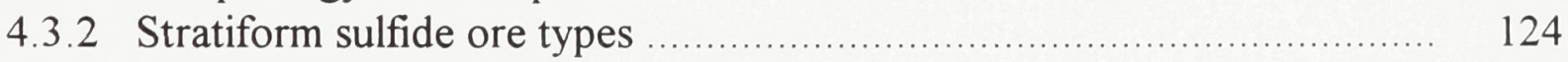

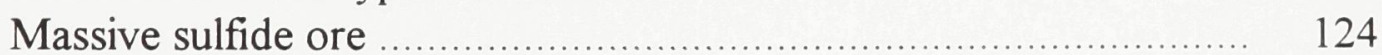

Fragmental sulfide ore ....................................................... 127

Layered sulfide ore …........................................................ 130

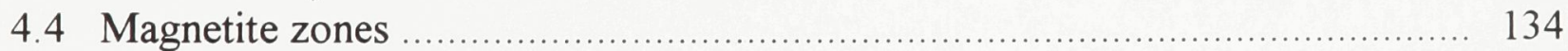

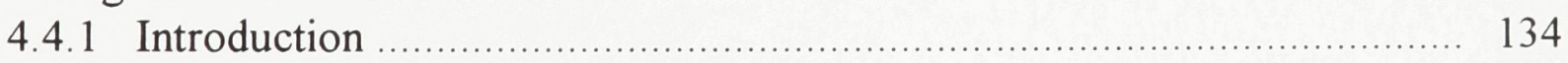

4.4.2 Magnetite distribution and morphology …..................................... 135

4.4.3 Internal morphology and composition ……................................. 137

4.5 Base and precious metal distribution ………...................................... 144

4.6 Summary of the characteristics of the Ansil orebody ............................... 147

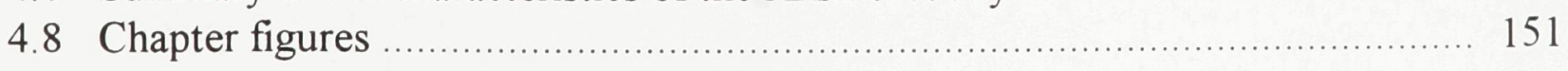




\section{CHAPTER 5. ALTERATION MORPHOLOGY, MINERALOGY AND CHEMISTRY}

5.1 Introduction

5.2 Devitrification and hydration

5.3 Diagenesis

5.4 Hydrothermal alteration

5.4.1 Regional spilitization ….......................................................... 196

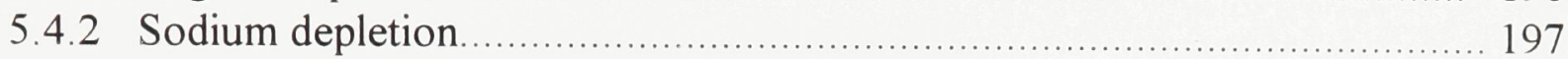

5.4.3 Quartz-chlorite alteration assemblage …........................................ 198

5.4.4 Zn-rich alteration mineral assemblages ........................................ 201

5.4.5 Cu-rich alteration mineral assemblages ......................................... 203

Chlorite-sulfide footwall assemblage ........................................ 203

Chlorite-sulfide-talc footwall assemblage …............................... 204

Massive chalcopyrite-pyrrhotite-talc-serpentine assemblage .............. 205

Sericite-chlorite transition assemblage .................................... 206

Massive sulfide-hangingwall transition assemblage ...................... 207

5.4.6 Magnetite-related alteration assemblages .................................... 211

Chlorite-magnetite footwall assemblage ...................................... 212

Ca-Fe skarn assemblages ..................................................... 213

Massive magnetite-amphibole assemblages …............................ 214

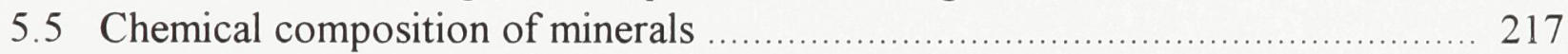

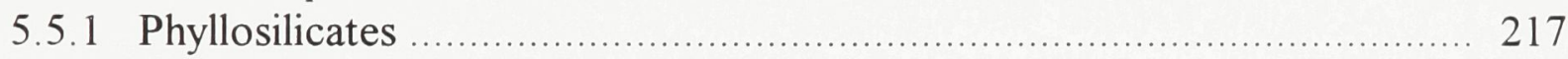

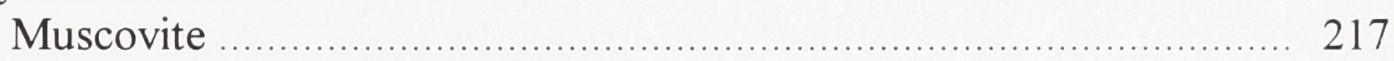

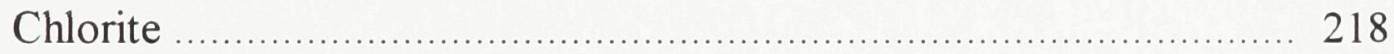

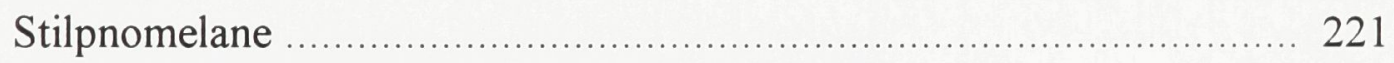

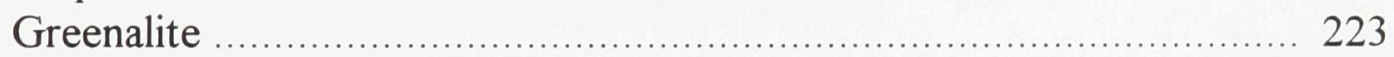

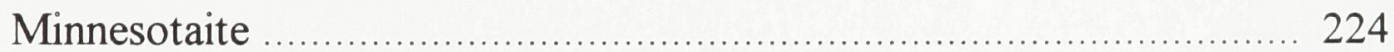

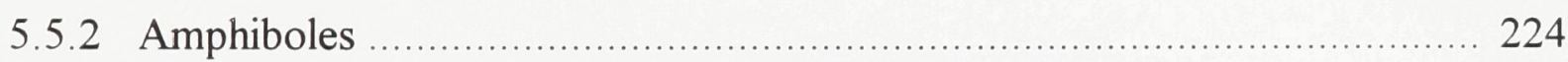

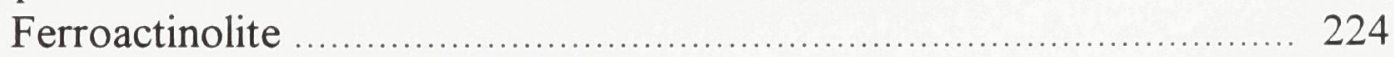

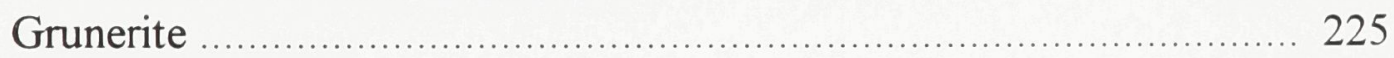

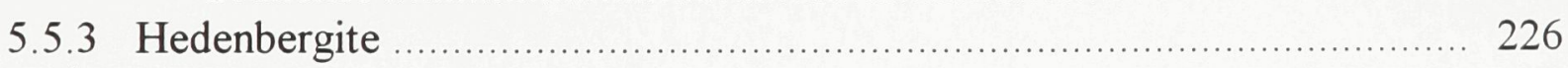

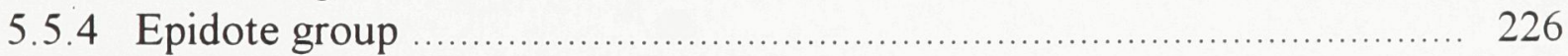

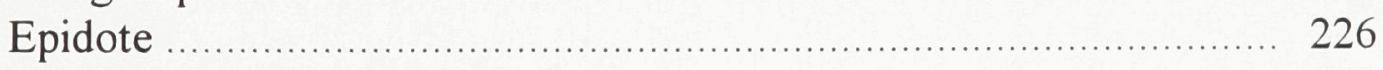

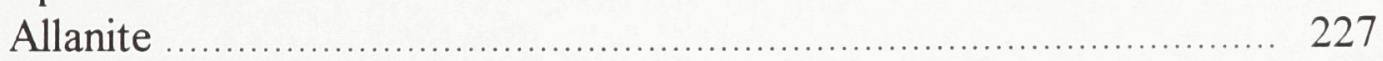

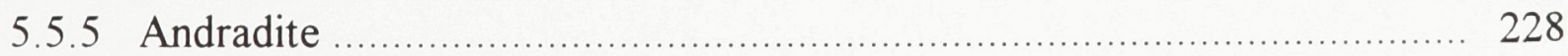

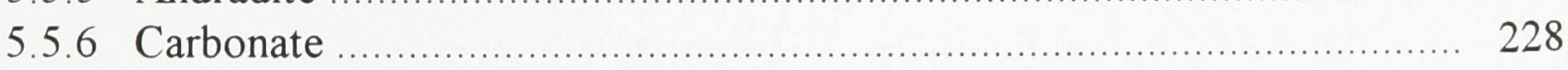

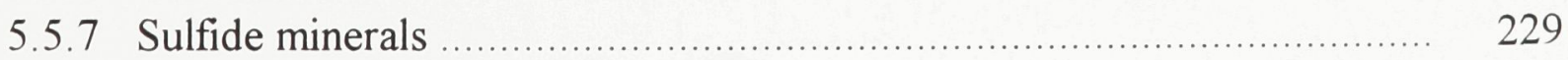

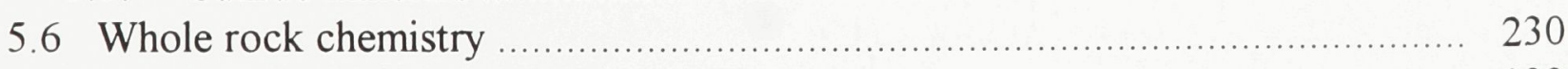

5.6.1 Major and trace element chemistry ............................................. 233 


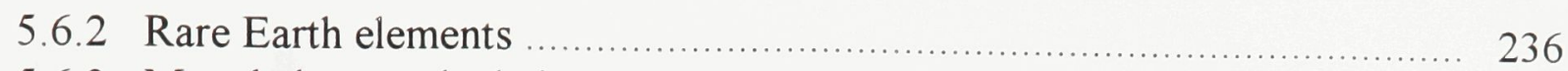

5.6.3 Mass balance calculations ................................................ 240

Treatment of Data ...................................................... 240

Ansil Results ........................................................... 243

5.7 Summary of alteration morphology, mineralogy and chemistry .................. 254

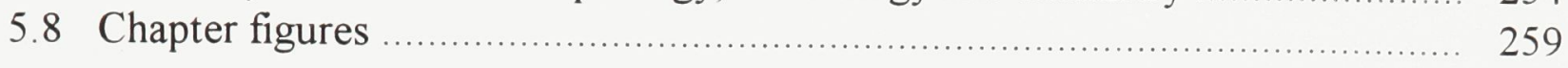

\section{CHAPTER 6. DISCUSSION AND CONCLUSIONS}

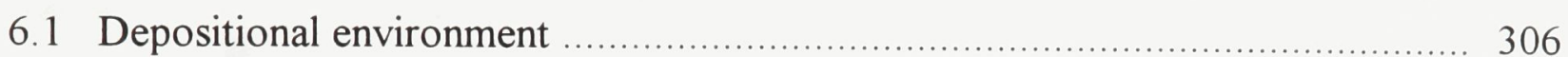

6.2 Structural controls on deposit formation ........................................... 309

6.3 Permeability control on deposit formation ......................................... 313

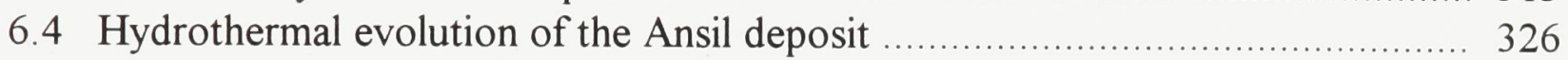

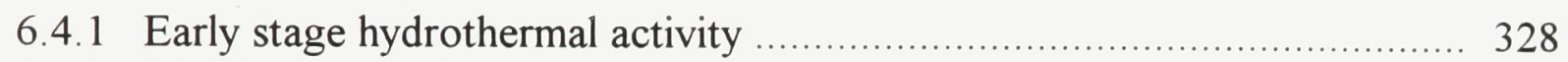

6.4.2 Middle stage hydrothermal activity ......................................... 332

6.4.3 Late stage hydrothermal activity ............................................. 342

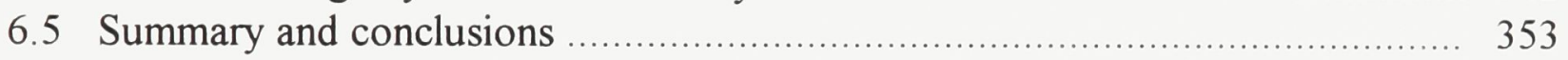

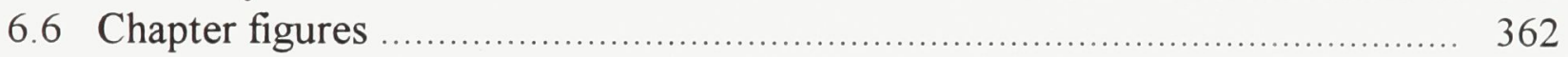

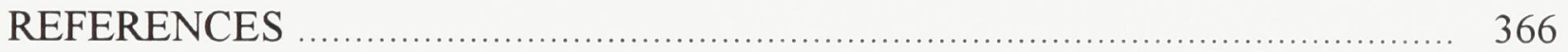

\section{APPENDICES}

Appendix I. 1:150 scale geology maps of the Ansil deposit

(GSC Open File 2681) ............................................... in Pocket

Appendix II Methods .............................................................. on diskette

Appendix III Sample Location Maps and Sample Descriptions ......................... 377

Appendix IV Whole Rock Chemical Analyses .................................... on diskette

Appendix V Mineral Analyses ................................................ on diskette 


\section{LIST OF TABLES}

Table 2.1 Lithostratigraphic subdivision of the Noranda Volcanic Complex, Blake River Group.

page

Table 2.2 Table of formations for the Noranda area.

Table 2.3 List of massive sulfide deposits and their stratigraphic positions relative to Gibsons (1989) lithostratigraphic subdivision.

Table 5.1 Relative mass changes calculated for the Ansil alteration facies.

Table 5.2 Absolute mass changes (in $\mathrm{g} / \mathrm{l00 \textrm {g }}$ ) for the Ansil alteration facies.

304

Table 5.3 Element losses and gains that took place during the alteration of the footwall rhyolite.

Table 5.4 Relative mass changes calculated for the alteration of the Cranston tuff. 


\section{LIST OF FIGURES}

Figure 1.1 Simplified geological map of the southern Abitibi Belt

Figure 2.1 Simplified geology of the Noranda Volcanic Complex and associated intrusions, with locations of massive sulfide deposits included ( deposit numbers correspond to names in Table 2)

Figure 2.2 North-south structural cross-section through the reconstructed Noranda Cauldron and Horne block showing relationship between eruption cycles, cauldron formation, and massive sulfide deposits.

Figure 2.3 Distribution of silicification and quartz-epidote alteration within the Noranda Cauldron.

Figure 2.4 Structural blocks, major structures and intrusions of the Blake River Group.

Figure 2.5 Distribution of regional metamorphic isograds and contact metamorphic aureoles.

Figure 2.6 A. Tectonic banding in massive chalcopyrite-pyrrhotite (Sublevel 6a) Centimetre card for scale.

B. Large chalcopyrite-quartz vein within the rhyolite-andesite contact shear approximately $12 \mathrm{~m}$ along strike of the south end of the massive sulfide lens.

C. Shear zone at the contact between the Rusty Ridge formation (top left) and the Northwest formation. These formations are the stratigraphic hangingwall and footwall respectively of the Ansil orebody.

D. Folded and boudinaged feldspar porphyritic mafic dykes transecting the massive sulfide lens.

E. Feldspar porphyritic syn-tectonic dyke with sharp boundaries characterized by sharp offsets believed to be a feature of the original fracturing of the rhyolite during dyke injection. 
F. Carbonate-rich alteration halos about syn-tectonic fractures related to shear zone along the main rhyolite-andesite contact $25 \mathrm{~m}$ south along strike of the massive sulfide lens (Drift 7-01).

Figure 2.7 Distribution of faults about the Ansil deposit.

$\begin{array}{ll}\text { Figure } 2.8 & \text { (a) Rose diagram of feldspar porphyritic mafic dyke }\end{array}$ distribution, and (b) morphology and orientation of dykes with respect to the massive sulfide lens.

Figure 2.9 A. Strongly sheared footwall vein stockwork zone, with pyrrhotite-chalcopyrite veins re-oriented sub-parallel to the shear plane (Sublevel 8A).

B. Tightly folded, layered massive sulfide from near the hangingwall contact of the orebody on Level 9.

C. Deformed fragmental sulfide ore along the base of the massive sulfide lens where it is transected by discrete shear zone (Sublevel 9C).

Figure 2.10 Stereographic projections showing the variation in strike of the contact shear.

Figure 3.1 East-west section through the host strata of the Ansil deposit.

Figure 3.2 Location of the Ansil deposit on the underlying North Flow rhyolite ridge, Northwest formation.

Figure 3.3 A. Photomicrograph of spherulite-rich, hyalophitic, quartzo-feldspathic domain in massive rhyolite cross-cut by chlorite-filled perlitic fractures.

B. Photomicrograph of agglomerated spherulites nucleating along perlitic fractures in chlorite-rich massive rhyolite.

C. Photomicrograph of quartzo-feldspathic and chloritic domains in massive rhyolite, with the former composed of agglomerated spherulites and glomeroporphyritic plagioclase 
microphenocrysts.

D. Photomicrograph of spherulites in chlorite-rich domain of a massive rhyolite flow.

Figure 3.4 Spherulitic massive rhyolite exposed in haulage drift 7-01.

Figure 3.5 Polished slab of spherulitic massive rhyolite.

Figure 3.6 A. Photomicrograph of elongate amygdules along rhyolite flow lobe margin, with chlorite-filled centre, quartz-rich rim and spherulitic halo.

B. Photomicrograph of an altered, obsidian flow margin with abundant perlitic fracturing.

C. Photomicrograph of rhyolite flow lobe margin with devitrified borders to perlitic fractures, and moderate chlorite alteration of intervening rhyolite.

D. Photomicrograph of rhyolite flow lobe margin with pseudo-breccia texture formed from extensive devitrification of perlitic fracture margins enveloping chlorite-rich remnants of rhyolite.

Figure 3.7 Polished slab of rhyolite flow breccia with chlorite altered fragments in milky blue-white, spherulite-rich, hyaloclastite groundmass.

Figure 3.8 Polished slab of rhyolite flow breccia with angular, chlorite altered fragments in a devitrified, hyaloclastite-rich groundmass.

Figure 3.9 Polished slab of rhyolite flow breccia with mottled texture due to the strong contrast between chlorite altered fragments and devitrified, hyaloclastite-rich groundmass.

Figure 3.10 Rhyolite flow breccia from Lower Amulet formation, with flow-banded, chlorite altered fragments in strongly devitrified matrix. For comparison with Figure 3.7a. 
Figure 3.11 Rhyolite hyaloclastite with chlorite altered fragments in bluish-white devitrified groundmass ("blue-quartz breccia") Haulage drift, Sublevel 8A.

Figure 3.12 Divitrified rhyolite hyaloclastite in Lower Amulet formation for comparison with Figure 3.11.

Figure 3.13 Flank breccia along the upper contact to the Northwest Formation south of the Ansil orebody. Crude normal grading towards the upper contact. Haulage drift 7-01.

Figure 3.14 Matrix-supported rhyolite flank breccia directly underlying the south flank of the Ansil massive sulfide lens.

Drawpoint \#1, Sublevel 7B.

Figure 3.15 Reconstruction through a north-south section of the North Flow rhyolite ridge below the Ansil deposit.

Figure 3.16 Two 1:150 scale cross-sections through a columnar-jointed rhyolite lobe.

Figure 3.17 Curving, segmented columns near the upper surface of a massive rhyolite flow lobe. Drawpoint \#2, Sublevel 8A.

Figure 3.18 Cross-secton of columnar-jointed rhyolite flow with chalcopyrite-pyrrhotite infilled joints. Drawpoint \#2, Sublevel 8A.

Figure 3.19 Isopach map with $10 \mathrm{~m}$ contours of the Ansil dacite unit in the vicinity of the Ansil deposit.

Figure 3.20 Irregular upper surface of dacite flow lobe overlain by draped beds of Cranston tuff. Drawpoint \#1, Sublevel 11A.

Figure 3.21 Cross-section through part of the Ansil dacite lobe-hyaloclastite flow.

Figure 3.22 Section through the Ansil dacite lobe-hyaloclastite flow. 
Figure 3.23 A $30 \mathrm{~cm}$ long section of cut and polished drill core through dacite flow margin, with abundant perlitic cooling fractures and pipe vesicles.

Figure 3.24 Polished slab of light grey, amygdaloidal dacite flow with abundant quartz-chlorite-pyrite filled gas cavities.

Figure 3.25 A. Photomicrograph of dacite flow with hyalopilitic texture defined by plagioclase microlites and quartz-rich spherulites in and aphanitic, quartz-plagioclase-sericite matrix.

B. Photomicrograph of dacite flow with abundant spherulites.

C. Photomicrograph of plagioclase phenocryst enveloping smaller plagioclase microlites.

D. Photomicrograph of perlitic fractures in dacite flow infilled with chlorite and Fe-oxides.

Figure 3.26 Polished slab of glassy dacite flow margin with extensive perlitic cooling fractures.

Figure 3.27 Dacite flow margin with rectangular fracture system controlled by concentric and radial cooling fractures. Zone of abundant perlitic fracturing also visible. Drawpoint \#1, Sublevel 11A.

Figure 3.28 Upper contact of dacite flow lobe with rectangular fracture pattern controlling formation of the flow breccia. Flow breccia overlain by thin carapace of dacite hyaloclastite, which is overlain by well layered Cranston tuff.

Figure 3.29 Funnel-shaped hydrothermal breccia underlying the north flank of the Ansil orebody.

Figure 3.30 Small disrupted breccia vein near base of hydrothermal breccia zone. Note abundant sphalerite mineralization of rhyolite wallrock (Sublevel 7B). 
Figure 3.31 Sphalerite-rich breccia zone below the south flank of the orebody (Zinc South Zone, Sublevel 7B). Larger fractures (arrow) infilled with finely laminated quartz.

Figure 3.32 Brecciation of dacite flow lobe during sericite-quartz alteration event. (Sublevel 11A).

Figure 3.33 Polished slab of disrupted, sphalerite-rich breccia showing poor sorting of angular to rounded fragments (Sublevel 9C).

Figure 3.34 Section through a hydrothermal breccia below the north flank of the deposit. Sublevel 9B, Drawpoint \#6.

Figure 3.35 Possible bedding contact within conformable, sphalerite-rich, hydrothermal breccia apron (Sublevel 10A).

Figure 3.36 Extent and internal facies distribution of Cranston QFP mass flows. Contours are in metres.

Figure 3.37 Composite stratigraphic section through the Cranston tuff in the vicinity of the Ansil deposit.

Figure 3.38 Isopach map showing the distribution of the Cranston tuff in the vicinity of the Ansil deposit.

Figure 3.39 Polished slab of contact between the Cranston tuff coarse- and fine-grained facies. Visible felsic grains include quartz and plagioclase phenoclasts.

Figure 3.40 A. Photomicrograph of coarse-grained tuff facies showing angular quartz phenoclasts and more rounded rhyolite fragments. Crossed polars.

B. Photomicrograph of coarse-grained tuff facies, with broken quartz phenoclasts, rhyolite fragment, and possible devitrified glass shard (arrow).

C. Broken quartz phenoclasts in coarse-grained base of normally-graded tuff layer. 
D. Contact between fine-grained top and coarse-grained base of beds in fine-grained tuff facies.

Figure 3.41 Fine-grained facies of the Cranston tuff. Note maroon colour from abundant, disseminated sphalerite

Figure 3.42 Polished slab of fine-grained facies, showing normally-graded layers ranging from fine-grained to finely laminated, quartz-phyric tuff.

Figure 3.43 Possible ripple marks in fine-grained facies of Cranston tuff. Polished slab from Sublevel 9B.

Figure 3.44 Possible ripple marks along base of bedding plane in fine-grained facies of Cranston tuff (Sublevel 10B).

Figure 3.45 Flame structures in laminated facies of the Cranston tuff (Sublevel 10B).

Figure 3.46 Laminated facies of the Cranston tuff (Sublevel 10B).

Figure 3.47 Finely laminated bedding top to Cranston tuff laminated facies (Sublevel 10B).

Figure 3.48 Section through moderately altered and mineralized andesite flows 20 to $25 \mathrm{~m}$ above the west end of the orebody (Ramp 6-7).

Figure 3.49 Reconstruction of the graben hosting the Ansil deposit.

Figure $4.1 \quad$ (a) Composite east-west geological section through the Ansil deposit and associated footwall alteration/mineralization, and (b) north-south geological section through the Ansil deposit and associated alteration/mineralization.

Figure 4.2 Composite plan view of the Ansil orebody. Scale true for deposit widths; plunge length is extended for easier viewing of each level. True plunge length approximately $325 \mathrm{~m}$.

Figure $4.3 \quad(a, b)$ Plan view of upper and lower parts of the footwall stockwork vein system. 
Figure 4.4 Discordant Zn-rich stockwork vein system cross-cutting sericite-quartz-albite altered rhyolite (Ore pass, Level 8).

Figure 4.5 Zn-rich, discordant vein stockwork with strongly sphalerite impregnated, maroon coloured rhyolite cross-cut by quartzsphalerite-pyrite veins. Larger veins are infilled with delicately banded chalcedony (arrow) (Sublevel 7B).

Figure 4.6 Coarse-grained, bleached fragment breccia, with sericite-quartz altered rhyolite fragments in a sphalerite-pyrite-pyrrhotite groundmass (Drawpoint \#6, Sublevel 9b).

Figure 4.7 Polished slab showing bleached fragment breccia from the north flank of the massive sulfide lens.

Figure 4.8 In situ brecciation of massive dacite flow lobe, with fracture infilling by quartz, pyrrhotite and sphalerite. Distinctive sericitealtered rims mark wallrock fragments (Sublevel 11A).

Figure 4.9 Polished slab showing mineralized dacite flow breccia with sericite alteration of shards and blocks (Sublevel 11A).

Figure 4.10 Cross-section through $\mathrm{Cu}$-rich vein stockwork exposed on (a) the ramp between levels $10 \mathrm{~A}$ and 11 , and (b) the ramp between levels 10 and 10A.

Figure 4.11 "Net-textured" pyrrhotite-chalcopyrite vein stockwork crosscutting rhyolite hyaloclastite.

Figure 4.12 "Net-textured" pyrrhotite-chalcopyrite vein stockwork becoming finer-grained from left to right, changing to blocky fragment sulfide ore.

Figure 4.13 Columnar-jointed rhyolite lobe with joints infilled with pyrrhotite -chalcopyrite and columns strongly chlorite altered.

Figure 4.14 Contoured plan view of the Ansil deposit, including the massive sulfide lens and underlying, semi-conformable pyrrhotitechalcopyrite vein stockwork.

Figure 4.15 Cartoon of Ansil orebody showing the different textural and compositional subdivisions.

Figure 4.16 Polished slab showing massive to sieve-textured massive sulfide, with wispy bands of pyrrhotite in a chalcopyrite groundmass. 
Figure 4.17 Closely spaced pyrrhotite banding in massive ore along hangingwall contact of the massive sulfide lens with pillowed andesitic flow. Banding is warped about a more massive segment of ore. Sublevel 6A.

Figure 4.18 Polished slab showing massive, banded sulfide ore with wispy, discontinuous bands of pyrrhotite in chalcopyrite. Sublevel $6 \mathrm{~A}$

Figure 4.19 Polished slab showing hangingwall fragmental ore from the top of the massive sulfide dome at the west end of the deposit.

Figure 4.20 Sphalerite-rich, fine-grained bleached fragment breccia containing 10 to $12 \% \mathrm{Zn}$ (ore drift, Sublevel $10 \mathrm{~A}$ ).

Figure 4.21 Polished slab showing discordant, Zn-rich zone cross-cutting pyrite-impregnated bleached fragment breccia

Ore drift, Sublevel 10A

Figure 4.22 Discordant, $\mathrm{Cu}$-rich zone crossing bleached fragment breccia, with chalcopyrite infilling between previously sericite-quartzsphalerite altered rhyolite fragments. Ore drift, Sublevel 10A.

Figure 4.23 Replacement of matrix of chlorite-altered flow breccia by massive pyrrhotite-chalcopyrite. Drawpoint \#1, Sublevel 8A.

Figure 4.24 Elongate fragment breccia ore overlying blocky fragment ore, and in gradational contact (to right) with massive sulfide ore. Drawpoint \#4, Sublevel 8A. Steel plate $15 \mathrm{~cm}$ wide for scale

Figure 4.25 Elongate fragment breccia ore formed from infilling and intense veining of rhyolite hyaloclastite.

Figure 4.26 Elongate fragment sulfide ore in gradational contact with massive ore

Figure 4.28 A. Photomicrograph of pyrrhotite, sphalerite and accompanying sericite alteration concentrated in coarse-grained base to Cranston tuff layer.

B. Photomicrograph of intergrown sphalerite and sericite in sericite altered Cranston tuff. 
C. Photomicrograph of zoned pyrite grain in Cranston tuff, with massive core rimmed with inclusion-rich subhedral pyrite

D. Photomicrograph of a corroded pyrite cube in Cranston tuff enveloped in pyrrhotite and chalcopyrite.

Figure 4.29 Sphalerite distribution along the synvolcanic fault-controlled rhyolite-Cranston tuff contact below the north flank of the deposit North wall of Drawpoint \#6, Sublevel 9B.

Figure 4.30 Remnant of sphalerite mineralized Cranston tuff within massive pyrrhotite-chalcopyrite near the top of the orebody.

Hangingwall access drift, Level 9C.

Figure 4.31 Selective overprinting of previously sphalerite mineralized layer of Cranston tuff by chalcopyrite-pyrrhotite. Ore cross-cut, Sublevel 11A.

Figure 4.32 Slab showing sphalerite-rich Cranston tuff overprinted by chalcopyrite-pyrrhotite. Ore cross-cut, Sublevel 11A.

Figure 4.33 Polished slab showing Cranston tuff replaced by sphalerite and pyrite, which is weakly overprinted by pyrrhotite-chalcopyrite. Sublevel 9B.

Figure 4.34 Polished slab of pyrite-sphalerite mineralized Cranston tuff with disseminated chalcopyrite-pyrrhotite infilling between volcaniclastic grains. Drawpoint \#5, Sublevel 9B

Figure 4.35 Polished slab from exposure shown in Figure 4.36. Presence of tectonically banded chalcopyrite-pyrrhotite in lower right corner, and fracturing of pyrite ovoids indicates moderate deformation of the orebody.

Figure 4.36 Exposure of pyrite-sphalerite mineralized Cranston tuff partially replaced by chalcopyrite-pyrrhotite to form layered chalcopyritepyrrhotite-pyrite-sphalerite massive ore. East end of orebody on Sublevel 10B.

Figure 4.37 Layered pyrrhotite-chalcopyrite-tuff ore along the contact between the base of the massive sulfide ore and the top of the elongate fragmental ore. Layered ore is up to $50 \mathrm{~cm}$ wide. Drawpoint \#5, Sublevel 8A. 
Figure 4.38 Polished slab of finely bedded to laminated pyrrhotite-chalcopyritetuff ore from the hangingwall contact of the massive sulfide lens. Remnants of tuff layers strongly chloritized, with scattered quartz phenoclasts. Hangingwall access drift, Sublevel 9C

Figure 4.39 Polished slab showing remnant of laminated facies, sphaleritemineralized Cranston tuff replaced along its margins by banded pyrrhotite-chalcopyrite ore.

Figure 4.40 Partially replaced Cranston tuff from the base of the massive sulfide lens. Remaining tuff chlorite altered. Layering from tuff still present in overprinting pyrrhotite-chalcopyrite.

Figure 4.41 A. Photomicrograph showing lit-par-lit replacement of Cranston tuff by chalcopyrite and pyrrhotite.

B. Photomicrograph of remnant coarse-grained tuff layer along the base of the pyrrhotite-chalcopyrite massive sulfide ore.

C. Photomicrograph of sieve-textured massive sulfide ore formed from partial replacement of Cranston tuff by pyrrhotitechalcopyrite.

Figure 4.42a N-S cross-sections of levels 9B and 9C showing the relationship of magnetite occurrences to earlier mineralization.

Figure 4.42b N-S cross-sections through levels 10 and $10 \mathrm{~A}$ showing the relationship between magnetite occurrences and earlier mineralization.

Figure 4.43 Massive magnetite vein crosscutting chlorite-sulfide alteration zone below orebody on Sublevel $8 \mathrm{~A}$.

Figure 4.44 Polished slab showing internal texture of large magnetite vein from below the orebody on Sublevel 8A.

Figure 4.45 Polished slab showing magnetite infilling chlorite-altered hyaloclastite in footwall to orebody on Sublevel 9C. 
Figure 4.46 A. Horizontal contact between massive magnetite and massive sulfide. Sublevel 10A.

B. Sulfide-quartz-carbonate veining in massive magnetite Sublevel 10A.

C. Thin occurrence of massive magnetite along hangingwall contact of the massive sulfide lens. Presence of fine layering suggests that it is replacing Cranston tuff. Level 9 ore drift.

Figure 4.47 Polished slab showing magnetite selectively replacing layers of Cranston tuff along the hangingwall contact of the massive sulfide lens. Sublevel 9B, drawpoint \#5.

Figure 4.48 Metal distribution within the Ansil orebody.

Figure 4.49a Long section showing distribution of $\mathrm{Cu}$ within the orebody.

Figure $4.49 \mathrm{~b}$ Long section showing the distribution of Au within the orebody.

Figure 5.1 A. Photomicrograph of a chlorite and quartz pseudomorph after zeolite. Also note perlitic fracture rimmed with inclusionrich quartz (after chalcedony) and infilled with clear quartz.

B. Photomicrograph of diagenetic alteration nucleating about perlitic fracture in quartz-chlorite altered rhyolite. Ovoid forms are a product of alteration of glass to gel palagonite which in turn is first replaced by chalcedony and then quartz.

C. Photomicrograph of advanced diagenetic alteration in quartzchlorite altered rhyolite, with silicification centred about perlitic fractures. Inclusion-rich quartz pseudomorphous after gel palagonite through chalcedony.

D. Photomicrograph of intricate liesegang banding of diagenetic structures about perlitic fractures in quartz-chlorite altered rhyolite Abundant Fe-oxide suggests a gel palagonite precursor 
E. Photomicrograph of granoblastic textured rhyolite product of late stage devitrification (granophyre). Infilling of perlitic fractures by axiolitic chlorite and granular quartz are diagenetic products after original fibrous palagonite and chalcedony.

F. Photomicrograph of late stage diagenetic alteration with abundant quartz (after chalcedony) alteration of glass adjacent to perlitic fractures and infilling the fractures. Note liesegang rings about fracture axis. This diagenetic alteration stage gives the quartz-chlorite altered rhyolite a distinctive mottled texture.

Figure 5.2 Polished slab showing quartz-chlorite-altered rhyolite breccia with abundant, chlorite inclusion-rich quartz (after chalcedony?) infilling hyaloclastite-rich matrix ("blue quartz breccias").

Figure 5.3 Polished slab showing intense silicification of rhyolite hyaloclastite found below the south flank of the orebody as part of the quartz-chlorite alteration facies.

Figure 5.4 Alteration facies distribution about the Ansil deposit.

Figure 5.5 Distribution of a discordant, fault-controlled Na-depletion zone that cross-cuts the Flavrian, Northwest, Rusty Ridge and Amulet formations.

Figure 5.6 Quartz-chlorite alteration of plagioclase glomeroporhyritic rhyolite dyke. Strong reticular fracture pattern infilled with chlorite, quartz and albite.

Figure 5.7 Polished slab showing intense quartz-chlorite alteration of plagioclase glomeroporphyritic felsic dyke imparts a distinctive, mottled texture on the rock. Overprinted by chlorite-pyrrhotitechalcopyrite alteration.

Figure 5.8 Polished slab showing intense quartz flooding of rhyolite hyaloclastite along the margins of the quartz-chlorite alteration zone under south flank of orebody.

Figure 5.9 Photomicrograph showing silicification of hydrated glass in a perlitic fractured, massive rhyolite lobe margin. Part of 
quartz-chlorite alteration facies.

Figure 5.10 Polished slab showing mottled texture of quartz-chlorite altered, plagioclase glomeroporphyritic felsic dyke. Some crystal clusters up to $3 \mathrm{~cm}$ across (arrow).

Figure 5.11 Polished slab showing intense silicification of rhyolite, accompanied by chlorite-quartz-albite veins.

Figure 5.12 Polished slab showing halo of intense sericite-quartz alteration about chlorite-quartz-albite vein.

Figure 5.13 A. Photomicrograph of intense sericite alteration of Cranston tuff.

B. Photomicrograph of normally graded Cranston tuff layer, with sericite-quartz-albite-sphalerite-Fe sulfide precipitation concentrated along the coarse-grained base.

C. Photomicrograph of intense sericite-quartz alteration of Cranston tuff with intergrown sphalerite and sericite.

D. Photomicrograph of quartz-albite cluster rimmed by sphalerite and pyrrhotite.

Figure 5.14 Fracture-controlled sericite-quartz alteration of in situ dacite fragments within an hydrothermal explosion breccia zone under the south flank of the orebody (Sublevel 11A).

Figure 5.15 Pervasive sericite-quartz alteration of fractured dacite from within a $\mathrm{Zn}$-rich zone below the south flank of the orebody (Sublevel 11A).

Figure 5.16 Polished slab showing a disrupted hydrothermal explosion breccia below the north flank of the orebody.

Figure 5.17 A. Backscatter image of delicately zoned pyrite crystal from sericite-quartz alteration facies. Crystal appears to be partly corroded, with rimming by pyrrhotite and chalcopryrite.

B. Backscatter inage of rutile crystal partially altered to ilmenite with the chlorite-sulfide alteration facies. 
C. Backscatter image of altered hangingwall andesite near the massive sulfide contact, with rutile altering to ilmenite in the presence of chalcopyrite.

D. Backscatter image showing complex intergrowth of allanite, apatite, titanite, rutile and xenotime within the chlorite-sulfide alteration facies.

E. Backscatter image of intergrown minnesotaite and chalcopyrite in $\mathrm{Mg}$-rich chlorite groundmass within core of chlorite-sulfide alteration facies.

F. Backscatter image of stilpnomelane intergrown with chalcopyrite in massive sulfide lens.

Figure 5.18 A. Photomicrograph of chlorite veinlet cross-cutting sericitequartz altered Cranston tuff at the margin of the massive sulfide lens.

B. Photomicrograph of weak chlorite spotting within sericitequartz altered Cranston tuff.

C. Photomicrograph of moderate chlorite mottling and replacement of sericite-quartz-altered Cranston tuff.

D. Photomicrograph of hydrothermal albite crystal aggregate rimmed and infilled by chalcopyrite and pyrrhotite in altered andesitic flow.

Figure 5.19 A. Photomicrograph of relatively unaltered Rusty Ridge andesite characterized by an albite-chlorite-actinoliteepidote-titanite mineral assemblage.

B. Photomicrograph of chlorite-quartz altered andesite in immediate hangingwall to Ansil orebody. 
C. Photomicrograph of partly ingested andesite along the hangingwall contact of the massive sulfide lens.

Quartz-chlorite-chalcopyrite-stilpnomelane altered andesite is being overprinted by chalcopyrite-pyrrhotite-quartzstilpnomelane.

D. Photomicrograph of completely altered andesite, with patchy domains of quartz-chlorite in coarser-grained quartzstilpnomelane-pyrrhotite-chalcopyrite. Note albite laths replaced by quartz (arrow).

E. Photomicrograph of remnant andesite domain within margin of massive sulfide lens.

F. Photomicrograph of quartz domains within massive chalcopyritepyrrhotite, with albite porphyroblasts pseudomorphous to quartz.

Figure 5.20 Polished slab showing weak quartz-chlorite alteration of hangingwall andesite, with chlorite-quartz filled amygdules connected by quartz veinlets with silicified margins.

Figure 5.21 Sericite-quartz alteration of hangingwall andesite above the south flank of the orebody (Sublevel 7B).

Figure 5.22 Polished slab showing sericite-quartz-chlorite-sulfide alteration of andesite pillow margin. Chorite-rich alteration replaces interpillow hyaloclastite.

Figure 5.23 Polished slab showing sericite-quartz altered pillow margin, with amygdules infilled with sulfide, quartz and chlorite.

Figure 5.24. Chlorite-sulfide alteration of the hangingwall andesite along the margin of the pyrrhotite-chalcopyrite spine that is part of the western end of the massive sulfide lens.

Figure 5.25. Reaction zone along the contact of the massive sulfide lens and the overlying andesite flows. 
Figure 5.26 A. Photomicrograph of magnetite-chlorite-calcite alteration controlled by perlitic fracturing of massive rhyolite lobe.

B. Photomicrograph of zoned epidote grains from the chloritemagnetite alteration zone, with allanite cores and epidote rims.

C. Photomicrograph of magnetite-chlorite-calcite alteration overprinting edge of epidote patch.

D. Photomicrograph of epidote grain replaced along its margins by calcite

E.. Photomicrograph of magnetite-rich domain within the chloritemagnetite alteration zone. Atoll structure of magnetite idiomorphs cored by chlorite and rimmed by calcite.

F. Photomicrograph of atoll-shaped magnetite crystals along the margin of a magnetite vein.

Figure 5.27 Large epidote patches within chlorite-magnetite alteration zone. 11-01 drift.

Figure 5.28 Polished slab showing a magnetite vein cross-cutting an epidote patch. 10A access drift.

Figure 5.29 Polished slab showing semi-massive magnetite zone overprinting hedenbergite-andradite-ferroactinolite skarn. Level 10 hangingwall drift.

Figure 5.30 Polished slab of hedenbergite-andradite-ferroactinolite skarn. Level 10 hangingwall drift.

Figure 5.31 Polished slab showing a coarse-grained ferroactinolite skarn from the base of a massive magnetite lens. Note magnetite overprinting margins of amphibole porphyroblasts. Drawpoint \#5, Sublevel 9B

Figure 5.32 Cross-section of reaction zone between massive magnetite and massive sulfide. 
Figure 5.33 A. Mineral assemblage within a massive magnetite zone, with ferroactinolite-quartz being replaced with $\mathrm{Fe}$-carbonate and finely intergrown chlorite-greenalite-stilpnomelane.

B. Near the contact between massive magnetite/sulfide the massive magnetite groundmass is composed of Fe-carbonate, greenalite and stilpnomelane and remnant patches of quartz.

C. Contact between massive magnetite and sulfide, with mixed magnetite and pyrrhotite in a Fe-carbonate-greenalite groundmass.

D. Chalcopyrite-pyrrhotite with disseminated magnetite grains.

Figure 5.34 Muscovite compositions from sericite-quartz alteration zone.

Figure 5.35 Variation in chlorite compositions from the Ansil alteration zones as Fe content normalized to $\mathrm{Mg}$.

Figure 5.36 Fe-Al-Mg ternary diagram showing range of chlorite compositions from the Ansil alteration zones.

Figure 5.37 Heys (1954) classification of chlorites with Ansil alteration zone data.

Figure 5.38 Whole rock vs. chlorite $\mathrm{Fe} / \mathrm{Fe}+\mathrm{Mg}$ ratios.

Figure 5.39 Mn vs. Fe diagram for the Ansil chlorite compositions.

Figure 5.40 Ternary FeO-Al2O3-MgO diagrams showing compositional variations in (a) stilpnomelane, (b) greenalite, and (c) mixed minnesotaite-greenalite.

Figure 5.41 $\mathrm{FeO}-\mathrm{CaO}-\mathrm{MgO}$ ternary plot with pyroxene and amphibole compositions from the Ca-Fe skarn alteration assemblage.

Figure 5.42 $\mathrm{FeO}-\mathrm{CaO}-\mathrm{MgO}$ ternary plots with compositions of (a) epidotes, (b) andradite, and (c) carbonates from the Ansil calc-silicate alteration assemblage. 
Figure 5.43 Mole \% FeS contents of Ansil sphalerites.

Figure 5.44 Harker diagram with the Gibson and Barrett standards plotted with the whole rock analyses from the Ansil footwall rhyolite.

Figure 5.45 Flattened tetrahedron with combinations of cations at each apex that define increasing alteration intensities by the losses of $\mathrm{Na}$ and $\mathrm{Ca}$, transitional gain, and then loss, of $\mathrm{K}$ and gains in $\mathrm{Fe}, \mathrm{Mn}, \mathrm{Mg}$ and $\mathrm{Al}$.

Figure 5.46 La/Lu ratios for the Ansil footwall alteration zones.

Figure 5.47 Chondrite normalized REE plots for the Ansil alteration facies.

Figure 5.48 $\quad \mathrm{TiO}_{2}$ vs. $\mathrm{Zr}$ plot for the Ansil alteration facies.

Figure 5.49a Plots of altered vs. unaltered samples, and corresponding histograms defining mass changes for the Ansil least altered and quartz-chlorite alteration facies.

Figure 5.49b Plots of data from altered vs. unaltered samples, and corresponding histograms defining mass changes for the Ansil sericite-quartz and chlorite-sulfide alteration facies.

Figure 5.49c Plots of altered vs. unaltered samples, and corresponding histograms defining mass changes for the Ansil chlorite-magnetite alteration facies.

Figure 5.50 Histograms showing relative mass changes of the Ansil alteration facies grouped by element.

Figure 6.1 Schematic diagram showing the probable routes for circulating hydrothermal fluid during the formation of the Ansil deposit.

Figure 6.2 Mineral paragenesis for the Ansil alteration system.

Figure 6.3 Stages in the formation of the Ansil orebody. 


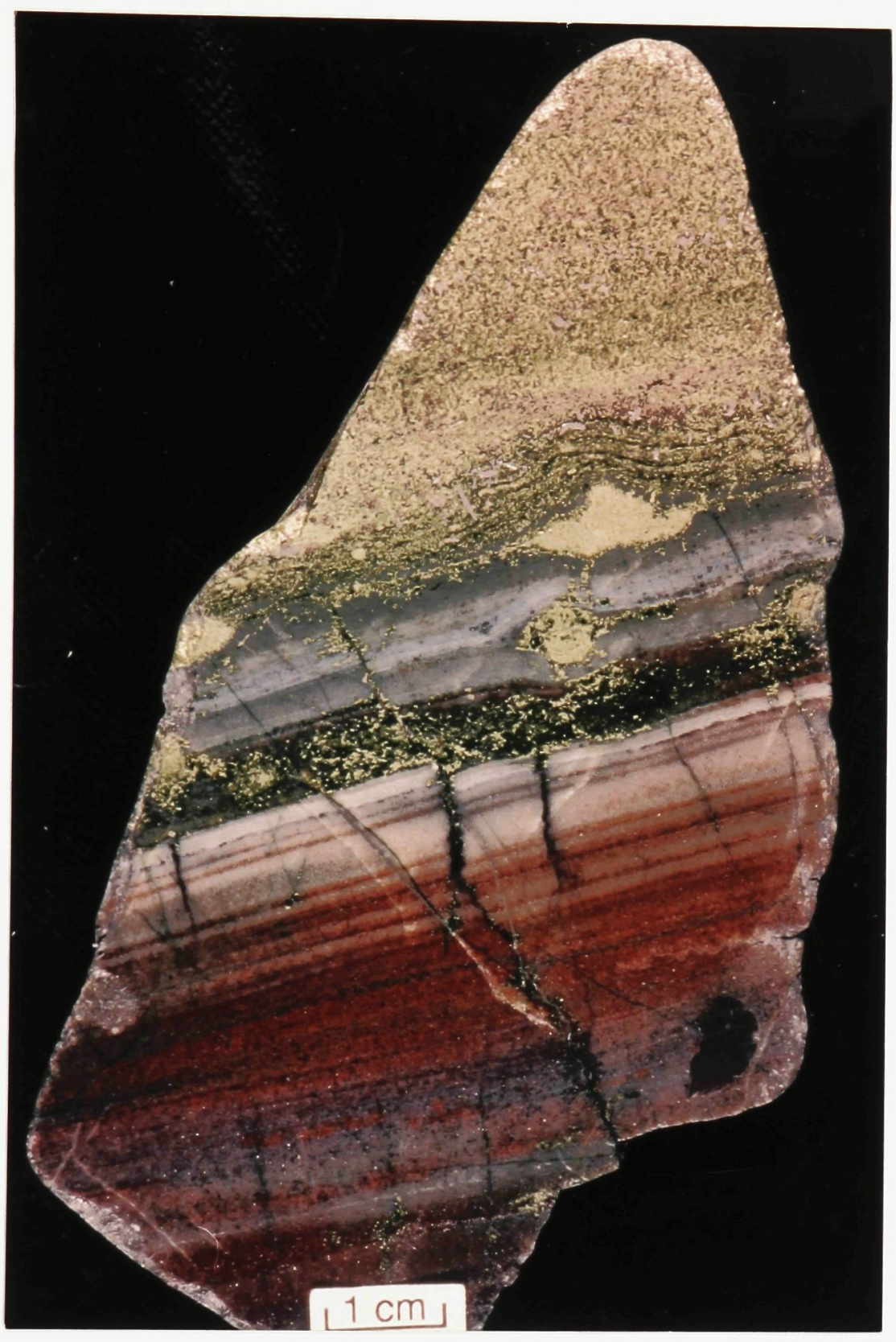

FRONTISPIECE: Polished slab from the top of the massive sulfide lens exposed in the hangingwall drift, Sublevel 9C. Previously sphalerite-enriched, laminated facies of the Cranston tuff is overprinted by pyrrhotite-chalcopyrite, with selective replacement of some layers by sulfide, and others by chlorite. Sample ANSL9C-029. 


\subsection{PURPOSE OF THE STUDY}

This integrated geological, petrographic and geochemical study of the Ansil volcanichosted massive sulfide (VHMS) deposit was undertaken with the cooperation and support of Metall Mining Corp. (formerly Minnova Inc.) for the purpose of understanding the distribution and origin of alteration and mineralized volcanic facies in and about the deposit in order to better understand controls on the deposition and location of this deposit. Much of the above company's success is based on the philosophy that detailed information must be gathered on the geology and geochemistry of a deposit in order that models may be constructed that would allow company personnel to recognize similar massive sulfidehosting volcanic environments.

A study of the Ansil deposit was considered a unique opportunity to investigate a massive sulfide orebody and its host strata. The morphology and small size $(1.58 \mathrm{mt})$ of the deposit resulted in mining methods that were very amenable to detailed mapping over several years. With the wealth of data available from preserved surface and underground exploration diamond drill holes it was possible to gain an understanding of the orebody and associated mineralization and alteration processes in a relatively short period of time. The high level of cooperation from knowledgeable mining and exploration staff expedited the assimilation and compilation of this vast store of information. 
The objective of the research was therefore to reconstruct the depositional environment of the Ansil deposit, and establish controls on mineral deposition and associated rock alteration, thereby defining the hydrothermal evolution of the deposit.

\subsection{LOCATION}

The Ansil deposit is located approximately 14 km northwest of Rouyn-Noranda, Québec within Duprat township (Figure 1.1). It is approximately $450 \mathrm{~km}$ northwest of Montreal and $500 \mathrm{~km}$ north of Ottawa. The mine site is reached by travelling north from Noranda on Hwy. 101 for $8 \mathrm{~km}$, turning west (left) on to the Chemin des Mines, and turning left at the first road junction and travelling north for another $3 \mathrm{~km}$. At the present time the mine site is being rehabilitated, and it is a matter of time before the distinctive landmark of the headframe disappears.

\subsection{HISTORY}

The Ansil deposit was discovered in January 1981 by Falconbridge Copper Ltd. The drill program that led to the discovery was directed at discovering new zones of discordant alteration similar to that below the Decoeur-Garon (DG) occurrence. After a thorough drill testing of the DG showing and alteration zone a reconnaissance drill program was initiated north of this showing, and then proceeded south, with systematic drilling proceeding from west (shallow) to east (deeper) on $250 \mathrm{~m}$ centres (see surface drill location map, Appendix I). The stratigraphy was tested to the contact with the Flavrian Pluton. The discovery hole 
(An-63) intersected alteration in the stratigraphic hangingwall, and then $20 \mathrm{~m}$ of massive chalcopyrite-pyrrhotite along the rhyolite-andesite contact.

The decision to initiate the systematic drill program was based on: (1) the recognition that the mineralization at the D-G showing was synvolcanic and part of a discordant alteration zone, (2) that the deposits in the Noranda camp lay along synvolcanic fault systems, and were controlled by fault junctions, and (3) contrary to previously accepted models that Noranda deposits only occurred higher in the stratigraphy, massive sulfide formation could occur at any contact within the 3000 m thick Central Mine Sequence.

The discovery hole intersected over $20 \mathrm{~m}$ of $4 \% \mathrm{Cu}$ at a depth of $1300 \mathrm{~m}$. Thirteen holes later it was determined that the massive sulfide lens extended from 1185 to $1480 \mathrm{~m}$ below surface, and had a preproduction reserve of $1.58 \mathrm{mt}$ grading $7.2 \% \mathrm{Cu}, 0.9 \% \mathrm{Zn}, 26.5 \mathrm{~g} / \mathrm{t}$ $\mathrm{Ag}$ and $1.6 \mathrm{~g} / \mathrm{t} \mathrm{Au} \mathrm{(Salmon,} \mathrm{company} \mathrm{report} \mathrm{1991).} \mathrm{Surface} \mathrm{drilling} \mathrm{continued} \mathrm{to} \mathrm{delineate}$ mineralization until 1984, when a production decision was made. Production began in March, 1989 and continued until April, 1993 when mineable reserves were exhausted. The deposit included over 200,000 tonnes of semi-massive to massive magnetite.

\subsection{PREVIOUS WORK}

The first published description of the Ansil deposit was made by the exploration and mining staff (Riverin et al., 1990). A bachelor's thesis on the sulfide mineralogy was completed in 1990 by J. Kabamoto at Tohoku University, Japan. This was followed by a paper on the magnetite distribution, composition and associated mineral assemblages by 
Westendorp et al. (1991), and completion of Westendorp's masters thesis on the same topic in 1992. Barrett et al. (1992) completed a largely geochemical study which includes the only published isotopic data of the deposit to date. Galley et al. (1991) described the distribution of zinc zones within the deposit, and Galley and Watkinson (1994) briefly described the nature of the mineralization in relation to sub-seafloor formation of massive sulfide deposits. There are also three internal company reports on the deposit by Galley $(1989,1990,1991)$ and an internal report on the distribution of gold by Salmon (1992). Regional-scale description of the host strata, reconstruction of the original configuration of the Noranda Cauldron, and descriptions of deposit settings and synvolcanic hydrothermal alteration are given by Gibson (1989).

\subsection{METHODS}

This thesis is based on a series of 1:150 scale geological maps from 15 of the 16 production levels. The production areas were completely mapped on seven levels, and partly mapped on eight other levels, as well as on various sections of the ramps. Six of the complete sections accompany this study (Appendix I), and parts of the other maps are present throughout the text as page-sized figures. In areas of particular interest 1:50 scale mapping was carried out. In many cases the distribution of dykes within the map areas was verified from excellent 1:250 scale mapping carried out by the mine staff. The company maps were also used to check contacts that were obscured through sulfide oxidation, and 
coatings from diesel exhaust fumes. Much of the footwall and hangingwall stratigraphy was determined by logging diamond drill core from underground and surface drilling.

More than 300 samples were taken from underground and drill core, of which over 200 were slabbed and polished, and over 300 polished thin sections were made. Specimens referred to in this thesis all carry the prefix ANSL, followed by the level (or sublevel) number, and then a number denoting the sequence in which it was obtained. Numbering is continuous from 001 , so that if the $45^{\text {th }}$ specimen was obtained from level 8 , its sample number would be ANSL8-45. The exceptions are specimens taken by Dr. Ian Jonasson before this study was initiated. These are prefaced by ANSL and the level number, but usually end in a textural short form (i.e. $\mathrm{BX}=$ Breccia, $\mathrm{TF}=$ tuff). Specimen locations are shown on page-sized level plans in the appendix.

Whole rock chemical analyses were completed on 75 samples, and carry the same numbers as the hand samples from which they were taken. Analyses are listed in Appendix IV. A preliminary selection of samples was analyzed by the Analytical Section of the Mineral Resources Division, Geological Survey of Canada, Ottawa. Systematic analyses for major, trace and REE elements were purchased from Activation Laboratories Ltd. Descriptions of analytical methods are given in Appendix II.

Over 300 mineral analyses were completed using the SEM at Carleton University, Ottawa, and approximately 160 analyses were completed on the CAMECA electron microprobe at the Geological Survey of Canada, Ottawa. 
Details of sample preparation, analytical methods, precision and accuracy are given in Appendix II, sample locations in Appendix III, whole rock analyses in Appendix IV, and mineral analyses in Appendix $\mathrm{V}$.

In the following descriptive chapters the distribution of lithologies, alteration, mineralization and structure are referred to at the mine scale in reference to the mine levels. Figure 2 correlates the various levels and sublevels to: a) their depth below surface, and b) their mine elevation, which defines the surface as an altitude above sealevel (in metres), plus $5000 \mathrm{~m}$. For example, Sublevel 6A is referred to in mine space as the 4140 level, which is $860 \mathrm{~m}$ below sealevel.

\subsection{NOMENCLATURE}

The formations mentioned and described have been informally named by de RosenSpence (1976), Gibson (1989) and Paradis (1989). Member and sub-formation (i.e. the North Flow of the Northwest formation and names of sedimentary units are taken from Gibson (1989).

Extrusive volcanic rocks are subdivided from smallest to largest units by lava flow, member and formation. A lava flow is defined a single pulse of lava that cooled individually. A series of flows that are texturally similar may be referred to as a flow unit. Flows are further subdivided into facies, referring to a flow segment that differs from others texturally and/or morphologically. Nomenclature for various facies, such as flow 
lobes, or flow breccia, is taken from Fischer and Schmincke (1984), compatible with terms used by Gibson (1989) for his descriptions of the same formations 


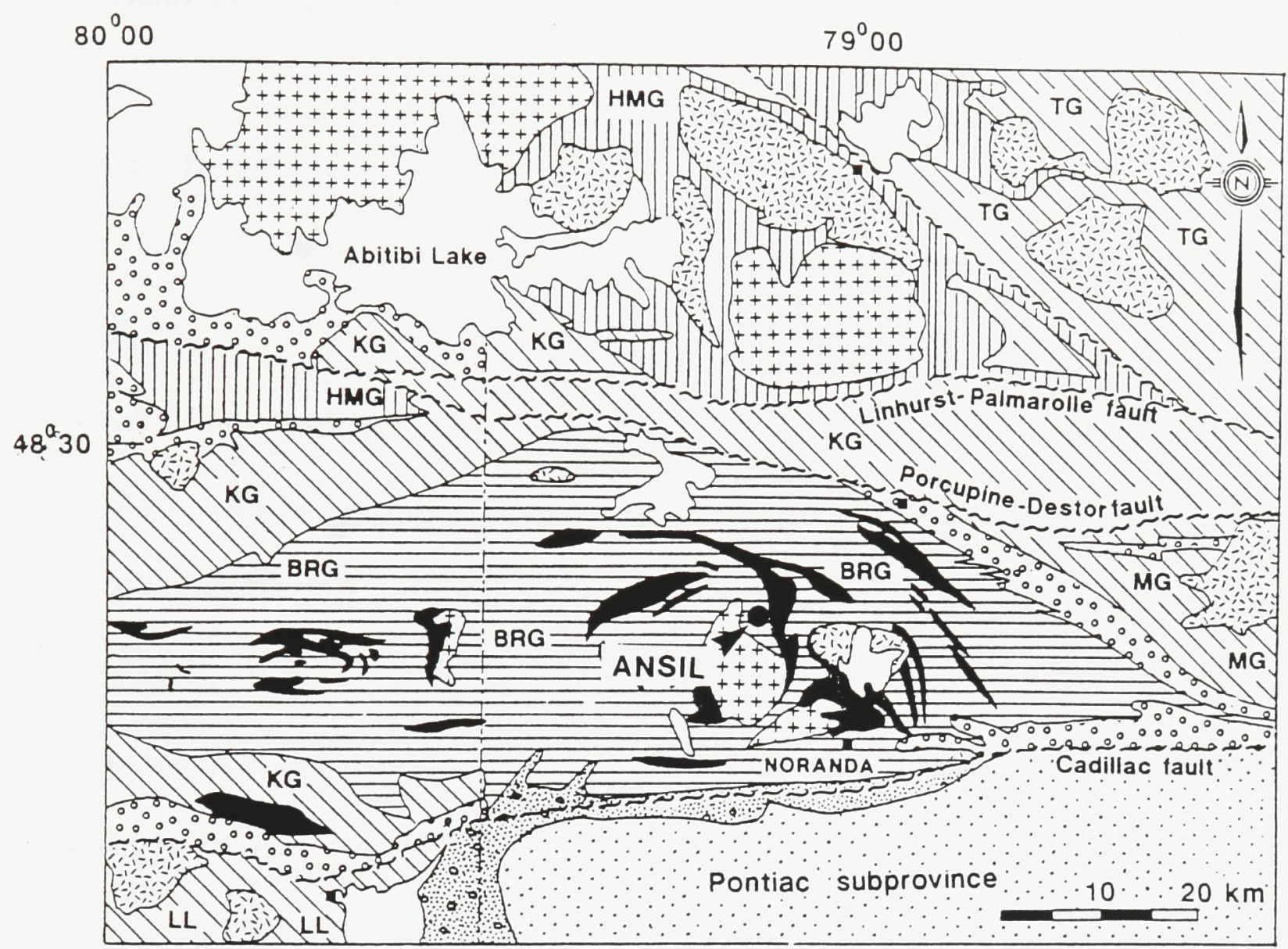

Volcanic rocks

\begin{tabular}{|c|c|c|}
\hline BRG- & Blake River Group & $\begin{array}{l}\text { Quartz-monzonite } \\
\text { Granodiorite }\end{array}$ \\
\hline$K G$ & Kinojevis Group & Tonalite and \\
\hline TG & Taschereau Group & $\#$ trondjhemite \\
\hline MG & Malartic Group & Sedimentary rocks \\
\hline QLL & Larder Lake Group & $\begin{array}{l}\because \because 0 \% \text { Archean } \\
\because \because 0 \text { metasediments }\end{array}$ \\
\hline HWG & $\begin{array}{l}\text { Hunter Mine Group } \\
\text { Rhyolitic rocks }\end{array}$ & $\begin{array}{l}\text { Post-Archean } \\
\text { sediments }\end{array}$ \\
\hline Symb & ols & \\
\hline$\sim \sim \sim$ & $\begin{array}{l}\text { Fault zone } \\
\text { Contact }\end{array}$ & \\
\hline
\end{tabular}

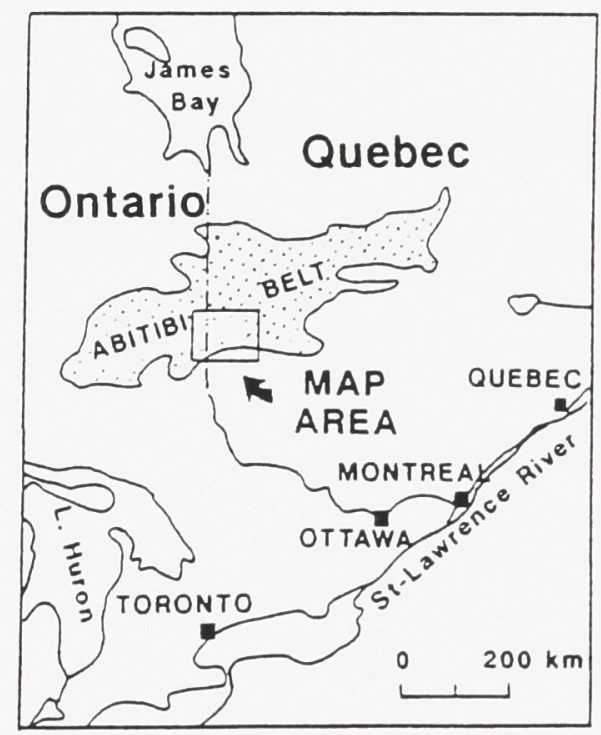

Figure 1.1 Simplified geological map of the southern Abitibi Belt (from Laflèche et al., 1992) 


\section{CHAPTER 2. GENERAL GEOLOGY}

\subsection{REGIONAL GEOLOGY}

The Ansil deposit is hosted by the Blake River Group of the Archean Abitibi subprovince (Figure 1.1). The $800 \mathrm{~km}$ long by $240 \mathrm{~km}$ wide domain is the largest Archean greenstone belt of the Superior Province (Card, 1990). It is bounded to the north by the Opatica plutonic-gneiss subprovince and to the west by the Kapuskasing Structural Zone (Percival, 1986), and to the south and east by the Pontiac subprovince and the Proterozoic Grenville Province. It is one of the most productive regions with respect to known VHMS deposits, with mined and geologic reserves of over 423 million tonnes with average grades of $2.1 \%$ $\mathrm{Cu}, 4.4 \% \mathrm{Zn}, 0.1 \% \mathrm{~Pb}, 1.3 \mathrm{~g} / \mathrm{t} \mathrm{Au}$ and $46 \mathrm{~g} / \mathrm{t} \mathrm{Ag}$ (Barrie et al., 1994). This is almost double the tonnage of the next largest VMS district in Canada (Bathurst-Newcastle at 250 million tonnes).

The Abitibi subprovince is divided into northern and southern zones (Dimroth et al., 1983), with the Noranda region within the latter. The southern Abitibi subprovince developed between 2750 and $2670 \mathrm{Ma}$, and is divided into four volcanic cycles in Ontario (Jensen, 1985) and two cycles in Quebec (Dimroth et al., 1983). Each of these cycles ranges in composition from komatiitic-tholeiitic through tholeiitic to calc-alkaline. Cycle I of Dimroth et al. (1983) consists of the 2730 to 2313 Ma (Mortensen, 1987) bimodal calcalkaline basalt-rhyolite rocks of the Hunter Group. Cycle II consists of the basal Roquemaure-Stoughton Group (komatiites) followed by tholeiitic rocks of the Kinojevis 
Group, and terminated in a transitional tholeiitic-calc alkaline sequence of the 2703 to 2698 Ma Blake River Group. The 19 to $24 \mathrm{~km}$ thick Cycle II was erupted between 2710 and 2700 Ma (Jensen, 1985, Mortensen, 1993)

The Cycle II volcanic rocks are unconformably overlain by the 2680 to $2670 \mathrm{Ma}$ Timiskaming Group (Corfu et al., 1991). The groups volcanic suite includes shoshonitic and trachytic extrusive and pyroclastic flows, and are associated with alluvial fluvial sedimentary strata, indicating a partly subaerial regime (Ujike, 1991, Ojakangas, 1985).

The Cycle II volcanic rocks are intruded by two suites of granitoid rocks, with synvolcanic intrusions including the Flavrian Pluton, Powell Stock and the Clericy Sill (Rive et al., 1990). The second suite of syn- to late-tectonic intrusions includes the D'Alembert and Lac Dufault granodiorites, and the Clericy, Nora, Aldermac and Tarsc syenites.

Some of the first tectonic models postulated to explain the volcanism of the southern Abitibi belt envisioned a succession of overlapping volcanic edifices formed from crustal rifting above a stationary hotspot (Goodwin, 1982; Gelinas, 1983). Dimroth et al. (1983), Ludden and Hubert (1986), Hodgson et al.(1990), Fyon and Jackson (1991) and Desrochers et al. (1993) all evoked modern tectonic concepts to explain the development of the belt. This included environments ranging from rifted island arc to immature back-arc. Corfu (1994) has postulated that the arrangement of arc volcanic suites with komatiitic and tholeiitic bimodal suites is consistent with the development of paired active arc and back arc systems, but Jackson and Fyon (1991) envision tectonically juxtaposed oceanfloor-arc regimes, and Desrochers et al. (1993) evoke an model of an extension-related calc-alkaline 
series overlain by deformed, accreted oceanic plateau. Trace element data from Barrie et al (1994) are compatible with evolution from thickened oceanic rift suites to rifted island arcs.

\subsubsection{Blake River Group}

The Blake River Group is the youngest volcanic suite of the Cycle II volcanics, and is located between the Larder Lake-Cadillac Fault Zone to the south, and the PorcupineDestor Fault Zone to the North (Figure 1.1). It was interpreted by Goodwin (1979) and Dimroth et al. (1983) as a series of central volcanic complexes whose centres are marked by concentrations of felsic volcanic rocks, erratic variation in unit thicknesses, and rapid facies changes. These authors believed that these volcanic centres developed sequentially from west to east, with increasing rhyolite proportion due to increased interaction between primitive basaltic magma and the overlying crust.

The most recent studies of the Blake River Group divide it into three subgroups (Péloquin et al., 1994). The Noranda subgroup forms the main central volcanic complex (Noranda Volcanic Complex) and consists of a bimodal andesite-rhyolite sequence. It is bordered to the south by tholeiitic basalt and andesite of the Garrison-Bowman subgroup, and to the west by andesite and minor rhyolite of the Misema Group. Rhyolite formations of similar composition occur in all three subgroups suggesting their contemporaneous extrusion. The variation in composition from Fe-enriched, LREE-poor tholeiites of the Garrison-Bowman subgroup to the mixed tholeiite-calc-alkaline (Fe-poor LREE-enriched) 
suites of the other two groups indicates change from mantle-derived magmatism along the margins of an extensional zone to magma differentiation and mixing in the core of the zone

\subsubsection{The Noranda Volcanic Complex}

The Noranda Volcanic Complex (NVC) (Spence, 1967; de Rosen-Spence, 1976; Dimroth et al., 1983; Gelinas et al., 1983) is the best documented of these volcanic centres. The NVC is a large, subaqueous shield volcano that was originally up to $50 \mathrm{~km}$ in diameter and is up to $14 \mathrm{~km}$ thick (Gibson, 1989, Péloquin et al., 1990). It now has a diameter of 35 $\mathrm{km}$ and consists of transitional tholeitic-calc alkaline rhyolite, basaltic andesite and basalt flows, with minor dacite and pyroclastic units (Gibson, 1989, Paradis, 1990) (Figure 2.1). The NVC was originally divided by Spence (1967) into 5 zones defined by the repeated occurrence of rhyolite. Gibson (1989) modified this division to define 5 cycles of volcanism, each cycle containing an andesite basal unit and a mixed rhyolite-andesite upper unit (Table 2.1). These cycles erupted between 2703 and $2698 \mathrm{Ma}$ (Mortensen, 1993), depositing up to $9000 \mathrm{~m}$ of volcanic rock in less than 5 million years. Cycles 1 and 2 are considered to have formed an early, pre-cauldron part of the Noranda shield volcano (Figure 2.2). Cycle 3 formed during two periods of cauldron subsidence, and Cycle 4 during a terminal phase of subsidence and volcanism, with the extrusive formations spilling out over the rim of the larger structure. Cycle 5 has a similar age to Cycle 2, and may be a tectonic repetition of the pre-cauldron cycle (Mortensen, 1987; Gibson, 1989). 
Cycle 3 (informally named the Central Mine Sequence) is a $3000 \mathrm{~m}$ thick bimodal sequence of basalt/andesite-rhyolite that hosts 17 massive sulfide deposits, including Ansil, and is interpreted to have erupted during a period of cauldron subsidence during the formation of the upper-central part of the NVC (Gibson et al., 1984). An area of subsidence was first recognized by Spence (1976) and is limited by the Hunter Creek and Cranston faults to the north, and the Quemont and Horne Creek faults to the south. The structure was first referred to as a caldera by Lichtblau and Dimroth (1980), Dimroth et al. (1982) and Gibson et al. (1984, 1986). Gibson (1989) modified the classification to a cauldron, which more appropriately reflects the uncertain form of the subsidence structure.

The Noranda Cauldron is an asymmetric structure with a north-south and east-west widths of $15 \mathrm{~km}$ and $20 \mathrm{~km}$ respectively (Gibson, 1989). Stratigraphic reconstruction indicates a minimum of $500 \mathrm{~m}$ of subsidence along the northern margin and a minimum of $1200 \mathrm{~m}$ along the southern margin. The structure contains two smaller depressions, the Despina and Delbridge cauldrons, each 2 to $5 \mathrm{~km}$ in diameter (Figure 2.2).

Initial subsidence commenced with the extrusion of the Flavrian formation and ended with the emplacement of the Amulet formation (Table 2.2; Figure 2.2). The andesites were dominantly fissure-fed and widespread, as revealed by facies changes (Cousineau and Dimroth, 1982; Gibson, 1989; Paradis, 1990). The rhyolites formed more restricted, low relief ridges above their feeder systems (Lichtblau and Dimroth, 1980; Gibson, 1989; Paradis, 1990). Subsequent subsidence took place along the south margin of the cauldron during emplacement of the Cycle 4 volcanic formations. 
The cauldron is centred over the Flavrian Pluton, a subvolcanic intrusive complex ranging in composition from quartz diorite to tonalite (Goldie, 1976; Kennedy, 1984). Comparison of compositions from the intrusive complex with the overlying Central Mine Sequence shows them to be cogenetic (Goldie, 1976; Paradis et al.,1983). The formation of the cauldron therefore took place as a result of the partial evacuation of the Flavrian magma chambers

The Noranda cauldron is cross-cut by intrusions other than the Flavrian Pluton (Figure 2.1). Several volcanic feeder dyke systems were recognized by Gibson (1989), including the felsic McDougall-Despina dykes and the andesitic Old Waite dyke swarm. These feeder dyke systems are believed to have fed flows on the seafloor along synvolcanic faults and fissures created during the formation of the cauldron. These subvolcanic fault systems and associated dykes are important foci for the upwelling segments of hydrothermal systems responsible for the generation of massive sulfide deposits (Gibson, 1989). The Central Mine Sequence is also crosscut by a series of thick, early syn-tectonic diorite sills and dykes (Figure 2.1).

\subsubsection{Distribution of Massive Sulfide Deposits}

Most massive sulfide deposits within the Blake River Group are hosted within the Noranda Volcanic Complex (Figures 2.1, 2.2, 2.3). Of these, 17 out of 26 occur within the Cycle 3 (Central Mine Sequence) syn-cauldron volcanic strata (Gibson and Watkinson, 1990; Kerr and Gibson, 1993). Three non-economic deposits within the pre-cauldron 
Cycles 1 and 2 consist of discordant, Cu-rich stockwork vein systems (4-Corners and Inmount) and a stratabound Zn-rich sulfide lens (Ivanex). Kerr and Gibson (1993) postulate that the Horne deposit ( $>150$ million tonnes) may be hosted by pre-cauldron strata, but the lack of age data makes this uncertain (Figure 2.2).

The 17 deposits and 8 small massive sulfide lenses within Cycle 3 are defined as intercauldron deposits (Kerr and Gibson, 1993). The Corbet and Ansil deposits occur within the first cauldron cycle. Millenbach-D68, Amulet, Old Waite, East Waite and Norbec deposits formed during onset of the second cauldron cycle. The limited size of these deposits ( $<5$ million tonnes) is due to their formation during periods of active volcanism. The 16 million tonne Quemont deposit formed near the edge of the cauldron; intercauldron volcanic activity did not dilute the sulfide accumulation. The intercauldron deposits are proximal VHMS, with a $\mathrm{Cu}-\mathrm{Zn}$, or $\mathrm{Zn}-\mathrm{Cu}$, stratabound, massive sulfide lens overlying a $\mathrm{Cu}$ rich, discordant stockwork vein system that may originate hundreds of metres down section (Gibson and Watkinson, 1990). Several of the deposits comprise a number of massive sulfide lenses; Millenbach has 14 lenses, many of which are vertically stacked within the same stockwork vein system (Knuckey et al., 1982). Many of the deposits are spatially associated with areally extensive, thin units of mixed chemical sedimentary rock and finegrained tuff (Comba, 1975; Knuckey and Watkins, 1982). These "tuffite" units are traditionally thought to represent the distal equivalents of the proximal massive sulfide lenses (Franklin et al., 1981; Kalogeropoulos and Scott, 1989). 
The Cycle 4 massive sulfide deposits developed during the formation of the Despina cauldron along the south margin of the Noranda Cauldron (Figure 2.2). These deposits differ from those within Cycle 3 in that they are quite $\mathrm{Zn}$-rich and $\mathrm{Cu}$-poor. The Mobrun deposit is within the Cycle 5 volcanics, which may be a tectonically duplicated segment of Cycle 2 (Gibson and Watkinson, 1990).

\subsubsection{Alteration of the Central Mine Sequence}

Parts of the Central Mine Sequence and associated intrusive rocks are affected by discordant and semi-conformable zones of synvolcanic, hydrothermal alteration. Zones of discordant chlorite, and minor sericite, alteration are associated with the discordant stockwork vein systems that underlie most of the intracauldron VHMS deposits. These alteration zones are usually less than $200 \mathrm{~m}$ in diameter, and may be traced hundreds of metres down section. The deposition of the sulfide veins and related alteration is a product of interaction between hot hydrothermal fluid and wallrock. These zones represent sites of focused hydrothermal upflow. The focused discharge of these fluids at the seafloor resulted in the precipitation of sulfides and associated gangue minerals to form the massive sulfide lenses.

The most extensive alteration within the cauldron is spilitization (Na-metasomatism) of almost all contained strata. Spilitization is a product of regional-scale, hydrothermal activity directly overlying the subvolcanic Flavrian intrusive complex (Cathles, 1993). This relatively high temperature alteration event $\left(>150^{\circ} \mathrm{C}\right.$ and $\left.<250^{\circ} \mathrm{C}\right)$ is overprinted by the discordant 
alteration zones and other types of semi-conformable alteration (Gibson, 1989). These include more volumetrically restricted zones of silicification and quartz-epidote alteration (Gibson, 1979; Gibson et al., 1983; Lesher et al., 1986; Gibson, 1989) (Figure 2.3). Zones of silicification within the Amulet andesite resulted in their preliminary identification as rhyolite (de Rosen-Spence, 1976). Detailed mapping and geochemistry demonstrated that these zones selectively replaced the most permeable parts of the andesite flows, with the most intense silicification localized within hydrothermal breccias (Gibson et al., 1983).

Epidote-quartz alteration also preferentially replaced the mafic rocks within the cauldron. It is most intense about the andesite dykes of the Old Waite dyke swarm, and invaded the andesite flows cross-cut by the dykes. Epidote-quartz-carbonate-magnetite alteration is pervasive to fracture-controlled within tonalitic phases of the underlying Flavrian intrusive complex (Kennedy, 1984).

The Flavrian intrusive complex is also host to zones of phyllic and argillic alteration associated with porphyry-type $\mathrm{Au}(\mathrm{Cu}-\mathrm{Mo})$ mineralization (Goldie, 1975, Pelletier and Jébrak, 1994) and syn-tectonic, shear-hosted Au mineralization (Kennedy, 1984).

\subsection{STRUCTURE AND METAMORPHISM}

Much of the deformation affecting the southern Abitibi Belt took place during the Kenoran Orogeny (approximately $2680 \mathrm{Ma}$ ). This comprised four deformational phases, beginning with the formation of originally north-northwest trending closed, upright, parallel, flexural folds, followed by east-west trending open, asymmetric flexural folds, which re- 
oriented the first phase structures (Trudel, 1978, Hubert et al., 1984). The third and fourth events involved brittle-ductile deformation and re-orientation of earlier structures along discrete, high strain corridors (Laflèche, 1989) (Figure 2.4)

The Noranda Volcanic Complex is an homoclinal sequence striking northwest to northeast. The variation in strike was first believed to be due to the presence of east trending folds (de Rosen-Spence, 1976; Hubert et al., 1984). Dimroth et al. (1983) and Gibson (1989) believe the variation in strike is due to rotation along numerous eastnortheast striking faults, and that the volcanic sequence was shielded from internal folding by the bounding Flavrian and Lac Dufault plutons (Figure 2.1). Most of the major faults within the volcanic complex are northeast and northwest trending. Gibson (1989) stated that many of these structures represent the reactivation of synvolcanic lineaments along which there was injection of synvolcanic feeder dykes; their distribution apparently controls the position of many of the massive sulfide deposits. Two block-bounding faults, the Hunter Creek and Horne Creek, are postulated to represent cauldron boundaries (Gibson, 1989).

There is some circumstantial evidence for bedding-parallel reverse faulting within the central volcanic complex. Similar U-Pb derived ages for both the Cycle 2 and 5 volcanic formations would suggest tectonic repetition (Gibson and Watkinson, 1990). Within Cycles 2 to 4 the margins of diorite sills are commonly faulted, with concomitant displacement of strata (Paradis, 1990)

The formations of the Noranda Volcanic Complex are affected by regional and contact metamorphism. Regional metamorphism did not exceed greenschist facies within the 
cauldron sequence with lower grade prehnite-pumpellyite facies assemblages observed locally north of the Hunter Creek Fault (Jolly, 1980). Contact metamorphic aureoles with amphibolite facies assemblages occur about the Lac Dufault Pluton and about the granodiorite phase in the core of the Flavrian Pluton (Kennedy, 1984; Gélinas et al., 1984).

\subsubsection{Structure and metamorphism of the Ansil area}

In order to deduce the pre-deformational history of the Ansil deposit it is essential to understand the degree to which it has been affected by deformation and metamorphism

\section{Metamorphism}

The Ansil area is affected by lower greenschist facies regional metamorphism that is typified by a chlorite-actinolite-albite-epidote-quartz-titanite/leucoxene mineral assemblage in the mafic to intermediate volcanic strata, and quartz-albite-chlorite-sericite-titanite assemblage within the felsic rocks. Within $50 \mathrm{~m}$ of the upper contact of the Flavrian intrusive complex the Flavrian andesite is overprinted by biotite-rich, lower amphibolite facies contact metamorphism which predates regional metamorphism.

Metasomatism related to this low grade regional metamorphic event appears to be limited to the millimetre-scale required for the generation of metamorphic minerals from synvolcanic precursors. The metamorphic mineral assemblages are similar to those formed during the regional spilitization event, and have about the same temperatures of formation as the hydrothermal mineral assemblages observed within the discordant alteration zones 
Zones of metasomatism are spatially associated with brittle fractures and veins, and brittle-ductile shears and shear veins that transect the Ansil deposit and associated mineralization and alteration. These discrete deformation zones commonly have halos of quartz-carbonate-sericite that overprint the synvolcanic hydrothermal alteration mineral assemblages (Figure 2.6f). These halos are commonly centimetres in width, but within zones of intense fracturing and veining may overprint a considerable part of the host rock.

\section{Structure}

The volcanic strata in the Ansil area strike north and dip $40^{\circ}$ to $50^{\circ}$ to the east. The strata are transected by two regional faults, the northwest-trending D-G Fault and the eastnortheast-trending Snoop Fault (Figure 2.7). The Snoop Fault has as much as $150 \mathrm{~m}$ of subvertical, normal displacement, downdropping the strata to the north of the deposit.

The principal deformational features affecting the deposit and its host strata are a series of fractures and shears that transect all of the supracrustal and intrusive rocks. The sequence of deformation at the Ansil deposit ranged from brittle through brittle-ductile to brittle, and includes the injection of dykes along brittle fractures, followed by formation of brittle-ductile shears and inhomogeneous deformation of the massive sulfide lens and altered footwall, and ending with the generation of brittle fracture sets.

The latest intrusive phase within the Ansil stratigraphic succession comprises a set of feldspar porphyritic mafic dykes. In the vicinity of the Ansil deposit they most commonly form in the rhyolite footwall below the north and south flanks of the deposit, increasing in 
abundance upsection towards the upper rhyolite contact. They also occur sporadically in the hangingwall mafic flow sequence. The thickest dykes strike north-northeast parallel to bedding in both the immediate footwall and hangingwall to the massive sulfide lens (Figure 2.8). These are accompanied by a conjugate set of smaller dykes that transect the massive sulfide lens and earlier formed felsic and mafic dykes. The dykes have sharp boundaries with the surrounding volcanic rocks, with sharp jogs along their strike length that appear to be a primary feature of the original fracturing (Figure 2.6b). The regularity of the dyke array suggests emplacement within a differential stress field in which the direction of maximum stress was perpendicular to primary layering. If the dykes were injected before tilting of the strata the brittle fracturing of the rocks was most likely caused through vertical dyke propagation and associated sill formation near contacts. Where the dykes transect the massive sulfide lens they are folded and boudinaged, indicating intrusion before the regional folding event (Figure 2.6c).

Dyke emplacement was followed by a compressional event that most likely coincided with the tilting of the volcanic strata into their present orientation. The tilting of the strata was accompanied by the deformation of the orebody and the formation of a series of shears; they form a conjugate set, with the principal shears subparallel to stratigraphic layering (striking north-northeast) and a second set striking northwest. Orientations other than these two sets are commonly due to shear formation along dykes contacts. The shears are commonly 10 to $20 \mathrm{~cm}$ wide, occasionally attaining $1 \mathrm{~m}$ (Figure $2.6 \mathrm{~d}$ ). In places they coalesce to form zones up to several metres wide. They are composed of chlorite, Fe- 
carbonate and quartz, with much of the quartz present as vein-filling. Graphite is common, but not ubiquitous, forming sheets along shear planes. Shear-hosted chalcopyrite-quartz veins are common along strike of the north and south flanks of the massive sulfide lens, with the quartz present as durchbewegung (tectonic clasts) within a sulfide matrix (Figure 2.6e).

Shearing is most intense along the margins of the massive sulfide lens and within the chlorite-altered footwall strata. Along the margins of the massive sulfide lens there are 1 to $2 \mathrm{~m}$ wide shear zones consisting of a series of thin, anastomosing shears along which there is centimetre-scale displacement of the ore lens, and remobilization of chalcopyrite(pyrrhotite) along the shear planes. One of the best exposed cross-sections of the contact shear is in the 7-01 drift at the entrance to Ramp 7-8 (Figure 2.6e). The shear zone is approximately $50 \mathrm{~cm}$ above the rhyolite-andesite contact. It is wedge-shaped, broadening down-dip to just over $1 \mathrm{~m}$ wide. The shear consists of a series of chlorite-carbonate-rich domains bordered by anastomosing shear planes defined by thin quartz-carbonate veins and a schistosity defined by the preferred orientation of chlorite ( $\mathrm{C}$-fabric). Within the domains there is a strong, asymmetric chlorite schistosity oblique to the bordering shear planes, and curving into the shear planes at their intersections. This S-fabric defines a consistent Z asymmetry indicating a component of reverse movement during shear formation.

Towards the centre of the massive sulfide lens, contact shearing is usually restricted to a single, less than $20 \mathrm{~cm}$ wide shear along the sulfide hangingwall contact, which disappears as the massive sulfide lens thickens to over 3 to $5 \mathrm{~m}$. The hangingwall contact above the thickest sections of massive sulfide is commonly undeformed, with little or no evidence of 
shearing. Under the thickest (central) part of the ore lens shearing is restricted to the altered footwall. There is commonly a thin, discontinuous zone of shearing along the base of the sulfide lens that is more prominent towards its flanks. An occasional shear is observed branching off this structure into the massive chalcopyrite-pyrrhotite body. The most common shear orientation within the altered footwall is northwest $\left(330^{\circ}\right.$ to $\left.340^{\circ}\right)$, dipping subvertically. These shear zones range in size from several centimetres to several metres thick. Within them the hydrothermal stockwork sulfide veins are re-oriented into planar veins that parallel the strike of the shear zone (Figure 2.9a). Chlorite flakes are commonly oriented in two directions; one is shear parallel and the other at an acute angle to the shear plane.

The orebody displays varying degrees of deformation. Within the thick, massive sections there is commonly a distinct tectonic banding, with contact-parallel, irregular wisps and bands of pyrrhotite within chalcopyrite (Figure 2.6a). These bands tend to increase in frequency and decrease in thickness towards the hangingwall contact. Parts of the orebody also display well-formed, steeply plunging sulfide-quartz slickensides. Finely layered parts of the orebody are commonly folded, with the folds displaying a consistent $\mathrm{Z}$ asymmetry and subhorizontal fold axes indicating reverse movement along the contact shear (Figure $2.9 b)$. Sulfide is commonly remobilized into AC fractures within the fold structures. The fragmental sulfide ores along the base of the orebody are strongly deformed where they are transected by discrete shears (Figure $2.9 \mathrm{c}$ ). 
The massive sulfide lens is most intensely deformed where in contact with massive magnetite. The orebody contains abundant chalcopyrite-pyrrhotite tectonic banding and is remobilized into shears along the hangingwall contact, and into brittle fractures within the massive magnetite.

Associated with the rhyolite-andesite contact shear is a conjugate set of carbonate-rich veins and fractures that are subperpendicular to the shear plane. Where the veins intersect the shear zone they are bent into the plane, indicating formation before, or during, shearing (Figure $2.6 \mathrm{c} \& \mathrm{~d}$ ). Veining is restricted within the hangingwall andesite to within $10 \mathrm{~m}$ of the lithologic contact, but vein sets may extend for over $60 \mathrm{~m}$ in the footwall rhyolite. The intersection line of the vein sets is subhorizontal, which indicates that they formed in a stress field in which the principal stress axis $(\sigma 1)$ was subhorizontal. This is further evidence that a large component of the movement along the contact shear was dip-slip.

Most of the strain imposed on the strata was irrotational, involving a large component of compression rather than shearing. There is no evidence for displacement along any of the footwall shear zones, and movement along the hangingwall contact shear is probably on the order of metres. The variation in the degree of deformation along the hangingwall contact is due to the varying thickness of the massive sulfide lens. The strain ratio (degree of strain/width of deformation zone) would have been much greater along the thinner parts of the orebody, resulting in intense deformation. The thicker parts of the massive sulfide lens would tend to distribute the same degree of strain over a larger volume, thereby decreasing the amount of deformation. 
In conclusion, the Ansil deposit underwent a moderate degree of ductile deformation in which much of the massive sulfide lens was affected through the development of a contact parallel tectonic banding and descrete shears. The schistosity developed within the hangingwall contact and footwall shear zones as a function of compression rather than shearing, although the presence of C-S fabrics within the rhyolite-andesite contact shear indicates some degree of shearing. Deformation of the orebody is least intense where it is thickest, with primary textures and structures preserved throughout the ore lens. In thinner parts of the sulfide lens primary features are preserved in isolated zones of less strain. 


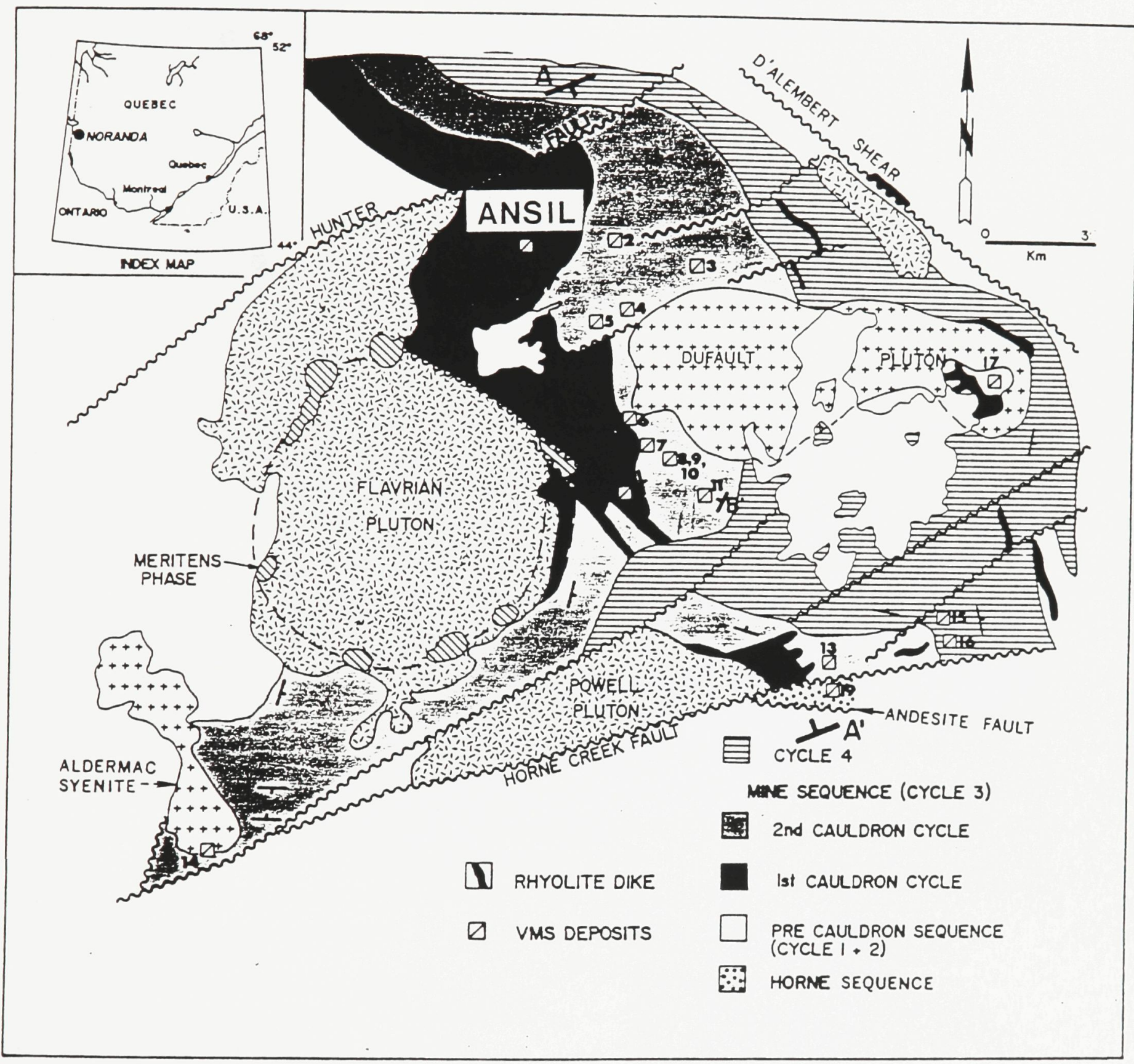

Figure 2.1 Simplified geology of the Noranda Volcanic Complex and associated intrusions, withi locations of massive sulphide deposits included ( deposit numbers correspond to names in Table 2.3) (modified from Kerr and Gibson, 1993). 


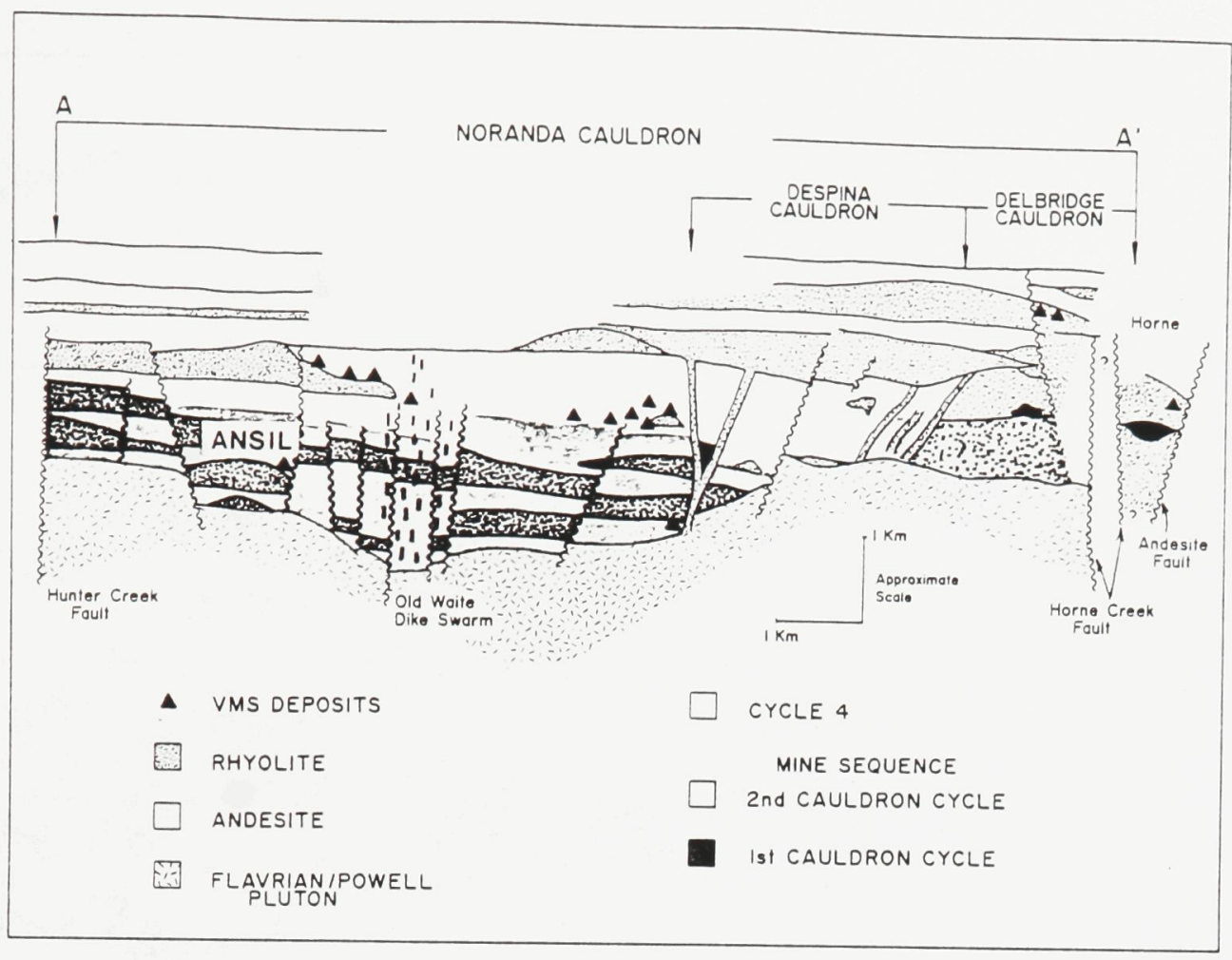

Figure 2.2 North-south structural cross-section through the reconstructed Noranda Cauldron and Horne block showing relationship between eruption cylces, cauldron formation, and massive sulphide deposits (Kerr and Gibson, 1993).
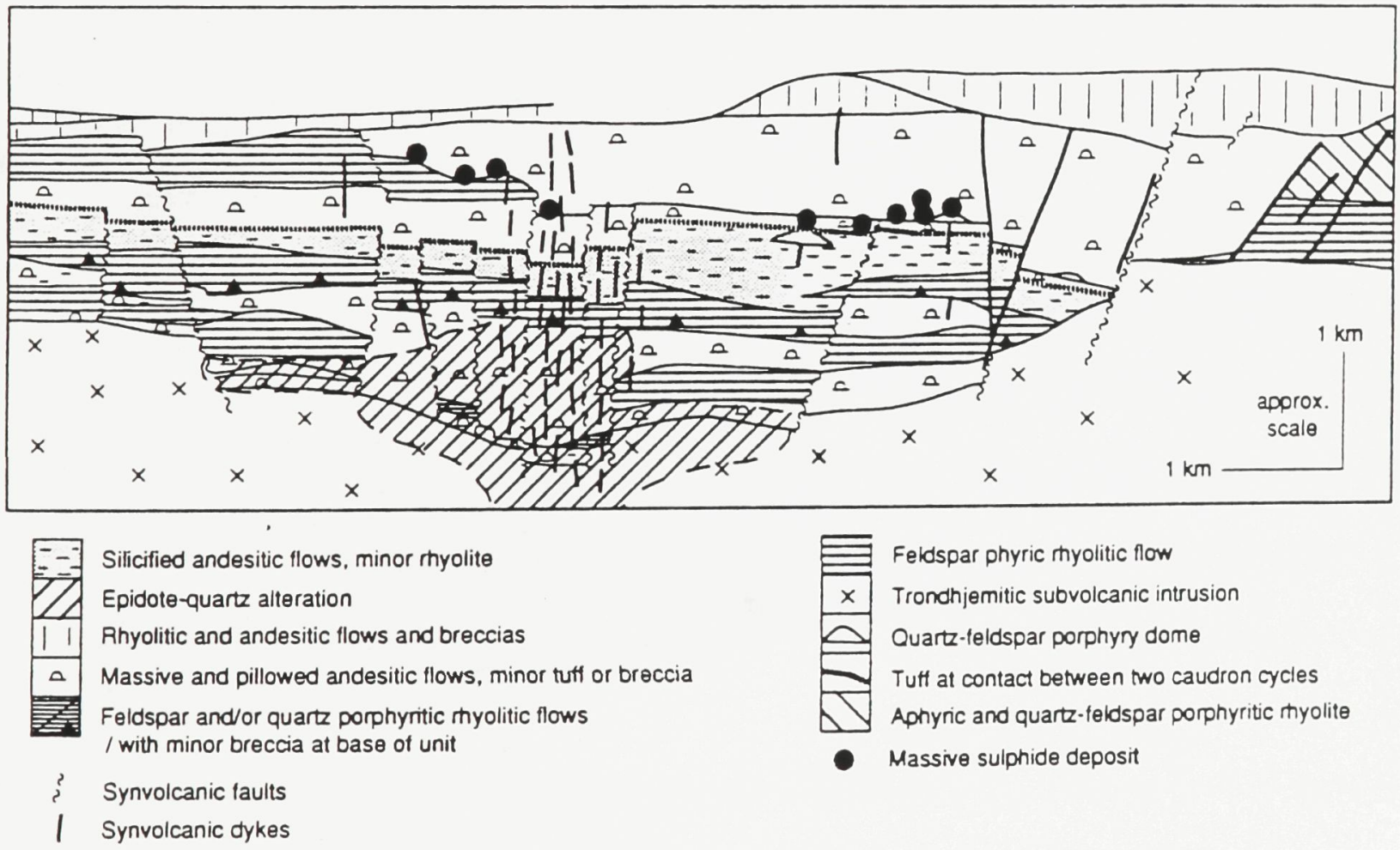

Figure 2.3 Distribution of silicification and quartz-epidote alteration within the Noranda Cauldron (Galley, 1993). 


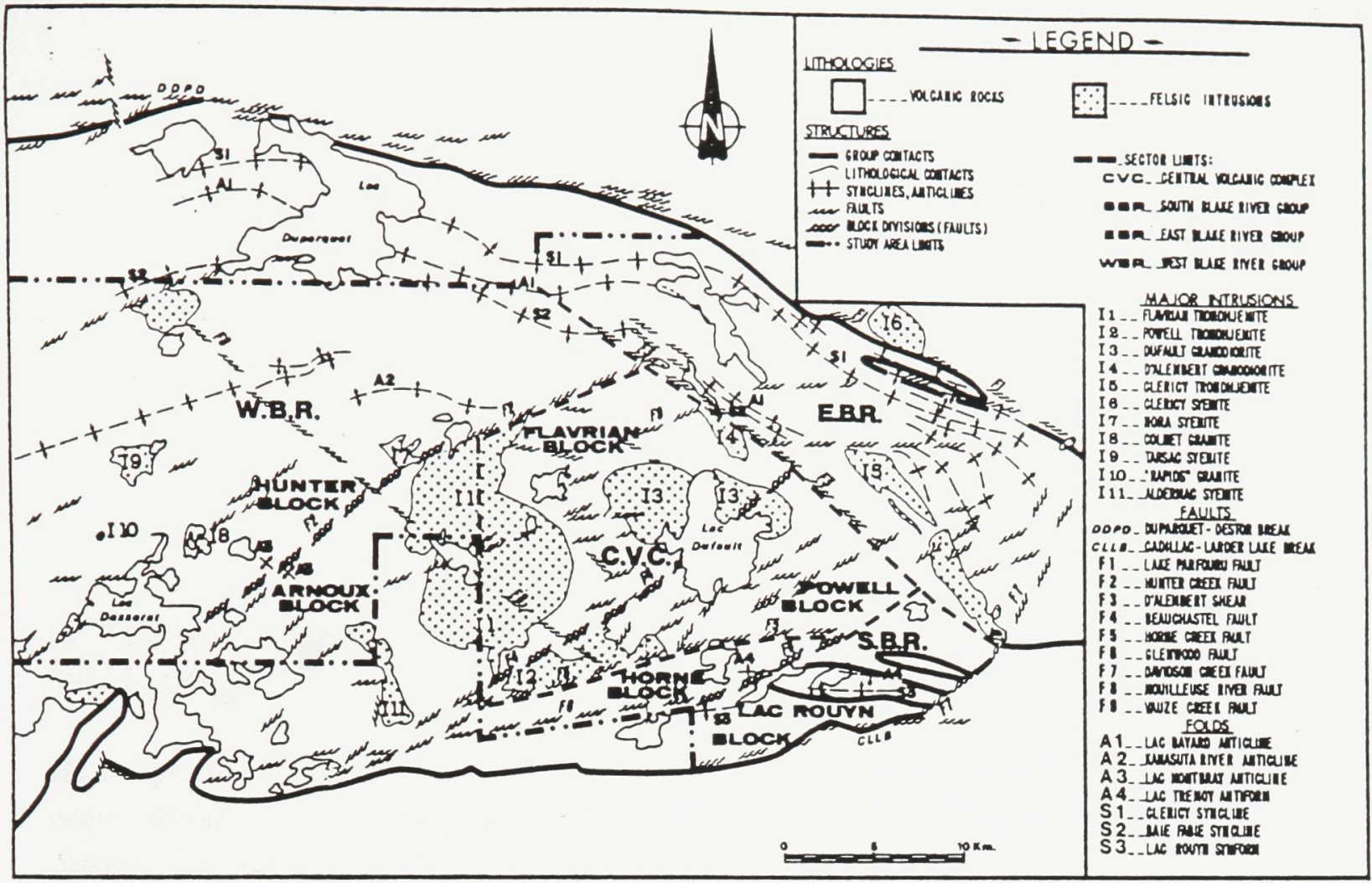

Figure 2.4 Structural blocks, major structures and intrusions of the Blake River Group (modified from Péloquin et al., 1990).

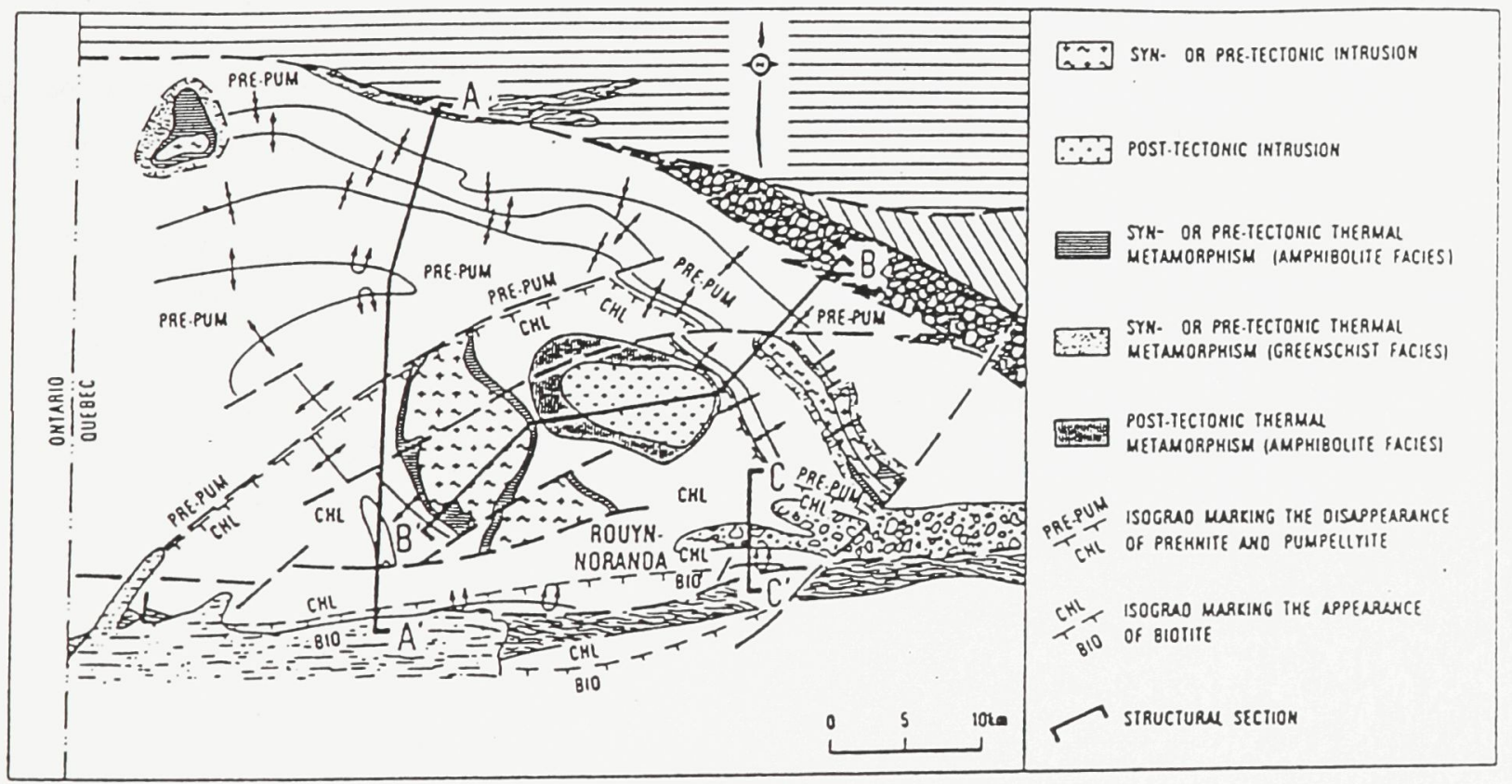

Figure 2.5 Distribution of regional metamorphic isograds and contact metamorphic aureoles (after Dimroth et al., 1982). 


\section{Figure 2.6}

A. Tectonic banding in massive chalcopyrite-pyrrhotite (Sublevel 6a). Centimetre card for scale.

B. Large chalcopyrite-quartz vein within the rhyolite-andesite contact shear approximately $12 \mathrm{~m}$ along strike of the south end of the massive sulphide lens. Metal plate $15 \mathrm{~cm}$ across for scale.

C. Shear zone at the contact between the Rusty Ridge formation (top left) and the Northwest formation. These formations are the stratigraphic hangingwall and footwall respectively of the Ansil orebody. Note carbonate-quartz-filled fractures bending into the plane of the shear zone. Centimetre scale card for scale.

D. Folded and boudinaged feldspar porphyritic mafic dykes transecting the massive sulphide lens. Metal plate $15 \mathrm{~cm}$ across for scale.

E. Feldspar porphyritic syn-tectonic dyke with sharp boundaries characterized by sharp offsets believed to be a feature of the original fracturing of the rhyolite during dyke injection.

F. Carbonate-rich alteration halos about syn-tectonic fractures related to shear zone along the main rhyolite-andesite contact $25 \mathrm{~m}$ south along strike of the massive sulphide lens (Drift 7-01). 

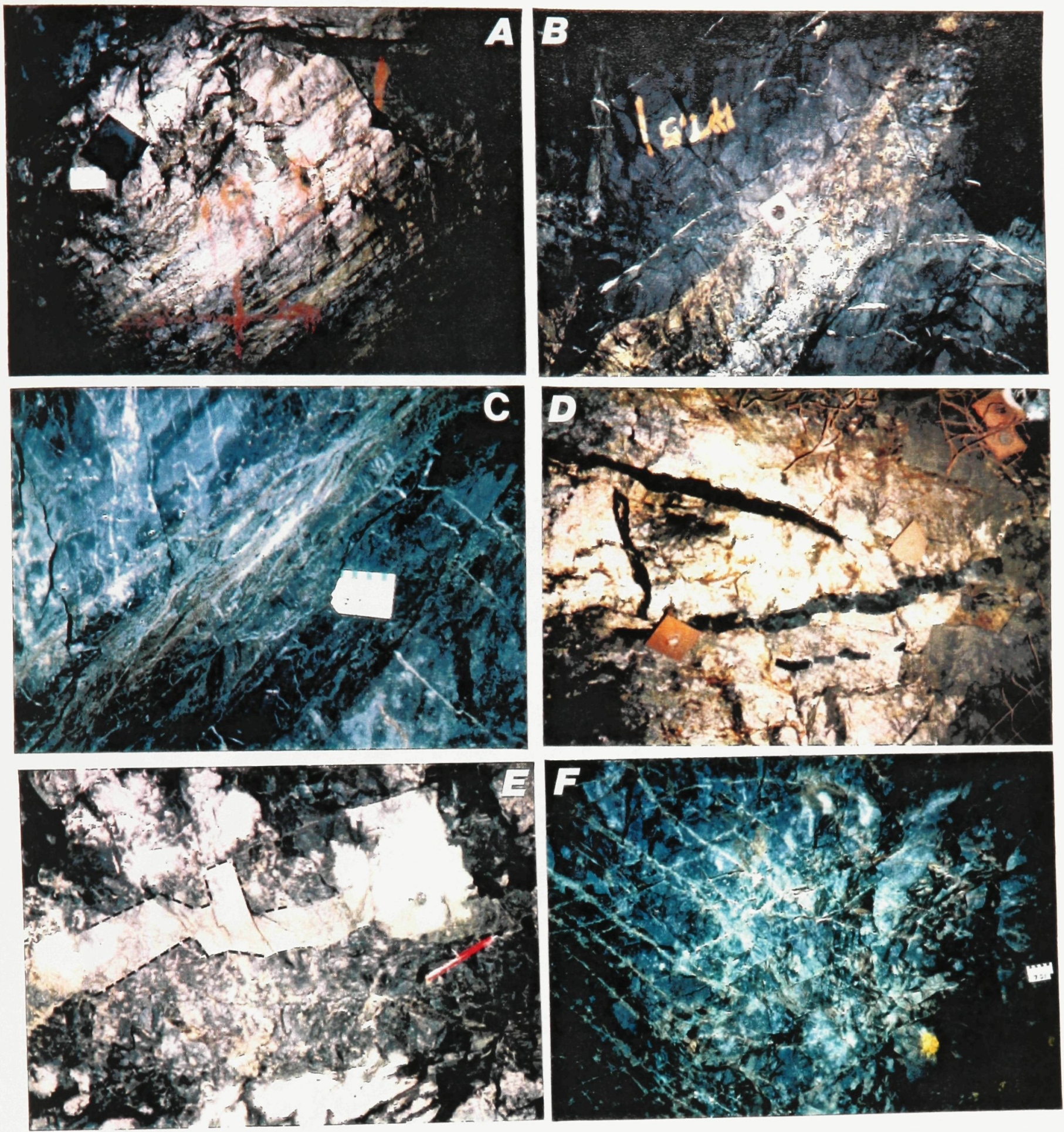


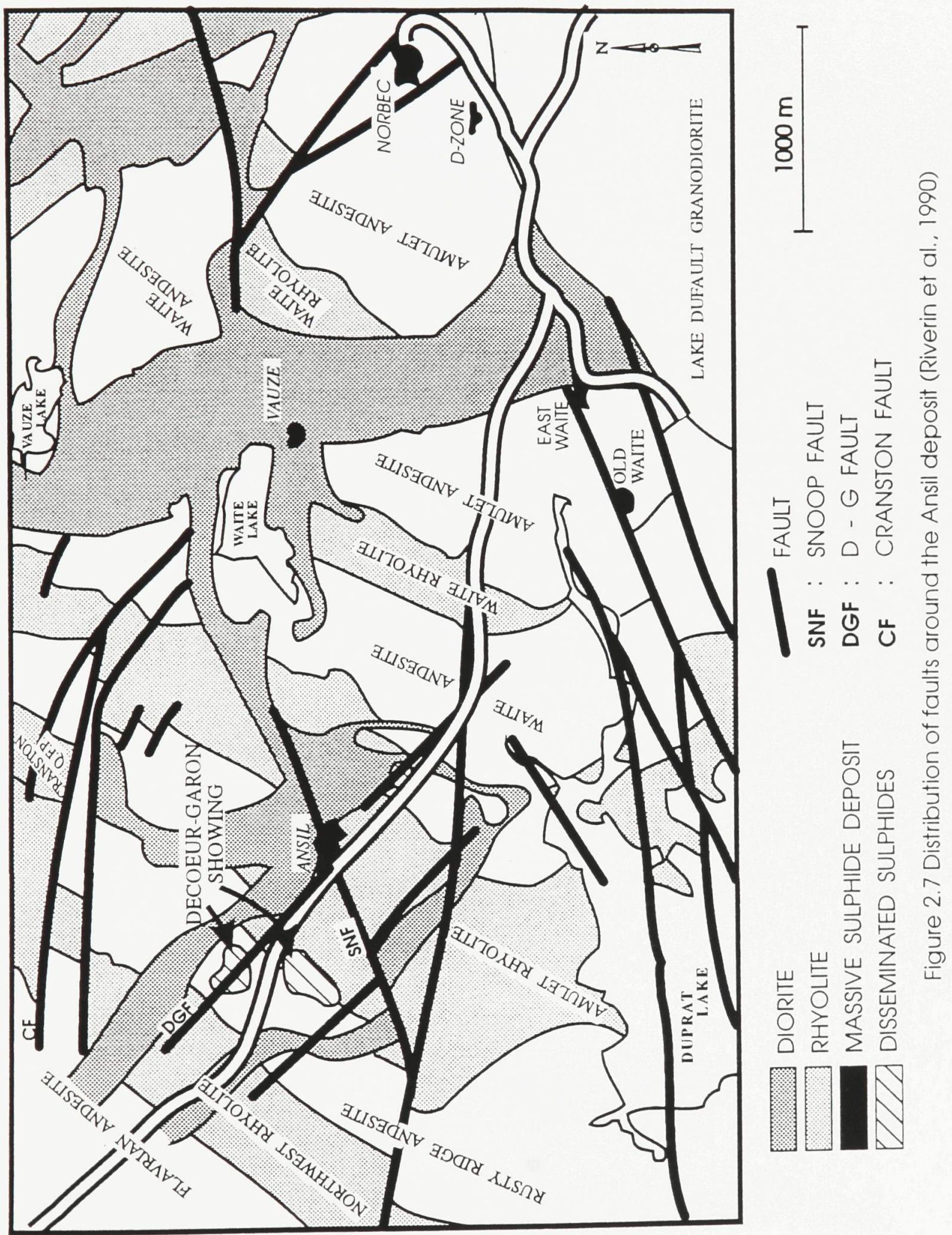


A.

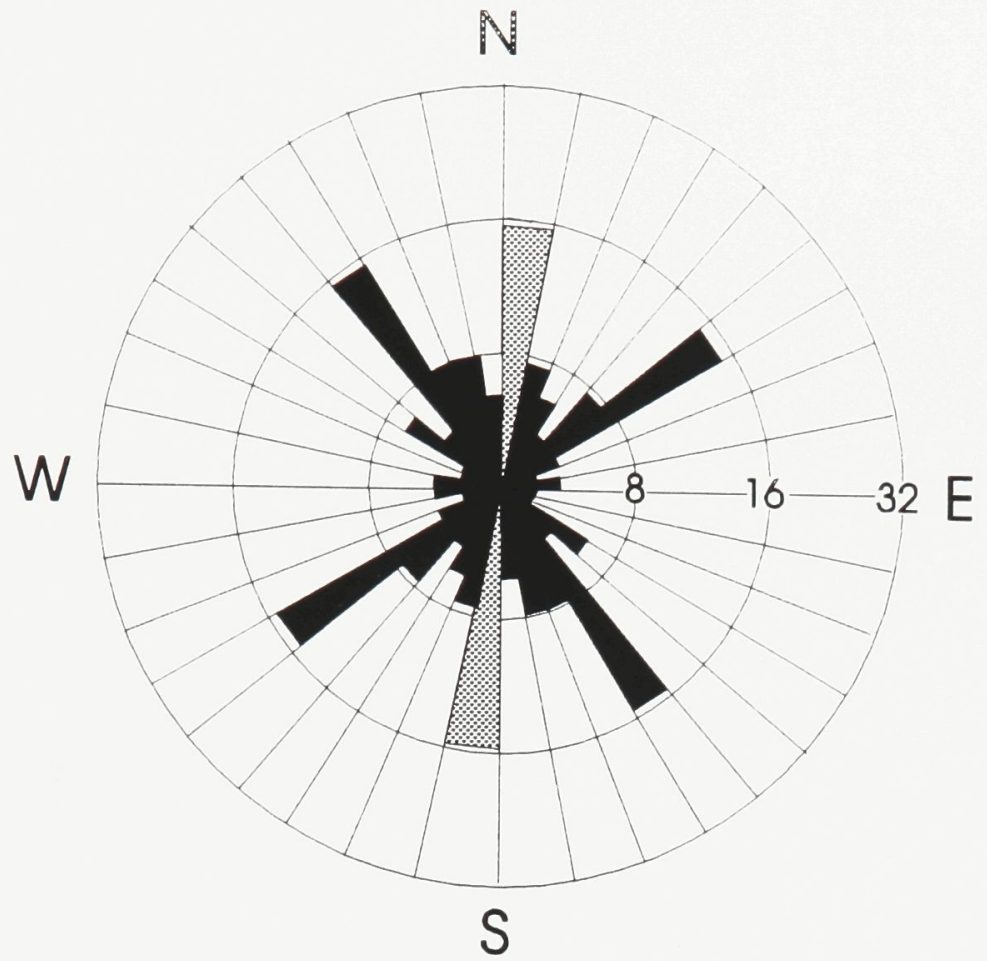

B.

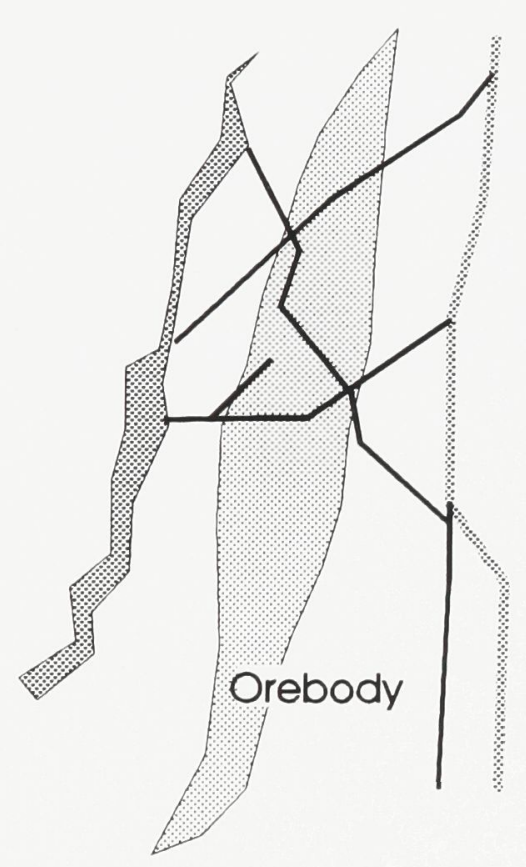

Orientation of

large dykes

Orientation of

minor dykes

Figure 2.8 (a) Rose diagram of feldspar porphyritic mafic dyke distribution, and (b) morphology and orientation of dykes with respect to the massive sulphide lens 
Figure 2.9

A. Tightly folded, layered massive sulphide from near the hangingwall contact of the orebody on Level 9. Sample ANSL9-001. Centimetre card for scale.

B. Deformed fragmental sulphide ore along the base of the massive sulphide lens where it is transected by discrete shear zone (Sublevel 9C). $12 \mathrm{~cm}$ long pencil magnet for scale.

C. Strongly sheared footwall vein stockwork zone, with pyrrhotite-chalcopyrite veins re-oriented sub-parallel to the shear plane (Sublevel 8A). Centimetre card for scale. 


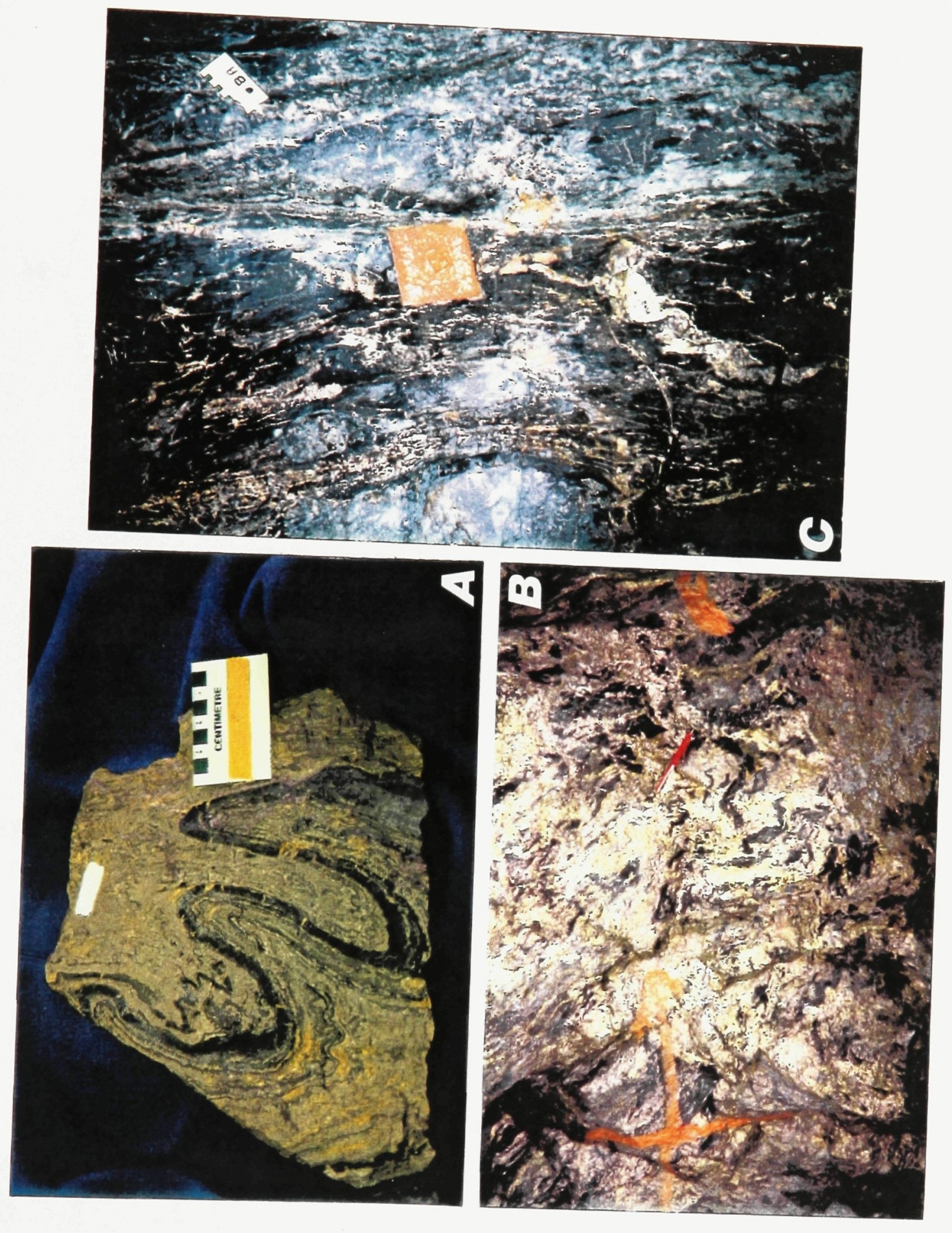


Sublevel 6A

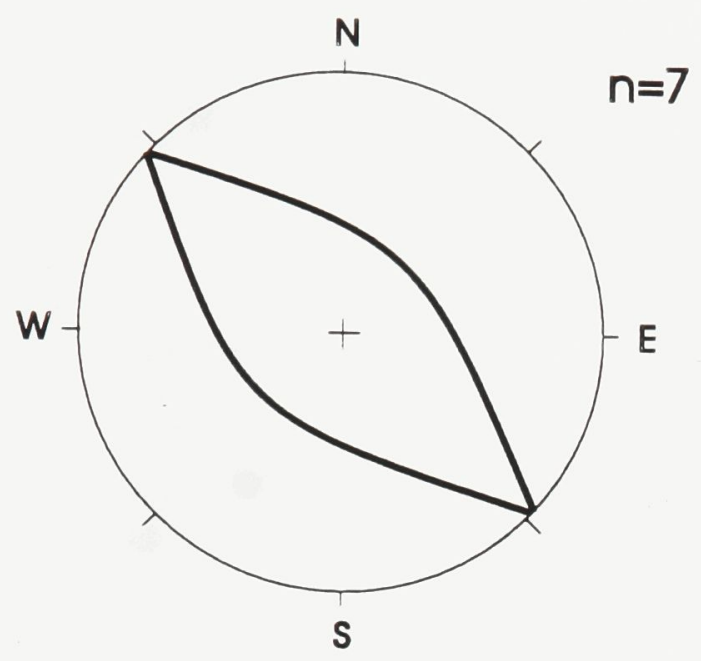

Level 8

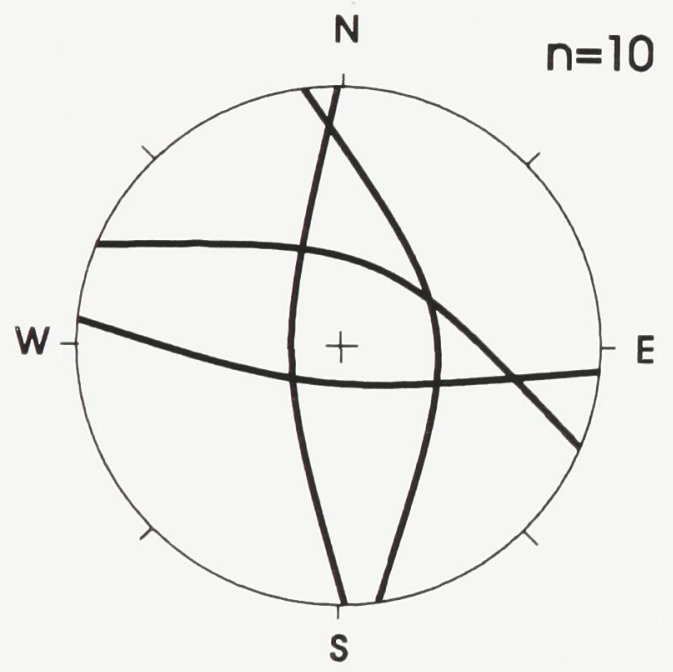

Sublevel 7B

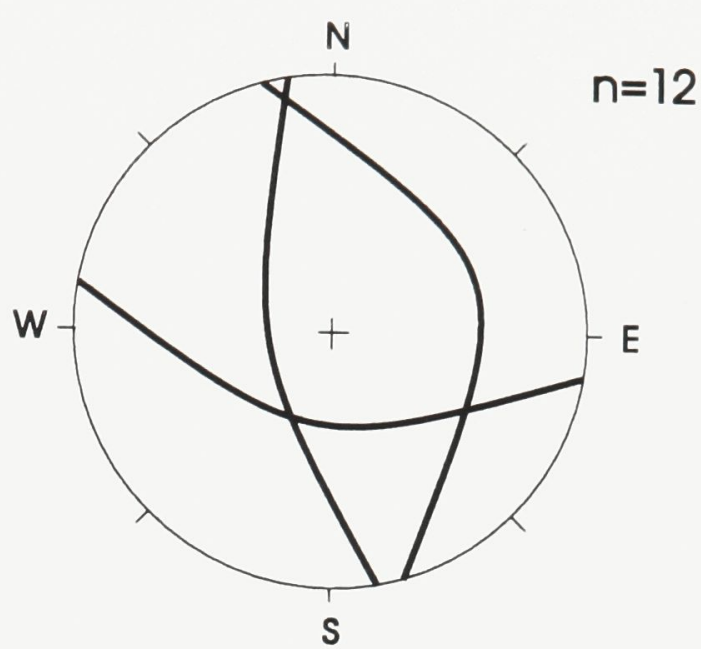

Level 9

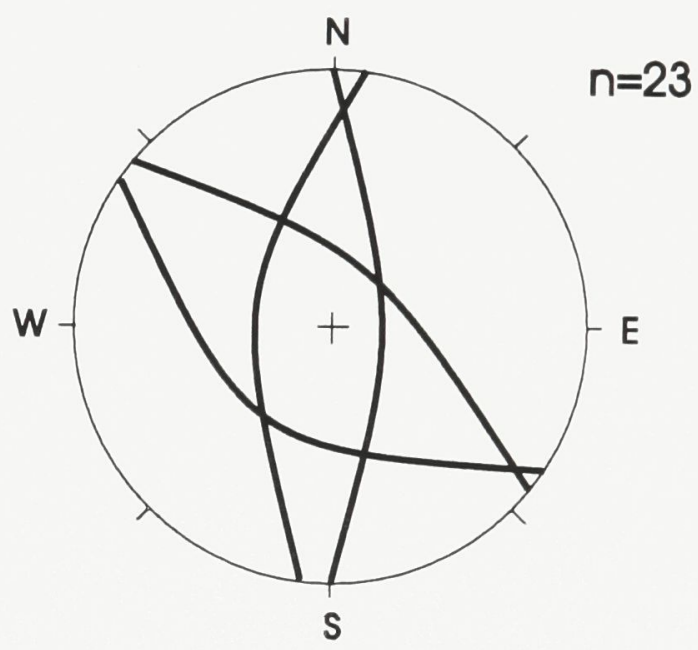

Figure 2. 10 Stereographic (equal area, lower hemisphere) projections showing the variation in strike of the contact and footwall shear zon from the west (top left) to east (lower right) ends of the orebody. 


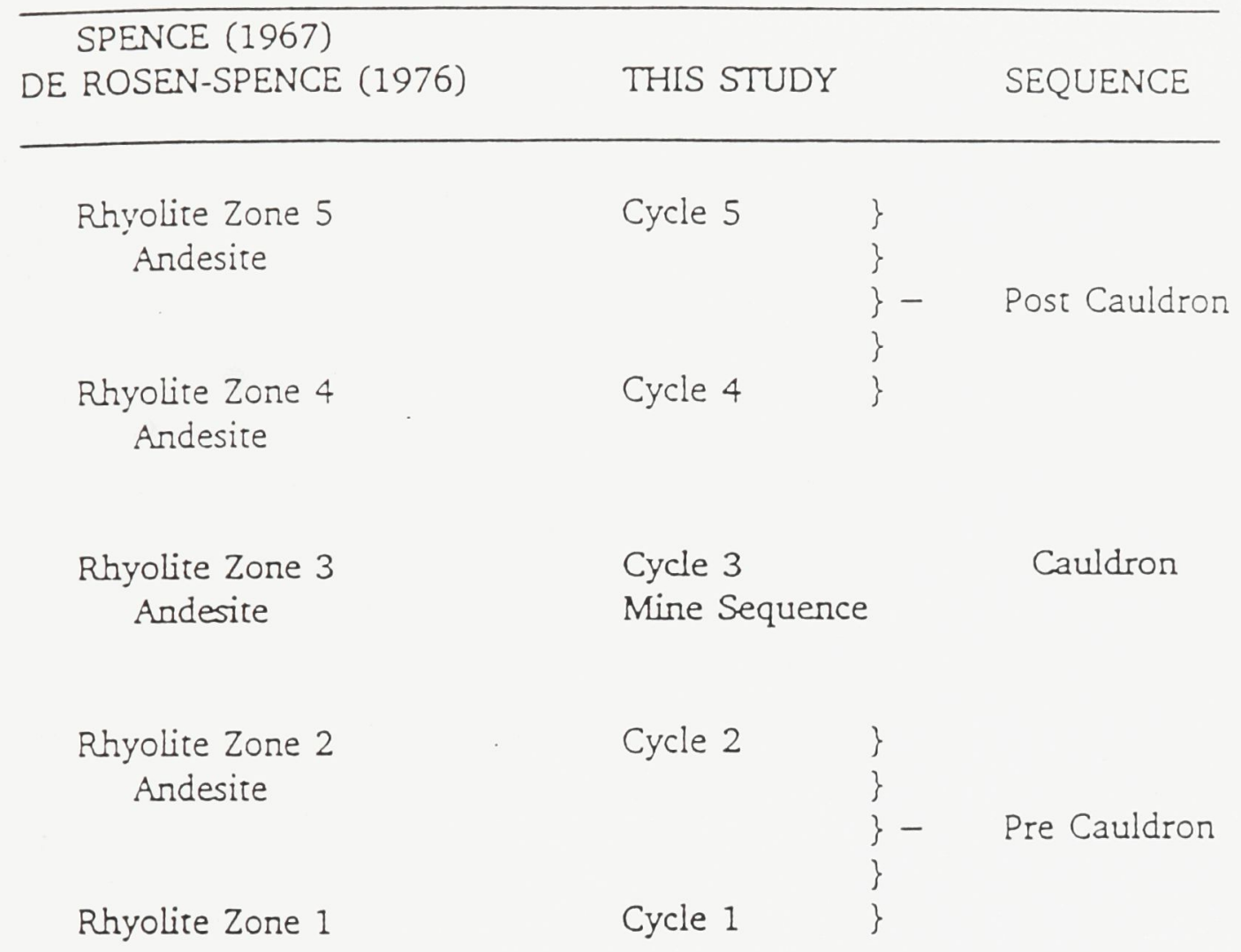

Table 2.1 Lithostratigraphic subdivision of the Noranda Volcanic Complex, Blake River Group (from Gibson, 1989). 


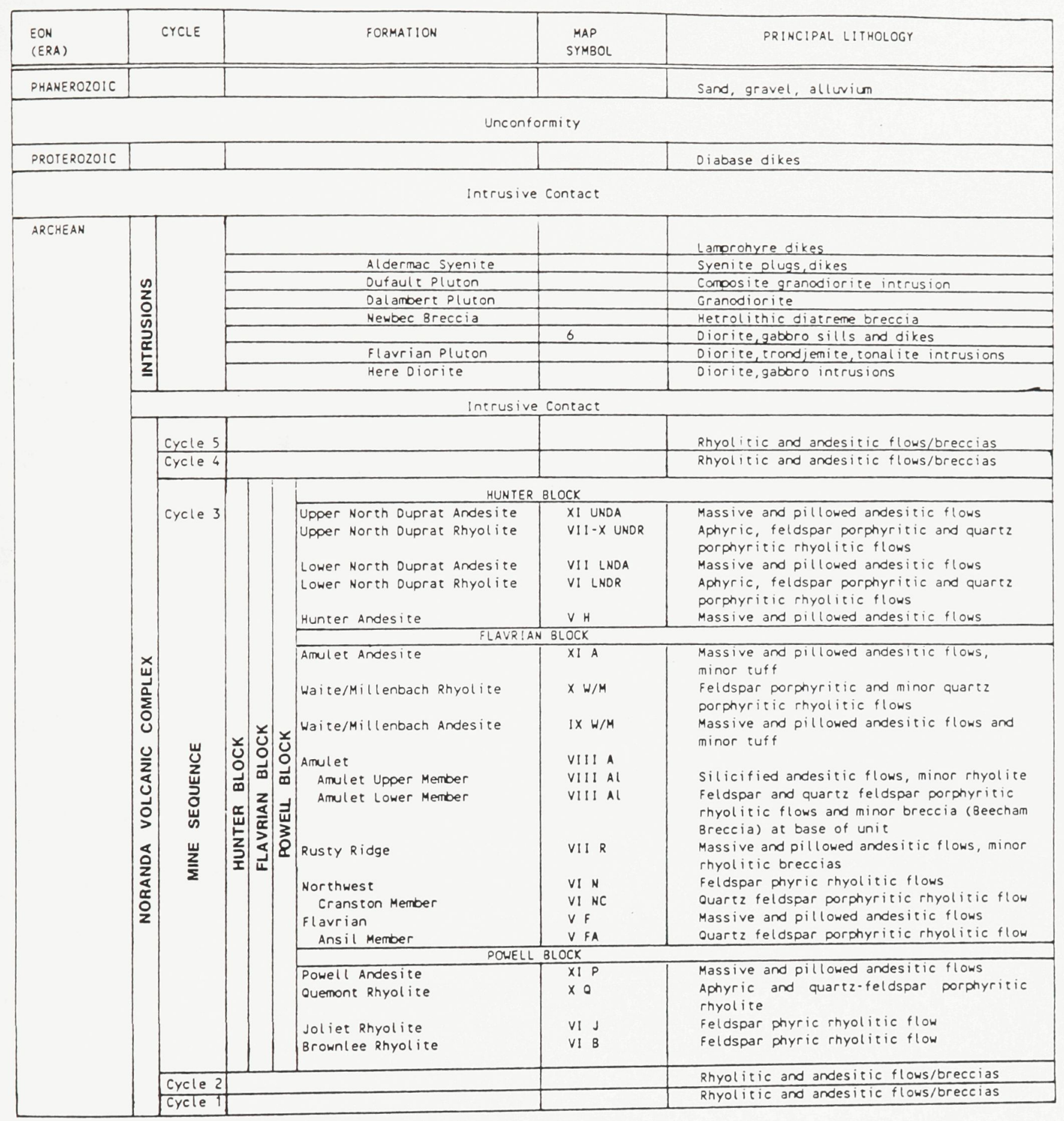

Roman numeral prefix indicates order of stratigraphic succession Cycle 5 may be the stratigraphic equivalent of Cycles 2 or 3

Table 2.2 Table of formations for the Noranda area (from Gibson, 1989). 


\begin{tabular}{|c|c|c|c|c|c|c|}
\hline Stratigraphic position & $\begin{array}{l}\text { Volcanogenic massive } \\
\text { sulfide deposit }{ }^{1}\end{array}$ & Mt $\left(10^{6}\right)$ & $\mathrm{Cu}(\%)$ & $\mathrm{Zn}(\%)$ & $\mathrm{Ag}(\mathrm{g} / \mathrm{t})$ & $\mathrm{Au}(\mathrm{g} / \mathrm{t})$ \\
\hline \multirow[t]{14}{*}{ Cycle 3 (Mine sequence) } & 1. Ansil & 1.58 & 7.2 & 0.9 & 27 & 1.6 \\
\hline & 2. Vauze & 0.35 & 2.94 & 0.94 & 24 & 0.7 \\
\hline & 3. Norbec & 3.95 & 2.77 & 4.50 & 48 & 0.7 \\
\hline & 4. East Waite & 1.50 & 4.10 & 3.25 & 31 & 1.8 \\
\hline & 5. Old Waite & 1.12 & 4.70 & 2.98 & 22 & 1.1 \\
\hline & 6. F-Shaft & 0.27 & 3.40 & 8.60 & 46 & 0.3 \\
\hline & 7. Amulet $\mathrm{C}$ & 0.57 & 2.20 & 8.54 & 87 & 0.6 \\
\hline & 8. Lower A & 4.69 & 5.14 & 5.28 & 44 & 1.4 \\
\hline & 9. Upper A & 0.19 & 2.37 & 6.12 & 46 & 2.0 \\
\hline & 10. Amulet 11 & 0.45 & 3.65 & 2.38 & 29 & 0.7 \\
\hline & 11. Millenbach & 3.56 & 3.46 & 4.33 & 56 & 1.0 \\
\hline & 12. Corbet & 2.78 & 3.00 & 1.96 & 21 & 1.0 \\
\hline & 13. Quemont & 13.8 & 1.32 & 2.44 & 31 & 5.5 \\
\hline & 14. Aldermac & 1.88 & 1.48 & & 7 & 0.3 \\
\hline \multirow[t]{3}{*}{ Cycle 4} & 15. Deldona & 0.09 & 0.30 & .5 .00 & 26 & 4.1 \\
\hline & 16. Delbridge & 0.36 & 0.55 & 8.60 & 69 & 2.4 \\
\hline & 17. Gallen & 2.9 .5 & 0.07 & 4.77 & 22 & 0.7 \\
\hline Cycle $5^{-2}$ & 18. Mobrun ${ }^{3}$ & 8.64 & 0.63 & 4.66 & 31 & 1.5 \\
\hline \multirow{2}{*}{ Undetermined } & 19. Horne (mined) & 54.3 & 2.22 & & 13 & 6.1 \\
\hline & Horne 5 zone & $\approx 150$ & 0.1 & 0.7 & & 0.3 \\
\hline
\end{tabular}

Data from Boldy (197T), compilations by D. MacNeil (Corporation Falconbridge Copper) and W. Bancroft (Noranda Mines) and from recent press releases (Audrey Resources)

${ }^{1}$ Deposit numbers refer to Figure l

- Stratigraphic relationship of cycle 5 to other cycles is uncertain

${ }^{3}$ Includes production and reserves of Main, Satellite, and New lenses

Table 2.3 List of massive sulphide deposits and their stratigraphic positions relative to Gibsons (1989) lithostratigraphic subdivision (from Gibson, 1989). 


\section{CHAPTER 3. GEOLOGICAL SETTING OF THE ANSIL DEPOSIT}

\subsection{INTRODUCTION}

The purpose of this chapter is to describe the geological setting of the Ansil deposit through descriptions of the host units, intrusive rocks and synvolcanic structures. The deposit occurs $400 \mathrm{~m}$ above the upper contact to the Flavrian Pluton at the contact between rhyolitic flows of the Northwest formation and overlying andesitic flows of the Rusty Ridge Formation, (Riverin et al., 1990) (Figure 3.1). A 10 to $20 \mathrm{~m}$ thick unit of aphyric dacite flows (herein referred to as the Ansil dacite) underlies the eastern third of the Ansil stratabound sulfide lens, and a succession of finely bedded rhyolitic volcaniclastics (the Cranston tuff) host the deposit. The strata are intruded by plagioclase glomeroporphyritic rhyolite, quartz-feldspar porphyritic rhyolite, aphyric mafic and plagioclase porphyritic mafic dykes. The strata form a moderately east-dipping homoclinal sequence offset by pre- to syn-kinematic block faults. A minor amount of oblique, synkinematic movement took place along the hangingwall contact to the Ansil massive sulfide lens, resulting in weak to moderate deformation of the deposit and immediate host rocks. The strata are regionally metamorphosed to lower greenschist facies, with the exception of the lower 50 to $100 \mathrm{~m}$ of the Flavrian formation, which is affected by biotite grade contact metamorphism associated with the intrusion of the underlying Flavrian Pluton. 


\subsection{NORTHWEST FORMATION}

The Northwest formation is divided into the North and South Flows, each originating from contemporaneous fissure eruptions controlled by northeast- and northwest-trending syn-volcanic faults respectively (Gibson, 1989) (Figure 3.2). The Ansil deposit lies along the southeast flank of the North Flow, which defines a ridge $3.5 \mathrm{~km}$ long (at the $300 \mathrm{~m}$ isopach) and up to $2 \mathrm{~km}$ wide (Gibson, 1989). The flow begins north of Lac Duprat and continues northeast, pinching out near the Hunter Creek Fault (Figure 3.2). The ridge generally rises to a height between 300 and $400 \mathrm{~m}$, with a relatively smooth surface, and slopes between 10 and $20^{\circ}$. It reaches its maximum height of $500 \mathrm{~m}$ near Ansil Hill, several hundred metres to the northwest of the Ansil deposit. Around the deposit the contoured isopachs for the rhyolite ridge are irregular, and the average paleoslope steepens to between 30 and $35^{\circ}$, implying the presence of faults (Gibson, 1989).

The North Flow is a low relief lava shield that is divided into a massive, lobehyaloclastite and breccia facies, capped at its northeast end by a steep-sided rhyolite dome (Cranston QFP) (Gibson, 1989). The base of the flow is plagioclase-phyric, and its upper section sparsely quartz-phyric. Massive to weakly brecciated, flow banded rhyolitic flows form the core of the ridge which grades outwards, and upwards, into a lobe-hyaloclastite facies characterized by irregular lobes of massive rhyolite surrounded by intact to weakly brecciated flow-banded rhyolite and hyaloclastite. The top of the rhyolite ridge is covered with a thin $(<2 \mathrm{~m}$ thick) deposit of carapace breccia, and the margins contain deposits of crudely layered flank breccia. 
The Ansil deposit is underlain by 250 to $125 \mathrm{~m}$ of rhyolite, with the formation thinning rapidly to the east and south through a series of steps along the upper contact (Figure 3.1). The deposit is approximately halfway down the southeast flank of the North Flow ridge. The Northwest formation is truncated by the upper contact of the Flavrian Pluton $100 \mathrm{~m}$ south of the deposit.

\subsubsection{North Flow stratigraphy}

The rhyolite ridge which underlies the Ansil deposit consists of 50 to $120 \mathrm{~m}$ of massive, rhyolite lobe-flow breccia at the base overlain by up to $130 \mathrm{~m}$ of lobe-hyaloclastite lava. A thin carapace breccia forms the top of the flow, and a coarse flank breccia is present under the south flank of the Ansil deposit.

Rhyolite lobes vary in size up to $70 \mathrm{~m}$ thick, and in shape from bun-shaped to thin, elongate toes. The larger ones are commonly composite, with internal flow contacts defined by silicified, flow-banded margins and an increased spherulite content (see Access Crosscut, Map 11A). Massive rhyolite is hyalopilitic, with an aphanitic, granular groundmass of equant, 0.25 to $0.5 \mathrm{~mm}$ quartz and feldspar grains with sutured boundaries, interspersed with up to $70 \%$ fine-grained chlorite (Figures 3.3a to d). Abundant 0.5 to 1 $\mathrm{mm}$ spherulites are present within the more chlorite-rich areas, along with 2 to $3 \%$, plagioclase microlites up to $2 \mathrm{~mm}$ long. Plagioclase forms single, euhedral crystals and glomeroporphyritic aggregates. 
Massive rhyolite has a mottled colouration and texture, with the dark green to greenishwhite chlorite-rich groundmass containing 5 to $30 \%$, cream to white quartzo-feldspathic domains up to $30 \mathrm{~cm}$ in length (Figure $3.4,3.5$ ). The domains are composed of 0.5 to 1 $\mathrm{mm}$ aggregates of recrystallized spherulites consisting of granoblastic quartz and plagioclase (Figure $3.3 \mathrm{~b}, \mathrm{c}$ ). Individual spherulites are up to $20 \mathrm{~mm}$ in diameter, but this is rare. The finer-grained spherulite aggregates form individual, rounded felsic domains up to $25 \mathrm{~mm}$, or the domains coalesce to from grape-like clusters up to $30 \mathrm{~cm}$ long (mega-orb texture; Lofgren, 1970). Spherulite distribution is variable, with some massive lobes having an even distribution over their entire thickness, whereas others have an increased concentration towards their upper contacts. Spherulite aggregates generally increase in size towards the lobe contacts. Individual, milky-white spherulites within the groundmass become more evident near flow contacts, giving the flow a coarse, granular appearance. These smaller spherulites commonly nucleate on amygdules present along the flow contacts, forming lighter coloured haloes (Figure 3.6a).

Amygdules are up to $5 \mathrm{~mm}$ in length, irregularly shaped and commonly flattened parallel to the flow contacts (Figure 3.6a). They are coarser-grained than the surrounding rhyolite, with axiolitic chlorite growth about their margins, and equigranular quartz, chlorite or plagioclase infilling the cores. Amygdule content generally increases towards the lobe contacts.

The massive rhyolite lobe margins are commonly aphanitic and devitrified, with abundant perlitic fractures (Figure 3.6b). Toward the edge of the flow lobe the perlitic 
fractures are loci for spherulite growth (Figure 3.6c). These fracture-controlled devitrifed zones increase in width and abundance closer to the flow margin until a pseudo-breccia is formed, with chlorite-altered remnants of the originally glassy rhyolite surrounded by devitrified glass (Figure 3.6d). The pseudo fragments vary in shape from angular, with arcuate to planar edges defined by perlitic fractures, to amoeboid and sub-rounded. This gives the flow margin a texture similar to associated hyaloclastite, commonly making distinction difficult in drill core and in underground exposures.

Lobe margins are surrounded by a 20 to $40 \mathrm{~cm}$ thick rind of flow breccia. The contacts are gradual over several centimetres, with the flow breccia defined by an increase in finergrained, hyaloclastite groundmass (Figure 3.7). Clasts are more chloritized than the groundmass; many are elongate parallel to the lobe margin (Figure 3.8, 3.9,3.10). The texture is mottled, with patchy, bluish-white to greenish-white concentrations of spherulites in a more chloritic groundmass (Figure 3.7).

The outer contact of the flow breccia is gradational over centimetres into finer-grained hyaloclastite. The hyaloclastite facies comprises up to $60 \%$ of the rhyolite sequence, consisting of strongly chloritized, sharp-sided angular fragments up to $20 \mathrm{~mm}$ in size, in a mottled, more siliceous groundmass (Figure 3.11, 3.12). The siliceous groundmass is bluish-white resulting in the name 'blue quartz breccia' in underground mapping. The blue colouration is due to the presence of very fine-grained chlorite. The groundmass contains abundant, 1 to $2 \mathrm{~mm}$, milky-white spherulites 
Carapace breccia occurs as a thin covering along the upper contact of the rhyolite north of the deposit. It is generally less than $2 \mathrm{~m}$ thick, and consists of unsorted, framework- and matrix-supported angular fragments of massive to flow-banded rhyolite in a matrix of hyaloclastite and smaller lithic fragments.

A coarse flank breccia underlies the south margin of the Ansil, deposit reaching a thickness of $12 \mathrm{~m}$ directly under the south flank of the massive sulfide lens, and rapidly pinching out to the north and south. It consists of angular blocks of spherulitic rhyolite, with silicified margins, in a matrix of smaller lithic fragments and subordinate hyaloclastite The flank breccia is crudely graded, with fragments up to $1 \mathrm{~m}$ long at the base, grading upwards through small boulder to cobble-sized clasts (Figures 3.13 and 3.14).

\subsubsection{Rhyolite facies distribution in the vicinity of the Ansil deposit}

There are well defined facies variations in the section of Northwest formation underlying the Ansil deposit (Figure 3.15). At the base of the section is 70 to $90 \mathrm{~m}$ of closely packed rhyolite lobes with minor, interstitial flow breccia. The lobes are usually 1 to $2 \mathrm{~m}$ long, and highly spherulitic. Above this is a 5 to $10 \mathrm{~m}$ interval of predominantly coarse-grained hyaloclastite with amoeboid flow breccia, overlain by a 10 to $15 \mathrm{~m}$ sequence of lobe-flow breccia containing $40 \%$ spherulitic lobes and $60 \%$ coarse breccia. Above this is a $5 \mathrm{~m}$ interval of hyaloclastite, overlain by 60 to $90 \mathrm{~m}$ of lobe-hyaloclastite, with 30 to $40 \%$ massive lobes up to $20 \mathrm{~m}$ long, and 60 to $70 \%$ hyaloclastite and coarser- 
grained, subordinate flow breccias. The upper surface of the Northwest formation consists of a 1 to $2 \mathrm{~m}$ thick veneer of carapace breccia

Near the Ansil massive sulfide lens in the north-northwest along the upper contact of the Northwest formation, the lobe-hyaloclastite facies steps down 30 to $35 \mathrm{~m}$ along an east-west trending scarp that forms the northern boundary to the deposit (Figure 3.15). South of this step the lobe-hyaloclastite upper surface of the rhyolite flow gradually rises over $150 \mathrm{~m}$ horizontal distance to form the south boundary to the east-west trending structure. The southern boundary to this asymmetric depression is a $70 \mathrm{~m}$ thick and $50 \mathrm{~m}$ wide rhyolite lobe that extends east-west for $200 \mathrm{~m}$.

The lobe's upper surface formed a berm along the southern boundary of the east-west trending depression, south of which the upper surface of the North Flow rapidly falls away to the south-southeast in a series of escarpments (the distribution and origin of which will be discussed in the following section on structure). The composite lobe contains four to six internal flow contacts that are defined by increased spherulite concentrations, silicification and flow banding. The absence of flow breccia along these contacts is evidence for the endogenous emplacement of the rhyolite lobe through inflation by subsequent pulses of lava.

The upper 2 to $4 \mathrm{~m}$ of the massive lobe is columnar-jointed, with the columns curving to meet the curved surface of the lobe at right angles (Figures 3.16, 3.17, 3.18). The columns are defined by a subvertical joint set with a 15 to $30 \mathrm{~cm}$ spacing, and are divided into segments of various lengths by a subhorizontal joint set (Figures $3.17,3.18$ ). The 
upper surface of the lobe is defined by a carapace breccia composed of rotated, rectangular fragments of columnar jointed rhyolite and other angular fragments of massive rhyolite

The 1 to $2 \mathrm{~m}$ thick carapace breccia is overlain by 2 to $3 \mathrm{~m}$ of fine- to coarse-grained hyaloclastite with platy rhyolite shards, which is in turn overlain by 2 to $12 \mathrm{~m}$ thick, coarse, crudely layered flank breccia that is thickest along the north edge of the large rhyolite lobe.

The hyaloclastite sequence overlying the large rhyolite flow lobe thickens $20 \mathrm{~m}$ to the north of the lobe, partially infilling the east-west depression created by the downdropping of the lobe-hyaloclastite upper surface below the Ansil deposit. The upper third of the hyaloclastite sequence is dominated by platy shards of rhyolite that lie with their long axes parallel to the stratigraphic contacts. The lower two thirds of the sequence consists of blocky, angular rhyolite shards. The thick pile of hyaloclastite contains a small number of thin, elongate rhyolite lobes.

The Ansil deposit, therefore, overlies the distal lobe-hyaloclastite facies that was erupted along the southeast flank of the North Flow rhyolite. The vertical facies change from massive flow to lobe-hyaloclastite below the deposit is typical of the distal flanks of a lobe-hyaloclastite rhyolite lava shield, and suggests a decrease in the eruption rate with time. Whereas there are no observed breaks within the lower massive flow sequence, the upper lobe-hyaloclastite member contains at least two units of hyaloclastite material indicating a change from continuous to intermittent flow. The disrupted isopach contours and the definition of a syn-depositional east-west depression below the Ansil deposit suggests that this area was one of active faulting. 


\subsection{ANSIL DACITE}

The Ansil dacite is an extrusive unit between the Northwest formation and the Cranston tuff; it was defined by the Ansil mine staff as intermediate in composition due to its light grey colour and morphological similarities with the underlying Northwest formation lobehyaloclastite facies. To the north of the Ansil deposit the rhyolite is separated from overlying Cranston QFP-related volcaniclastics by a thin sequence of andesitic flows of the Rusty Ridge formation (Gibson, 1989). The stratigraphic correlation between the basal andesitic flows and the Ansil dacite implies that the latter unit may be an altered equivalent of the former.

The Ansil dacite is more than $80 \mathrm{~m}$ thick $450 \mathrm{~m}$ southeast of the Ansil deposit, and thins to the northwest where it banked up against the underlying rhyolite ridge (Figure 3.19). The dacite underlies the eastern $120 \mathrm{~m}$ of the Ansil massive sulfide lens, infilling step-like offsets along the rhyolite upper contact. The upper contact to the dacite is planar on a large scale, but 1:150 scale mapping reveals its rubbly and irregular surface, with rapid vertical changes up to 1 to $2 \mathrm{~m}$ (Figure 3.20).

The formation is composed of lobe-hyaloclastite flows, with lobe, flow breccia and hyaloclastite facies (Figure 3.21). The sequence is dominated by $70 \%$ flow lobes, which are ellipsoidal to tongue-like in shape, with individual lobes up to $17 \mathrm{~m}$ thick (Figure 3.22). The lobes are light grey to grey-green, aphanitic to sparsely plagioclase-phyric, with 3 to $5 \%$ amygdules and pipe vesicles (Figures $3.23,3.24$ ). Amygdules vary in shape from 
elongate and equidimensional, sharp-walled cavities to more irregular, pipe-like features The long axis of elongate amygdules commonly parallels the edge of the flow lobe. They are rimmed by axiolitic chlorite and have cores infilled with anhedral to euhedral quartz and minor plagioclase. The dacite has a hyalophitic texture, with $25 \%$ fine feldspar microlites in a spherulite-rich devitrified groundmass composed of varying amounts of chlorite, sericite and quartz (Figure $3.25 \mathrm{a}, 25 \mathrm{~b}$ ). Rounded to subrounded quartz blebs up to $0.2 \mathrm{~mm}$ in diameter occur individually or as aggregates up to $0.4 \mathrm{~mm}$ in diameter. They compose 20 to $30 \%$ of the dacite. Euhedral to subhedral plagioclase microphenocrysts $(1 \mathrm{~mm})$ compose 1 to $3 \%$ of the rock (Figure $3.25 \mathrm{c}$ ) where they sometimes form glomeroporphyritic, poikilitic clots, containing randomly oriented feldspar microlites. Small perlitic fractures typically cross-cut the devitrified groundmass, and contain fine-grained chlorite and quartz, and coarser-grained Fe-oxides (Figure 3.25d)

The larger lobes have hyalophitic cores and spherulite-rich vitrophyric margins with abundant perlitic fracturing, whereas some of the smaller lobes were completely glassy and are strongly spherulitic (Figure 3.26). The margins of the flow lobes contain well defined concentric, and more poorly defined radial cooling fractures. These fractures control the formation of flow breccias along the lobe margins. The fractures define an irregular, rectangular pattern along the lobe margins, with the fractures widening towards the flow edge to form an in situ flow breccia (Figure 3.27). The flow breccia has a gradational outer contact over 10 to $20 \mathrm{~cm}$ with coarse- to fine-grained hyaloclastite (Figure 3.28). The hyaloclastite has a texture and grain size similar to those observed within the underlying 
rhyolite, with dominantly blocky, angular shards, and 5 to $10 \mathrm{~mm}$ equidimensional amygdules within a spherulite-rich, silicified groundmass.

There are at least two 20 to $40 \mathrm{~cm}$ thick units of thinly laminated felsic tuff present within the dacite lobe-hyaloclastite sequence. These tuff units are similar in texture and composition to the overlying Cranston tuff member, indicating a similar source for the two rock types. Deposition of the dacite flows therefore took place during at least three separate eruptions, the end of each eruptive event allowed the deposition of the quartz phyric tuff.

\subsection{PHREATIC-HYDROTHERMAL BRECCIA}

A period of phreatic activity took place after emplacement of the Northwest formation and Ansil dacite, and before the emplacement of the overlying Cranston tuff. The evidence for this explosive activity includes a series of discordant and conformable breccias along the north and south margins of the east-west depression host to the Ansil massive sulfide deposit. The discordant breccias, which include in situ and disrupted facies, directly underlie the conformable breccias.

Discordant breccias are observed underlying the north margin of the massive sulfide deposit on Levels 9, 9B, 9C, and 11A. They underlie the south margin of the deposit on Levels 7B, 11, 11A and in Ramp section 10A-11. These discordant zones are usually less than $10 \mathrm{~m}$ wide and $30 \mathrm{~m}$ long, although the breccia observed in Ramp 10A-11 extends at least $100 \mathrm{~m}$ below the upper dacite contact. The zones are funnel-shaped, with the neck of 
the funnel composed of in situ breccia, and the upper part of chaotic, or disrupted breccia (Figure 3.29).

Zones of in situ breccia consist of an intense veining of rhyolite and dacite (Figures 3.30 and 3.31). The anastomosing vein systems consist of fracture infilling by finely layered chalcedonic quartz with variable amounts of aphanitic sphalerite and pyrite. Vein-hosted, lozenge-shaped blocks of rhyolite wallrock are 30 to $40 \mathrm{~cm}$ long. Where a discordant breccia system cross-cuts the dacite, in situ brecciation commonly follows the radial and concentric cooling fractures within the flow lobes (Figure 3.26).

As the quartz-sulfide-filled fractures widen up section, the enclosed host rock fragments are further brecciated, rotated and dislocated (Figure 3.32). Within this disrupted breccia facies the range of fragment sizes increase, with sub-angular to sub-rounded fragments 10 and $60 \mathrm{~cm}$ in size, in a matrix of smaller fragments (Figure 3.33). The matrix fragments are commonly angular, with concave surfaces from brecciation along perlitic fractures. There is a wide variation in clast morphology from massive through to amydaloidal and flowbanded.

Directly overlying the discordant breccia pipes are aprons of conformable, chaotic breccia with clast morphology and composition similar to the upper facies of the underlying pipes. The conformable breccias form wedge-shaped deposits up to $20 \mathrm{~m}$ thick, along the north and south flanks of the Ansil deposit where they are in sharp, disconformable contact with the underlying rhyolite or Ansil dacite flows (Figure 3.34). The breccias rapidly thin towards the centre of the overlying massive sulfide lens. Some 
conformable breccia lenses display a crude normal clast size grading from coarse, blocky fragments along their base through pebble- to sand-sized fragments near the top. Size grading exists along strike, with larger fragments overlying the discordant breccia pipes and pebble-sized fragments within the thinner apron (Figure 3.29).

The breccia formations were compared by Galley et al. (1990) to phreatic breccia deposits observed within the Upper Amulet formation (Gibson et al., 1983; Gibson and Watkinson, 1991). The lack of abundant pumiceous material within the breccias preclude formation by explosive magmatic, or phreato-magmatic processes (Sheridan and Woehletz, 1984). The funnel shape of the discordant breccia pipes and the presence of smoothwalled, conchoidal glass shards is more typical of phreatic breccias formed by water-rock interaction. These breccias may be the product of explosive interaction between cooling volcanic rocks and infiltrating seawater, where rapid steam generation and expansion caused overpressuring, that resulted in brecciation and ejection onto the seafloor.

The phreatic breccia zones are the loci for hydrothermal alteration and associated sulfide deposition which raises the question as to whether they are hydrothermal explosion breccias.

\subsection{CRANSTON TUFF}

\subsubsection{Regional distribution}

The Cranston tuff occupies the same stratigraphic position as the Ansil massive sulfide lens, and is part of a submarine mass flow sequence originating $2000 \mathrm{~m}$ to the north along 
the flank of the Cranston QFP dome (Figure 3.36). The mass flow unit has a coarse, monolithologic breccia basal facies that originated along the south flank of the QFP dome The breccia facies forms an ellipsoidal deposit striking southwest, thickening away from the dome, and ending abruptly after $1000 \mathrm{~m}$. Along strike from the breccia is a second sedimentary facies composed of coarse- to fine-grained, massive to thickly bedded quartzplagioclase- to quartz-phyric tuff. The coarse- to fine-grained tuff facies infills several depressions in the underlying North Flow rhyolite ridge, including the depression containing the Ansil deposit. The coarse- to fine-grained tuff facies is roughly $1000 \mathrm{~m}$ long, terminating to the southwest against an intrusive contact with the Flavrian Pluton. The third facies of the Cranston debris flow is a finely laminated, fine-grained, quartz phyric tuff that forms a blanket deposit up to $1 \mathrm{~m}$ thick, up to $1000 \mathrm{~m}$ wide and $2000 \mathrm{~m}$ long, that covers the other two volcaniclastic facies, plus the southern part of the QFP dome. This finely laminated, aphanitic unit is commonly sulfidic, and contains varying amounts of andesitic tuff that increases in abundance towards the upper contact of this facies.

The Cranston mass flow consists of more than one gravity flow, as the breccia facies interfingers with lower flows of the overlying Rusty Ridge formation. In the area surrounding the Ansil deposit the Ansil dacite flows contain at least three thin interlayers of finely laminated tuff.

The Cranston volcaniclastic debris unit in the Ansil deposit area consists of three facies that include coarse-grained tuff, fine-grained tuff and finely laminated tuff, and are known 
collectively as the Cranston tuff (Figure 3.37). The contact between the basal coarsegrained and fine-grained tuff facies is fairly sharp, whereas the contact between the finegrained and overlying laminated facies is gradational.

The Cranston tuff is host to the stratabound sulfides comprising the Ansil deposit, with the fine-grained tuff forming the immediate footwall and the laminated tuff the immediate hangingwall. The tuff is as thick as $20 \mathrm{~m}$, infilling the $150 \mathrm{~m}$ wide, east-west striking depression on the upper surface of the rhyolite in which the Ansil deposit is situated (Figure 3.38). The coarse- and fine-grained bedding sets are restricted to the depression, with the laminated bedding set forming a blanket deposit that extends beyond its boundaries.

\subsubsection{Coarse-grained (basal) facies}

The basal, coarse-grained bedding set is massive to crudely layered, with a sharp upper contact with the overlying fine-grained tuff (Figure 3.39). It consists of 20 to $30 \%$ quartz and $3 \%$ plagioclase phenoclasts, and 10 to $15 \%$ lithic fragments in a finer-grained matrix of quartz grains, and chlorite-stilpnomelane altered glass shards (Figures 3.40a and b). Phenoclasts and lithic clasts range up to $1 \mathrm{~mm}$ in size. The quartz phenoclasts are rounded and equant, to thin and elongate, with curved sides (Figure 3.40c). In many cases the phenoclasts are strongly fractured. Rare plagioclase phenoclasts are stubby, with subangular to subrounded edges. Crystal ends are commonly broken and ragged. Lithic clasts are dominantly subangular, fine-grained, equigranular rhyolite, although there are a 
few spherulitic, and possibly pumiceous clasts. Felsophyric clasts with equigranular, coarse-grained quartz and feldspar are rare. The matrix consists of very fine-grained quartz grains and chlorite, with slightly larger angular, chlorite-altered glass shards to $0.2 \mathrm{~mm}$. The glass shards are mainly blocky, or equant, with some cuspate margins representing bubble walls (Figure 3.33). Rare whole and fragmented spherulites occur, and consist of radiating, twinned albite crystals.

\subsubsection{Fine-grained (middle) facies}

The middle bedding set is a doubly graded sequence of thickly bedded to thickly laminated, fine-grained to aphanitic crystal-lithic tuff (Figures 3.41 and 3.42). It contains bedding subsets of fine-grained and aphanitic, finely laminated tuff couplets. The finegrained tuff layers are 1 to $2 \mathrm{~m}$ thick at the base of the member, decreasing down to 10 to $20 \mathrm{~cm}$ thick near the top. The aphanitic-laminated tuff layers vary up to $70 \mathrm{~cm}$ in thickness , becoming more abundant towards the top of the member. Planar bedding is the dominant layering, with rare ripples, flames and planar cross-beds.

The fine-grained tuff consists of up to $30 \%$ quartz phenoclasts and 1 to $5 \%$ lithic clasts ranging in size up from 0.1 to $1 \mathrm{~mm}$ (average size $0.3 \mathrm{~mm}$ ). The groundmass is dominated by rounded quartz grains (to $0.04 \mathrm{~mm}$ ), plus subordinate chlorite or sericite. The lithic clasts are similar in composition to those in the basal facies, and the quartz phenoclasts are subangular to angular, with curved faces. Both phenoclasts and lithic clasts are normally graded. The contact between the fine-grained tuff and overlying aphanitic-laminated tuff 
cosets is sharp to gradational over less than $1 \mathrm{~mm}$. Contacts between the fine-grained tuff and the aphanitic-laminated tuff from an underlying coset are commonly more undulose, with phenoclasts and lithic clasts sagging into the underlying, finer-grained rock (Figure 3.40d).

The upper part of each coset consists of aphanitic, thinly laminated tuff. The 2 to $5 \mathrm{~mm}$ thick beds are most commonly planar, with small scale ripple marks and rare flame structures sometimes present (Figures 3.43,44 and 3.45). The flame structures are inclined to the south, indicating a north to south flow direction for the mass flow (Figure 3.39). The aphanitic-laminated tuff is composed of a matrix of equigranular quartz grains, and subordinate chlorite, less than $0.02 \mathrm{~mm}$ in size. Angular quartz phenoclasts $(5 \%)$ and more rounded lithic fragments $(1 \%)$ are up to $0.05 \mathrm{~mm}$ in size, and occur evenly throughout the cryptocrystalline matrix. Some of the lithic fragments are composed of orbicular quartz domains representing either amygdules or spherulites.

\subsubsection{Laminated (upper) facies}

The laminated tuff facies has a 10 to $15 \mathrm{~cm}$ gradational contact with the underlying finegrained tuff facies, across which the laminated tuff layers become dominant (Figure 3.46 and 3.47). Above the contact the tuff is thinly laminated, with cream white, 5 to $10 \mathrm{~mm}$ thick cryptocrystalline layers interspersed with 1 to $2 \mathrm{~mm}$ beds of normally graded, finegrained tuff. The fine-grained tuff is commonly maroon due to the presence of fine-grained sphalerite; this give the rock a bold, striped appearance (Figure 3.47). The upper part of 
the laminated bedding set contains well preserved, chlorite-rich shards that increase in abundance towards the contact with the overlying andesitic flows. The chlorite-rich upper part of the bedding set resembles the 'tuffite' units that are so well documented within the Mine Sequence (Gibson, 1989). These shards are believed to have been originally andesite, representing a fine, aquagene ash. This ash is perhaps a product of Strombolian-type eruptions that initiated the less explosive emplacement of the andesitic lavas.

The composition of the laminated tuff bedding set is similar to that described for the fine-grained tuff bedding set, except that the normally-graded tuff layers are somewhat finer-grained and much thinner.

\subsubsection{Facies distribution}

The laminated tuff facies set is the most widely distributed at the deposit scale, followed by the fine-grained and then coarse-grained facies. Beginning at Level 7B, thin, discontinuous lenses of fine-grained and aphanitic-laminated tuff cosets occur along the massive sulfide footwall contact. By Level 9 segments of cherty tuff are recognized along the upper contact to the sulfide lens, and a 1 by $4 \mathrm{~m}$ segment of fine-grained tuff is hosted within the lens. Below Level 9 all three tuff facies are recognized underlying the north flank of the deposit. By Level 10B the massive sulfide lens is underlain by the fine-grained tuff facies, and overlain by both the fine-grained and cherty facies. From this point until the massive sulfide lens disappears down-plunge to the east its host is the fine-grained tuff bedding set. 
The distribution of the breccia, fine-grained and laminated tuff facies of the Cranston volcaniclastic mass flow unit with respect to the Cranston QFP blocky rhyolite dome suggests gravity flow emplacement through sequential collapse of a growing dome (Escher, 1933), or by an inclined blast from the base of an emerging dome (Perret, 1937). The breccia and tuff may represent proximal and distal mass flow facies respectively, whereas the laminated tuff facies may be a product of the ash suspension that rose above the gravity flow. The proximal breccia is composed principally of cognate rhyolite blocks, whereas the tuff facies are mainly juvenile material. Where these strata host the Ansil deposit, the lateral facies transitions are repeated as vertical facies changes from a coarsegrained tuff base, through a doubly graded, fine-grained tuff, to a thinly laminated aphanitic tuff top. These three facies are also characteristic of turbidite sequences, representing A, $\mathrm{AE}$ and $\mathrm{E}$ divisions respectively (Bouma, 1962). The change upwards from a thick, massive basal section through a doubly graded sequence of $\mathrm{AE}$ subsets indicates that the tuff member was formed from numerous turbidite currents, each successively weaker than the former. The fact that the coarse- and fine-grained tuffs are thickest where they infill depressions in the underlying Northwest rhyolite is further evidence for channeled bottom flow.

Textural evidence suggests that the mass flows may be products of explosive volcanism, i.e., submarine pyroclastic, or pyroturbidite flows. The large proportion of juvenile material and the presence of abundant, broken phenoclasts of quartz and plagioclase suggests that the facies variations, and their lateral gradation into flanks 
breccias to the Cranston QFP originated from mass flows formed by gravitational collapse of the dome, possibly as a result of hydrovolcanic explosions. The lack of abundant pumice, or bubble-wall shards limits the process of formation to phreatomagmatic, or phreatic, where glassy shards are formed through thermal shock, rather than through the explosive expansion and release of magmatic volatiles (Heiken, 1972). There is abundant evidence for phreatomagmatic activity throughout the Mine Sequence that includes the formation of breccia dykes (Setterfield, 1987), bleached fragment breccias such as at Buttercup Hill (Gibson et al., 1983), mass flows associated with the Millenbach Upper QFP rhyolite dome and Cranston QFP (Comba and Gibson, 1983), and the tuff cone hosting the Corbet deposit (Gibson et al., 1993).

\subsection{RUSTY RIDGE FORMATION}

The basaltic-andesite flows of the Rusty Ridge formation are a regionally extensive succession emplaced during passive fissure eruptions fed by the northeast-trending Old Waite dyke swarm, the northern boundary of which is approximately $2000 \mathrm{~m}$ south of the Ansil deposit. This dyke swarm formed along the axis of the Noranda Cauldron, and was the feeder zone for most of the andesite volcanism within the Central Mine Sequence (Gibson, 1989). The andesitic formation is nearly $600 \mathrm{~m}$ thick along the southeast edge of the Northwest formation's North Flow, gradually thinning as the originally flat-lying flows over-rode the rhyolite ridge. This unconformable relationship between the Rusty Ridge formation and the underlying Northwest formation is accentuated in the vicinity of the 
Ansil deposit, where the slopes of the rhyolite flow were steeper (up to $30^{\circ}$ ). The result is a partial stratigraphic cross-section of the Rusty Ridge formation along its lower contact.

The first evidence for the commencement of andesitic volcanism is intermixing of finegrained, chlorite-rich shards with the upper, finely laminated bedding set of the underlying Cranston tuff. Below the $1310 \mathrm{~m}$ level (8A of the Ansil deposit) the emplacement of this fine-grained, water-lain tuff is followed by a series of thick, massive flows with sparsely amygdaloidal tops ( less than $5 \%, 1$ to $3 \mathrm{~mm}$ amygdules), and thin margins (less than 50 $\mathrm{cm}$ ) containing contact-parallel cooling laminations. Flows are generally over $20 \mathrm{~m}$ thick, but seldom more than $60 \mathrm{~m}$ thick. Pillowed flow tops are rare, and flow top breccias thin to absent. Above the $1310 \mathrm{~m}$ mine level pillowed flows are more prevalent, and interflow volcaniclastics common. There is a wide variation in pillow shapes and sizes from 'openended' mega pillows over $5 \mathrm{~m}$ long, to mattress pillows up to $1.5 \mathrm{~m}$ long, and smaller spherical and bun-shaped pillows (Figure 3.48). Reentrant selvages are common, as are budding pillows. The larger pillows are tightly packed, with obvious draping. Pillow contacts are marked by 1 to $2 \mathrm{~cm}$ devitrified, chlorite-rich selvages. Smaller pillows form in groups, and are isolated from one another by 5 to $10 \mathrm{~cm}$ wide halos of fine-grained, chlorite-rich hyaloclastite formed from the in situ fragmentation of the pillow rims. Pillows usually have massive cores, and upper margins with up to $20 \%, 1$ to $5 \mathrm{~mm}$ amygdules. In some cases the amygdules are uniformly distributed. Concentric cooling fractures are common around pillow margins; radial cooling fractures are rare 
Flow tops are marked by accumulations of flow-top breccia averaging 1 to $2 \mathrm{~m}$ thick, occasionally up to $12 \mathrm{~m}$. These vary in character from cobble breccia with angular, blocky fragments in a fine-grained hyaloclastite groundmass, to pillow breccias, with recognizable pillow fragments. Amoeboid pillow breccias occur, with irregular-shaped, budding pillows intruding into an overlying hyaloclastite layer

The basaltic-andesite flows are generally fine-grained to aphanitic, with a texture ranging from hyalophitic to intersertal. Most flows contain 3 to $5 \%$ microphenocrysts of plagioclase (to $1 \mathrm{~mm}$ ), in a groundmass of felted plagioclase microlites and fine-grained chlorite, actinolite, carbonate, epidote and Fe-oxides representing metamorphic products of devitrification. Some of the thicker, massive flows are medium-grained near their centres, and are difficult to distinguish from gabbro sills, whose presence has been identified during the exploration drill program.

In summary, the succession of basaltic-andesitic flows in the hangingwall to the Ansil deposit varies upsection from massive, thick, sparsely amygdaloidal flows with scant interflow sediment to interlayered, amygdaloidal pillowed and massive flows separated by varying thicknesses of flow top breccias. The intermittent presence of the thin mafic tuff along the basal contact may be due to the fact that flow emplacement was preceded by explosive volcanism during which fine-grained ash was injected into the overlying water column. From our knowledge of shallow submarine to subaqueous mafic fissure eruptions, Surtseyian-type phreatomagmatic activity may well initiate a period of voluminous lava emplacement (Cas and Wright, 1988). Early, voluminous basaltic-andesite lavas erupted in 
rapid succession building up a thick, monotonous pile, leaving little time for cooling and fragmentation of the upper flow surfaces. As eruptions decreased in volume and intensity the lavas were channeled into bifurcating tubes. This allowed greater time for contact of upper flow surfaces with the overlying seawater. Cooling of the lava resulted in fracturing and incorporation of seawater by the flows. Rapid expansion of the superheated seawater caused brecciation and the formation of overlying hyaloclastite.

The vertical facies changes within the Rusty Ridge formation are important in that the distribution of hydrothermal alteration and sulfidation of the deposit's hangingwall strata are strongly controlled by primary permeability of the andesitic succession.

\subsection{INTRUSIVE ROCKS}

The host rocks to the Ansil deposit are transected by four intrusion types. The rhyolite below the Ansil deposit is intruded by irregular-shaped, plagioclase glomeroporphyritic felsic dykes. Mafic intrusions similar in composition to the Rusty Ridge formation are cross-cut by rhyolitic dykes related to the Lower Amulet formation (Barrett et al., 1991). The three sets of synvolcanic dykes are cross-cut by early syn-kinematic, plagioclase porphyry mafic dykes.

\subsubsection{Mafic dykes}

A dark green, aphanitic basaltic dyke up to $8 \mathrm{~m}$ wide intermittently follows the rhyoliteandesite contact along the plunge length of the orebody. It intrudes the rhyolite as a sill- 
like body several metres below the rhyolite-andesite contact below the western half of the orebody. Between Levels 7 and 8 it takes a right angle turn to 3300 just below the deposit's flank. At this point several (<1 m thick) mafic dykes appear parallel to $330^{\circ}$. The mafic dyke was not observed until Sublevel 9B, where it reappears in the immediate hangingwall of the deposit as faulted segments. Between Sublevel 9C and Level 10 the dyke crosses the orebody to intrude the rhyolite, where it remains along the east end of the orebody.

\subsubsection{Rhyolitic dykes}

Two types of felsic dyke occur within the Ansil strata. Directly below the massive sulfide lens are several plagioclase, glomeroporphyritic dykes whose original size and dimensions are obscured by overprinting silicification and chlorite alteration. The largest is exposed in the ore passes on levels $7 \mathrm{~B}, 8$ and $8 \mathrm{~A}$, and has an irregular shape, with a width of up to $5 \mathrm{~m}$. Smaller segments of this dyke-type are within the strongly chloritized rhyolite directly under the orebody. These dykes have not been identified elsewhere in the vicinity of the Ansil deposit, although similar dykes occur within the Amulet rhyolite $(\mathrm{H}$. Gibson, pers comm.). The dykes are aphanitic, with $10 \%$ plagioclase phenocryst aggregates up to 3 $\mathrm{cm}$ in diameter. Where the dykes are silicified the plagioclase aggregates blend into the groundmass, but when strongly chloritized, they become prominent as white domains against a dark green groundmass. 
The second type of rhyolite dyke is aphyric, light to dark grey, and up to $10 \mathrm{~m}$ wide. It transects the rhyolite-andesite contact at a high angle along the south margin of the Ansil orebody. It is commonly flow-banded at the contacts and has spherulitic margins. Flow banding is in places strongly contorted, and where it transects the Cranston tuff the bedding in the volcaniclastic rock is folded and contorted. Both of these features would suggest that the dyke was emplaced at a high level in the volcanic pile at a time when the Cranston tuff was not fully consolidated. The dyke can be distinguished from the surrounding rhyolite flows by its lack of alteration and devitrified texture

The aphyric felsic dyke is thickest within the rhyolite, thinning to under $5 \mathrm{~m}$ where it crosses into the overlying andesitic flows. From the centre of the orebody to its eastern end the dyke tends to parallel the massive sulfide-andesite contact. At the north end of the deposit an apophyse strikes off into the andesite at a high angle to bedding. Where the dyke follows the massive sulfide-andesite contact it is less than $2 \mathrm{~m}$ thick, with strongly sheared margins.

\subsubsection{Plagioclase porphyry mafic dykes}

Light grey, fine-grained, plagioclase-porphyritic mafic dykes with 5 to $7 \%$ white, euhedral plagioclase phenocrysts to $3 \mathrm{~mm}$ are observed on most of the mine levels. Examination of diamond drill logs from the Ansil area show that the dykes appear approximately $200 \mathrm{~m}$ below the deposit, increase in abundance towards the rhyoliteandesite contact, and then diminish in numbers and size up-section for about $300 \mathrm{~m}$, and 
then disappear. A 2 to $3 \mathrm{~m}$ wide dyke commonly parallels the contact within $30 \mathrm{~m}$ of the upper surface of the rhyolite. Numerous smaller dykes form conjugate northwest-northeast striking swarms that cross-cut the massive sulfide lens at its north and south ends, sometimes linking to a 0.5 to $1 \mathrm{~m}$ wide dyke the intrudes the andesite parallel to bedding. The dykes have thin chilled margins and sharp, high angle contacts with the surrounding strata, indicating intrusion along brittle fractures. Where the dykes transect the massive sulfide lens they are strongly folded and boudinaged.

The strong structural control on the dyke distribution, intrusion along brittle fractures, and subsequent ductile deformation within the orebody indicates dyke emplacement within a directional stress field in which the strata were being subjected to brittle deformation, followed by ductile deformation in a higher PT tectono-metamorphic environment. This suggests emplacement early in the tectono-metamorphic history of the region.

\subsection{SYNVOLCANIC FAULTS}

Synvolcanic faulting that took place during formation of the Noranda cauldron was an important control in the deposition of volcanic formations, distribution of stratigraphic facies and in channeling hydrothermal fluids that formed the volcanic-hosted massive sulfide deposits (Gibson, 1989). There is abundant evidence within the host strata to the Ansil deposit that synvolcanic faulting played a dominant role in volcanic and hydrothermal history of the area. Northwest-. trending faults were interpreted by Gibson (1989) to control unit contacts between Rusty Ridge andesite flows outcropping $1000 \mathrm{~m}$ to the 
northwest of the Ansil deposit. East-west cross-sections (Riverin et al., 1990) of the Ansil deposit indicated that the paleosurface upon which the massive sulfide lens rested followed a number of step-like drops from west to east (Riverin et al., 1990). These were believed to be manifestations of the northwest-striking synvolcanic fault system recognized earlier on surface. It was postulated that the deposit formed as mounds along two fault steps, connected by thinner sulfide accumulations. Riverin et al. (1990) further postulated that these faults also controlled the distribution of the sulfide/magnetite vein system below the deposit, and were therefore a major control on synvolcanic hydrothermal fluid flow

A linear zone striking 090 to $110^{\circ}$ was recognized during the Ansil exploration drill program through the distribution of Na-depleted strata. The alteration zone forms a corridor over $2000 \mathrm{~m}$ long and averaging $200 \mathrm{~m}$ wide from the Flavrian Pluton contact east to several hundred metres beyond the Ansil deposit. In the immediate vicinity of the Ansil deposit evidence indicates that this east-west trending alteration zone is a manifestation of a fault system that hosts the orebody. This evidence includes:

(1) Dislocation of the upper Northwest rhyolite contact immediately north and south of the orebody. Along the northern flank of the orebody the rhyolite contact is offset $30 \mathrm{~m}$ to the west to form the northern edge of the $150 \mathrm{~m}$ wide basin in which there is a thick accumulation of rhyolite hyaloclastite. The basin is bordered to the south by a large rhyolite lobe that extends for over $200 \mathrm{~m}$ along the south side of the orebody. South of the flow lobe is another westerly jog in the upper rhyolite contact, marking another dislocation along this east-west fault scarp. 
(2) The phreatic breccia zones that disrupt the upper surfaces of the Northwest rhyolite and Ansil dacite are distributed along the north and south margins of the orebody, and mark the boundaries to the deposit-hosting basin. It is probable that this explosive phreatic activity was fault controlled.

(3) The distribution of the coarse- and fine-grained facies of the Cranston tuff indicates the presence of two east-southeast trending depressions in the upper surface of the Northwest rhyolite, one containing the Ansil deposit (Figure 3.36). The overall trend of the Cranston mass flow, and of another small accumulation of Cranston tuff southeast of the deposit would suggest a strong northeast linear control of sedimentation.

(4) The large rhyolitic dyke located in the footwall to the Ansil deposit lies along its southern margin, cross-cutting strata at a high angle. The spatial relationship between the dyke, a zone of phreatic brecciation of the rhyolite flows, and abrupt dislocation of the upper rhyolite contact implies that the dyke intruded along a pre-existing fault zone during later volcanic activity.

The restriction of the regional zone of $\mathrm{Na}$ depletion to within the easterly striking fault zone, and the fact that the Ansil orebody is confined by the margins of this zone indicates that synvolcanic faulting played a major role in the migration of hydrothermal fluids and deposition of massive sulfide deposits. The restriction of an orebody to a specific site along a fault system is commonly the result of cross-faulting, where the intersection between faults results in a zone of dilation, thereby allowing hydrothermal fluids to escape to the seafloor (Lydon and Galley, 1986). The plunge of the vein stockwork zone below the 
deposit may therefore represent this intersection. Assuming that the east-striking fault system has a major influence on hydrothermal fluid migration, the vein stockwork must lie on this fault plane (Figure 3.49). The vein stockwork trends $250^{\circ}$, plunging at $50^{\circ}$. In order to lie on the plane of the east-west fault zone, the fault plane would therefore dip south at $75^{\circ}$, and the intersecting fault would strike $340^{\circ}$, dipping $50^{\circ}$ southeast. If a $30^{\circ}$ tectonic dip on bedding is corrected for, the original fault orientations would be 090/78 and 340/76. The presence of northwesterly striking cross-faults would agree with Gibson's (1989) observations on surface; his 'Ansil Hill' fault zone may be extrapolated down dip and along strike to intersect the Ansil deposit.

\subsection{SUMMARY OF THE DEPOSITIONAL ENVIRONMENT FOR THE ANSIL DEPOSIT}

The Ansil deposit lies within a narrow east-west graben, along the southeast flank of the North Flow of the Northwest formation (Figure 3.49). Several facies of lobehyaloclastite rhyolite are present below the deposit, with a 50 to $60 \mathrm{~m}$ thick basal section of rhyolite flow lobes and subsidiary flow breccia, a thin unit of fine-grained hyaloclastite followed by 10 to $30 \mathrm{~m}$ of $60 \%$ rhyolite lobes and $40 \%$ flow breccia. This is followed by another thin unit of fine-grained hyaloclastite, and then 80 to $100 \mathrm{~m}$ of $50 \%$ hyaloclastite, $30 \%$ rhyolite flow lobes and $20 \%$ flow breccia. The transition upsection from flow- to volcaniclastic-rich facies indicates a decrease in eruption rate and volume with time. 
The basin containing the Ansil deposit is partly infilled with up to $25 \mathrm{~m}$ of fine-grained rhyolite hyaloclastite, phreatic breccia talus, lobe-hyaloclastite dacitic flows at its east end, and up to $20 \mathrm{~m}$ of Cranston tuff. The Cranston tuff is the distal facies of a mass flow originating at the Cranston QFP dome $2000 \mathrm{~m}$ to the north; it is host to the Ansil deposit. The upper, laminated facies of the Cranston tuff contains an increasing abundance of mafic shards towards the top of the unit, evidence for the commencement of andesite fissure eruptions responsible for the emplacement of the overlying Rusty Ridge formation.

The andesitic flows of the Rusty Ridge formation bank up against the North Flow rhyolite ridge with individual flow contacts at an acute angle to the underlying formation. The basal flows are massive to slightly amygdaloidal, aphyric to plagioclase-porphyritic, with a small percentage of pillowed flows and interflow sediment. Halfway along the plunge length of the Ansil deposit the Rusty Ridge andesite is more pillowed with abundant flow breccia, amoeboid pillow breccia and thin, laminated tuff horizons.

The narrow basin containing the Ansil deposit is constrained by an easterly striking fault system that generated steeply south-dipping fault scarps near the south termination of the North Flow rhyolite ridge. The Ansil deposit developed within a part of the fault system where it is intersected by a southeast striking fault zone identified on surface at 'Ansil Hill' and extrapolated down to the deposit. This setting compares favourably with that described for the generation of massive sulfide deposits within oceanic spreading ridge systems. Abundant diffuse hydrothermal discharge takes place along the length of an axial rift, resulting in widespread, patchy alteration of the basaltic flows. Focused hydrothermal 
discharge takes place at intervals along the rift where the floor has been fractured, commonly by extensional faults crossing the axial valley at high angles. Examples of this are documented along the Juan de Fuca Ridge at Megaplume and Gorda Ridge (Koski et al, 1993; Rona and Clague, 1988). 


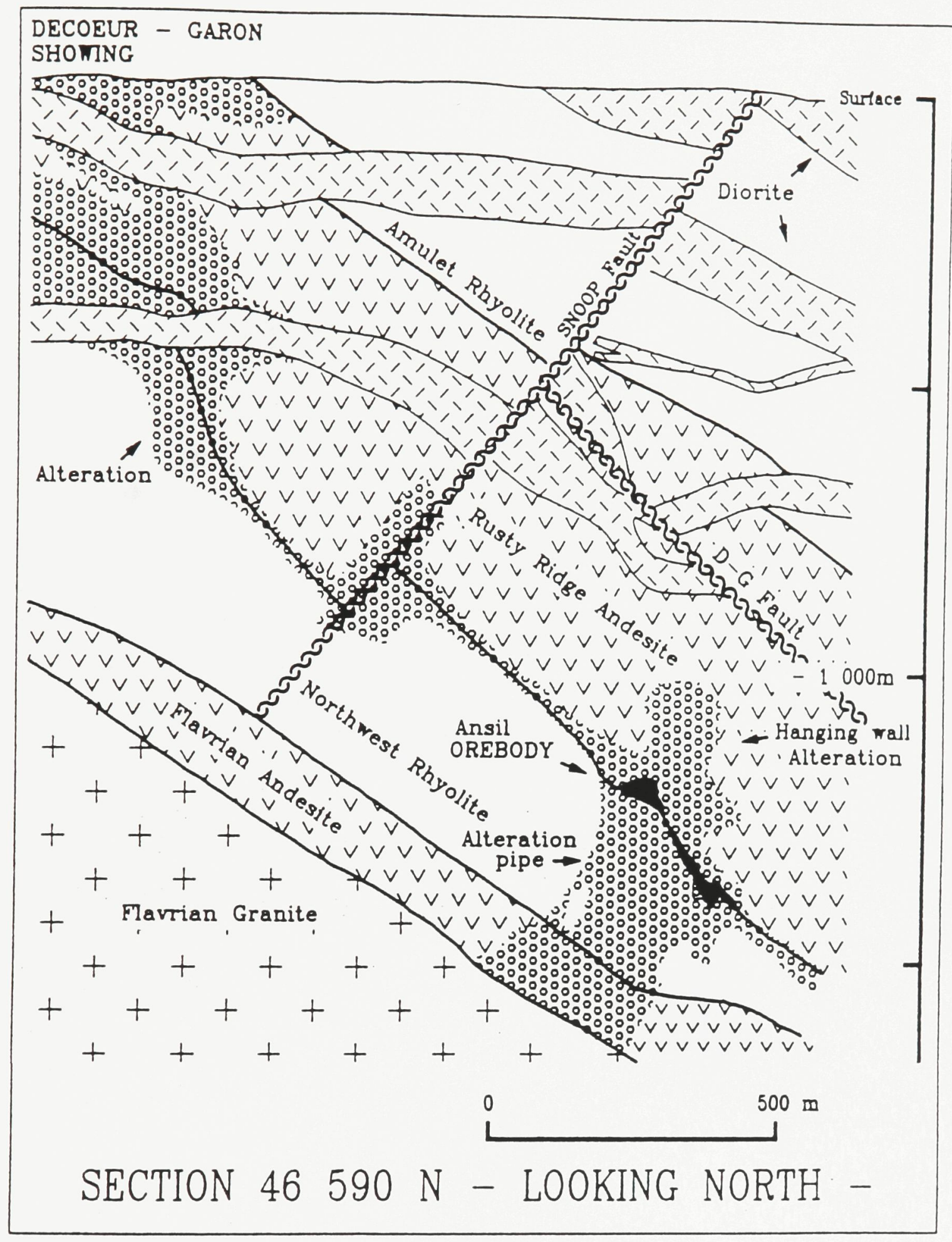

Figure 3.1. East-west section through the host stratigraphy to the Ansil deposit (from Riverin et al., 1990). 


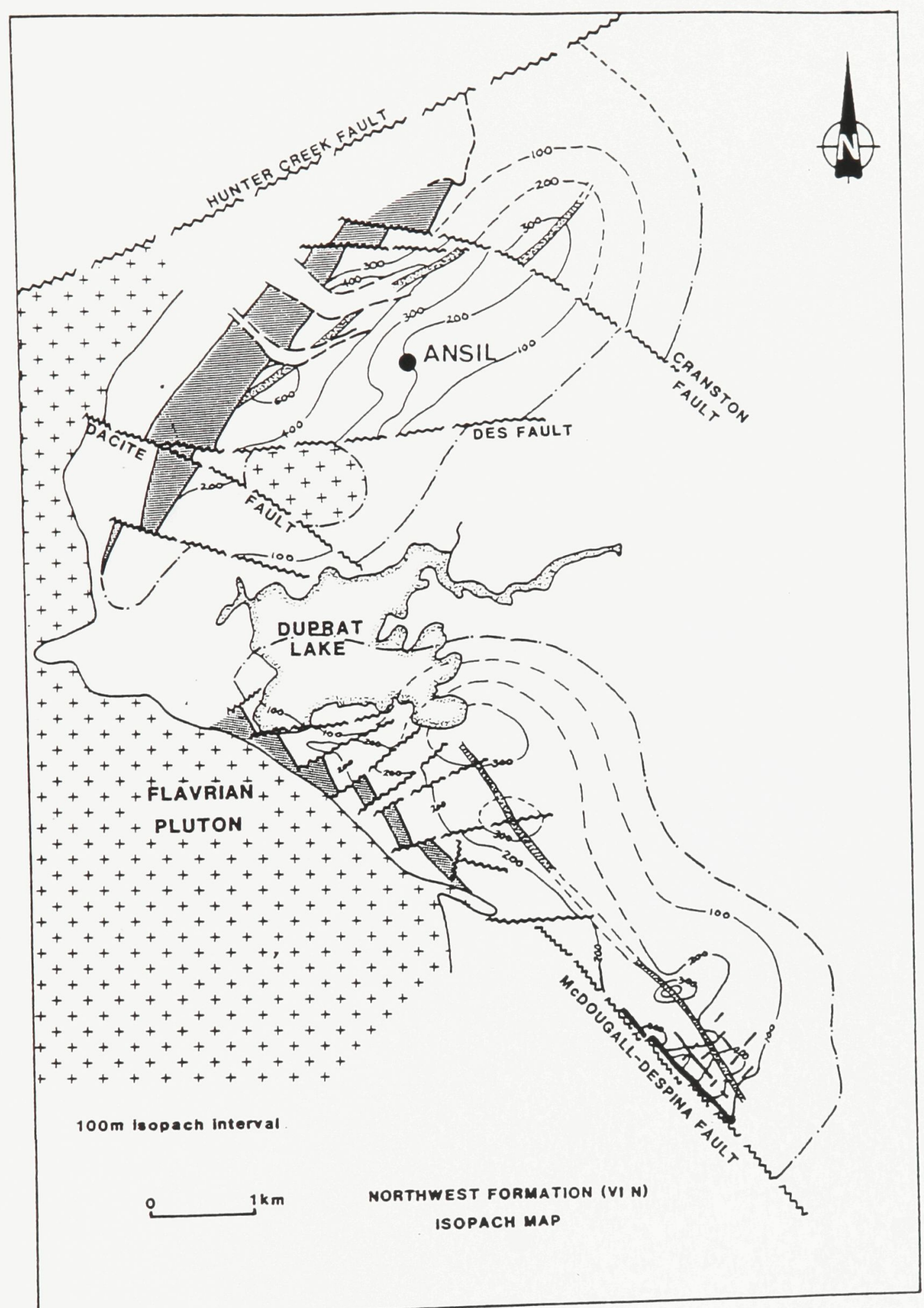

Figure 3.2. Location of the Ansil deposit on the underlying North Flow rhyolite ridge, Northwest Formation (modified from Gibson, 1989). 


\section{Figure 3.3}

A. Photomicrograph of spherulite-rich, hyalophitic, quartzo-feldspathic domain in massive rhyolite cross-cut by chlorite-filled perlitic fractures.

B. Photomicrograph of agglomerated spherulites nucleating along perlitic fractures in chlorite-rich massive rhyolite.

C. Photomicrograph of quartzo-feldspathic and chloritic domains in massive rhyolite, with the former composed of agglomerated spherulites and glomeroporphyritic plagioclase microphenocryts.

D. Photomicrograph of spherulites in chlorite-rich domain of a massive rhyolite flow. 

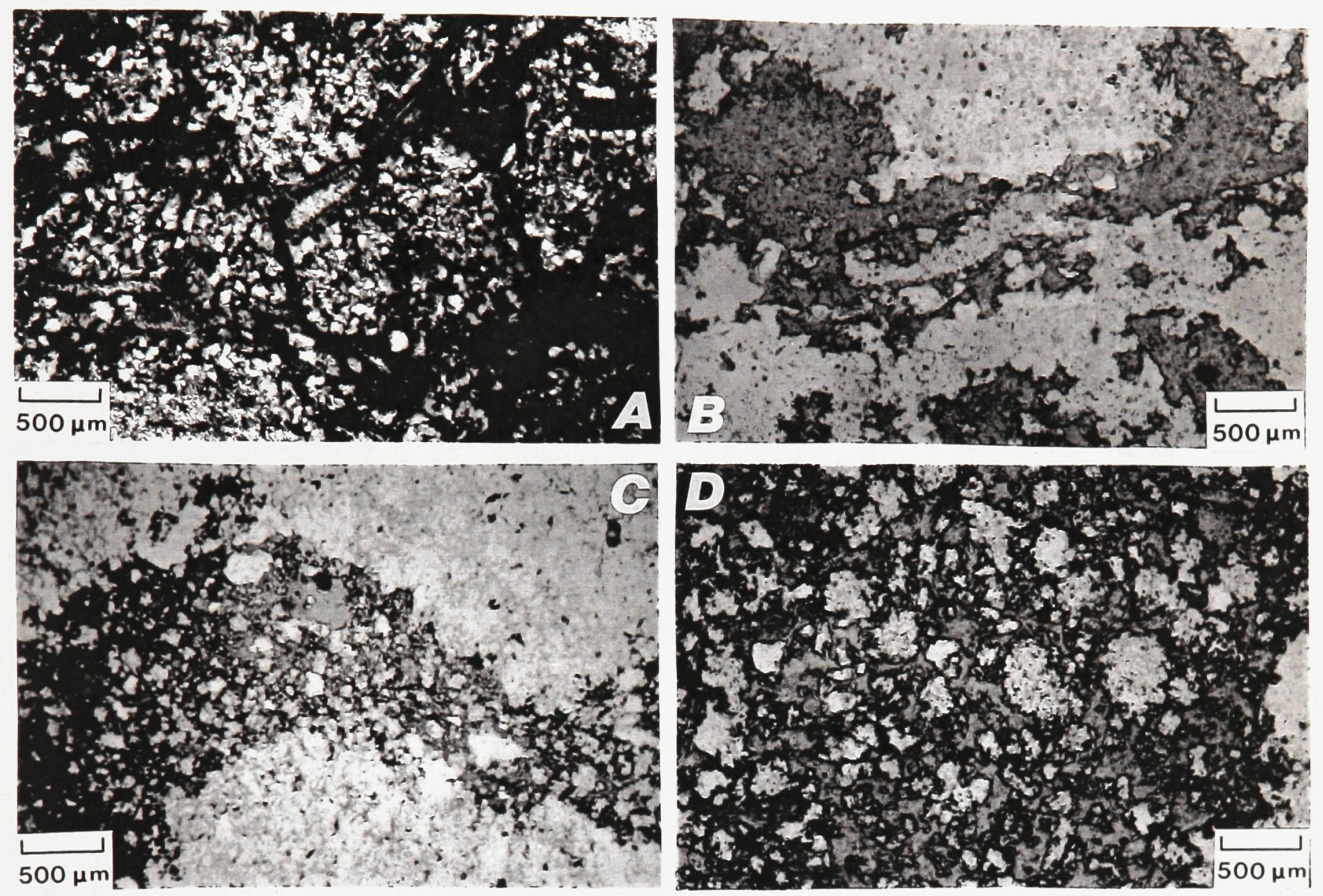


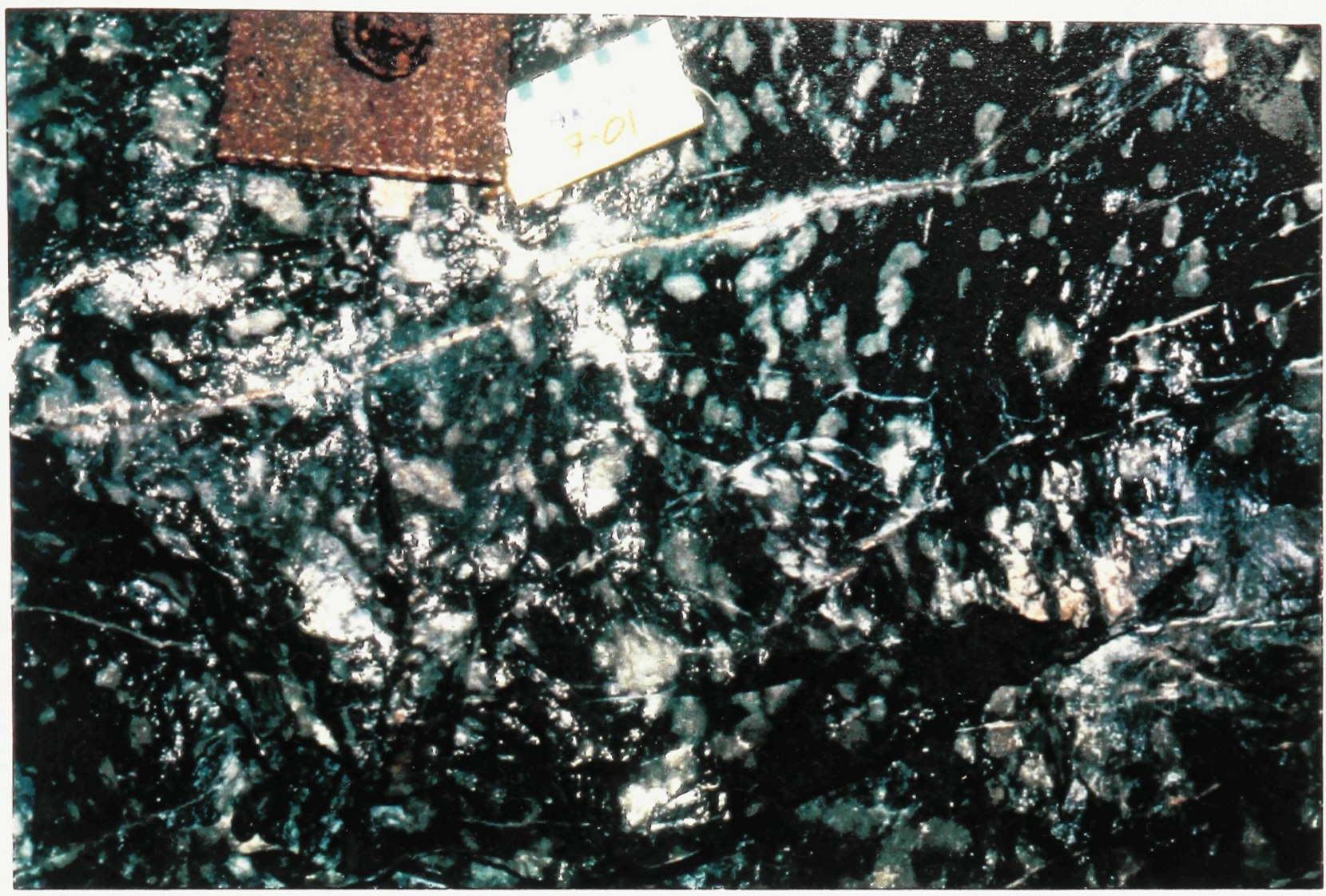

Figure 3.4 Spherulitic massive rhyolite exposed in haulage drift 7-01

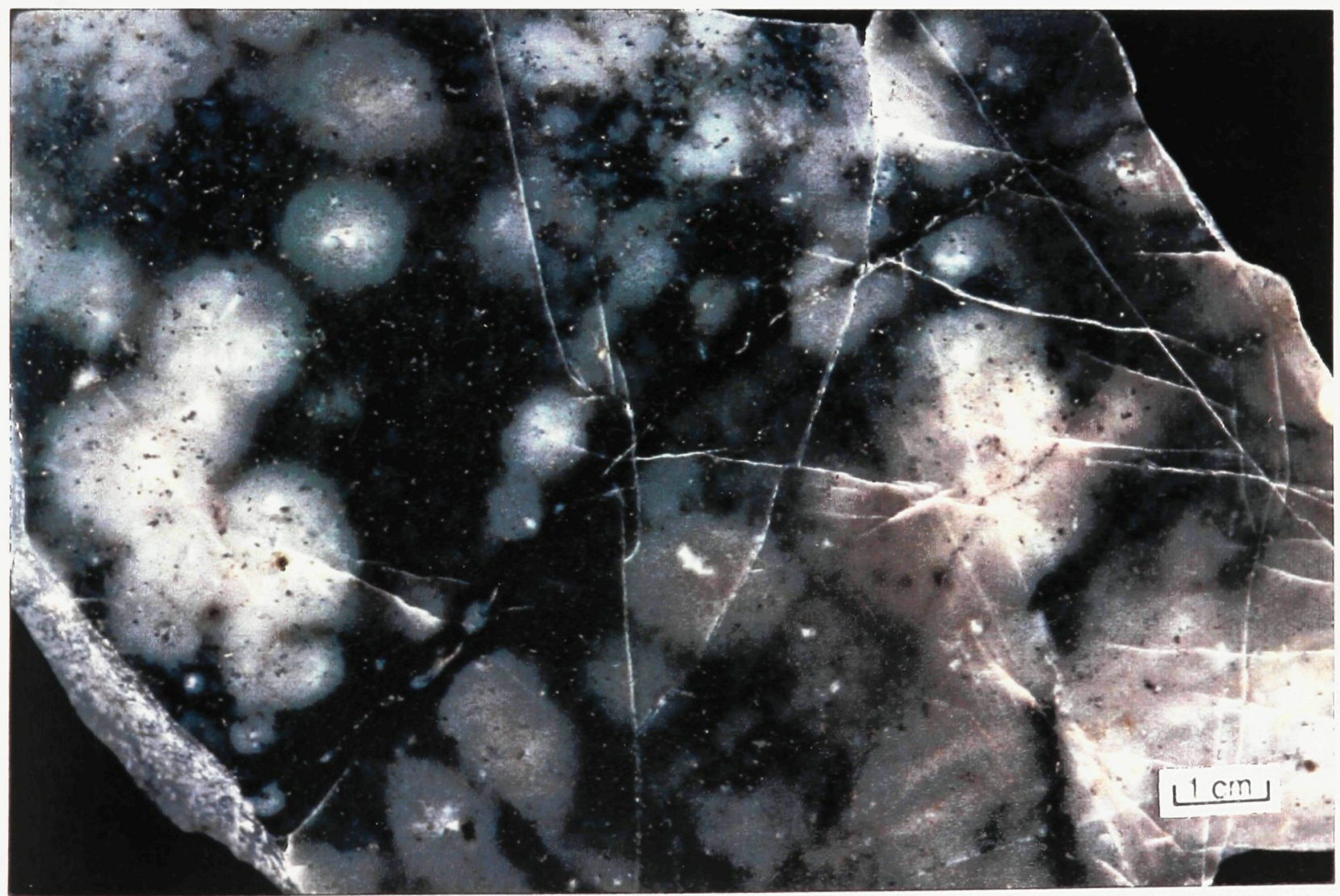

Figure 3.5 Polished slab of spherulitic massive rhyolite. Sample ANSL7B-134. 


\section{Figure 3.6}

A. Photomicrograph of elongate amygdules along rhyolite flow lobe margin, with chloritefilled centre, quartz-rich rim and spherulitic halo.

B. Photomicrograph of an altered, obsidian flow margin with abundant perlitic fracturing.

C. Photomicrograph of rhyolite flow lobe margin with devitrified borders to perlitic fractures, and moderate chlorite alteration of intervening rhyolite.

D. Photomicrograph of rhyolite flow lobe margin with pseudo-breccia texture formed from extensive devitrification of perlitic fracture margins enveloping chlorite-rich remnants of rhyolite. 

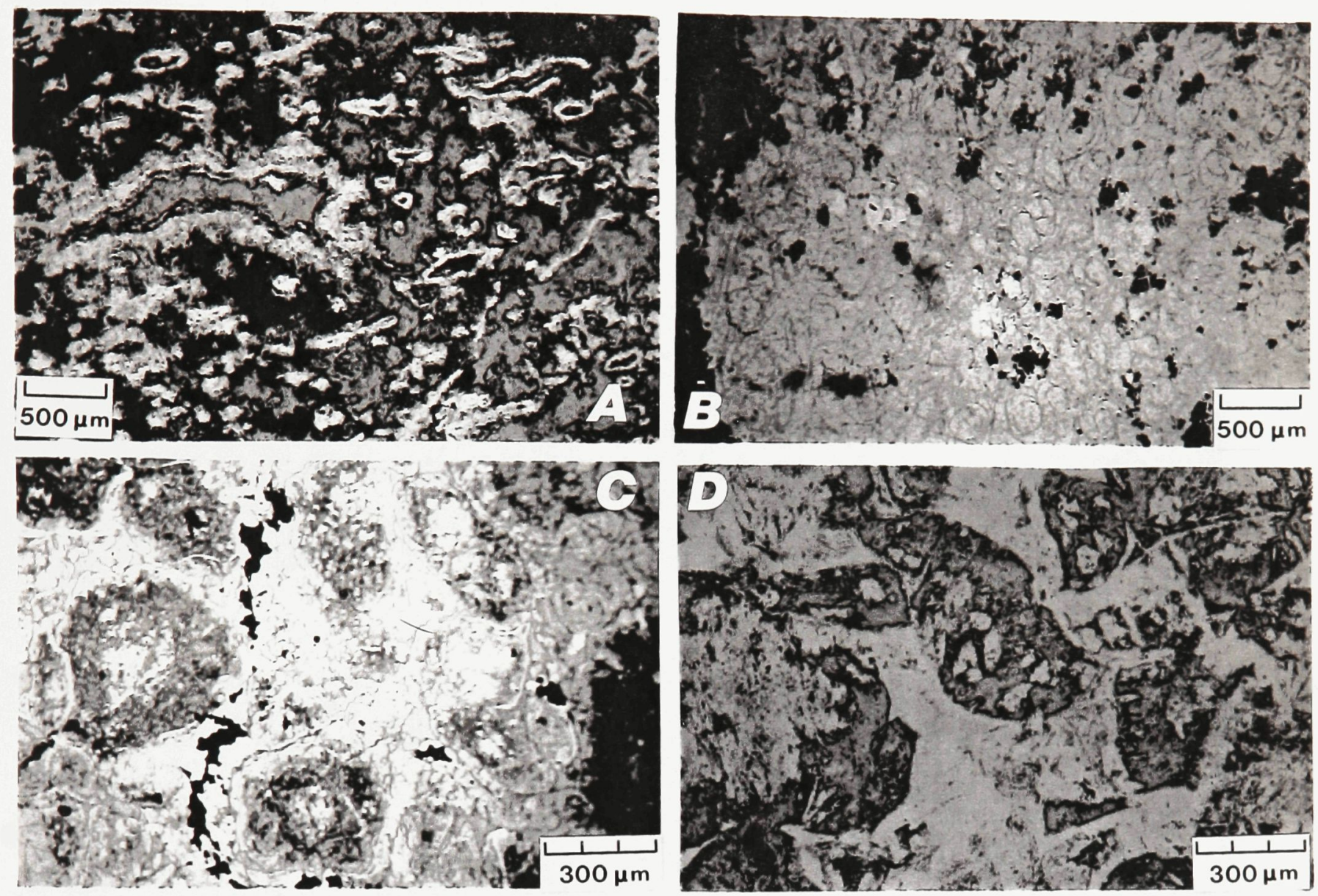


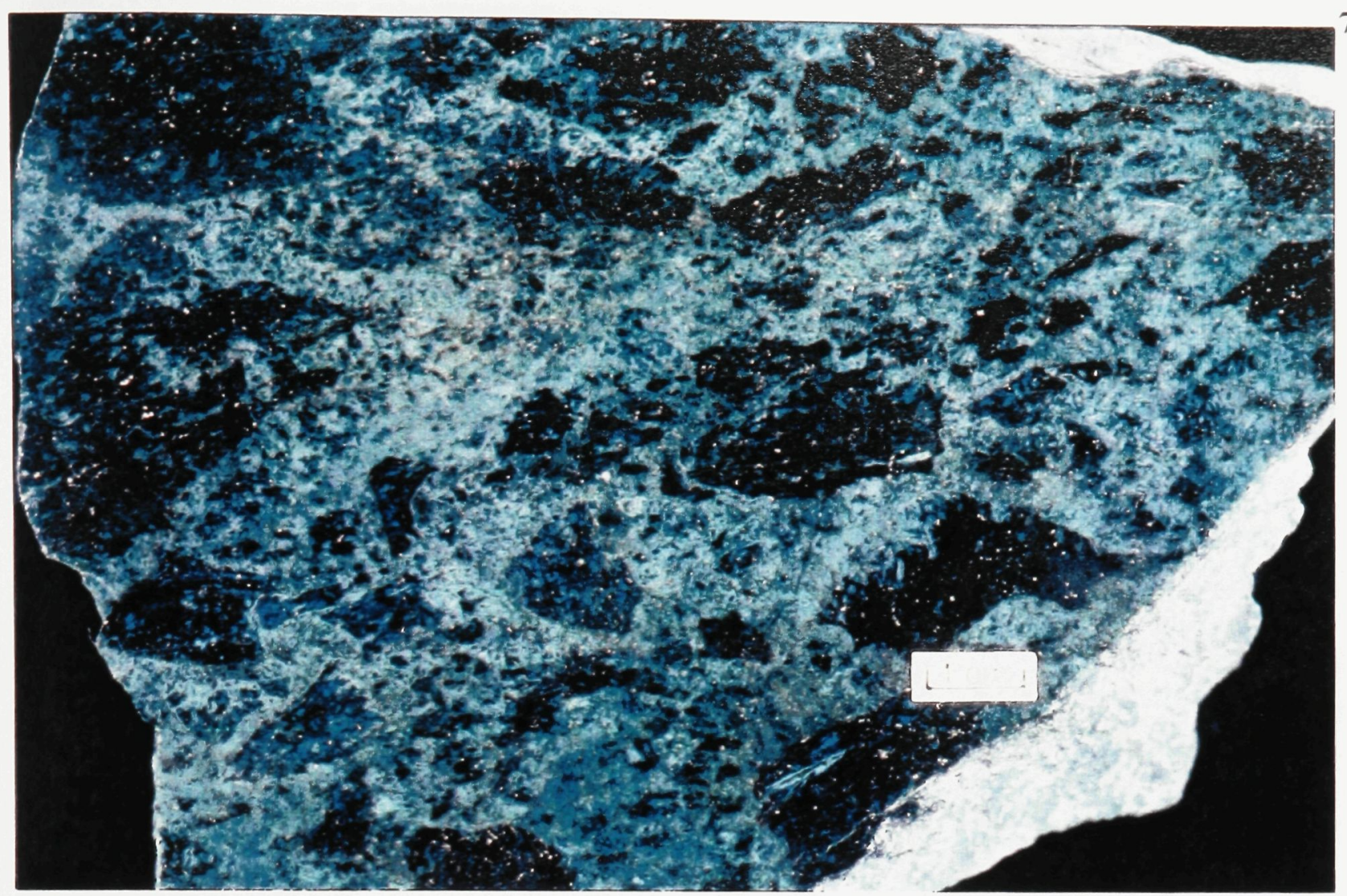

Figure 3.7 Polished slab of rhyolite flow breccia with chlorite altered fragments in milky blue-white, spherulite-rich, hyaloclastite groundmass. Samle ANSL8A-109

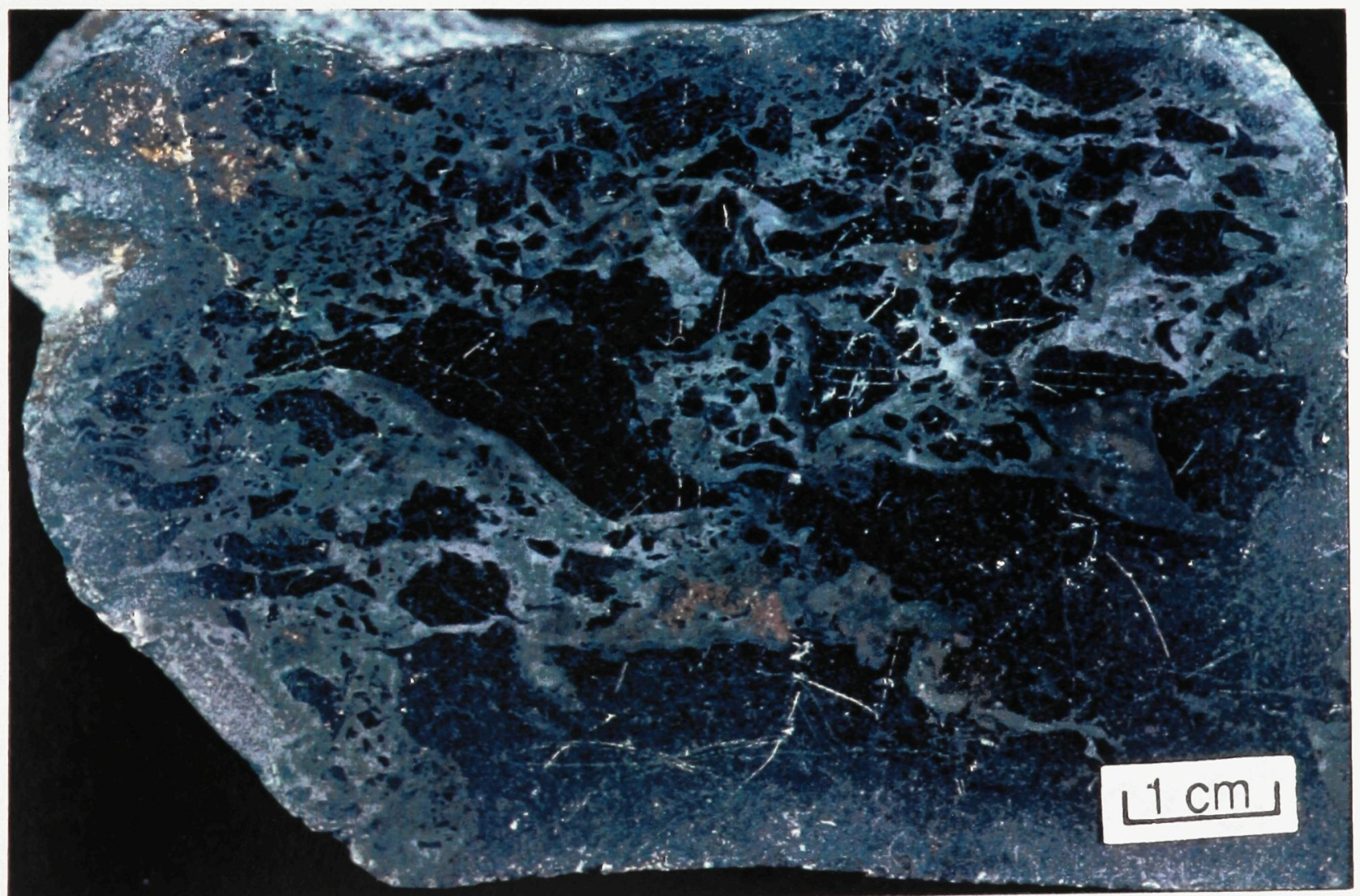

Figure 3.8 Polished slab of rhyolite flow breccia with angular, chlorite altered fragments in a devitrified, hyaloclastite-rich groundmass. Sample ANSL8-61. 


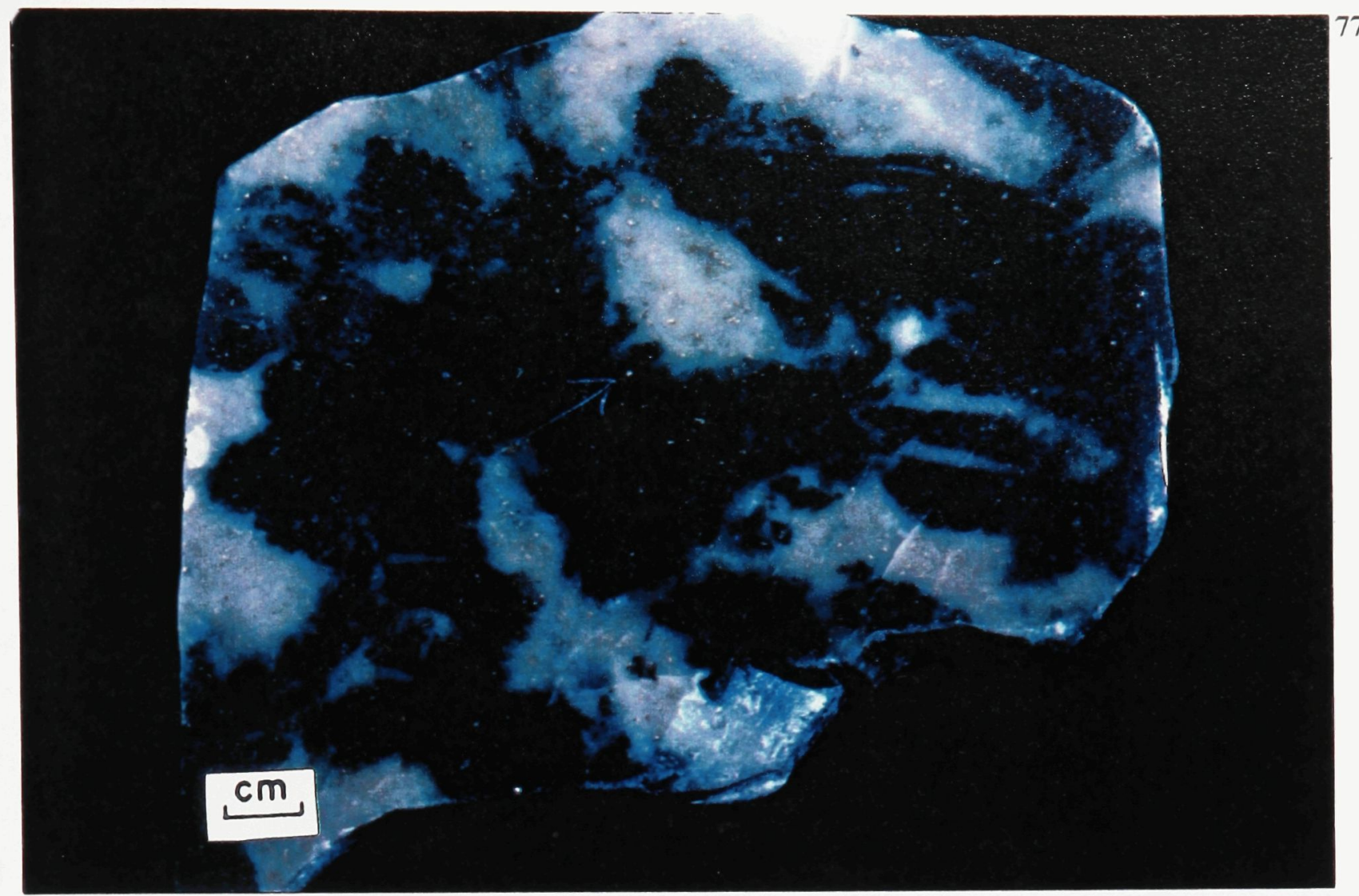

Figure 3.9 Polished slab of rhyolite flow breccia with mottled texture due to chlorite altered fragments in a devitrified, hyaloclastite-rich groundmass. Sample ANSL7B-30.

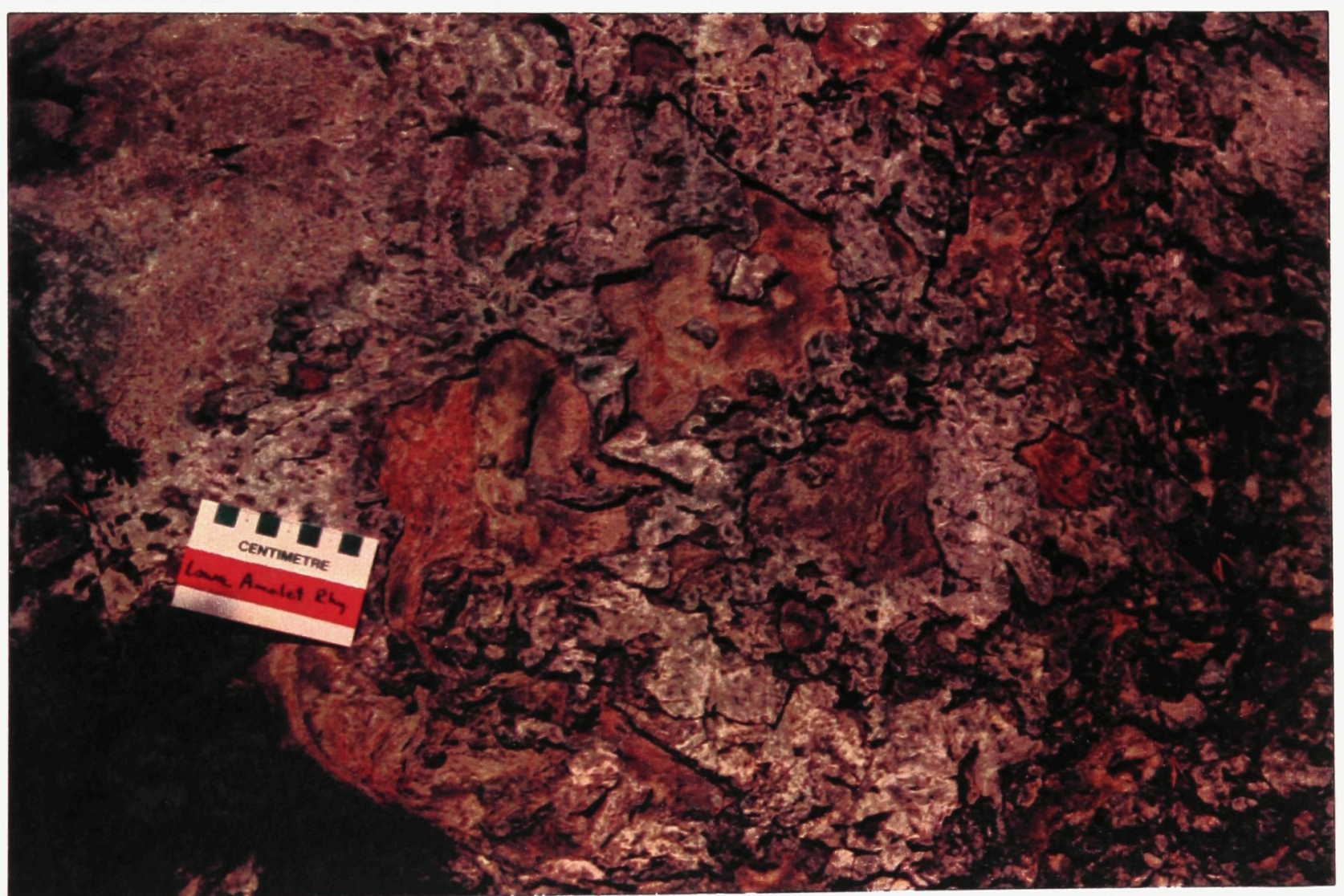

Figure 3.10 Rhyolite flow breccia from Lower Amulet Formation, with flow-banded, chlorite altered fragments in strongly devitrified matrix. For comparison with Figure 3.9 


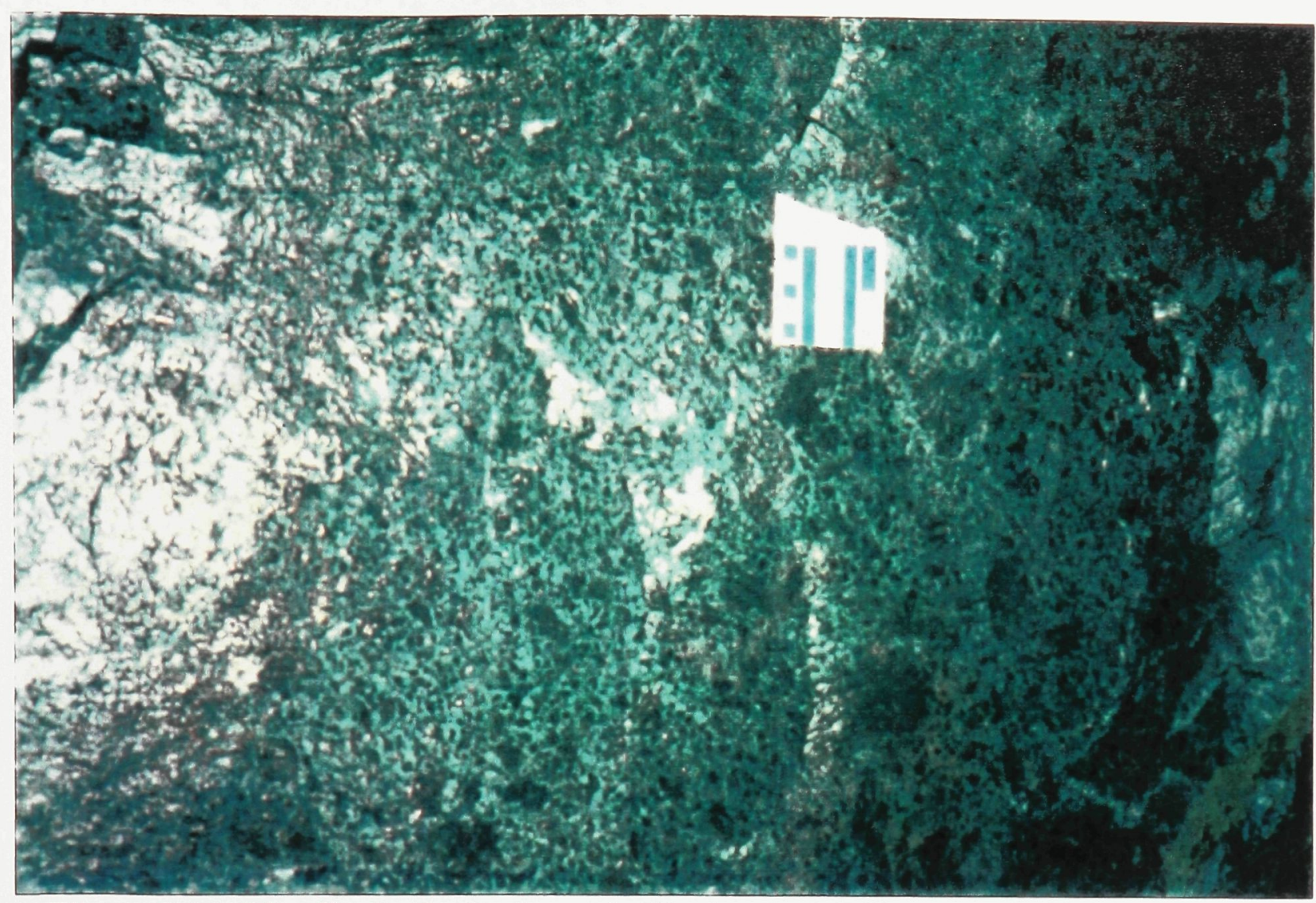

Figure 3.11 Rhyolite hyaloclastite with chlorite altered fragments in bluish-white devitrified groundmass ("blue-quartz breccia"). Haulage drift, Sublevel 8A.

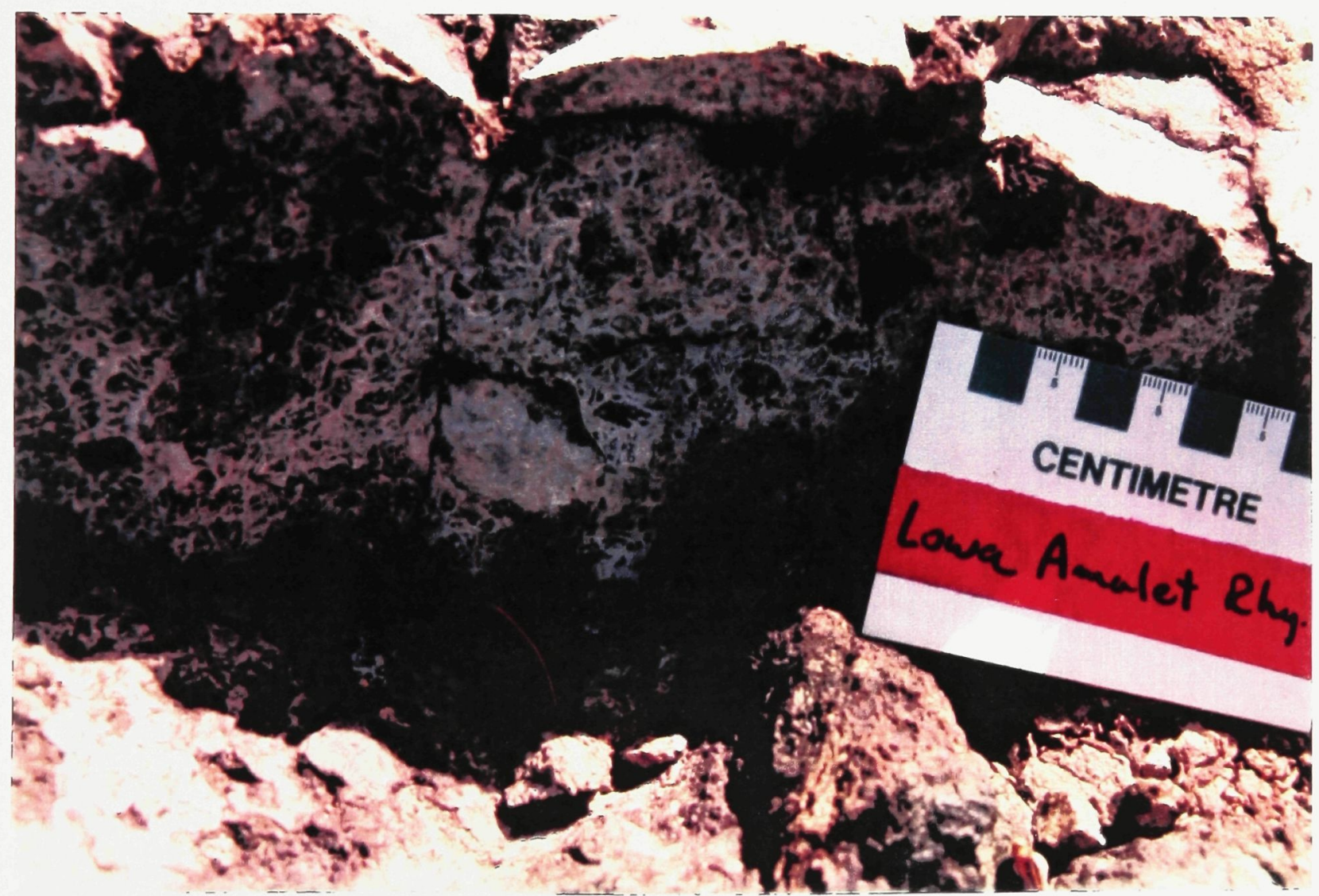

Figure 3.12 Divitrified rhyolite hyaloclastite in Lower Amulet Formation for comparison with Figure 3.11 . 


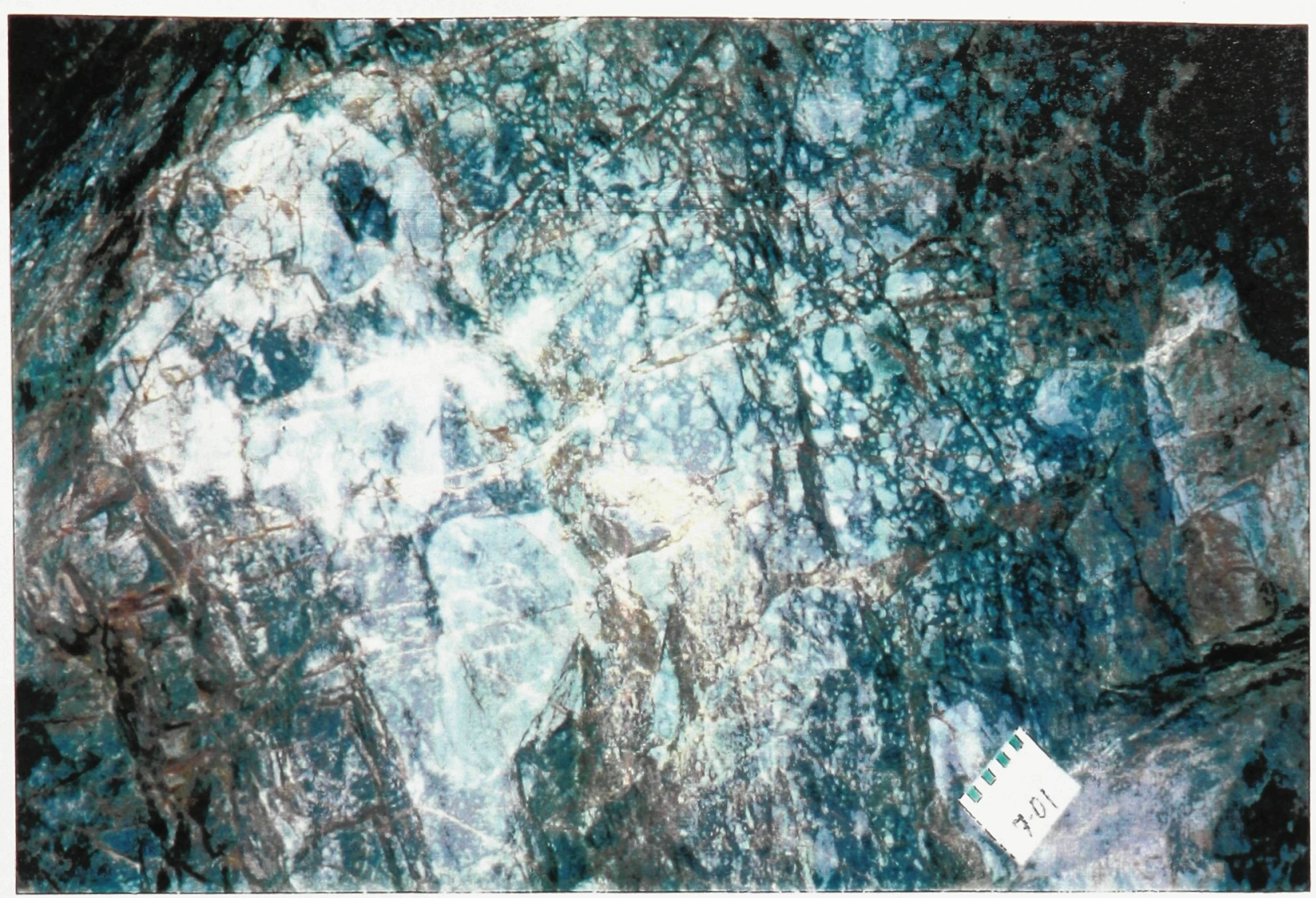

Figure 3.13 Flank breccia along the upper contact to the Northwest Formation south of the Ansil orebody. Crude normal grading towards the upper contact. Haulage drift 7-01.

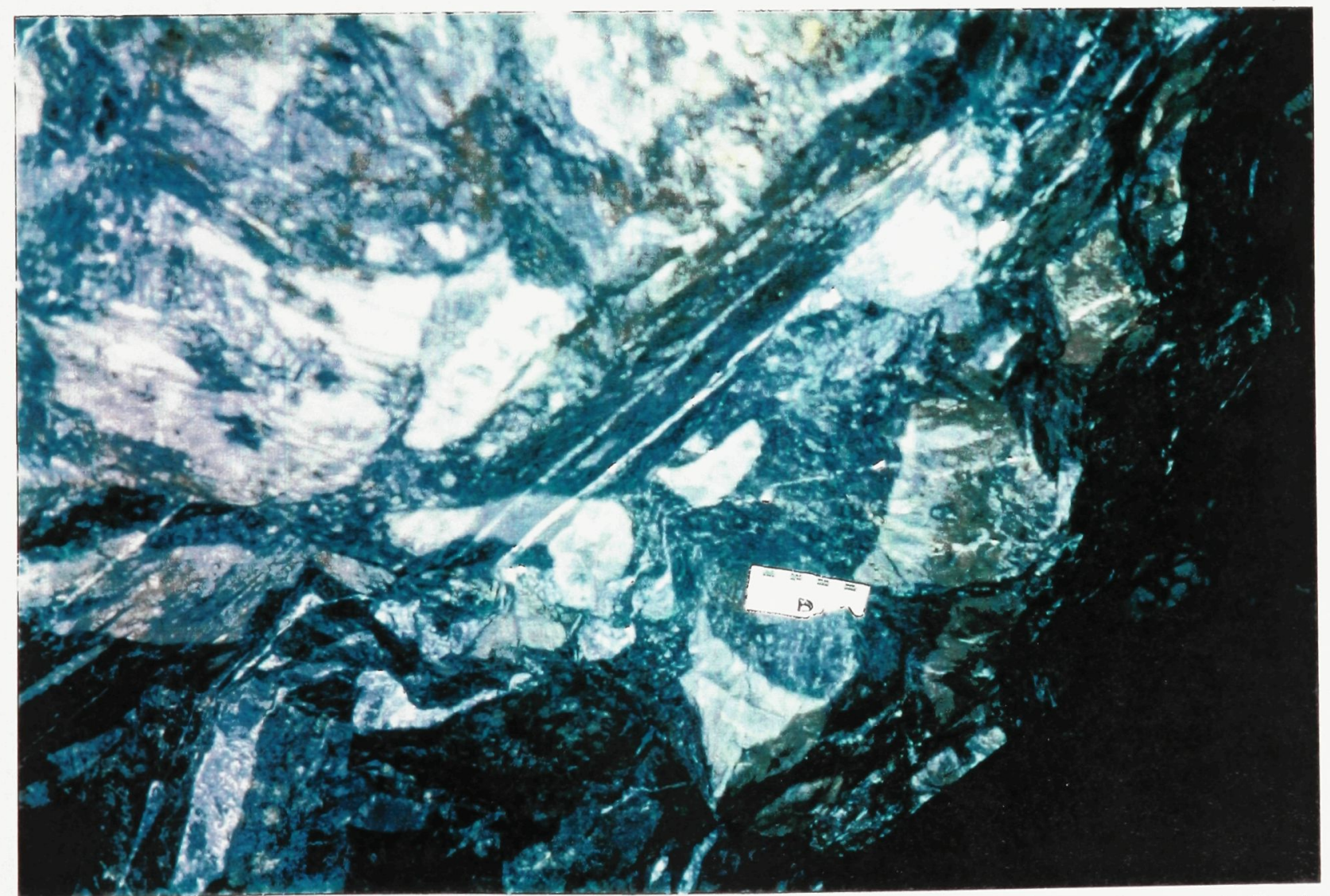

Figure 3.14 Matrix-supported rhyolite flank breccia directly underlying the south flank of the Ansil massive sulphide lens. Drawpoint \#1, Sublevel 7B. 


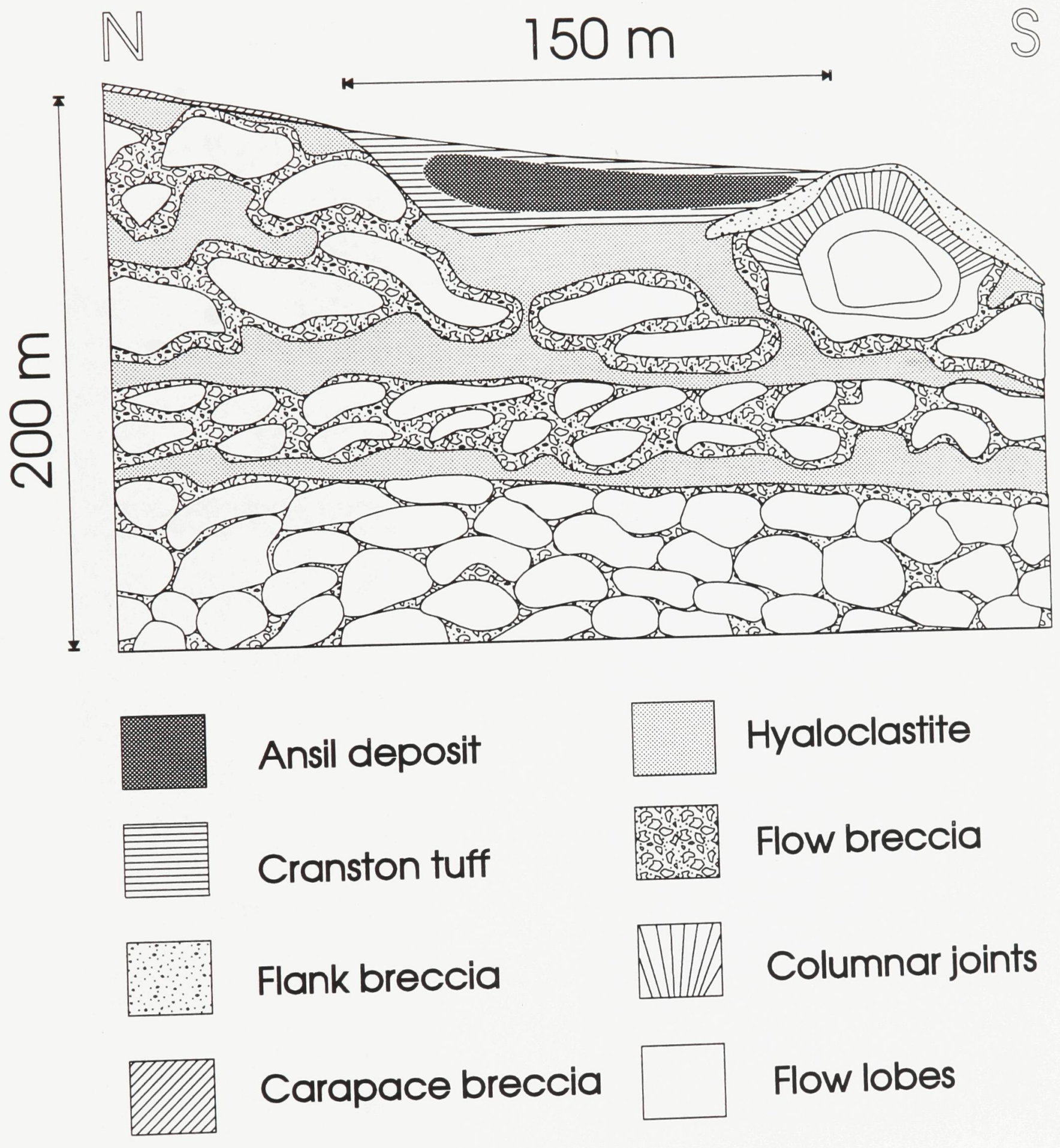
Figure 3.15 Reconstruction through a north-south section
of the North Flow rhyolite ridge below the Ansil deposit 

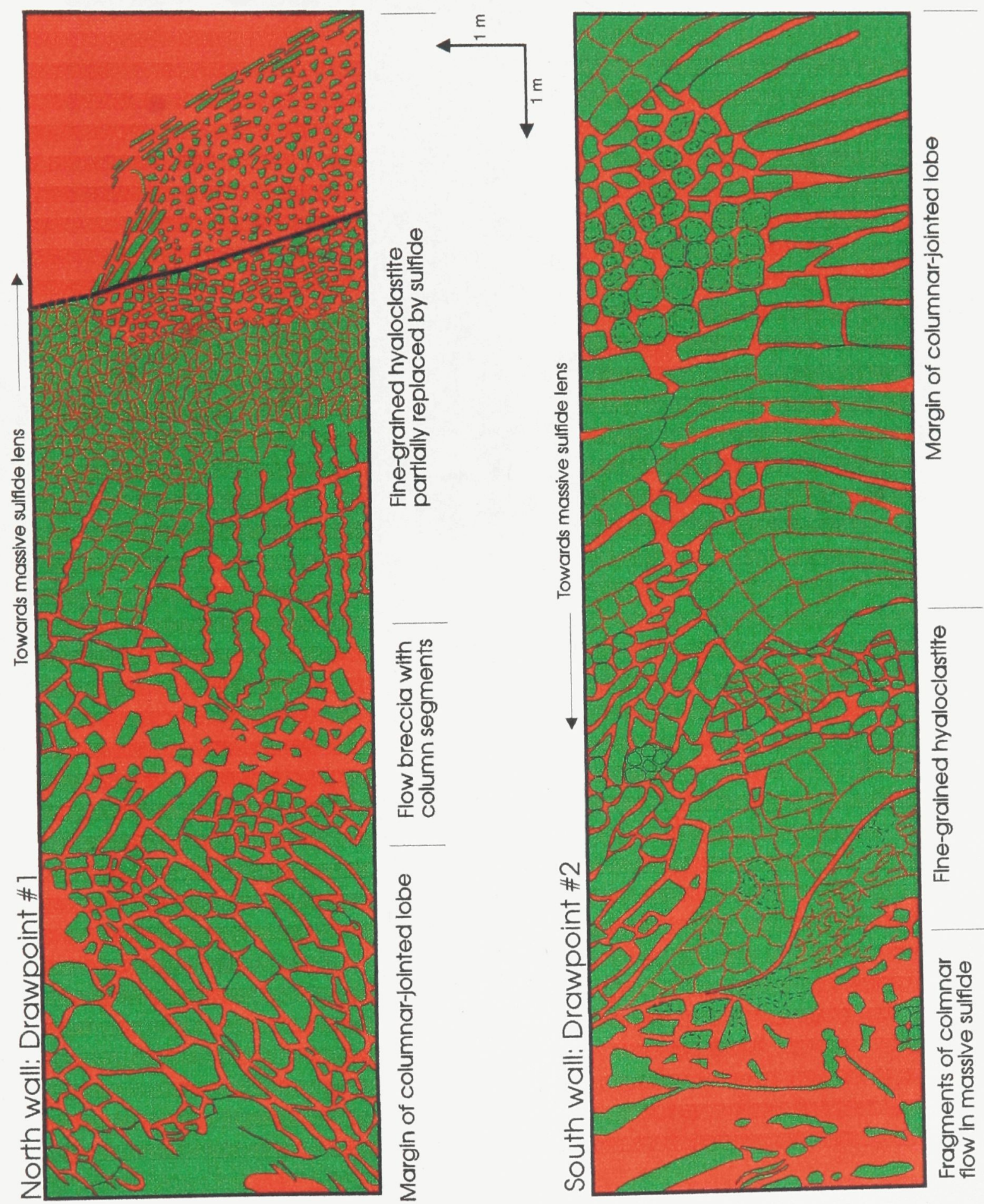

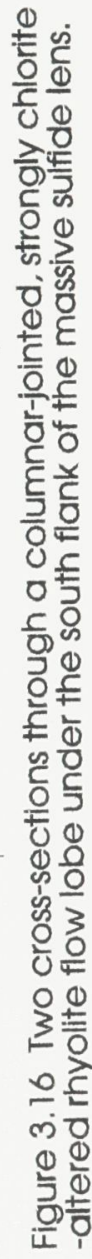




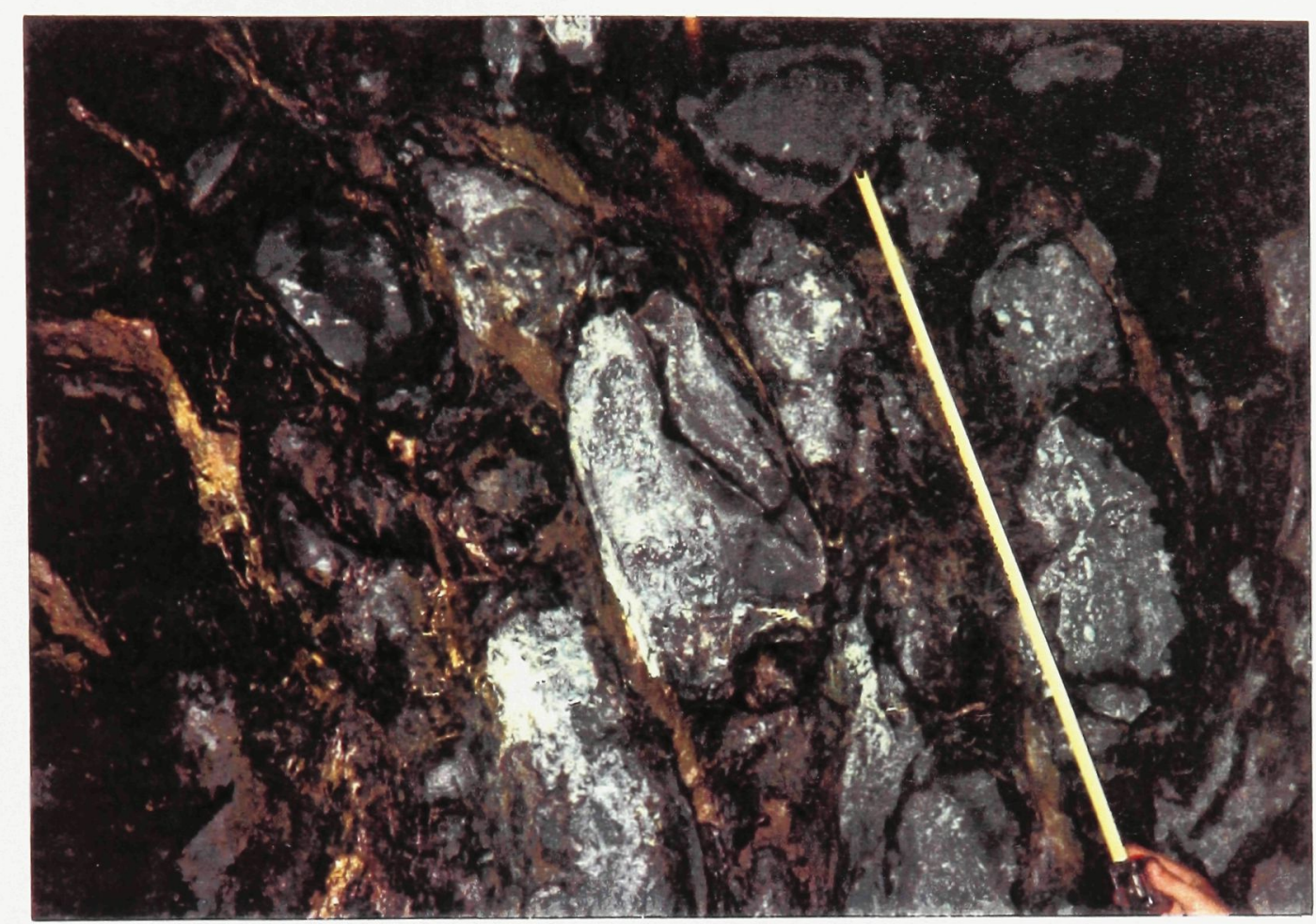

Figure 3.17 Curving, segmented columns near the upper surface of a massive rhyolite flow lobe. Drawpoint \#2, Sublevel 8A. 


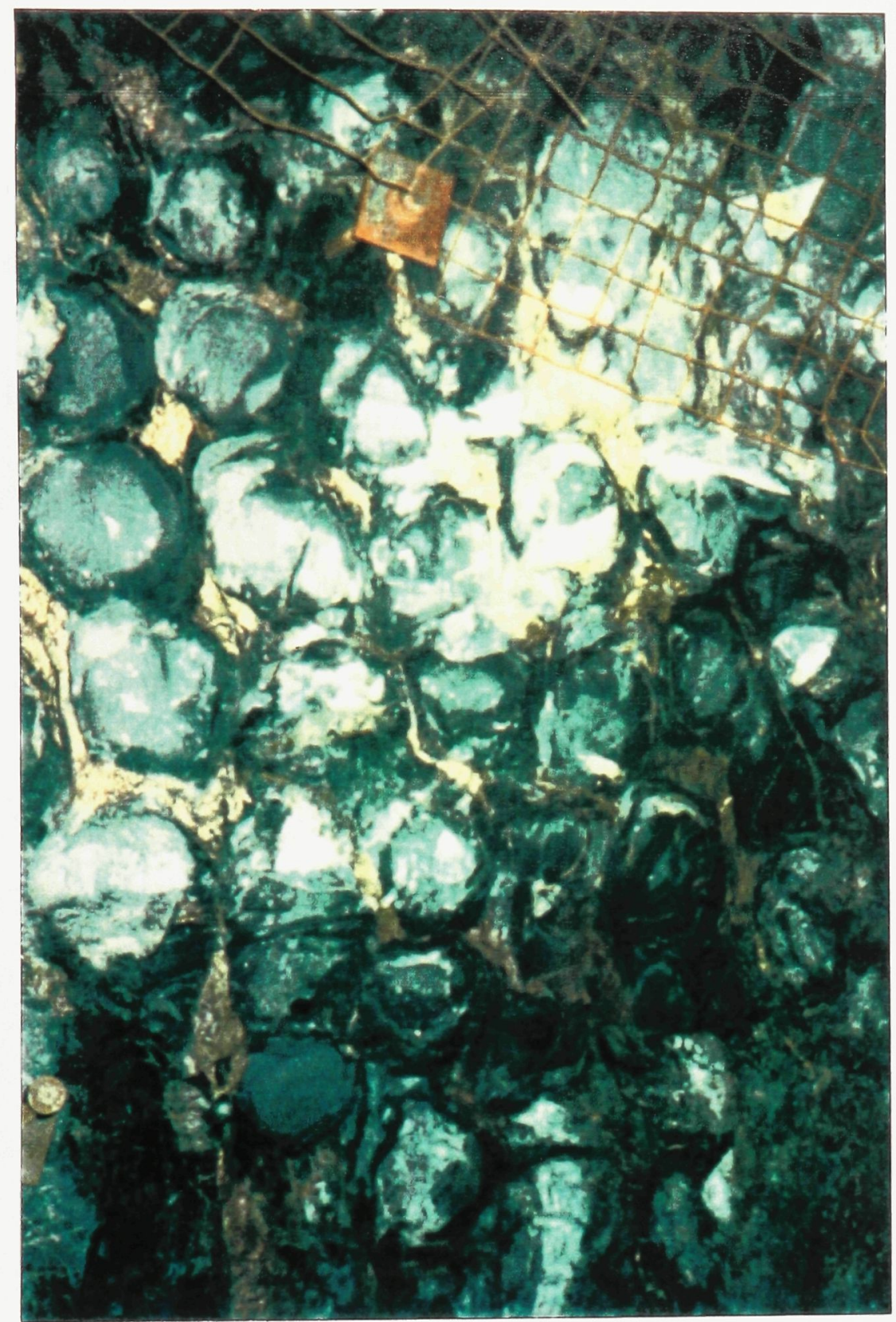

Figure 3.18 Cross-secton of columnar-jointed rhyolite flow with chalcopyrite-pyrrhotite infilled joints. Bolt plate $20 \mathrm{~cm}$ in diameter. Drawpoint \#2, Sublevel 8A. 


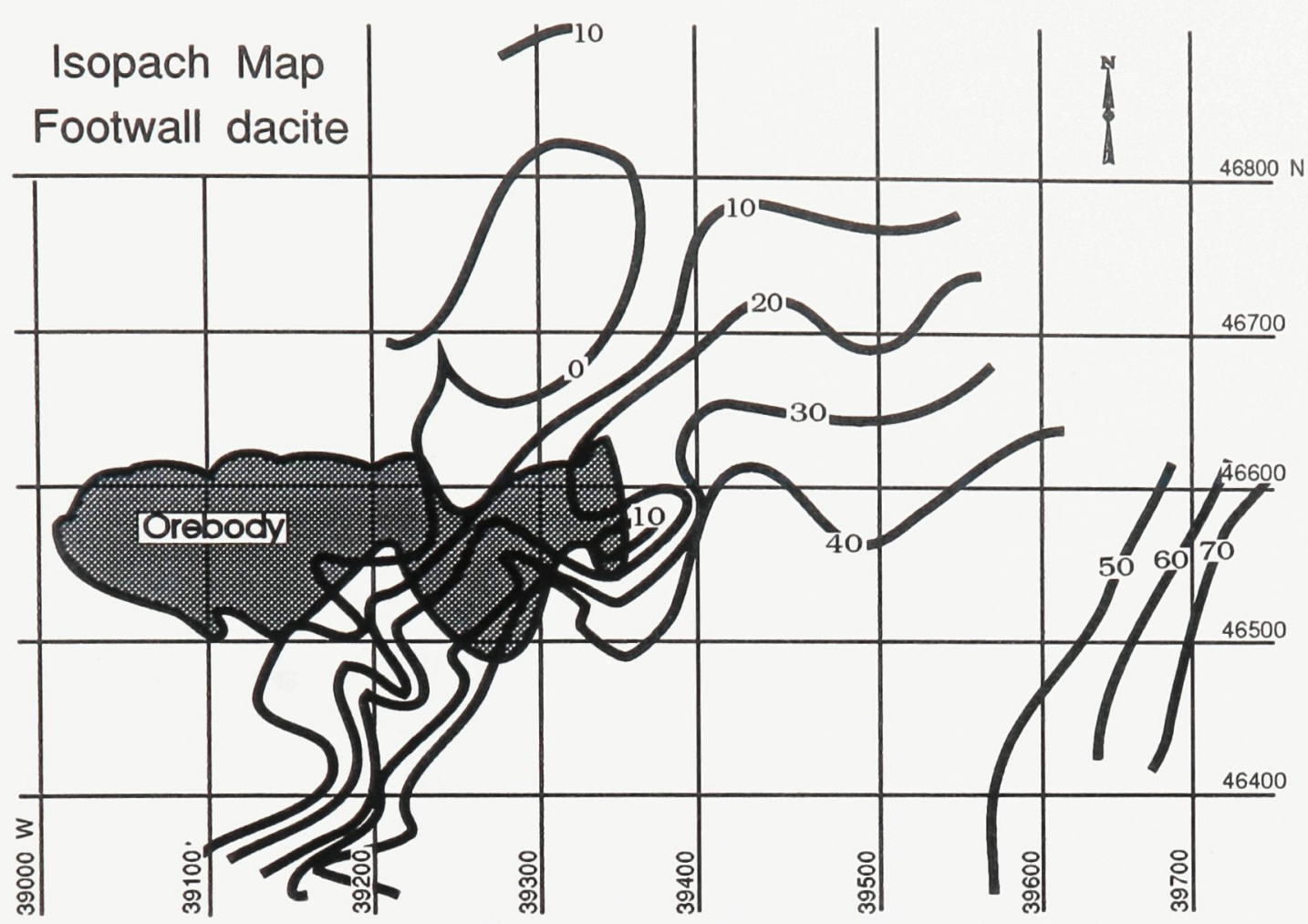

Figure 3.19 lsopach map with $10 \mathrm{~m}$ contours of the daclte flows In the vicinity of the Ansil deposit

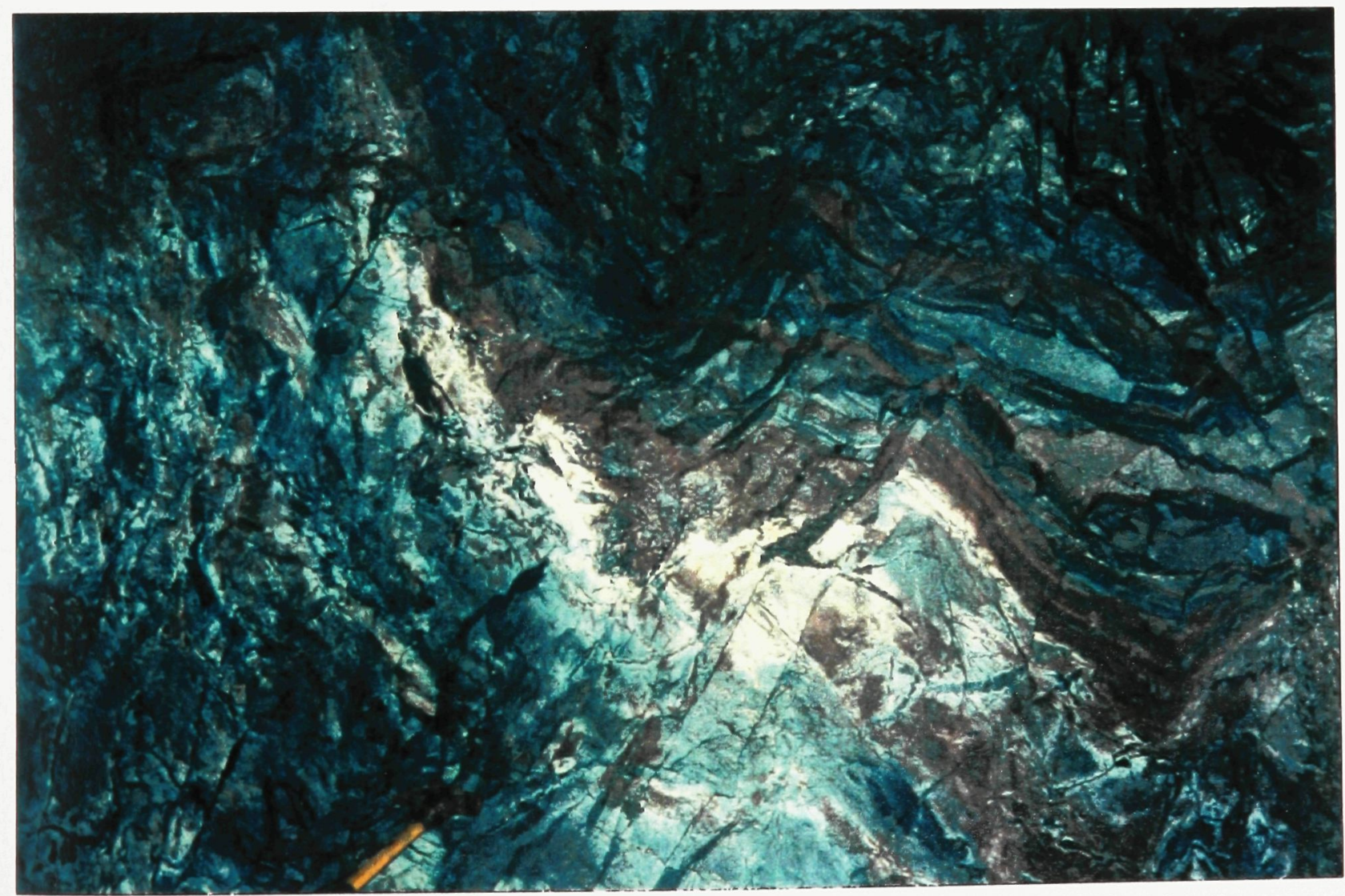

Flgure 3.2 Irregular upper surface of daclte flow lobe overlain by draped beds of Cranston tuff. Hammer in lower left corner for scale. Stope, Sublevel 11A. 


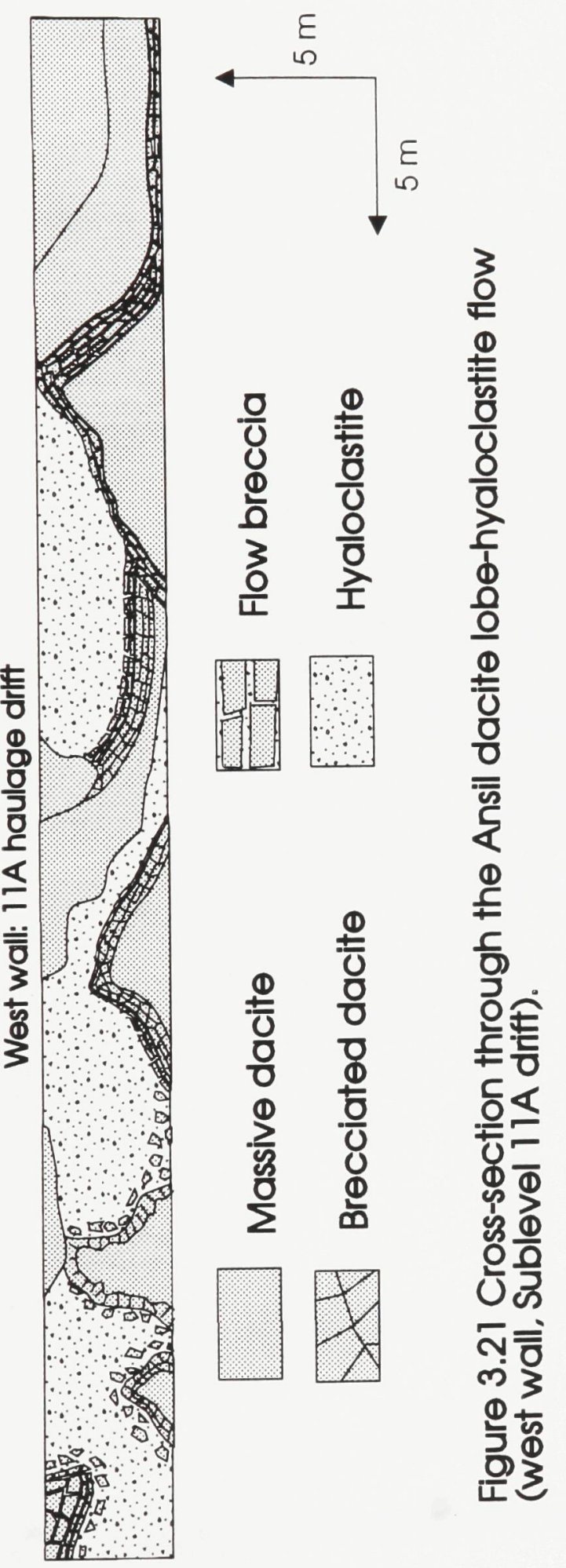




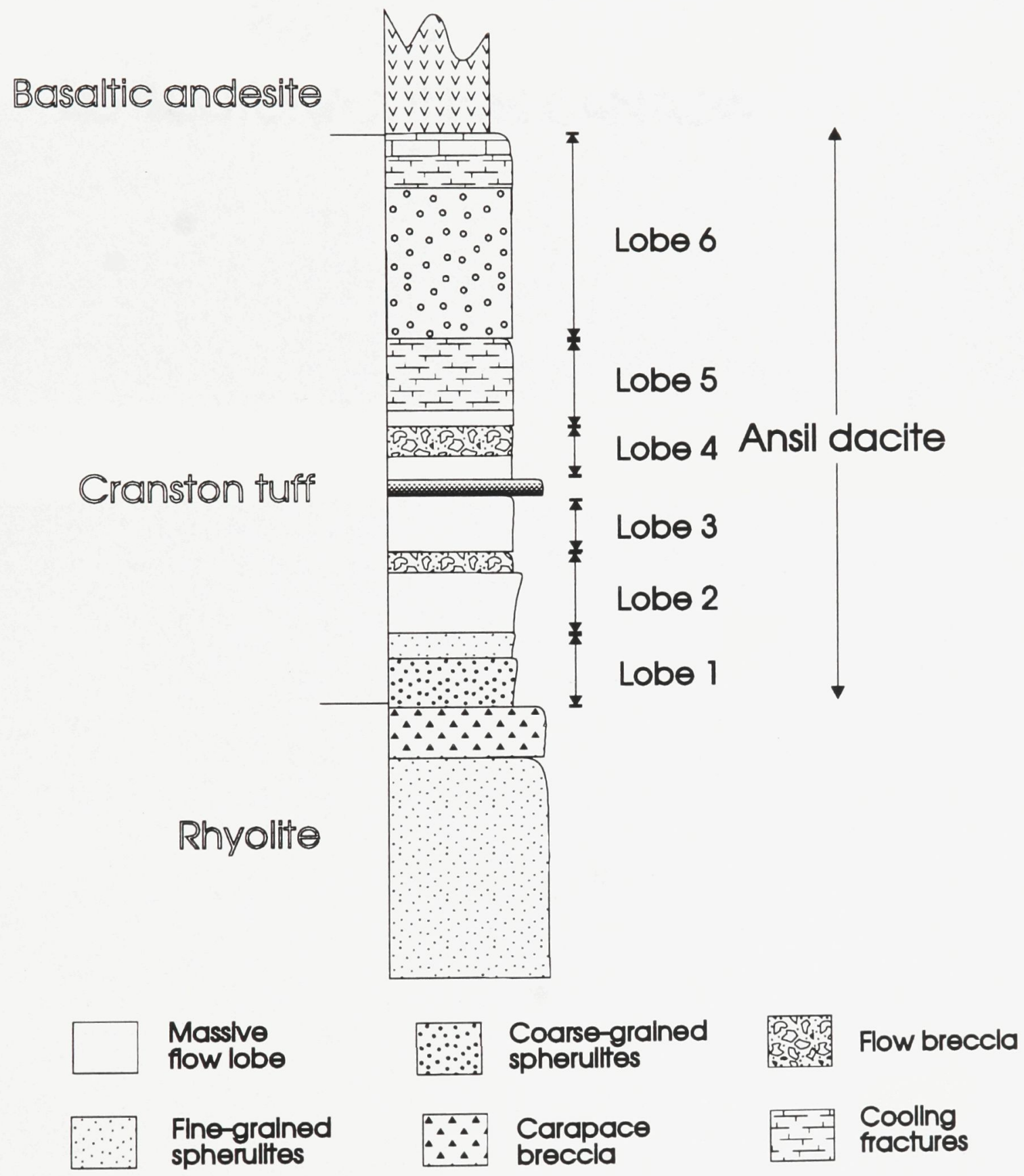

Flgure 3.22 Section through Ansil dactte lobe-hyaloclasttte flow sequence (from DDH AN-395) 


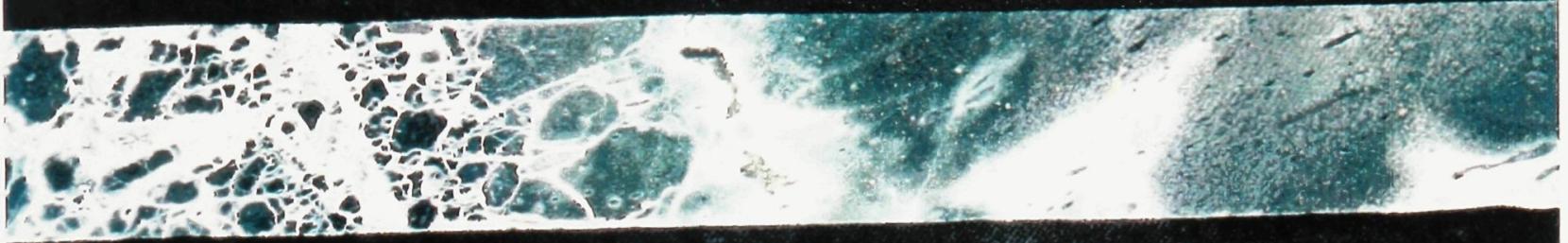

Figure 3.23 A $30 \mathrm{~cm}$ long section of cut and polished drill core through dacite flow margin, with abundant perlitic cooling fractures and pipe vesicles.

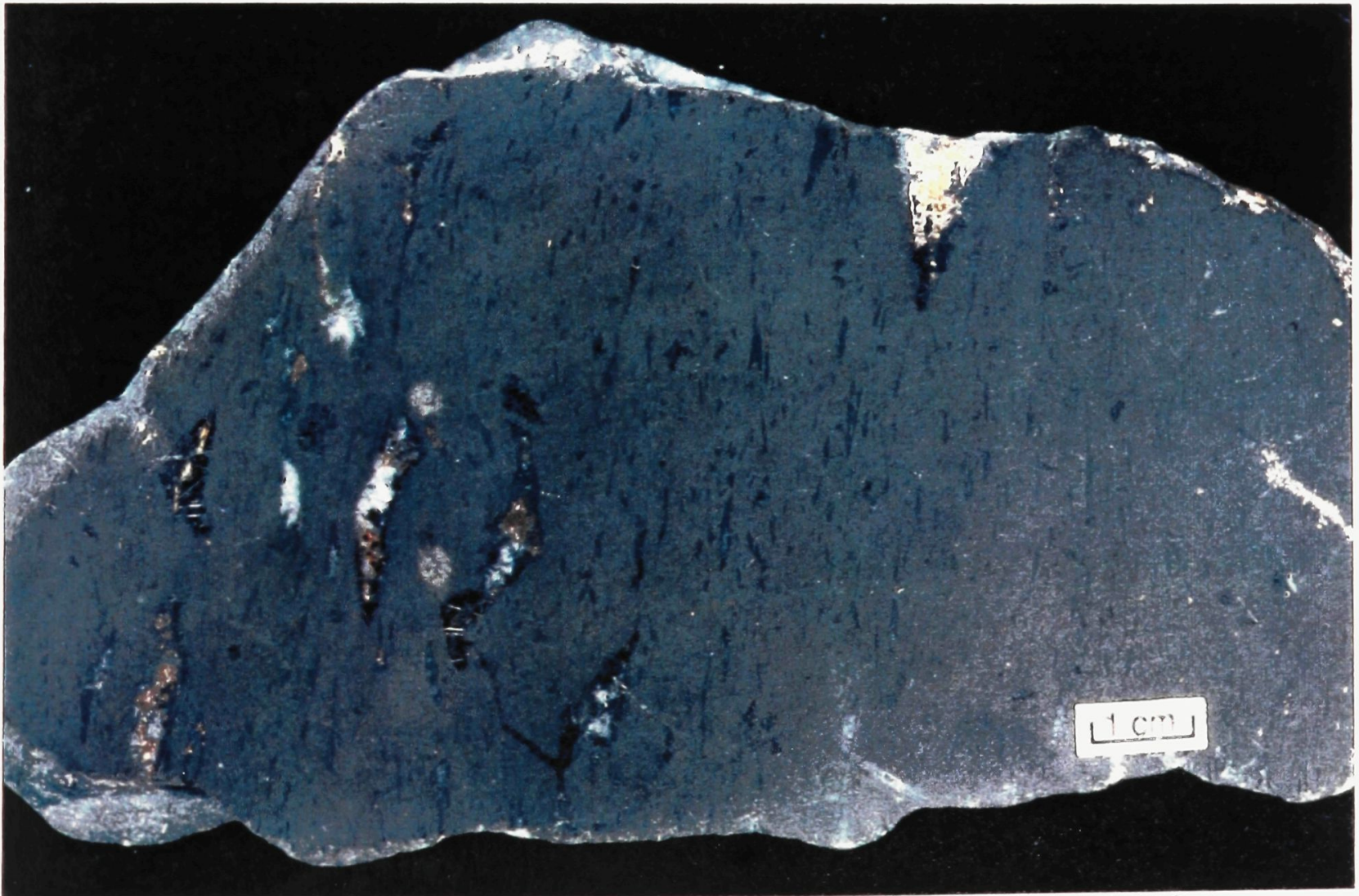

Figure 3.24 Polished slab of light grey, amygdaloidal dacite flow with abundant quartzchlorite-pyrite filled gas cavities. Sample ANSL11A-240 


\section{Figure 3.25}

A. Photomicrograph of dacite flow with hyalopilitic texture defined by plagioclase micolites and quartz-rich spherulites in and aphanitic, quartz-plagioclase-sericite matrix. Field of view $4 \mathrm{~mm}$ across.

B. Photomicrograph of dacite flow with abundant spherulites. Field of view $4 \mathrm{~mm}$ across.

C. Photomicrograph of plagioclase phenocryst enveloping smaller plagioclase microlites. Field of view $4 \mathrm{~mm}$ across.

D. Photomicrograph of perlitic fractures in dacite flow infilled with chlorite and Fe-oxides. Field of view $4 \mathrm{~mm}$ across 

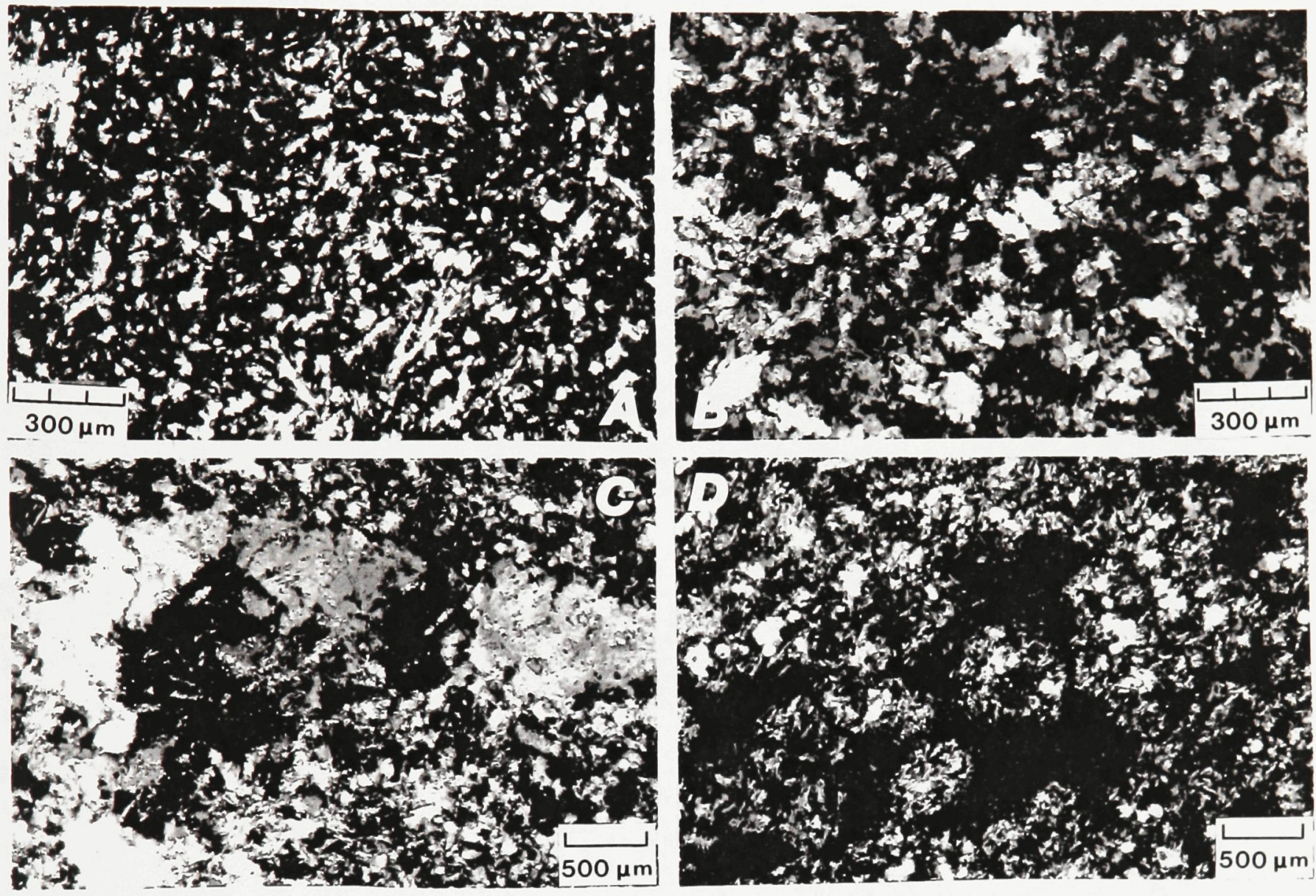


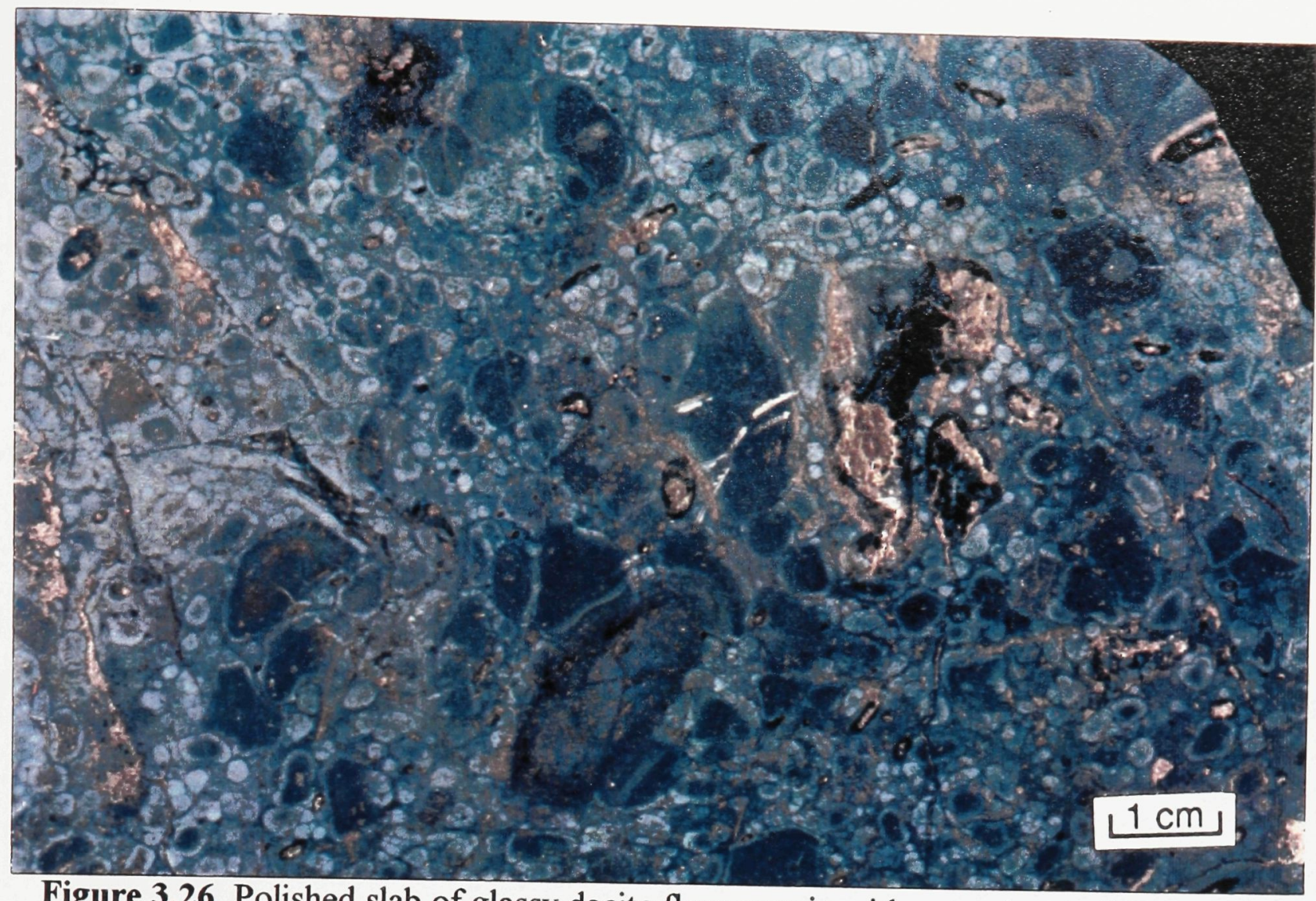

Figure 3.26 Polished slab of glassy dacite flow margin with extensive perlitic cooling fractures. Sample ANSL11A-250B.

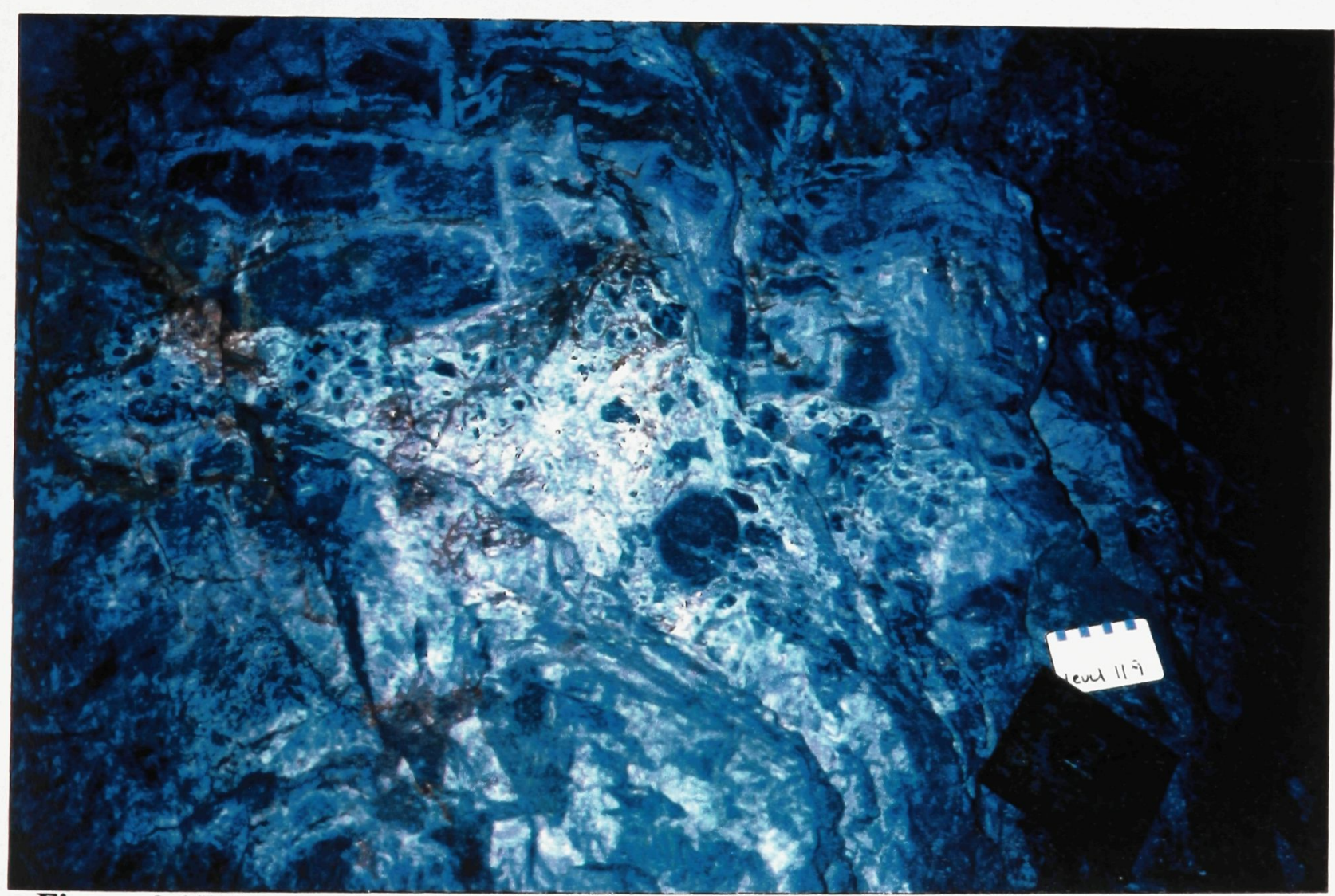

Figure 3.27 Dacite flow margin with rectangular fracture system controlled by concentric and radial cooling fractures. Zone of abundant perlitic fracturing also visible. Drawpoint \#1, Sublevel 11A. 


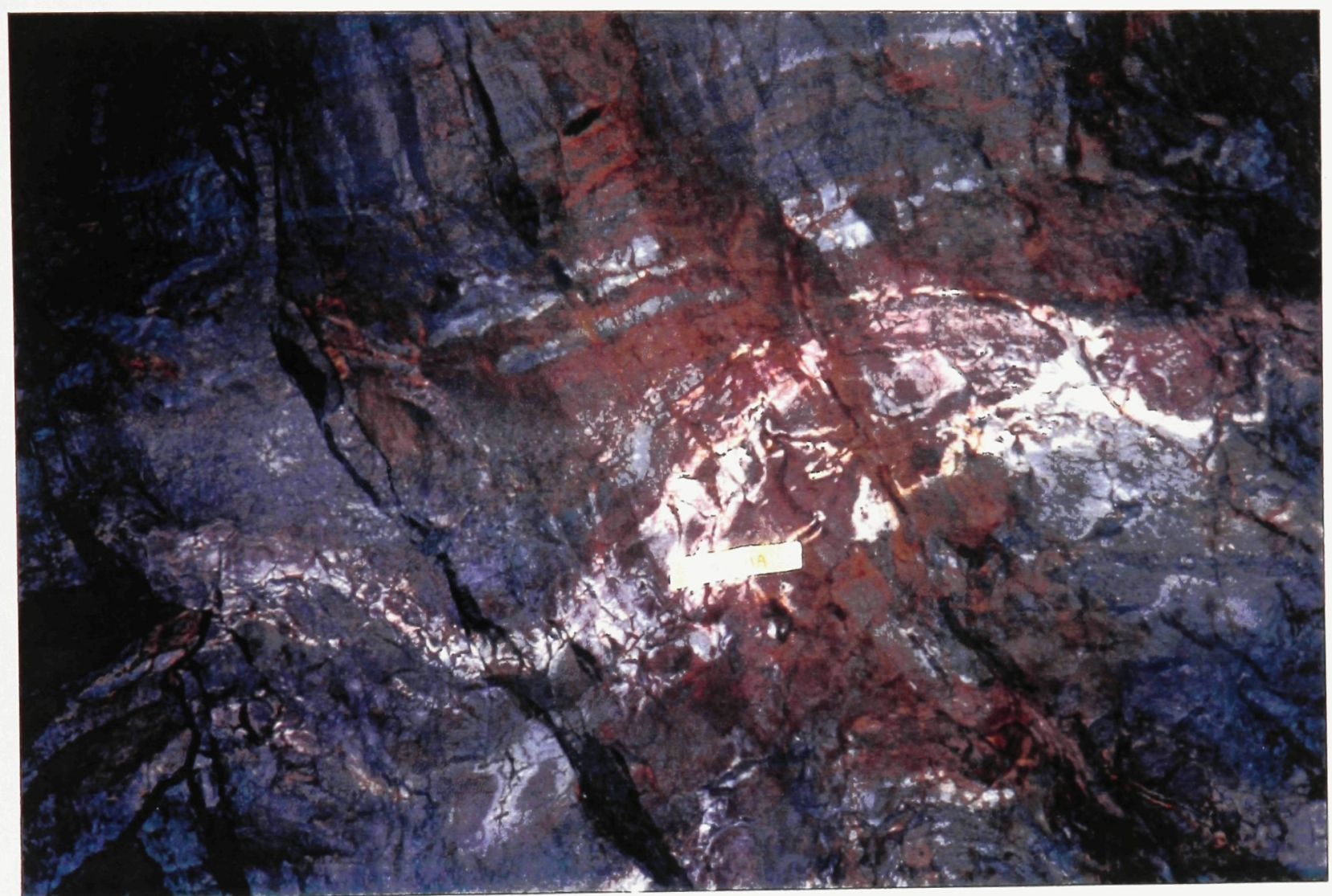

Figure 3.28 Upper contact of dacite flow lobe with rectangular fracture pattern controlling formation of the flow breccia. Flow breccia overlain by thin carapace of dacite hyaloclastite, which is overlain by well layered Cranston tuff. Yellow tape $15 \mathrm{~cm}$ long. 


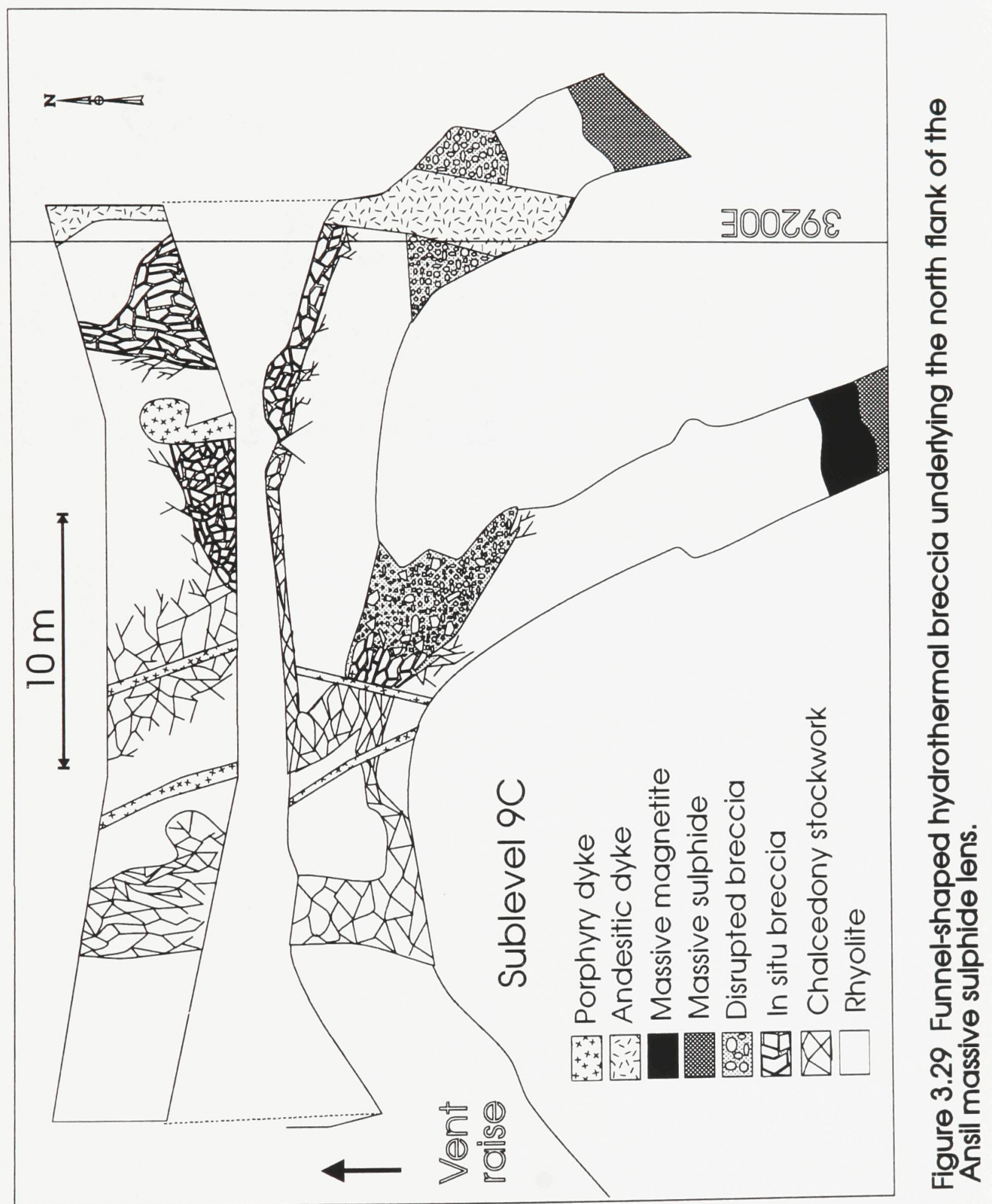




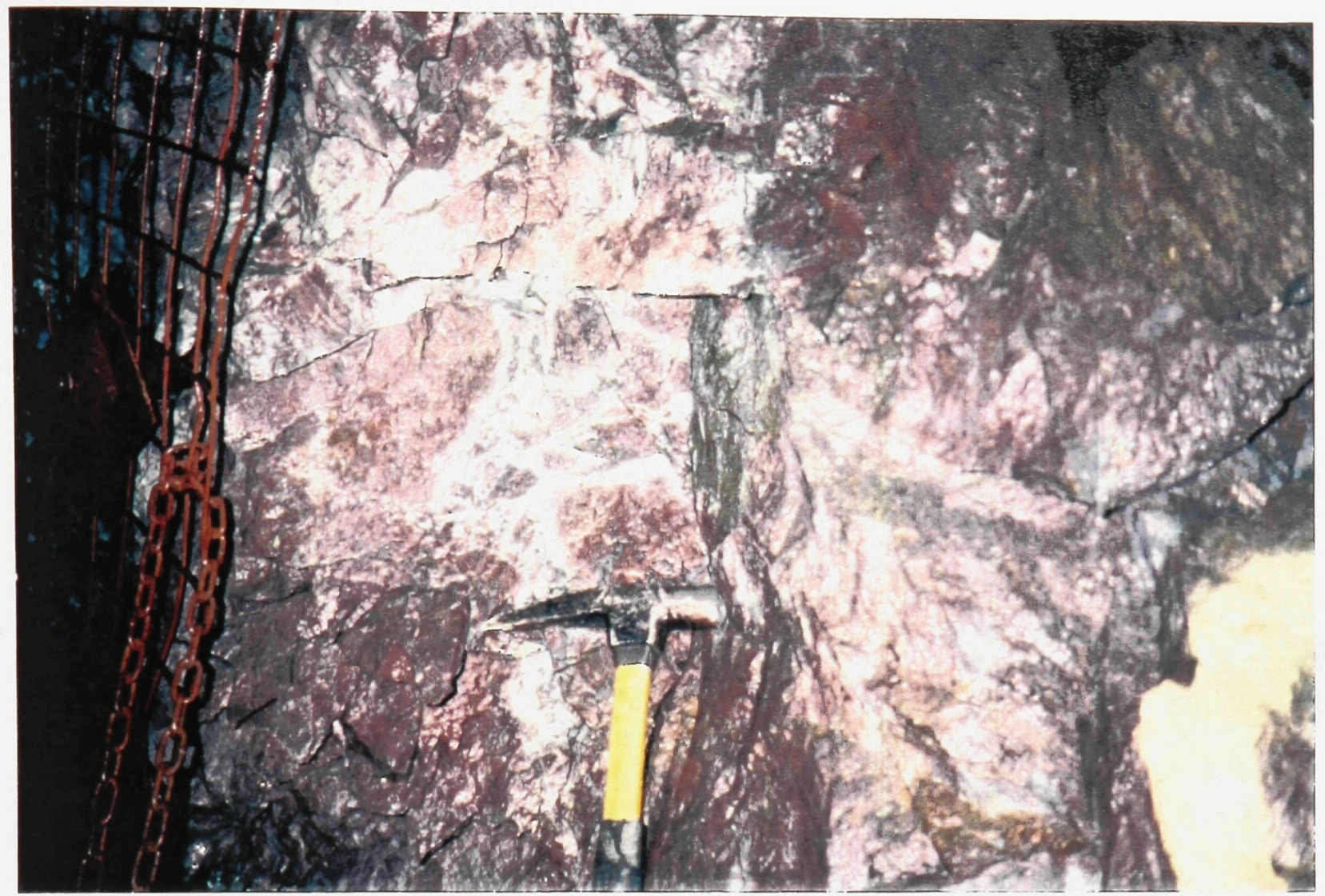

Figure 3.30 Small disrupted breccia vein near base of hydrothermal breccia zone. Note abundant sphalerite mineralization of rhyolite wallrock (Sublevel 7B). Hammer for scale.

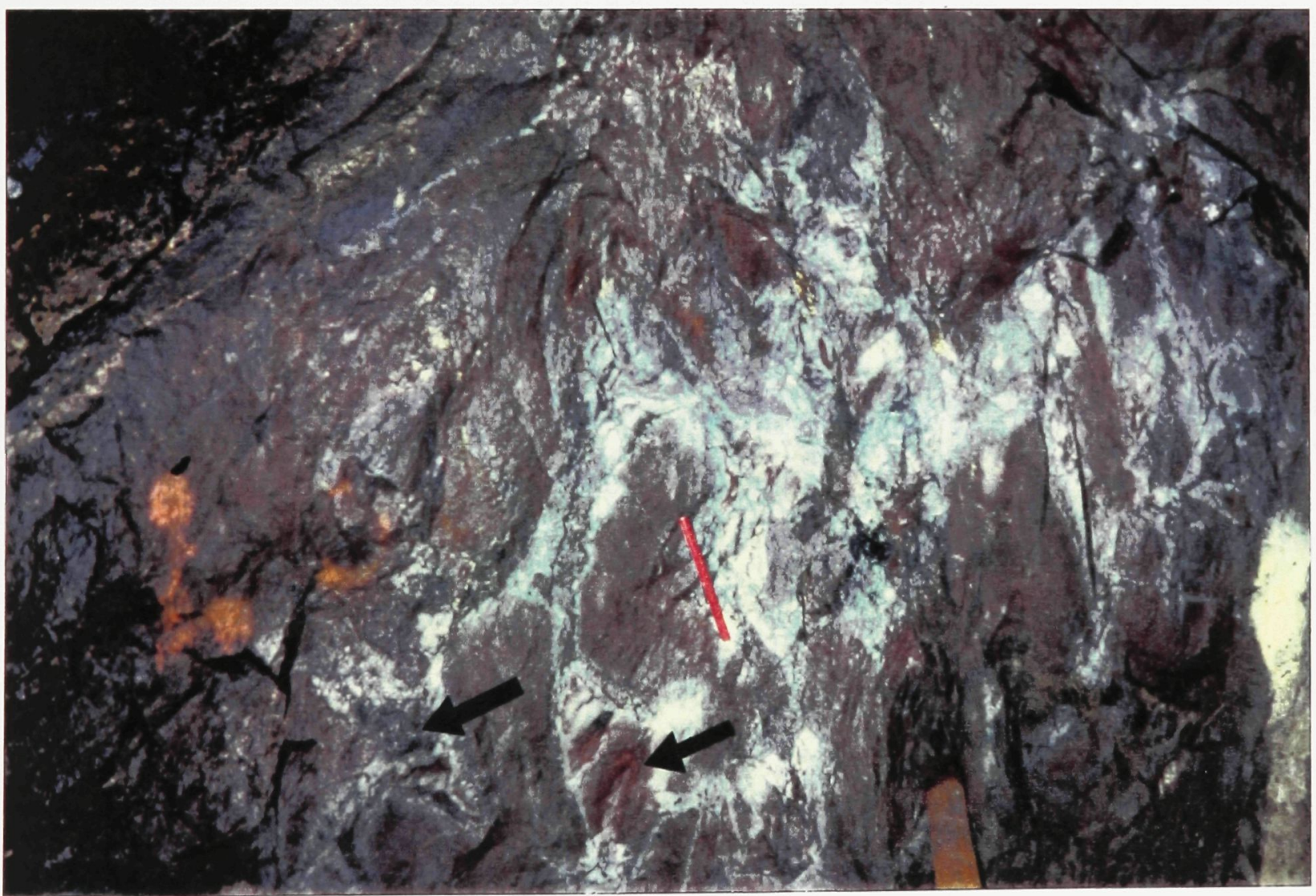

Figure 3.31 Sphalerite-rich breccia zone below the south flank of the orebody (Zinc South Zone, Sublevel 7B). Larger fractures (arrow) infilled with finely laminated quartz. 


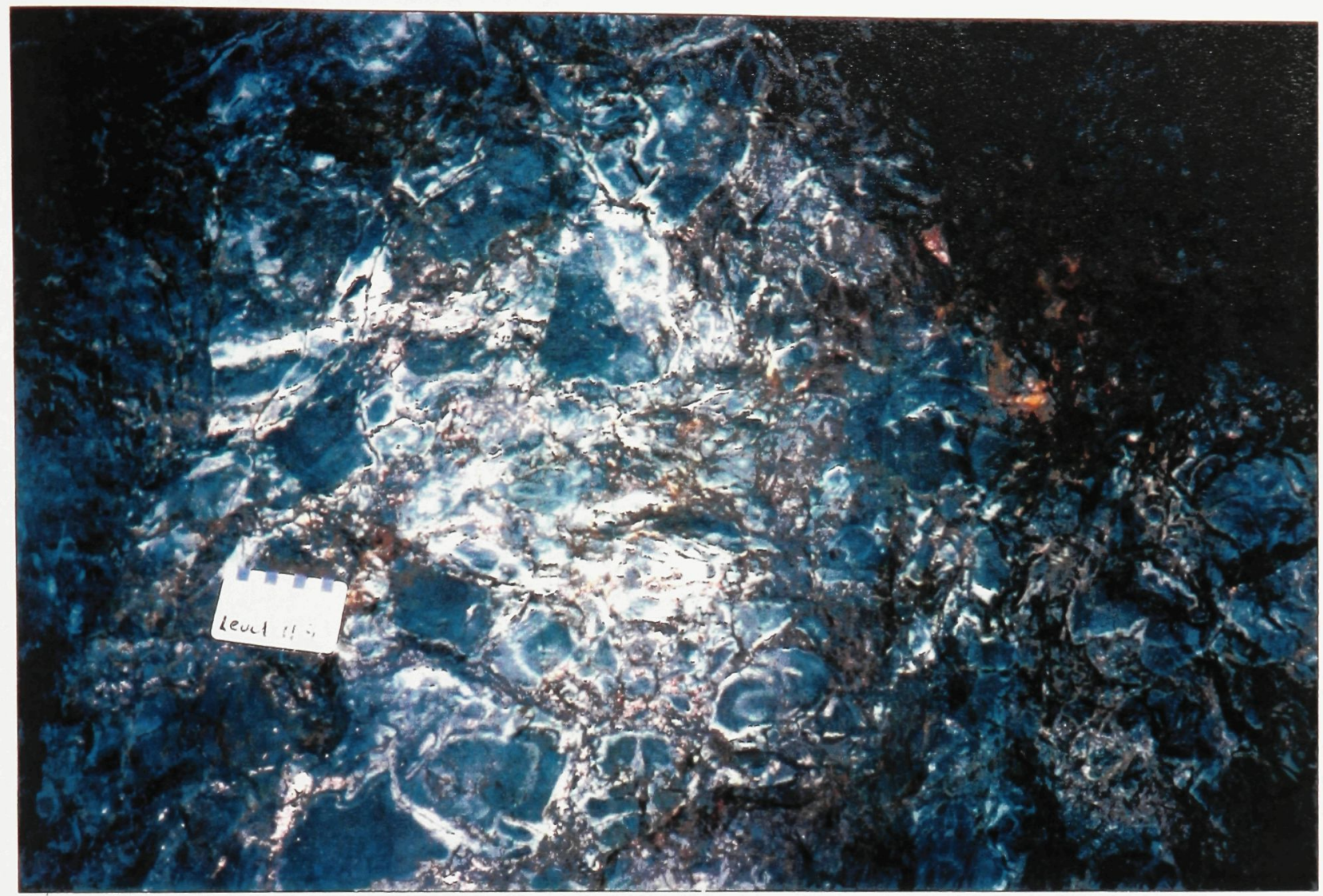

Figure 3.32 Brecciation of dacite flow lobe during sericite-quartz alteration event. (Sublevel 11A). Centimetre card for scale.

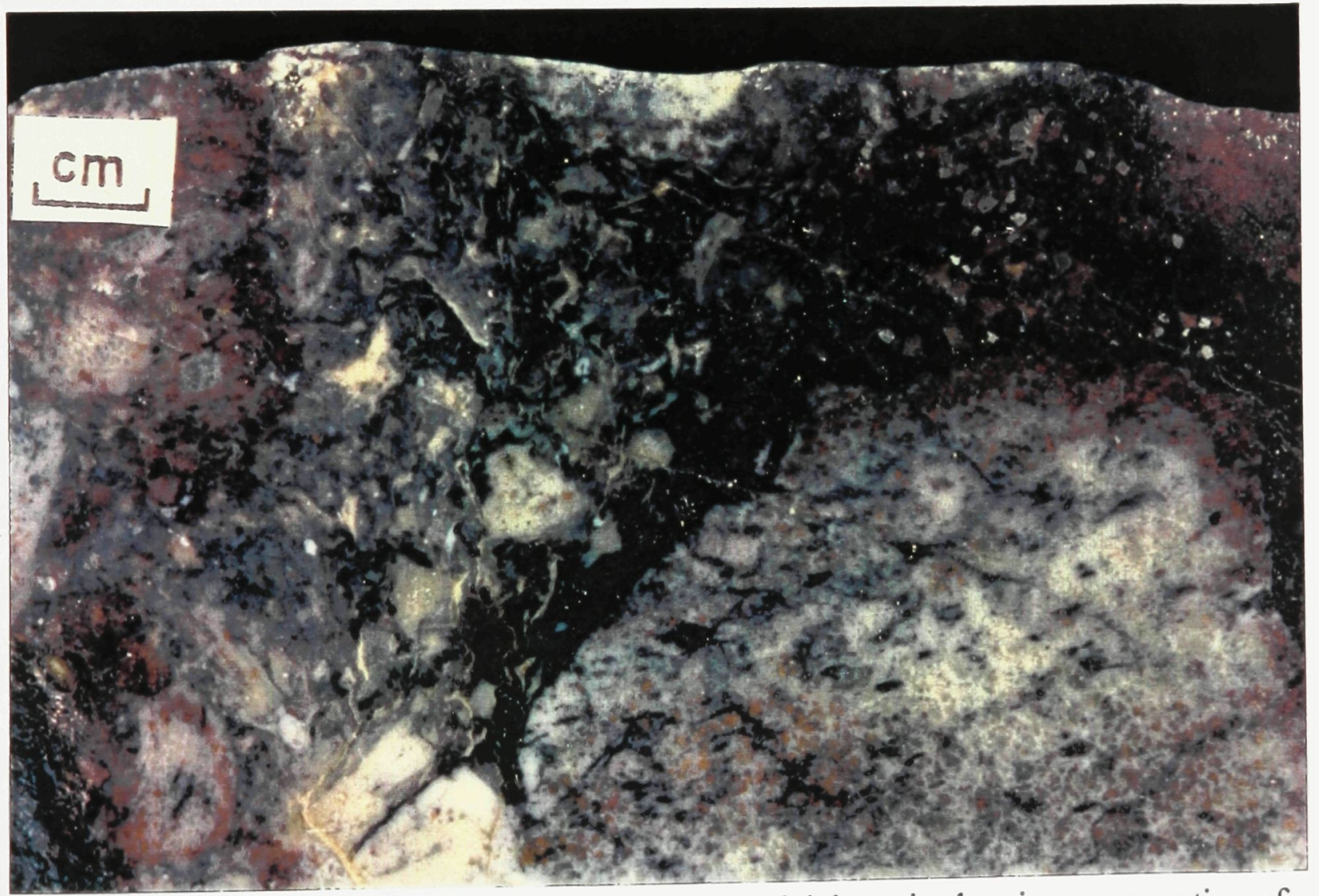

Figure 3.33 Polished slab of disrupted, sphalerite-rich breccia showing poor sorting of angular to rounded fragments (Sublevel 9C). 


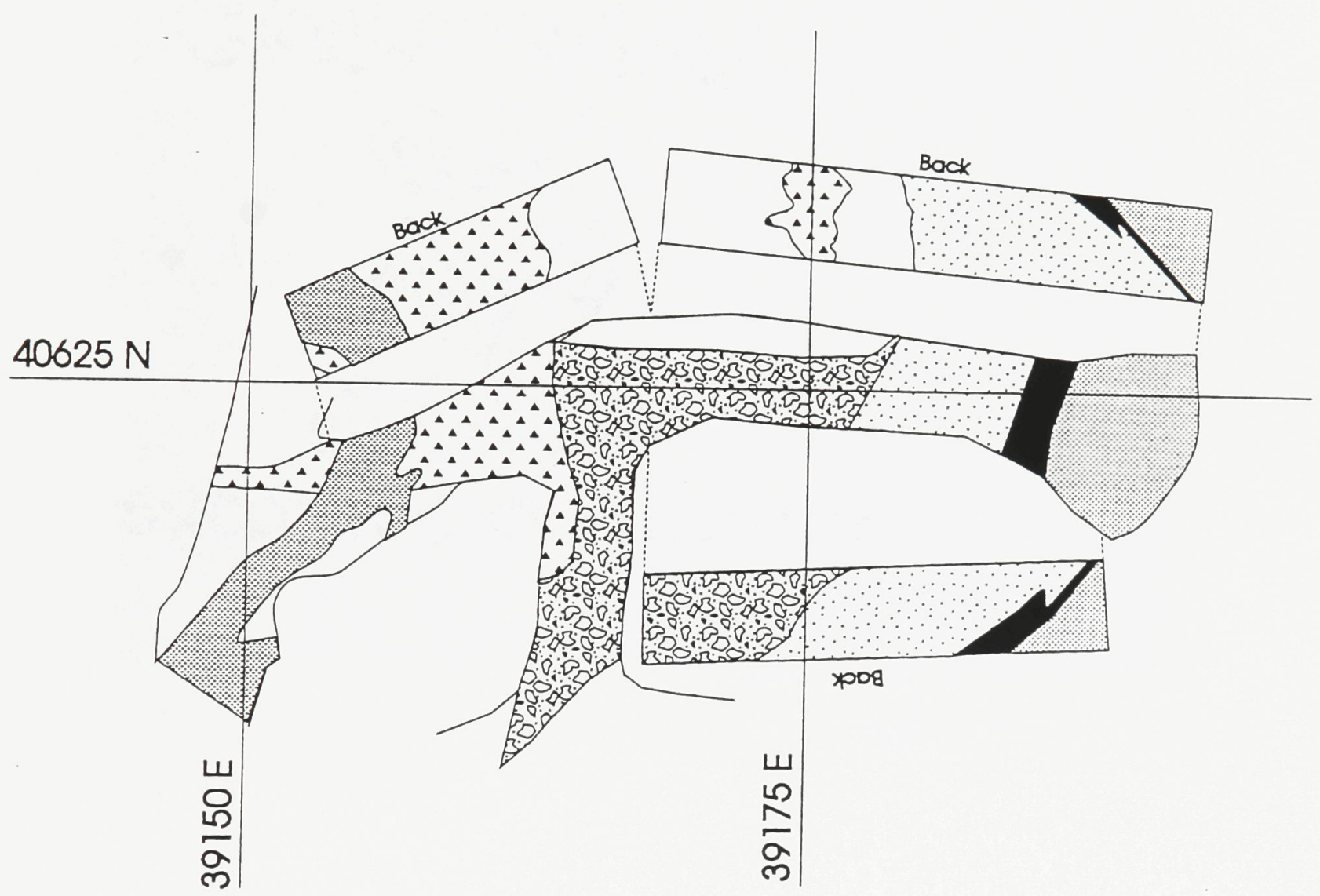

$\begin{array}{llll}\text { Rhyolite } & \end{array}$

Massive

sulfide
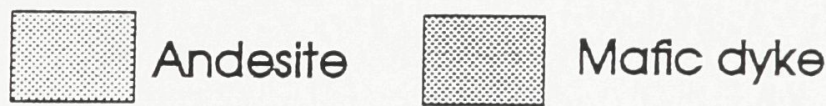

Flgure 3.34 Section through a hydrothermal breccla deposit below the north flank of the massive sulfide lens. Sublevel $9 b$, Drowpoint $\neq 6$. 


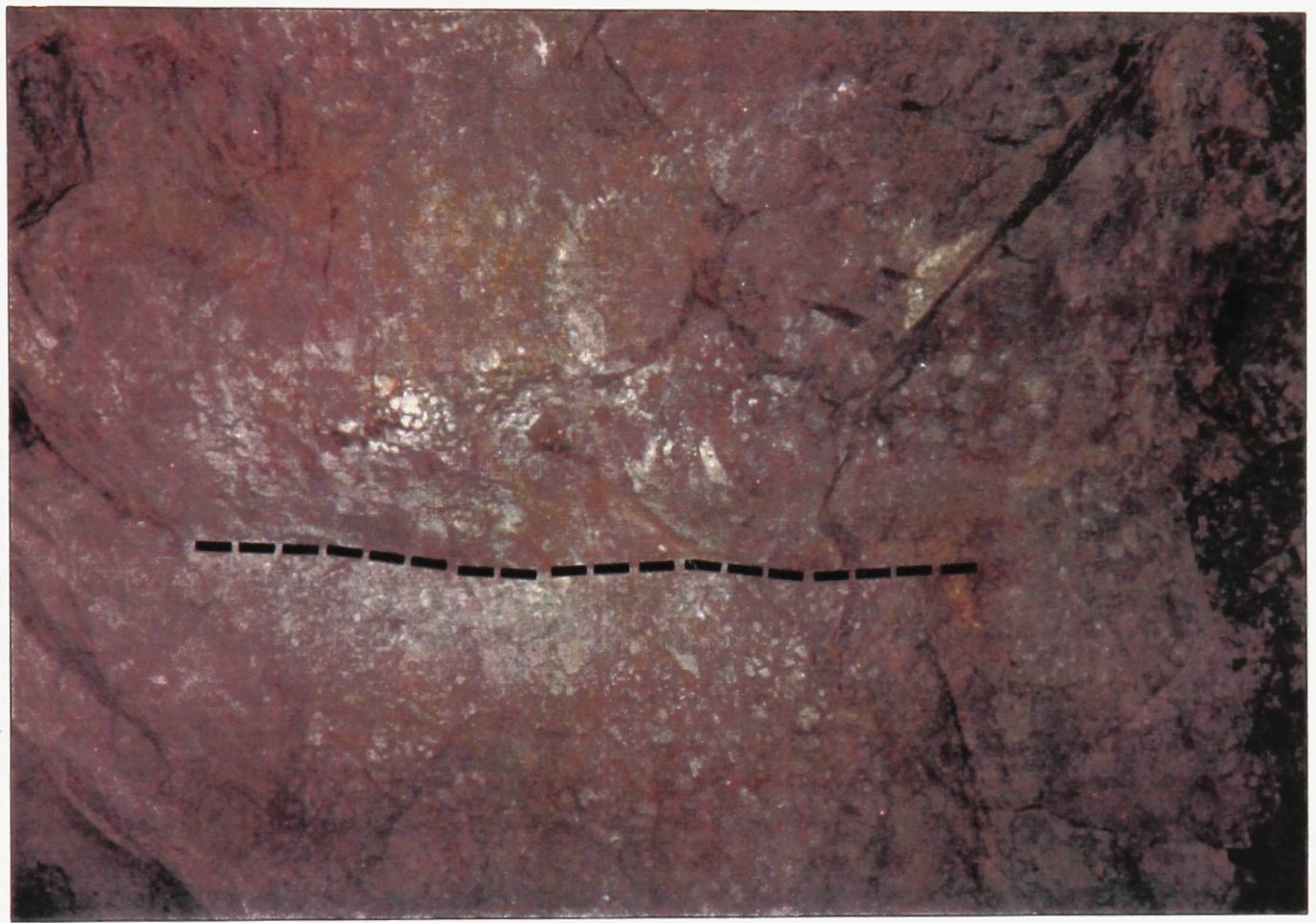

Figure 3.35 Possible bedding contact within conformable, sphalerite-rich, hydrothermal breccia apron (Sublevel 10A). 


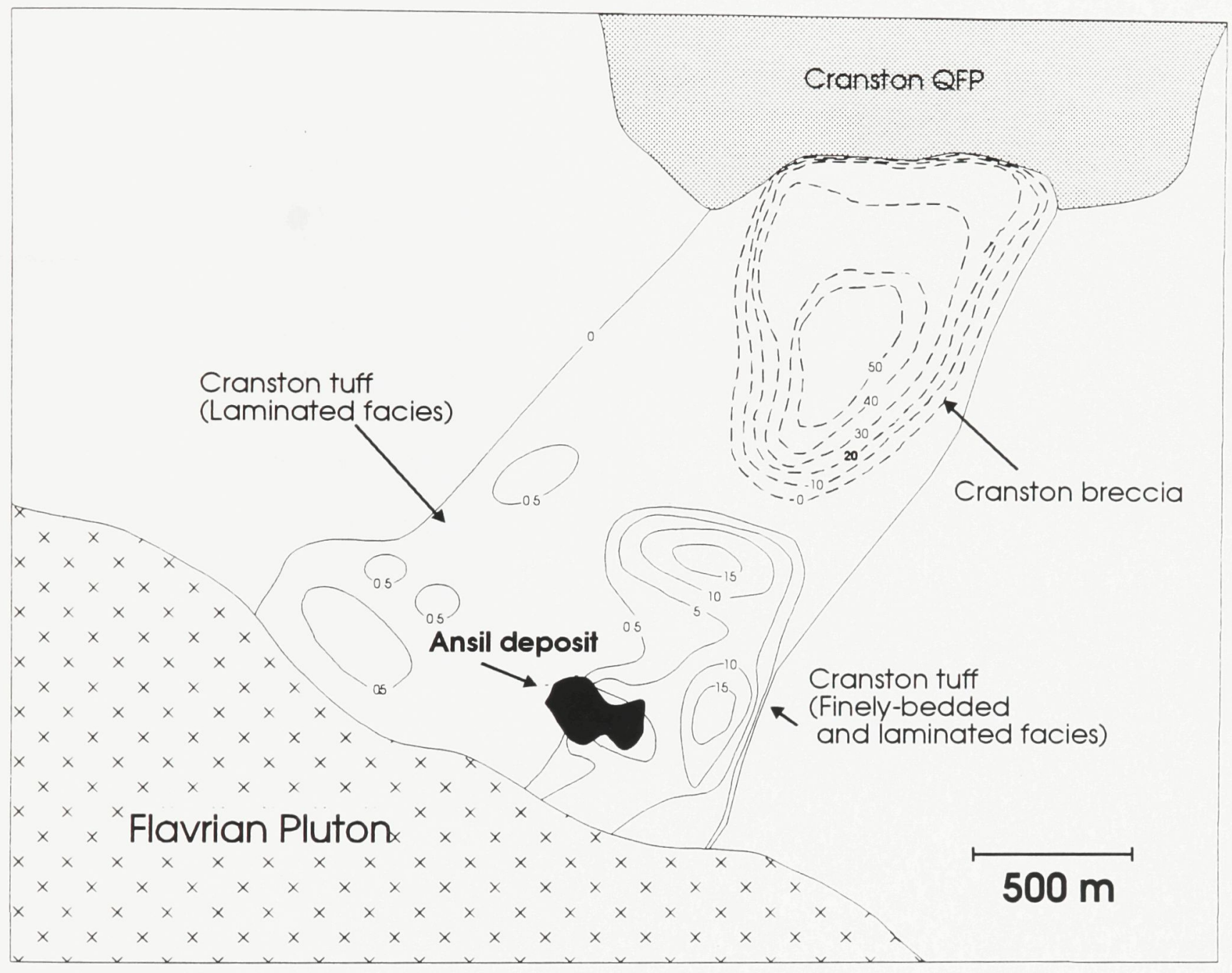

Figure 3.36 Extent and internal facies distribution of the Cranston mass flows. Contours are in metres. 


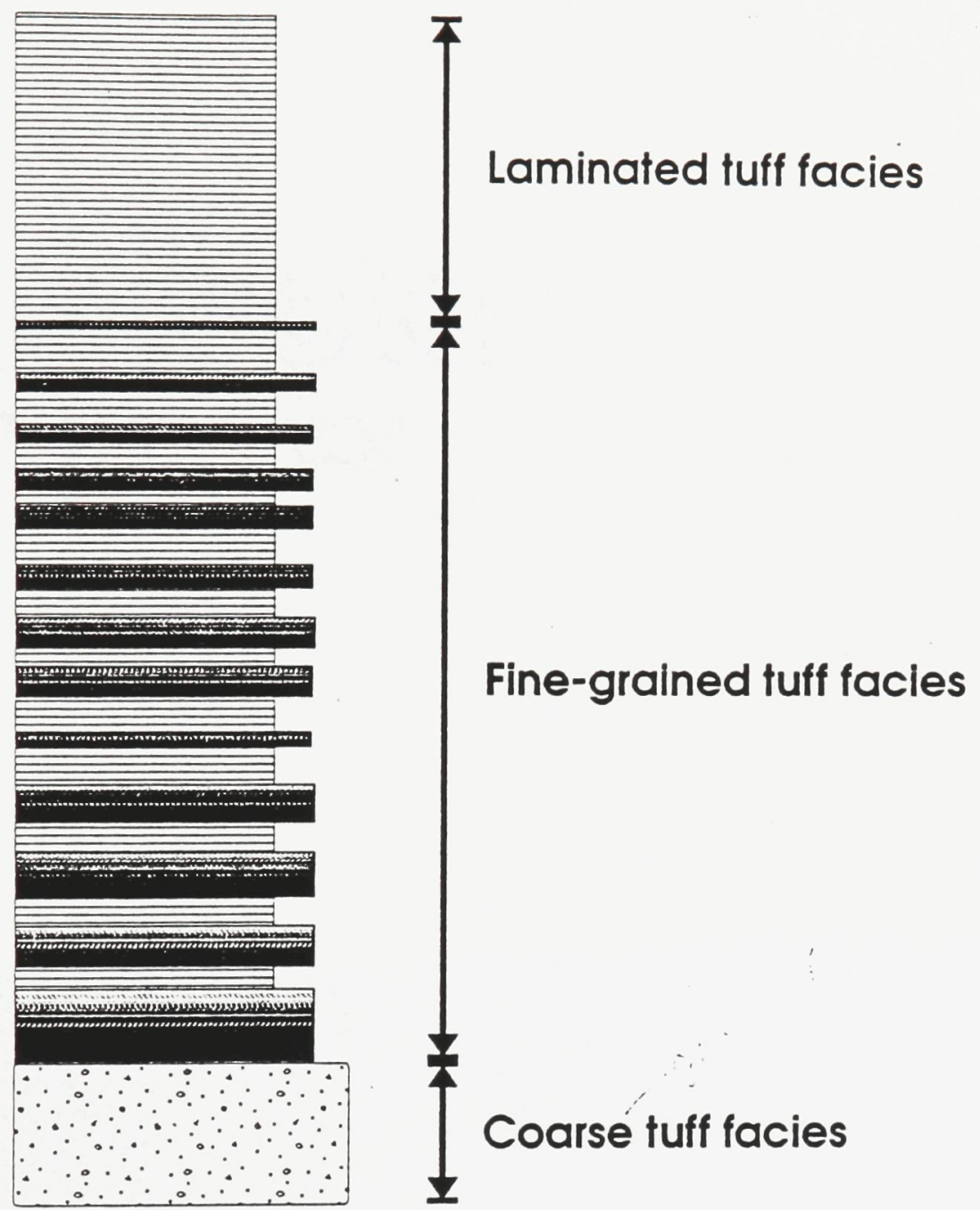

Figure 3.37 Composite stratigraphic section through the Cranston tuff in the vicinity of the Ansil deposit. 


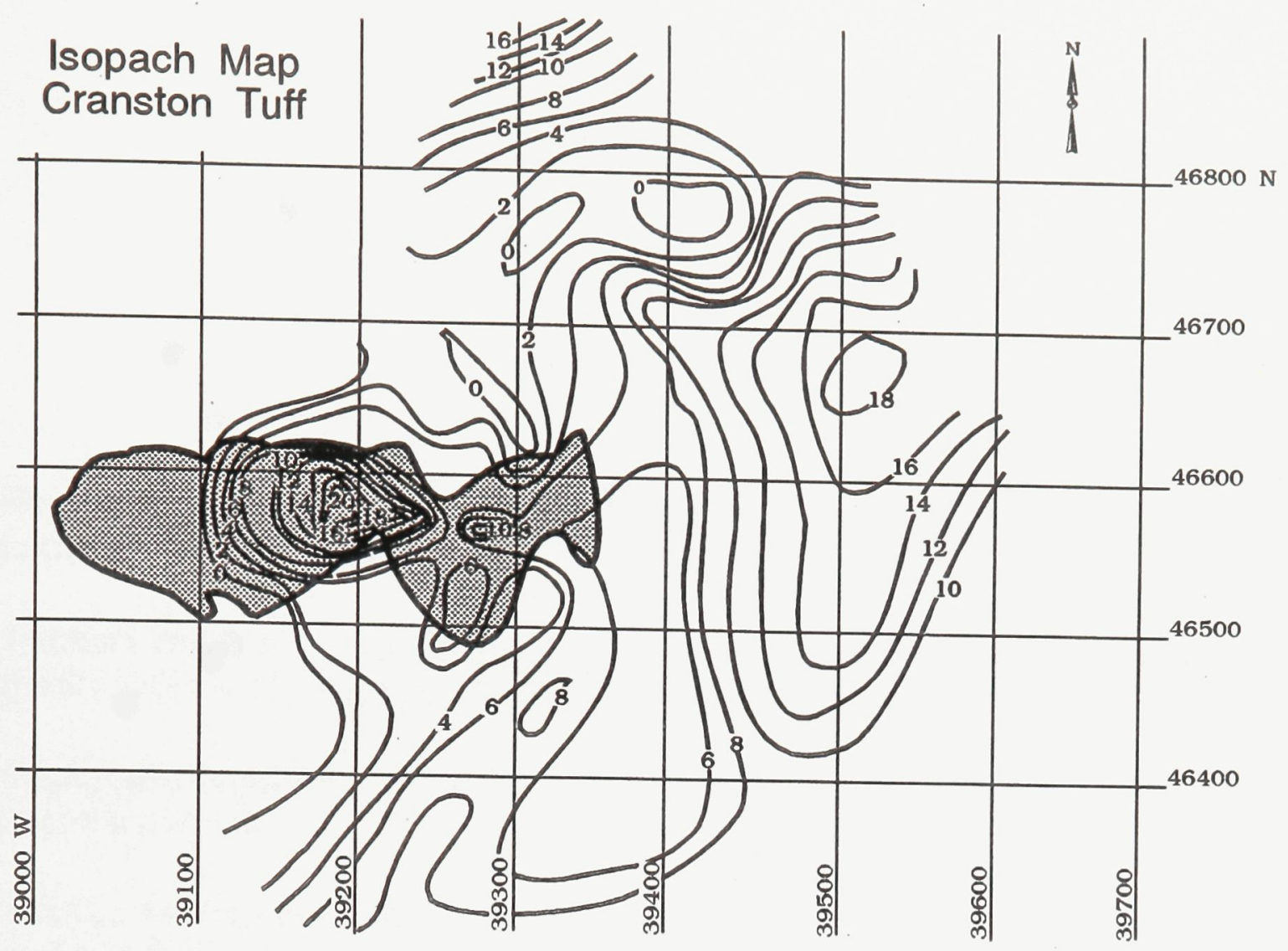

Figure 3.38 Isopach map showing the distribution of the Cranston tuff in the vicinity of the Ansil deposit

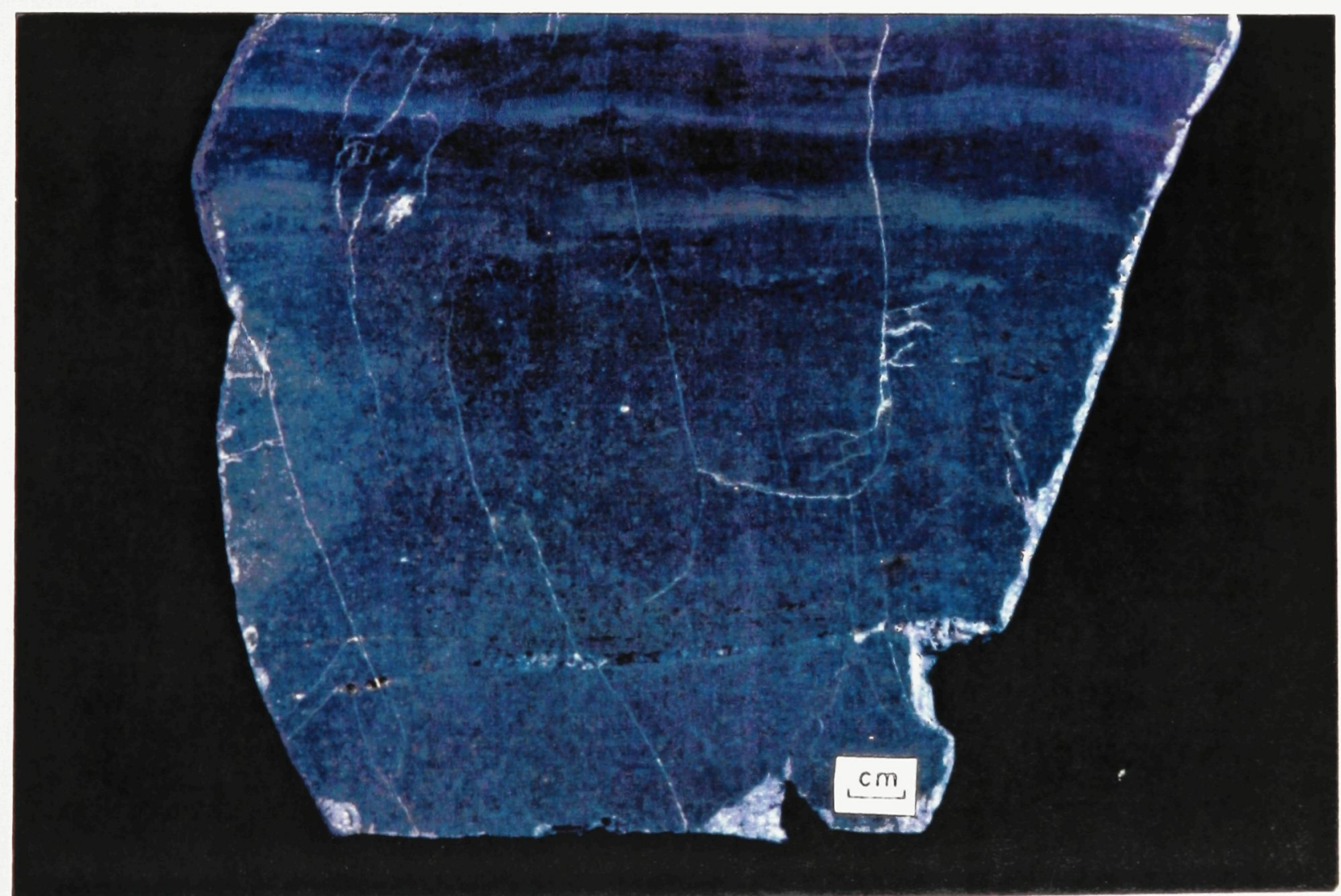

Figure 3.39 Pollshed slab of contact of the Cranston coarse- and fine-grained facies. Visible felsic grains inlcude quartz and felspar phenoclasts. 


\section{Figure 3.40}

A. Photomicrograph of coarse-grained tuff facies showing angular quartz phenoclasts and more rounded rhyolite fragments. Crossed polars. Field of view $4 \mathrm{~mm}$ across.

B. Photomicrograph of coarse-grained tuff facies, with broken quartz phenoclasts, rhyolite fragment, and possible devitrified glass shard (arrow). Field of view $4 \mathrm{~mm}$ across.

C. Broken quartz phenoclasts in coarse-grained base of normally-graded tuff layer. Field of view $4 \mathrm{~mm}$ across.

D. Contact between fine-grained top and coarse-grained base of beds in fine-grained tuff facies. Field of view $4 \mathrm{~mm}$. 

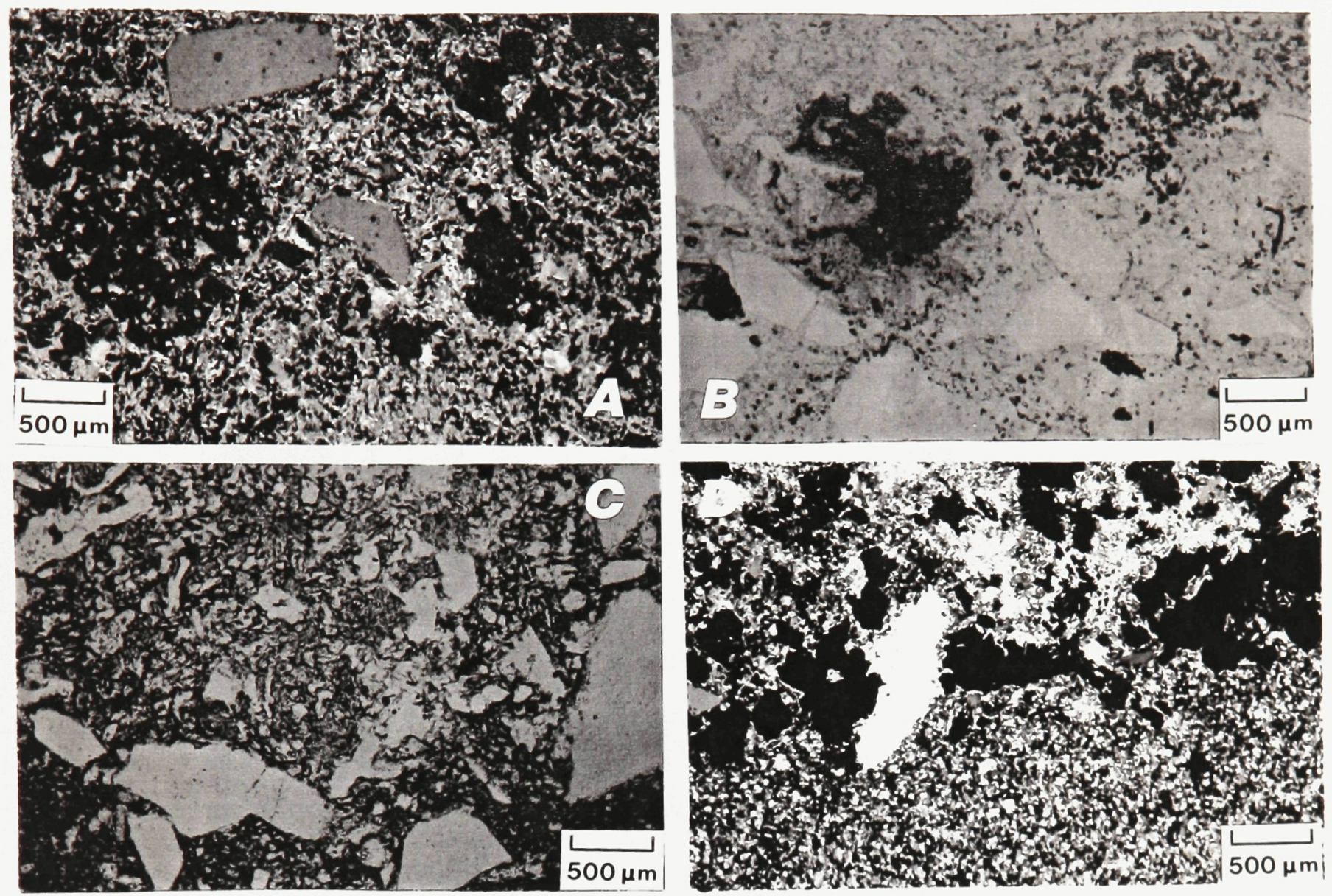


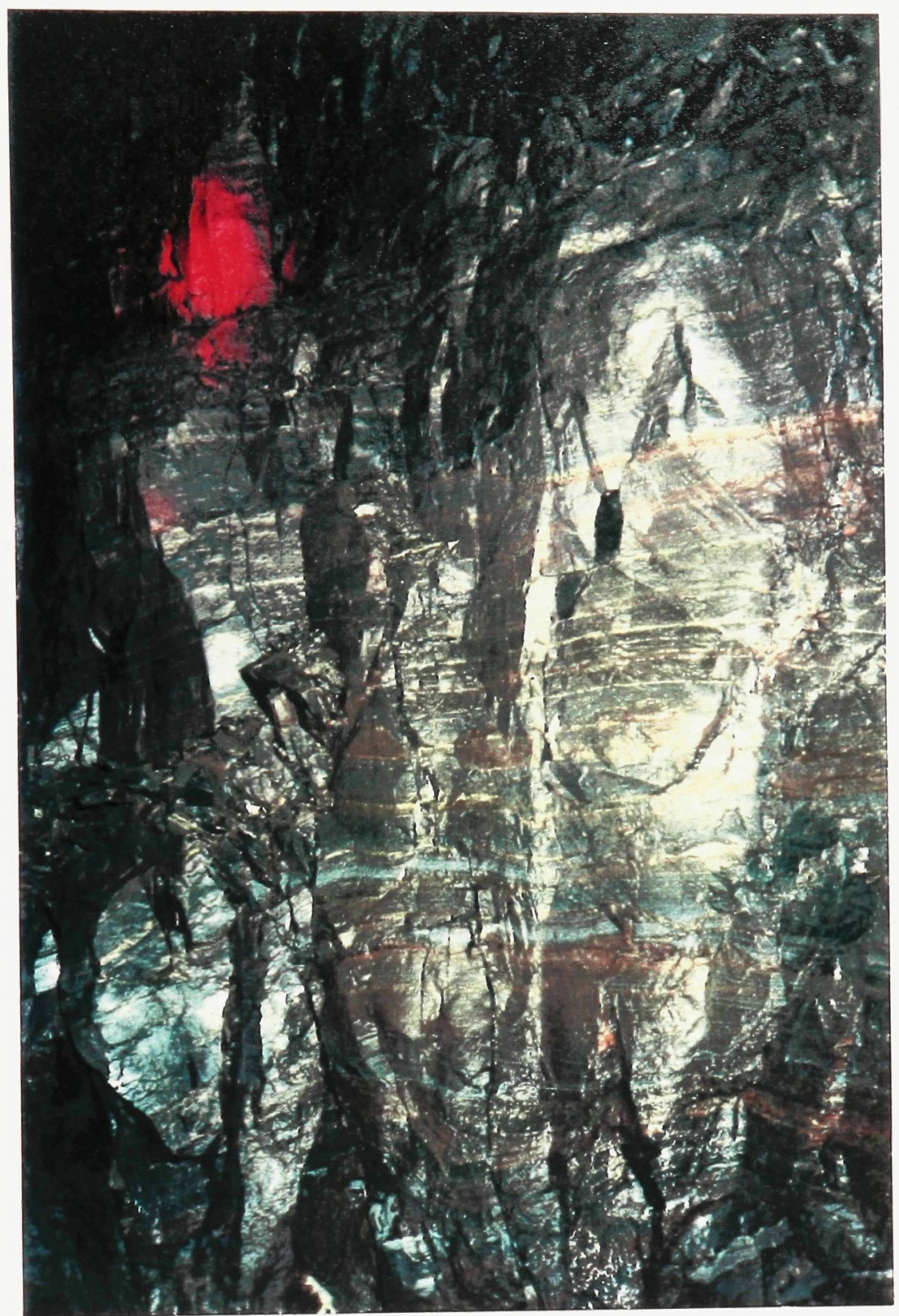

Figure 3.41 Fine-grained facies of the Cranston tuff. Note maroon colour from abundant, disseminated sphalerite. Paint spot 10 to $15 \mathrm{~cm}$ across. Stope $11 \mathrm{~A}$. 


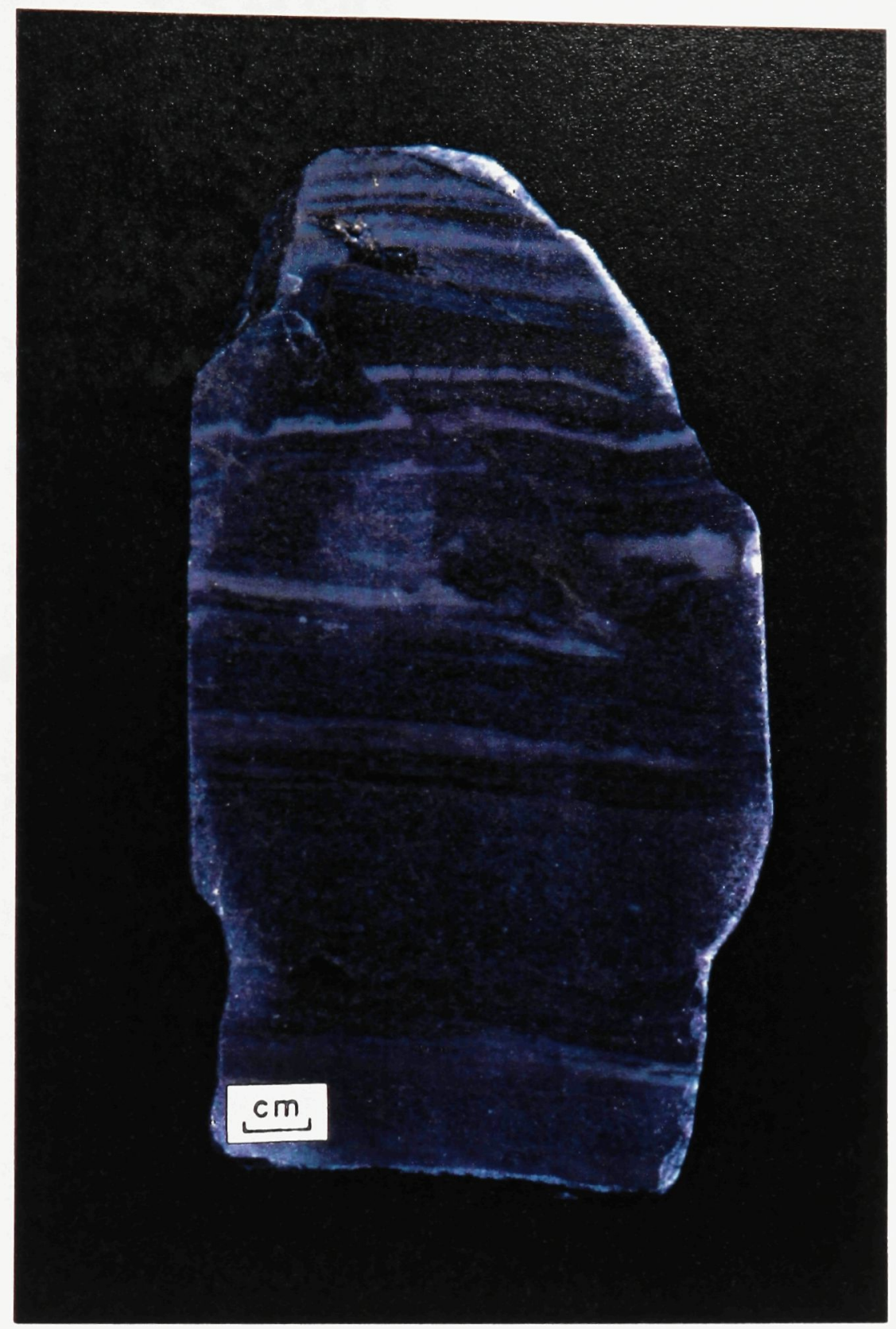

Figure 3.42 Polished slab of fine-grained facies, showing normally-graded layers ranging from fine-grained to finely laminated, quartz-phyric tuff. Sample ANSL9B2-SP. 


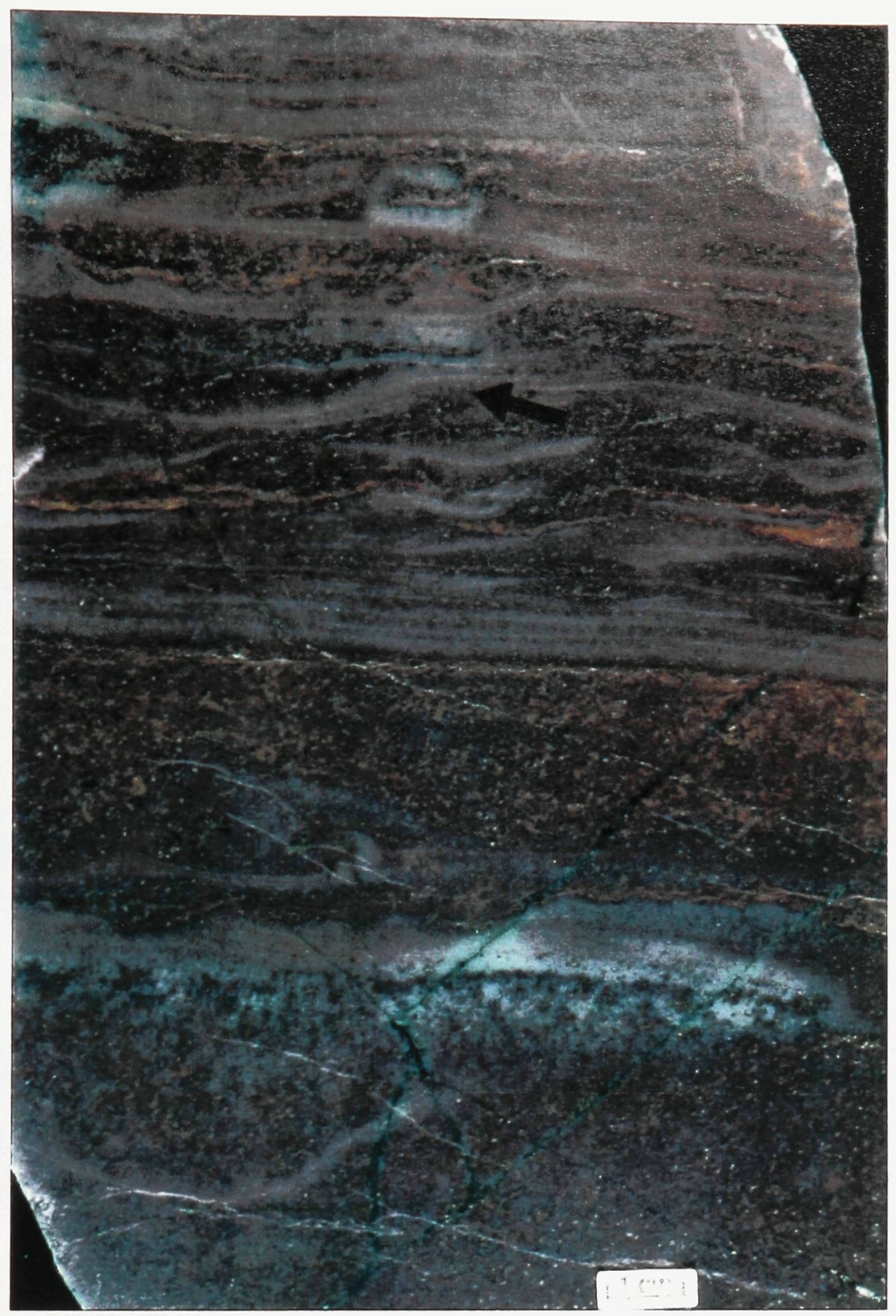

104

Figure 3.43 Possible ripple marks in fine-grained facies of Cranston tuff. Polished slab from Sublevel 9B. Sample ANSL9B-TF1. 


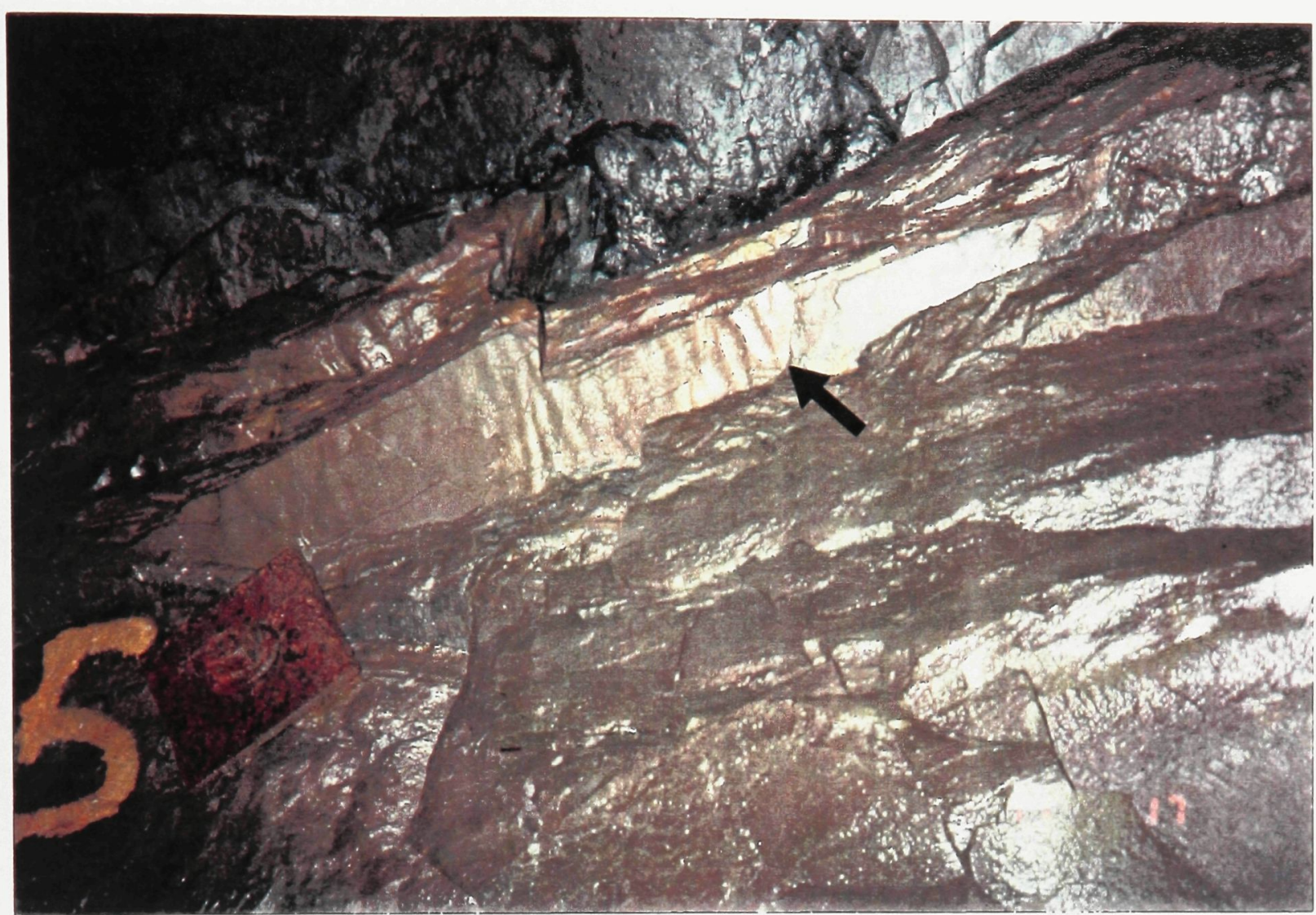

Figure 3.44 Possible ripple marks along base of bedding plane in fine-grained facies of Cranston tuff (Sublevel 10B). Metal plate $15 \mathrm{~cm}$ across.

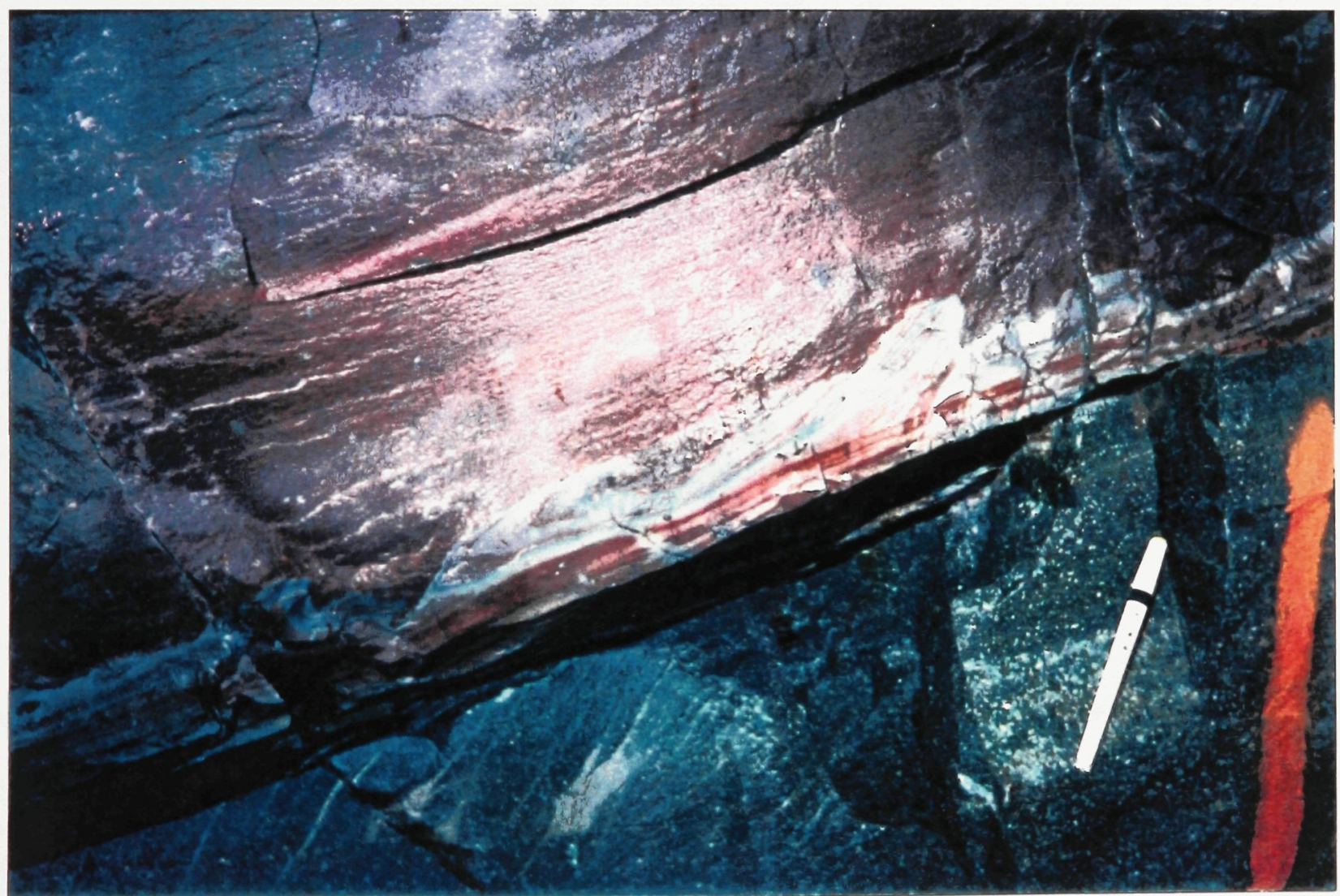

Figure 3.45 Flame structures in laminated facies of the Cranston tuff (Sublevel 10B). Rapidograph pen $10 \mathrm{~cm}$ long for scale. 


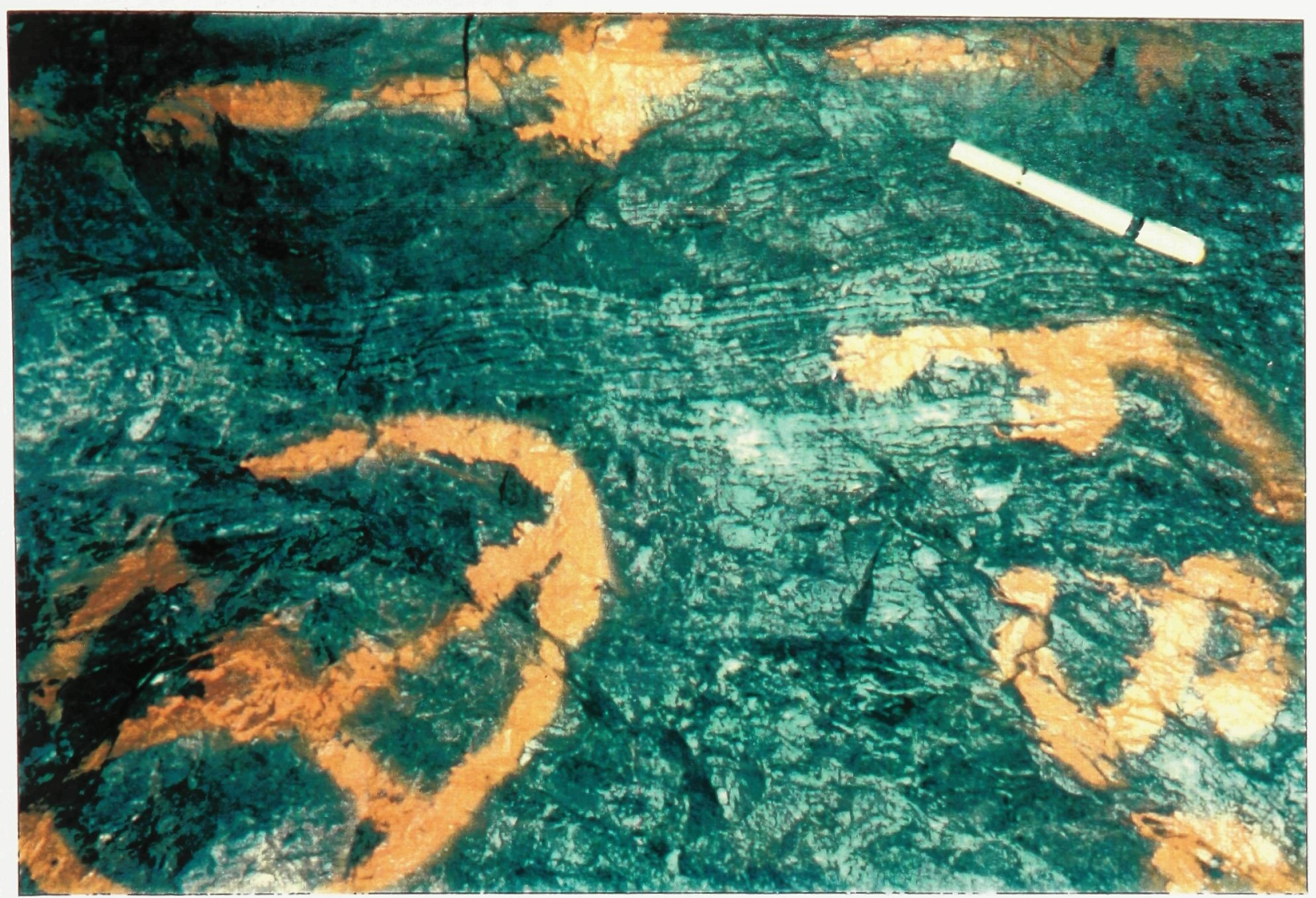

Figure 3.46 Laminated facies of the Cranston tuff (Sublevel 10B). $10 \mathrm{~cm}$ long rapidograph pen for scale.

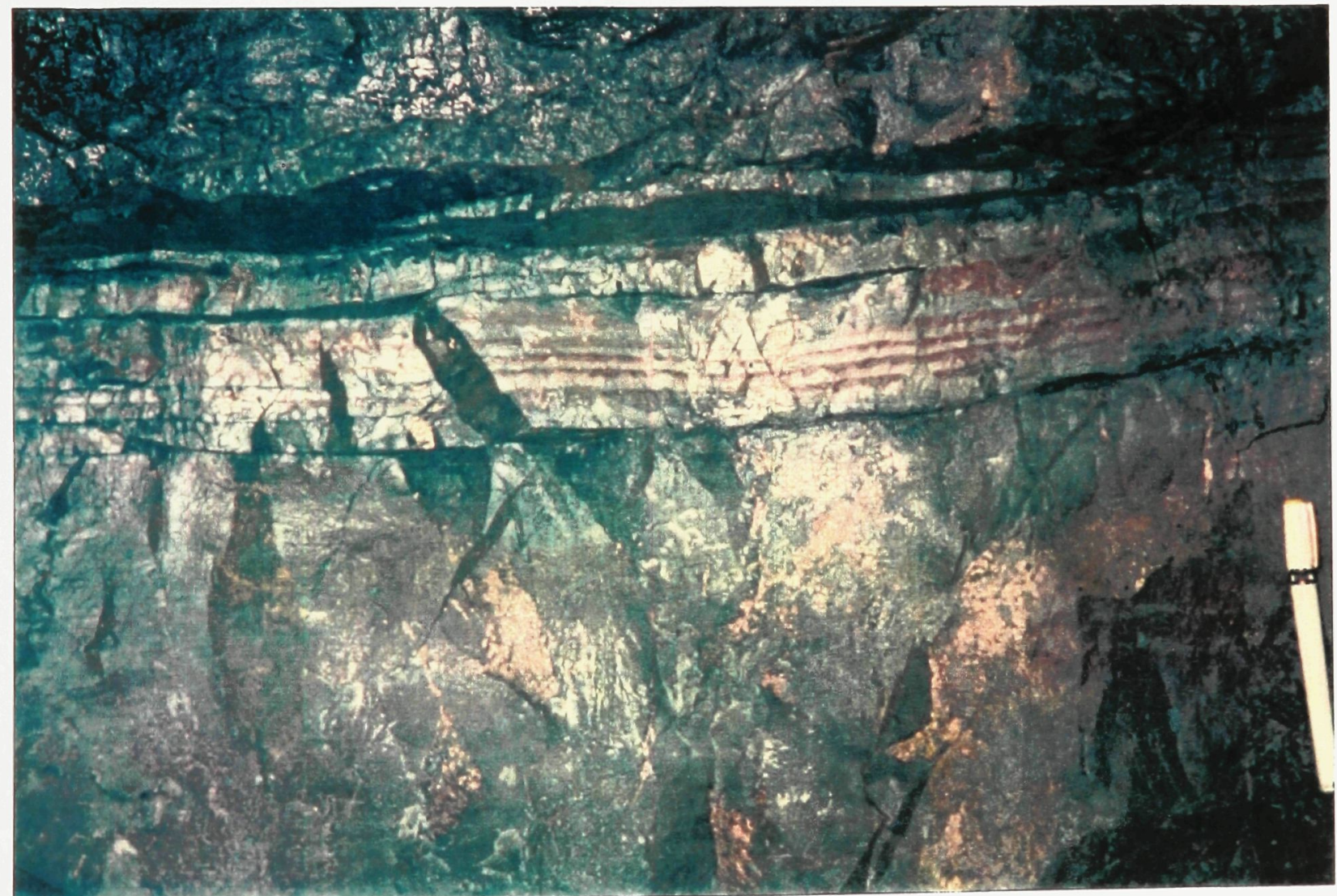

Figure 3.47 Finely laminated bedding top to Cranston tuff laminated facies (Sublevel 10B). $10 \mathrm{~cm}$ long pen for scale. 


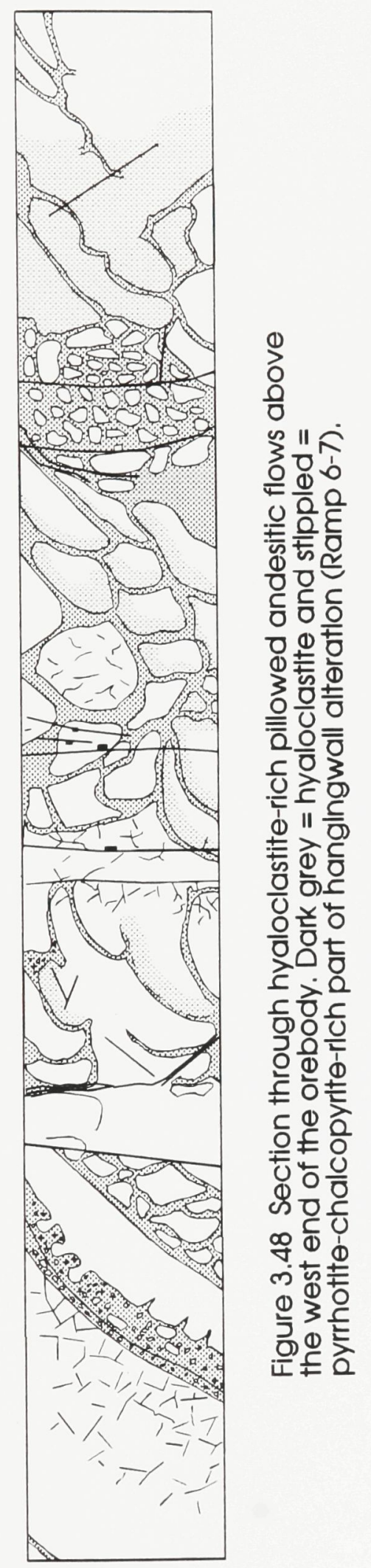


PAGINATION ERROR.

TEXT COMPLETE.

NATIONAL LIBRARY OF CANADA. CANADIAN THESES SERVICE.
ERREUR DE PAGINATION.

LE TEXTE EST COMPLET.

BIBLIOTHEQUE NATIONALE DU CANADA. SERVICE DES THESES CANADIENNES. 


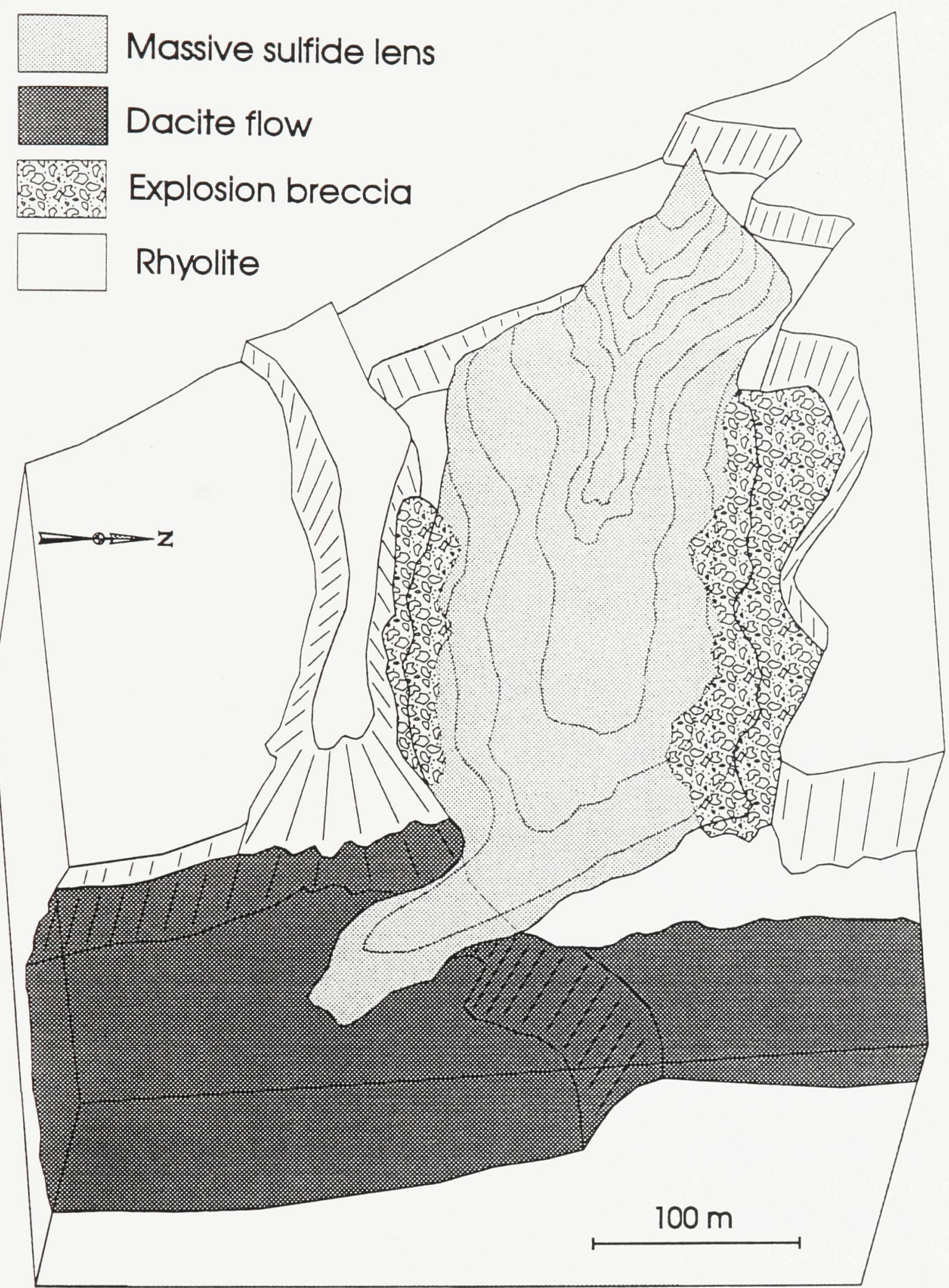

Figure 3.49 Reconstruction of the graben hosting the Ansil deposit. 


\section{CHAPTER 4: ANSIL OREBODY AND ASSOCIATED MINERALIZATION}

\subsection{INTRODUCTION}

This chapter describes the distribution, morphology and composition of the stratiform semi-massive to massive sulfide/magnetite lens and associated sulfide and magnetite units in the stratigraphic footwall and hangingwall to the deposit. The characteristics of the accompanying alteration mineral assemblages will be discussed in Chapter 5 .

The Ansil deposit consists of a single, stratiform to semi-conformable massive sulfide/magnetite lens composed of $1.58 \mathrm{mt}$ grading $8.03 \% \mathrm{Cu}, 0.09 \% \mathrm{Zn}, 45 \mathrm{~g} / \mathrm{t} \mathrm{Ag}$ and $3.08 \mathrm{~g} / \mathrm{t} \mathrm{Au}$ and approximately 300,000 tonnes of semi-massive to massive magnetite. It is underlain and overlain by an extensive, semi-conformable to discordant sulfide/magnetite vein system that extends for almost a thousand metres up through the stratigraphic footwall and up into the hangingwall of the ore lens (Figure 4.1a,b). The massive sulfide/magnetite lens has a plunge length of $320 \mathrm{~m}$, a strike length of up to $150 \mathrm{~m}$, and a maximum thickness of $35 \mathrm{~m}$ at its western end. It trends to the east with plunges varying from 0 to $60^{\circ}$ over top of a step-like, irregular surface of the Northwest Formation. The lens begins abruptly at its western end, thinning to the east where it grades into the host Cranston tuff (Figure 4.2). The sulfide part of the lens is chalcopyrite-pyrrhotite-rich at its western end, becoming more sphalerite-rich down plunge. Much of the sphalerite is present as semi-massive to disseminated ore within the Cranston tuff and underlying phreatic breccias where they are in contact with the massive sulfide lens. Massive magnetite lenses 
occur along the footwall contact of the massive sulfide, locally within the orebody, and intermittently as a thin veneer along its upper contact.

The orebody is underlain by a vein-stockwork system that trends westerly parallel to the long axis of the orebody and plunging approximately $50^{\circ}$ (Figure 4.1a,b). It begins at the upper contact of the Flavrian Pluton, and extends upwards for $100 \mathrm{~m}$ through the Flavrian Formation. It disappears for approximately $50 \mathrm{~m}$ at the base of the Northwest Formation, and then reappears to extend $200 \mathrm{~m}$ upsection to the base of the massive sulfide lens. The footwall stringer zone is up to $200 \mathrm{~m}$ long parallel to the long axis of the massive sulfide/magnetite lens, and up to $100 \mathrm{~m}$ wide. It consists of a series of branching and coalescing, highly discordant to semi-conformable vein systems that join the massive sulfide/magnetite lens near its western and eastern ends. Sphalerite-rich stockwork is less extensive, being restricted to the discordant phreatic breccia zones below the flanks of the massive sulfide/magnetite lens.

An extensive zone of pyrrhotite-sphalerite-chalcopyrite enrichment forms a halo $400 \mathrm{~m}$ high and up to $220 \mathrm{~m}$ wide above the stratiform orebody. The zone has a fir-tree morphology, with a chalcopyrite-rich discordant 'trunk' and more sphalerite-rich 'limbs' (Figure 4.1b). The sulfide-enriched zone is centred over the upper third of the massive sulfide/magnetite lens, and includes small massive sulfide/magnetite lenses, disseminations and veinlets of sulfide and magnetite 


\subsection{FOOTWALL SULFIDE VEIN STOCKWORK}

The footwall vein stockwork occurs as a series of discordant and semi-conformable stringer zones that widen up-section to form a halo about the footwall periphery of the massive sulfide lens up to $200 \mathrm{~m}$ wide and $300 \mathrm{~m}$ long parallel to the long axis of the deposit. In plan view the sulfide stockwork system has a $\mathrm{Zn}$-rich, annular ring peripheral to the sulfide lens, and a $\mathrm{Cu}$-rich core directly underlying the orebody (Figure 4.3a,b). The Cu-rich stockwork is volumetrically the most extensive, comprising the keel of the sulfide vein system, and the $\mathrm{Zn}$-rich vein systems are restricted to tens of metres below the massive sulfide lower contact.

\subsubsection{Zn-rich footwall stockwork system}

\section{Morphology}

The $\mathrm{Zn}$-rich part of the footwall stockwork system is peripheral to the $\mathrm{Cu}$-rich stockwork and underlies the flanks of the massive sulfide lens (Figures 4.2 and $4.3 \mathrm{a}, \mathrm{b}$ ). The $\mathrm{Zn}$-rich stockwork is generally shallower than its $\mathrm{Cu}$-rich counterpart, with several elongate, discordant stockworks leading upwards into a broad zone of semi-conformable sericitequartz altered, sphalerite-enriched rhyolite, dacite and Cranston tuff (Figure 4.2)

Five sphalerite-rich, discordant vein-stockworks transect the footwall rhyolite around the east-west margins of the massive chalcopyrite-pyrrhotite lens. They range from 30 to $100 \mathrm{~m}$ in length, and merge near the upper rhyolite contact with semi-conformable, $\mathrm{Zn}$-rich stockwork mineralization. Two discordant vein-stockworks, one on the south flank (39100 
E, $46480 \mathrm{~N}$ ), and the other under the north flank of the massive sulfide lens (39180 E, $46640 \mathrm{~N})$ are elongate east-west, and cross-cut rhyolite hyaloclastite and flow lobes (Figure 4.3a,b). The lower sections of the remaining three discordant vein-stockworks cross-cut rhyolite, and their upper sections transect Ansil dacite flows. These include a small east-west trending vein-stockwork under the northeast flank of the orebody, a $50 \mathrm{~m}$ by $25 \mathrm{~m}$ north-south trending pipe along the east edge, and a $110 \mathrm{~m}$ by $30 \mathrm{~m}$ stockwork zone that varies in trend from east-west to north-south, and back to east-west. Under the north flank of the massive sulfide lens the stratigraphic footwall contains several small, east-west trending discordant stockwork zones.

\section{Internal morphology and composition}

The deep discordant stockwork zone along the south flank of the deposit consists of strongly sericite-altered rhyolite in which there is 2 to $5 \%$ fine-grained sphalerite, and 5 to $7 \%$, slightly coarser-grained pyrite as disseminations and fracture infilling with quartz. The zone is cross-cut by thin chalcopyrite-pyrrhotite veinlets that increase in intensity along its north margin, where it is overprinted by a pyrrhotite-chalcopyrite vein stockwork.

The shallower discordant $\mathrm{Zn}$ stockwork zones centred about the explosion breccias described in Chapter 3 are aligned along the synvolcanic faults that define the north and south flanks of the deposit. Where the roots of the zones are within massive rhyolite they are 1 to $2 \mathrm{~m}$ wide, with 2 to $3 \mathrm{~mm}$ wide quartz veins filled with cubes of pyrite. The cubes have skeletal cores and multiple rims of more massive pyrite. The veins have variably 
sericite-altered margins. Where the lower parts of these zones cross rhyolite hyaloclastite the quartz-pyrite veins are generally restricted to the devitrified groundmass.

Discordant quartz-pyrite-sphalerite vein-stockworks near the upper rhyolite contact the surrounding rocks are progressively more sericite-quartz altered, the veins wider, and sphalerite is the dominant sulfide mineral. About this sphalerite-rich core there is a margin containing 5 to $10 \%$ disseminated pyrite. Within the sphalerite-rich core the wallrocks are maroon with up to $20 \%$ finely disseminated sphalerite. The veins are 10 to $30 \mathrm{~cm}$ wide, forming larger spaces where there is an intersection of veins. The larger openings are filled with finely layered chalcedony, with a delicate creamy white to maroon striping defined by alternating sphalerite-rich and poor layers (Figures 4.4 and 4.5). The rhyolite wallrock between veins commonly has a sericite-quartz rich, white rim and maroon quartz-sericitesphalerite core. The stockwork zones average 5 to $6 \% \mathrm{Zn}$, with concentrations up to $11.6 \% \mathrm{Zn}$.

A facies change within the explosion breccia pipe from intense veining to a chaotic breccia is accompanied by a dramatic increase in the amount of sulfide present, with the fine-grained matrix to the breccias infilled with semi-massive to massive pyrite, pyrrhotite and sphalerite (Figures 4.6 and 4.7). Breccia fragments are commonly rimmed with pyrite and pyrrhotite, with sphalerite infilling the intervening matrix. The disrupted, sphaleriterich breccia pipes change upwards into sulfide-enriched, overlying, conformable breccia (bleached fragment sulfide ore). 
Where the $\mathrm{Zn}$-rich vein-stockworks transect dacite flows there is in situ brecciation, with fractures infilled with pyrrhotite, sphalerite, quartz and abundant wallrock fragments (Figure 4.8). The wallrock fragments and vein walls have distinctive, 1 to $2 \mathrm{~cm}$ wide sericite-rich rims. The quartz veins were reactivated, with open space infilling by pyrrhotite. The veins sometimes contain corroded grains of pyrite. Amygdules in the surrounding wallrock are infilled with quartz, albite, pyrrhotite and pyrite. Near the top of the dacite sequence veining becomes more intense, with the stockwork changing character from in situ brecciation to disrupted, or chaotic breccias (Figure 4.9). Sericite alteration of the wallrock fragments within the disrupted breccias becomes more intense. Where the discordant vein stockworks cross flow tops and flow breccia the thermal cooling fractures control alteration and sulfide distribution, with the quartz-pyrrhotite zones spreading laterally along the flow tops to form 1 to $2 \mathrm{~m}$ wide zones of semi-conformable sulfide enrichment and sericite alteration. Sphalerite occurs within the flow-top breccia zones, and there is commonly a zonation from pyrrhotite-rich flow-tops to sphalerite-rich flow top breccias. As the amount of hyaloclastite increases near the top of the dacite sequence the semi-conformable pyrrhotite-sphalerite zones begin to dominate the discordant stockworks, forming the broad zones of semi-conformable sulfide-enrichment along the flanks of the deposit (Map 11A, Appendix). One to $5 \mathrm{~mm}$ wide, fragment-rich sphalerite veins transect the Cranston tuff directly overlying the sphalerite-pyrrhotite-enriched dacite hyaloclastite 


\subsubsection{Cu-rich footwall stockwork system}

\section{Morphology}

The Cu-rich footwall pyrrhotite-chalcopyrite vein-stockwork first appears approximately $130 \mathrm{~m}$ below the massive sulfide lens as four discordant zones, each several metres wide, unevenly spaced over $100 \mathrm{~m}$ along a west-southwest axis (Figures 4.1 and 4.3a,b). Each stockwork zone is elongate north-south, with strike lengths of up to $60 \mathrm{~m}$. Approximately $60 \mathrm{~m}$ below the massive sulfide lens the discordant vein-stockworks widen and merge to form a zone of semi-conformable pyrrhotite-chalcopyrite vein-stockwork up to $150 \mathrm{~m}$ long along a west-southwest axis, up to $25 \mathrm{~m}$ thick and $65 \mathrm{~m}$ wide. Two discordant stockwork zones connect the semi-conformable vein-stockwork to the base of the massive sulfide lens. The easterly discordant zone (at 39180E) consists of two elongate vein-stockworks with a total $50 \mathrm{~m}$ east-west strike length. These merge with the massive sulfide orebody between Sublevel 9C and Level 10. The west-end discordant zone is up to $20 \mathrm{~m}$ wide, with a $40 \mathrm{~m}$ north-south strike length. It merges with the massive sulfide lens between Level 9 and Sublevel 9B. Approximately $20 \mathrm{~m}$ below the massive sulfide lens this vein-stockwork furcates to form smaller, parallel stockwork zones that join the stratiform orebody between Sublevels 7B and 8A (Figure 4.1a).

The morphology of the upper discordant pyrrhotite-chalcopyrite vein-stockworks is quite complex, with numerous, bedding-parallel apophyses branching out for up to $15 \mathrm{~m}$ from the main axis of the structure. Twenty to $25 \mathrm{~m}$ below the massive sulfide lens the main stockwork zones is divided into a number of smaller vein-stockworks. The two 
western stockwork zones divide into 2 to 3 smaller pipes that form a series of northwesterly-striking keels that are transitional into the footwall fragmental pyrrhotitechalcopyrite ores along the north-south width of the massive sulfide lens (Figure 4.2). The branching out of the discordant pyrrhotite-chalcopyrite vein-stockwork across the width of the massive sulfide lens defines an upper semi-conformable stockwork zone. The branching within the eastern two pipes remains tighter under the central part of the lens.

\section{Internal morphology and compositions}

The lower discordant pyrrhotite-chalcopyrite vein-stockworks farthest downsection from the massive sulfide lens are rooted within zones of strongly chlorite altered rhyolite. The zone contains 1 to $2 \%$ disseminated pyrrhotite and pyrite, the latter as cubes to $2 \mathrm{~mm}$, and 2 to $3 \%$ veinlets with chalcopyrite cores, silicic margins and chlorite-rich rims. Some pyrite-pyrrhotite-chalcopyrite veinlets are present. As the discordant pipe begins to widen up-section the accompanying zone of strong chlorite alteration contains 10 to $20 \mathrm{~cm}$ wide pyrrhotite-chalcopyrite-rich zones with disseminated pyrite-pyrrhotite and 2 to $20 \mathrm{~mm}$ wide sharp-walled veins with pyrrhotite cores, chalcopyrite margins and thin, quartz-rich rims. The larger veins contain angular fragments of strongly chloritized rhyolite. As the discordant stockwork zones widen the disseminated pyrite disappears from their cores, and is restricted to the margins, where it rims anhedral pyrrhotite blebs.

The intensity of alteration and sulfide enrichment within the lower discordant vein stockworks is not uniform across the width of the structure. The internal morphology of 
the stockwork zones is controlled to a large extent by the primary morphology of the host rhyolite (Figure 4.10a). Massive rhyolite flow lobes are strongly chlorite altered, with sparse amounts of disseminated pyrrhotite and widely-spaced, wallrock fragment-filled veins. The interflow hyaloclastite contains more abundant sulfide as closely spaced, discontinuous veins and veinlets and disseminations, with the latter concentrated around the rims of strongly chloritized blocky shards. The core of the stockwork zones contain irregular-shaped, discontinuous chalcopyrite-pyrrhotite veins in a strongly chlorite-altered groundmass, and the margins contain larger, wallrock fragment-filled veins forming 1 to $4 \mathrm{~m}$ wide breccia zones within less altered rhyolite.

The lower semi-conformable pyrrhotite-chalcopyrite stockwork forms at a level within the footwall rhyolite where there is a change from a tightly packed, basal rhyolitic flow lobe-breccia sequence to an upper section with abundant hyaloclastite (Figure 3.15). At the intersection of the lower discordant stockwork zones and the semi-conformable stockwork there is a zone of 20 to $30 \%$ chalcopyrite-pyrrhotite veining. This zone of semimassive sulfide veining continues along the core of the semi-conformable stockwork zone within strongly chloritized rhyolite as 10 to $30 \mathrm{~cm}$ wide wallrock fragment-rich veins interconnected by a finer, "net-textured" veining. The finer veins consist of filigree-textured chalcopyrite and pyrrhotite as 1 to $4 \mathrm{~mm}$ sized anhedral blebs within a chlorite groundmass coalescing into linear zones to form semi-massive veins and disseminations.

The upper discordant pyrrhotite-chalcopyite stockworks are generally more consistent than the lower zones, with sulfide enrichment more evenly distributed across 
their widths. The lower sections of the upper vein-stockworks are 20 to $30 \mathrm{~m}$ wide at their intersection with the lower semi-conformable stockwork. These western pipes are less than $10 \mathrm{~m}$ at their middle, and then widen out at the top to form the upper semiconformable stockwork zone (Figures 4.2 and 4.3b). The eastern discordant stockworks are consistently 20 to $30 \mathrm{~m}$ wide for their entire plunge length.

A typical cross-section through the lower to middle section of the upper discordant stockworks shows a 3 to $5 \mathrm{~m}$ wide margin of moderately chlorite-altered rhyolite cross-cut by 10 to $30 \mathrm{~cm}$ wide, wallrock fragment-rich chalcopyrite-pyrrhotite veins forming a crackle breccia zone (Figure 4.10b). The veins have 0.5 to $2 \mathrm{~mm}$ wide, quartz-rich rims, or have thin branching veinlets with 2 to $5 \mathrm{~mm}$ wide quartz-rich halos. There is then an abrupt contact into intensely chlorite-altered rhyolite containing remnant, corroded fragments of moderately chlorite-altered wallrock. Within the chlorite-altered rhyolite are more fragment-rich sulfide veins with thin, quartz-rich halos. The vein pattern becomes reticular, more concentrated, and the veins thinner. Towards the core of the discordant stockwork zone the fragment-rich veins become thinner still, and interconnected by a fine, "net-textured" pyrrhotite-chalcopyrite vein system. In the core of the discordant stockwork there is 10 to $15 \%$ disseminated pyrrhotite-chalcopyrite, thin discontinuous pyrrhotitechalcopyrite veinlets and small lenses of fragment-rich veins. In the lower sections of the eastern upper discordant stockwork zones the cores also contain veinlets and veins of sphalerite. 
The upper sections of the two eastern stockwork zones differ from the lower sections in that they contain quartz-sericite-sphalerite-rich zones in their cores. These silicified, $\mathrm{Zn}$ rich zones include chaotic breccias similar to those observed within the explosion breccias below the north and south flanks of the massive sulfide lens. They may be evidence for formation of a $\mathrm{Zn}$-rich stockwork below the centre axis of the graben before the emplacement of the $\mathrm{Cu}$-rich stockwork zone.

In the upper section of the western vein-stockworks, where they divide into smaller stockwork systems, there is a variation in internal morphology and texture. Ten to $30 \mathrm{~m}$ below the massive sulfide lens the pipes cross-cut rhyolite hyaloclastite with little or no accompanying alteration halo. The veins vary in width from 1 to $15 \mathrm{~cm}$. Where the smaller veins form the stockworks, they have a net-texture (Figure 4.11). In places the pyrrhotitechalcopyrite permeates the matrix to the blocky shards to form zones of fragment-rich semi-massive sulfide. The veins have chlorite-rich margins that increase in width near the intersection of the vein stockwork and the massive sulfide lens, until the hyaloclastite within the pipe margins becomes pervasively chloritized. Within the strongly chloritealtered hyaloclastite the net-texture of the pyrrhotite-chalcopyrite veins breaks down to disseminated blebs of sulfide that coalesce in places to form filigree-textured, semi-massive sulfide (Figure 4.12).

Within the pipes composed of larger veins the host hyaloclastite is divided up into subangular blocks that vary up to $2.5 \mathrm{~m}$ in diameter. The chlorite content of the veins increases up-plunge towards the massive sulfide lens, and the vein network is finer- 
textured. Just below the massive sulfide contact the vein morphology is either a fine, nettexture within an increasingly chlorite-altered hyaloclastite, or the chlorite-rich veins coalesce, with remnants of moderately altered hyaloclastite rimmed with pyrrhotitechalcopyrite within a chlorite matrix

Regardless of which internal morphology occurs within the stockwork zones, the vein systems become semi-conformable 1 to $10 \mathrm{~m}$ below the massive sulfide lens, with a gradational contact into overlying fragment-rich massive sulfide ore. Where the upper semi-conformable stockwork overlaps the massive rhyolite flow lobes under the south flank of the massive sulfide lens, pyrrhotite-chalcopyrite enrichment is concentrated along columnar joints (Figures 3.16, 3.17, 3.18 and 4.13). The spaces between the columns are strongly chlorite-altered, as are the corroded margins of the columns. Along the chloritealtered margins of the columns chalcopyrite and pyrrhotite infill elongate amygdules. In the intercolumn areas the sulfides form filigree-textured, branching patterns within the chlorite groundmass. Semi-massive chalcopyrite-pyrrhotite veins cross-cut a primary lamination, with smaller veins formed from fine-grained sulfide intergrowths branching out along the primary layering (most likely flow banding). In places the sulfide infilling becomes massive, with corroded, subrounded rhyolite columns surrounded with chalcopyrite and pyrrhotite. 


\subsection{STRATIFORM MASSIVE SULFIDE LENS}

\subsubsection{Morphology and composition}

The morphology and composition of the massive sulfide lens varies considerably along its plunge length (Figure 4.2). The western end of the lens begins abruptly as a conical, steep-sided ( 50 to $70^{\circ}$ ) chalcopyrite-pyrrhotite-rich mound $75 \mathrm{~m}$ in diameter and up to 50 $\mathrm{m}$ thick with its base along the rhyolite-andesite contact, and projecting up into the overlying andesite. At the top of the mound is a 2 to $3 \mathrm{~m}$ wide spine of massive sulfide that projects further into the overlying andesite. Contacts with the enveloping andesite flows and flow breccia are sharp to diffuse, with abundant shearing along the north contact and along the margins of the sulfide spine.

The sulfide mound reaches its maximum thickness by Sublevel $6 \mathrm{C}$, and then begins to thin down plunge (Figures 4.2 and 4.14). The thinning of the orebody coincides with a sudden increase in the dip of the underlying rhyolite contact from 20 to $60^{\circ}$ (Figure 4.1). By Level 8 the sulfide lens has flattened to a maximum thickness of $7 \mathrm{~m}$ (averaging 4 to 5 $\mathrm{m})$, and a $100 \mathrm{~m}$ strike length. Roughly one half of the lens's thickness is below the rhyolite-andesite contact. The contacts near its two ends are strongly sheared, and the upper contact is irregular, with sulfide extending into the overlying pillowed flows along the hyaloclastite-filled pillow interstices. In some instances individual pillows are completely surrounded by chalcopyrite-pyrrhotite so that they are part of the massive sulfide lens (Map 8, Appendix). In plan view the irregularity of the lens's upper surface is accentuated by the moderately steep dip of the contact. A spine of sulfide $6 \mathrm{~m}$ wide and 
several metres long projects into the overlying andesite $45 \mathrm{~m}$ from the northern termination of the sulfide lens; the remnant of the larger spine present further up-plunge.

Over the next $125 \mathrm{~m}$ of plunge length the massive sulfide lens gradually thickens along its central axis to over $17 \mathrm{~m}$, with an average thickness of the lens being $8.5 \mathrm{~m}$. The thickening of the sulfide lens is a result of massive sulfide formation within the underlying rhyolite sequence, with the thickest section projecting down section to form the top of the underlying discordant sulfide vein stockwork. At Level 9 the lens is confined between two well-defined offsets in the rhyolite contact, with its north and south flanks underlain by wedges of conformable phreatic/talus breccia. This is the first level where the margins of the small, fault-bounded basin containing the orebody are observed. Intermittent along the upper contact of the massive sulfide lens are thin remnants of finely laminated Cranston tuff. Where the tuff is absent the upper contact is more irregular, with replacement of andesite hyaloclastite between pillows.

Segments of Cranston tuff, up to $1 \mathrm{~m}$ thick and $4 \mathrm{~m}$ long, occur in the massive sulfide lens down-plunge from Sublevel 8A. By Sublevel 9B the north flank of the sulfide lens interfingers with, and is underlain by Cranston tuff. The sphalerite content of the massive sulfide orebody begins to increase with the presence of the tuff, and the volcaniclastic unit and underlying phreatic breccia are host to disseminated to semi-massive sphalerite-pyrite and sphalerite-pyrrhotite. Below Level 9C the massive chalcopyrite-pyrrhotite-sphaleritepyrite lens thins and narrows rapidly within the host Cranston tuff. Its upper contact is very irregular, with lenses of chalcopyrite-pyrrhotite branching out along bedding planes in the 
Cranston tuff resulting in lit-par-lit replacement of the sphalerite-rich volcaniclastic unit The north and south ends of the orebody are commonly sheared, with sulfide remobilized into the shear planes. By Sublevel 11A the massive sulfide lens is less than $2 \mathrm{~m}$ thick and has a strike length of less than $10 \mathrm{~m}$. Its contacts feather out into the surrounding Cranston tuff. Down plunge from the end of the massive sulfide lens the Cranston tuff continues to contain disseminations and bedding-parallel veins of sphalerite-pyrite-pyrrhotite and minor chalcopyrite for at least $100 \mathrm{~m}$.

\subsubsection{Stratiform sulfide ore types}

The massive sulfide lens consists of three ore types defined by textural and compositional variations (Figure 4.15). In many cases there are transitional contacts between ore types, and it is evident from overprinting relationships that the different textures and compositions define various stages in deposit evolution.

\section{Massive sulfide ore}

Massive sulfide ore composes $60 \%$ of the stratiform orebody and defines the core of the deposit. It is divided into massive, banded and sieve-textured.

Massive ore consists of greater than $95 \%$ sulfide and is divided into chalcopyritepyrrhotite and pyrrhotite-chalcopyrite types, the former being more abundant. Chalcopyrite-pyrrhotite massive ore consists of 60 to $75 \%$ massive chalcopyrite containing irregular wisps and clots of pyrrhotite (Figure 4.16). Pyrrhotite forms sub-rounded, 
anhedral grains that coalesce into aggregates with polygonal intergrain boundaries. The pyrrhotite is strongly anisotropic, non-magnetic, and contains abundant annealed fractures and inclusions filled with quartz, sphalerite, stilpnomelane and rare galena. Chalcopyrite contains minor inclusions of sphalerite and small $(0.1$ to $0.2 \mathrm{~mm})$, irregular-shaped domains of microcrystalline to very fine-grained sutured quartz with subordinate stilpnomelane.

The pyrrhotite-chalcopyrite massive ore contains up to $90 \%$ pyrrhotite as tightly packed 0.2 to $0.4 \mathrm{~mm}$ sized pyrrhotite grains with subrounded to polygonal grain boundaries Anhedral chalcopyrite occurs between pyrrhotite grains. In places larger concentrations of chalcopyrite occur as wispy, planar to contorted bands up to several centimetres long and 15 to $20 \mathrm{~mm}$ wide. Trace sphalerite is present as anhedral blebs in the pyrrhotite and chalcopyrite. Small microbreccia zones are present, with angular pyrrhotite fragments in a matrix of pyrrhotite, chalcopyrite and quartz. Irregular blebs, up to $2 \mathrm{~mm}$ long, of microcrystalline sutured quartz with minor chlorite, stilpnomelane and greenalite compose 2 to $5 \%$ of the massive ore. In places the quartz rich blebs occur as patchy concentrations, and in other places form 5 to $10 \mathrm{~mm}$ wide bands parallel to the contacts of the massive sulfide/magnetite lens.

Banded sulfide ore is a variation on massive chalcopyrite-pyrrhotite ore where the pyrrhotite is present as closely spaced, parallel, discontinuous bands tens of centimetres long and up to $20 \mathrm{~mm}$ wide (Figures 4.17 and 4.18). The banding is most common along the hangingwall contact of the massive sulfide lens, with the banding more abundant and 
individual bands thinner towards the contact. Annealed fractures and rare twinning within the pyrrhotite grains tend to parallel the banding.

Banding also occurs where the massive sulfide is strongly deformed and sheared. This tectonized massive sulfide is invariably chalcopyrite-rich, with contact-parallel, discontinuous bands of pyrrhotite parallel to the sulfide lens margins. The streaks consist of elongate grains and chains of smaller, more equidimensional grains 2 to $4 \mathrm{~mm}$ long. Within these high strain zones the chalcopyrite is strongly twinned

Sieve-textured sulfide ore occurs as zones within the massive ore where there is a high concentration of irregular-shaped, $<5 \mathrm{~mm}$ sized quartz-rich blebs (Figure 4.16). The quartz-rich blebs form patches tens of centimetres in diameter within the massive ore or discontinuous bands. The sieve-textured ore consists of $20 \%$ or more of these blebs which consist of very fine-grained to microcrystalline, sutured quartz grains, or of $<0.2 \mathrm{~mm}$ sized single, elongate to equidimensional, subhedral quartz grains. The polycrystalline domains commonly have coarser quartz in contact with the surrounding sulfide. The grains are generally equidimensional, with rare elongate grains composed of one or more crystals. The margins of the domains are ragged and irregular, with small veinlets and disseminations of sulfide. Also present are minor amounts of stilpnomelane, chlorite and greenalite.

The sieve-textured sulfide ores are most common in the lower third of the sulfide lens and along the sulfide andesite contact. Along this upper contact the quartz-rich domains, within the sieve-textured ore, graduate into patches of chlorite-quartz-ilmenite altered andesite 
containing elongate laths of quartz pseudomorphs after plagioclase microlites. This sievetexture may therefore be remnants of the andesitic flows that have been replaced to varying degrees by the sulfide.

\section{Fragmental sulfide ore}

Fragmental sulfide ore is present along the footwall and hangingwall margins of the massive sulfide lens (Figure 4.15). In the hangingwall it is restricted to the discordant massive sulfide spine at the top of the orebody between sublevels $6 \mathrm{~A}$ and 8 , and accounts for less than $5 \%$ of the orebody. It is best observed on Sublevel 7A (see Map Sublevel 7A) where the upper part of the massive sulfide lens contains large, chlorite-altered blocks of andesite along a very irregular contact marked by numerous, up to $1 \mathrm{~m}$ thick, sulfide veins (Figure 4.19). The tip of the massive sulfide spine consists of an amoeboid pillow breccia in which the matrix is replaced by chalcopyrite-pyrrhotite. The margins and tip of the spine are enclosed in abundant chalcopyrite-pyrrhotite veins. This vein system continues upsection as the root for the hangingwall zone of sulfide enrichment (Figure 4.1b).

The largest concentration of fragmental sulfide ore is along the footwall contact of the massive sulfide lens, accounting for approximately $15 \%$ of its total volume (Figure 4.15 ). These fragmental ores define a semi-conformable base to the stratiform orebody, with their lower contacts cross-cutting strata to join with the discordant sulfide vein stockwork that underlies the deposit. Sulfide fragmental ores are divided into bleached, elongate and blocky fragment types. 
Bleached fragment sulfide ore is a sulfide-replaced part of the conformable, phreatic/talus breccias that are located along the synvolcanic faults that bound the north and south margins of the deposit. It first appears under the north flank of the massive sulfide lens on Level 8 as a 1 to $2 \mathrm{~m}$ thick wedge that thins and pinches out to the south after several metres (Maps 8, 8A, 9, Appendix). By Level 9 it is present under both the north and south flanks of the massive sulfide lens where it occurs as less than $2 \mathrm{~m}$ thick wedges that gradually thin towards the central axis of the orebody. In places it is interlayered and intermixed with the elongate and blocky fragment breccias. It is up to 12 $\mathrm{m}$ thick for the remaining plunge length of the deposit, and is generally more extensive under the deposit's north flank.

Under the north flank of the massive sulfide lens the bleached fragment breccias are sphalerite-pyrite rich, with the quartz-sericite altered rhyolite clasts ranging in colour from beige to maroon depending on their content of fine-grained, disseminated sphalerite (Figure 4.20). Sphalerite can be either evenly distributed throughout the clast, concentrated in the clast core or margins, or as slightly coarser grains infilling vesicles. The groundmass may be strongly silicified, or contain varying amounts of sphalerite and pyrite. Where present in the matrix the sphalerite is coarser-grained (1 to $2 \mathrm{~mm}$ ), and fills inter-fragment void space, surrounded by 0.5 to $2 \mathrm{~mm}$ subhedral pyrite grains that form rims about the fragments. Pyrite-sphalerite ratios vary considerably across a section of the breccia, but the pyrite is always within the matrix and not the fragments. On Sublevel 10A sphalerite-rich fragments are contained within a pyrite-rich matrix that is cross-cut by sub-vertical zones 
of semi-massive to massive sphalerite (Figure 4.21 and Map 10A, Appendix). These crosscutting zones may represent hydrothermal fluid pathways.

In wedges of bleached fragment breccia along the lower massive sulfide contact the pyrite-sphalerite is overprinted by pyrrhotite and chalcopyrite (Figure 4.22).

Elongate and blocky fragment ores are products of sulfide enrichment of rhyolite breccias and hyaloclastite either through open space filling or replacement. In both cases the contained fragments are dark green-black due to intense chloritization. Open space filling is most common in the blocky fragment ore, where massive, amygdaloidal and flow-banded fragments have 1 to $2 \mathrm{~mm}$ rims of pyrrhotite or chalcopyrite and the remaining interfragment space is infilled with a mixture of quartz, pyrrhotite and chalcopyrite (Figures 4.23 and 4.24). The elongate fragment ore consists of angular to subangular clasts of strongly altered rhyolite with long axes parallel or sub-parallel to bedding. In some cases long, platy fragments are a product of in situ exfoliation of rhyolite lobe contacts (Figures 4.24 and 4.25). Elsewhere the ore is similar in texture to the more blocky 'blue quartz' breccias, with the devitrified and silicified matrix replaced by pyrrhotite and chalcopyrite. Where the precursor to the fragmental ore was a fine-grained hyaloclastite, sulfides occur farthest from the stratiform orebody as coarse veining, with the veins decreasing in size and increasing in intensity upsection. The vein intensity increases to a point where a pseudo-breccia is formed, with remnants of the strongly altered hyaloclastite in semi-massive to massive pyrrhotite-chalcopyrite (Figure 4.26). 


\section{Layered sulfide ore}

Layered semi-massive to massive sulfide accounts for approximately 10 to $15 \%$ of the Ansil orebody (Figure 4.15). It is divided into sulfide-rich Cranston tuff, layered chalcopyrite-pyrrhotite/pyrite-sphalerite and layered chalcopyrite-pyrrhotite-tuff

Sulfide-rich Cranston tuff is distinguished by its maroon colour, which is due to the presence of fine-grained sphalerite that is present in a range of abundances from aphanitic disseminations ( 1 to $3 \%$ ) to semi-massive sphalerite-pyrite layers and veinlets containing up to $25 \%$ sphalerite (Figure 4.27 ).

The most common type of sulfide-rich Cranston tuff is hosted by the fine-grained and laminated facies, where fine-grained sphalerite, pyrite and pyrrhotite are concentrated within the coarser-grained layers. These maroon-coloured layers stand out in stark contrast to the laminated tops of the beds, which are milky white due to silicification (Figure 4.27). Within the coarse-grained bases of the normally graded layers sphalerite forms 0.5 to $1 \mathrm{~mm}$ anhedral blebs between quartz phenoclasts and lithic clasts, and is commonly intergrown with sericite flakes, and more rarely stubby albite crystals (Figures 4.28a,b). Pyrite forms euhedral twinned cubes with very inclusion-rich zones, and pyrrhotite forms as anhedral to subhedral grains with sphalerite, or as coatings and inclusions in pyrite grains (Figures $4.28 \mathrm{c}, \mathrm{d}$ ). The siliceous laminated beds are in places fractured parallel to, and at right angles to bedding, with 2 to $5 \mathrm{~mm}$ wide fractures infilled with quartz fragment-rich massive sphalerite. 
The sulfide-rich Cranston tuff is most sphalerite-rich where it overlies one of the discordant zones of phreatic breccia, and at its synvolcanic fault contact with the rhyolite footwall. On Sublevel 9B there is intense sphalerite enrichment of the tuff immediately along the fault contact and there spreads out from the contact along the coarser-grained beds within the volcaniclastic unit (Figure 4.29).

The contact between the sulfide-rich Cranston tuff and the more chalcopyrite-pyrrhotite rich parts of the orebody is irregular and diffuse, with elongate segments of sphalerite-rich tuff within the latter (Figure 4.30). At the eastern termination of the orebody the chalcopyrite-rich ore dissipates into the surrounding sphalerite-rich Cranston tuff, forming stratabound zones of massive to semi-massive chalcopyrite-pyrrhotite at various levels in the volcaniclastic unit (Figure 4.31). In other places there is a diffuse halo of disseminated chalcopyrite and pyrrhotite in the tuff surrounding the massive sulfide (Figure 4.32).

Layered chalcopyrite-pyrrhotite/pyrite-sphalerite ore occurs between Level 9 and Sublevel 9B in conjunction with the appearance of large segments of Cranston tuff within the orebody and a $10 \mathrm{~m}$ thick sequence of tuff along the north flank of the deposit. The ore type has a limited distribution as a transition zone between the chalcopyrite-pyrrhotite lens and the sphalerite-rich Cranston tuff (Figure 4.15). Within the Cranston tuff there is a sharp increase in the pyrite content in the form of thin massive layers and abundant spheroidal to ellipsoidal concretions up to $15 \mathrm{~mm}$ in diameter (Figure 4.33). The laminated tuff layers are more sphalerite rich giving the rock a striped appearance (Figure 4.34). In proximity to the $\mathrm{Cu}$-rich massive sulfide lens finely disseminated chalcopyrite-pyrrhotite 
appears within the coarser-grained tuff layers. Pyrite grains are corroded, with rims of pyrrhotite and chalcopyrite. The coarser-grained tuff layers are more chalcopyrite-rich with the exclusion of pyrite, and thin pyrrhotite-rich streaks occur. At this stage the ore is composed of discontinuous layers of fine-grained sphalerite-pyrite within sieve-textured chalcopyrite-pyrrhotite (Figures 4.35 and 4.36). The blebs within the sieve-textured ore are composed of quartz and sphalerite. The transition from layered chalcopyritepyrrhotite/pyrite-sphalerite ore to massive ore consists of massive chalcopyrite-pyrrhotite with up to $10 \mathrm{~cm}$ wide, discontinuous layers of streaky sphalerite-quartz and scattered, corroded pyrite concretions with abundant quartz inclusions.

Above Level 10 layered chalcopyrite-pyrrhotite/pyrite-sphalerite ore is a minor component of the $\mathrm{Cu}$-rich massive sulfide lens and restricted to its contacts with Cranston tuff. On Sublevels 10B and 11A it defines most of the $\mathrm{Cu}$-rich ore.

Layered pyrrhotite-chalcopyrite-tuff occurs as thin, elongate segments intermittently along the contact between the footwall fragmental and massive ores, within the massive ore, and along the andesite-massive sulfide contact (Figures 4.37 and 4.38). At the western end of the orebody it appears between Sublevel 7B and Level 8 along the northern half of the upper contact to the footwall fragmental ore as 20 to $30 \mathrm{~cm}$ wide segments up to several metres long. On Sublevel 8A it occurs intermittently along the same contact and, less commonly, as remnants within the massive ore. On Level 9 it occurs intermittently along the fragmental/massive sulfide ore and massive sulfide/andesite contacts in the north 
end of the orebody. On Sublevel 9C it is restricted to the massive sulfide/andesite contact. This type of layered ore is not observed in the remainder of the orebody.

The layered pyrrhotite-chalcopyrite-tuff consists of chloritized and sulfidized layers of quartz-phyric Cranston tuff and semi-massive to massive sulfide. Along the lower contact of the massive ore the layered ore is clearly a product of sulfide replacement of the preexisting fine-grained facies of the Cranston tuff (Figure 4.39). Coarser tuff layers consist of massive to semi-massive pyrrhotite-chalcopyrite with remnant quartz phenoclasts and finegrained, quartz-chlorite intergrowths. The sulfide layers are in sharp contact with overlying, finely laminated tuff in which the coarser bases of the laminae are partially replaced with sphalerite and pyrrhotite. Along the margins of the layered pyrrhotitechalcopyrite-tuff ore segments the bedding is truncated at a high angle by massive sulfide in which "ghost" bedding structures continue for a several centimetres into the massive sulfide (Figure 4.40).

Along the hangingwall contact to the orebody layered pyrrhotite-chalcopyrite ore replaced the Cranston tuff laminated facies. The lower contact to the layered ore consists of massive to sieve-textured pyrrhotite-chalcopyrite with remnant layering defined by concentrations of fine-grained to microcrystalline quartz (Figures $4.41 \mathrm{a}, \mathrm{b}, \mathrm{c}$ ). The layered ore consists as either semi-massive sulfide, with partial replacement of the tuff, or as delicately banded massive pyrrhotite-chalcopyrite containing remnant lamellae of chloritealtered, fine-grained tuff. 
Pyrrhotite ovoids up to $12 \mathrm{~mm}$ in diameter occur within remnants of finely laminated tuff. Layering is wrapped around these concretions (Frontispiece and Figure 4.39).

\subsection{MAGNETITE ZONES}

\subsubsection{Introduction}

One of the unusual aspects of the Ansil deposit is the amount of magnetite associated with the massive sulfide orebody and discordant vein stockworks (Riverin et al., 1990). The original reserve estimate for the deposit grossly undercalculated the total volume of magnetite present; subsequent underground development and drilling eventually delineated over 300,000 tonnes of massive to semi-massive magnetite in contact with the stratiform massive sulfide lens. The deep surface drill holes determined that although much of the magnetite present is directly associated with the massive sulfide lens, small massive magnetite lenses, veins and disseminations are present in the stratigraphic hangingwall and footwall. Magnetite veins and disseminations in the footwall are traced down the plunge length of the alteration zone over $400 \mathrm{~m}$ to the underlying Flavrian Pluton.

Detailed studies of the magnetite were carried out by Westendorp et al. (1991) and Westendorp (1991) described the nature of magnetite distribution and its relationship with both the massive sulfide lens and vein stockworks and association with the Cranston tuff. In particular these studies defined the presence of zoned magnetite crystals containing up to 3.4 weight percent $\mathrm{Si}$ in the spinel structure. 


\subsubsection{Magnetite distribution and morphology}

Magnetite distribution is divided into three major zones with respect to their position relative to the massive sulfide deposit: (1) Footwall magnetite veins, and disseminations, (2) Ore zone magnetite with massive to semi-massive pods directly in contact with the massive sulfide lens, and (3) Hangingwall magnetite with massive to semi-massive lenses and disseminations stratigraphically above the Ansil deposit (Figures 4.2 and 4.42a,b)

Footwall magnetite zones are concentrated around the margins of the chalcopyritepyrrhotite stockwork zones as a 10 to $20 \mathrm{~m}$ wide halo (Figure 4 .1a). The magnetite halo begins below the sulfide stockwork zone near the Flavrian-rhyolite contact, and envelops the western lower discordant chalcopyrite-pyrrhotite pipe, spreading out to underplate the lower semi-conformable stockwork. Above the lower semi-conformable sulfide stockwork it forms a thinner ( 5 to $10 \mathrm{~m}$ ) discontinuous halo about the eastern pyrrhotite-chalcopyrite pipes. Magnetite veining is also localized along the southern margins of the western sulfide stockwork zones near their junction with the upper pyrrhotite-chalcopyrite semiconformable stockwork zone. These margins are typically 1 to $5 \mathrm{~m}$ wide. Plan view of the footwall magnetite distribution shows a number of zones paralleling the north-south trends of the chalcopyrite-pyrrhotite stockworks, suggesting similar structural control for the two stages of hydrothermal activity.

Ore zone magnetite has a distribution with relation to the massive sulfide lens that varies along the plunge length of the orebody (Figure 4.2). Massive to semi-massive pods of varying dimensions occur on all of the mine levels. From Sublevels $6 \mathrm{~A}$ to $6 \mathrm{C}$ it occurs as 
less than a $30 \mathrm{~cm}$ thick, discontinuous rim about the margin of the chalcopyrite-pyrrhotite lens. Further east a thicker pod of massive magnetite occurs under the south flank of the massive sulfide lens, growing to $27 \mathrm{~m}$ long and $5 \mathrm{~m}$ thick between Sublevels $6 \mathrm{C}$ and $7 \mathrm{~A}$. By Sublevel 7A the magnetite lens surrounds the south end of the massive sulfide lens, and under its centre there is a second massive magnetite lens with a $25 \mathrm{~m}$ wide base that extends $20 \mathrm{~m}$ up into the massive sulfide lens. By Sublevel 7B the south and central massive magnetite lenses have coalesced to form a single pod $55 \mathrm{~m}$ long and $5 \mathrm{~m}$ thick, with a magnetite spine coring the centre of the massive sulfide lens. Down plunge from Sublevel 7B the magnetite core to the deposit transects the upper contact of the massive sulfide lens as a pod several metres thick along its upper contact.

Below Sublevel 7B the amount of massive magnetite diminishes rapidly so that by Level 8 it is restricted to a small pod surrounding the south end of the massive sulfide lens, with a second, 1.5 by $3 \mathrm{~m}$ pod $15 \mathrm{~m}$ to the north along the orebody's lower contact. Massive magnetite disappears from the footwall contact by Sublevel 8A. On Level 9, a $15 \mathrm{~cm}$ thick section of Cranston tuff along the hangingwall contact of the massive sulfide lens contains several 10 to $15 \mathrm{~mm}$ thick layers of massive to semi-massive magnetite. Sublevel 9B exposes a $37 \mathrm{~m}$ wide by $6 \mathrm{~m}$ thick massive magnetite lens under the centre of the massive sulfide lens and a series of small, 1 to $2 \mathrm{~m}$ thick lenses under the deposits south flank. Massive magnetite occurs along the orebody's hangingwall contact as layers within Cranston tuff and as massive magnetite that forms a short spine above the massive sulfide lens to connect to a smaller massive pyrrhotite-chalcopyrite-sphalerite lens. By Sublevel 9C 
massive magnetite almost completely surrounds the massive sulfide lens, and by Level 10 over $50 \%$ of the deposit's volume is massive to semi-massive magnetite, with segments of massive sulfide remaining at the north and south ends. On Sublevel 10A massive to semimassive magnetite forms the footwall and hangingwall contacts to the massive sulfide lens, which forms a small pod under the south flank of the orebody on Sublevel 10B. Most of the magnetite present on Sublevel 11A is hosted by the Cranston tuff both above and below the orebody. It occurs as semi-massive to massive layers and discordant stockwork zones within the tuff.

Hangingwall magnetite has the most restricted distribution of the three zones. Fifty metres above the massive sulfide lens there is a $1.3 \mathrm{~m}$ thick massive magnetite lens associated with a $6 \mathrm{~m}$ thick lens of massive pyrrhotite occurring in andesitic interflow breccias. A halo of 3 to $5 \%$ disseminated magnetite is present for several tens of metres above the western end of the massive sulfide lens.

\subsubsection{Internal morphologies and compositions}

The roots of the footwall magnetite zone occur within hornfelsed Flavrian Formation andesitic flows $400 \mathrm{~m}$ below the Ansil massive sulfide lens. The discordant zone is $27 \mathrm{~m}$ wide, the east half consisting of $12 \mathrm{~m}$ of 3 to $5 \%$ finely disseminate magnetite grains. This is followed to the west by $15 \mathrm{~m}$ with 5 to $10 \%$ fine-grained, disseminated magnetite interspersed between $5 \%$ thin chalcopyrite-pyrrhotite veinlets and 1 to $2 \%$ disseminated chalcopyrite-pyrrhotite. The lower part of the footwall magnetite zone terminates $100 \mathrm{~m}$ 
below the Flavrian-Northwest Formations contact, and reappears 60 to $70 \mathrm{~m}$ upsection within the rhyolite formation just below the beginning of the sulfide stockwork zone as 5 to $10 \%$ disseminated magnetite intergrown with epidote and epidote-pyrite, and thin, irregular magnetite veinlets. Along the edges of the sulfide stockwork the magnetite zone contains an outer margin of disseminated magnetite, magnetite-epidote and magnetite-epidote-pyrite changing to 10 to $15 \%$ magnetite veinlets and veins up to $6 \mathrm{~mm}$ wide nearer the sulfide stringer. The magnetite stringer zone contains 3 to $5 \%$ pyrite-pyrrhotite, pyrite and chalcopyrite veinlets. The magnetite/sulfide distribution is patchy, with higher percentages occurring within the originally more permeable, hyaloclastite parts of the rhyolitic lobehyaloclastite flow.

Above the lower semi-conformable chalcopyrite-pyrrhotite zone magnetite stringer zones become wider and more intense, particularly about the eastern sulfide stringer zones (Figures 4.43 and 4.44). Veins 5 to $10 \mathrm{~mm}$ wide have magnetite-chlorite-calcite-rich margins and epidote-quartz-magnetite-rich cores. Thinner epidosite veinlets contain magnetite euhedra rimmed with calcite; chlorite-calcite-magnetite veinlets occur. Where magnetite zones affect rhyolite flow lobes, perlitic fractures along the lobe margins are commonly infilled with chlorite-magnetite-calcite. There are semi-massive zones of magnetite in the hyaloclastite-rich parts of the host rhyolite, with fine-grained magnetite euhedra forming rims about blocky shards, and the remainder of the groundmass containing quartz and chlorite, with scattered clots of epidote. 
Magnetite-rich zones are up to $15 \mathrm{~m}$ wide occur within 20 to $30 \mathrm{~m}$ of the footwall contact to the massive sulfide lens, with the largest zones usually underlying the larger concentrations of massive magnetite within the deposit (Map 8, Appendix). They contain 5 to $10 \%$ disseminated magnetite with 1 to $3 \%$ disseminated pyrite, semi-massive magnetitefilled breccias replacing hyaloclastite and discrete veins up to $6 \mathrm{~cm}$ wide. Where columnar jointing occurs in the massive rhyolite flow lobe below the south flank of the deposit magnetite veins infill the joints (Map 8, Appendix). The larger veins (up to $6 \mathrm{~cm}$ wide) have margins consisting of 60 to $70 \% 0.5$ to $1 \mathrm{~mm}$ magnetite crystals that coalesce to form a lacy texture, with cubic to rhombic shapes with interstices infilled with chlorite and calcite (Figure 4.44). Interstitial quartz, chlorite, epidote and calcite compose 40 to $60 \%$ of the vein cores, with magnetite euhedra defining the rest of the vein fill. The larger veins are typically sinuous, with rapid thinning and thickening along their strike length. Their margins are sharp, with abundant magnetite-rich veinlets branching out at high angles to the main vein.

Where semi-massive to massive chalcopyrite-pyrrhotite defines the upper discordant stockwork zones there is commonly a 5 to $15 \mathrm{~cm}$ margin of massive magnetite, with quartz and ferroactinolite. The massive magnetite has a halo up to several metres wide of ferroactinolite-altered rhyolite with abundant disseminated magnetite.

The abundance of sulfide minerals within the magnetite zone generally increases with decreasing distance to the massive sulfide lens. Fine-grained pyrrhotite (up to $5 \%$ ) is interstitial to magnetite grains within the larger veins, and smaller veins can grade from 
magnetite-chlorite-calcite to pyrrhotite-chlorite-chalcopyrite. In places along some veinlets there is a chlorite-rich interval between sulfide and magnetite parts of the structure. The contact between the magnetite and chalcopyrite-pyrrhotite stringer zones can be either sharp, or diffuse, but generally is defined by a gradual disappearance of magnetite over several decimetres and increase in pyrrhotite-chalcopyrite veinlets.

Defining primary textures in the Ore Lens Magnetite is difficult in places due to the degree of deformation associated with many of the massive to semi-massive magnetite occurrences. The high competency contrast between the magnetite zones and the chalcopyrite-pyrrhotite massive sulfide lens has resulted in the development of high strain zones during regional deformation, with fracturing and boudinage of the brittle magnetite and ductile deformation of the surrounding sulfide and silicate minerals. The contact between the Rusty Ridge andesite and magnetite zones along the hangingwall contact of the massive sulfide lens is commonly sheared and veined. Some caution must be exercised in defining relative ages of some of the veins associated with the magnetite lenses.

All of the ore lens magnetite zones consist of semi-massive to massive concentrations of 10 to $30 \mu \mathrm{m}$, subhedral to euhedral magnetite grains. Cubic to rhombic magnetite grains form tightly packed crystal aggregates with halos of disseminated magnetite euhedra.

The magnetite zone present along the hangingwall contact to the chalcopyrite-pyrrhotite lens at the western end of the orebody (Sublevels $6 \mathrm{~A}, 6 \mathrm{~B}$ and $6 \mathrm{C}$ ) is 15 to $30 \mathrm{~cm}$ wide, with its contact with the overlying andesite flows commonly sheared. Deformation is particularly strong along the orebodies north hangingwall contact, where the magnetite 
zone has a strong, layer-parallel schistosity and abundant carbonate-chalcopyrite-quartz veining perpendicular to unit contacts.

The contact between the magnetite zone and underlying chalcopyrite-pyrrhotite massive sulfide is sharp, with a scalloped edge along which apophyses of magnetite up to $30 \mathrm{~cm}$ across reach into the massive sulfide (Figure 4.46a). There are occasional, rounded domains of chalcopyrite-pyrrhotite within the magnetite zone, commonly with a thin pyrrhotite margin (Figure $4.46 \mathrm{~b}$ ). The magnetite along the contact is relatively massive $(>60 \%)$, with closely packed aggregates of 10 to $30 \mu \mathrm{m}$, subhedral to euhedral cubes and rhombs of magnetite interspersed with areas infilled with Fe-rich calcite and ankerite, plus minor quartz. These interstitial zones also contain well formed stilpnomelane intergrown with pyrrhotite and chalcopyrite. Disseminated magnetite euhedra overgrow these other minerals.

The magnetite-sulfide contact is marked by a $<2 \mathrm{~mm}$ wide zone containing bands of pyrrhotite, and minor chalcopyrite, intergrown with discontinuous bands of magnetite grain aggregates in a quartz-carbonate matrix. Chalcopyrite commonly cores blebs of subhedral pyrrhotite. The sulfides are intergrown with stilpnomelane and minnesotaite-greenalite. The amount of Fe-calcite, minnesotaite-greenalite and pyrrhotite increases towards the massive sulfide, with 3 to $5 \%$ discrete magnetite euhedra within the pyrrhotite blebs. The massive chalcopyrite-pyrrhotite contains minnesotaite-greenalite flakes intergrown with the sulfide, interstitial calcite, and 2 to $3 \%$ disseminated magnetite euhedra. 
Towards the andesite contact the magnetite zone becomes semi-massive $(<40 \%$ magnetite), with abundant Fe-calcite containing felted masses of fine-grained minnesotaitegreenalite, minor stilpnomelane, and intergrown pyrrhotite-chalcopyrite-minnesotaite (Figure $4.46 \mathrm{c}$ ). Fine-grained chlorite is present along the edges of the minnesotaitegreenalite rosettes. Magnetite crystal aggregates form linear arrays parallel to the unit contacts, and spheroidal clusters are possibly replaced amygdules. The alignment of magnetite aggregates appears to be primary, as they are overprinted by a fracture cleavage associated with shearing. In places the magnetite and associated alteration overprint andesite in which amygdules were previously infilled with chalcopyrite-pyrrhotite.

Levels 7 through 7B expose a magnetite lens along the footwall massive sulfide contact that progressively enlarges downplunge from a small pod under the south corner to a large lens that occupies the core of the massive sulfide lens, and forms the upper contact to the apex of the sulfide mound. A $1 \mathrm{~m}$ thick section of the footwall magnetite zone exposed in \#1 Drawpoint, Sublevel 7B, has a 5 to $15 \mathrm{~cm}$ thick base of finely laminated, siliceous rock, followed by massive ( $>70 \%)$ magnetite consisting of well-packed aggregates of 10 to 30 $\mu \mathrm{m}$, subhedral to euhedral magnetite grains. Interstitial to the magnetite are felted masses of ferroactinolite and stilpnomelane-minnesotaite in an Fe-calcite-quartz matrix. In less massive parts of the zone the magnetite euhedra form thin rims around what may be strongly actinolite-altered, blocky rhyolite shards. The magnetite zone is cross-cut by chalcopyrite-rich 10 to $20 \mathrm{~cm}$ wide brittle-ductile shear zones containing quartz- 
chalcopyrite-pyrrhotite-calcite veins with halos of fine-grained chalcopyrite interstitial to the massive magnetite

On Sublevel 7B (cut and fill hangingwall access), the hangingwall contact to the orebody is strongly deformed chalcopyrite-pyrrhotite in contact with massive magnetite. The massive magnetite is strongly fractured, with re-entrants of chalcopyrite containing cataclastic vein quartz along with carbonate and pyrrhotite. The veins commonly have pyrrhotite-rich cores and chalcopyrite-rich margins. The larger (>10 mm wide) veins have 10 to $15 \mathrm{~cm}$ halos of disseminated chalcopyrite interstitial to the massive, fine-grained magnetite. The magnetite-massive sulfide contacts are commonly diffuse over $\mathrm{mm}$ to $\mathrm{cm}$. The massive magnetite contains epidote-rich zones with tremolite rims, and patches of epidote-tremolite-ilvaite-magnetite

The large concentration of ore lens magnetite in the eastern half of the massive sulfide deposit is centered on Level 10, where a $15 \mathrm{~m}$ long, discordant massive magnetite pipe joins with a $15 \mathrm{~m}$ thick by $75 \mathrm{~m}$ long massive magnetite body that comprises $2 / 3$ of the volume of the ore horizon (Figure 4.42b). To the east and west of Level 10 the volume of magnetite diminishes so that it is present as discrete pods along both the hangingwall and footwall contacts of the massive sulfide lens. The magnetite zones along the footwall and within the massive sulfide lens are generally massive to semi-massive, but along the hangingwall contact, and at the eastern termination of the orebody, the magnetite zones consist of finely interlayered magnetite and altered Cranston tuff (Figure 4.47). East of 
Level 10 there is patchy development of a magnetite-rich Ca-Fe skarn along both footwall and hangingwall massive sulfide contacts.

\subsection{BASE AND PRECIOUS METAL DISTRIBUTION}

The principal metals composing the deposit are $\mathrm{Cu}, \mathrm{Zn}, \mathrm{Ag}$ and $\mathrm{Au}$, and trace amounts of $\mathrm{Pb}, \mathrm{Cd}, \mathrm{Se}, \mathrm{Co}, \mathrm{Ni}$ and $\mathrm{Bi}$. The only $\mathrm{Cu}$ mineral present is chalcopyrite, which is most abundant directly over top of the discordant pyrrhotite-chalcopyrite vein stockworks where they intersect the western and eastern ends of the ore lens (Figure 4.48). The $\mathrm{Cu}$-rich zones continue upwards from the base to form the core of the sulfide lens (Figure 4.49a). The majority of the massive sulfide lens contains $<5 \% \mathrm{Cu}$, but the core contains $>15 \%$. There is also a relationship between high $\mathrm{Cu}$ concentrations and proximity to massive magnetite lenses, with chalcopyrite-rich sections over a metre thick containing up to $22 \% \mathrm{Cu}$. The discordant pyrrhotite-chalcopyrite vein stockwork contained mineable zones with over $2 \%$ $\mathrm{Cu}$, usually located at the intersection between the discordant and semi-conformable vein stockworks.

Sphalerite is the only $\mathrm{Zn}$-bearing sulfide recognized, and it is concentrated about the margins of the western $2 / 3$ of the $\mathrm{Cu}$-rich massive sulfide lens (Figure 4.48). There is less than $1 \%$ sphalerite within the massive pyrrhotite-chalcopyrite ore. The Zn South Zone, along the south flank of the orebody between levels 7 and 8 , contains up to $12 \% \mathrm{Zn}$. Along the northern flank of the massive sulfide lens most of the sphalerite is concentrated within the Cranston tuff, with zones of over $20 \%$ sphalerite. In the eastern third of the orebody 
sphalerite concentrations increase significantly, particularly in the presence of the layered sulfide ore. The layered ores may contain up to $14 \%$ sphalerite, but usually between 6 to $8 \%$. The concentrations of sphalerite in the pyrrhotite-chalcopyrite footwall vein stockwork zone is usually less than $1 \%$, with the exception of a zone of quartz-sericite altered rhyolite in the core of the eastern, upper discordant pyrrhotite-chalcopyrite vein stockwork, which has up to $12 \%$ sphalerite.

Galena occurs in only trace amounts, usually within the top $50 \mathrm{~cm}$ of the massive sulfide lens. It occurs as $<1 \mathrm{~mm}$ sized anhedral grains scattered within quartzstilpnomelane-minnesotaite-rich, pyrrhotite-chalcopyrite ore, and in the remnants of sulfide-rich Cranston tuff. It is spatially associated with visible gold grains.

Native Au and electrum were observed along the upper contact of the massive sulfide lens, along the $\mathrm{Cu}$-rich margins of the massive magnetite lenses, and in siderite within the magnetite and massive sulfide lenses. Along the upper margins of the massive sulfide lens it occurs as 100 to $200 \mu \mathrm{m}$ anhedral grains closely associated with slightly larger galena grains. In the siderite veins within the massive sulfide lens it forms grains up to $1 \mathrm{~mm}$ long, and small veinlets of electrum. Within the $\mathrm{Cu}$-rich margin to the massive magnetite lenses $\mathrm{Au}$ is concentrated between boudins of siderite veins, commonly as grains with Au-Agrich cores, Ag-Au margins and $\mathrm{Bi}-\mathrm{Se}$-rich rims. The grains are spatially associated with 50 to $100 \mu \mathrm{m}$ sized grains of $\mathbf{B i}$ telluride. Chalcopyrite within both the ore lens and the vein stockwork contains up to $0.46 \% \mathrm{Au}$. 
The distribution of $\mathrm{Au}$ and $\mathrm{Ag}$ within the orebody is similar to $\mathrm{Cu}$, with high concentrations of one correlative with the other (Figure 4.48). The high grade $\mathrm{Cu}$ core of the massive sulfide dome at the western end of the deposit averages $12 \mathrm{~g} / \mathrm{t}$ Au (Figure 4.49b). Metall Mining Corp determined that the difference between their diluted reserve estimates and recovered $\mathrm{Au}$ was a great as $63 \%$ in favour of the concentrate (Salmon, 1991). This was most likely due to the coarseness of the Au present, resulting in a "nugget effect" during assaying. The actual Au concentration could be as much as twice the published value. This would make the Au concentrations at Ansil exponentially higher than the average value for an Archean massive sulfide deposit $(0.66 \mathrm{~g} / \mathrm{t})$. The presence of coarse-grained Au is unusual in a massive sulfide deposit, where it is usually contained within the sulfide minerals. In modern seafloor VHMS deposits native Au is usually restricted to their oxidized outer margins (Herzig et al., 1991), although some visible gold has been observed in the outer margin of sulfide chimneys from the Lau Basin (Herzig et al., 1993)

Arsenopyrite and cobaltite occur in trace amounts, both associated with sphalerite. The Zn-rich Cranston tuff also contains anomalous, but erratic, concentrations of Sn, but the Sn-bearing mineral has not been identified. 


\subsection{SUMMARY OF THE CHARACTERISTICS OF THE ANSIL DEPOSIT}

The Ansil deposit is divided into a footwall vein stockwork system a massive sulfidemagnetite orebody, and the hangingwall vein stockwork zone. There are three spatially and compositionally distinct parts to the footwall mineralization. The $\mathrm{Zn}$-rich vein stockwork system is restricted to less than $100 \mathrm{~m}$ below the massive sulfide lens, and is centred on discordant, funnel-shaped hydrothermal breccia zones which are infilled by finely laminated quartz, probably after chalcedony, albite, Fe-sulfide, sericite and sphalerite. Included wallrock fragments are strongly sphalerite impregnated. The distribution of these breccia zones is controlled by the east-west -trending walls of the graben hosting the orebody.

The $\mathrm{Cu}$-rich vein stockwork system begins $400 \mathrm{~m}$ below the orebody at the contact between the Flavrian Pluton and the andesite flows of the Flavrian formation. It is weak and discontinuous within the Flavrian and lower Northwest formations. Approximately 130 $\mathrm{m}$ below the orebody it forms three, distinct, discordant pyrrhotite-chalcopyrite vein stockworks that merge up-section into a semi-conformable vein stockwork zone. Above this the stockwork mineralization forms two discordant vein systems that merge up-section below the massive sulfide lens. The overall discordant morphology of the $\mathrm{Cu}$-rich vein stockwork is controlled by northerly-trending faults or fractures, but the internal morphology is $80 \%$ controlled by the primary permeability of the rhyolite lobe-hyaloclastite flow, and $20 \%$ controlled by hydrothermal fracturing. The pyrrhotite-chalcopyrite-rich 
zones contain pyrrhotite, chalcopyrite, quartz, Fe- and Mg-chlorite, minnesotaite and greenalite.

The $\mathrm{Cu}$-rich stockwork zone is overprinted by a magnetite-rich vein system that forms a discontinuous margin about the latter. Disseminated magnetite occurs about the base of the $\mathrm{Cu}$-rich stockwork zone within the Flavrian formation, and magnetite veinlets and veins occur above the base of the Northwest formation. These magnetite-rich veins generally widen upsection to merge with massive magnetite lenses at the base of the massive sulfide orebody. Near the base of the orebody magnetite mineralization is partially controlled by primary flow permeability, infilling interlobe hyaloclastite and fractures in columnar-jointed rhyolite.

The orebody consists of 1.58 million tonnes of massive sulfide and 300,000 tonnes of massive magnetite. The base of the massive sulfide lens is composed of fragmental, pyrrhotite-chalcopyrite ore that contains sericite-quartz- $(10 \%)$ and strongly chloritealtered $(90 \%)$ rhyolite fragments. The sericite-quartz-altered (bleached) fragment breccia is replaced hydrothermal explosion breccia formed during the earlier $\mathrm{Zn}$-mineralizing event. The chlorite-altered breccia is mainly replaced hyaloclastite and flow breccia, representing the transition between the vein stockwork zone and the massive sulfide lens. Another facies of fragmental ore occurs within the massive sulfide dome at the west end of the deposit. These fragments of aphyric mafic rock are believed to be partially replaced andesitic hyaloclastite and flow breccia from the base of the hangingwall formation. 
A thin, discontinuous zone of partly replaced Cranston tuff overlies the fragmental ore in the eastern $2 / 3$ of the orebody. Above this the ore lens consists of massive to sievetextured pyrrhotite-chalcopyrite, with tectonically banded sulfide occurring along its contacts. The massive ore contains remnants of sphalerite-rich Cranston tuff. The eastern third of the orebody consists of layered pyrrhotite-chalcopyrite-spahlerite-pyrite that is transitional along its flanks and eastern end to sphalerite-rich Cranston tuff.

The massive sulfide lens is most $\mathrm{Cu}$-rich $(>15 \%)$ above its intersection with the vein stockwork zone, with the remainder of the lens averaging between 5 to $10 \% \mathrm{Cu}$. Au and $\mathrm{Ag}$ values increase within increased $\mathrm{Cu}$ concentrations. Higher $\mathrm{Au}$ and $\mathrm{Cu}$ concentrations also occur along the margins of the massive magnetite lenses (up to $20 \mathrm{~g} / \mathrm{t}$ and $22 \%$ respectively). High $\mathrm{Zn}$ values are restricted to the Cranston tuff and parts of the hydrothermal explosion breccias. Trace concentrations of $\mathrm{As}, \mathrm{Cd}, \mathrm{Co}, \mathrm{Se}$, and $\mathrm{Bi}$ are also present.

Massive magnetite lenses occur along the base of the massive sulfide lens where it intersects the $\mathrm{Cu}$ - and magnetite-rich vein stockworks. In the western part of the orebody there is a central core of massive magnetite that joins with a thin massive magnetite lens along the orebody's hangingwall contact. Above the eastern $\mathrm{Cu}$-rich vein stockwork zone the massive magnetite has replaced approximately $50 \%$ of the massive sulfide and sulfide vein stockwork. Magnetite also replaces parts of the Cranston tuff. 
The hangingwall vein stockwork zone forms a $+400 \mathrm{~m}$ high "Christmas tree" above the orebody, with its roots in the massive sulfide spine that tops the western half of the deposit. The sulfide spine formed through the infilling and replacement of pillow breccia, amoeboid pillow breccia and hyaloclastite. The restriction of the spine to above the western half of the deposit is due to a facies change in the hangingwall formation, from massive flows over the eastern half of the orebody to hyaloclastite-rich, pillowed flows over the western half. Much of the morphology of the hangingwall vein stockwork zone was controlled by the primary permeability of the andesitic flows, with sulfide infilling, and replacement of interflow hyaloclastite. The hangingwall zone is $\mathrm{Cu}$-rich at its base and core, and $\mathrm{Zn}$-rich up-section and along its "branches". 


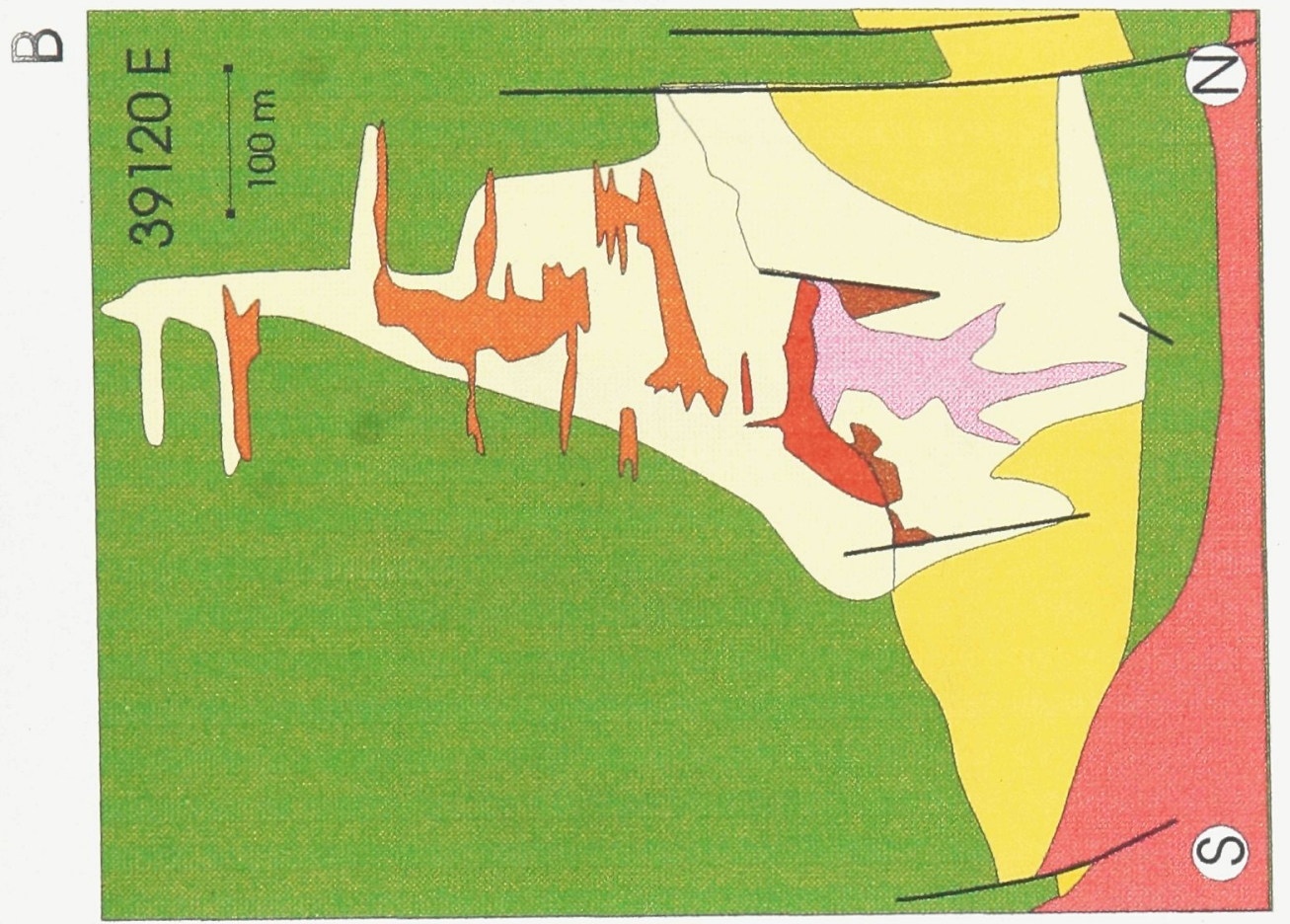

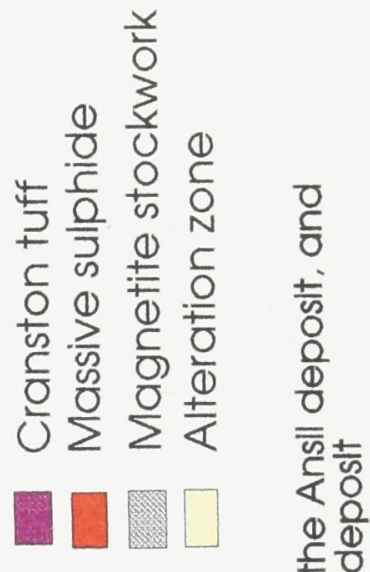

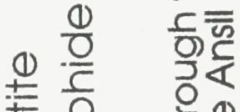

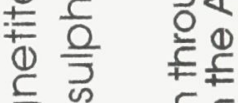

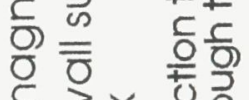
E 我

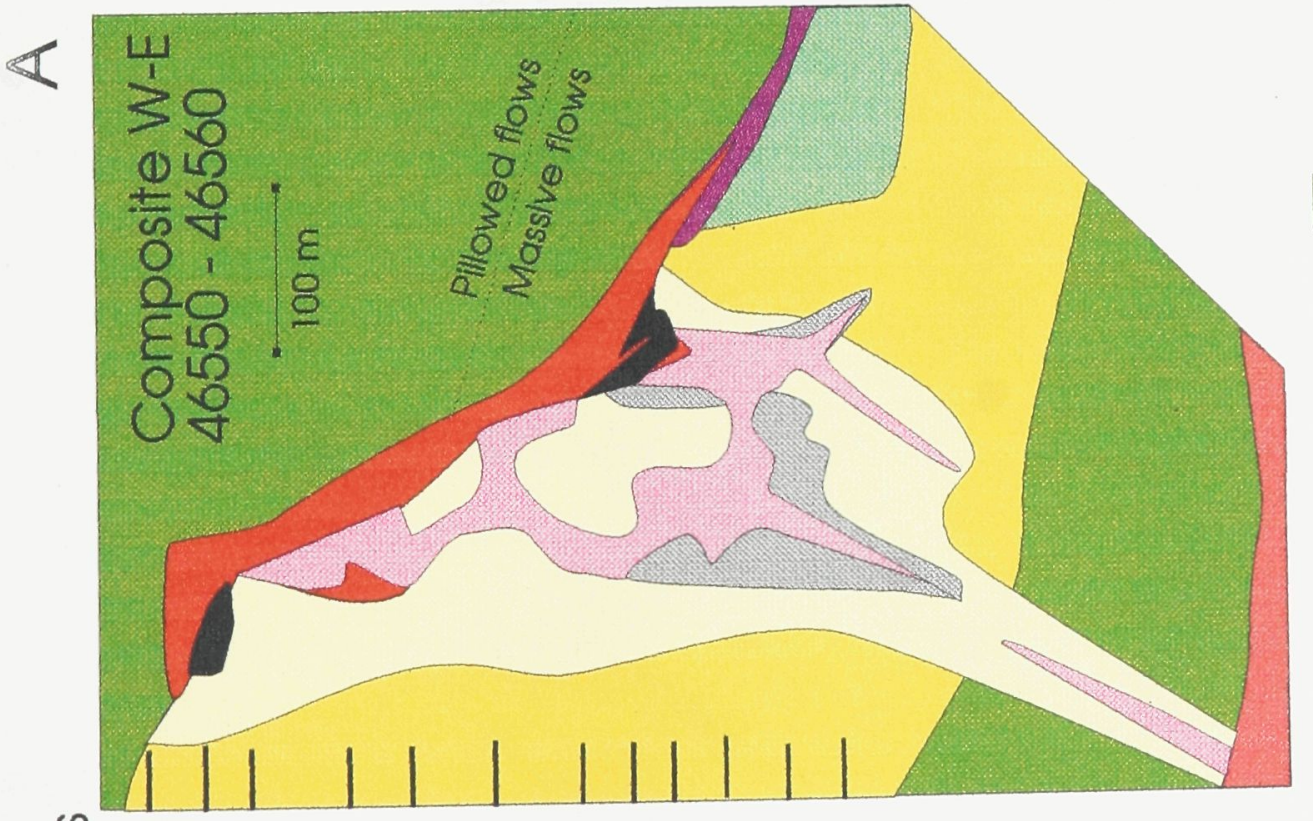
(1) (1) O) क 든 笪

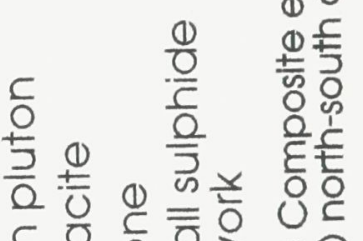

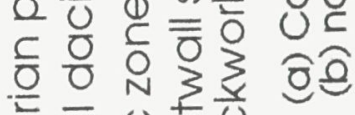

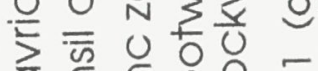

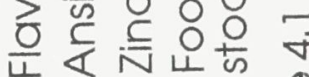

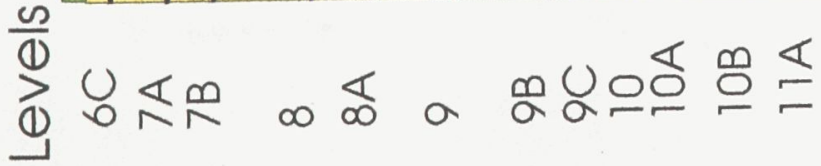




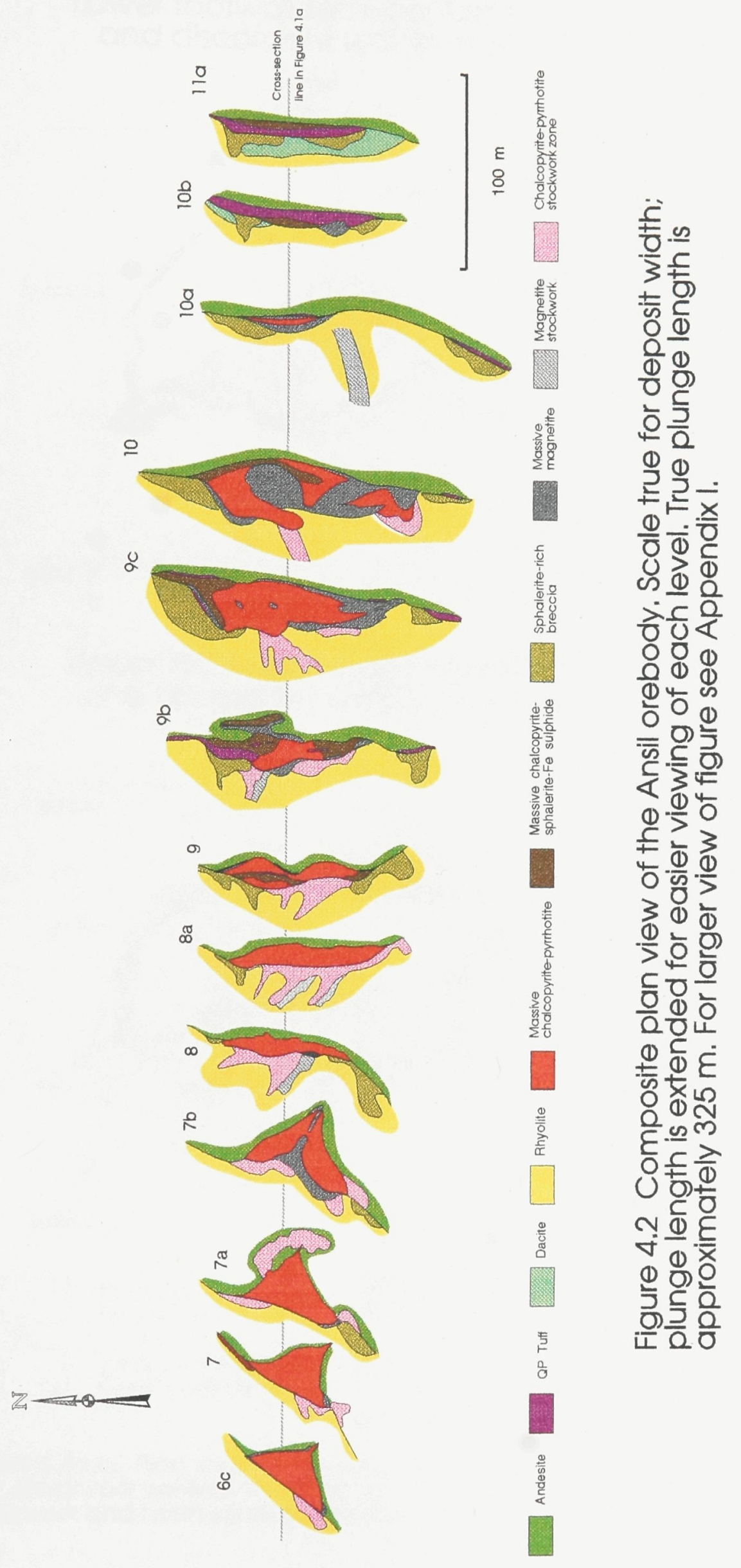


Lower footwall semi-conformable

and discordant sulfide zones

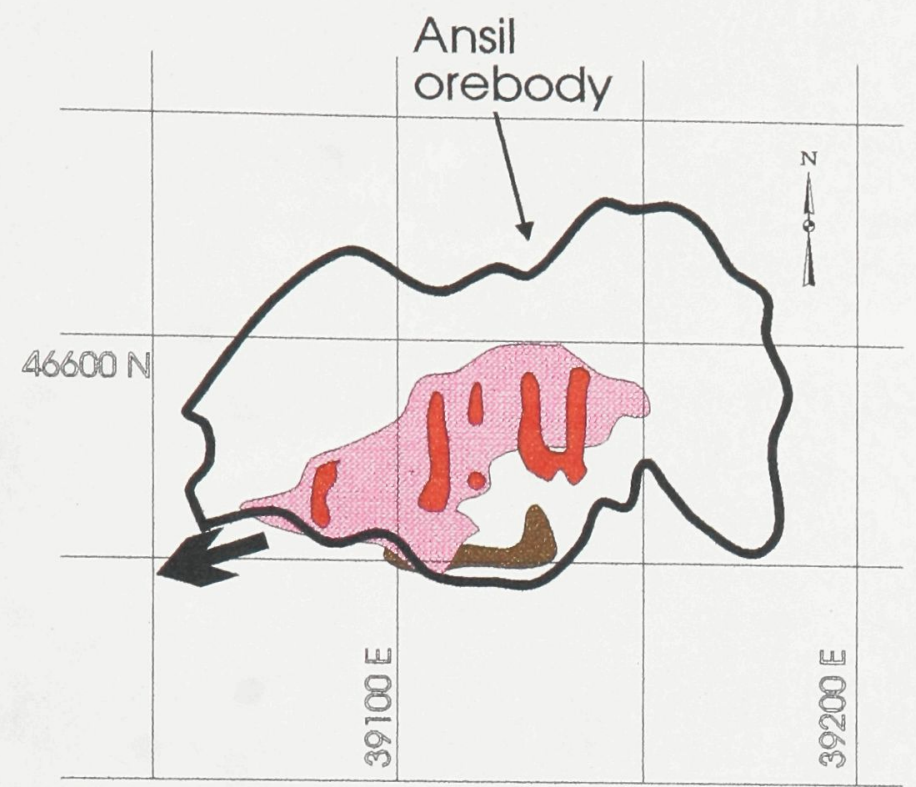

$46400 \mathrm{~N}$

Upper footwall sem-conformable and discordant sulfide zones

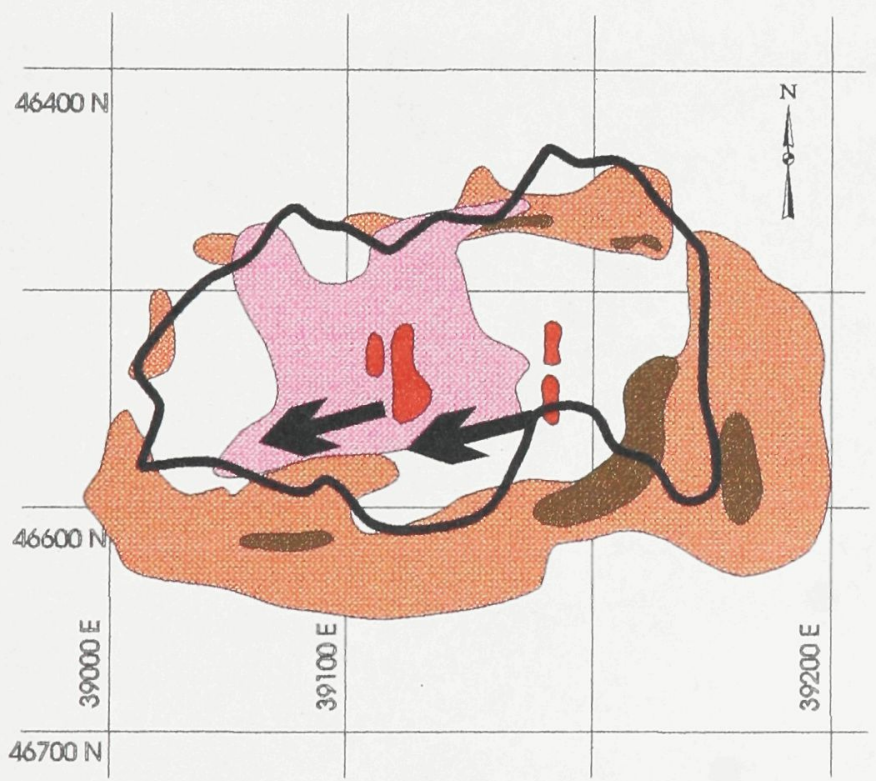

\section{Discordant}

Cu-rich stockwork

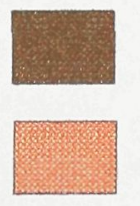

Discordant Zn-rich słockwork

Semi-conformable Cu-rich stockwork

Semi-conformable Zn-rich stockwork

Figure $4.3 a, b$. Plan view of the upper and lower parts of the footwall vein stockwork systems. Note the east-west orientation to the $\mathrm{Zn}$-rich stockwork and north-south orientation to the Cu-rich stockwork. 


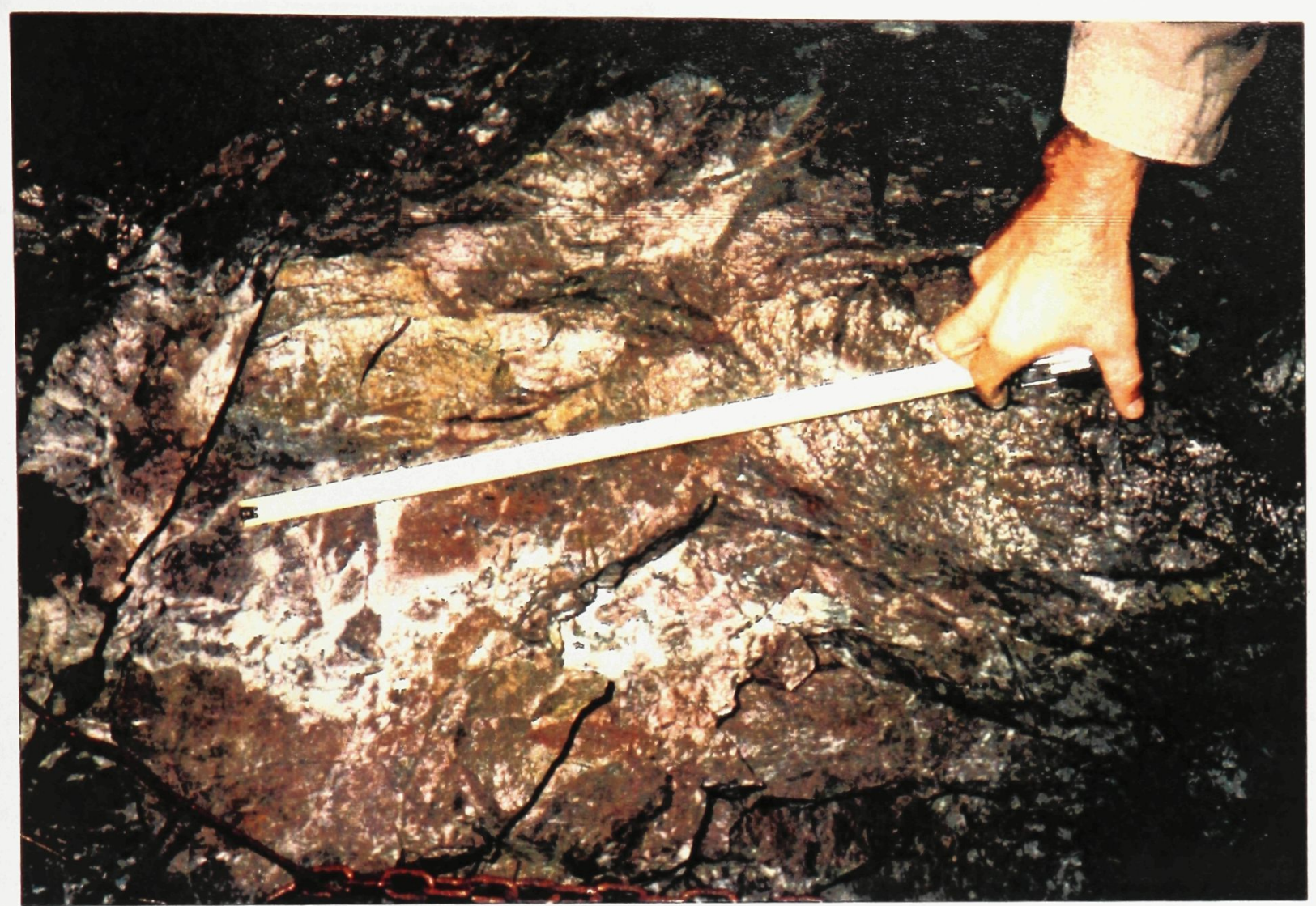

Figure 4.4. Discordant $\mathrm{Zn}$-rich stockwork vein system cross-cutting sericite-quartz-albite altered rhyolite (Ore pass, Level 8). Tape $1 \mathrm{~m}$ long for scale.

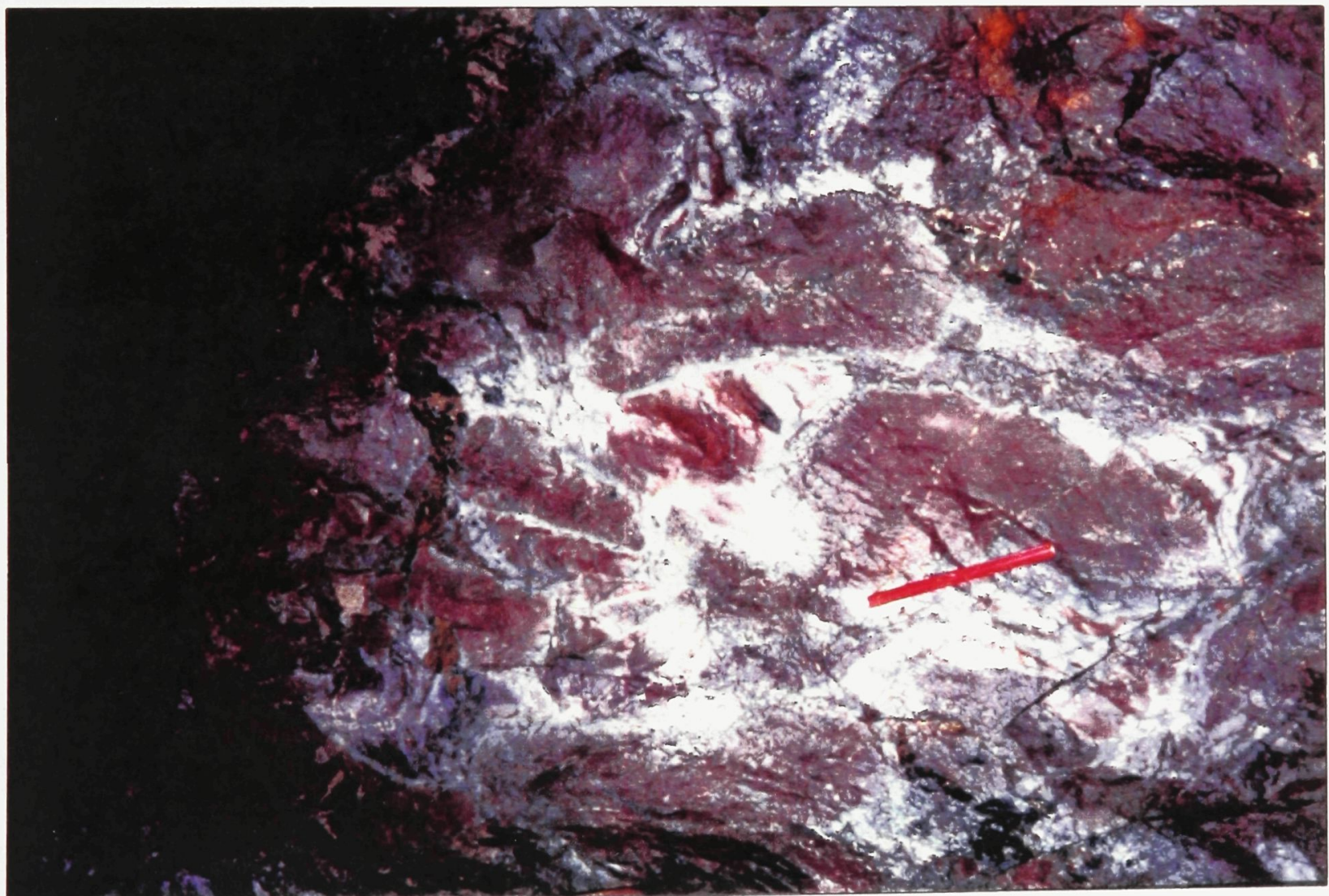

Figure 4.5. Zn-rich, discordant vein stockwork with strongly sphalerite impregnated, maroon coloured rhyolite cross-cut by quartz-sphalerite-pyrite veins. Larger veins are infilled with delicately banded chalcedony (arrow) (Sublevel 7B). Magnet $12 \mathrm{~cm}$ long. 


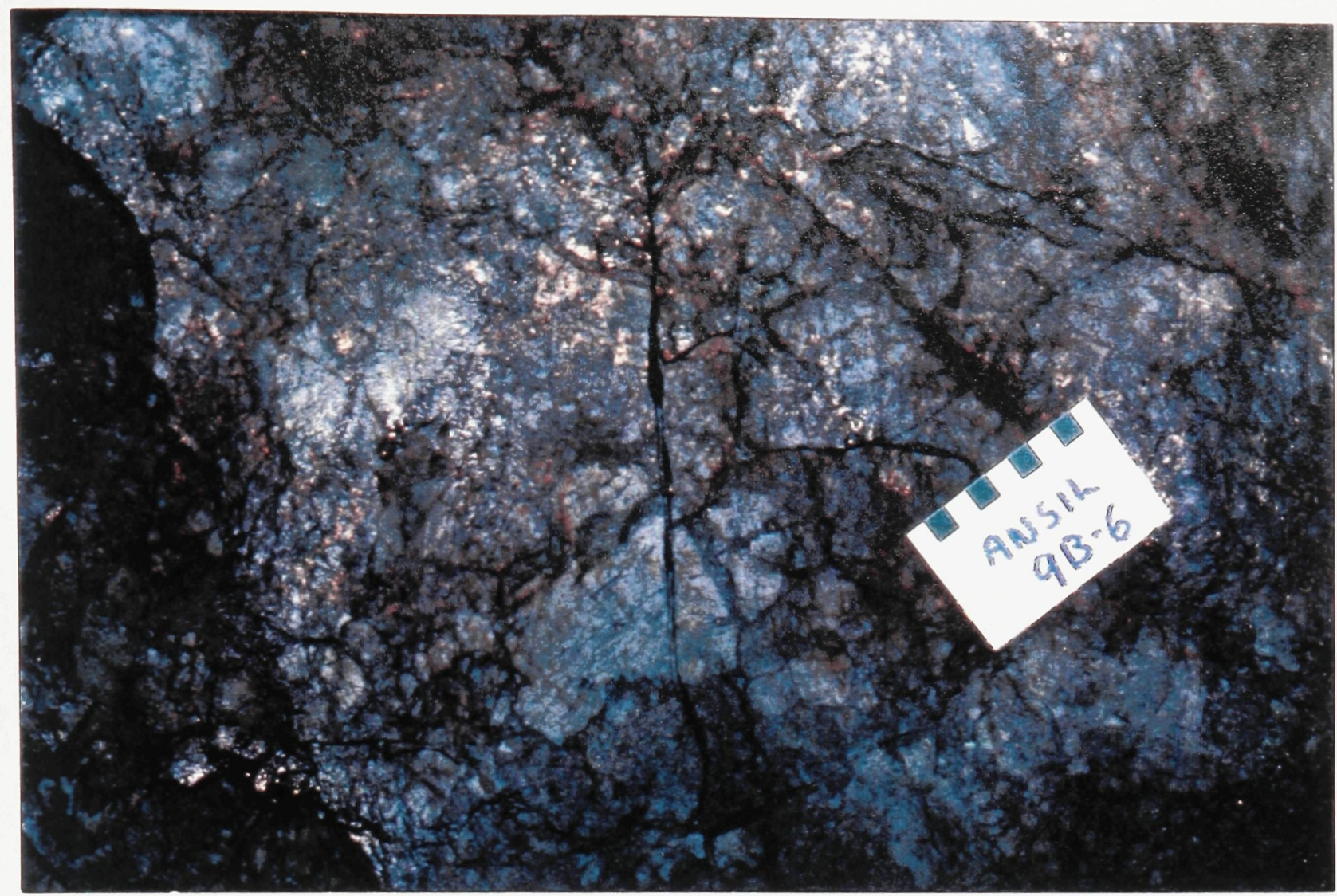

Figure 4.6 Coarse-grained, bleached fragment breccia, with sericite-quartz altered rhyolite fragments in a sphalerite-pyrite-pyrrhotite groundmass (Drawpoint \#6, Sublevel 9b). Scale card in centimetres.

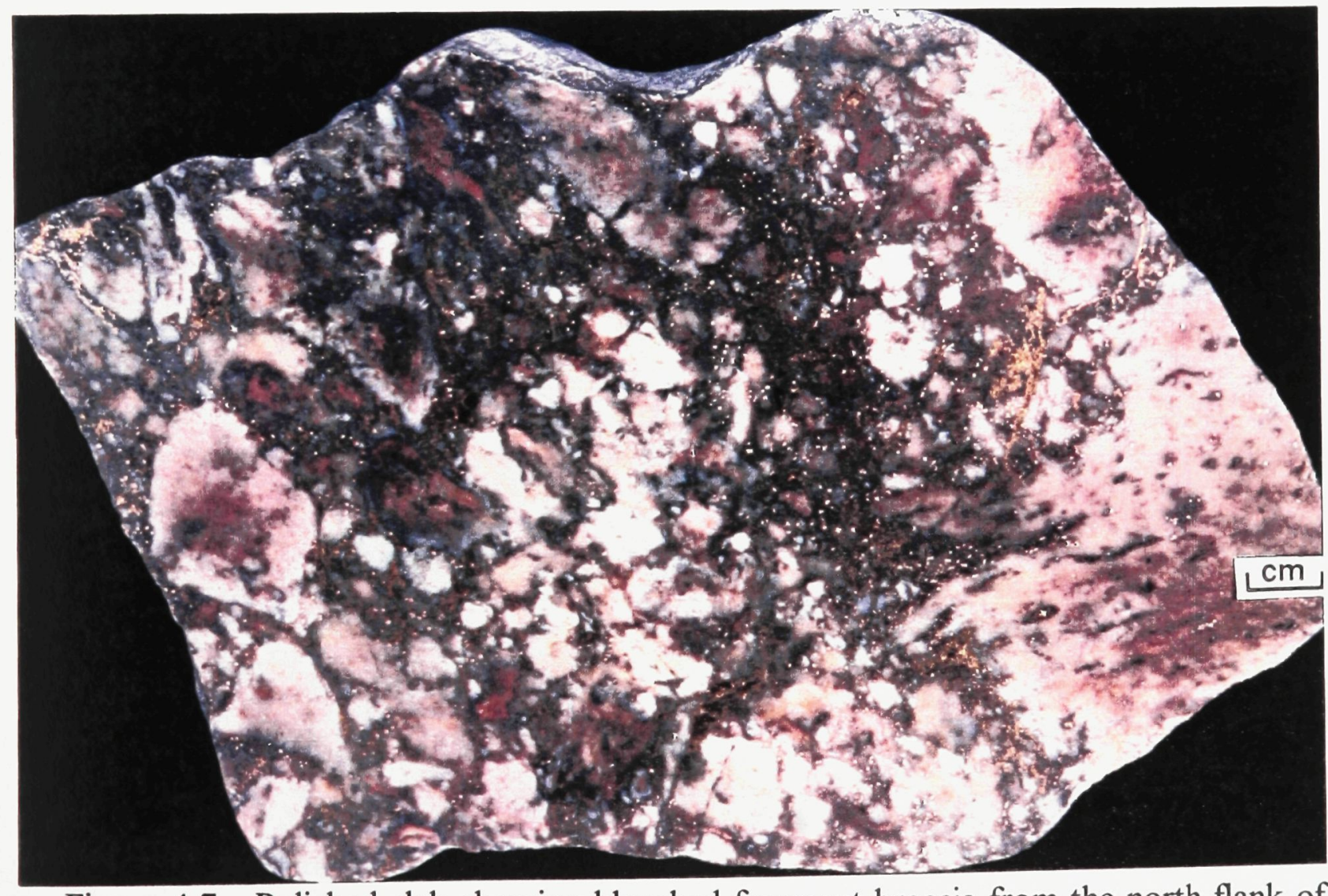

Figure 4.7 Polished slab showing bleached fragment breccia from the north flank of the massive sulphide lens. Sample ANSL9-164 


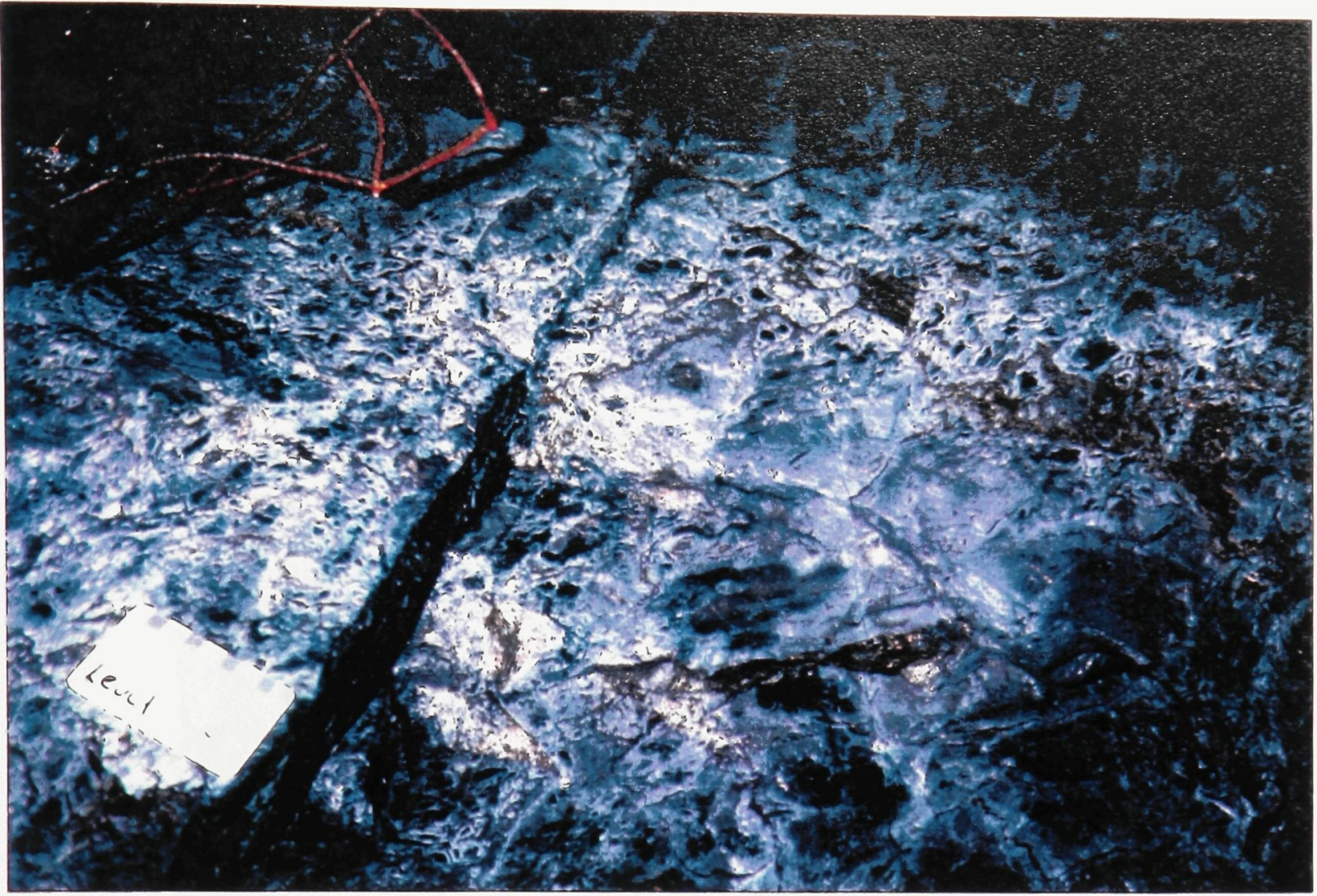

Figure 4.8 Insitu brecciation of massive dacite flow lobe, with fracture infilling by quartz, pyrrhotite and sphalerite. Distinctive sericite-altered rims mark wallrock fragments (Sublevel 11A). Centimetre graduated scale.

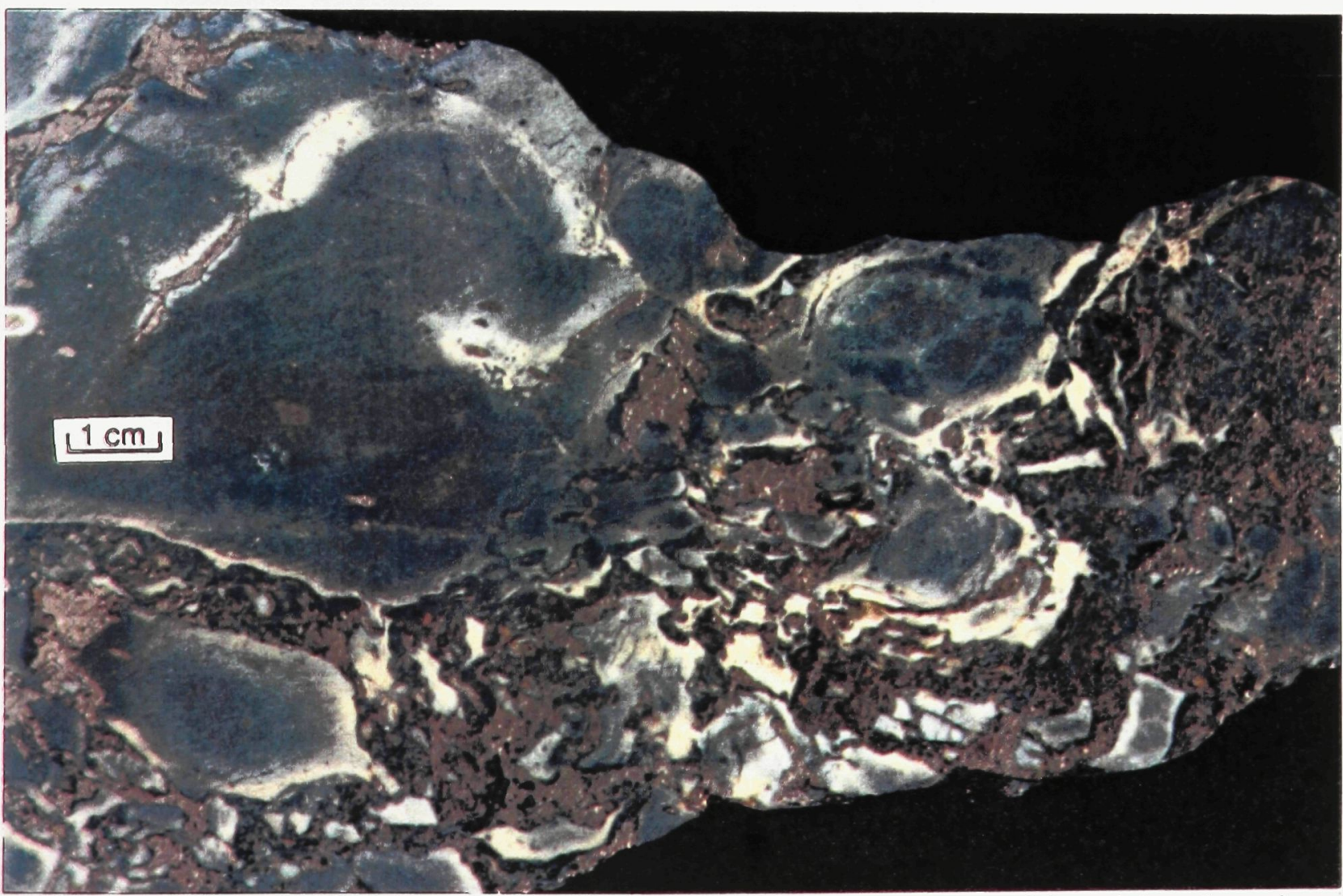

Figure 4.9 Polished slab showing mineralized dacite flow breccia with sericite alteration of shards and blocks (Sublevel 11A). Sample ANSL11A-250. 


$$
1 !
$$




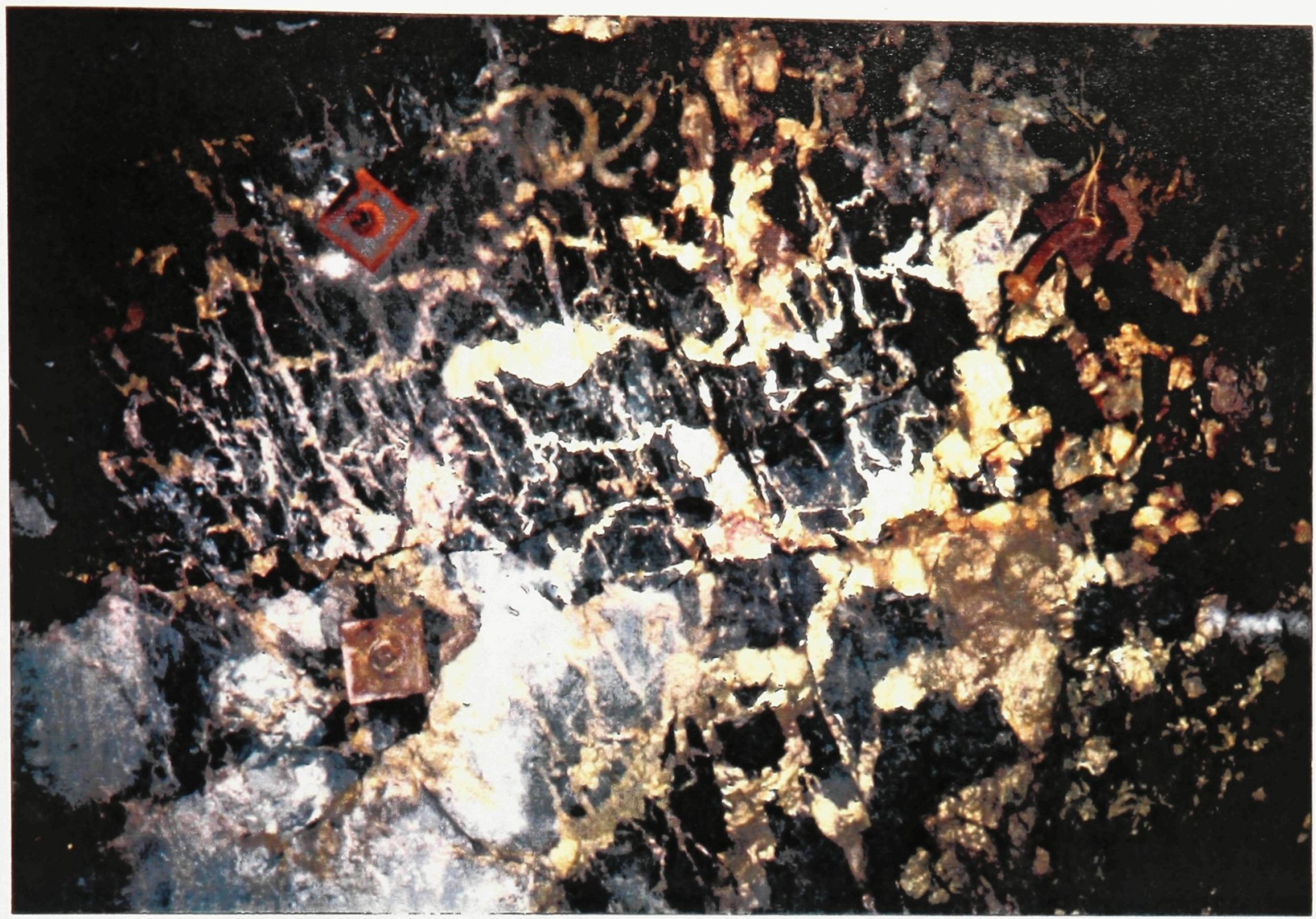

Figure 4.11 "Net-textured" pyrrhotite-chalcopyrite vein stockwork crosscutting rhyolite hyaloclastite. Metal plate $15 \mathrm{~cm}$ across.

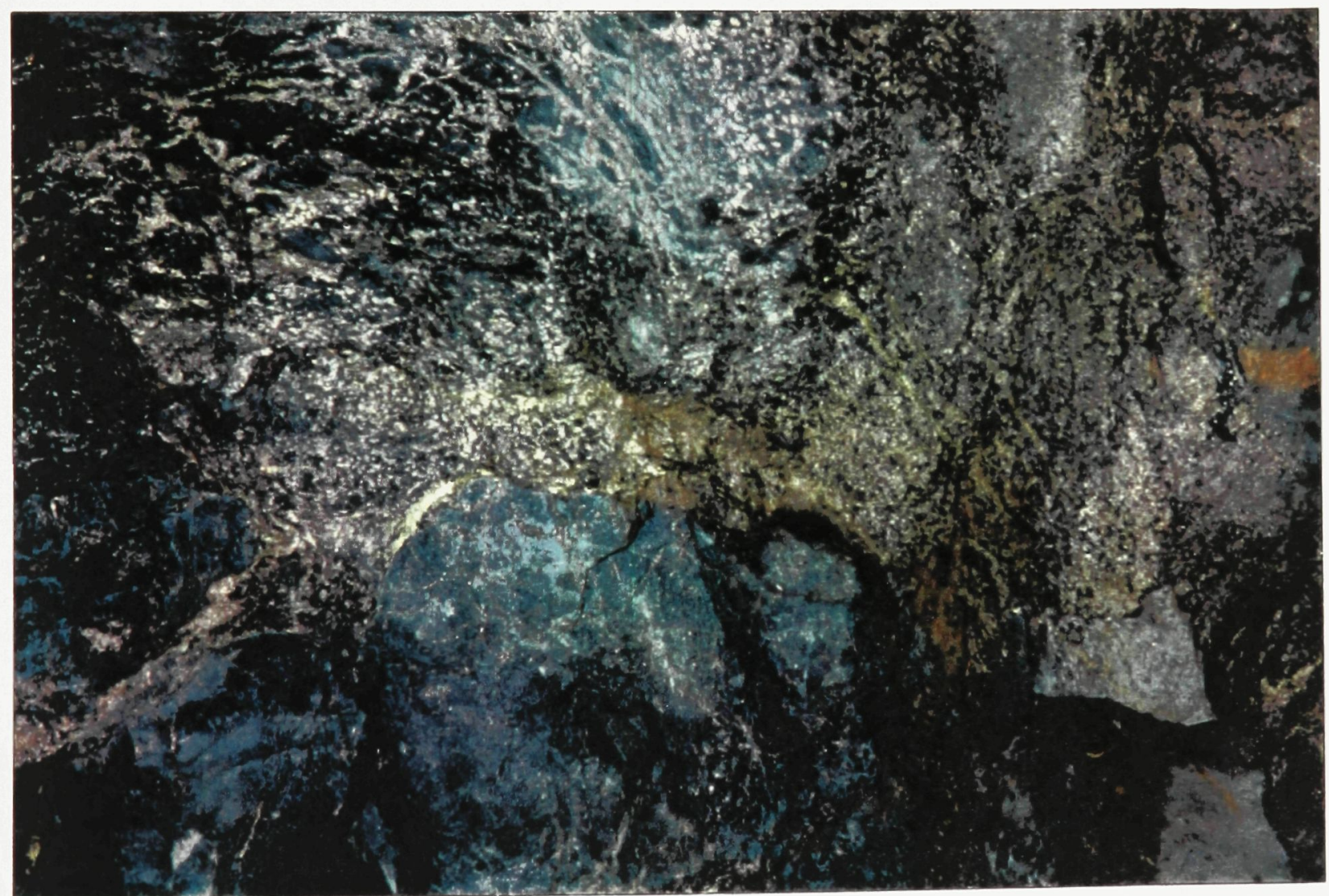

Figure 4.12 "Net-textured" pyrrhotite-chalcopyrite vein stockwork becoming finer-grained from left to right, changing to blocky fragment sulphide ore. Note rhyolite lobe at bottom of photo. Field of view $2 \mathrm{~m}$ across 


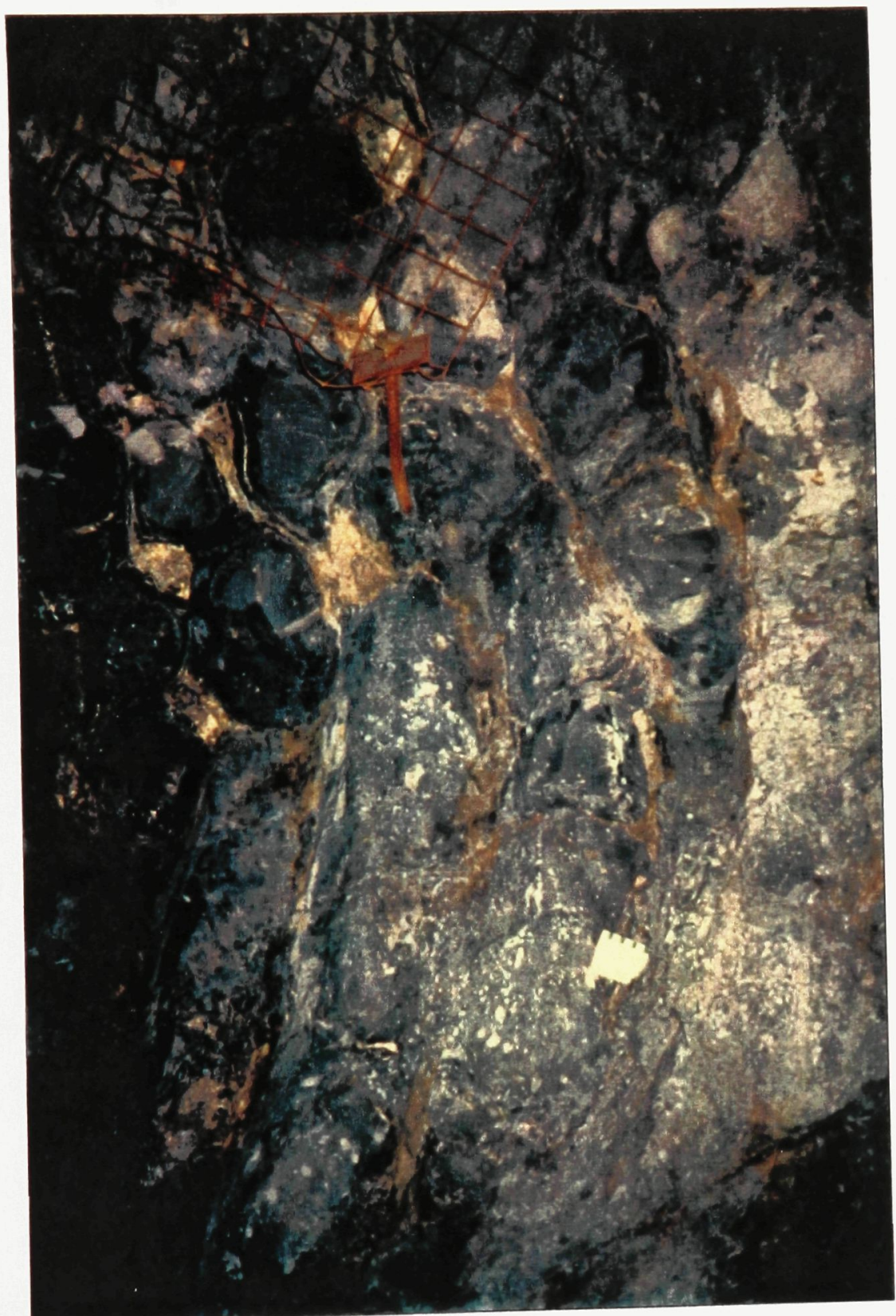

Figure 4.13 Columnar-jointed rhyolite with pyrrhotite-chalcopyrite stockwork controlled by joints. Sublevel 8 A. Centimetre card for scale 


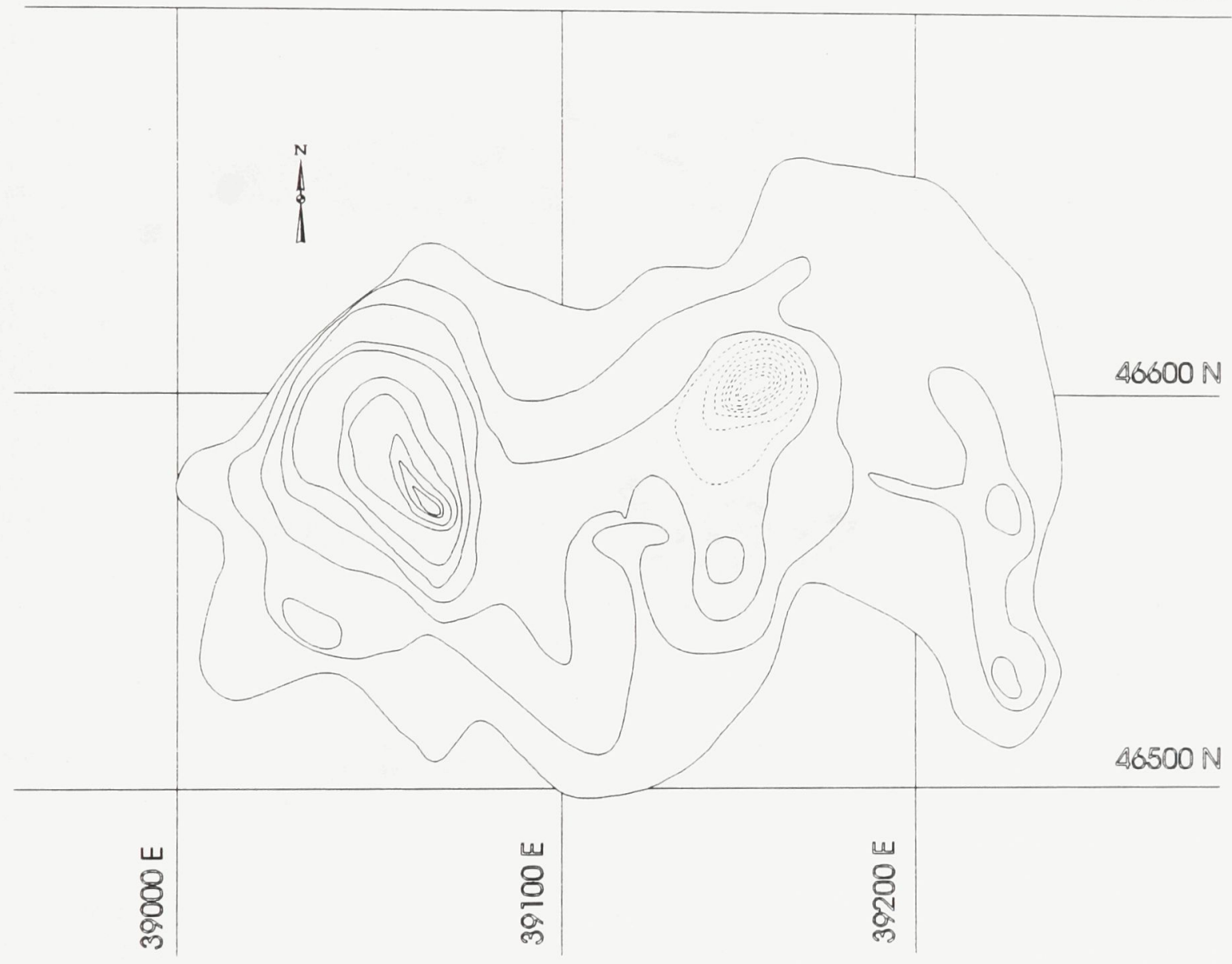

Figure 4.14 Contoured plan view of the Ansil deposit. Dashed contours represent the depth of the underlying, semi-massive to massive sulphide vein stockwork that is included as mineable ore. Contours at $5 \mathrm{~m}$ intervals. 


\section{North}
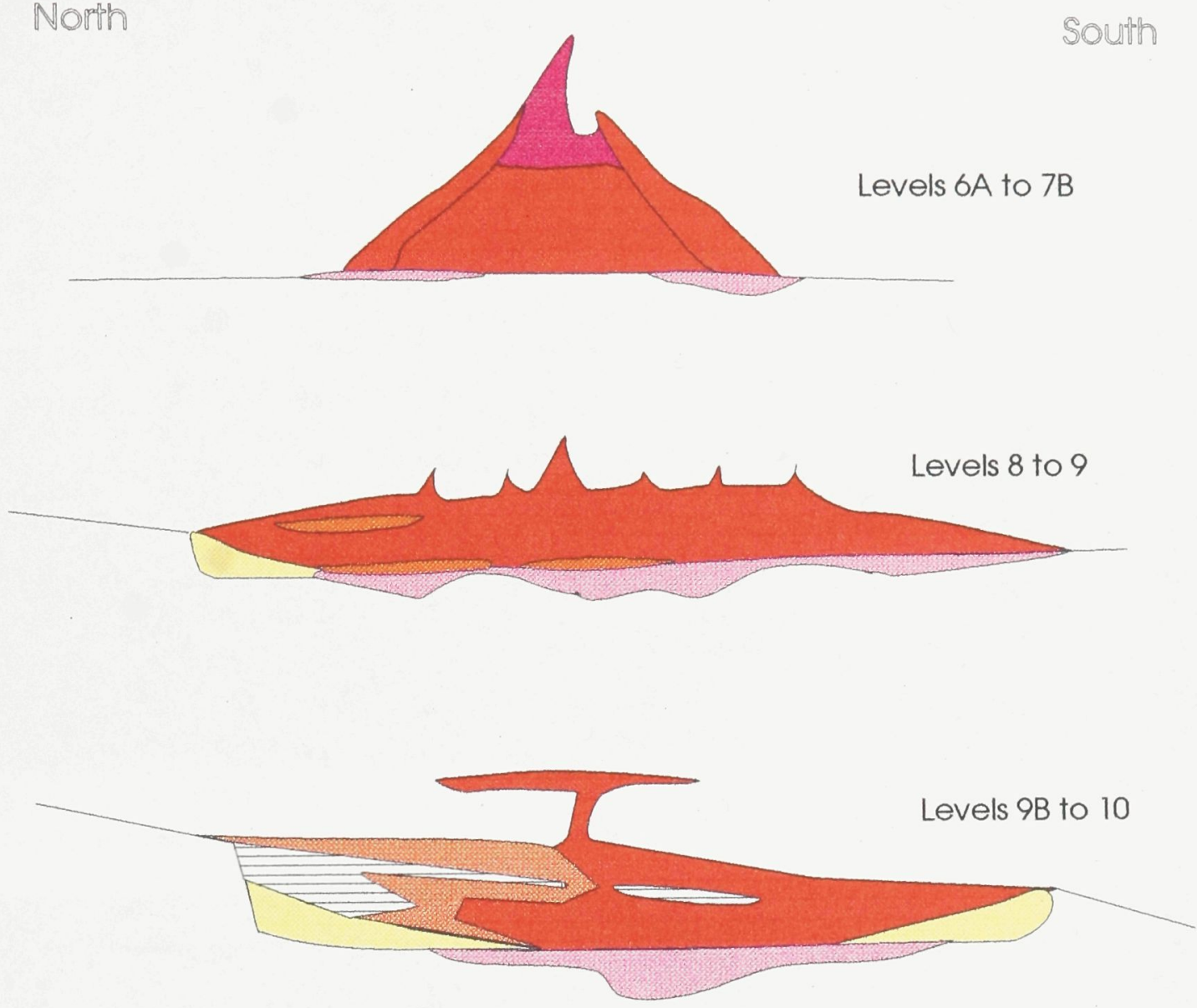

Levels 10A to 1A

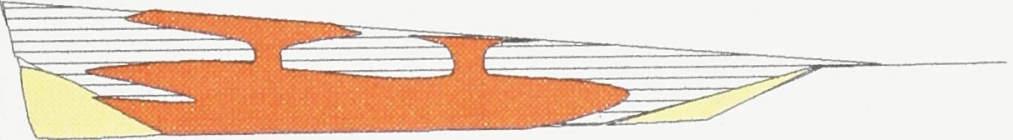

Bleached fragment ore

Elongate and blocky fragment ore

Hangingwall fragmental ore

Sulphide-rich

Cranston tuff
Layered chalcopyritepyrrhohtite-tuff ore

Layered chalcopyrite-pyrrhotite/ pyrite-sphalerite ore

Banded massive ore

Massive and sievetextured ore

Figure 4.15 Cross-sections through the Ansil orebody showing the different textural and compositional subdivisions. 


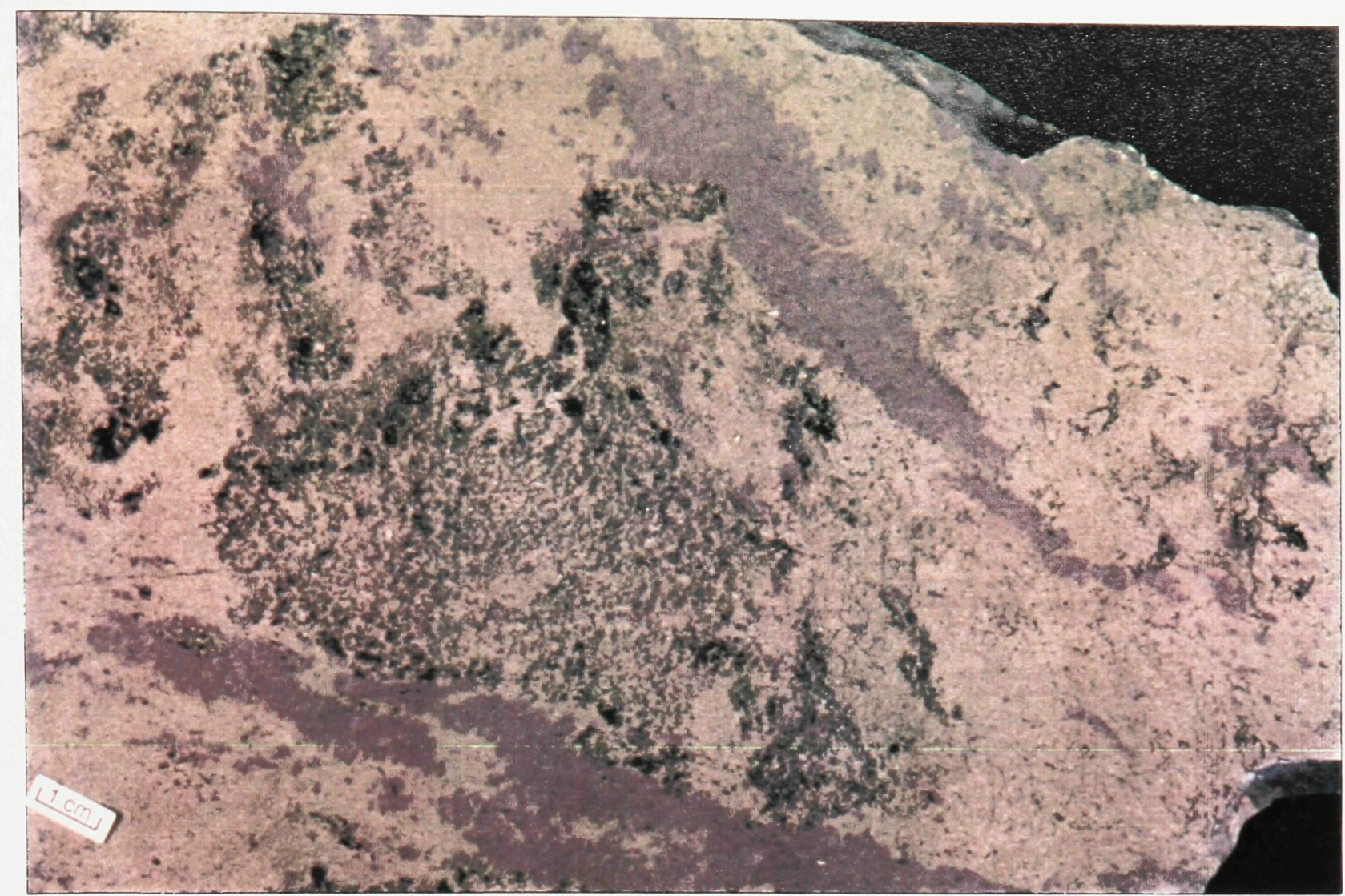

Figure 4.16 Polished slab showing massive to sieve-textured massive sulphide, with wispy bands of pyrrhotite in a chalcopyrite groundmass. Sample ANSL10-21.

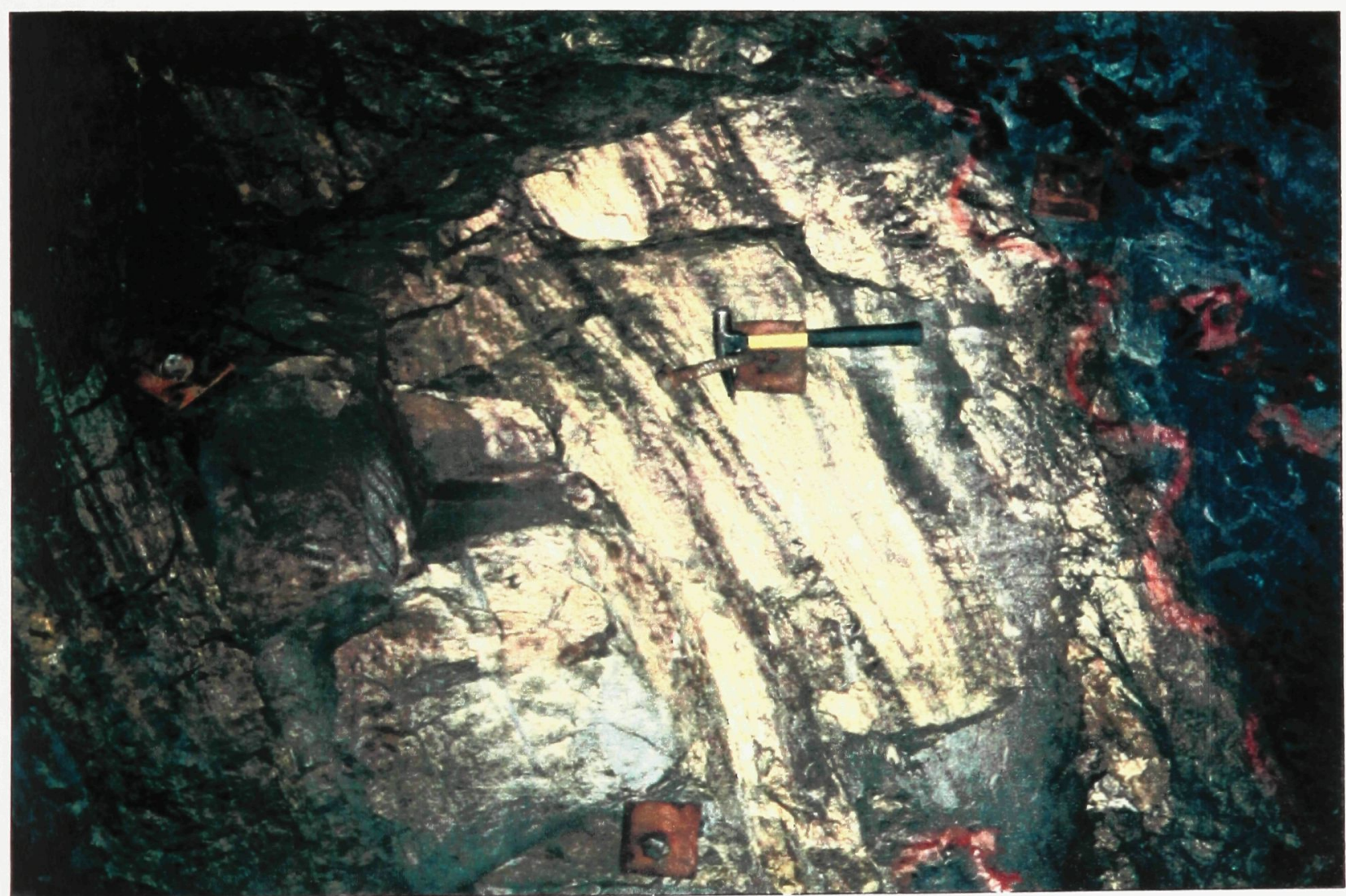

Figure 4.17 Closely spaced pyrrhotite banding in massive ore along hangingwall contact of the massive sulphide lens with pillowed andesitic flow. Banding is warped about a more massive segment of ore. Sublevel 6A. Hammer for scale. 


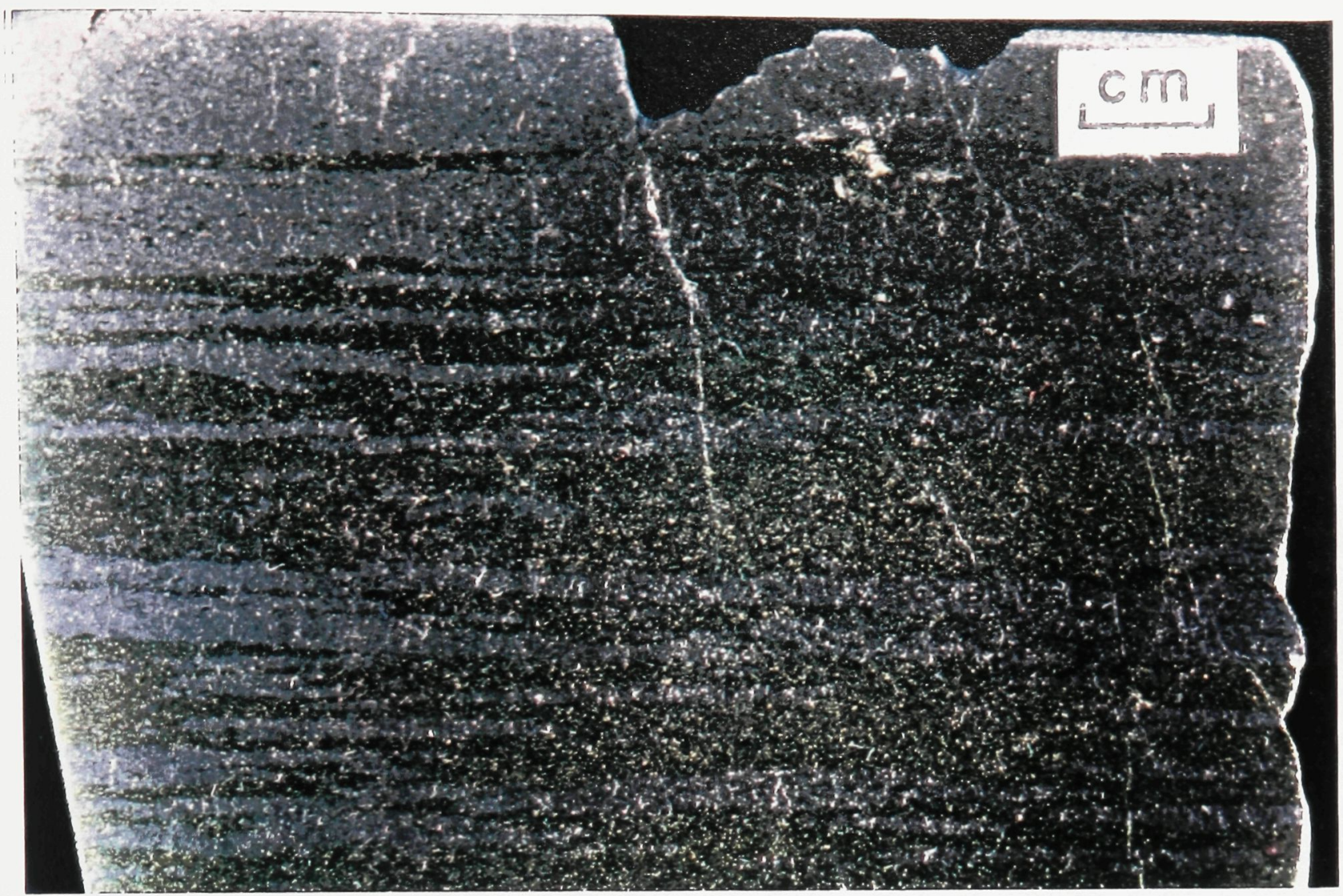

Figure 4.18 Polished slab showing massive, banded sulphide ore with wispy, discontinuous bands of pyrrhotite in chalcopyrite. Sublevel 6A. Sample ANSL6A-4140.

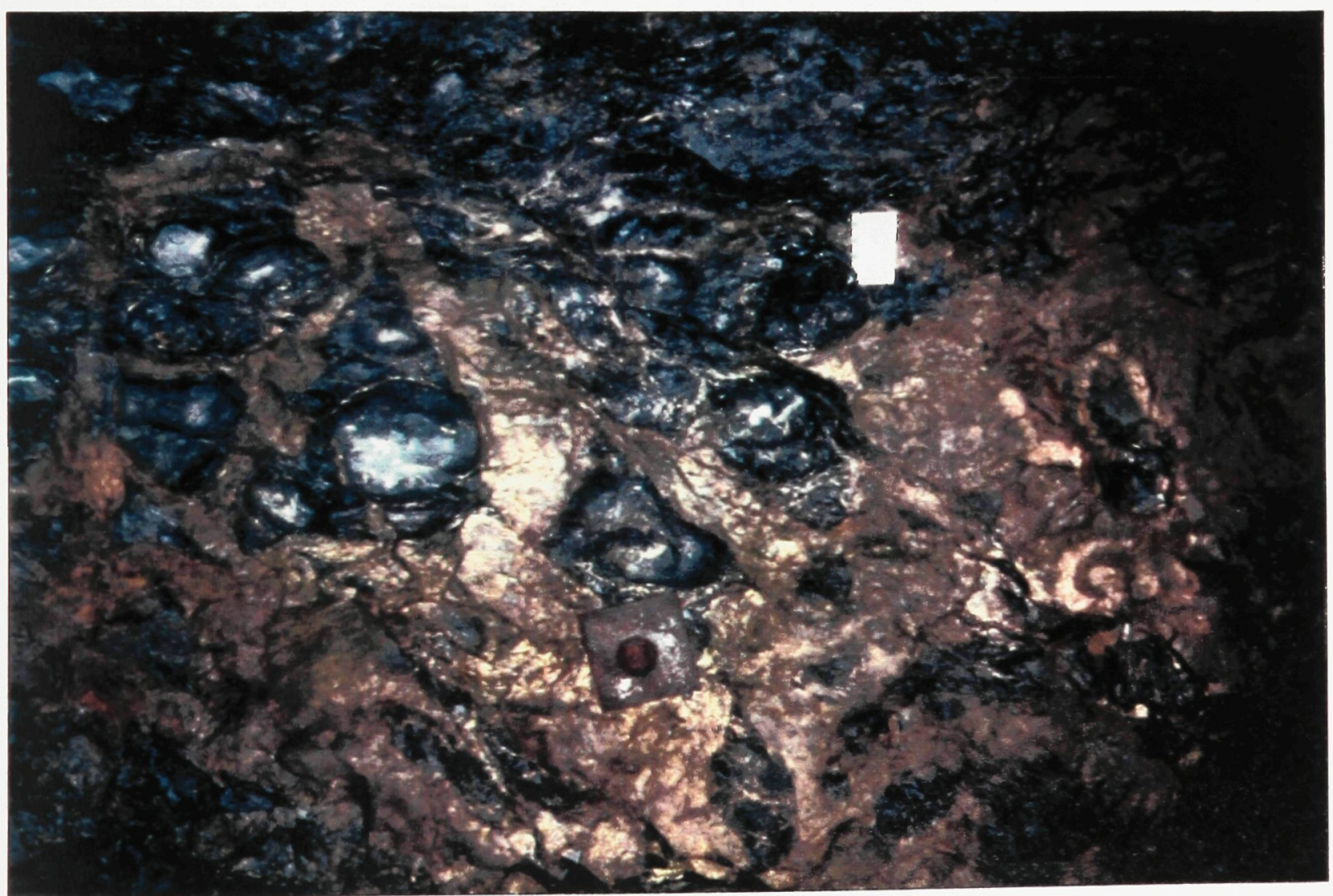

Figure 4.19 Hangingwall fragmental ore from the top of the massive sulfide lens at the west end of the deposit. Sublevel 8. Centimetre card for scale. 


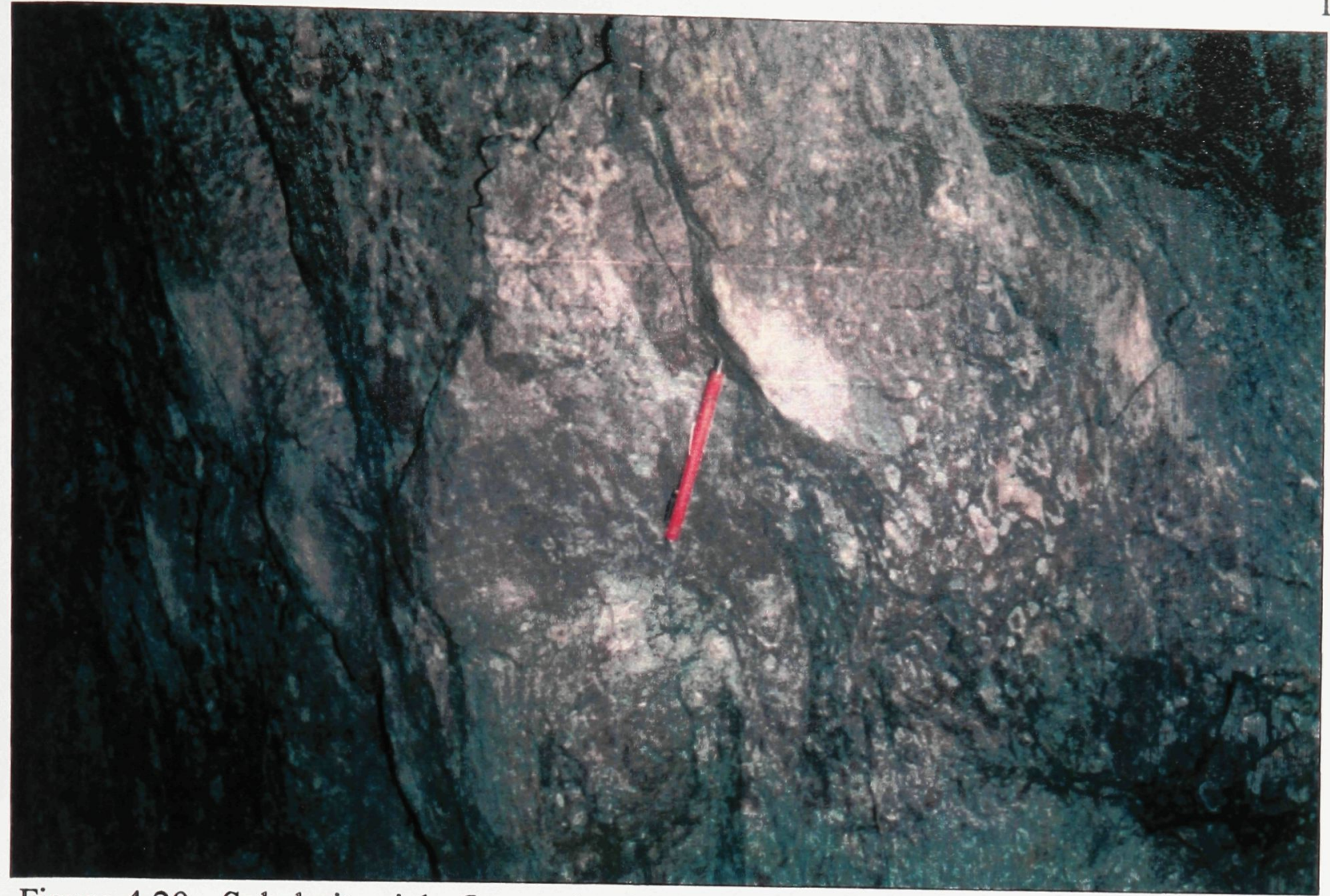

Figure 4.20 Sphalerite-rich, fine-grained bleached fragment breccia containing 10 to $12 \%$ Zn (ore drift, Sublevel 10A). Magnet $12 \mathrm{~cm}$ long

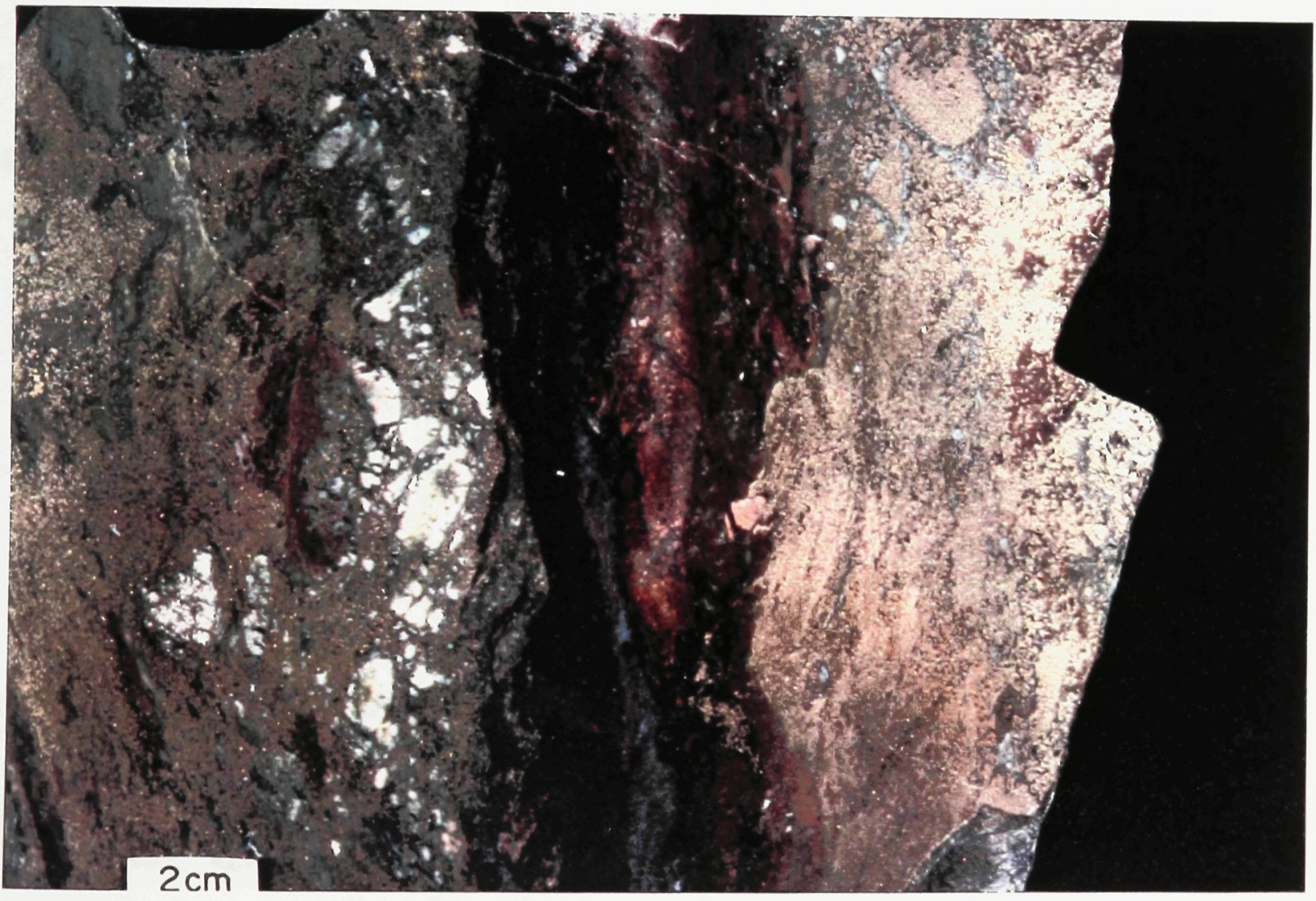

Figure 4.21 Polished slab showing discordant, Zn-rich zone cross-cutting pyriteimpregnated bleached fragment breccia. Ore drift, Sublevel 10A. Sample ANSL10A-197. 


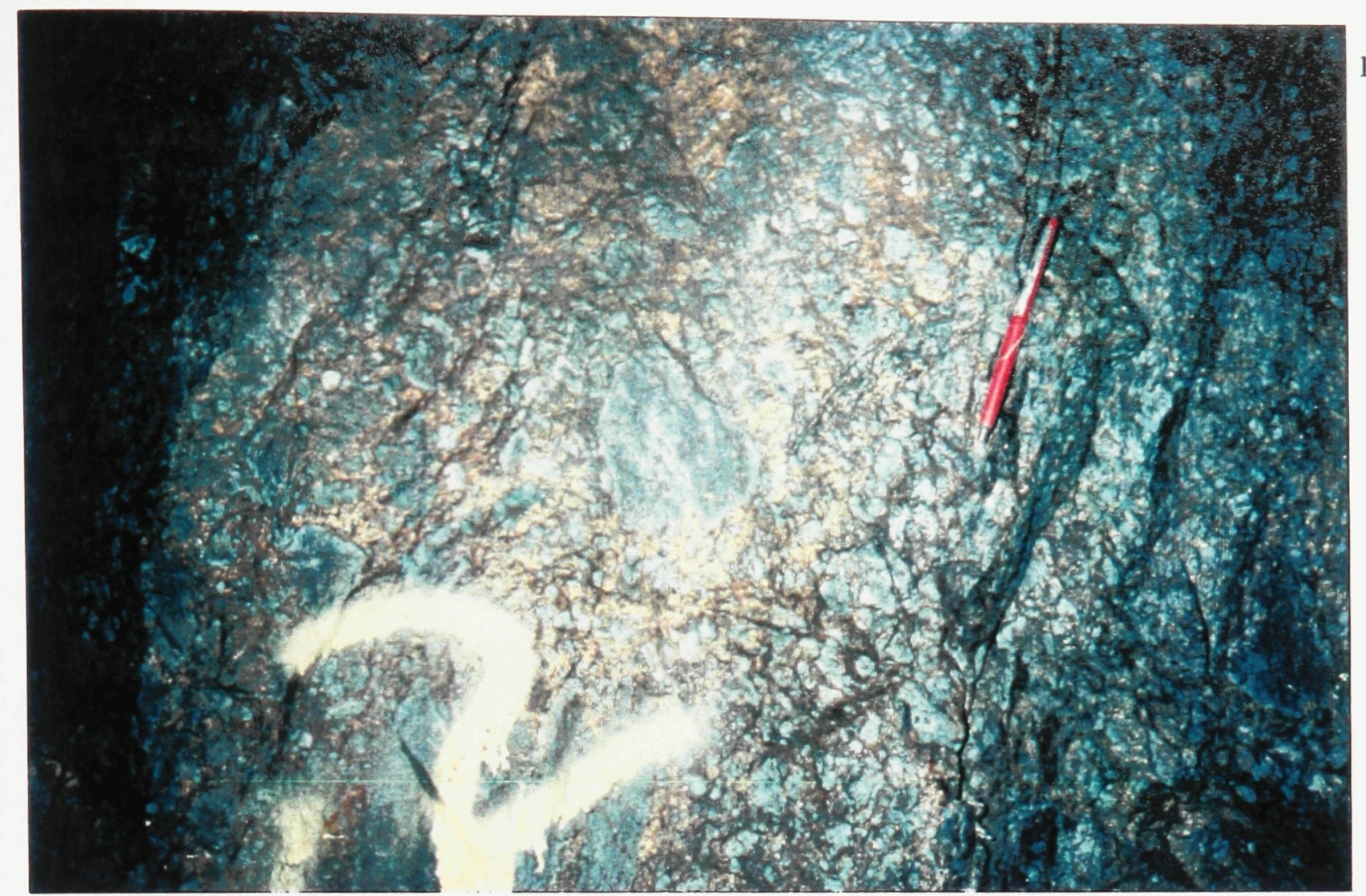

Figure 4.22 Discordant, Cu-rich zone crossing bleached fragment breccia, with chalcopyrite infilling between previously sericite-quartz-sphalerite altered rhyolite fragments. Ore drift, Sublevel 10A.

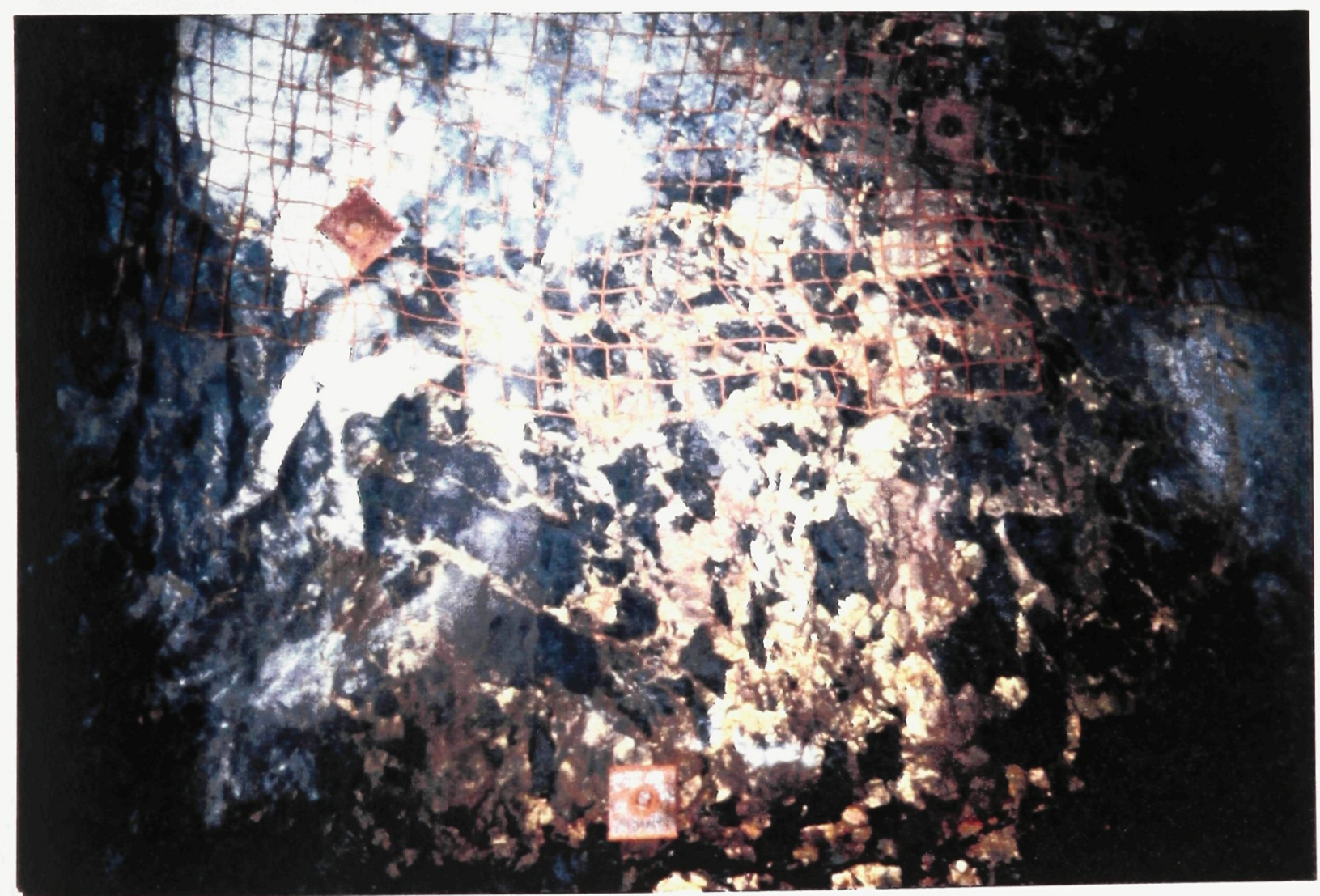

Figure 4.23 Replacement of matrix of chlorite-altered flow breccia by massive pyrrhotitechalcopyrite.Drawpoint \#1, Sublevel 8A. Steel plate $15 \mathrm{~cm}$ wide. 


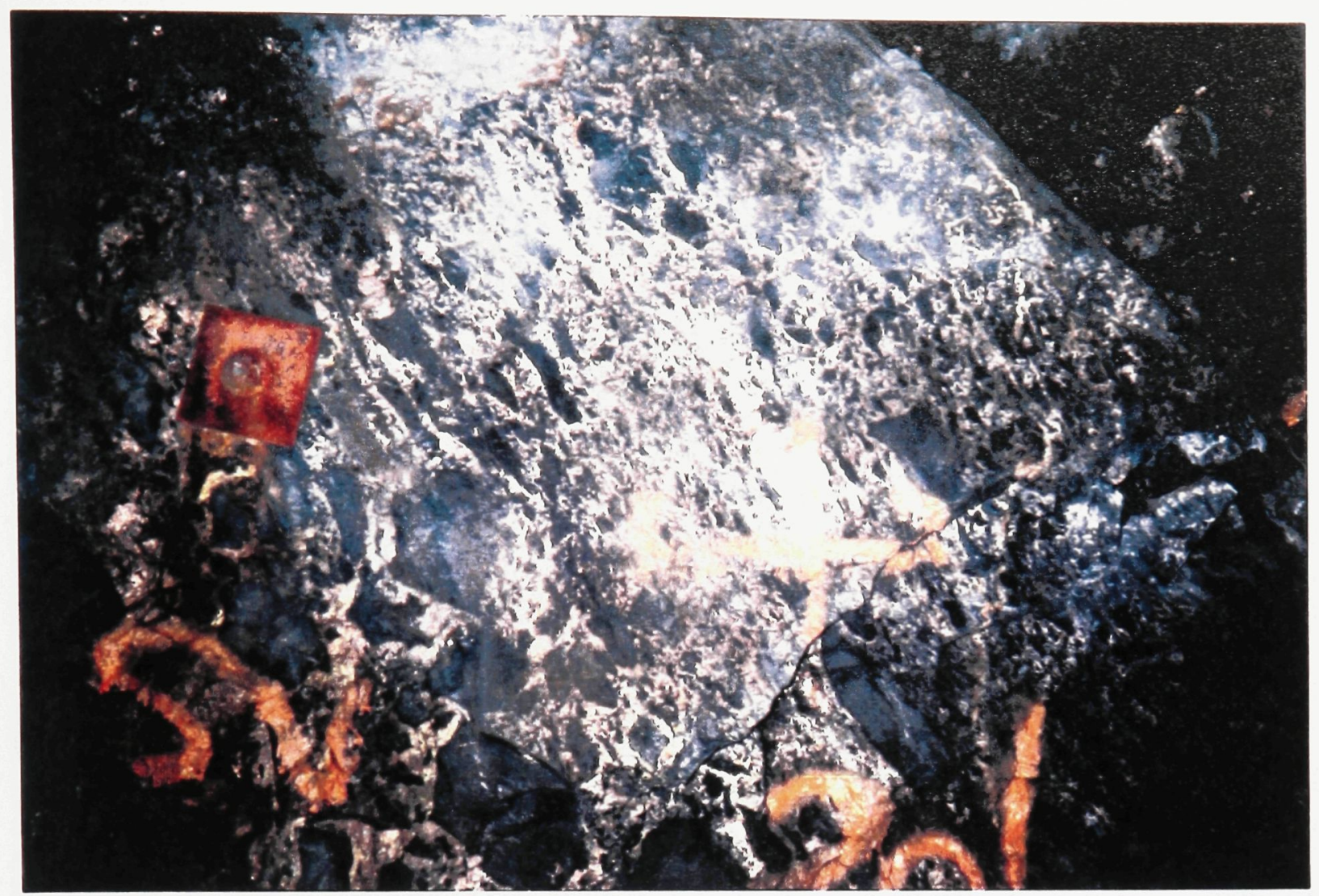

Figure 4.24 Elongate fragment breccia ore overlying blocky fragment ore, and in gradational contact (to right) with massive sulphide ore. Drawpoint \#4, Sublevel 8A. Steel plate $15 \mathrm{~cm}$ wide for scale.

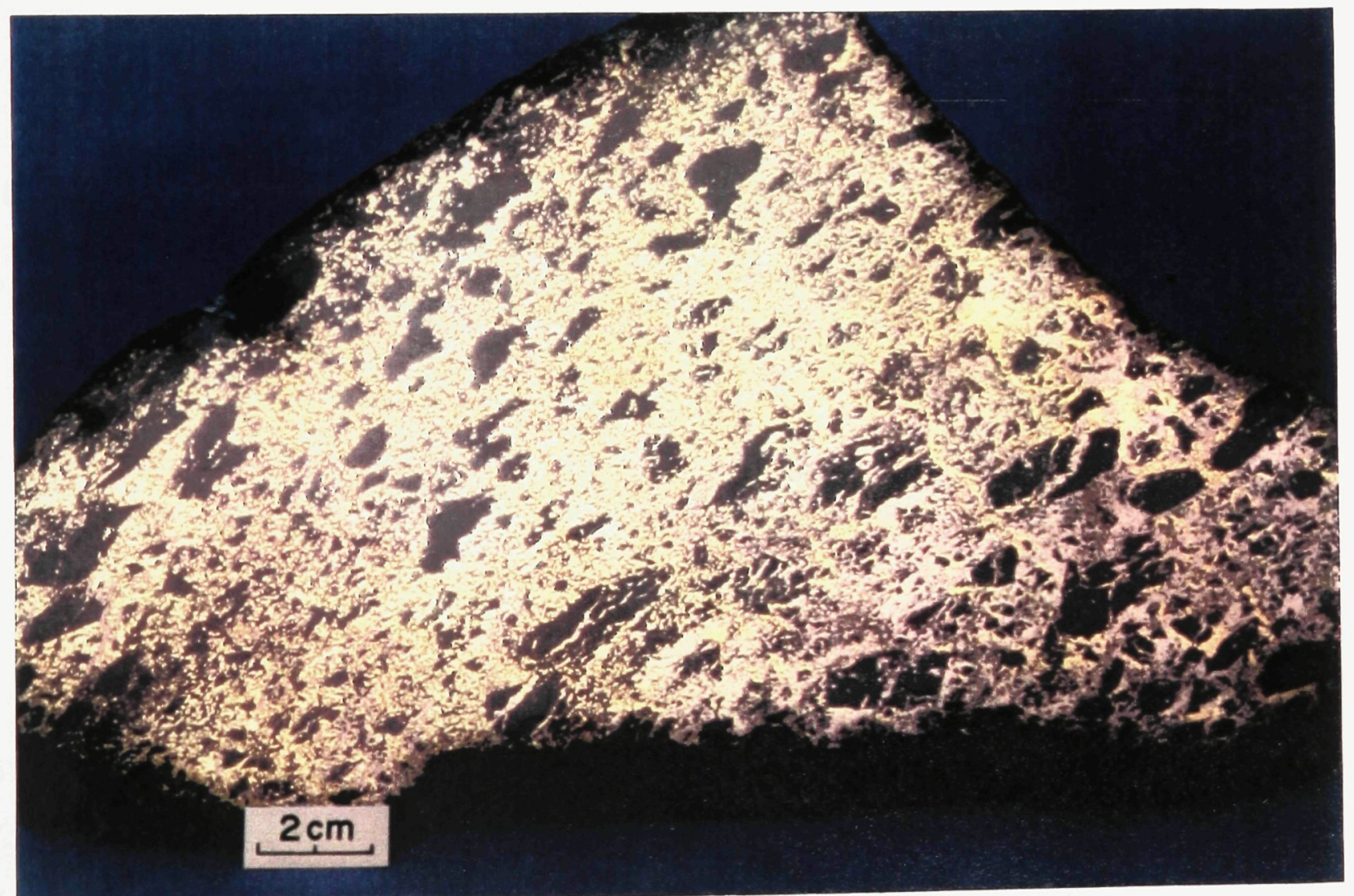

Figure 4.25 Elongate fragment breccia ore formed from infilling and intense veining of rhyolite hyaloclastite. Sample ANSL8A-45. 


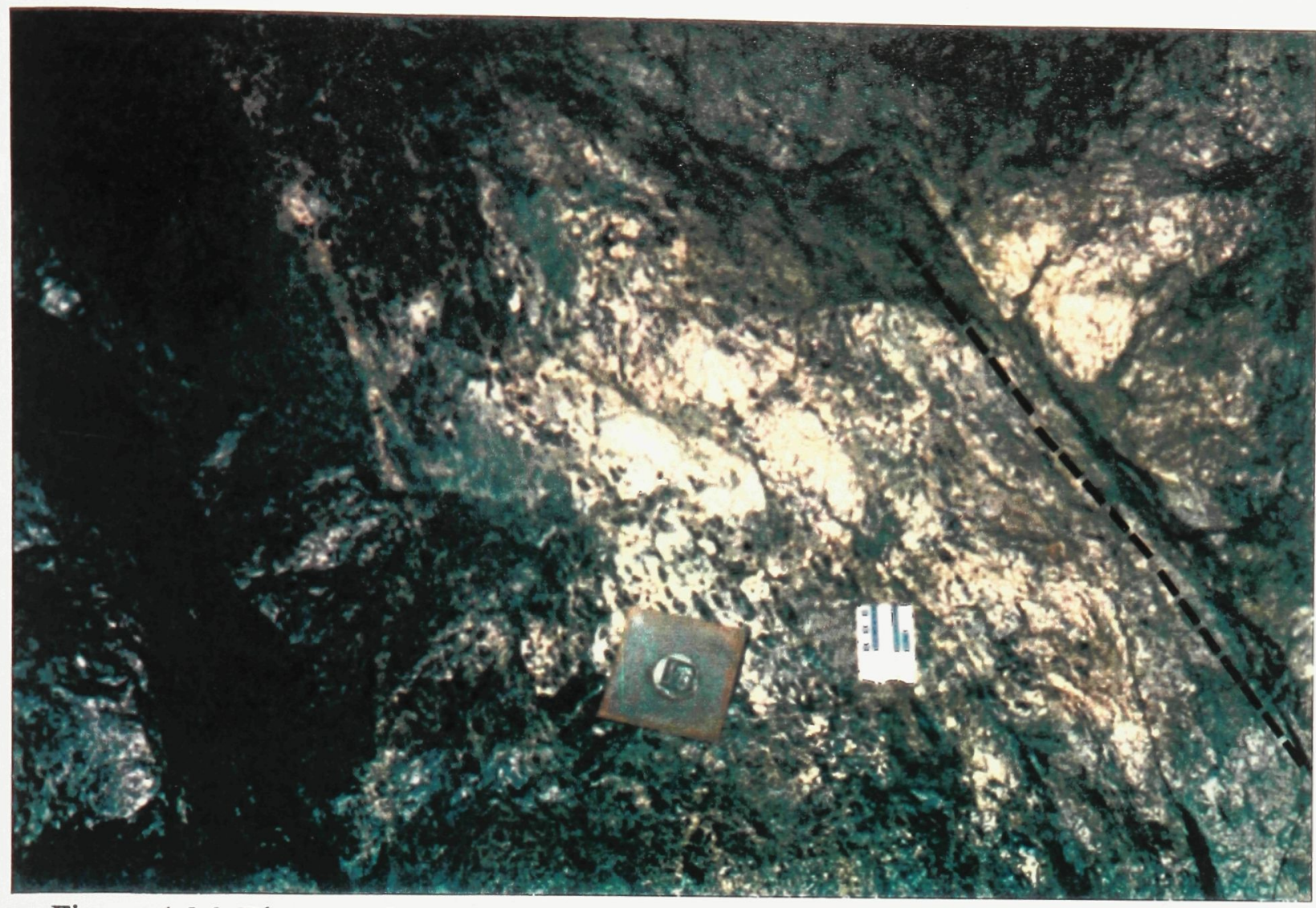

Figure 4.26 Elongate fragment sulphide ore in gradational contact with massive ore.

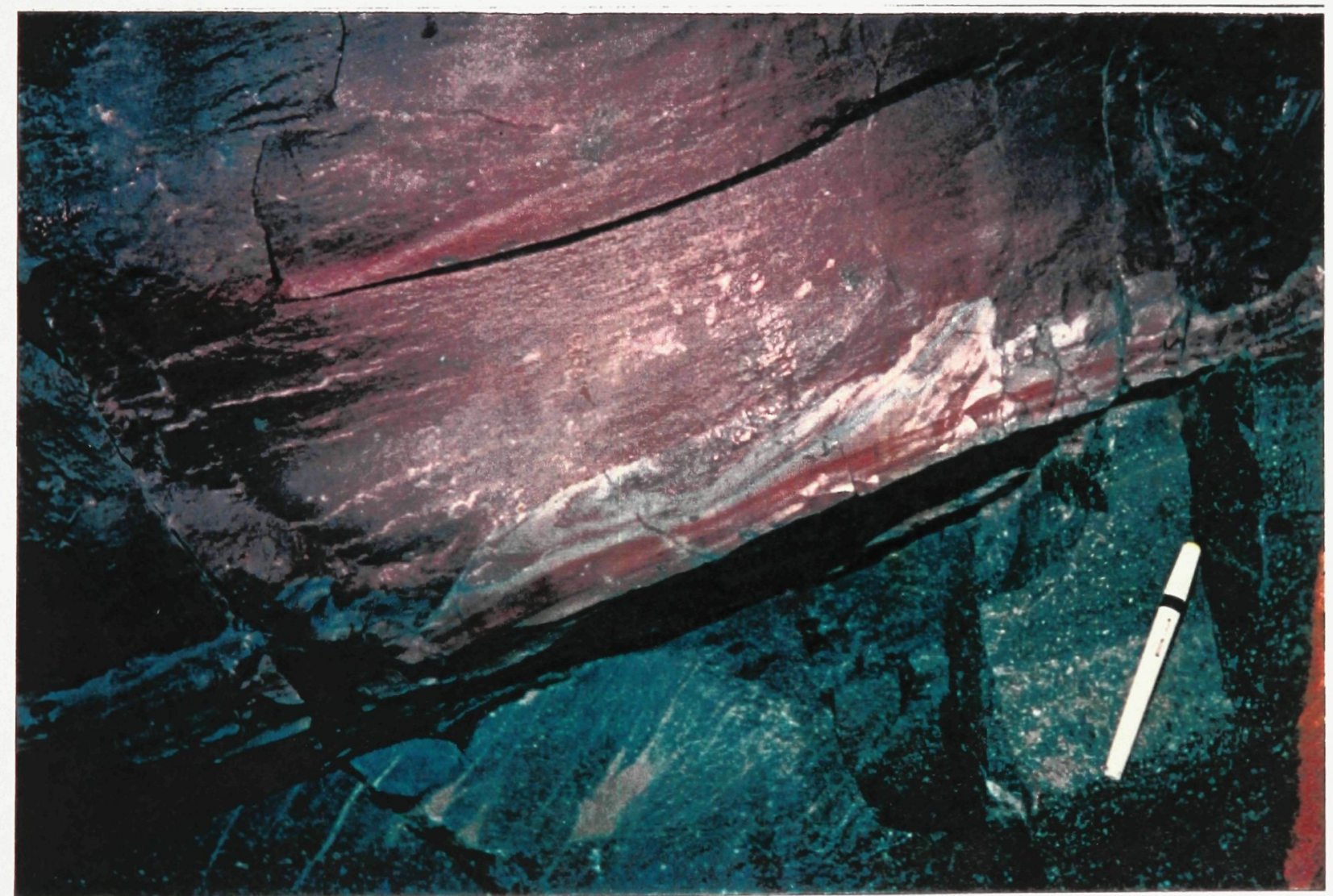

Figure 4.27 Sphalerite-rich Cranston tuff. Ore drift, Sublevel 10B. $12 \mathrm{~cm}$ long pen for scale. 
Figure 4.28

A. Photomicrograph of pyrrhotite, sphalerite and accompanying sericite alteration concentrated in coarse-grained base to Cranston tuff layer. Sharp contact with top to underlying tuff bed. Note sphalerite enveloping quartz grains. Field of view $4 \mathrm{~mm}$.

B. Photomicrograph of intergrown sphalerite and sericite in sericite altered Cranston tuff . Field of view $1 \mathrm{~mm}$.

C. Photomicrograph of zoned pyrite grain in Cranston tuff, with massive core rimmed with inclusion-rich subhedral pyrite. Field of view $4 \mathrm{~mm}$.

D. Photomicrograph of a corroded pyrite cube in Cranston tuff enveloped in pyrrhotite and chalcopyrite. Field of view $4 \mathrm{~mm}$. 

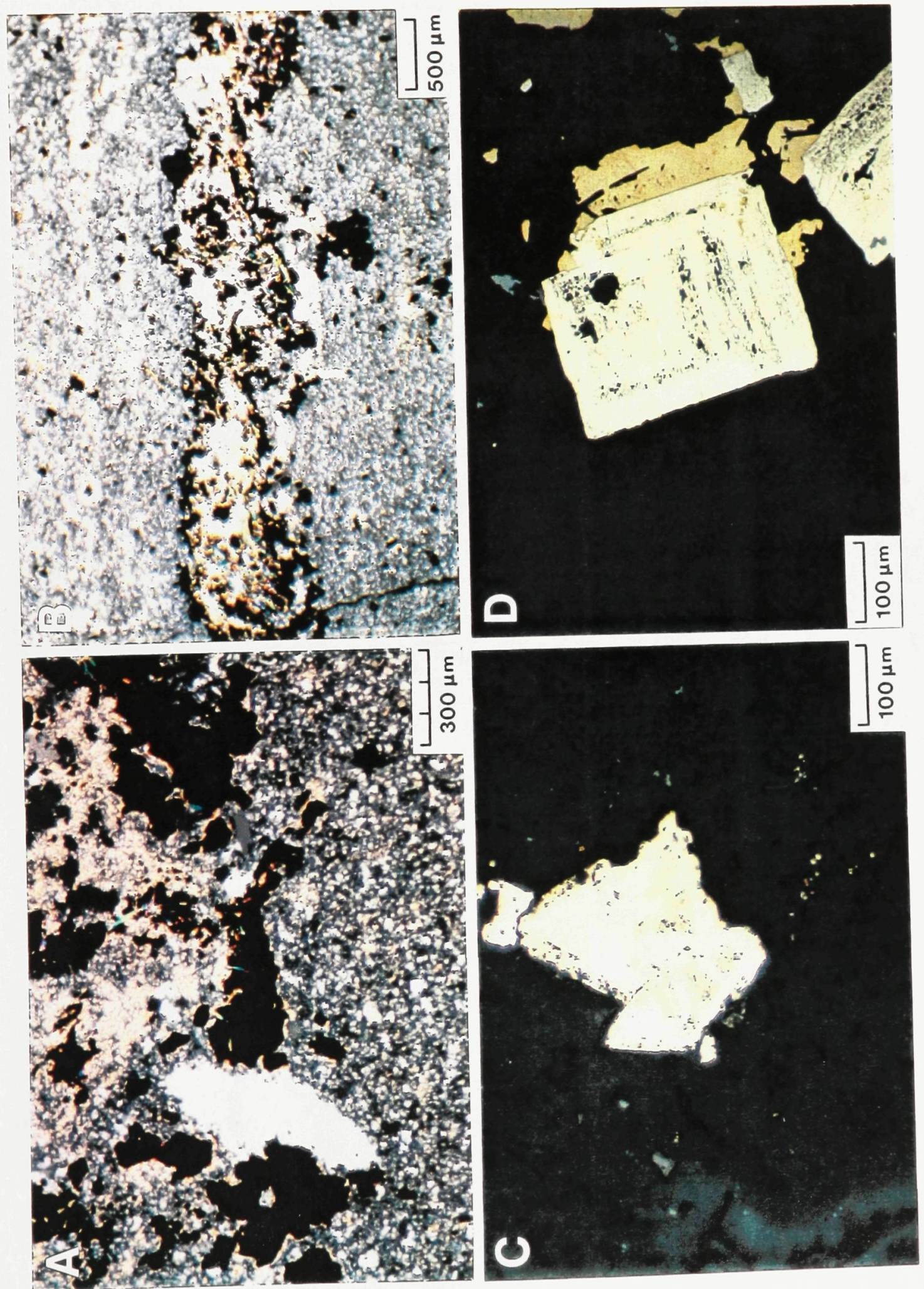
Drowpoint \#6: North wall

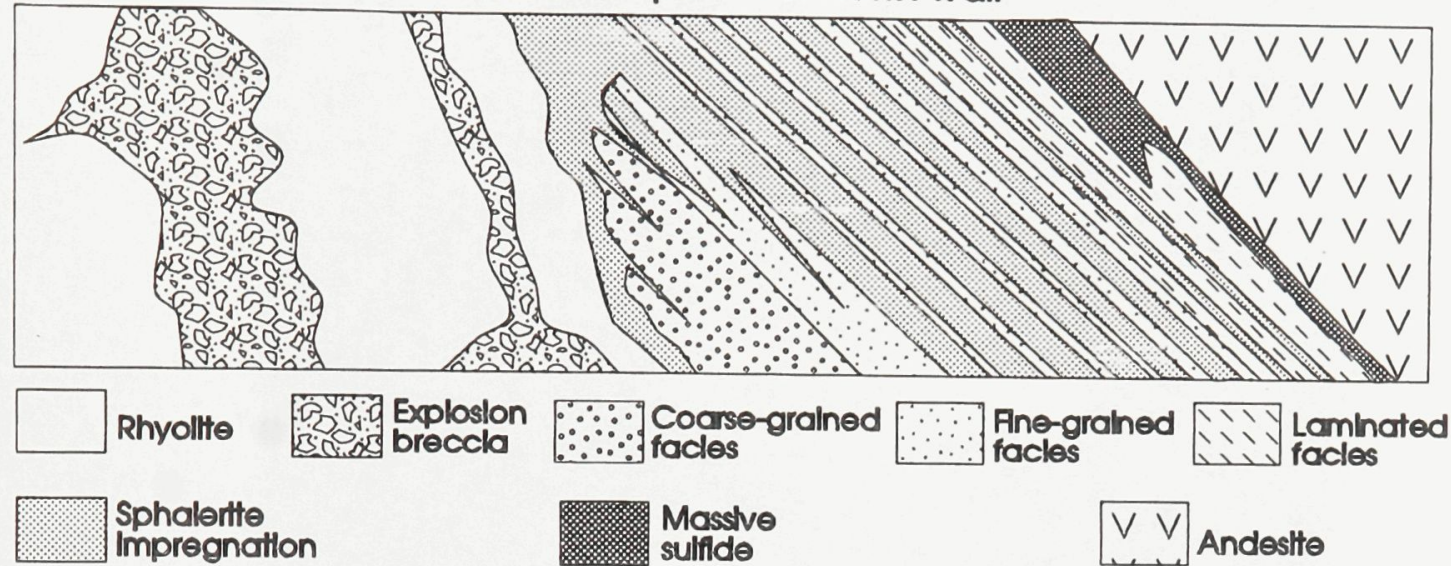

Figure 4.29 Sphalerite distribution along the synvolcanic fault-controlled rhyoliteCranston tuff contact below the north flank of the deposit. North wall of Drawpoint \#6, Sublevel 9B.

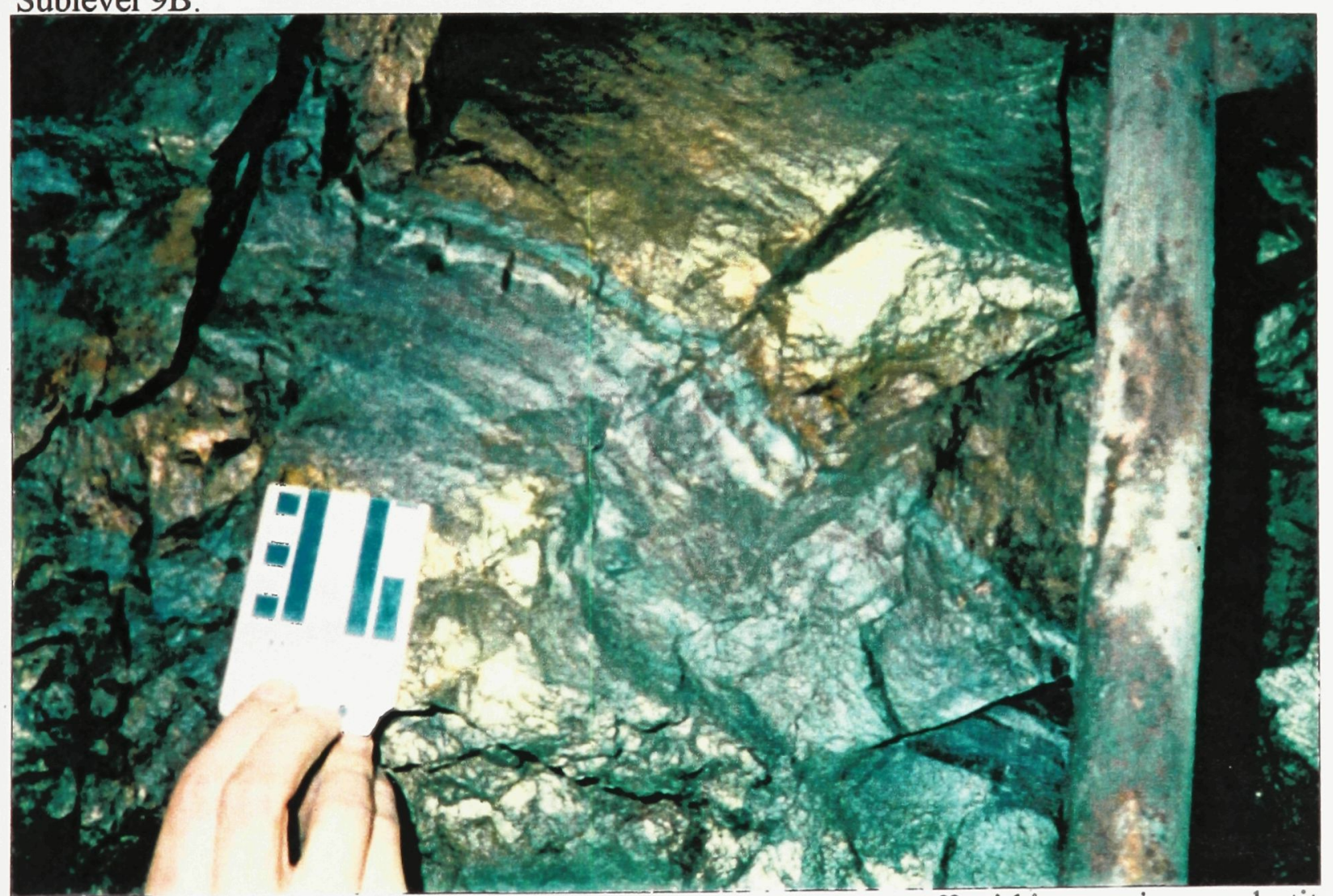

Figure 4.30 Remnant of sphalerite mineralized Cranston tuff within massive pyrrhotitechalcopyrite near the top of the orebody. Hangingwall access drift, Level 9C. 


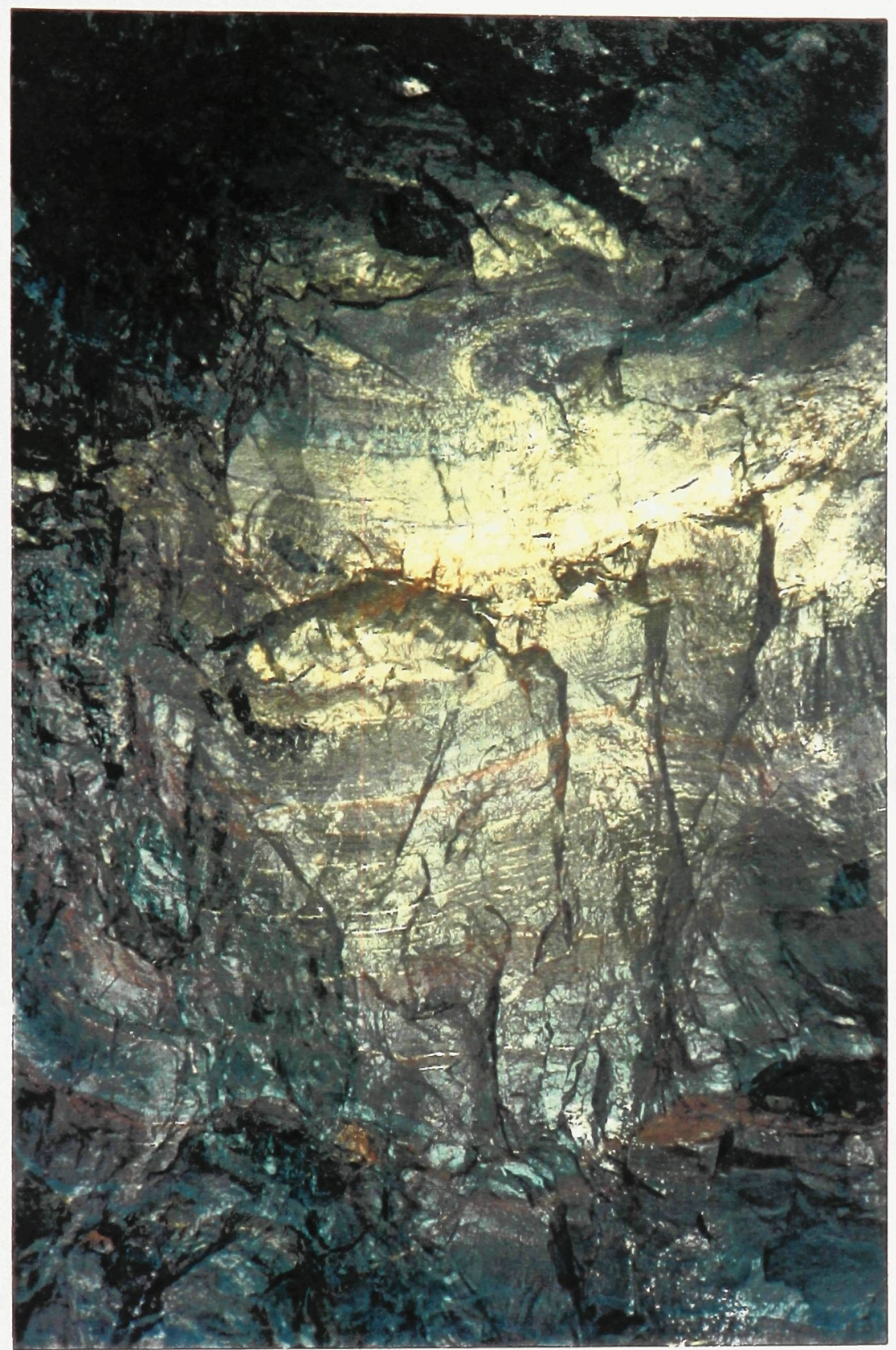

Figure 4.31 Selective overprinting of previously sphalerite mineralized layer of Cranston tuff by chalcopyrite-pyrrhotite. Ore cross-cut, Sublevel 11A. 1.5 to $2 \mathrm{~m}$ field of view. 


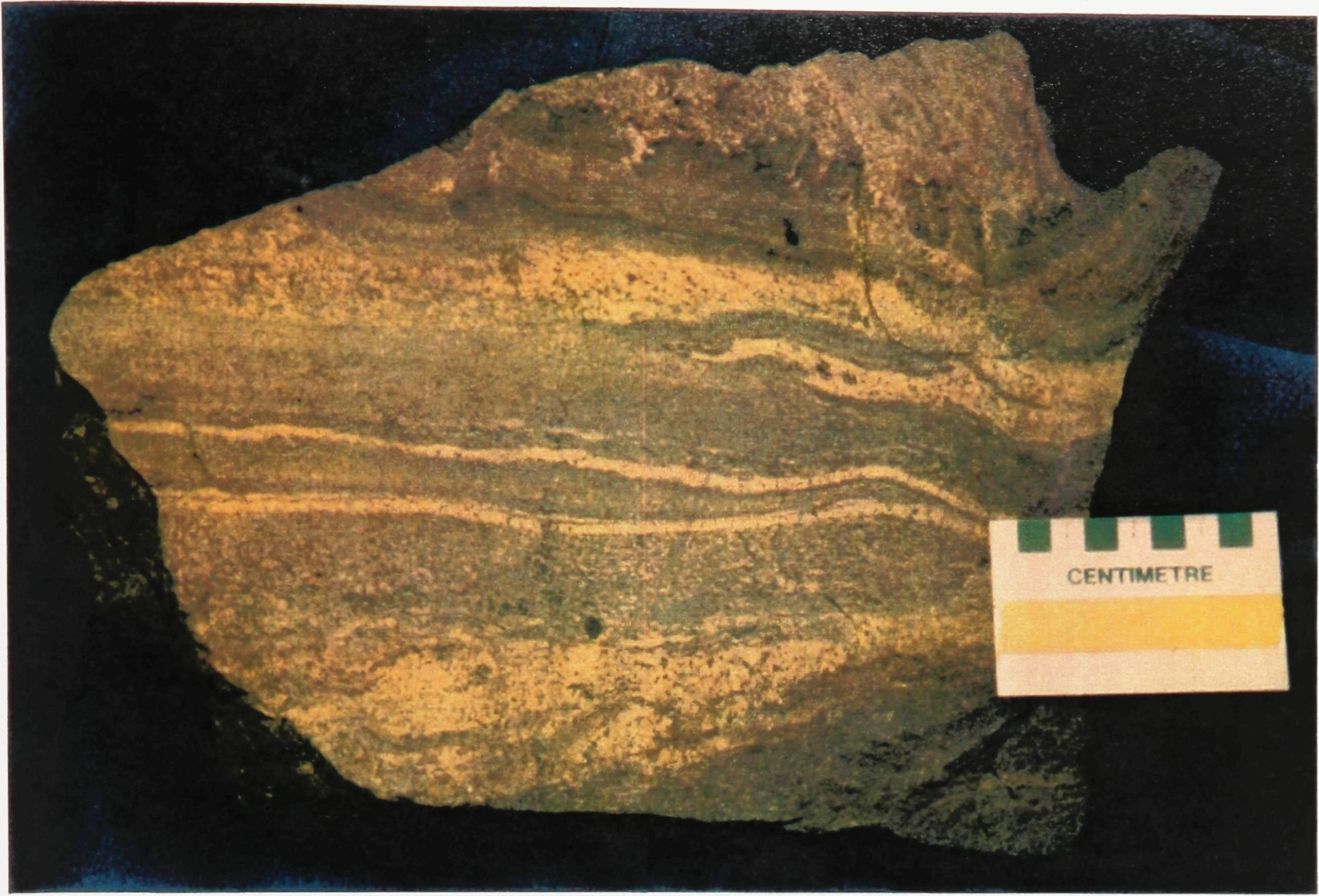

Figure 4.32 Slab showing sphalerite-rich Cranston tuff overprinted by chalcopyritepyrrhotite. Ore cross-cut, Sublevel 11A.

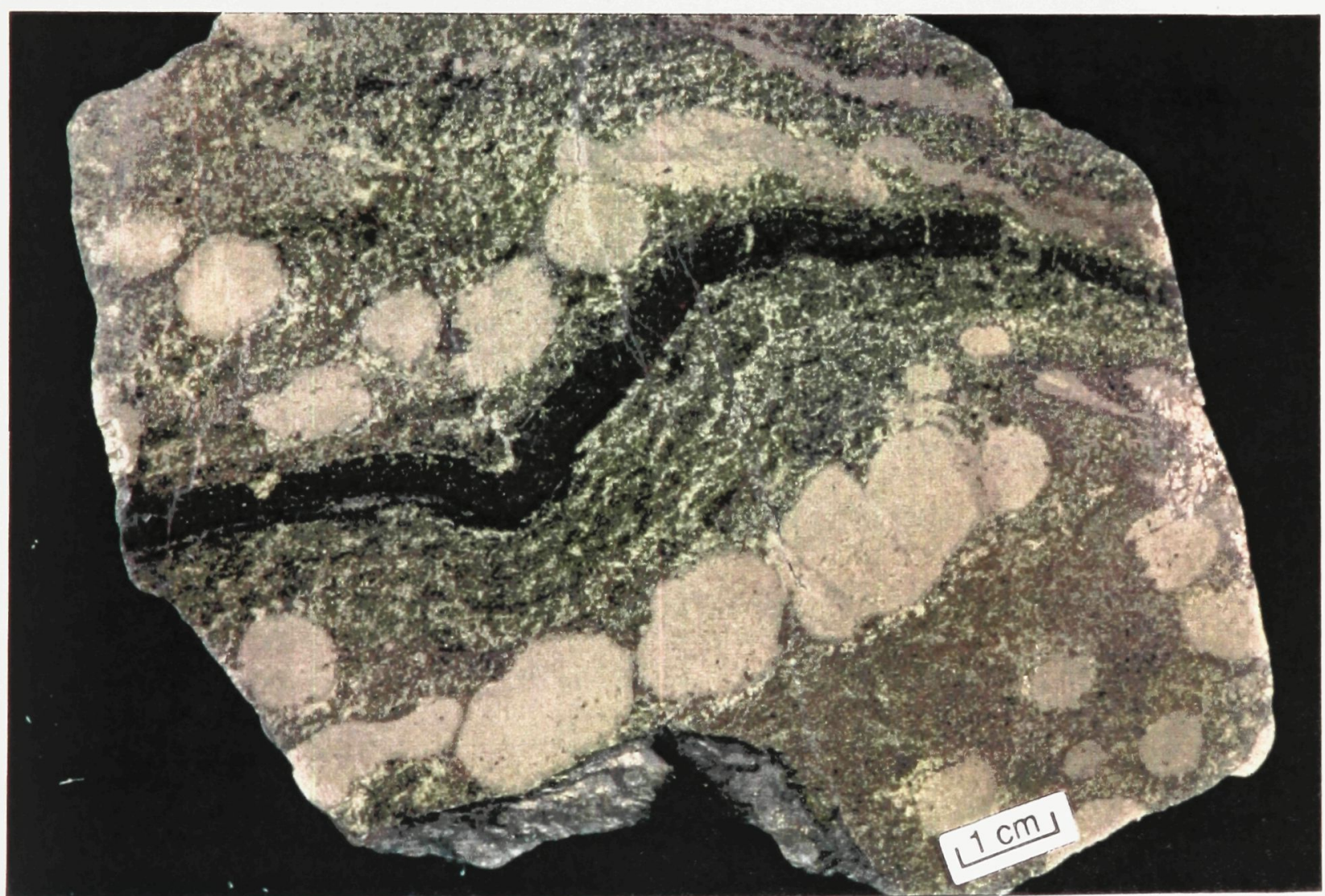

Figure 4.33 Polished slab showing Cranston tuff replaced by sphalerite and pyrite, which is weakly overprinted by pyrrhotite-chalcopyrite. Note large pyrite spheroids. Sublevel 9B. 


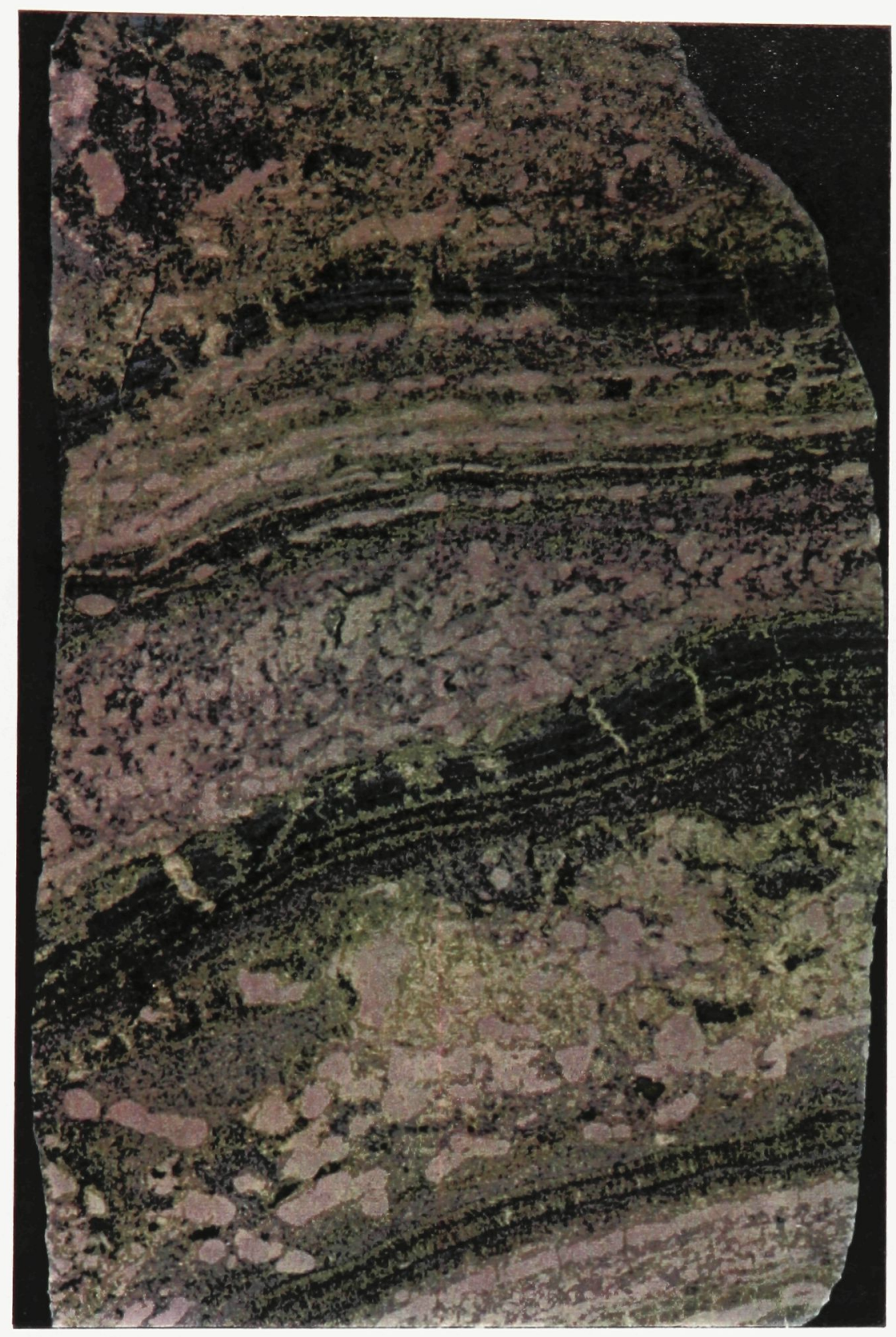

Figure 4.34 Polished slab of pyrite-sphalerite mineralized Cranston tuff with disseminated chalcopyrite-pyrrhotite infilling between volcaniclastic grains. Drawpoint \#5, Sublevel 9B. 


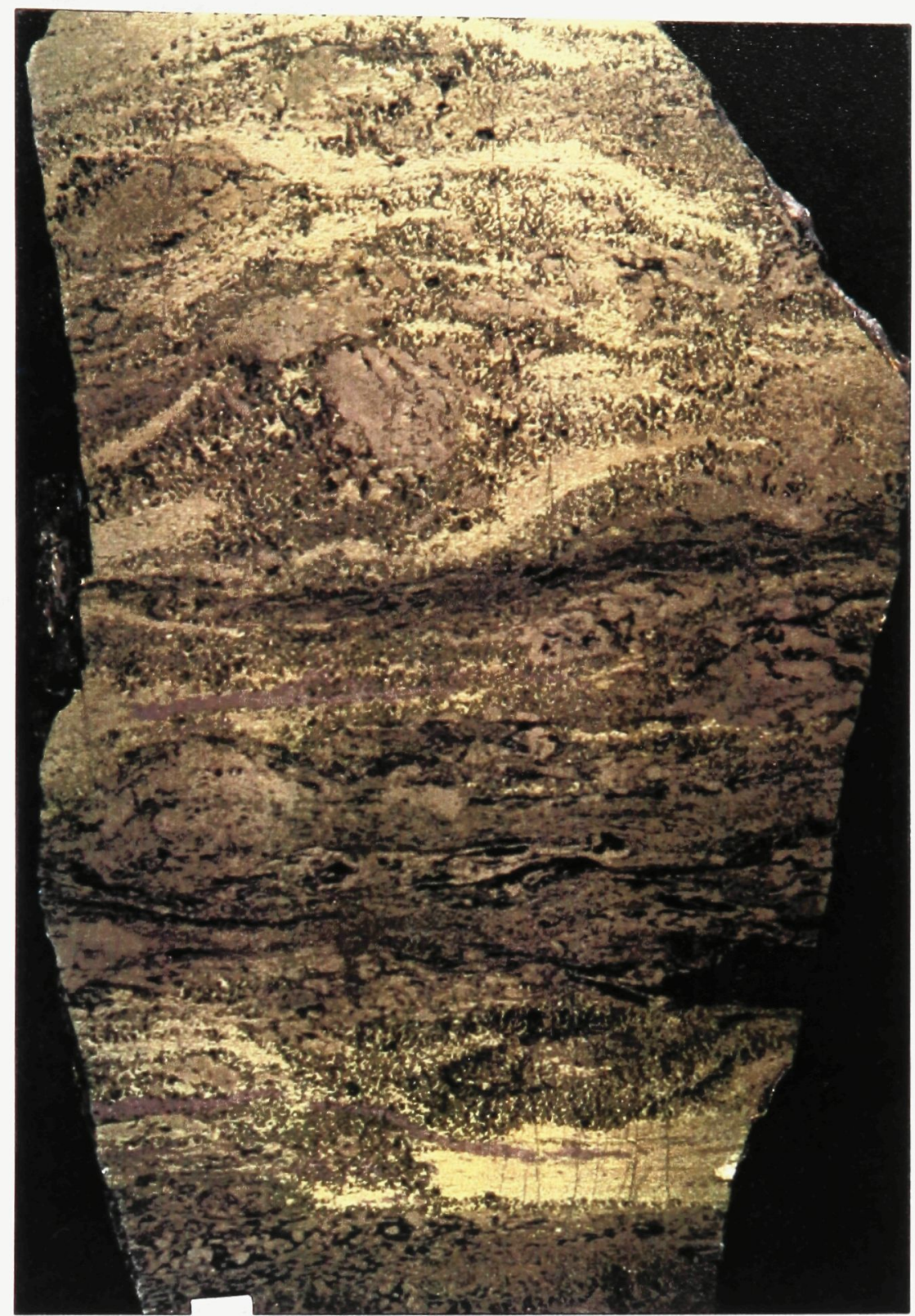

Figure 4.35 Polished slab from exposure shown in Figure 4.36. Presence of tectonically banded chalcopyrite-pyrrhotite in lower right corner, and fracturing of pyrite ovoids indicates moderate deformation of the orebody ie. some of the layering is tectonic. Sample ANSL10B-231A. 


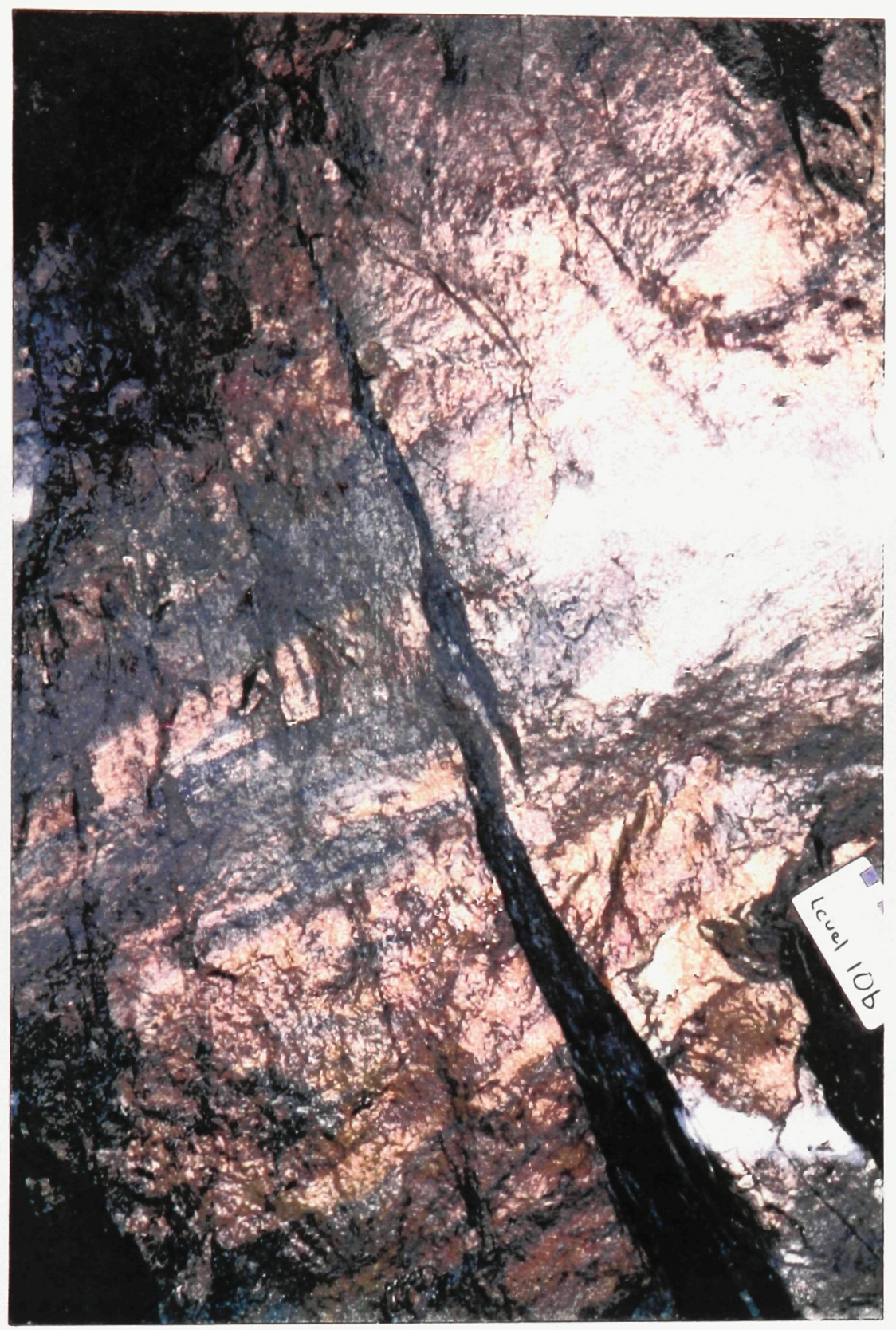

Figure 4.36 Exposure of pyrite-sphalerite mineralized Cranston tuff partially replaced by chalcopyrite-pyrrhotite to form layered chalcopyrite-pyrrhotite-pyrite-sphalerite massive ore. East end of orebody on Sublevel 10B. 


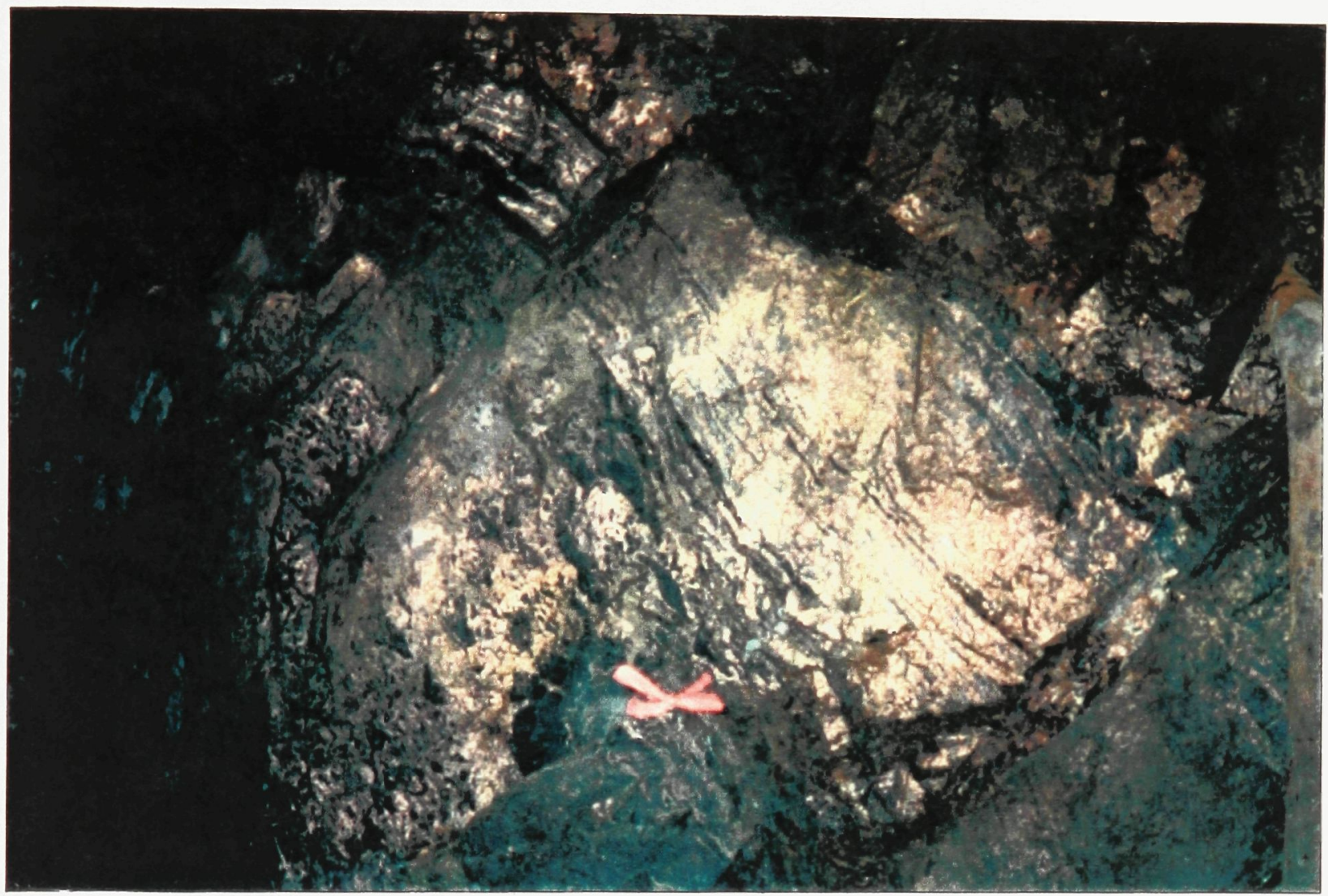

Figure 4.37 Layered pyrrhotite-chalcopyrite-tuff ore along the contact between the base of the massive sulphide ore and the top of the elongate fragmental ore. Layered ore is up to $50 \mathrm{~cm}$ wide. Drawpoint \#5, Sublevel 8 A. 


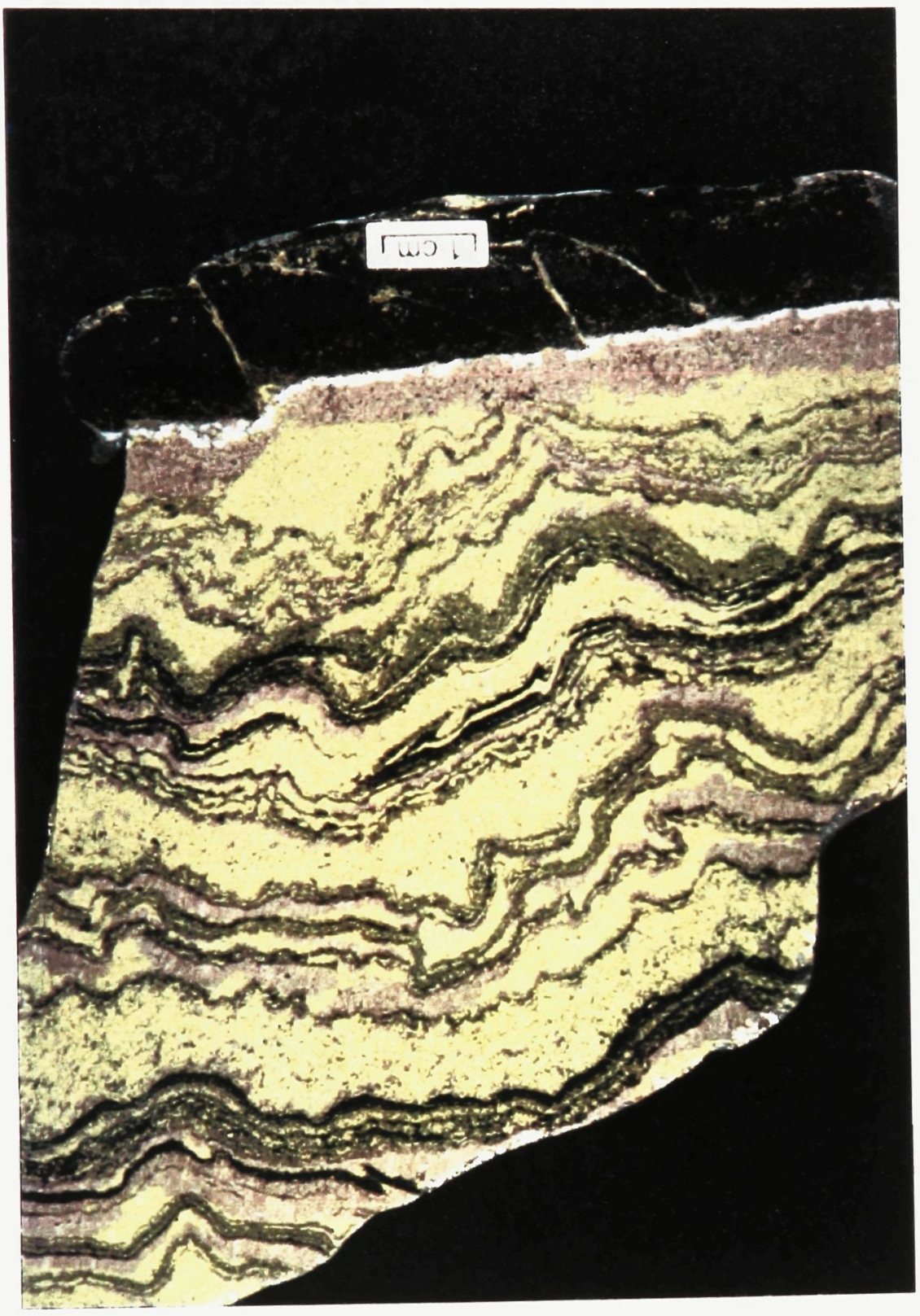

Figure 4.39 Polished slab showing remnant of laminated facies, sphalerite-mineralized Cranston tuff replaced along its margins by banded pyrrhotite-chalcopyrite ore. Note pyrrhotite spheroid pseudomorphous after pyrite. Centimetre card at lower right. Sample ANSL9C-28. 


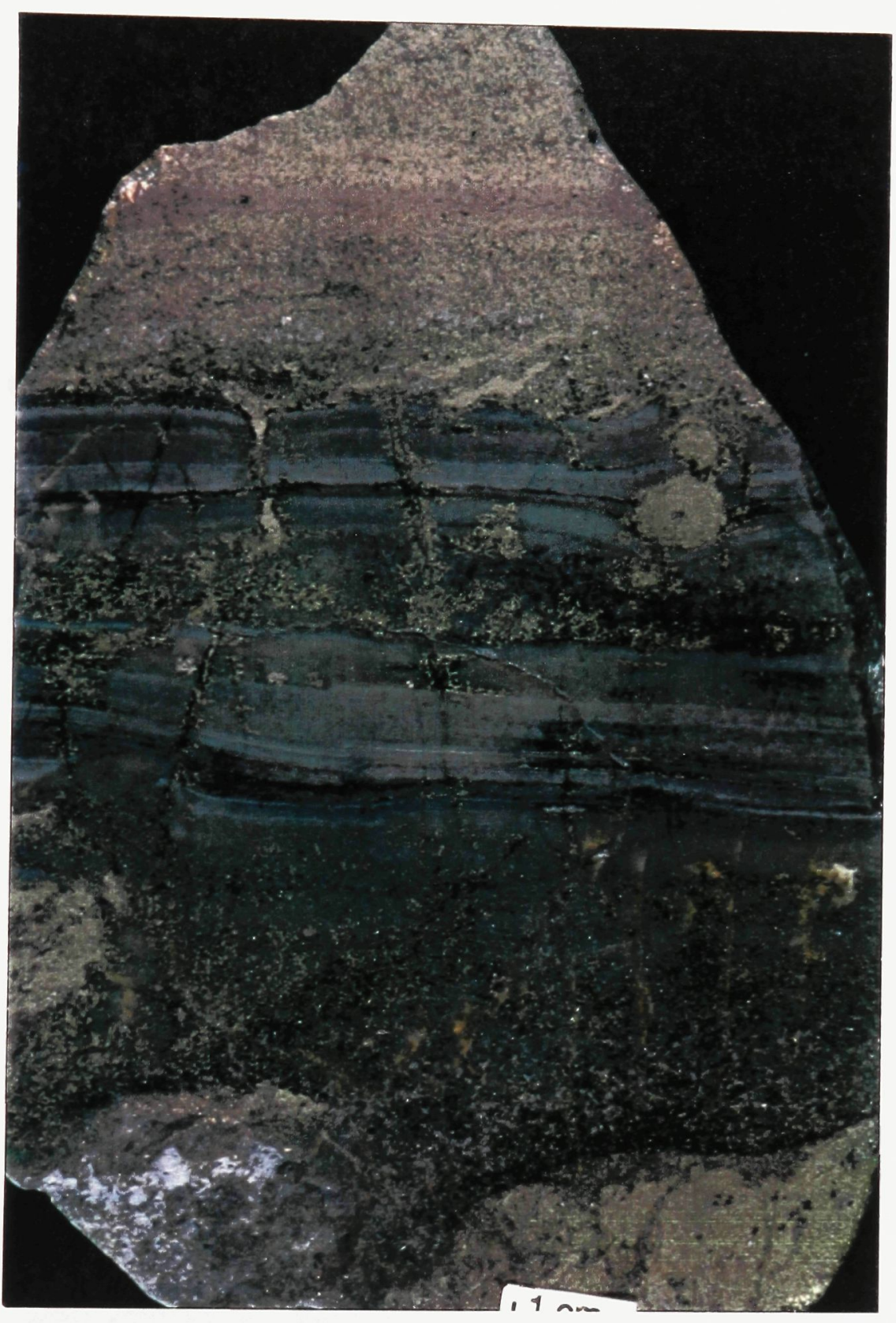

Figure 4.39 Polished slab showing remnant of laminated facies, sphalerite-mineralized Cranston tuff replaced along its margins by banded pyrrhotite-chalcopyrite ore. Note pyrrhotite spheroid pseudomorphous after pyrite. Centimetre card at lower right. Sample ANSL9C-28. 


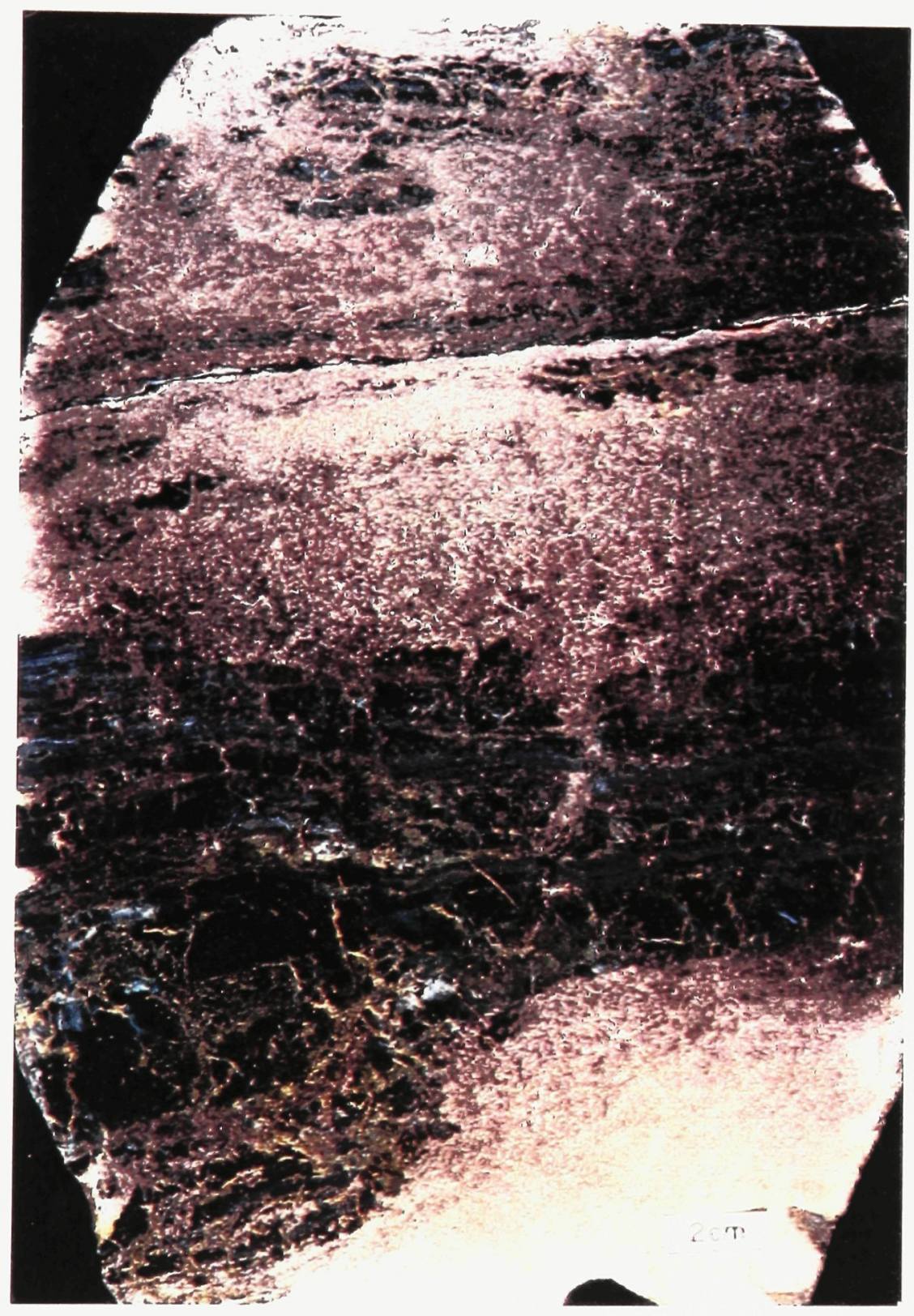

Figure 4.40 Partly replaced Cranston tuff from the base of the massive sulphide lens. Remaining tuff chlorite altered. Layering from tuff still present in overprinting pyrrhotitechalcopyrite. Sample ANSL 8A-100 
Figure 4.41

A. Photomicrograph showing lit-par-lit replacement of Cranston tuff by chalcopyrite and pyrrhotite. Field of view $4 \mathrm{~mm}$.

B. Photomicrograph of remnant coarse-grained tuff layer along the base of the pyrrhotitechalcopyrite massive sulphide ore. Field of view $4 \mathrm{~mm}$.

C. Photomicrograph of sieve-textured massive sulphide ore formed from partial replacement of Cranston tuff by pyrrhotite-chalcopyrite. Field of view $4 \mathrm{~mm}$. 


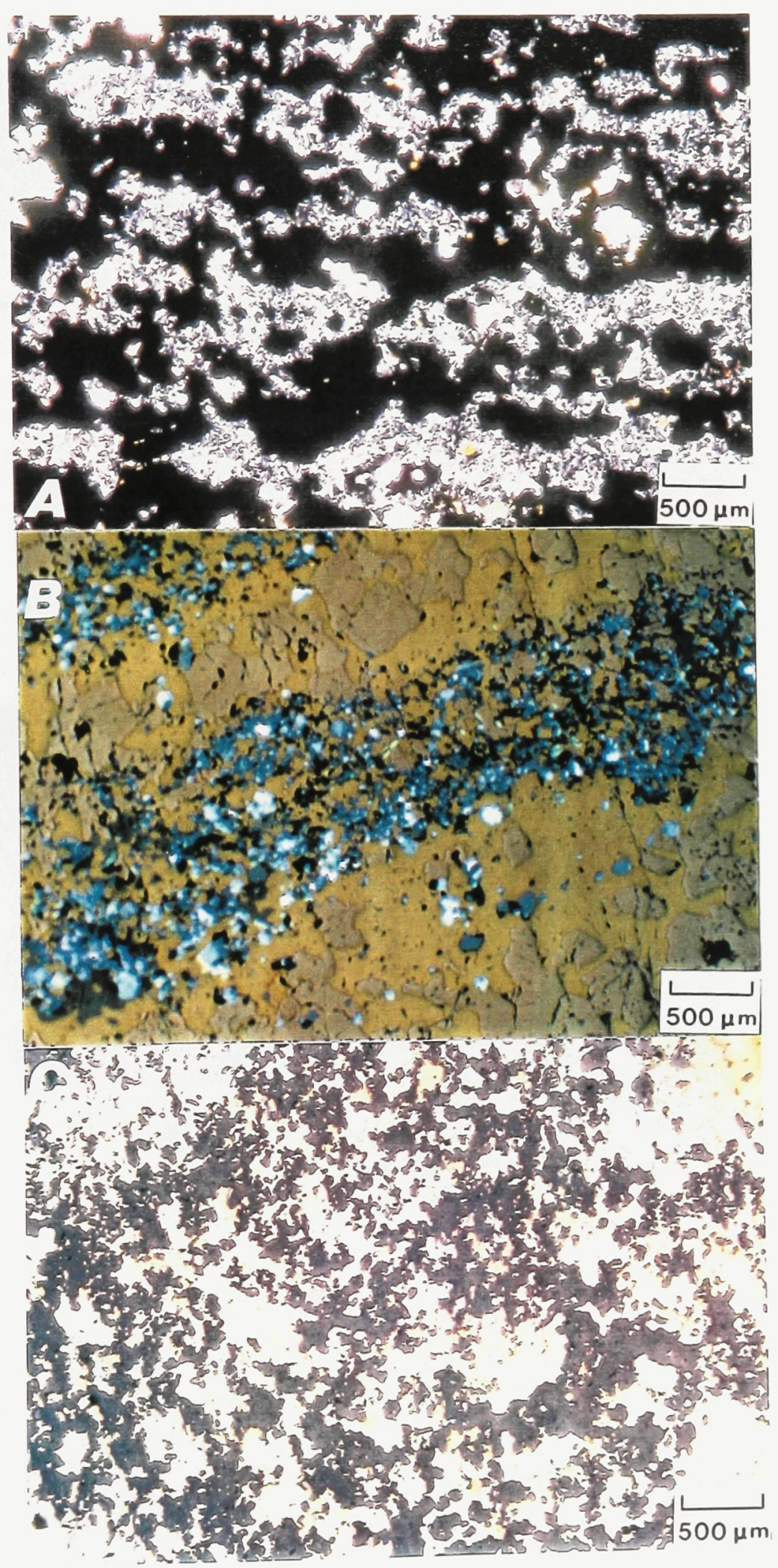



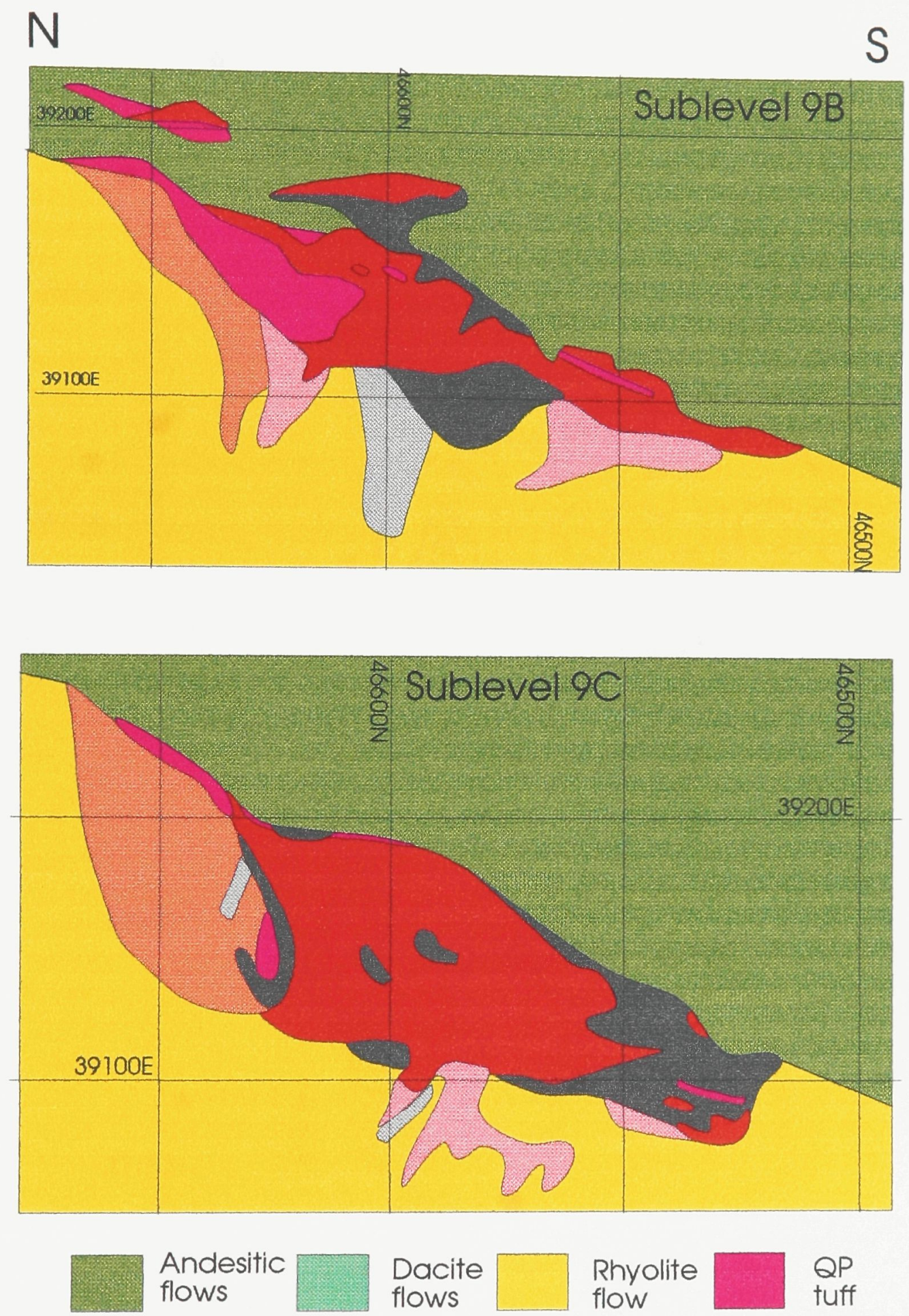

Rhyolite
flow
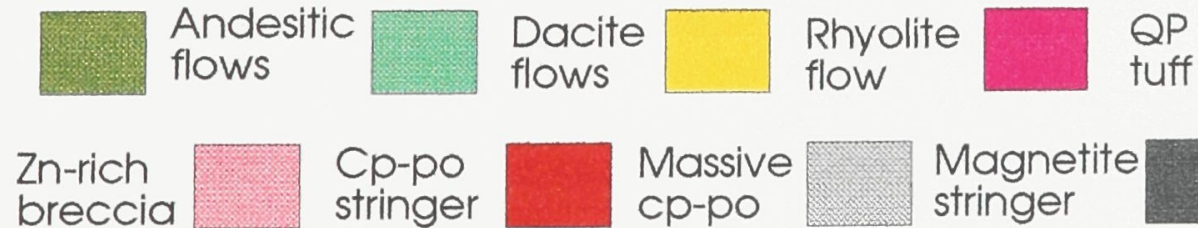

Cp-po stringer
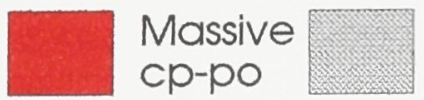

Magnetite
stringer

Massive

magnetite

Figure 4.42a North-south cross-sections of levels $9 \mathrm{~B}$ and $9 \mathrm{C}$ showing the relationship of magnetite occurrences to earller minerallzation. 

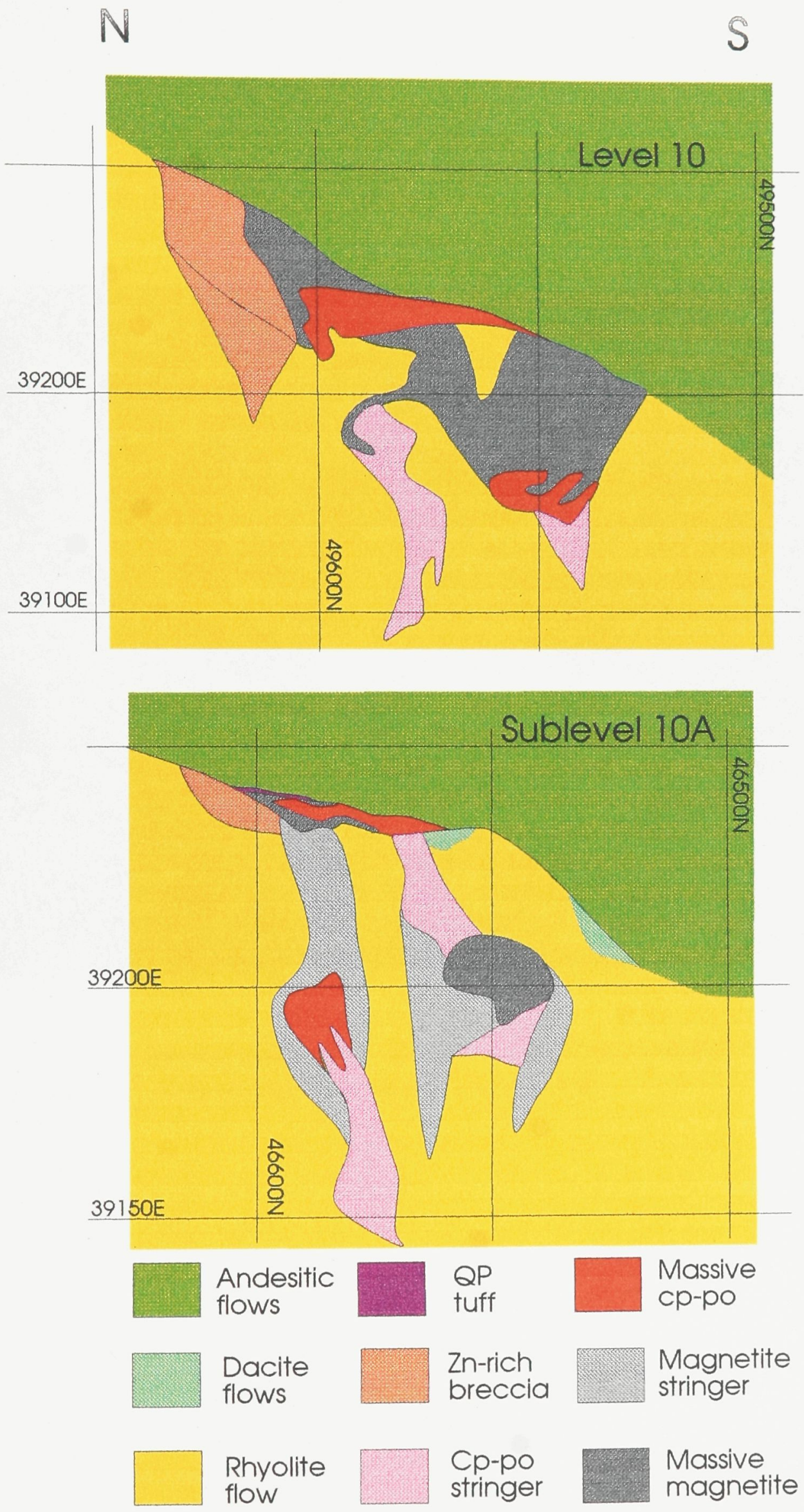

Figure 4.42b North-south cross-sections through levels 10 and 10A showing relationship between magnetite occurrences and earlier mineralization 


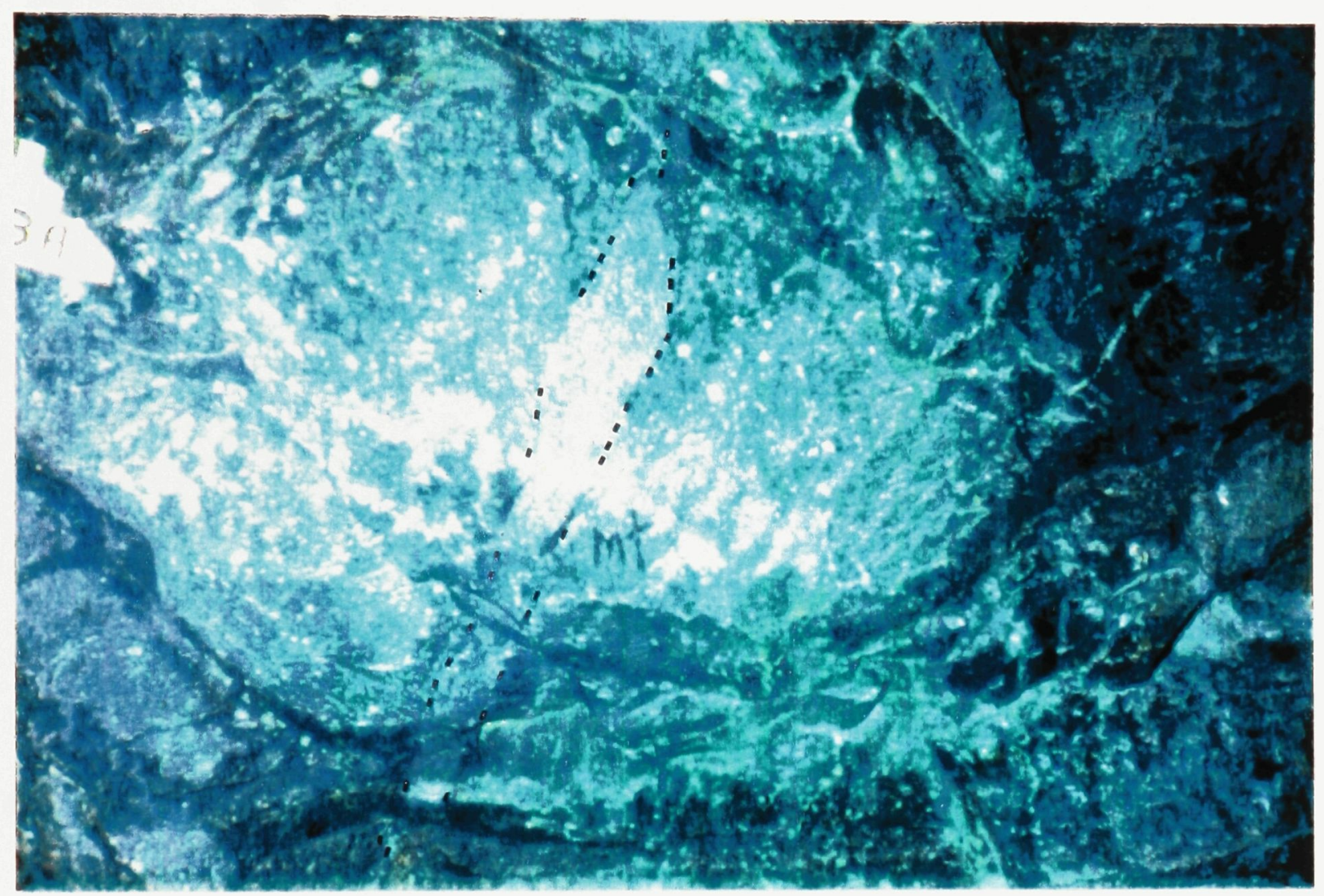

Figure 4.43 Massive magnetite vein crosscutting the chlorite-sulphide alteration zone below the orebody. Sublevel 8A. Centimetre card for scale 


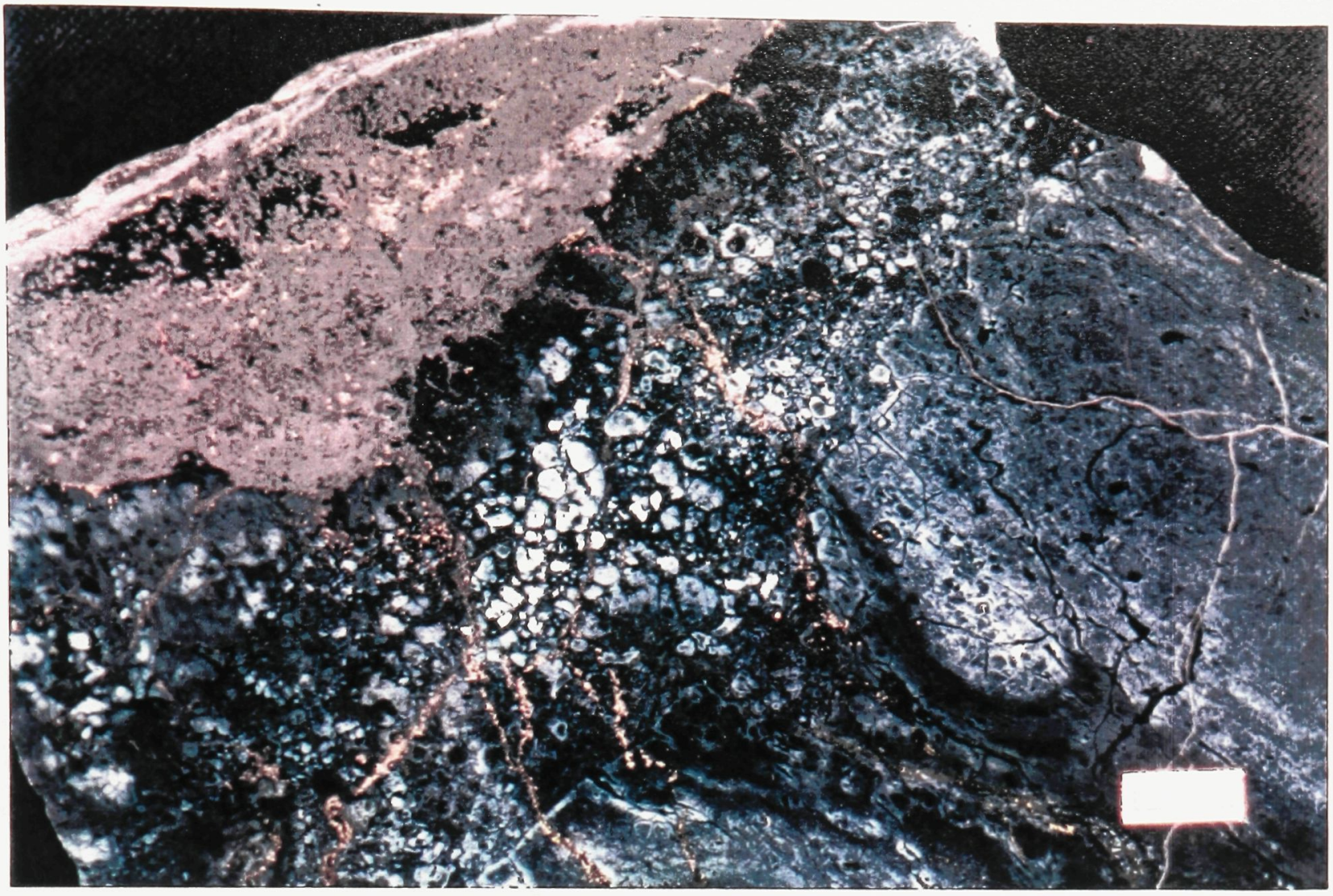

Figure 4.44 Polished slab showing internal texture of large magnetite vein from below the orebody on Sublevel 8A. Sample ANSL8A-219. 
Figure 4.46
A. Horizontal contact between massive magnetite and massive sulphide. Sublevel 10A.
B. Sulphide-quartz-carbonate veining in massive magnetite. Sublevel 10A.
C. Thin occurrence of massive magnetite along hangingwall contact of the massive sulphide lens. Presence of fine layering suggests that it is replacing Cranston tuff. Level 9 ore drift. 

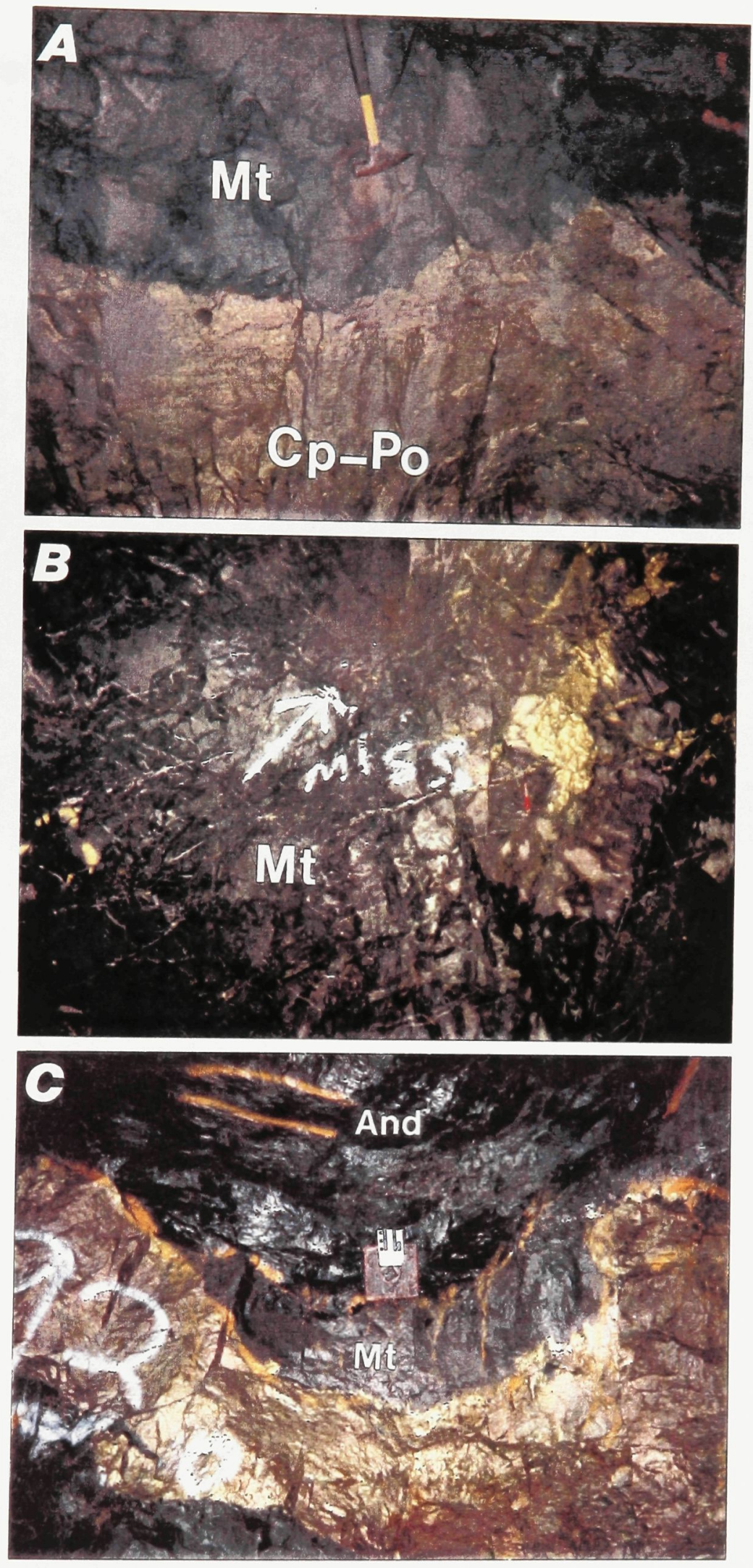


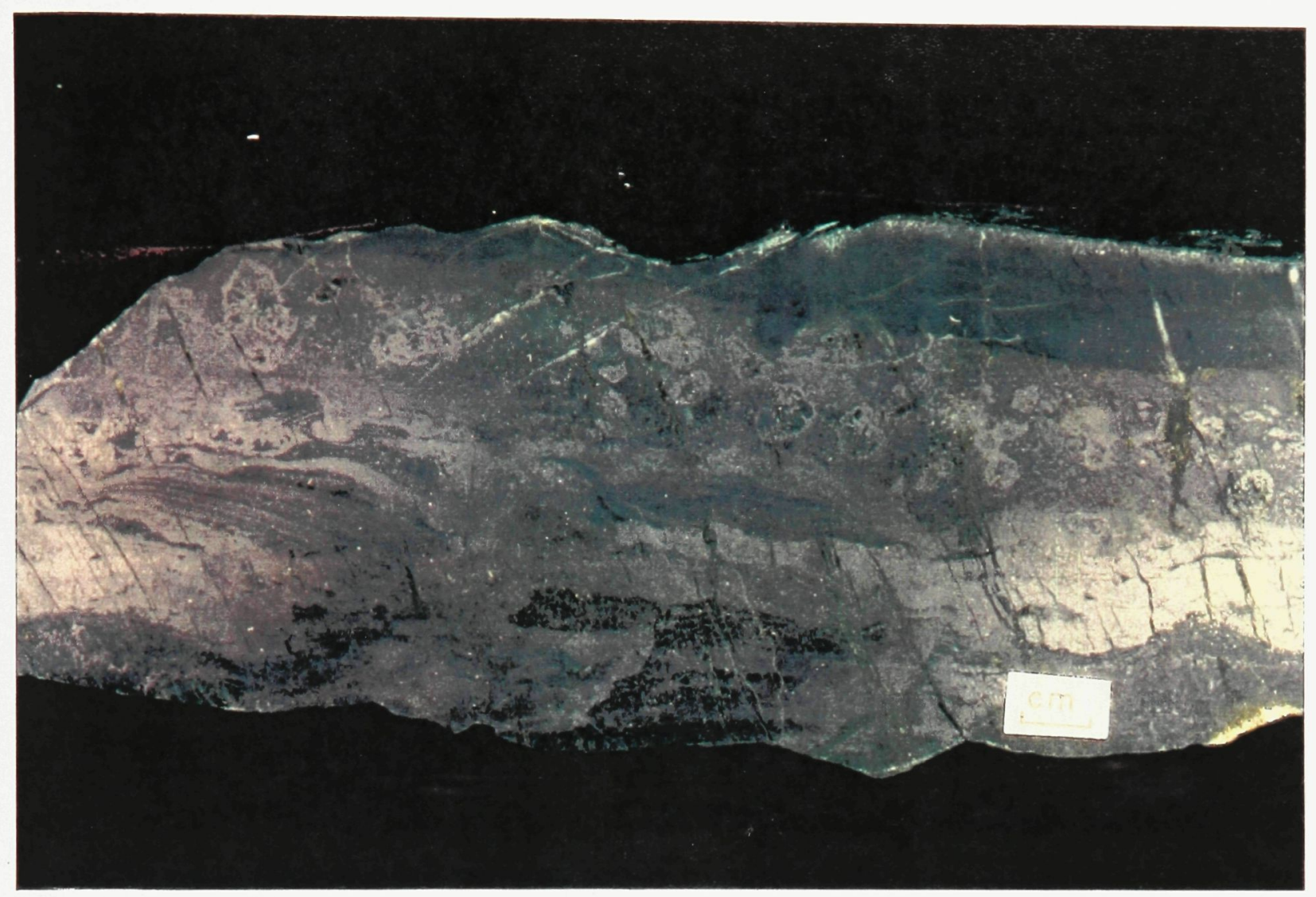

Figure 4.47 Polished slab showing magnetite selectively replacing layers of Cranston tuff along the hangingwall contact of the massive sulphide lens. Note the spheroids - most likely pseudomorphous after pyrite. Sublevel 9B, drawpoint \#5. 

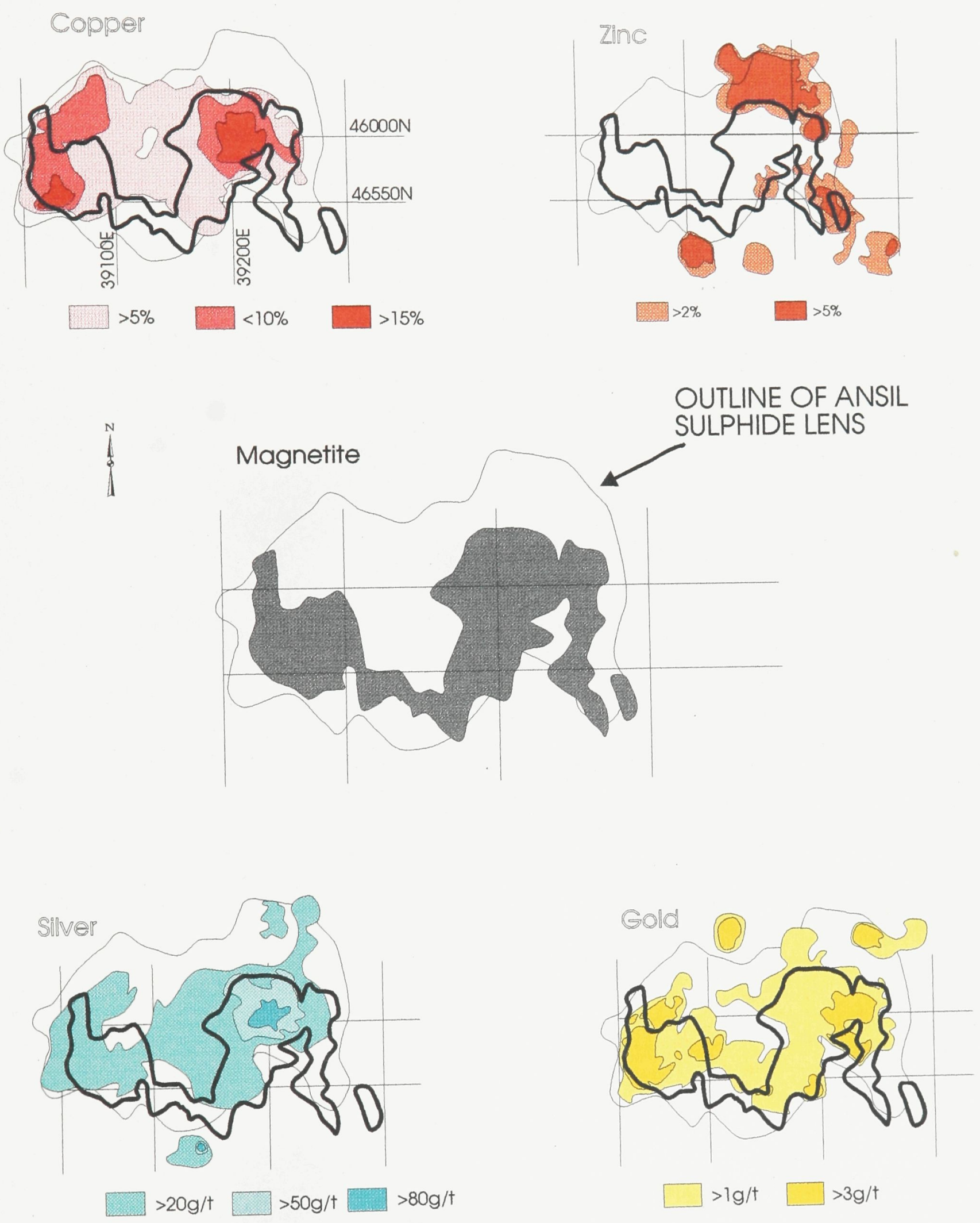

Figure 4.48 Metal distribution within the Ansil orebody (Riverin et al., 1990) 

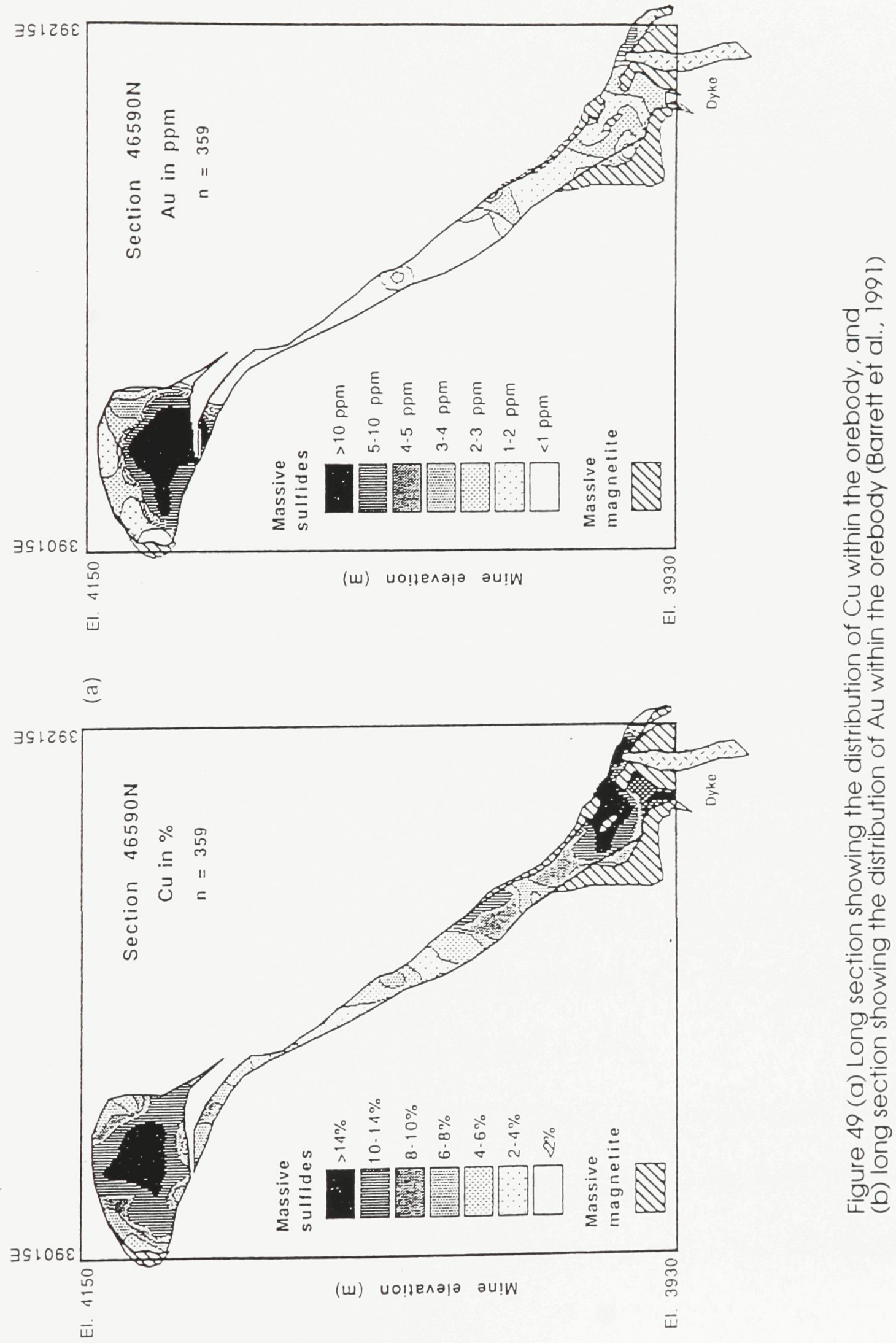


\section{CHAPTER 5. ALTERATION MORPHOLOGY, MINERALOGY AND CHEMISTRY}

\subsection{INTRODUCTION}

This chapter is concerned with the paragenetic sequence of alteration undergone by the Ansil host strata before and during the formation of the orebody. The mineralogical and chemical changes undergone by the strata will be examined in the context of the mineralforming events described in Chapter 4.

The host strata to the Ansil deposit have undergone a sequence of fluid-rock reactions that have altered the original textures, mineralogy and chemical composition of the rocks. These reactions involve devitrification and hydration, diagenesis and hydrothermal alteration, burial and tectono-metamorphism (Allen, 1993). None of these processes can be considered isochemical where the rocks are undergoing mineralogical/textural changes in the presence of a fluid. The extrusion of the Northwest rhyolite in a submarine environment would result in varying rates of cooling, devitrification and hydration depending on the extent of exposure to seawater. With nominal water/rock ratios there can be significant changes in whole rock chemical composition during devitrification and hydration, with variations in $\mathrm{SiO}_{2}, \mathrm{H}_{2} \mathrm{O}, \mathrm{Fe}_{2} \mathrm{O}_{3}, \mathrm{Na}_{2} \mathrm{O}$ and $\mathrm{K}_{2} \mathrm{O}$ (Lipman, 1965).

Diagenesis involves mineralogical, chemical and textural changes associated with the early stages of lithification and burial of a rock system (Fischer and Schminke, 1984, Cas and Wright, 1988). In a submarine environment diagenesis involves not only the realignment 
of mineral structures due to compaction, but also low temperature (50 to $100{ }^{\circ} \mathrm{C}$ ) interactions between the rock and shallowly circulating seawater. The glass first alters through hydration and ion exchange to a waxy-appearing material called palagonite (Moore, 1966; Macdonald, 1972). Palagonite forms as either a gel or fibres (Peacock, 1926) that in part is composed of mixed layer montmorillonite-illite or phillipsite. The former forms massive or banded deposits next to unaltered glass, and the latter forms a fibrous, radiating texture next to gel palagonite. Palagonitization is initiated along any free surface such as perlitic fractures or glass shard boundaries, and may be accompanied by open-space filling by opaline silica, zeolites and calcite. Where the open-space infilling occurs in hyaloclastite it has the potential to cement the shards together (Jakobsson, 1978).

Prolonged diagenesis involves the alteration of the remaining glass to chlorite, and devitrified areas to granophyre. The palagonite is thermally upgraded through further ionexchange to first opal CT, and then chalcedony, and may be distinguished from silica in open-space fillings by its optical orientation (typically length slow) and content of finely disseminated oxide minerals (Gibson, 1989).

Within regions of focused high heat flow there may be a progression from diagenesis to higher temperature, hydrothermal alteration. In the stratigraphic footwall to the Roseberry and Hellyer massive sulfide deposits (Allen and Cas, 1990; Gemmell and Large, 1992) diagenetic features increase significantly in intensity resulting in the formation of pseudoclastic textures (Allen, 1993). Within areas of hydrothermal activity these diagenetic features are overprinted by progressively higher temperature fluid/rock interactions that 
commonly define the discordant alteration systems below volcanic-hosted massive sulfide deposits.

\subsection{DEVITRIFICATION AND HYDRATION}

The lobe-hyaloclastite flow sequence below the Ansil deposit consists of glassy rhyolite that has undergone various degrees of devitrification and hydration. The interiors of the massive flow lobes contain intense, perlitic fracturing and scattered clusters of spherulites (Figure 3.6b). This texture represents a rapidly cooled, undersaturated magma that had little contact with seawater (Lofgren, 1971). Subsequent hydration of the glassy material to what is now a fine-grained assemblage of quartz, chlorite and plagioclase took place at temperatures less than $200^{\circ} \mathrm{C}$.

Towards the margins of the flow lobes, and within the surrounding flow breccia and hyaloclastite, the cooling rhyolite was subjected to higher, but variable, water/rock ratios. This resulted in intense spherulite formation in some areas and scattered spherulite growth in others (Figure 3.5). This patchy devitrification resulted in a piebald, patchy, domainal texture, with the boundaries between the domains known as devitrification fronts (Lofgren, 1971) (Figure 3.3c). This texture is very common in the lobe-flow breccia sections in the Ansil footwall, with the spherulite-rich, felsite domains now having a fine-grained, granoblastic texture that is a product of late-stage devitrification (granophyric stage, Lofgren, 1971), or from later diagenesis (Figure 3.9). The glassy domains are now mainly chlorite, with isolated spherules of quartz (Figure 3.3d). 
In the finer-grained hyaloclastite the rapid quenching of the glassy shards in contact with seawater resulted in very little spherulite formation. As a result the shards are now chloriterich due to later alteration of the glass during diagenesis and hydrothermal alteration.

\subsection{DIAGENESIS}

The effects of diagenesis within the Ansil footwall strata are most pronounced in the vitrophyric parts of the lobe-hyaloclastite sequence. In sections of the massive flows showing domainal textures due to patchy devitrification, the chlorite-rich domains contain small, radiating quartz structures pseudomorphous after zeolites (Figure 5.1a). Within perlitic vitrophyre the fracture margins are replaced by opaque-rich quartz that has botryoidal to scalloped contacts with the chlorite-altered glass (Figure 5.1b,c,d). The quartz is in sharp contrast to clear quartz that infills the perlitic cracks (Figure 5.1a,c). The opaque-rich quartz is commonly optically continuous, suggesting a chalcedony precursor. The scalloped contacts to the silicified margins may be evidence that the silica replaced earlier-formed gel-palagonite.

Within the vitrophyre-rich flow breccias and hyaloclastite, diagenesis has resulted in the cementing of the clasts by inclusion-rich quartz that has formed about the shard margins (Figure 5.2 and 5.3). The spaces between quartz margins have rims of radiating chlorite crystals (after fibrous palogonite or zeolite) and cores of clear, equant quartz (Figure 5.1e). Inclusions within the quartz margins include microcrystalline opaques and 5 to $10 \mu \mathrm{m}$ chlorite grains. In rare cases the opaques are aligned within thin, rhythmic bands (liesegang 
rings) that parallel the shard contact (Figure $5.1 \mathrm{~d}, \mathrm{f}$ ). These structures may have formed by periodic precipitation of oxides in former gel-palagonite (Gibson, 1990). In thin section the finely disseminated opaques impart to the quartz a brownish tinge (Figure 5.1c), but in hand specimen the quartz has a bluish tinge, possibly due to the disseminated chlorite (Figure 5.2). This bluish tinge gives these diagenetically altered hyaloclastites a distinctive appearance; they were mapped underground at the Ansil deposit as "blue-quartz breccias"

Amygdules within rhyolite lobe margins and in the surrounding volcaniclastic rocks are commonly rimmed with clots of radiating, fibrous chlorite crystals and infilled with clear, equant quartz. The fibrous nature of the chlorite suggests that it is pseudomorphous after a zeolite.

The only evidence of diagenesis within the Cranston tuff is thin rims of clear quartz about some of the larger quartz phenoclasts.

\subsection{HYDROTHERMAL ALTERATION}

The Ansil deposit lies within a discordant zone of hydrothermal alteration that extends for over $800 \mathrm{~m}$ upsection from the Flavrian Pluton to include over $14.3 \times 10^{6} \mathrm{~m}^{3}$ of volcanic strata (Figure 4.1a,b). The stratiform sulfide-magnetite orebody lies within this alteration zone, and is a product of hydrothermal alteration of parts of the Northwest rhyolite, Cranston tuff and Rusty Ridge andesite. For this reason a description of the silicate mineralogy of the orebody is included in this chapter. 
Regional-scale spilitization was the first hydrothermal event to affect the Ansil strata. The outer limits of the hydrothermal upflow zone in which the deposit developed is defined by a zone of Na-depletion that overprints the spilitization. Within this zone of Na-depletion there is a discordant alteration system that envelopes the deposit. It contains ten discrete alteration facies (Figure 5.4). Two of these events produced mineral assemblages characterized by quartz-chlorite-sericite and quartz-chlorite; they are essentially barren of sulfide or magnetite, and could well be defined as a diagenetic event. The remaining eight alteration facies are spatially related to the periods of $\mathrm{Zn}-, \mathrm{Cu}$ - and $\mathrm{Fe}$-enrichment that constitute the Ansil mineralizing event.

\subsubsection{Regional Spilitization}

The strata within the Noranda Cauldron are affected by a regional-scale spilitization that has increased the average $\mathrm{Na}$ content of both the felsic and mafic volcanic rocks to around $4 \mathrm{wt} \%$ (Gibson, 1989). The resulting mineral assemblages are indistinguishable from typical greenschist facies regional metamorphic mineral assemblages (Winkler, 1974), with the mafic rocks containing a chlorite-actinolite-albite-epidote-titanite mineral assemblage, and the felsic rocks a quartz-albite-chlorite-sericite-titanite mineral assemblage (Jolly, 1980).

Spilitization affects all of the Mine Sequence strata, and yet is overprinted by the discordant alteration zones that underlie the intracauldron deposits. It represents a relatively high temperature event $\left(>150\right.$ and $\left.<250^{\circ} \mathrm{C}\right)($ Seyfried et al., 1988), in which moderately evolved, downwelling, $\mathrm{Na}-\mathrm{Ca}-\mathrm{Si}$ enriched and $\mathrm{K}-\mathrm{Mg}$ depleted seawater reacts 
with the volcanic rocks. These reactions commonly take place several hundred metres below the seafloor, unless there is an exceptionally high regional geothermal gradient present. Paradis (1990) demonstrated that the bulk rock and mineral $\delta^{18} \mathrm{O}$ trends within the Mine Sequence increase in value upsection, and increase in value from the bottom top of each formation. This suggests that the regional-scale alteration of the strata occurred incrementally, altering each formation in sequence.

\subsubsection{Sodium Depletion (Feldspar Destruction)}

The Ansil deposit lies within an envelope of $\mathrm{Na}$ depleted strata that extends as a tabular east-west corridor up to $300 \mathrm{~m}$ wide and over $2000 \mathrm{~m}$ long (Figure 5.5). This broad, discordant alteration zone, in which hydrothermal albite that formed during the spilitization event is replaced by chlorite and/or sericite, extends from the contact of the Flavrian intrusion for over $1000 \mathrm{~m}$ up through the Flavrian, Northwest, and Rusty Ridge formations into the Amulet formation (Figure). The regionally spilitized andesite and rhyolite formations average over 4 weight $\% \mathrm{Na}_{2} \mathrm{O}$. The corridor of $\mathrm{Na}$ depletion is defined by a boundary of less than $3 \% \mathrm{Na}_{2} \mathrm{O}$, with internal, crudely concentric zones defined at $2 \%$ and $1 \% \mathrm{Na}_{2} \mathrm{O}$ contours. One of these bulleyes is centred on the Ansil deposit, and another the Decoeur-Garon showing.

The strong east-west orientation of the $\mathrm{Na}$ depletion zone is distorted within the upper part of the Northwest, and in the overlying Rusty Ridge formations, by a north-south trending apophyse. This combination of strong east-west and north-south linear control on 
the regional-scale alteration is mimicked at the scale of the Ansil deposit by the orientation of the $\mathrm{Zn}$ - and $\mathrm{Cu}$-rich stockwork zones.

The outer boundaries of the $\mathrm{Na}$ depletion zone are marked by the replacement of albite with chlorite. The alteration facies was defined by Minnova Inc. exploration geologists through the application of an alteration index on lithogeochemical analyses systematically collected during their drill programs.

The pervasive nature of the Na-depletion zone is best defined at larger scales (greater than 1:2000); at detailed scales it is evident that this alteration type is patchy in distribution. Some of the least-altered samples of rhyolite (with over $4 \% \mathrm{Na}_{2} \mathrm{O}$ ) from this study were collected within $10 \mathrm{~m}$ of the footwall contact of the massive sulfide lens. The degree of $\mathrm{Na}$ depletion is controlled by the primary permeability of the host rhyolite, with the cores of the massive flow lobes much less affected than the lobe margins or inter-lobe volcaniclastics. This control of alteration by primary permeability was observed by Gibson (1989) for the more intense alteration types in the Noranda area. In the Iberian Pyrite Belt much of the regional spilitization of the volcanic strata is controlled by the primary permeability of the strata (Munha and Kerrich, 1981).

\subsubsection{Quartz-chlorite alteration assemblage}

Underlying the Ansil massive sulfide lens between Sublevel 7A and Level 9 are several occurrences of strongly mottled and bleached massive rhyolite that are barren of sulfide or oxide minerals (Figure 5.6). These occurrences are located near the flanks of the deposit 
(Levels 8A and 9), along the margins of the chlorite-pyrrhotite-chalcopyrite zone (Levels 7B, 8 and 8A) and as remnants within the chlorite-pyrrhotite-chalcopyrite zone (Levels 8 , 8A and 9) (Figure 5.7, Maps in Appendix I). The zones represent various intensities of alteration to quartz-sericite-chlorite, with the weakest alteration below the flanks of the deposit and the strongest closer to its centre (Figure 5.4)

The zones of weak alteration form discordant structures 5 to 10 metres wide and up to $45 \mathrm{~m}$ long below the margins of the massive sulfide lens. They consist of abundant, creamy white to light green, very fine-grained quartz containing weakly to moderately chloritesericite-altered, angular fragments of rhyolite ranging in size up to 20 to $25 \mathrm{~cm}$ (Figure 5.3 and 5.8). The silica-rich domains contain smaller rhyolite fragments that are completely silicified with a very fine-grained, granoblastic texture in a slightly coarser-grained matrix. In some cases the zones of most intense silicification are cored by perlitic fractures infilled by a clearer quartz (Figure 5.9). These quartz-sericite-chlorite alteration zones appear as restricted areas within coarse-grained rhyolite flow breccias.

Zones of more intense quartz-sericite-chlorite alteration lie below the centre of the massive sulfide lens. Two large occurrences are exposed on Level 8, one in the ore pass about $25 \mathrm{~m}$ below the sulfide lens and another 60 to $80 \mathrm{~m}$ below the upper rhyolite contact (Map 8, Appendix I). The "ore pass" occurrence is the most extensive, being present about the ore passes on Levels 7B, 8 and $8 \mathrm{~A}$. Remnant patches of this alteration type are observed closer to the massive sulfide footwall contact within the overprinting zone of intense chlorite-pyrrhotite-chalcopyrite (Figure 5.7). 
The rhyolite within these zones has a very striking texture defined by 10 to $15 \%$ strongly silica-sericite altered, subrounded plagioclase aggregates, 5 to $20 \mathrm{~mm}$ in diameter in an extensively perlitic-fractured groundmass (Figure 5.10). The perlitic fractures have 1 to 2 $\mathrm{mm}$ silica-rich rims which are scalloped along their margins (Figures 5.1d and 5.9). The remaining rhyolite is altered to fine-grained, intergrown chlorite, sericite and granoblastic quartz.

The plagioclase-porphyritic, bleached rhyolite is fractured into a reticulate pattern by 10 to $20 \mathrm{~mm}$ wide chlorite-quartz-albite veins with strongly quartz-sericite-altered margins (Figures 5.6, 5.11 and 5.12). The veins have rims of euhedral quartz crystals oriented perpendicular to the vein walls, and are infilled with radiating bunches of coarse chlorite crystals. Single albite crystals up to $2 \mathrm{~mm}$ long occur centrally along the vein axial planes: they are moderately to strongly sericite- altered.

The apparent contrast in primary composition of these altered rocks from the surrounding rhyolite flows, and their apparent discordant morphology suggests that they are dykes related to the emplacement of the Northwest formation. Much of the striking texture of the rock may be explained as a product of strong diagenesis, overprinted by a weak sericite alteration. This does not explain the reticulate pattern of the chlorite-quartz-albite veins that overprints some of the assemblage, but the sericite alteration of the contained albite indicates that the chlorite veining took place before the pervasive, sericite alteration event. 


\subsubsection{Zn-rich alteration mineral assemblages}

Sericite-quartz-albite-sphalerite assemblages occur within the footwall rhyolite as discordant zones up to $70 \mathrm{~m}$ long forming haloes about the quartz-sphalerite-pyritepyrrhotite vein systems below the north and south flanks of the massive sulfide lens (Figure 5.4). It forms semi-conformable zones within the upper few metres of the rhyolite and dacite, in the wedges of explosion breccias and in the overlying Cranston tuff. Within the rhyolite plagioclase microphenocrysts and microlites are completely altered to fine-grained sericite and quartz, resulting in up to $25 \%$ sericite forming a matrix for remaining, rounded grains of quartz (Figure 5.13a). Sericite is also concentrated within arcuate bands that may represent perlitic fractures within the massive rhyolite and dacite (Figure 5.14). In other places perlitic fractures have a thin rim of silicified rhyolite. Where fine-grained, delicately zoned pyrite euhedra occur they are partially rimmed with pyrrhotite and sphalerite. In many cases the outer edge of the pyrite cystals is partially corroded. Pyrrhotite and sphalerite are commonly intergrown with 10 to $20 \mu \mathrm{m}$ long sericite flakes, quartz and albite. Quartz also forms thin rims about amygdules infilled with fine-grained sericite. Where veining is present the vein margins contain fibrous quartz oriented at right angle to the vein walls. The vein centres contain microcrystalline quartz with 50 to $100 \mu \mathrm{m}$ wide bands rich in coarsergrained sericite, pyrrhotite, sphalerite and quartz. Veins are commonly rimmed with 1 to 5 $\mathrm{mm}$ wide zones of bleached, silicified rhyolite, with only minor sericite and sulfide minerals.

Within the wedge-shaped deposits of explosion breccia the rhyolite and dacite fragments are strongly sericite altered and contain up to $10 \%$ finely disseminated sphalerite and 
pyrrhotite and pyrite (Figure 5.15 and 5.16). They sometimes have bleached, strongly silicified rims, particularly where there are abundant sulfides in the surrounding matrix. The matrix contains disseminated 50 to $200 \mu \mathrm{m}$ sized pyrite euhedra surrounded by anhedral pyrrhotite and sphalerite. The pyrrhotite and sphalerite contain grains of quartz, sericite and unaltered albite. The margins on the albite grains commonly appear corroded. The remaining matrix consists of small, strongly sericite-quartz altered rhyolite fragments.

Sericite-rich alteration of the Cranston tuff is generally restricted to the coarser -grained base of graded beds (Figure 5.13b). The primary plagioclase phenoclasts are strongly altered to masses of very fine-grained sericite; coarser sericite flakes are intergrown with pyrrhotite, sphalerite, quartz and albite (Figures $5.13 \mathrm{c}, \mathrm{d}$ ). The sericite-quartz-sphaleritealbite altered tuff is cross-cut by white zones containing 30 to $40 \%$ fine-grained sericite as haloes about veins of sphalerite-quartz-albite-sericite-chlorite and quartz-chalcopyritesphalerite-stilpnomelane-carbonate (see Map 11A).

There is some evidence that there were zones of sericite-quartz-sphalerite-albite alteration along the floor of the graben hosting the massive sulfide lens. On Sublevels 8A and 9C, and along the 11-01 access drift the chlorite-pyrrhotite-chalcopyrite vein stockwork contains remnants of a quartz-sericite-sphalerite-pyrrhotite assemblage containing high $\mathrm{Zn}$ values.

\subsubsection{Cu-rich alteration mineral assemblages}

The alteration system associated with the phase of $\mathrm{Cu}$-rich sulfide emplacement is divided into five facies (Figure 5.4): in the footwall to the massive sulfide-magnetite lens are two 
chlorite-rich alteration facies that are associated with the pyrrhotite-chalcopyrite stockwork vein system. The massive chalcopyrite-pyrrhotite lens defines a third, talc-serpentine-rich facies chlorite-pyrrhotite-chalcopyrite alteration zone, and the other two alteration facies represent transition zones between the $\mathrm{Zn}$ - and $\mathrm{Cu}$-rich alteration zones along the margins of the massive sulfide lens, and between the Cu-rich alteration and the Cranston tuff and andesite flows in the stratigraphic hangingwall.

\section{Chlorite-sulfide footwall assemblage}

Abundant chlorite alteration accompanies the Cu-rich footwall stockwork vein system. The previously described, complex semi-conformable-discordant morphology of the stockwork zone is the same for the distribution of the accompanying chlorite alteration, with semi-conformable zones of alteration controlled by the primary permeability of the rhyolite pile (Figure 4.1a,b). In the stratigraphically lower parts, and along the margins of the discordant zones, chlorite alteration forms haloes about individual chalcopyritepyrrhotite veins that contain angular fragments of strongly chlorite-altered wallrock. The halo margins are disseminated chlorite overprinting the still recognizable primary textures of the host rhyolite. Closer to the vein margins the chlorite alteration is destructive, completely replacing early diagenetic features with cryptocyrystalline, blue-brown birefringent chlorite In places the veins have 1 to $3 \mathrm{~mm}$ white rims of cryptocrystalline quartz.

Towards the core of the stockwork zones the chlorite alteration is pervasive, first replacing previously phyllosilicate-rich parts of the rhyolite with chlorite and the plagioclase 
with chlorite and/or silica. The previously quartz-plagioclase-rich domains acquire a granoblastic texture, with spaces between quartz grains and silica-replaced plagioclase phenocrysts infilled with cryptocrystalline chlorite. More pervasive alteration results in the replacement of the silica-rich domains. In the vitrophyric parts of the rhyolite flow the silicified margins of the perlitic fractures survive the first stage, and spherulites are silicified. The more intense alteration results in the removal of the silica to form a cryptocrystalline, chlorite-rich rock crosscut by pyrrhotite-chalcopyrite-quartz veins and veinlets.

The outer margin of the chlorite zone is marked by the rimming of small grains of rutile by first titanite and then ilmenite (Figure $5.17 \mathrm{~b}, \mathrm{c}$ ). Up to $2 \%$ of finely disseminated ilmenite is present in the more intensely altered parts of the stockwork zone. Chalcopyrite-pyrrhotite veinlets also contain trace amounts of ilmenite. Also present in trace amounts are 100 to $300 \mu \mathrm{m}$ domains of intergrown allanite, apatite, titanite and xenotime (Figure 5.17d). In places these intergrowths are mantled with chalcopyrite-pyrrhotite.

\section{Chlorite-sulfide-talc footwall assemblage}

The core of the chlorite alteration zone is characterized by a chlorite-chalcopyritepyrrhotite-quartz-minnesotaite mineral assemblage. Brown, cryptocrystalline chlorite forms the mesostasis to up to $1 \%$ fine-grained $(100 \mu \mathrm{m})$, disseminated clusters of micro- to cryptocrystalline minnesotaite $\left\{\left(\mathrm{Fe}^{+2}, \mathrm{Mg}\right)_{6}\left[\mathrm{Si}_{8} \mathrm{O}_{20}\right](\mathrm{OH})_{4}\right\}$ and subordinate quartz. The rock is transected by chalcopyrite-pyrrhotite veins and veinlets with the sulfide intergrown 
with minnesotaite and quartz (Figure 5.17e). The larger veins are zoned, with the quartz and minnesotaite concentrated about the margins.

The Mg-chlorite-rich zone was identified in the upper discordant stockwork zone between Levels 10 and 11, and there in one sample from Sublevel 8A. The sample distribution is not complete enough to ascertain that it is always present in the core of the chlorite alteration zone.

\section{Massive chalcopyrite-pyrrhotite-talc-serpentine assemblage}

The massive chalcopyrite-pyrrhotite part of the stratiform orebody contains varying concentrations of silicate minerals. Quartz is the dominant silicate, followed by stilpnomelane, greenalite-minnesotaite and chlorite. In the more massive ores the silicates form 50 to $100 \mu \mathrm{m}$ monomineralic domains, with xenomorphic grains of polycrystalline quartz and single flakes and axiolites of stilpnomelane and greenalite. Chlorite morphology varies from cryptocrystalline aggregates to single small, pale green flakes. In the sievetextured ore the polycrystalline quartz domains contain rosettes of greenalite, with mixed chlorite-stilpnomelane along the margins. Much of the stilpnomelane present is intergrown with the chalcopyrite-pyrrhotite (Figure 5.17f).

\section{Sericite-chlorite transition assemblage}

The transition zone along the north and south flanks, and east end of the stratiform orebody is a gradational zone that correlates with the transition from sericite-quartz- 
sphalerite altered Cranston tuff through banded chalcopyrite-pyrrhotite-sphalerite-pyrite ore to massive chalcopyrite-pyrrhotite ore (Figure 4.15). The outer margin of the zone is marked by discordant chlorite-quartz veinlets less than $1 \mathrm{~mm}$ wide, with haloes up to three times vein width of disseminated chlorite and subordinate chalcopyrite, pyrrhotite and sphalerite (Figure 5.18a). The xenomorphic sulfide grains are larger (up to $0.5 \mathrm{~mm}$ ) than the sphalerite and pyrrhotite in the overprinted sericite-quartz alteration.

Further into the transition zone are bedding-parallel zones of chlorite spotting (Figure $5.18 \mathrm{~b}$ ). The formation of these irregularly-shaped spots involved the complete dissolution of the pre-existing minerals and replacement by chlorite and minor allanite-epidote-apatitetitanite-xenotime intergrowths, and trace ilmenite (Figure 5.18c). The chlorite spots are more abundant towards the massive sulfide lens, and the coarser-grained bases to the tuff beds are replaced with chlorite, pyrrhotite and minor chalcopyrite (Figure 4.38). The appearance of semi-massive to massive pyrrhotite-chalcopyrite along select bedding planes is accompanied by the gradual disappearance of chlorite and appearance of stilpnomelane and greenalite.

The remnants of Cranston tuff along the base of the eastern half of the massive sulfide lens are chlorite-altered, with little evidence of previous alteration by sericite-quartzsphalerite (Figure 4.40). The total lack of significant quantities of sphalerite about these segments, and the absence of any remnant sericite alteration, may indicate that not all of the Cranston tuff had been affected by the sericite-quartz-sphalerite alteration phase. This may be particularly true near the centre of the deposit-hosting graben if much of the early 
hydrothermal fluid flow was controlled by the graben-bounding faults. These tuff segments contain layers of chlorite-pyrrhotite-chalcopyrite-(ilmenite), quartz-chlorite and quartzpyrrhotite-chalcopyrite. Within the quartz-chlorite layers the chlorite forms between the quartz grains and in higher concentrations as chlorite-rich patches.

\section{Massive sulfide-hangingwall transition assemblage}

The upper contact of the stratiform orebody either has massive chalcopyrite-pyrrhotite directly in contact with andesitic flows, or there are thin (less than $50 \mathrm{~cm}$ ), discontinuous segments of altered Cranston tuff between the two rock types. In both cases there are transitional contacts of either massive sulfide overprinting tuff, massive sulfide overprinting andesite, or both.

Where there are remnants of Cranston tuff along the upper massive sulfide contact some of the segments contain a sericite-quartz-sphalerite assemblage (Figure 4.30). In most cases the tuff is overprinted by chlorite associated with the emplacement of the massive chalcopyrite-pyrrhotite (Figure 4.38). The chlorite-rich alteration mineral assemblage includes chlorite, siderite, stilpnomelane, titanite and albite, with trace gold, galena and sphalerite. The chlorite is a pale green, with a gray birefringence, and is present as cryptocrystalline masses within the polycrystalline, quartz-rich layers, or as idiomorphic flakes up to $0.5 \mathrm{~mm}$ within the chalcopyrite-pyrrhotite-rich layers. Chlorite also appears to replace shards of andesitic tuff interlayered with the Cranston tuff. The cryptocrystalline chlorite domains commonly contain coarse flakes of stilpnomelane, which is also present as 
idiomorphic flakes within the sulfide aggregates. Fe-rich calcite and siderite are present within mixed layers of quartz-chlorite-albite-carbonate, and as blebs within sulfide. Clear, twinned, xenomorphic albite grains and coarse flakes of muscovite altering to chlorite are present along the margins of the sulfide layers (Figure 5.18d).

The hangingwall andesitic flows are variably altered along the entire plunge length of the massive sulfide lens (Figure 5.4). Altered andesite above the eastern third of the orebody is restricted to within $2 \mathrm{~m}$ of the underlying massive sulfide contact. The alteration zones widen above the western half of the deposit with the transition from dominantly massive flows and minor interflow sediment to pillowed flows with interpillow hyaloclastite and interflow sediment (Figure 4.1a).

Alteration types vary from weak silicification through sericite-quartz-sphalerite and sericite-chlorite-sulfide to chlorite-sulfide assemblages. Alteration is progressively more pervasive near the west end of the deposit, where the sulfide 'spine' at the top of the massive sulfide mound forms the root to an extensive zone of hangingwall alteration that extends more than $400 \mathrm{~m}$ into the overlying andesitic flows (Figure $4.1 \mathrm{~b}$ )

The emplacement of the discordant Na-depletion zone about the vein stockwork systems resulted in the formation of a chlorite-quartz-epidote-ilmenite assemblage in the andesitic flows (Figure 5.19a). Three more discrete alteration types are superimposed on this alteration assemblage, and are strongly controlled by the primary permeability of the andesite. 
a) Quartz-chlorite is the weakest of the proximal alteration types and commonly forms the outer margin to the two sulfide-associated alteration types. Quartz-chlorite alteration occurs within the pillowed flow sequence for up to $30 \mathrm{~m}$ above the massive sulfide contact. The interpillow hyaloclastite is commonly chloritized, and the amygdaloidal pillow rims are transected by numerous, less than $2 \mathrm{~mm}$ wide, irregular veinlets with chlorite cores and quartz-rich rims (Figure 5.10). These veinlets form connections between the amygdules, which themselves have cores of axiolitic chlorite and rims of hypidiomorphic quartz. The veinlets and amygdules have white, silicified margins less than $1 \mathrm{~mm}$ wide of microcrystalline quartz. Silicification is also controlled by concentric cooling cracks. Some interflow breccias have a white matrix due to cryptocrystalline quartz rimming the blocky shards.

This alteration type may be compared to the quartz-chlorite-sericite alteration zone in the stratigraphic footwall to the orebody in that they are both barren of sulfide and may represent a transition between enhanced diagenesis and low intensity hydrothermal alteration.

b) Sericite-quartz-chlorite-sulfide alteration is observed above the eastern end of the deposit where the $\mathrm{Zn}$ - and $\mathrm{Cu}$-enriched Cranston tuff and semi-massive stratiform sulfide is in contact with the massive andesitic flows. The base of the andesitic flow sequence is pervasively sericite-quartz altered for 1 to $2 \mathrm{~m}$ above the contact, with fine-grained disseminated sphalerite and amygdules infilled with pyrrhotite and quartz (Figure 5.21). This alteration type is also observed along the south flank of the massive sulfide lens between 
Levels 7 and $7 \mathrm{~B}$, coinciding with the presence of the 'Zinc South' zone in the underlying rhyolite. The matrix of a basal flow breccia is infilled with maroon-coloured chert, and the overlying andesitic flows contain $\mathrm{Zn}$-rich discordant zones up to $7 \mathrm{~m}$ above the massive sulfide contact. The andesite contains disseminated pyrrhotite, with amygdules and fractures infilled with pyrrhotite and pyrite in their cores with quartz-rich rims and thin chlorite-rich margins. The groundmass is quartz, sericite and sulfide (Figures 5.22 and 5.23).

Sericite-quartz-chlorite-sulfide alteration is spatially associated with sericite-quartzsphalerite mineralization along the south flank of the deposit on Level $7 \mathrm{~B}$, and occurs in the same location on Level 9 (Map 9, Appendix I). The hyaloclastite in the interpillow areas is altered to a mixture of chalcopyrite, pyrrhotite, sphalerite, quartz, chlorite, sericite and minor carbonate. The pillow rims are strongly chlorite altered and up to $6 \mathrm{~cm}$ of pillow margin is strongly sericite altered. Amygdules have chalcopyrite and pyrrhotite cores and quartz-chlorite-filled margins. Pyrrhotite, pyrite and sphalerite infill concentric and radial cooling cracks, overprinting the earlier quartz-chlorite alteration.

c) Chlorite-quartz-sulfide alteration occurs above the centre of the western third of the massive sulfide lens where chalcopyrite-pyrrhotite-sphalerite formed a sulfide spine by replacing interpillow hyaloclastite and amoeboid pillow breccia (Figures 4.19 and 4.24). The andesite is strongly chlorite-altered, with the chlorite as 200 to $300 \mu \mathrm{m}$ axiolitic rosettes and as $100 \mu \mathrm{m}$ randomly oriented flakes (Figure 5.19b). Much of the quartz from the previous alteration assemblage disappears, and the ilmenite is first rimmed with rutile and then preferentially replaced with chalcopyrite. Epidote is replaced by allanite-monazite-titanite 
intergrowths. Chalcopyrite, pyrrhotite and sphalerite form veinlets which crosscut previously formed quartz-chlorite veinlets. In vitrophyric flows the sulfides form along perlitic fractures. Large (2 to $4 \mathrm{~mm}$ ) sulfide blebs contain clusters of idiomorphic albite laths (Figure 5.19d).

The chlorite alteration may form haloes metres wide about the massive sulfide-andesite contacts. Within several centimetres of the contact the andesite is replaced through a number of reaction zones (Figure 5.25). The zone furthest from the contact involves the replacement of the hydrothermal albite within the sulfide blebs with quartz, and the growth of greenalite-minnesotaite flakes within the sulfide (Figure 5.19c). This is followed by a zone of mixed quartz-sulfide-chlorite, with incipient replacement of the chlorite with stilpnomelane (Figures $5.19 \mathrm{c}, \mathrm{d}$ ). Much of the chlorite then disappears, leaving sievetextured quartz-sulfide. The quartz is microcrystalline, containing clusters of pseudomorphous plagioclase laths (Figure 5.19e). The margin of the massive sulfide lens contains small, isolated domains of quartz, stilpnomelane, chlorite and greenalite representing remnant domains of altered andesitic lava (Figure 5.19f).

\subsubsection{Magnetite-related alteration assemblages}

Magnetite-related alteration is divided into three main facies: chlorite-epidote, hedenbergite-andradite-amphibole and massive magnetite (Figure 5.4). The first is associated with the magnetite stockwork vein system in the stratigraphic footwall to the orebody, the second to the formation of a coarse-grained, Ca-Fe skarn on the periphery of 
the orebody and the third to the formation of the semi-massive to massive magnetite lenses in association with the massive sulfide. The first two calc-silicate facies are overprinted by carbonate-magnetite alteration related to the emplacement of the footwall magnetite veins and the massive magnetite lenses. Within these main alteration facies are subordinate variations in alteration mineral assemblages.

\section{Chlorite-magnetite footwall assemblage}

The chlorite-magnetite alteration has the same spatial distribution previously described for the magnetite stockwork vein system, forming an envelope about the chlorite-sulfide alteration zone up to the immediate footwall to the stratiform orebody (Figures $4.1 \mathrm{a}$ and 5.4), where it transects the earlier alteration phase to connect to a series of massive magnetite lenses. Chlorite, epidote, quartz, albite and calcite are the main constituents (excluding the magnetite veins), with subordinate amounts of disseminated magnetite and pyrite. Bright green masses of xenomorphic chlorite may account for up to $60 \%$ of the zones volume, disseminated magnetite up to $15 \%$ epidote $10 \%$, pyrite and calcite $5 \%$ each. The distribution of alteration is largely controlled by the primary permeability of the rhyolite flow, with alteration restricted to magnetite-calcite-chlorite vein margins within the massive flow lobes (Figure 5.26a). In the lower part of the stockwork zone magnetite and pyrite are finely disseminated within a chlorite-quartz groundmass, with fine-grained epidote, albite and calcite replacing plagioclase microlites. Most of the epidote grains are homogeneous, but some have allanite cores and epidote rims (Figure 5.26b). Also present in the deep 
footwall are patches of medium-grained, axiolitic clusters pseudomorphous to chlorite; these may have been amphibole porphyroblasts. Large, fine-grained epidote patches up to $25 \mathrm{~cm}$ in diameter appear 60 to $70 \mathrm{~m}$ below the orebody (Figure 5.27). They contain disseminated pyrite and magnetite. The magnetite is part of an overprinting mineral assemblage of chlorite-calcite-magnetite that occurs where the epidote patches are transected by magnetite veins (Figure 5.28). The epidote is replaced (Figures $5.26 \mathrm{c}$,d) with idiomorphic magnetite grains having a thin rim of calcite and a broader margin of chlorite (Figure 5.26e). The magnetite commonly has an atoll structure, infilled with calcite and/or chlorite (Figure 5.26f). In some cases the atoll structures have a rhombic shape, suggesting replacement of earlier formed carbonate (Westendorp et al., 1990). Some epidote patches are crosscut by magnetite veins composed of an outer margin of calcite and a core of magnetite crystals in a chlorite groundmass. Within $50 \mathrm{~m}$ of the lower contact to the stratiform massive sulfide-magnetite lens epidosite veinlets crosscut both the epidote patches and magnetite-calcite-chlorite veins.

The paragenesis is chlorite-epidote-albite-pyrite, followed by magnetite-chlorite-calcite.

\section{Ca-Fe skarn zone}

Coarse-grained $\mathrm{Ca}-\mathrm{Fe}$ skarns occur with varying concentrations of magnetite along the upper massive sulfide contact on Levels $7 \mathrm{~B}, 10$ and $10 \mathrm{~A}$, and along the footwall massive sulfide contact on Sublevels $10 \mathrm{~A}$ and $10 \mathrm{~B}$. Zones up to $5 \mathrm{~m}$ long and $2 \mathrm{~m}$ wide contain patches of semi-massive magnetite surrounded by intergrown ferroactinolite, magnetite, 
calcite, ilvaite, hedenbergite and andradite (Figure 5.29). Areas of massive to semi-massive andradite infilled with magnetite, calcite and chalcopyrite occur with porphyroblasts of andradite, ferroactinolite and ilvaite up to $3 \mathrm{~cm}$ (Figure 5.30 and 5.31). The paragenesis is hedenbergite and andradite overgrown by ilvaite, ferroactinolite, carbonate, and magnetite. Fine-grained disseminations of chalcopyrite occur within the ferroactinolite and as veinlets within the andradite. Areas of the deposit containing the $\mathrm{Ca}-\mathrm{Fe}$ skarns and associated massive magnetite are commonly sheared, displacing original contact relationships. From the few intact contact relationships the $\mathrm{Ca}-\mathrm{Fe}$ skarns formed along the boundaries between the massive magnetite and sulfide lenses; on Sublevels $10 \mathrm{~A}$ and 10B, the skarns are restricted to the Cranston tuff.

\section{Massive magnetite-amphibole assemblage}

There are a number of amphibole-dominated alteration mineral assemblages associated with the massive magnetite lenses. The massive magnetite lenses consist of densely packed magnetite grains in their core, with minor amounts of interstitial quartz, siderite and ferroactinolite. Closer to the margins the lenses are semi-massive, consisting of intergrown magnetite grains infilled with silicates and carbonates. Some are infilled by quartz, with included needles of ferroactinolite and cummingtonite-grunerite. Others contain quartz, siderite and ankerite, with axiolitic clusters of silpnomelane, amphibole, greenalite and minnesotaite. When in contact with carbonate the stilpnomelane crystals have thin rims of greenalite. 
The massive magnetite-massive sulfide contact is marked by increasing quantities of intergrown chalcopyrite and greenalite within the massive magnetite, all rimmed with pyrrhotite. These sulfide-filled interstices are commonly overprinted with magnetite grains. The contact margins are complexly zoned over a distance of several millimetres (Figure 5.32). The massive magnetite contains interstitial ferroactinolite and quartz, overprinted by Fe-carbonate, stilpnomelane, and finely intergrown chlorite-greenalite-minnesotaite (Figure 5.33a). This changes towards the massive sulfide contact, with the disappearance of the ferroactinolite and chlorite, reduction in quartz, and increase in Fe-carbonate, greenalite, minnesotaite and stilpnomelane (Figure 5.33b). This is followed by a zone of pyrrhotite containing 10 to $15 \%$ disseminated magnetite grains, and domains of Fe-carbonate, quartz, greenalite-minnesotaite and stilpnomelane. The quartz was clearly being altered, resulting in ragged margins and thin rims of a rusty-red amorphous material with liesegang rings. There is then a zone of mixed pyrrhotite-magnetite, with a groundmass of Fe-carbonate, quartz, greenalite and stilpnomelane (Figure $5.33 \mathrm{c}$ ), followed by massive chalcopyrite-pyrrhotite, with disseminated magnetite grains, quartz and greenalite (Figure 5.33d).

The massive magnetite-rhyolite contact is marked by zones of amphibole-rich alteration that commonly affects 1 to $2 \mathrm{~m}$ of the upper rhyolite contact, but may extend as discordant alteration zones for over $20 \mathrm{~m}$ into the rhyolite flow (Figure 5.31). The chloritequartz-sulfide altered rhyolite is overprinted by magnetite-infilled breccias formed from the replacement of the rhyolite hyaloclastite matrix with magnetite, quartz, cummingtonitegrunerite, ankerite and stilpnomelane. Magnetite may also fill in fractures within a 
hydrothermally brecciated rhyolite. The brecciated rhyolite is altered to cummingtonitegrunerite, ankerite and stilpnomelane. There is a paragenetic relationship within the alteration assemblage, with cummingtonite-grunerite partially replaced with ankeritestilpnomelane. This assemblage is then overprinted with magnetite euhedra, with accompanying alteration of stilpnomelane to chlorite.

Closer to the massive magnetite contact the rhyolite is altered to coarse-grained ferroactinolite, quartz, magnetite, Fe-carbonate and stilpnomelane. Blades of ferroactinolite up to $15 \mathrm{~cm}$ in length are perpendicular to the massive magnetite contact. There is a paragenetic relationship within the alteration assemblage, with ferroactinolite and quartz replaced by $\mathrm{Fe}$-carbonate and stilpnomelane, with subsequent replacement by magnetite. Within the coarse-grained ferroactinolite zones are irregularly shaped remnants of chalcopyrite surrounded by magnetite and ilvaite.

Semi-massive magnetite-Cranston tuff contacts occur along the massive chalcopyritepyrrhotite orebody hangingwall contact east from Level 9B. The partial replacement of the tuff by aggregates of magnetite euhedra is accompanied by ferroactinolite, Fe-calcite, chlorite and stilpnomelane. The magnetite crystals commonly have infillings of ferroactinolite and chlorite. Finer-grained laminations in the tuff contain Fe-carbonate and ferroactinolite close to the magnetite impregnations, and chlorite-Fe-carbonate further away. The ferroactinolite-rich layers also contain overprinting, axiolitic growths of stilpnomelane. 


\subsection{CHEMICAL COMPOSITION OF MINERALS}

Over 250 mineral analyses were generated in order to determine: a) the composition of the minerals present in the alteration system, b) if there were chemical trends present within mineral groups and chemical correlations between mineral groups, c) whether balanced equations of stoichiometric mineral compositions could be constructed to explain trends in the alteration system, and d) to compare these results with mass balance calculations determined from whole rock geochemistry in order to understand the evolution of the hydrothermal system.

There are consistent mineral compositional changes between defined alteration zones. The imposition of tectonic fabrics on the phyllosilicates in some areas of the alteration system did not appear to radically change their compositions with respect to their unoriented counterparts; most compositions within alteration groups formed tight clusters on various discrimination diagrams.

\subsubsection{Phyllosilicates}

\section{Muscovite}

Muscovite occurs only in the sericite-quartz-albite-sphalerite alteration zone and weakly overprints diagenetically quartz-chlorite altered rhyolite. In the former case it replaces plagioclase phenoclasts in the Cranston tuff and rhyolite flows, and is intergrown with sphalerite, pyrrhotite and albite. In the quartz-chlorite altered rhyolite it replaces plagioclase aggregates and albite in chlorite-quartz-albite veins. It is usually present as very fine-grained 
flakes, with the coarsest crystals (300-500 $\mu \mathrm{m})$ restricted to the sphalerite-pyrrhotite-albite intergrowths. It also occurs in the hangingwall alteration zone as fine-grained disseminations along altered pillow margins.

The rhyolite and Cranston tuff-hosted muscovite has a very tight, stoichiometric compositional range (Figure 5.34). Unlike many muscovites associated with massive sulfide deposits (Franklin et al., 1982) it is not phengitic. The Ba content, which increases in proportion to the K content of the muscovite, does not appear to be spatially systematic.

\section{Chlorite}

Chlorite is present in all the diagenetic and alteration zones as a major mineral with the exception of the sericite-quartz alteration, where it overprints chlorite-sulfide alteration. Chlorite compositions from the least altered and altered rhyolite, Cranston tuff, massive magnetite and sulfide lenses cover a broad range as defined by their $\mathrm{XFe}$ ratios $\left(\mathrm{Fe}^{\mathrm{t}} /\left(\mathrm{Fe}^{\mathrm{t}}+\mathrm{Mg}\right)\right.$ ) (Figures 5.35 and 5.36). Most chlorite lies within the Fe-rich chlorite, or chamosite, field as defined by Bayliss (1975), with most having XFe ratios between 0.6 and 0.85. The least (diagenetically) altered samples have the smallest range of values, lying between 0.6 and 0.7 . The 'transition' zone, where the sericite-quartz altered rhyolite and Cranston tuff are overprinted by vein-controlled chlorite-quartz-sulfide, in XFe ranges from 0.7 to 1.0 . XFe of sulfide stockwork chlorites covers a broad range between 0.4 and 0.8 , with the massive sulfide hosting chlorites more Fe-rich between 0.75 and 1.0. The magnetite stockwork chlorites vary in Fmg number between 0.7 and 0.95 . 
The distribution between the different zones is clear on an Fmg vs. mole \% Si diagram (Heys, 1954) (Figure 5.37). The least altered samples form a tight cluster in the Fe-ripidolite field. The transition zone chlorites extend off the end of the sulfide stockwork zone, forming an extensive linear cluster from Mg-ripidolite to daphnite. The magnetite stockwork chlorites cluster in the Fe-ripidolite field close to the daphnite border, with two analyses extending into the latter. The massive sulfide chlorites parallel the sulfide stockwork analyses, but are more Fe-rich.

The sulfide stockwork zone contains the widest range of chlorite compositions. The composition closest to that of the transition-zone chlorites is taken from a chlorite-altered Cranston tuff segment at the base of the orebody, and the one closest to the magnetite stockwork field is spatially proximal to that zone in a deep section of the stockwork system. The middle cluster is from the chalcopyrite-pyrrhotite stockwork directly underlying the massive sulfide lens, and the lone analysis closer to the $0.5 \mathrm{Fmg}$ line is from deep below the orebody. The three Mg-rich chlorites are from the core of the chalcopyrite-pyrrhotite stockwork zone: one is located $4 \mathrm{~m}$ below the massive sulfide lens, another $90 \mathrm{~m}$ below the lens, and the last approximately $150 \mathrm{~m}$ below the orebody.

The transition zone includes samples from the layered massive sulfide-tuff unit along the top of the massive sulfide lens and from the margins of the sulfide stockwork zone where it is in contact with earlier sericite-quartz altered rhyolite and Cranston tuff. There is roughly a bimodal population, with the more Fe-rich chlorites in direct contact with the massive 
sulfide lens and the others in contact with the chalcopyrite-pyrrhotite stockwork alteration zone.

The massive sulfide zone chlorites have a large spread of Si and Fmg values. The sample closest to the magnetite stockwork field is from chalcopyrite-pyrrhotite in contact with massive magnetite. The remaining two are located on Level 9, and there is no apparent reason for their widely separated compositions.

The magnetite stockwork field chlorite compositions occur mainly as Fe-ripidolites, but close to the daphnite field. The two more Fe-rich samples are from near a large magnetite vein within $22 \mathrm{~m}$ of the massive sulfide lens, and the other is from massive magnetite along the magnetite-andesite contact.

A comparison between the average Fmg ratios for the chlorites and from average whole rock analyses of the same alteration zones shows that all values lie above the line defining a 1:1 slope, indicating that the whole rock ratios are greater (Figure 5.38). This suggests that the chlorite compositions do not reflect the Mg content of their host rocks, but rather act as sinks for any available $\mathrm{Mg}$. This is readily apparent for the chalcopyrite-pyrrhotite stockwork, where the most Mg-rich chlorites are in the core of the zone, which contains the lowest $\mathrm{Mg}$ concentrations. Clinochlore is also present in chalcopyrite-pyrrhotite-quartzchlorite veins in the core of the footwall chlorite alteration zone underlying the Matagami Lake deposit (Costa et al., 1983). The presence of high Mg chlorite in the centre of an Fechlorite-rich zone was interpreted by Roberts and Reardon (1978) and Lydon and Galley (1986) to be due to the entrainment of seawater into the uppermost part of the footwall vein 
stockwork systems, and by Riverin and Hodgson (1980) as being derived from the hydrothermal fluid. The presence of pseudomorphous amphibole in the lower part of the chlorite-sulfide zone would support a function of late, less evolved seawater-dominated hydrothermal fluid

The Mn contents of the chlorites are crudely zoned between alteration assemblages (Figure 5.39). The lowest Mn concentrations are within the massive sulfide lens, followed by the chalcopyrite-pyrrhotite stockwork zone. The sericite-chlorite transition zone chlorites have the second highest Mn values, with the magnetite stockwork zone having the highest. This is in contrast to most VHMS deposits, where Mn values usually increase towards the top and along the Zn-rich flanks of the deposit (Franklin et al., 1981). The Mn content of the Ansil chlorites is on average a tenth that of the Matagami Lake deposit, another magnetite-rich VHMS deposit. The Mn content of the chlorites at Ansil appears controlled by the $\mathrm{Fe}^{+3}$ content of the host rock, with the highest average values within the magnetite stockwork alteration zone.

\section{Stilpnomelane}

There is an inverse relationship between the presence of stilpnomelane and chlorite, and a positive correlation with greenalite and minnesotaite (Figure 5.40a). Stilpnomelane is most abundant within the massive sulfide and magnetite lenses. In the massive sulfide dark brown stilpnomelane forms single flakes intergrown with chalcopyrite-pyrrhotite, or as sheaves within small quartz-rich domains (Figures $5.17 \mathrm{e}, \mathrm{f}$ ). In the latter case it appears to replace 
chlorite. Stilpnomelane also occurs intergrown with chalcopyrite in quartz-sulfide stilpnomelane veinlets along the margins of the chlorite-sulfide stockwork zone. It is present in the massive magnetite intergrown with greenalite and minnesotaite in carbonate-quartzrich domains

There is a wide variation in $\mathrm{Si}, \mathrm{Al}, \mathrm{Mg}$ and $\mathrm{K}$ and $\mathrm{Mn}$ contents (Figure 5.40a). There is an overall trend in the stilpnomelanes away from the Ansil chlorite compositions towards the $\mathrm{FeO}$ end member, with the most $\mathrm{Al}$ - and $\mathrm{Mg}$-rich compositions from the massive sulfide and hangingwall magnetite zones. The highest $\mathrm{K}$ and lowest $\mathrm{Mn}$ values also come from these samples, with higher Mn contents within the massive magnetite and magnetite stockwork zones. A wide variation in $\mathrm{SiO}_{2}$ from 16 to $23 \%$ may be a function of small grain size and close spatial relationships with greenalite, which is observed to replace stilpnomelane in the presence of Fe-carbonate.

Stilpnomelane (as are greenalite and minnesotaite) is a reservoir for $\mathrm{Cl}$, with concentrations ranging up to $0.28 \%$. In the footwall magnetite lenses there are intergrowths of Cl- and K-rich stilpnomelane.

\section{Greenalite $\left[\mathrm{Fe}^{+2}{ }_{4.5} \mathrm{Fe}^{+3} \mathrm{Si}_{4} \mathrm{O}_{10}(\mathrm{OH})_{8}\right]$}

Greenalite is an Fe-serpentine mineral that is volumetrically minor in the Ansil alteration system, and yet is distributed pervasively through the massive sulfide and magnetite lenses, and in the upper part of the magnetite stockwork zone. It is reported in both ancient and modern massive sulfide deposits (Costa et al., 1983; Paradis et al., 1988). Mg-serpentines 
are fairly common in massive sulfide mounds and chimneys of modern oceanfloor hydrothermal systems (Ames et al., 1994; Percival et al., 1994). At Ansil it is intimately associated with minnesotaite and stilpnomelane. In one sample greenalite is observed to form $5 \mu \mathrm{m}$ thick rims about chlorite in the presence of carbonate. It is commonly intergrown with minnesotaite and rims stilpnomelane in the presence of Fe-carbonate. It has a fairly consistent $\mathrm{Fe} / \mathrm{Si}$ content and can contain up to a few percent Mg (Figure 5.40b). As with the other phyllosilicates it has relatively low concentrations of Mn (less than $0.5 \%$ ). The distinguishing feature of greenalite is its content of up to $1.27 \% \mathrm{Cl}$. Small concentrations of $\mathrm{Ca}$ and $\mathrm{Al}$ almost always occur in greenalite in the magnetite stockwork and at the massive sulfide-magnetite-andesite hangingwall contact. This is unusual for greenalite, but not for cronstedtite $\left[\left(\mathrm{Fe}^{+2} \mathrm{Fe}^{+3}, \mathrm{Al}\right)_{4.6}\left(\mathrm{Si}_{2} \mathrm{Fe}^{+3}{ }_{2}\right) \mathrm{O}_{10}(\mathrm{OH})_{8}\right]$, in which small amounts of $\mathrm{Ca}$ and $\mathrm{Al}$ may substitute for $\mathrm{Fe}^{+2}$ in the octahedral layer (Gruner, 1936). The presence of both minerals may be a function of the availability of $\mathrm{Ca}$ and $\mathrm{Al}$, which is more abundant within the magnetite stockwork zone and along the reaction margin between the andesite flows and the orebody.

Also present is a weakly crystalline mineral composed principally of $\mathrm{Fe}-\mathrm{Si}-\mathrm{OH}$, with minor $\mathrm{Mg}, \mathrm{Mn}, \mathrm{Ca}$ and $\mathrm{K}$. It has a composition between stilpnomelane and greenalite, and may represent an amorphous precursor to both minerals. Klein (1974) suggested that in oxide-silicate iron formation the primary Fe-silicates were probably hydrous silicate gels. 


\section{Minnesotaite $\left(\mathrm{Fe}^{+2} \mathrm{Mg}\right)_{6}\left[\mathrm{Si}_{8} \mathrm{O}_{20}\right](\mathrm{OH})_{4}$}

Minnesotaite is a talc mineral in which there is almost complete substitution of $\mathrm{Fe}^{+2}$ for Mg (Gruner, 1944). It is present as small, radiating clusters in the core of the chlorite-rich, chalcopyrite-pyrrhotite and magnetite stockwork zones, and in the massive magnetite and chalcopyrite-pyrrhotite lenses. It differs from the other phyllosilicates in that it is present in both the chlorite and stilpnomelane-greenalite bearing alteration zones.

The minnesotaite has relatively constant $\mathrm{Fe} / \mathrm{Si}$ ratios, with some variation in the $\mathrm{Mg}$ and Mn contents (Figure 5.40c). The highest $\mathrm{Mg}$ values are from the massive chalcopyritepyrrhotite lens and the highest $\mathrm{Mn}$ from the massive magnetite and magnetite stockwork zone. It contains up to $1.12 \% \mathrm{Cl}$ in the massive magnetite.

Fe-talc is present along with high Mg-chlorite in the core of the chalcopyrite-pyrrhotite stockwork zone. It is intergrown with chalcopyrite grains and quartz in small veinlets, and occurs as small, radiating crystal clusters within the chlorite groundmass.

\subsubsection{Amphibole}

\section{Ferroactinolite}

Ferroactinolite is associated with the massive magnetite lenses along the footwall contact of the Ansil orebody and is a constituent of the Ca-Fe skarns located along footwall and hangingwall contacts of the eastern end of the ore lens. The footwall ferroactinolite forms a discontinuous rim of densely packed, prismatic porphyroblasts up to $20 \mathrm{~cm}$ long along, and perpendicular to, the lower contact of the massive magnetite lens between levels $9 \mathrm{~B}$ and 10 
Spaces between porphyroblasts are infilled with magnetite and Fe-carbonate. It also occurs with quartz in the massive magnetite lenses. Down-plunge from Level 10 very fine-grained, fibrous masses of ferroactinolite replace porphyroblasts of hedenbergite and form thin rims around andradite euhedra within coarse-grained $\mathrm{Ca}-\mathrm{Fe}$ skarns. Within the carbonate it forms 100 to $200 \mu \mathrm{m}$ idiomorphs commonly surrounded by magnetite and quartz. It also replaces hedenbergite in a small occurrence of calc-silicate skarn along the massive magnetiteandesite contact exposed on Sublevel 7B and Level 10.

The ferroactinolite has an $\mathrm{XFe}$ ratio that varies from $42: 1$ in the ferroactinolite skarn to 11:1 in the hedenbergite-andradite-rich skarns (Figure 5.41). The Al content is higher in the latter, and both have low Mn contents ( 0.3 to $0.55 \%)$.

\section{Grunerite}

Grunerite is present in the amphibole skarn zone at the base of the footwall massive magnetite lenses. It occurs along with carbonate-chlorite-magnetite-rich patches, with the latter appearing to replace the amphibole. The grunerite is much finer-grained than the ferroactinolite (5 to $10 \mathrm{~mm}$ ). According to Westendorp (1992) it also occurs within the ferroactinolite skarns.

\section{Hedenbergite}

Hedenbergite occurs within the coarse-grained Fe-Ca skarns along the footwall and hangingwall contact of the massive sulfide lens between Levels 10 and 11. The pyroxene 
forms ragged porphyroblasts completely rimmed by fresher ferroactinolite. It was not observed in contact with andradite, but it appears to predate garnet growth. The compositions are close to stoichiometric, with an $\mathrm{Fe} / \mathrm{Ca}$ ratio of 1.3 , and up to $3 \% \mathrm{MgO}$ (Figure 5.41)

\section{Epidote group}

\section{Epidote}

Epidote is present in the magnetite stockwork alteration zone where it is part of a chlorite-epidote-magnetite-calcite-pyrite mineral assemblage. It is present as fine-grained pseudomorphs after plagioclase, infills patches of rhyolite groundmass, and forms dense orbicular patches up to $25 \mathrm{~cm}$ in diameter of coarser-grained, idiomorphic crystals. It also forms veinlets in the upper part of the magnetite stockwork zone that crosscut the earlierformed epidote patches and associated chlorite-magnetite-calcite retrograde alteration. Epidote is also present in the hangingwall andesite flows not directly affected by the Ansil hydrothermal system. It forms spectacular, coarse-grained, idiomorphic clusters within amygdules and occur as smaller grains replacing plagioclase microlites. There is a small range of compositions, but no trend recognized (Figure 5.42a).

\section{Allanite}

Y-rich allanite occurs in the quartz-chlorite-sericite, sericite-quartz-sphalerite, chloritechalcopyrite-pyrrhotite and chlorite-magnetite alteration zones as clusters up to $200 \mu \mathrm{m}$ in 
diameter of fine-grained crystals associated with monazite, apatite, xenotime and rutile These clusters are commonly centered on altered plagioclase microlites and glomeroporphs In the chlorite-magnetite alteration zone these clusters form the nucleus for epidote growth, with the latter forming thick rims about the former. In the sericite-quartz-sphalerite alteration zone allanite and monazite form partial rims about sphalerite grains.

The ubiquitous nature of these mineral clusters within the footwall alteration zones suggests that they act as sinks for REE during the breakdown of the primary and diagenetic mineral assemblages. The allanite and monazite tend to collect the LREE, whereas the xenotime acts as a trap for the HREE. REE mobility continued in the sericite-quartzsphalerite alteration zone during and after sulfide mineral precipitation, and in the chloritemagnetite zone the REE-rich mineral clusters formed before the formation of epidote. The presence of these REE 'sinks' is evidence for the limited mobility of these elements within most of the alteration zones. Its absence in the massive magnetite and sulfide lenses indicate the lack of appropriate host minerals in these zones.

\subsubsection{Andradite}

Andradite is restricted to the Ca-Fe skarns that formed along the massive sulfide contacts between Levels 10 and 10B. The andradite forms as individual, idiomorphic crystals up to $20 \mathrm{~mm}$ in diameter that coalesce in places to form semi-massive garnet. It has a consistent composition $\left(\mathrm{Ca}_{3} \mathrm{Fe}_{2} \mathrm{Si}_{3} \mathrm{O}_{12}\right)$, with less than $0.3 \% \mathrm{Mn}$ and $0.2 \% \mathrm{Al}$ (Figure 5.42b). The porphyroblasts are strongly fractured along cleavage planes, with the fractures infilled with 
carbonate, chalcopyrite, magnetite, idiomorphic ferroactinolite and rare quartz. The garnets have thin $(200 \mu \mathrm{m})$ rims of fibrous ferroactinolite and carbonate separating them from relict hedenbergite

\subsubsection{Carbonate}

There are three carbonate species that precipitated in the Ansil hydrothermal system: calcite $\left(\mathrm{CaCO}_{3}\right)$, ferrodolomite $(\mathrm{Fe}, \mathrm{Mg}, \mathrm{Ca}) \mathrm{CO}_{3}$ and siderite $\left(\mathrm{FeCO}_{3}\right)$ (Figure 5.42c). The carbonates are a product of the original hydrothermal process and of syn-kinematic, brittleductile shears and fractures. The synvolcanic hydrothermal carbonates are distributed throughout the magnetite-rich parts of the deposit, its underlying magnetite stockwork zone, and along the reaction zone between the chalcopyrite-pyrrhotite massive sulfide and the overlying andesite. They also occur in carbonate-sulfide-gold veinlets within the massive magnetite and sulfide along the contact between the two. As these veins formed perpendicular to the massive magnetite contact along a contact defining a strong competency contrast, they are assumed to be syn-kinematic. As they as commonly boudinaged they must have formed relatively early in the kinematic history of the deposit. Syn-kinematic carbonate also forms within shears cross-cutting all rocks types, and forms centimetre-wide halos about associated planar fractures and quartz-carbonate-chloritesulfide veins. The synkinematic carbonate ranges from siderite within the carbonate-sulfidegold veins to ferrodolomite within the shears and fractures. 
The distribution of the synvolcanic, hydrothermal carbonate species is divided into two areas: calcite is restricted to the chlorite-epidote-carbonate-pyrite alteration of the magnetite stockwork zone, where it replaces previously altered plagioclase and parts of the epidote patches. It is also present in veinlets with magnetite, chlorite and epidote. Ferrodolomite and siderite are restricted to the massive magnetite lenses and to the thin reaction rim between massive sulfide and andesite. The Fe-carbonates commonly occupy the cores of skeletal magnetite crystals with chlorite. The carbonates also host stilpnomelane, greenalite, minnesotaite and disseminated magnetite within the massive magnetite.

\subsubsection{Sulfide minerals}

Microprobe analysis was carried out on chalcopyrite, pyrrhotite, sphalerite and pyrite from the various parts of the Ansil deposit. A common thread between the three principal sulfide minerals is their consistent major element compositions. The chalcopyrite analyzed from the sulfide footwall stockwork zone, stratabound massive sulfide lens and its contact zone with the $\mathrm{Zn}$-rich Cranston tuff all define a stoichiometric composition $\left(\mathrm{CuFeS}_{2}\right)$. Trace concentration elements vary considerably, with 0.00 to $0.21 \% \mathrm{Au}$ (averages $0.06 \%$ ), up to $0.10 \% \mathrm{Se}, 0.36 \% \mathrm{Ag}$ and $0.22 \%$ As (see Appendix IV, Table 2 ).

Pyrrhotite was analyzed from the $\mathrm{Zn}$ - and $\mathrm{Cu}$-rich stockwork and stratabound sulfide zones, and from the massive magnetite zone. Irrespective of coexistence with pyrite sphalerite, chalcopyrite or magnetite, the pyrrhotite shows little compositional variation, besides a slight decrease in $\mathrm{Fe}$ content within the magnetite zone (Fe:S changes from 1.7 to 
1.6). The composition is non-stoichiometric, and is defined by the formula $\mathrm{Fe}_{0.93} \mathrm{~S}$. Trace elements present include $\mathrm{Zn}$ (up to $0.87 \%$ ), $\mathrm{Ni}$ (up to $0.08 \%$ ), $\mathrm{Au}$ (up to $0.18 \%$ ), and $\mathrm{Ag}$ (up to $0.13 \%$ )

Sphalerite is most abundant within the Zn-rich Cranston tuff and underlying rhyolite hydrothermal breccia, is a major component of some of the banded massive sulfide ore and a minor constituent in the massive chalcopyrite-pyrrhotite ore and footwall stockwork vein system. All of the sphalerites have moderate contents of FeS ( 9 to 14 mole\%), with an average of $12 \%$ (Figure 5.43 ). There is no correlation with any sulfide mineral assemblages across this range. Trace elements present include $\mathrm{Ag}$ (up to $1.03 \%$ ), $\mathrm{Bi}$ (up to $0.45 \%$ ), $\mathrm{Cd}$ (up to $0.39 \%$ ), As (up to $0.26 \%$ ) and $\mathrm{Se}(0.24 \%$ ).

Pyrite contains concentrations of As (up to $0.6 \%$ ), Se (up to $0.18 \%$ ), and Au (up to $0.13 \%)$

\subsection{WHOLE ROCK CHEMISTRY}

There are four formations affected by the Ansil alteration system, two andesite (Flavrian and Rusty Ridge) and two rhyolite (Northwest and Cranston), with the Cranston being a unit within the Northwest formation. The geochemical part of this study concentrated on the affects of hydrothermal alteration upon the Northwest rhyolite in the stratigraphic footwall to, and flanking, the Ansil deposit, and on the Cranston tuff, which hosts a large part of the deposit. 
The data for the altered rhyolites is presented on various bivariant and polyvariant plots in comparison to average, least altered analyses for the Northwest formation published by Barrett et al. (1990) and unpublished data from H.L. Gibson. The Barrett standard represents the least altered rhyolite composition in the immediate vicinity of the deposit, and the Gibson standard is an average composition for the South Flow of the Northwest formation (Appendix III). The Gibson standard is used as a precursor composition for the Ansil hydrothermal system in the section of this study on calculating relative mass change. This is followed by the Barrett standard as a 'first stage', weakly hydrothermally altered protolith, thereby allowing one more increment in the alteration paragenesis to be documented.

There are no available analyses for relatively unaltered Cranston tuff. As it is considered to be a late stage phase of the Northwest formation, this study will assume that its major element composition generally conforms with the Gibson standard for a least-altered rhyolite

The data used to construct the various diagrams in this chapter are presented in table form in Appendix III. The data have not been normalized in any fashion. The assumption is made that any variation in volatile concentration from the average, least-altered rock is a function of the alteration undergone by the rocks during subsequent diagenesis, hydrothermal alteration and regional metamorphism. The accepted practice of calculating out the sulfide, $\mathrm{CO}_{2}$ and $\mathrm{H}_{2} \mathrm{O}$ contents is appropriate for determining original igneous compositions, but not for determining relative real mass and volume changes. Unless petrographic evidence points 
to the contrary, a further assumption is made that regional metamorphism was isochemical, and all chemical variations are a result of either diagenesis or hydrothermal alteration. If dehydration took place during regional metamorphism, then a further assumption must be made that it affected all of the rhyolite equally.

The analyses are divided into the previously defined alteration categories in relation to the mineral assemblages present in the polished hand specimens and polished thin sections that accompany each chemical analysis. The overlapping of the alteration fields on various discriminate diagrams is a function of original overprinting as determined by the paragenetic history of the hydrothermal alteration system. The presence of this overlapping would not have been determined through straight geochemical discrimination, emphasizing the need to integrate any geochemical program with vigorous petrographic examination.

The whole rock chemistry section is divided into three subsections: a) presentation of major and trace element data to define differences between alteration zones, trends between zones, and to define the least mobile elements, b) presentation of chondrite normalized REE data to define variations in mobility of the lanthanide elements, and relative net mass gain of loss, and c) mass balance calculations to define relative changes in mass and volume through progressive hydrothermal alteration of the strata and formation of the orebody. 


\subsubsection{Major and trace element geochemistry}

One of the main characteristics of the volcanic strata within the Noranda cauldron is their overall enrichment in $\mathrm{Na}$. The high background concentrations accentuate the zones of $\mathrm{Na}$ depletion associated with the discordant alteration zones hosting the massive sulfide deposits. At Ansil the samples from the various alteration zones are depleted in Na relative to the Gibson and Barrett standards (Figure 5.44). The least altered and chlorite-sulfide altered samples form a ' $\mathrm{Na}$ depletion trend' marked by an initial, sharp loss, followed by a shallowing of the curve between 0.3 and $0.1 \% \mathrm{Na}_{2} \mathrm{O}$. The quartz-chlorite alteration samples are scattered about the alteration field due to a combination of $\mathrm{Na}$ depletion and erratic $\mathrm{K}$ enrichment due to overprinting by sericite-quartz alteration. A ' $\mathrm{K}$ enrichment trend' includes all of the sericite-quartz-sphalerite altered samples and a scattering of chlorite-sulfide samples from its contact with the former zone. The most $\mathrm{K}$ enriched samples are from the remnants of sericite-quartz-sphalerite altered rock within the chlorite-sulfide alteration stockwork zone. Samples of chlorite-magnetite are either Na-K depleted, or K enriched.

\section{$\left(\mathrm{Fe}_{2} \mathrm{O}_{3}+\mathrm{Mn}+\mathrm{Mg}\right)-\mathrm{Al}_{2} \mathrm{O}_{3}-\mathrm{K}_{2} \mathrm{O}-\left(\mathrm{Na}_{2} \mathrm{O}+\mathrm{CaO}\right)$ tetrahedron}

The most common major elements used to define the presence of a hydrothermal discharge zone are $\mathrm{Na}, \mathrm{Ca}$ (for their loss) and $\mathrm{Fe}, \mathrm{Mn}, \mathrm{Mg}$ and $\mathrm{K}$ (for their relative gains). It is generally believed that the first two elements are progressively stripped from the host rock under conditions of low $\mathrm{pH}$ and high fluid/rock ratios. The deposition of Fe and $\mathrm{Mn}$ from the hydrothermal fluid is a function of changes in $\mathrm{f}_{\mathrm{S} 2}, \mathrm{f}_{\mathrm{O} 2}$, and temperature, and $\mathrm{Mg}$ and 
$\mathrm{K}$ are added through the interaction of the rising hydrothermal fluid with cooler, shallowly circulating seawater.

A flattened tetrahedron with these elements distributed about its apices can be employed to define the relative changes in concentrations between these major element components of the alteration system (Figure 5.45). Exploration companies employ this discriminant diagram to vector towards potential massive sulfide mineralization under the assumption that within a 'classic' footwall alteration zone depletion of $\mathrm{Na}$ and $\mathrm{Ca}$ is followed by $\mathrm{K}$ addition along the margins of the stockwork vein system, through $\mathrm{Mg}-\mathrm{K}$ and $\mathrm{Mg}-\mathrm{Fe}$ enrichment to an Fe-rich core (Franklin et al., 1982). This zonation is postulated to be due either to overprinting by progressively hotter and more evolved hydrothermal fluids (Riverin and Hodgson, 1980), or due to interaction between the rising hydrothemal fluid and shallowly circulating seawater (Heaton and Sheppard, 1977).

The Ansil samples clearly define two trends within each of the four sections of the tetrahedron (Figure 4.45). One linear trend begins with the least altered rhyolite and progresses through the chlorite-sulfide altered rhyolite towards the Fe-Mn-Mg apex. In the $\mathrm{Al}-\mathrm{K}-(\mathrm{Na}+\mathrm{Ca})$ ternary plot a linear trend starts with the least altered samples furthest from the Al apex, and includes first the quartz-chlorite samples and then the chlorite-sulfide samples closest to this apex.

The second trend is defined by the sericite-quartz-sphalerite altered samples. In the $(\mathrm{Fe}+\mathrm{Mn}+\mathrm{Mg})-\mathrm{K}-(\mathrm{Na}+\mathrm{Ca})$ ternary plot this alteration type define a line along the $\mathrm{K}$ $(\mathrm{Fe}+\mathrm{Mn}+\mathrm{Mg})$ boundary that ends at the Fe-rich apex. In the other two ternary plots that 
share the $\mathrm{Fe}+\mathrm{Mn}+\mathrm{Mg}$ apex the sericite-quartz-sphalerite samples form trends away from the $\mathrm{Al}$ apex towards the Fe-rich corner. In the $\mathrm{Al}-\mathrm{K}-(\mathrm{Na}-\mathrm{Ca})$ ternary section the sericite-quartzsphalerite samples form a cluster along the $\mathrm{K}-\mathrm{Al}$ boundary.

The presence of two separate trends involving the least altered and sericite-quartzsphalerite altered samples would occur if both these alteration phases were present before the imposition of the Fe-Mg rich chlorite-sulfide alteration. This supports the field evidence for two physically and temporally distinct alteration phases. If all of the alteration phases evolved from a single hydrothermal event there should be one continuous line from least altered through sericite-quartz-sphalerite to chlorite-sulfide

The same reasoning applies to the quartz-chlorite altered samples. Petrographic evidence indicates that this alteration type pre-dates the sericite-quartz-sphalerite alteration. If it represents a hydrothermal alteration phase intermediate between least and sericite-quartzsphalerite altered the samples should lie on a line between the two, which it does not. This would support the supposition that the quartz-chlorite alteration was produced through enhanced diagenesis that is chemically unrelated to the overprinting hydrothermal events. The presence of this alteration type may be solely a function of an elevated geothermal gradient about the plagioclase glomeroporphyritic rhyolite dykes and stocks.

The chlorite-magnetite altered samples form a linear trend towards the $\mathrm{Na}+\mathrm{Ca}$ apex in all four ternary plots, with a sharp reversal towards the $\mathrm{Fe}+\mathrm{Mn}+\mathrm{Mg}$ apex when the actinolite skarn sample is included. This corresponds to the increasing concentrations of epidote and calcite towards the base of the massive magnetite lenses. The increase in $\mathrm{Fe} / \mathrm{Ca}$ ratio within 
the actinolite skarn relates to the sudden disappearance of epidote and replacement of some calcite by Fe-carbonates.

\subsubsection{Rare Earth Elements}

The inherent stability of the rare earth element (REE) group under most geologic conditions makes it ideal for identifying precursors to strongly altered rocks, and for quickly determining whether hydrothermal alteration has involved net mass gains or losses. The stability and similar chemical and physical properties of this group is because they have a shielded $4 \mathrm{f}$ orbital. They all maintain a tripositive oxidation state in most geological environments and can fit into a broad range of cation coordination polyhedra in the rockforming minerals (Henderson, 1984). Ce and $\mathrm{Eu}$ are the least stable as they will form tetrapositive and bipositive cations under strongly oxidizing and reducing conditions respectively. The decrease in ionic radii from $\mathrm{La}$ to $\mathrm{Lu}$ result in a higher ionization potential for the heavy rare earth (HREE) (Gd to $\mathrm{Lu}$ ) than the light rare earth (LREE) (La to Eu) elements. This results in stronger LREE variations between primary rock compositions due to magma fractionation and preferential concentration of LREE with the incompatible elements. The $\mathrm{La} / \mathrm{Lu}$ ratio is therefore a practical discriminant for distinguishing primary rock compositions in highly altered strata (Lotermoser, 1992).

The average $\mathrm{La} / \mathrm{Lu}$ ratios for regional, unaltered rhyolite samples is 26.5 , and for Barrett's least altered samples 24.7 (Figure 5.46). The altered rhyolite samples from Ansil form a loose cluster about, and mainly between the Gibson-Barrett averages and the origin, but not 
on a well defined line. Field and petrographic evidence indicates that the altered samples had rhyolite precursors, therefore some REE mobility took place during the alteration events. If the Gibson average rhyolite composition is taken as the least altered rhyolite precursor, altered samples lying along a line drawn through this point to the origin would have maintained their primary $\mathrm{La} / \mathrm{Lu}$ ratio. This includes some of the quartz-chlorite, chloritesulfide and chlorite-magnetite samples. Most of the least altered Ansil samples cluster closely about the Barrett average composition, with the remainder of the quartz-chlorite, and some chlorite-sulfide samples lying on a crude line between the Barrett composition and the origin. Most of the sericite-quartz-sphalerite, and the remainder of the chlorite-sulfide samples lie below these two slopes.

Chondrite-normalized plots of the REE from the Ansil rhyolite samples were constructed to give a visual representation of some of the changes that occurred during alteration. The least altered samples (Figure 5.47) define a tight group with very similar profiles characterized by moderate to strong Eu depletions. When compared to the quartz-chlorite altered samples (Figure 5.47), the REE/chondrite ratios and profiles of the latter group are scattered over a broad range below the former, denoting both net mass gain and REE mobility. The variations in the profiles within this group reflect alteration intensity, possibly due to controls by primary permeability. This would be expected as much of this alteration affects the plagioclase glomeroporphyritic dykes, whose permeability would be greater along the margins than at the cores. The negative Eu anomaly maintains its intensity but the flat left side of the profile denotes a general reduction in the LREE concentrations. Some 
HREE mobility also occurred. The absence of the negative Eu anomaly in samples 7B-85 and 9-74, and its decrease in samples 7B-84 and 8-59B are a result of varying degrees of strong silicification (Hopf, 1993).

The sericite-quartz alteration comprises two groups of REE/chondrite profiles (Figure 5.47). The lower group ranges from overlap with the least altered field to lower $\mathrm{REE} /$ chondrite ratios denoting net mass gain relative to the least altered rhyolite. There is a general flattening of the profiles due to loss of LREE. The weak development of the negative Eu anomalies, and the presence of one positive anomaly, with respect to the least altered rhyolite indicates that it has been fractionated relative to the rest of the REE. The presence of hydrothermal plagioclase may account for some Eu increase, but its near endmember albite composition would preclude too much incorporation of $\mathrm{Eu}^{+2}$ into the feldspar structure. Hopf (1993) suggested that illite may be a sink for $\mathrm{Eu}^{+2}$ under certain conditions. As illite was the most likely precursor to sericite this may explain the anomalous Eu in this alteration zone.

The second group of sericite-quartz altered samples is from the remnant domains within the core of the chlorite-chalcopyrite-pyrrhotite alteration zone (Figure 5.47). This group has strongly elevated $\mathrm{REE} /$ chondrite ratios indicating net mass loss. The siliceous nature of these samples would suggest that they are a product of strong leaching. Two of the samples show a relative loss in HREE and positive Eu anomalies, whereas the third sample has a profile that subparallels that of the least altered rhyolite. 
For the chlorite-sulfide alteration zone most of the REE/chondrite ratio profiles define a broad spectrum that lie below, but sub-parallel the least altered rhyolite field, indicating a net mass gain relative to least altered rhyolite (Figure 5.47). In general the negative Eu anomalies are larger, but vary considerably, with $\mathrm{La} / \mathrm{Eu}$ ratios ranging from 7.2 to 30.7 (least altered rhyolite averages 19.3). The smallest ratio belongs to a sample of chloritechalcopyrite-pyrrhotite altered Cranston tuff at the base of the massive sulfide lens. The generally large negative Eu anomalies are due to the complete destruction of feldspar. The average $\mathrm{La} / \mathrm{Lu}$ ratio of 22 indicates a depletion in LREE from least altered concentrations (average $\mathrm{La} / \mathrm{Lu}=25.6$ ).

The chlorite-magnetite alteration zone samples have similar $\mathrm{La} / \mathrm{Lu}$ ratios to the least altered rhyolite (average $=25.3$ ), with the REE/chondrite profiles lying within and above the least altered rhyolite field (Figure 5.47). La/Eu ratios range from 6 to 31 indicating a wide variation in Eu fractionation. This may be due to varying amounts of epidote and calcite present, where $\mathrm{Eu}^{+2}$ may substitute for $\mathrm{Ca}^{+2}$.

The actinolite skarn sample shows a gross depletion in REE abundances due to large increases in $\mathrm{Fe}$ and $\mathrm{Ca}$, which more than offset the apparent depletion in $\mathrm{Si}$ (Figure 5.47). The REE/chondrite profile of the skarn is so far removed from that of the least altered rhyolite that it is difficult to believe that the latter is the precursor. Its radically different profile indicates that the host rock had very little input as a buffer during fluid/rock interaction, which is evidence for very large fluid/rock ratios during this alteration event. The small, aggregate grains of monazite, allanite and xenotime are present in all of the 
alteration zones with the exception of the Fe-Ca skarns. It is therefore apparent that they must be the major sinks for REE in the Ansil alteration system.

\subsubsection{MASS BALANCE CALCULATIONS}

\section{Treatment of data}

Various methods have been employed to quantitatively determine elemental net mass gains and losses that take place during hydrothermal alteration. Gresens (1967) developed formulae to determine composition-volume relationships from chemical analyses and specific gravity data. The technique requires that: a) the composition be known for both the unaltered protolith and for the altered equivalents, b) that one or more elements be considered immobile, or c) an assumption is made regarding volume and/or mass changes. If volume changes are assumed, the specific gravities of both the protolith and altered equivalents must be determined through density measurements. Element mobility in relation to volume change was defined through composition-volume diagrams, where arbitrary volumes changes are assumed, and the changes in mass relative to the protolith are calculated for each element. Lines are then drawn between points representing the same element on two or more volume lines. Where the curves for several points intersect at a particular volume, these elements are considered to be least mobile. The concentrations of these 'immobile' elements within a particular alteration type may then be used to determine net mass. 
Grant (1986) introduced a graphical method using Gresens' equations to determine mass change. Altered versus unaltered values for each element are plotted against one another. Elements that lie along a line (the 'isocon')drawn through the origin are considered to be least mobile. Any variation in the slope from 1 defines either a change in mass or volume. If densities are known, then the relative density (and volume) change of the altered rock may be calculated.

Relative mass changes can be calculated from the isocon, as elements that increased in mass lie above the line and elements that have lost mass will plot below. The relative mass changes $\left(\mathrm{dC}_{\mathrm{a}}\right)$ are related to the altered composition $\left(\mathrm{C}_{\mathrm{a}}\right)$ by:

$\mathrm{dC}_{\mathrm{a}}(\%)=100\left[\mathrm{C}_{\mathrm{a}} /\left(\mathrm{sC}_{\mathrm{o}}\right)-1\right] \quad($ Grant, 1986$)$

where $\mathrm{C}_{0}=$ element concentration in protolith $\mathrm{s}=$ slope of the isocon

Absolute mass changes may be calculated by:

$$
\mathrm{dC}_{\mathrm{a}}(\mathrm{g} / 100 \mathrm{~g})=\left[\mathrm{dC}_{\mathrm{a}}(\%) / 100\right]\left[\mathrm{C}_{0}(\mathrm{~g} / 100 \mathrm{~g})\right] \quad \text { Grant }(1986)
$$

The accuracy of the calculated relative and absolute net mass change is limited by the accuracy of the unaltered composition in reflecting the composition of the protolith, and the 
lack of compositional variation within the protolith. Both limitations can be minimized by taking the average of a number of least altered samples. The limitations can be characterized by estimating the means and standard deviations of the samples used. In any case, the unquantifiable variations that can be imposed on the least altered samples due to elemental shifts during devitrification and diagenesis should be taken into account by ignoring small apparent mass changes $(<10 \%)$.

Grant's (1986) isocon diagrams can be difficult to interpret and compare unless consistent scaling factors are employed. These scaling factors are necessary in order to plot all the elemental ratios from an altered sample on a single diagram, as these concentrations may vary exponentially. Huston (1993) employed a variation of Grant's (1986) isocon method by placing the elements in a sequence where those that have undergone large mass gains (such as $\mathrm{S}, \mathrm{Cu}, \mathrm{Zn}, \mathrm{Pb}, \mathrm{Au}$ and $\mathrm{Ag}$ ) are placed early in the sequence, and those that have undergone smaller mass gains or mass losses (such as $\mathrm{Na}, \mathrm{Sr}, \mathrm{Si}, \mathrm{K}$ ) are placed late in the sequence. Immobile elements are then arbitrarily dispersed throughout the sequence. The elements are then assigned an integer $\left(\mathrm{n}_{\mathrm{i}}\right)$ according to the position in the sequence. A scaling factor is then determined for each element as follows:

$\mathrm{F}_{\mathrm{i}}=\mathrm{n}_{\mathrm{i}} / \mathrm{C}_{\mathrm{o}}$

where $F_{i}=$ the scaling factor for element $i$, and $C_{0}=$ the concentration of the element in the least altered equivalent. The scaled value is calculated as follows: 
$\mathrm{C}_{\mathrm{s}}=\mathrm{F}_{\mathrm{i}} \mathrm{C}_{\mathrm{i}}$

where $\mathrm{C}_{\mathrm{s}}=$ the scaled concentration of the element in the sample, and $\mathrm{C}_{\mathrm{i}}=$ the concentration of the element in the sample. The scaled concentration of the element in the least altered equivalent relates to its assigned integer (i.e. $\left.C_{s}=\left(n_{i} / C_{0}\right) C_{0}=n_{i}\right)$. The scaled values of the least altered equivalent then occur at regular intervals along the abscissa of the isocon diagram, and the elements can be labelled below the assigned integer. If the same scaling factor is applied to each diagram, they may be compared directly.

\section{Ansil Results}

For the Ansil deposit the Gibson standard was used for the least altered Northwest formation protolith in assessing mass changes in both the North Flow that underlies the deposit, and for the Cranston Tuff that hosts the massive sulfide lens and related, $\mathrm{Zn}$-rich semi-massive mineralization. The use of the rhyolite composition for the Cranston precusor was necessary as there are no suitable analyses available for the Cranston QFP, the source rock for the Cranston Tuff unit. This may be justified by the fact that the Cranston QFP is the youngest unit within the Northwest formation, and therefore it may be assumed that there are no large major element variations between unit and the remainder of the formation. If any variation is present it would be most obvious in the incompatible (high field strength) element concentrations. $\mathrm{Nb}, \mathrm{Hf}, \mathrm{Y}$ or $\mathrm{Zr}$ are not assumed to be immobile in 
this study, and therefore any differences in primary concentrations should not affect the mass balance calculations.

Any mass changes that have taken place during the evolution of the Ansil hydrothermal system can be assumed to be incremental, in that each successive alteration zone involved fluid/rock interaction between the hydrothermal fluid and the altered composition of the preceding zone. It therefore follows that the protolith composition should only be used as the 'least altered' precursor for comparison with the first-formed alteration zone (Galley et al., 1993). Calculations in mass change for the succeeding alteration zones should employ the composition of the immediately preceding alteration zone as the 'least altered' protolith.

This would apply if there was a consistent spatial overprinting of succeeding alteration zones, as suggested by the model for a 'classic' volcanic-hosted massive sulfide alteration system (Riverin and Hodgson, 1981; Lydon, 1984; Gemmel, 1992). The preceding descriptions of the distribution and paragenesis of the Ansil footwall alteration system define a distinct spatial separation between the $\mathrm{Zn}$ - and $\mathrm{Cu}$-rich alteration zones, and the irregular distribution of the quartz-chlorite-sericite alteration (Figure 5.4), precludes any assumptions as to the degree of overlap that took place during their formation. The uncertainty in distribution of overprinted diagenetic and hydrothermal alteration zones makes it therefore necessary to use the Gibson standard as the precursor for all of the alteration zones. This restricts the conclusions that can be made regarding the incremental changes that took place during the formation of the hydrothermal system, and gives only finite mass changes. 
The Ti vs. Zr diagram shows that most of the analyses plot between the Gibson standard and the origin, indicating that most of the alteration involved net mass gain (Figure 5.48). The exceptions are two from the sericite-quartz-sphalerite zone, two from the chloritesulfide zone and three analyses from the chlorite-magnetite zone. The sericite-quartzsphalerite samples are all from remnants of this alteration type within the core of the chlorite-sulfide alteration zone. The two chlorite-sulfide samples are from discordant and conformable chlorite alteration zones directly below the massive sulfide lens, and the chlorite-magnetite samples are from a cross-section through a deep part of the alteration zone close to the basal contact to the Northwest formation.

On each plot of altered versus least altered (Figures 5.49a,b,c) a line was drawn between the average value of elements aligned along a slope to the origin. These elements are defined as the least mobile. All of the alteration plots show $\mathrm{Al}$ and $\mathrm{Ti}$ to be consistently least mobile. These elements were therefore used to define the slope used to calculate element mobility relative to the average Gibson sample. Histograms were then plotted (Figures $5.49 \mathrm{a}, \mathrm{b}, \mathrm{c})$ ) from the average loss/gain percentage of each element relative to the Gibson standard. For simplicity these average values are then grouped by element (Figure 5.50) for a graphic representation of the elemental variations between the various alteration zones. Elements in the first row were calculated to be the least mobile. The second row defines the element group most abundant (along with $\mathrm{Al}$ ) in the average Gibson rhyolite. Loss/gain variations in these elements define the largest absolute mass changes during alteration (Tables 5.1 and 5.2). The remainder of the elements are grouped according to their inter- 
element affinities. Table 5.3 summarizes elemental loss/gains for each of the alteration zones.

$\mathrm{Al}$ and $\mathrm{Ti}$ show relative variations of less than $6 \%$ throughout the alteration process, with the largest variation for both elements in the the two weakest alteration zones. Although $\mathrm{Zr}$ and $\mathrm{Y}$ show relative mass losses up to $60 \%$, the losses are fairly consistent for all of the alteration zones. This suggests that they are also relatively immobile, but the concentrations for the two elements as defined in the Gibson standard do not represent the true original rhyolite values. This may be due to differing precursors or analytical error. Field mapping, petrographic and trace element analysis by both Gibson (1989) and from this study indicate that any primary compositional variation between parts of the North Flow are minor, and possibly due to variations in phenocryst content. The exception may be the plagioclase glomeroporphyritic rhyolite dykes that focussed the quartz-chlorite alteration, but there does not appear to be any other evidence for large primary compositional differences. The presence of the phenocrysts may explain the slight relative incease in $\mathrm{Al}$, but this also occurs in the least altered samples from Ansil, which are not plagioclase-glomerporphyritic. The same analytical technique and company produced data for both the altered and average samples, but the analyses were performed during different time periods. The conclusion is that the Gibson standard concentrations for both $\mathrm{Zr}$ and $\mathrm{Y}$ were lower than defined by the analyses. Figure 5.50 shows a similar pattern for $\mathrm{Co}$, with large, but fairly consistent losses for all of the alteration types. 


\section{Least altered Ansil rhyolite}

The least altered rhyolite in the immediate vicinity of the Ansil deposit shows relatively small variations with respect to the Gibson standard, with minor increases $(<50 \%)$ in $\mathrm{Si}$, $\mathrm{Mg}, \mathrm{Fe}, \mathrm{Ca}$, and $\mathrm{Sr}$, moderate increases (between 50 and 150\%) in $\mathrm{Mn}, \mathrm{Rb}, \mathrm{Ba}$ and $\mathrm{Au}$, and large increases $(>150 \%)$ in $\mathrm{K}, \mathrm{Zn}, \mathrm{Pb}$ and $\mathrm{Cu}$. The large increases in $\mathrm{Zn}-\mathrm{Pb}$ and $\mathrm{Cu}$ are accounted for by 2 of the 7 least altered samples, both within close proximity to sericitequartz-albite-sphalerite and chlorite-sulfide alteration respectively. The largest consistent relative increases are $\mathrm{K}$, followed by $\mathrm{Rb}$ and $\mathrm{Ba}$, indicating low level sericite alteration. In absolute terms the largest increases are in $\mathrm{Si}$, followed by $\mathrm{Fe}, \mathrm{K}$ and $\mathrm{Ca}$, with loss of almost a quarter of precursor concentrations of $\mathrm{Na}$. The $\mathrm{Na}$ losses correspond to the alteration of albite to chlorite and sericite.

There is an overall mass gain during this low-grade alteration of $7.7 \mathrm{~g} / 100 \mathrm{~g}$.

\section{Quartz-chlorite altered rhyolite}

The development of the quartz-chlorite alteration zone involved significant increases in $\mathrm{Si}$, $\mathrm{Fe}, \mathrm{Mg}, \mathrm{Mn}, \mathrm{K}, \mathrm{Rb}, \mathrm{Ba}$ and $\mathrm{Au}, \mathrm{Cu}, \mathrm{Zn}$ and $\mathrm{Pb}$. There were significant losses in $\mathrm{Na}, \mathrm{Ca}$ and $\mathrm{Sr}$. The high $\mathrm{Zn}$ value is the result of a single sample, with the remainder showing erratic, and mainly below average values. $\mathrm{Cu}$ values are generally slightly elevated, but very erratic. These base metal values can be accounted for by overprinting of this alteration zone by $\mathrm{Zn}$ and $\mathrm{Cu}$-rich alteration that postdates it. The most significant absolute mass change is $\mathrm{Si}$, 
with a $47.44 \mathrm{~g} / 100 \mathrm{~g}$ mass gain. This is followed by $\mathrm{K}$ and Fe. The Si gain can be accounted for through the silicification of perlitic fracture margins and dumping of silica within the fractures, giving the rock its distinctive, piebald appearance. Increase in $\mathrm{K}$ (and corresponding increases in $\mathrm{Rb}$ and $\mathrm{Ba}$ ) are accounted for through the sericite alteration of albite and chlorite during the overprinting sericite-quartz-albite-sphalerite event. Increase in $\mathrm{Fe}, \mathrm{Mg}$ and $\mathrm{Mn}$ are accounted for by the formation of chlorite. Significant losses in $\mathrm{Na}$, and smaller losses in $\mathrm{Ca}$ and $\mathrm{Sr}$ are due to the complete overprinting of albite by chlorite and sericite.

There is an overall mass gain during this phase of silicification of $54 \mathrm{~g} / 100 \mathrm{~g}$

\section{Sericite-quartz altered rhyolite}

The sericite-quartz alteration zone is marked by significant increases in $\mathrm{K}, \mathrm{Rb}, \mathrm{Ba}, \mathrm{Fe}, \mathrm{Au}$ and the base metals, and a small increase in $\mathrm{Si}$. Significant losses occur for $\mathrm{Na}, \mathrm{Mg}, \mathrm{Ca}, \mathrm{Sr}$ and $\mathrm{Mn}$. The large concentrations of sericite account for increases in $\mathrm{K}, \mathrm{Ba}$ and $\mathrm{Rb}$, whereas the disappearance of chlorite is responsible for losses in $\mathrm{Mg}$ and $\mathrm{Mn}$. The growth of hydrothermal albite is restricted mainly to veins within the rhyolite and to the Cranston tuff, and therefore does not show up in the mass balance calculations. The large loss of $\mathrm{Na}$ is due to the destruction of albite formed during pre-Ansil spilitization of the volcanic strata. Gains in $\mathrm{Au}, \mathrm{Cu}, \mathrm{Zn}, \mathrm{Pb}$ and $\mathrm{Fe}$ correlate with the presence of sphalerite, Fe-sulfides and chalcopyrite.

There is an overall mass gain from the Gibson rhyolite standard of $11 \mathrm{~g} / 100 \mathrm{~g}$. 


\section{Chlorite-sulfide altered rhyolite}

The formation of the chlorite-sulfide zone involved large increases in $\mathrm{Fe}, \mathrm{K}, \mathrm{Ba}, \mathrm{Cu}, \mathrm{Zn}$, $\mathrm{Pb}$ and $\mathrm{Au}$ and moderate increases in $\mathrm{Mg}, \mathrm{Mn}$, and $\mathrm{Rb}$. Significant losses occurred for $\mathrm{Si}$, $\mathrm{Na}, \mathrm{Ca}$ and $\mathrm{Sr}$. Gains in $\mathrm{K}, \mathrm{Ba}$ and $\mathrm{Rb}$ are restricted to 3 samples of chlorite alteration that formed in proximity to earlier-formed sericite-quartz alteration under the north flank of the massive sulfide lens. Without these three samples there is a significant decrease in the amount of $\mathrm{K}, \mathrm{Ba}$ and $\mathrm{Rb}$ within the chlorite alteration zone. Increases in $\mathrm{Fe}$ are due to the presence of pyrrhotite, chalcopyrite and minor sphalerite, and due to the large amounts of Fe-rich chlorite present. The formation of large amounts of chlorite is also responsible for the increases in $\mathrm{Mn}$ and $\mathrm{Mg}$, and for the losses in $\mathrm{Si}$ (due to dissolution of quartz) and $\mathrm{Na}-$ $\mathrm{Ca}-\mathrm{Sr}$ (due to destruction of plagioclase).

The formation of the chlorite alteration zone is characterized by an average mass loss of $7 \mathrm{~g} / 100 \mathrm{~g}$.

\section{Chlorite-magnetite altered rhyolite}

The chlorite-magnetite zone is characterized by a broad range of element values in the samples chosen for mass balance calculations. This is due to the inhomogeneous texture of most of the zone, with irregular distibution of epidote pods and magnetite veining, and irregular overprinting of the previously formed chlorite-sulfide, and possibly the sericitequartz-sphalerite, alteration zones. The chlorite-magnetite zone shows the largest decrease 
in $\mathrm{Si}$, averaging $18 \mathrm{~g} / 100 \mathrm{~g}$, or almost one fifth of the total weight of the unaltered rhyolite With the exception of two samples directly underlying a massive magnetite lens, there is a consistent, large decrease in $\mathrm{Na}$. The larger concentrations of $\mathrm{Na}$ near the top of the chlorite-magnetite zone coincides with the greatest concentrations of epidote pods and associated alteration, which includes relatively fresh albite. There are large increases in $\mathrm{Ca}$ near the top of the alteration zone, which diminish down section with the disappearance of the large epidote pods. The increase in $\mathrm{Ca}$ is matched by a large increase in $\mathrm{Sr}$. The zone shows the largest relative increase in $\mathrm{Fe}$, with a two-fold increase from the top to the bottom of the altered section. There is an increase in Mg relative to the Gibson standard, but a decrease relative to the chlorite-sulfide zone. This is evidenced by the presence of more Fe-rich chlorite compositions (Figure 5.37). The highest $\mathrm{Mg}$ gain is from the lower part of the chlorite-magnetite zone close to the basal rhyolite contact. This sample contains chlorite pseudomorphous after 2 to $3 \mathrm{~mm}$ diameter, radiating clusters of amphibole

The oddest relative mass gains are for $\mathrm{K}$ and $\mathrm{Ba}$, which both increase significantly down section through the alteration zone. There is no apparent correlation with concentrations of sericite, which is responsible for K-Ba anomalies within the sericite-quartz-sphalerite alteration zone. Both $\mathrm{Cu}$ and $\mathrm{Au}$ are high, but considerably lower in concentration compared to the chlorite-sulfide zone. Relative mass gains in $\mathrm{Zn}$ and $\mathrm{Pb}$ are restricted to one sample from directly below a massive magnetite lens. 


\section{Cranston tuff}

A series of ten samples were chosen to cover the spectrum of incremental alteration and replacement of the Cranston tuff (Table 5.4). At one end of the spectrum is the least altered tuff, which is least affected by sericite-quartz-sphalerite alteration, but still visibly altered The next four samples represent increasing degrees of sericite-quartz alteration and associated emplacement of disseminated to semi-massive sphalerite, pyrrhotite and chalcopyrite. ANSL 8A-100A represents a strongly chloritized remnant of Cranston tuff from the base of the massive sulfide lens. The following two samples are semi-massive chalcopyrite-pyrrhotite with layers of Cranston tuff and massive chalcopyrite-pyrrhotite respectively. The remaining two samples are semi-massive to massive magnetite.

Considering the range of element concentrations shown by the rhyolite samples used to determine mass loss/gain for the footwall rhyolite, it would be unreasonable to assume that one sample from each stage of alteration of the Cranston tuff is representative of absolute mass change. The exercise does allow one to determine trends in mass change that accompanied the progressive replacement of the felsic volcaniclastic unit to form the massive sulfide and magnetite lenses.

Each of the samples was compared with the Gibson average rhyolite value to determine mass change using Huston's (1993) variation of Grant's (1986) method.

All ten data sets were run through the preliminary equations in order to determine at which point the least mobile elements present could be used to calculate mass change. The four samples which show varying degrees of sericite-quartz-sphalerite alteration have steady 
concentrations of $\mathrm{Al}, \mathrm{Ti}$, and $\mathrm{Y}$ relative to the Gibson standard. The following samples of chlorite and chlorite-sulfide alteration begin to show some mobility in these elements, whereas the remaining sulfide and magnetite samples contain very little of three elements, making mass change calculations unreliable.

Despite the apparently steady decrease in Si values from least altered to massive sulfide (Table 5.4), mass change calculations show a large increase in $\mathrm{Si}$ in the least altered tuff to a level that remains steady until the unit is affected by strong chloritization (ANSL8A-100A). The semi-massive sulfide-tuff sample shows the same level of silica enrichment as it contains relatively little chlorite alteration with respect to the amount of sulfide enrichment.

$\mathrm{Fe}, \mathrm{Mg}$ and $\mathrm{Mn}$ all show similar trends, with increases relative to unaltered rhyolite for the weak to moderately sericite-quartz-sphalerite altered samples, decreases in the strongly sericite altered tuff relative to the first two samples, and then increases in the chloritealtered sample. This trend may be related to the gradual destruction of $\mathrm{Mg}$-Fe smectites during sericitization, followed by the introduction of $\mathrm{Fe}$ and $\mathrm{Cu}$ sulfides and associated hydrothermal chlorite. The high sulfur values for the first two least altered samples indicate that some of the high Fe-Mn values are also due to the presence of sulfides.

The trend of increasing $\mathrm{K}$ and $\mathrm{Ba}$ values with increasing sericite-quartz-sphalerite alteration was expected, with large losses occurring in the strongly chloritized sample. Despite the presence of small quantities of hydrothermal albite in the sericitized tuff, the $\mathrm{Na}$ values are uniformily low. The low $\mathrm{Ca}$ and $\mathrm{Sr}$ values correspond to the destruction of primary plagioclase early in the alteration history of the deposit. Co is uniformily leached 
except in the semi-massive chalcopyrite-pyrrhotite sample, where it is enriched. Strongly increased values for $\mathrm{P}$ and $\mathrm{Cr}$ are present, with strong decreases in both elements within the strongly chlorite-altered tuff.

\subsection{SUMMARY OF ALTERATION MORPHOLOGY, MINERALOGY AND CHEMISTRY}

The host strata to the Ansil deposit have undergone 2 phases of pre-hydrothermal alteration and 4 phases of hydrothermal alteration, 3 of which were directly related to the formation of the orebody. The cooling footwall rhyolite lobe-hyaloclastite flow underwent varying degrees of devitrification and hydration. The glassy margins of the flow lobes underwent perlitic fracturing and devitrification, with abundant spherulite growth, whereas the more permeable, glass-rich interlobe hyaloclastite was more strongly affected by palagonization and clay formation. The cooling event was accompanied by the remobilization of $\mathrm{Si}$, with silica precipitation along perlitic fractures and as patchy concentrations within the hyaloclastite.

The graben containing the Ansil deposit was the focus of hydrothermal activity from the time the Flavrian andesite was erupted to the formation of the Amulet rhyolite. The presence of an elelvated geothermal gradient along this structure during the emplacement and cooling of the Northwest rhyolite resulted in enhanced diagenetic alteration in the near subsurface below the graben floor. This involved the alteration of the devitrified rhyolite to a fine-grained, granoblastic texture, and palagonite-rich fracture margins to chalcedony. The 
fracture-controlled alteration resulted in the formation of pseudoclastic textures developing along flow margins. Silica, chlorite and zeolites were deposited in open spaces within the hyaloclastite and flow breccias, and in vesicles within the flow lobes and breccia fragments. This alteration phase was responsible for the formation of the "blue quartz breccias", in which parts of the interlobe hyaloclastite was cemented together by chlorite inclusion-rich quartz.

It was during diagenesis that plagioclase porphyritic felsic dykes intruded below the graben. The heating of the surrounding, water-rich rhyolite resulted in the rapid silicification of the dykes and precipitation of silica in the surrounding rhyolite to form the quartzchlorite alteration zones. This phase of silicification and silica-dumping pre-dated the incursion of metal-rich fluids, and may represent the transition between diagenesis and hydrothermal activity.

Hydrothermal activity commenced with the formation of broad-scale spilitization of the host strata. This spilitization is overprinted by the alteration hydrothermal alteration directly related with the formation of the deposit, and therefore must pre-date it. Fluid-rock interaction responsible for spilitization requires conditions in which albite is stable, usually interaction with a slightly evolved seawater $\mathrm{Na}-\mathrm{Ca}$-Si-rich fluid, undersaturated with respect to $\mathrm{Mg}$ and $\mathrm{K}$, at over $200^{\circ} \mathrm{C}$ ) (Bischoff and Seyfried, 1966). These conditions are not usually present in the shallow subseafloor unless an unusually high geothermal gradient is present. With the close proximity of the underlying Flavrian Pluton, these conditions may 
have prevailed before the formation of the Ansil deposit, and denote the pervasive downdrawing of seawater into the cooling volcanic pile.

Local hydrothermal activity was initiated by hydrothermal brecciation of the rhyolite and Ansil dacite flows along the graben walls, infilling of the fracture system with Si-Na-Fe-Zn rich fluids, and attendant sericite-quartz alteration of the wallrocks. The emplacement of the Cranston tuff during this phase of hydrothermal activity resulted in the upflow of the fluids into the tuffs, and emplacement of sericite, quartz, albite, Fe-sulfides and sphalerite. This event involved net mass gains in $\mathrm{Si}, \mathrm{K}, \mathrm{Ba}, \mathrm{Fe}, \mathrm{Zn}, \mathrm{Pb}, \mathrm{Cu}$, and $\mathrm{Au}$, plus undetermined gains in $\mathrm{As}, \mathrm{Cd}, \mathrm{Ag}$ and $\mathrm{Se}$.

The sericite-quartz-sphalerite alteration event was overprinted by a phase of chlorite alteration which accompanied the formation of the footwall, pyrrhotite-chalcopyrite vein stockwork system. This fluid event occurred during the emplacement of the hangingwall andesitic flows, as it affects all of the Ansil host rocks. It would appear that the Nadepletion halo that surrounds the deposit formed as a front preceding this alteration phase. Alteration of the footwall rhyolite involved chlorite-quartz alteration of the hyaloclastite and flow breccia, with complete alteration of the previously clay-altered vitrophyre to chlorite and precipitation of quartz, pyrrhotite and chalcopyrite. Further into the centre of the upflow zone the rocks are completely chloritized, with finer-grained material replaced by pyrrhotite and chalcopyite. In the core of the alteration zone are zones of disseminated minnesotaite-greenalite, usually associated with quartz-chalcopyrite and pyrrhotitechalcopyrite veins. 
The formation of the massive sulfide orebody involved the replacement and dissolution of parts of the graben-hosted Cranston tuff and hyaloclastite-rich parts of the overlying andesitic flows. The fine-grained matrix of the Cranston tuff was replaced by chlorite, then chlorite-pyrrhotite-chalcopyrite and finally pyrrhotite-chalcopyrite, with minor quartz, stilpnomelane, minnesotaite and greenalite. Quartz phenoclasts were largely resorbed, with the coarse-grained bases to the tuff layers remaining to form the sieve-textured ore.

The hydrothermal activity responsible for the formation of the orebody continued up through the hangingwall andesitic flows, with fluids altering hyaloclastite-rich flow contacts and precipitiating sulfides. This resulted in a dendritic alteration system with a chlorite-Curich core and sericite-Zn-rich margins.

The chlorite-sulfide phase was followed calc-silcate alteration, during which a chloriteepidote-albite-pyrite alteration assemblage formed in the footwall rhyolite, and a coarsegrained, hedenbergite-andradite skarn formed in patches about the massive sulfide lens. The second half of this alteration phase involved emplacement of magnetite-rich veins in the footwall, with attendant chlorite-carbonate-magnetite alteration of the previously-formed epidote. The hedenbergite-andradite skarn was first altered to ferroactinolite and quartz, and then to Fe-dolomite-magnetite-stilpnomelane-greenalite. This alteration phase involved the replacement of parts of the massive sulfide lens with magnetite-carbonatestilpnomelane-greenalite.

The formation of the massive sulfide lens through gradual replacement of Cranston tuff and the base of the hangingwall andesite took place during the hydrothermal activity that 
resulted in the alteration and mineralization of the andesite for $500 \mathrm{~m}$ above the deposit.

For this reason the formation of the deposit is considered to be part of a through-going hydrothermal fluid system, and not the end-product. 
PAGINATION ERROR.

TEXT COMPLETE.

NATIONAL LIBRARY OF CANADA. CANADIAN THESES SERVICE.
ERREUR DE PAGINATION.

LE TEXTE EST COMPLET.

BIBLIOTHEQUE NATIONALE DO CANADA. SERVICE DES THESES CANADIENNES. 
Figure 5.1

A. Photomicrograph of a chlorite and quartz pseudomorph after zeolite. Also note perlitic fracture rimmed with inclusion-rich quartz (after chalcedony) and infilled with clear quartz. Field of view $2 \mathrm{~mm}$ across.

B. Photomicrograph of diagenetic alteration nucleating about perlitic fracture in quartzchlorite altered rhyolite. Ovoid forms are a product of alteration of glass to gel palagonite which in turn is first replaced by chalcedony and then quartz. Field of view $4 \mathrm{~mm}$ across.

C. Photomicrograph of advanced diagenetic alteration in quartz-chlorite altered rhyolite, with silicification centred about perlitic fractures. Inclusion-rich quartz pseudomorphous after gel palagonite through chalcedony. Note possible liesegang rings of Fe-oxide enriched quartz. Field of view $4 \mathrm{~mm}$ across.

D. Photomicrograph of intricate liesegang banding of diagenetic structures about perlitic fractures in quartz-chlorite altered rhyolite. Abundant Fe-oxide suggests a gel palagonite precursor. Field of view $2 \mathrm{~mm}$.

E. Photomicrograph of granoblastic textured rhyolite product of late stage devitrification (granophyre). Infilling of perlitic fractures by axiolitic chlorite and granular quartz are diagenetic products after original fibrous palagonite and chalcedony. Field of view $4 \mathrm{~mm}$.

F. Photomicrograph of late stage diagenetic alteration with abundant quartz (after chalcedony) alteration of glass adjacent to perlitic fractures and infilling the fractures. Note liesegang rings about fracture axis. This diagenetic alteration stage gives the quartzchlorite altered rhyolite a distinctive mottled texture. Field of view $4 \mathrm{~mm}$. 

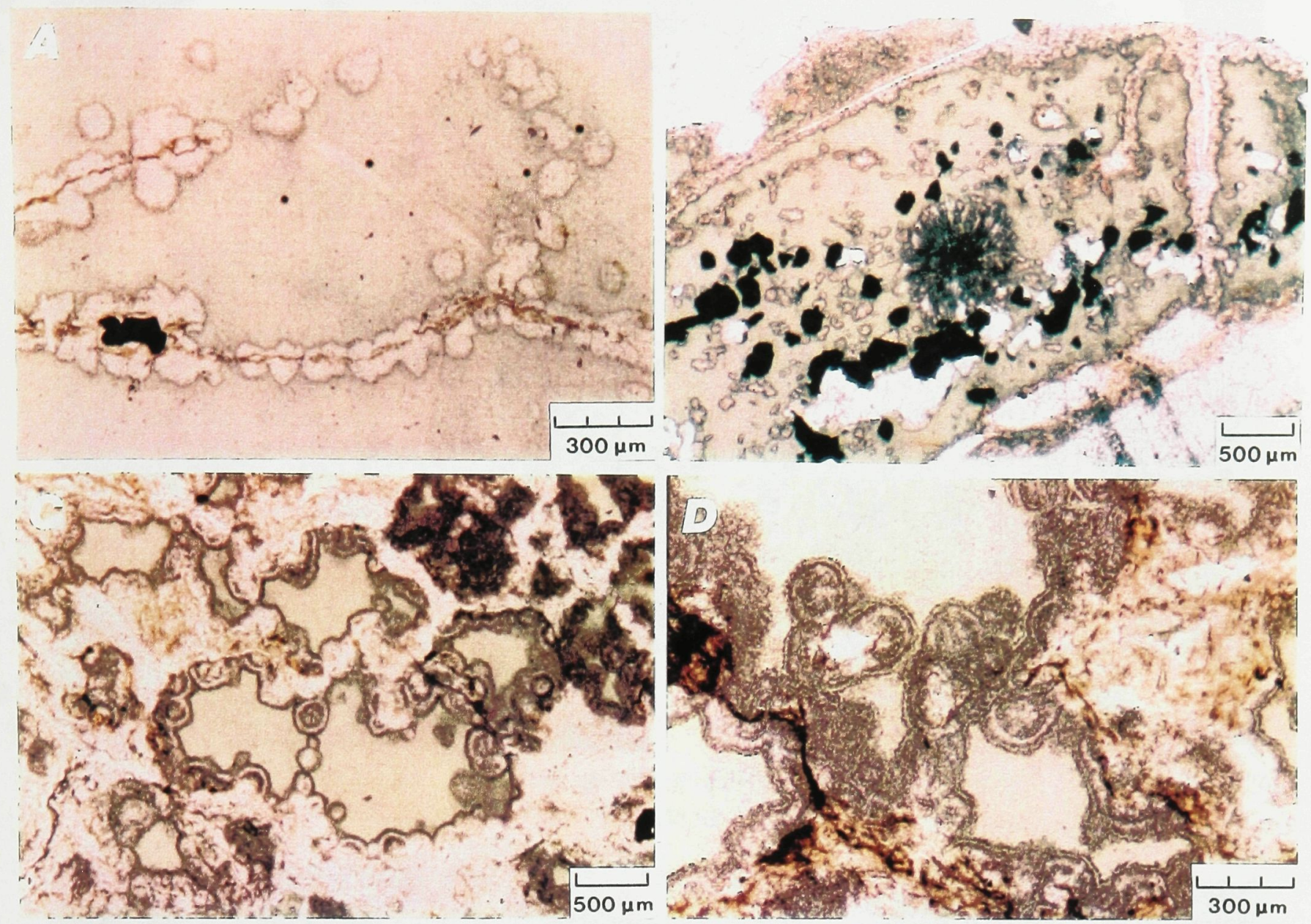

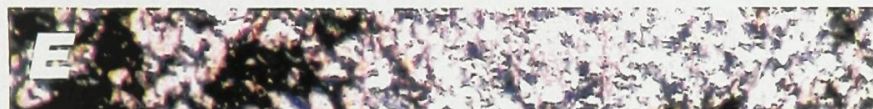

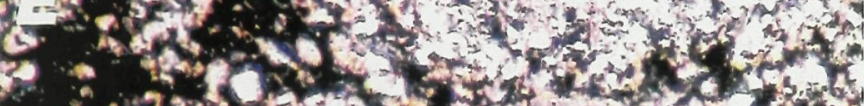

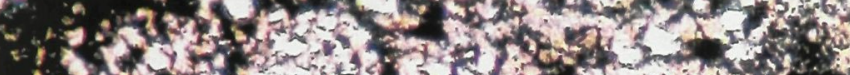

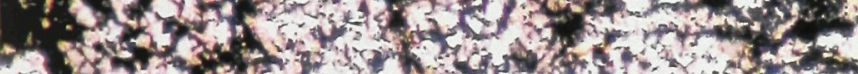

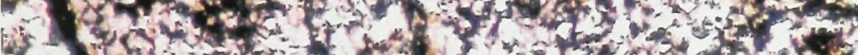

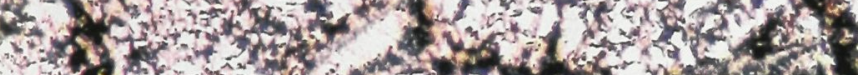

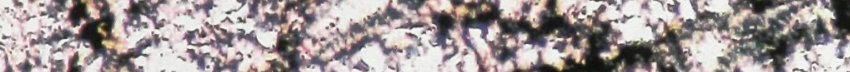

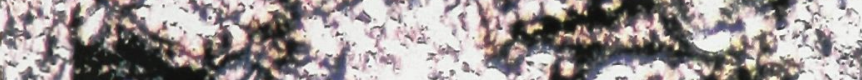

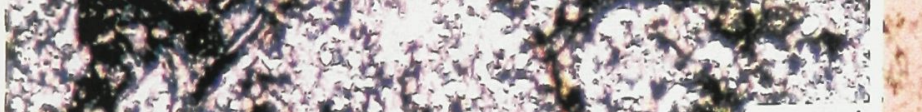

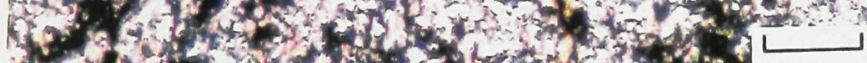

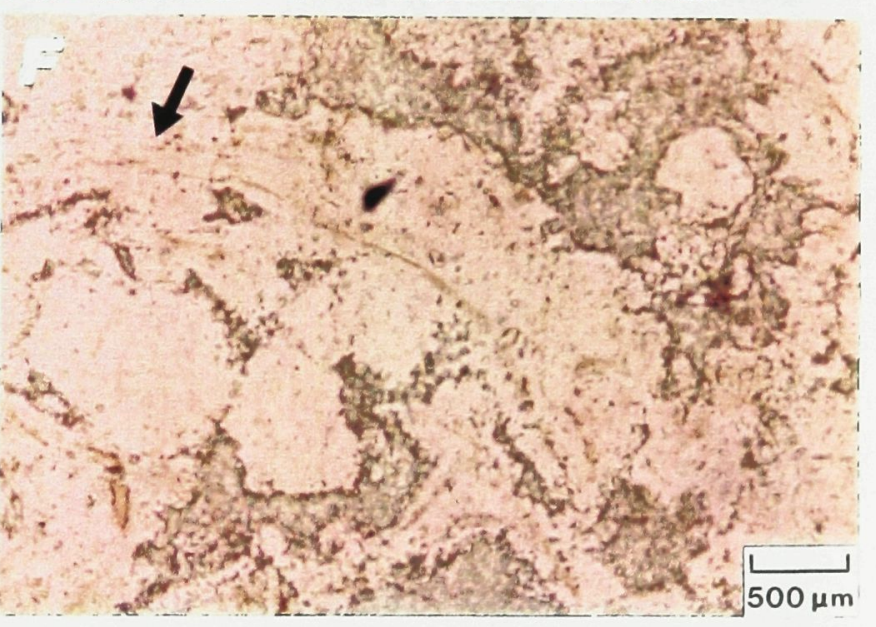




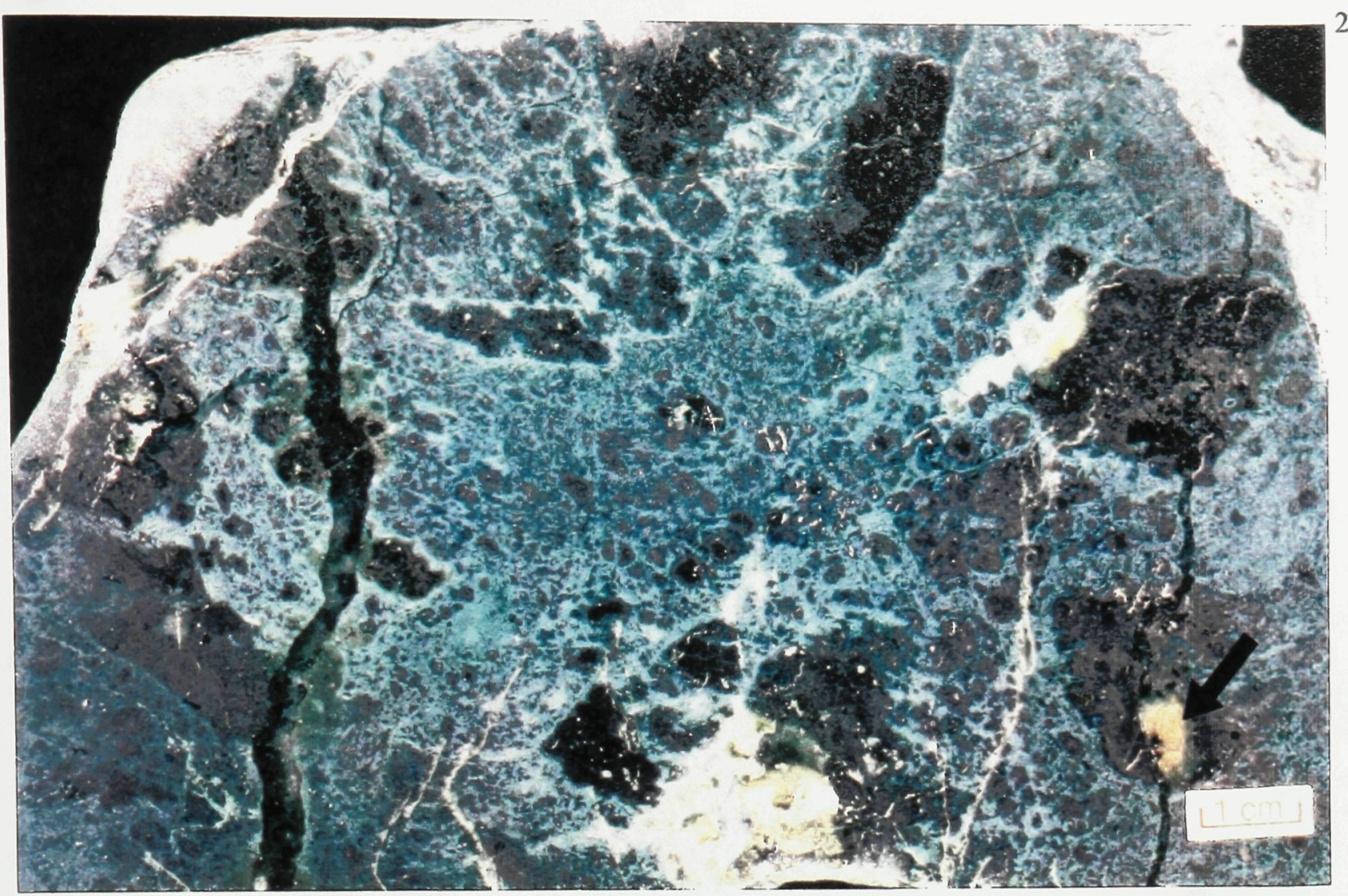

Figure 5.2 Polished slab showing quartz-chlorite-altered rhyolite breccia with abundant, chlorite inclusion-rich quartz (after chalcedony?) infilling hyaloclastite-rich matrix ("blue quartz breccias"). Sample ANSL8A-118

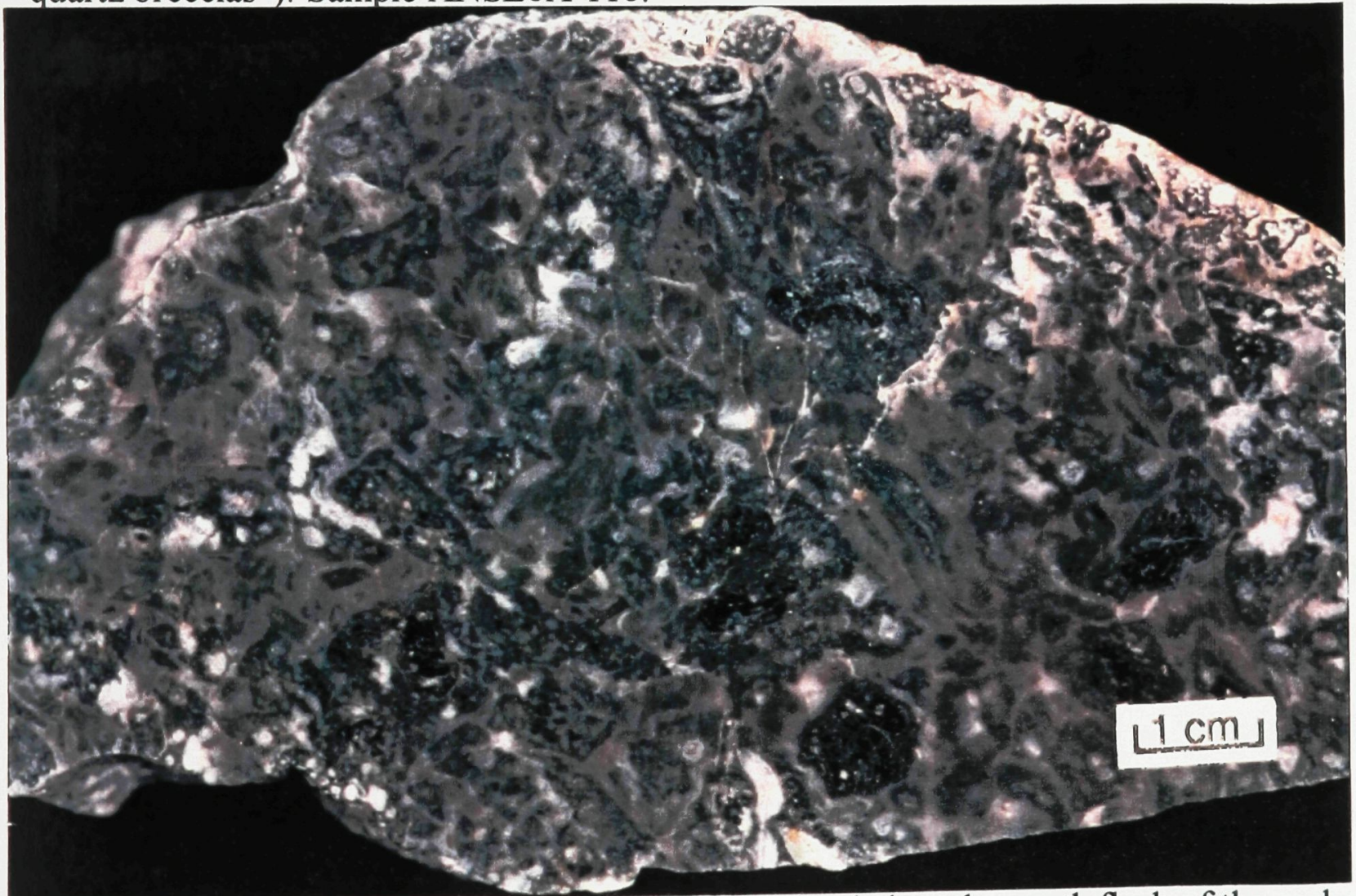

Figure 5.3 Polished slab showing intense silicification below the south flank of the orebody as part of the quartz-chlorite alteration facies. Sample ANSL8A-172. 
Figure 5.4 Alteration facies at the Ansil deposit

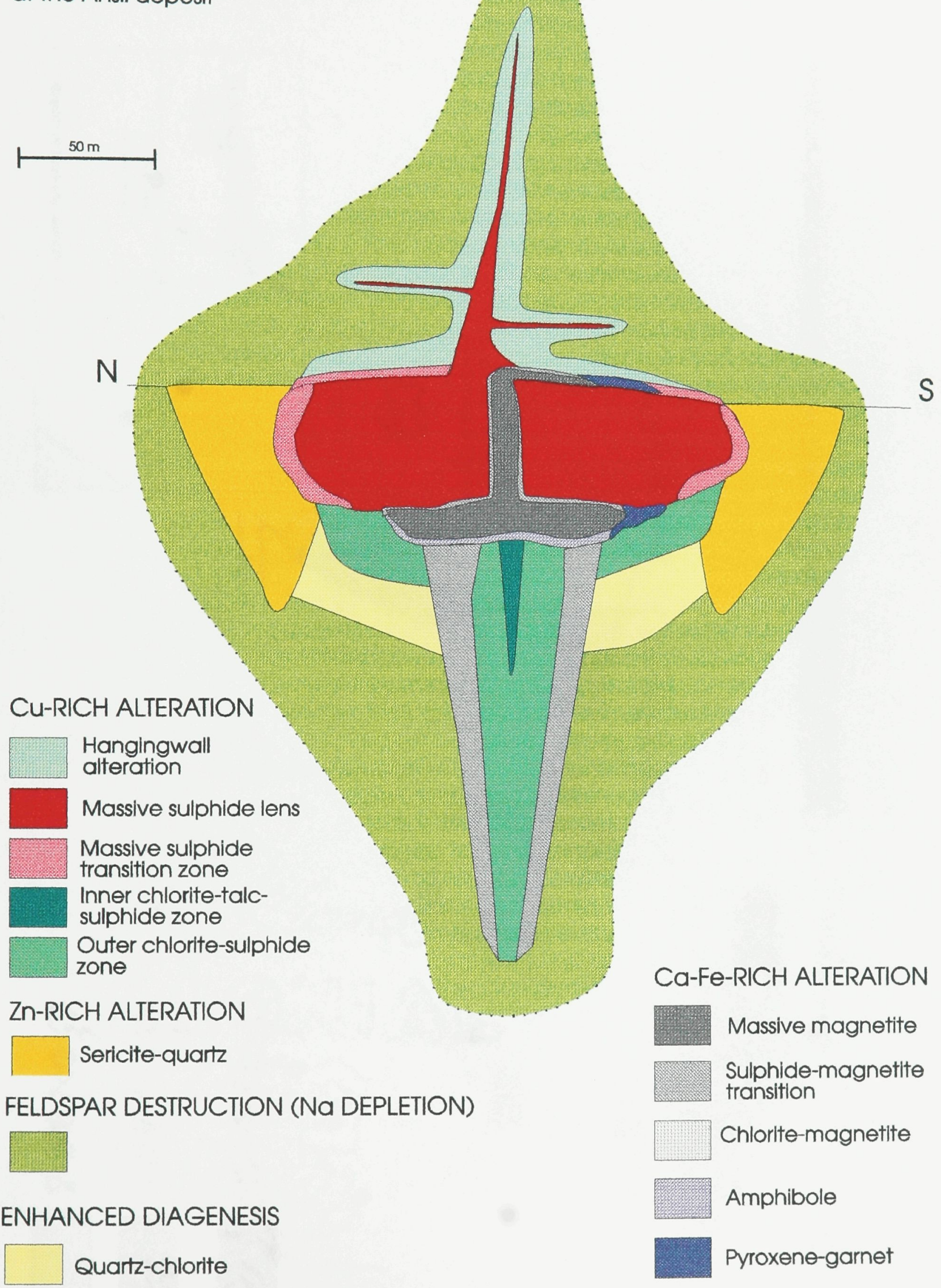




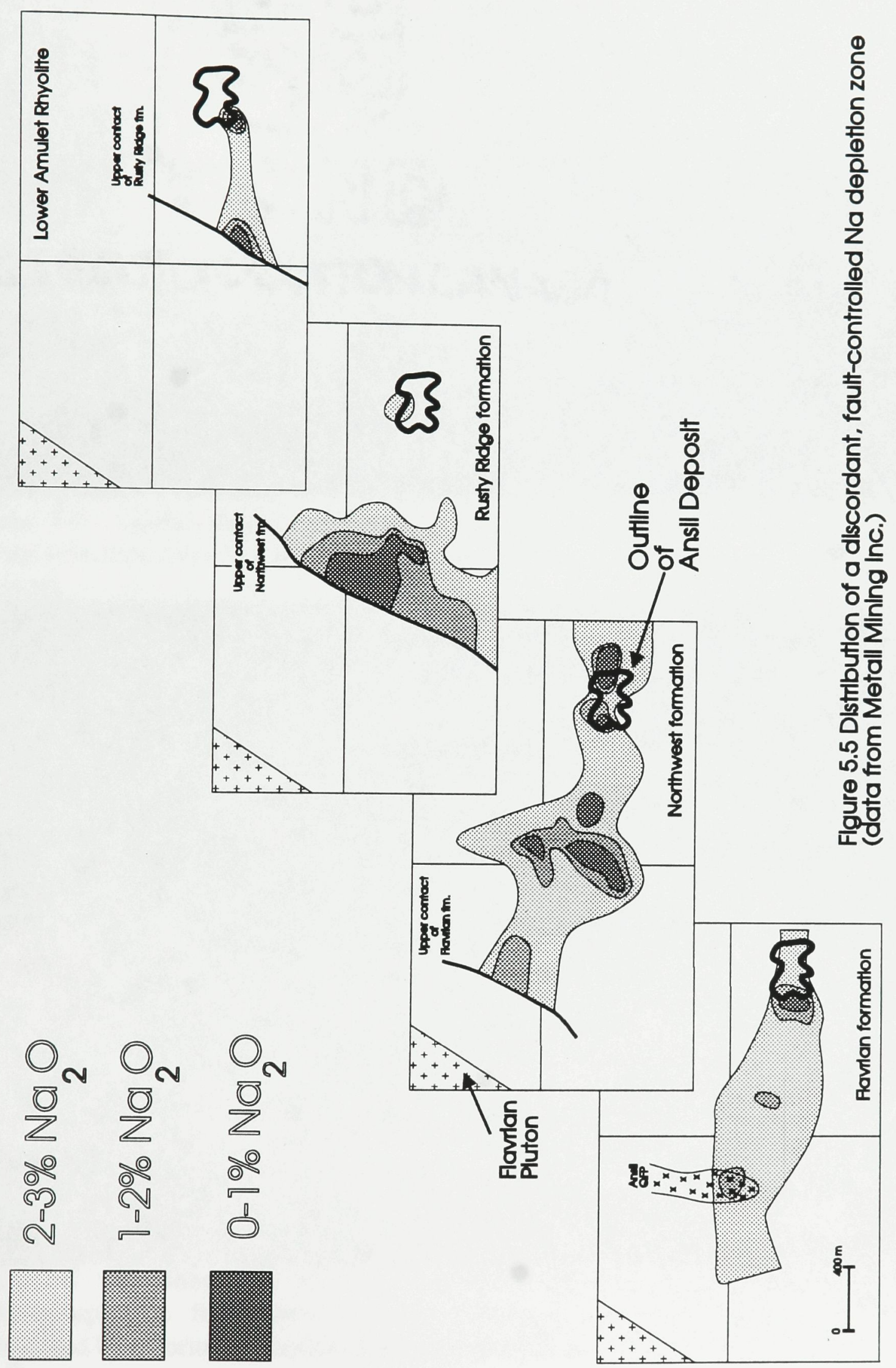




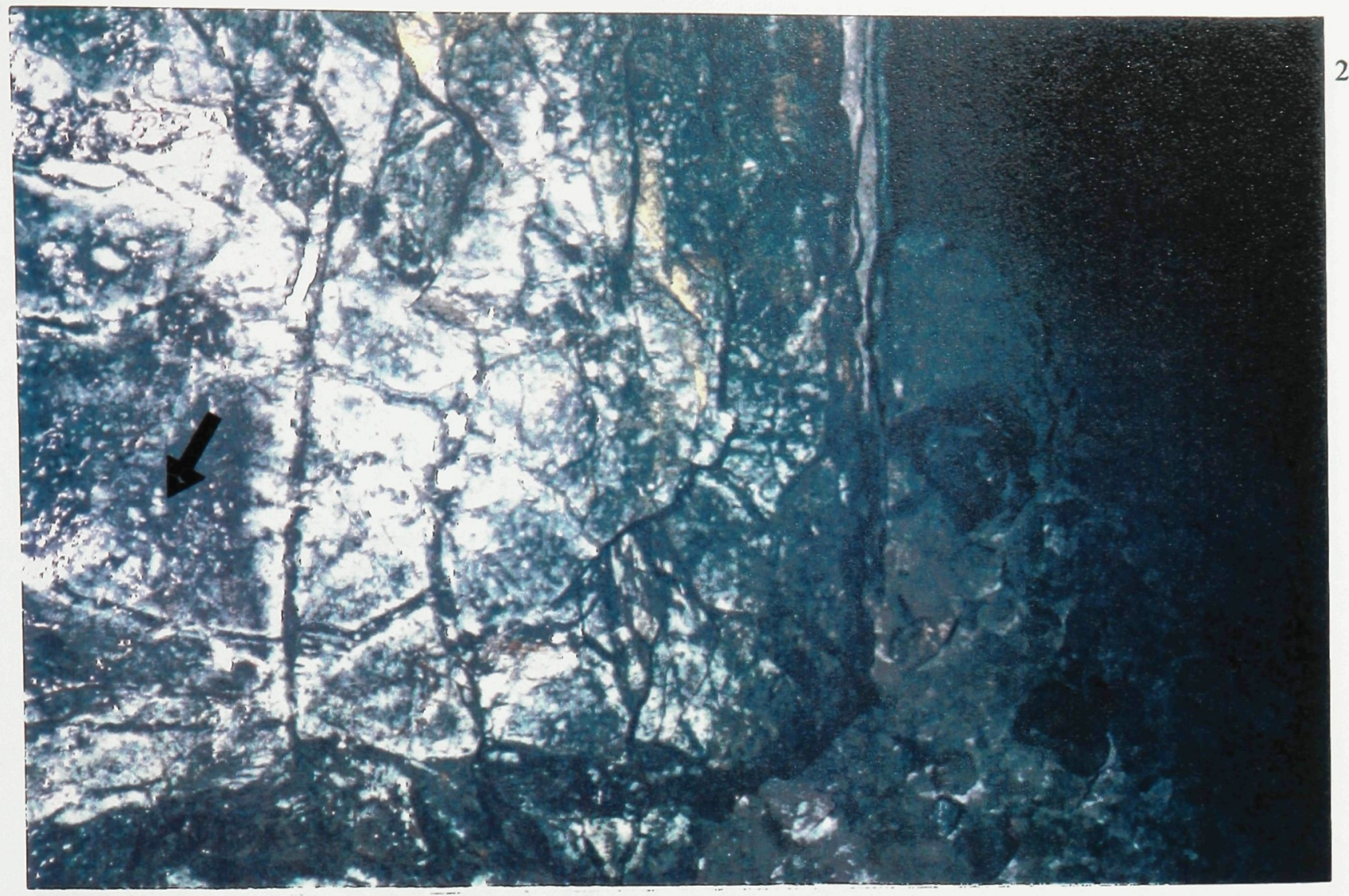

Figure 5.6 Quartz-chlorite alteration of plagioclase glomeroporhyritic rhyolite dyke. Strong reticulate fracture pattern infilled with chlorite, quartz and albite. Field of view 2.5 $\mathrm{m}$ across.

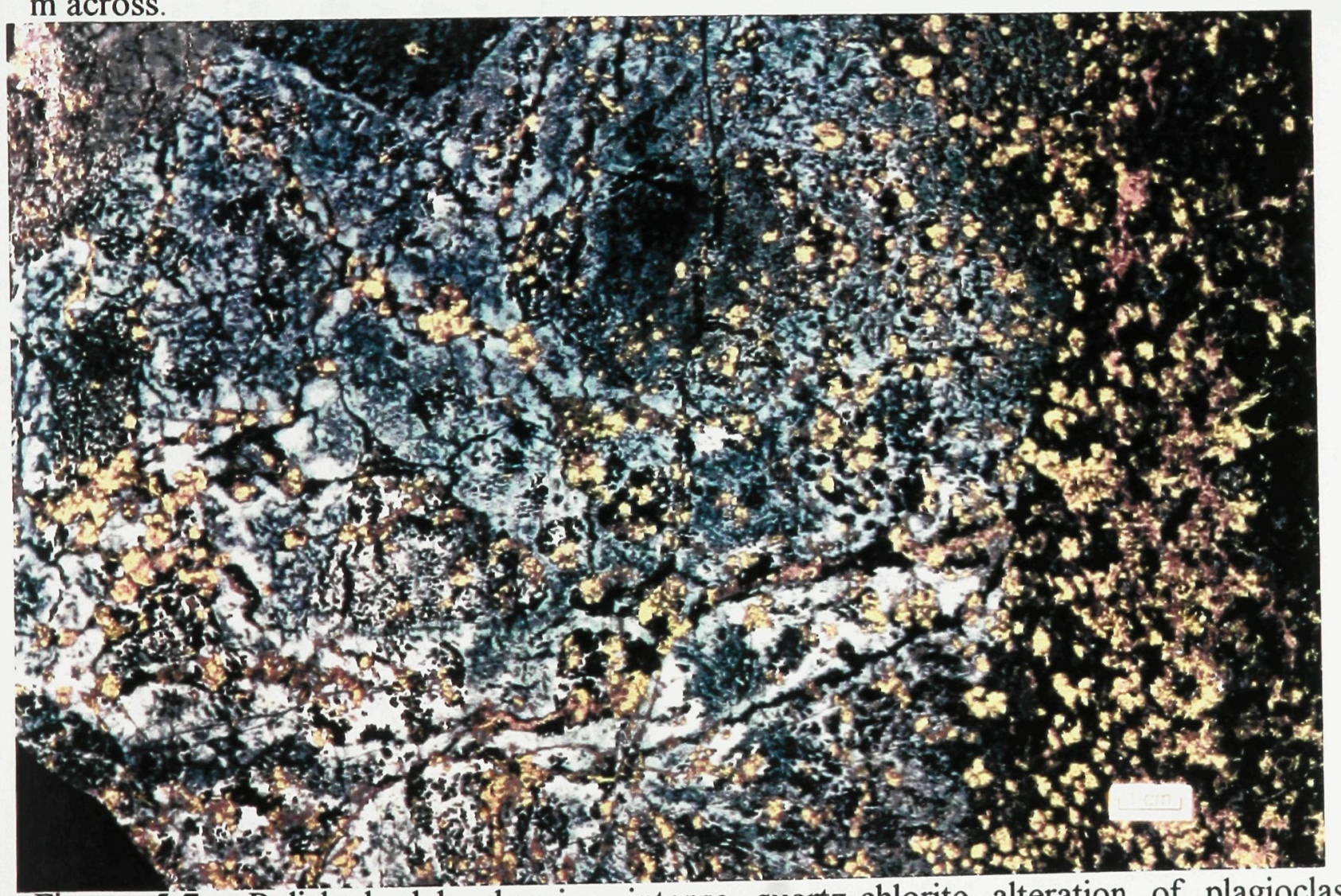

Figure 5.7 Polished slab showing intense quartz-chlorite alteration of plagioclase glomeroporphyritic felsic dyke imparts a distinctive, mottled texture on the rock. Overprinted by chlorite-pyrrhotite-chalcopyrite alteration. Sample ANSL7B-87. 


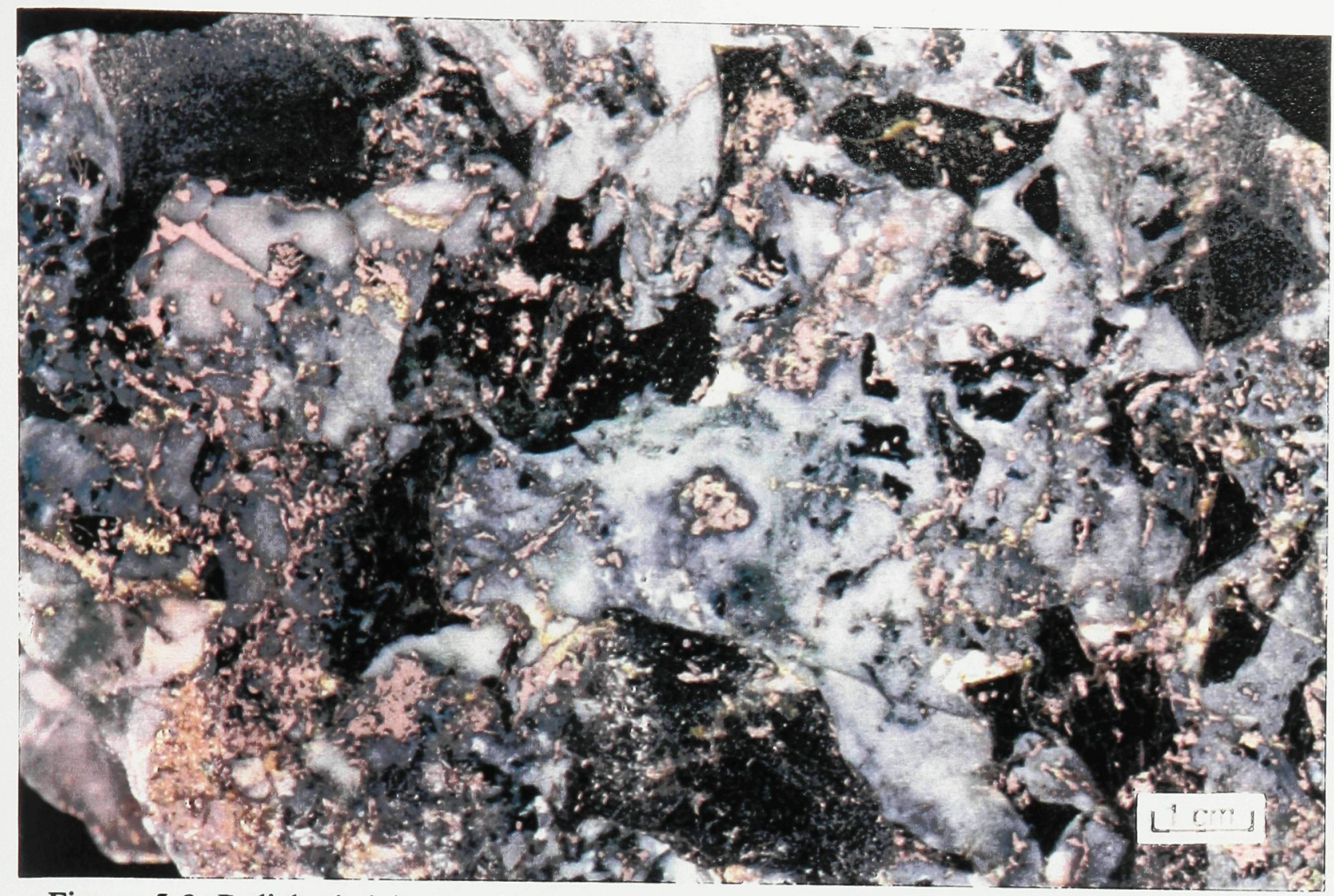

Figure 5.8 Polished slab showing intense quartz flooding of rhyolite hyaloclastite along the margins of the quartz-chlorite alteration zone under south flank of orebody. Sample ANSL9-170.

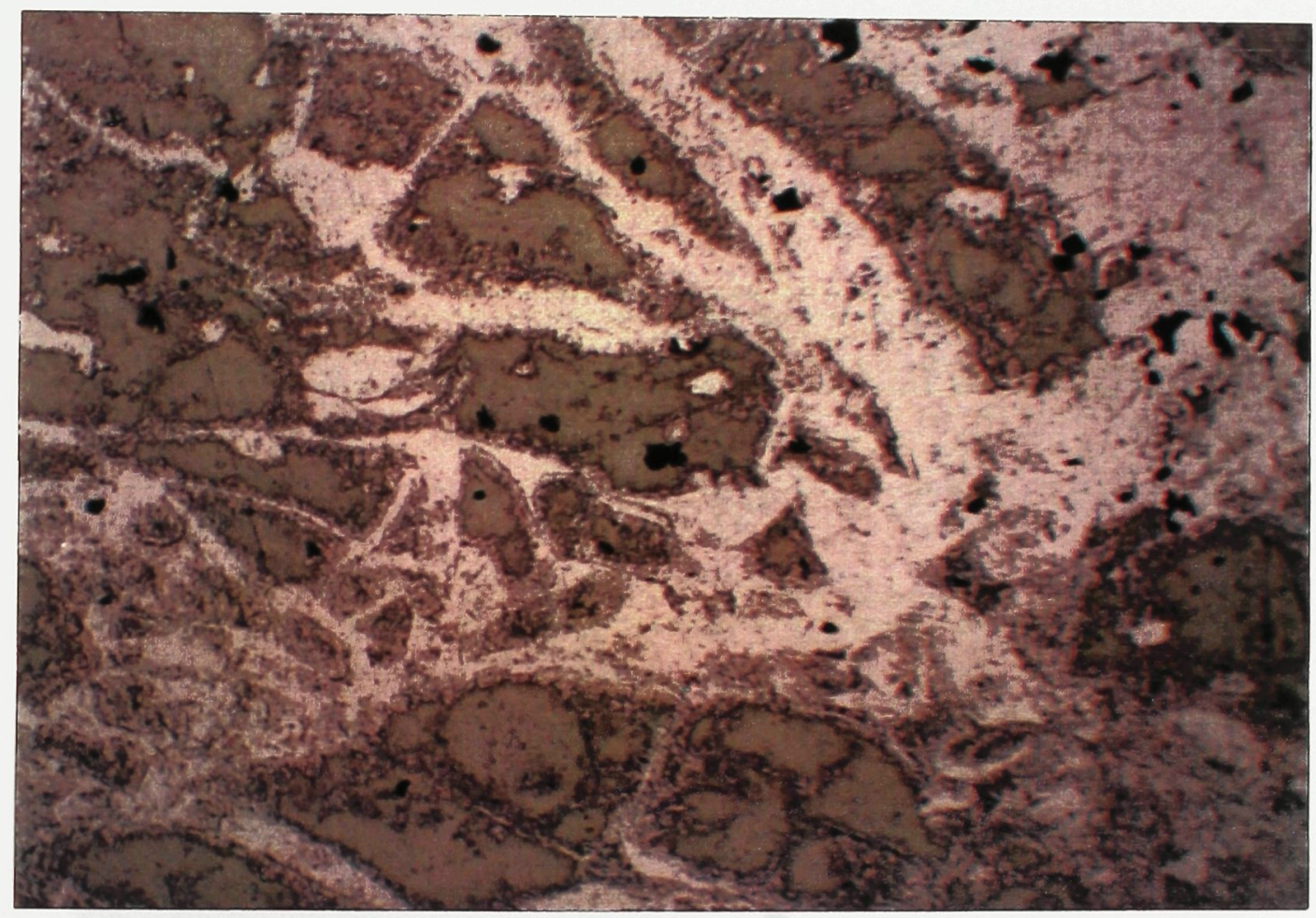

Figure 5.9 Photomicrograph showing silicification of hydrated glass in a perlitic fractured, massive rhyolite lobe margin. Part of quartz-chlorite alteration facies. Field of view $4 \mathrm{~mm}$. Sample ANSL8-55A. 


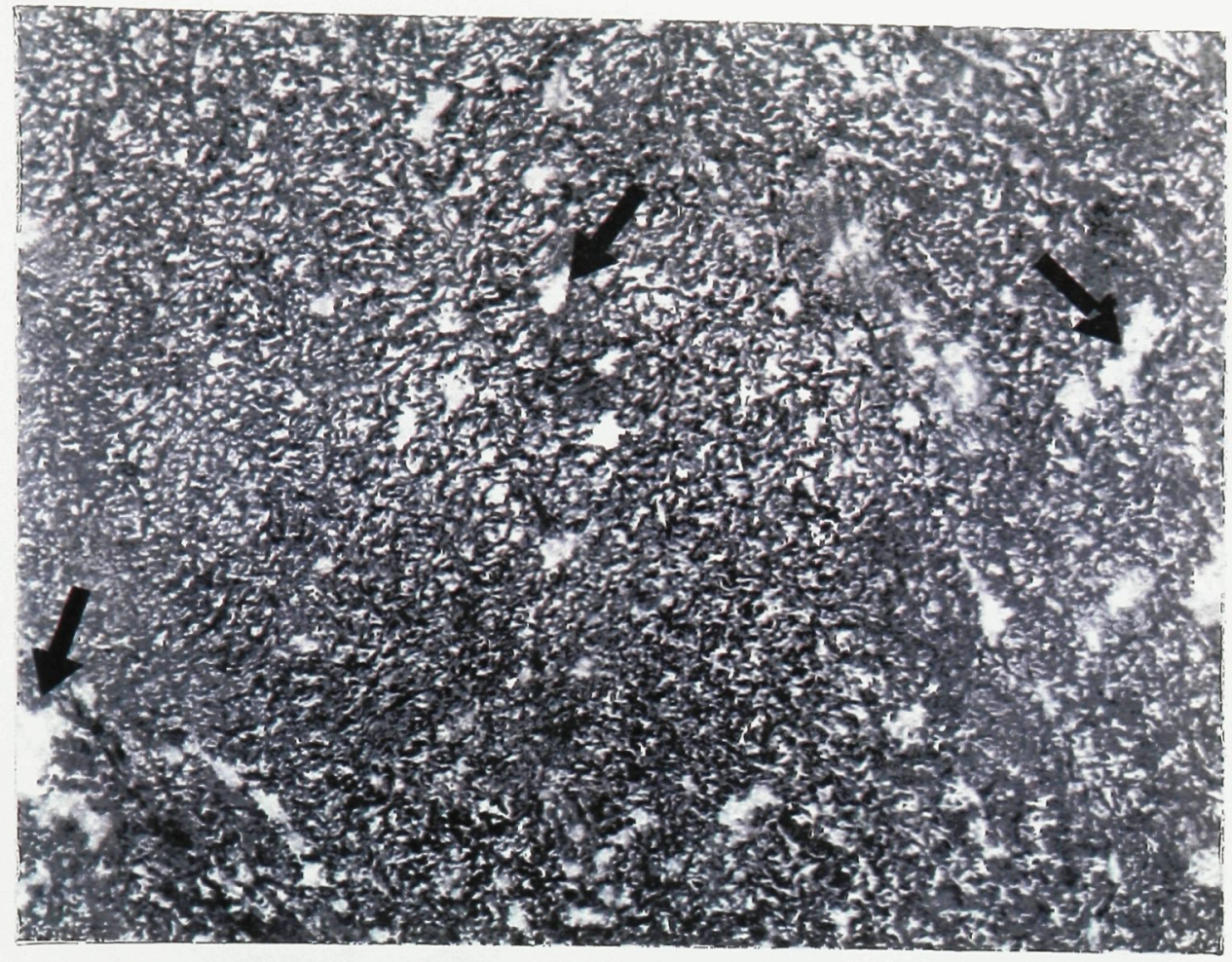

Figure 5.10 Polished slab showing mottled texture of quartz-chlorite altered, plagioclase glomeroporhyritic felsic dyke. Some crystal clusters up to $3 \mathrm{~cm}$ across (arrow). Sample ANSL7B-84.

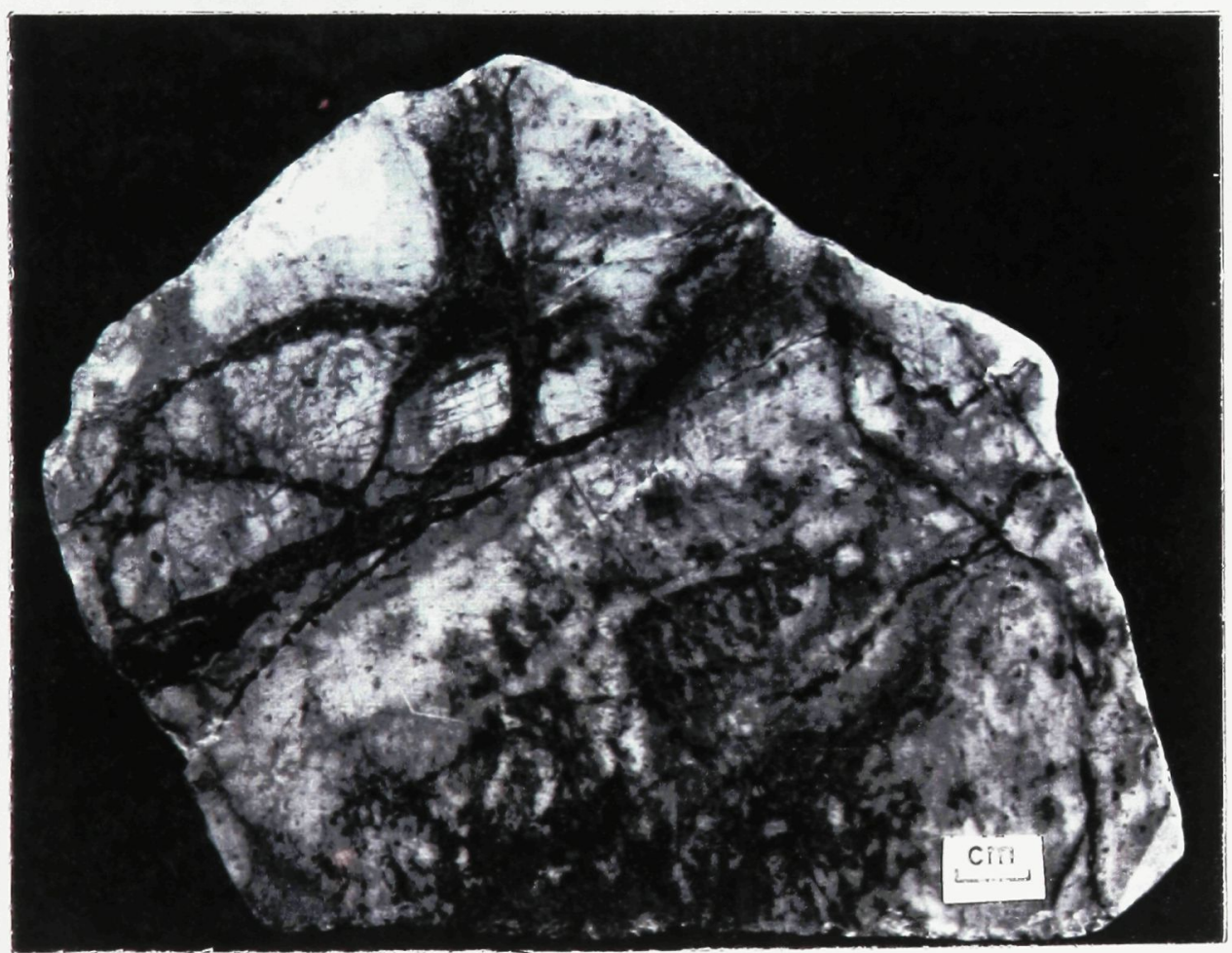

Figure 5.11 Polished slab showing intense silicification of rhyolite, accompanied by chlorite-quartz-albite veins. Sample ANSL8-59. 


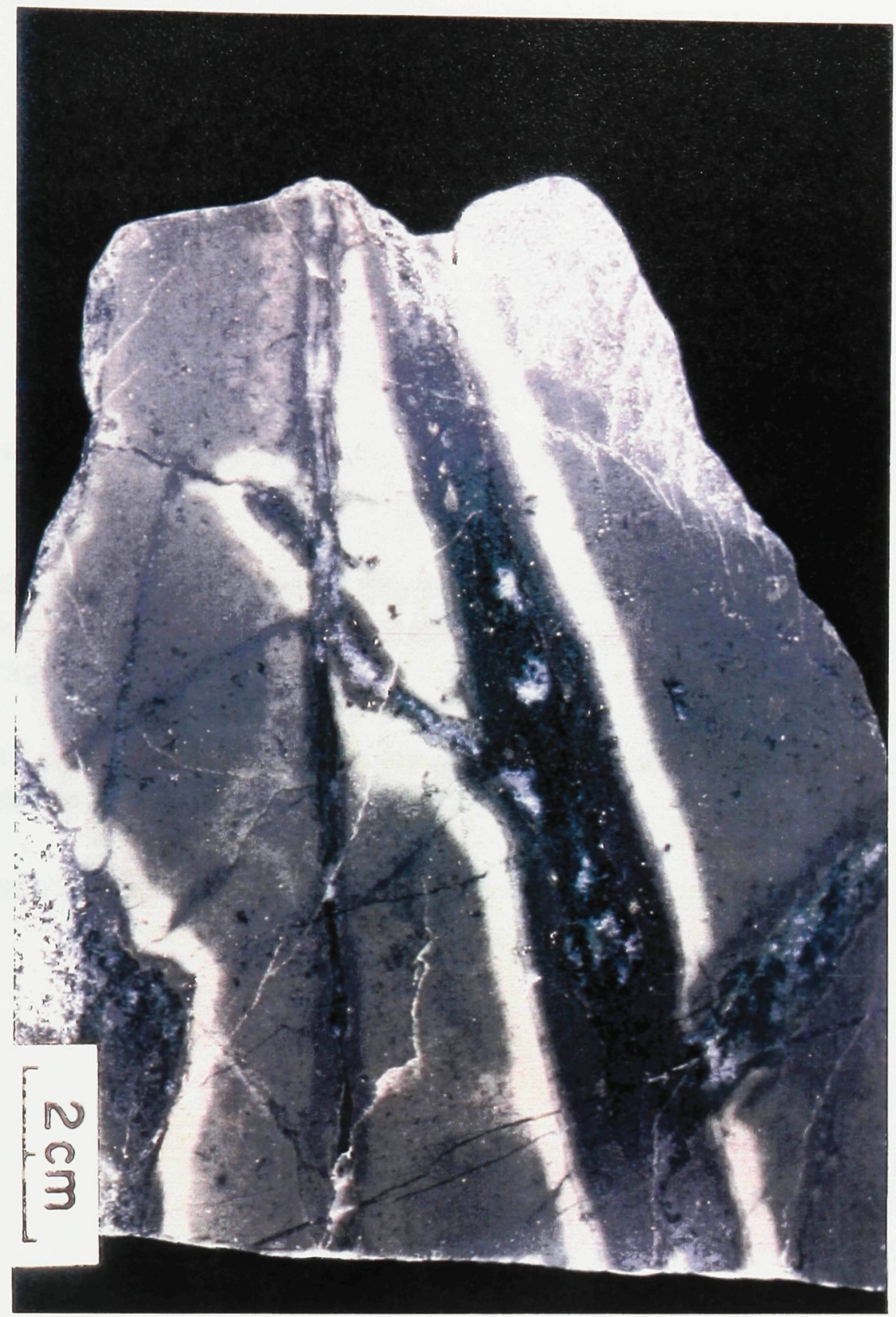

Figure 5.12 Polished slab showing halo of intense sericite-quartz alteration about chloritequartz-albite vein. Sample ANSL8-47. 
Figure 5.13

A. Photomicrograph of intense sericite alteration of Cranston tuff. Field of view $4 \mathrm{~mm}$ across.

B. Photomicrograph of normally graded Cranston tuff layer, with sericite-quartz-albitesphalerite-Fe sulphide precipitation concentrated along the coarse-grained base. Field of view $4 \mathrm{~mm}$ across.

C. Photomicrograph of intense sericite-quartz alteration of Cranston tuff with intergrown sphalerite and sericite. Field of view $2 \mathrm{~mm}$ across.

D. Photomicrograph of quartz-albite cluster rimmed by sphalerite and pyrrhotite. Field of view $1 \mathrm{~mm}$. 


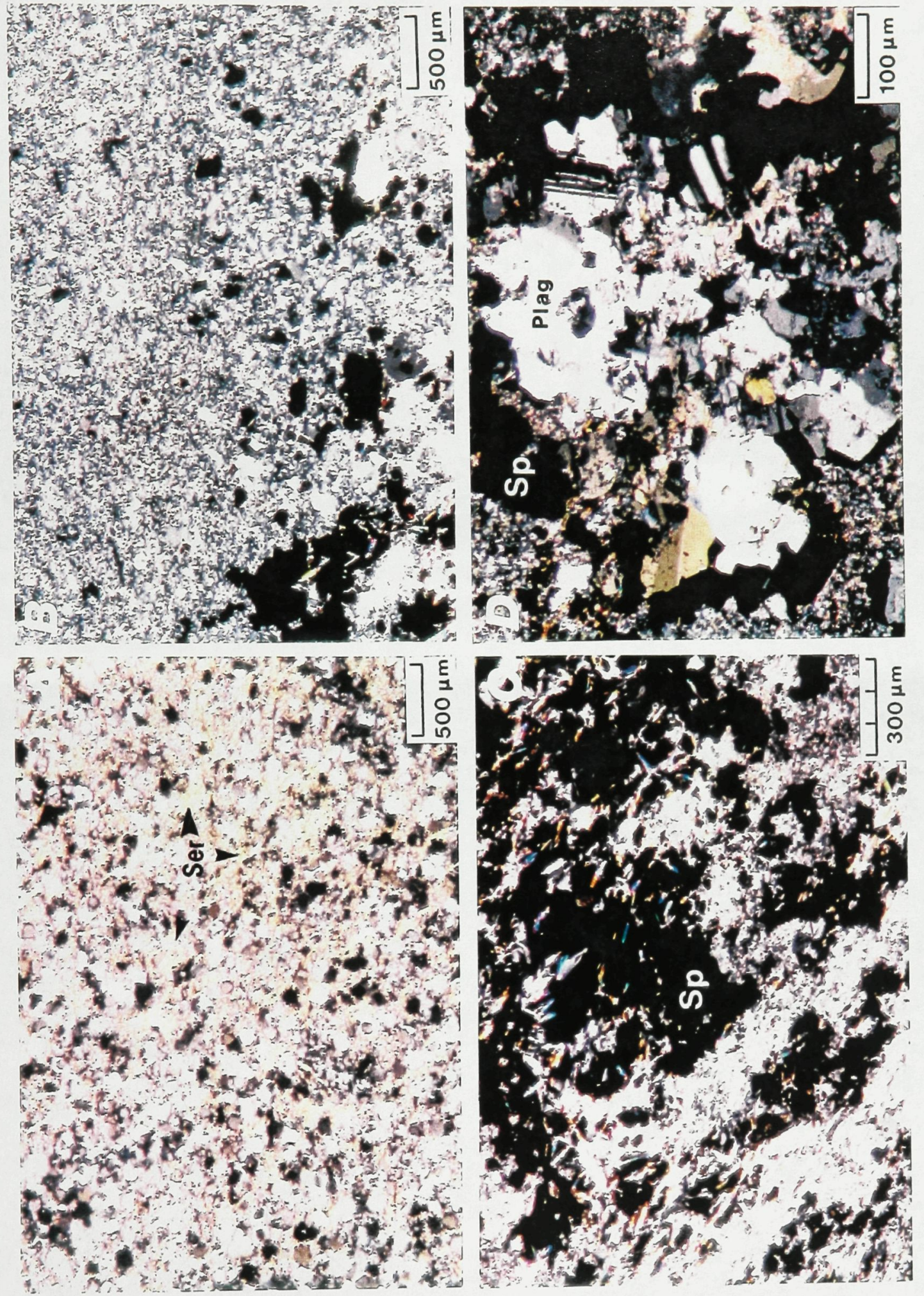




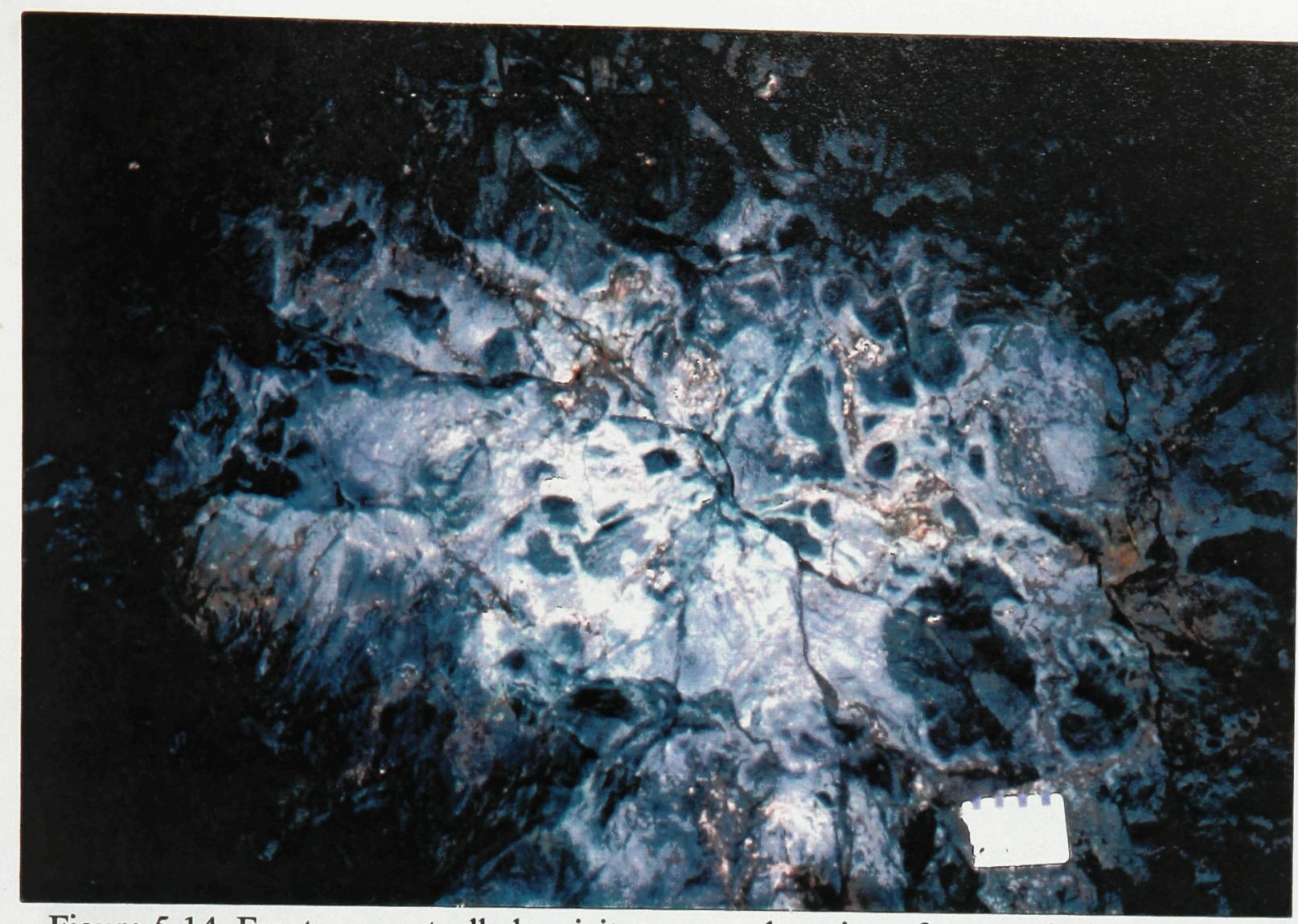

Figure 5.14 Fracture-controlled sericite-quartz alteration of in situ dacite fragments within an hydrothermal explosion breccia zone under the south flank of the orebody (Sublevel 11A). Centimetre card for scale.

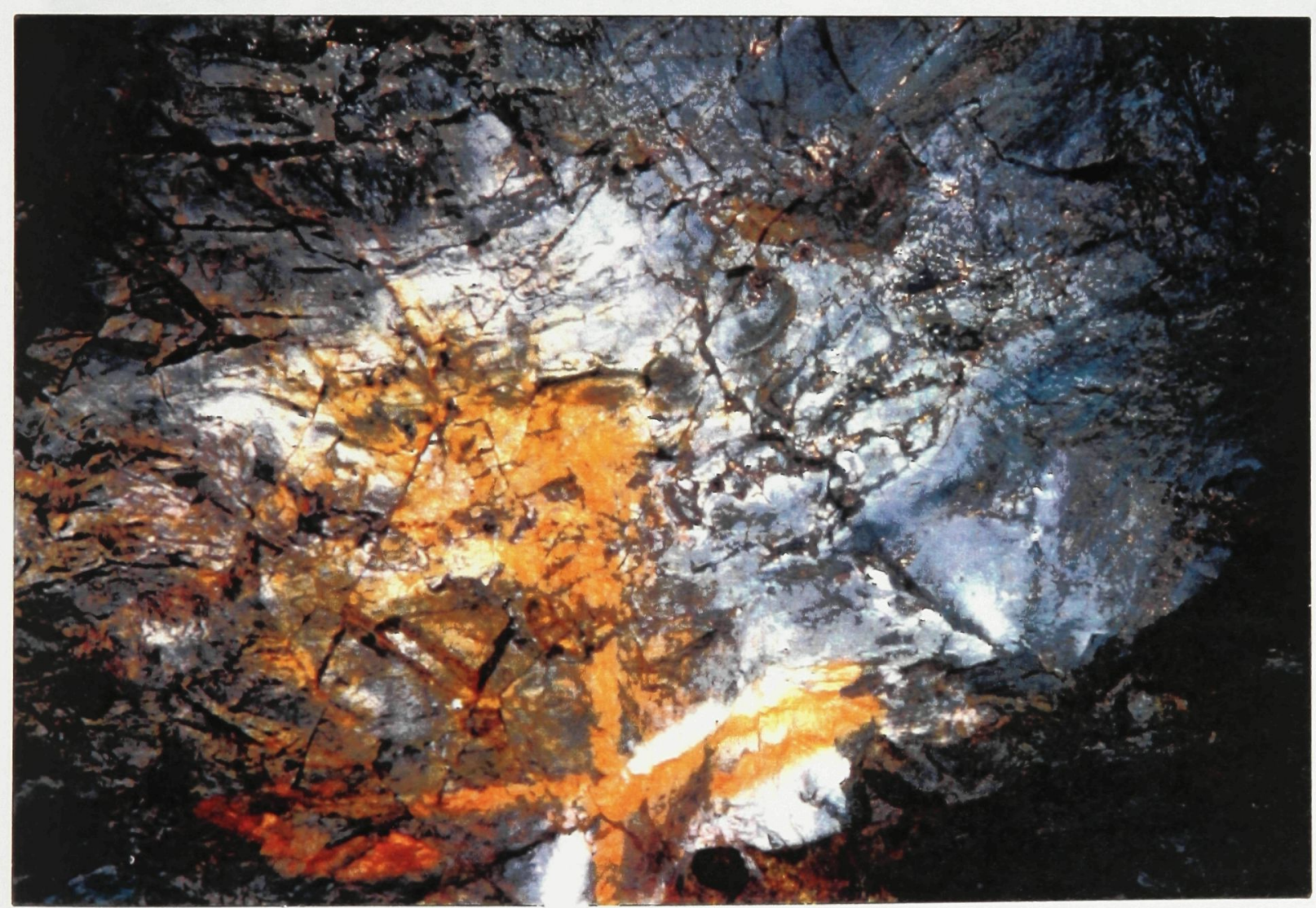

Figure 5.15 Pervasive sericite-quartz alteration of fractured dacite from within a $\mathrm{Zn}$-rich zone below the south flank of the orebody (Sublevel 11A). 


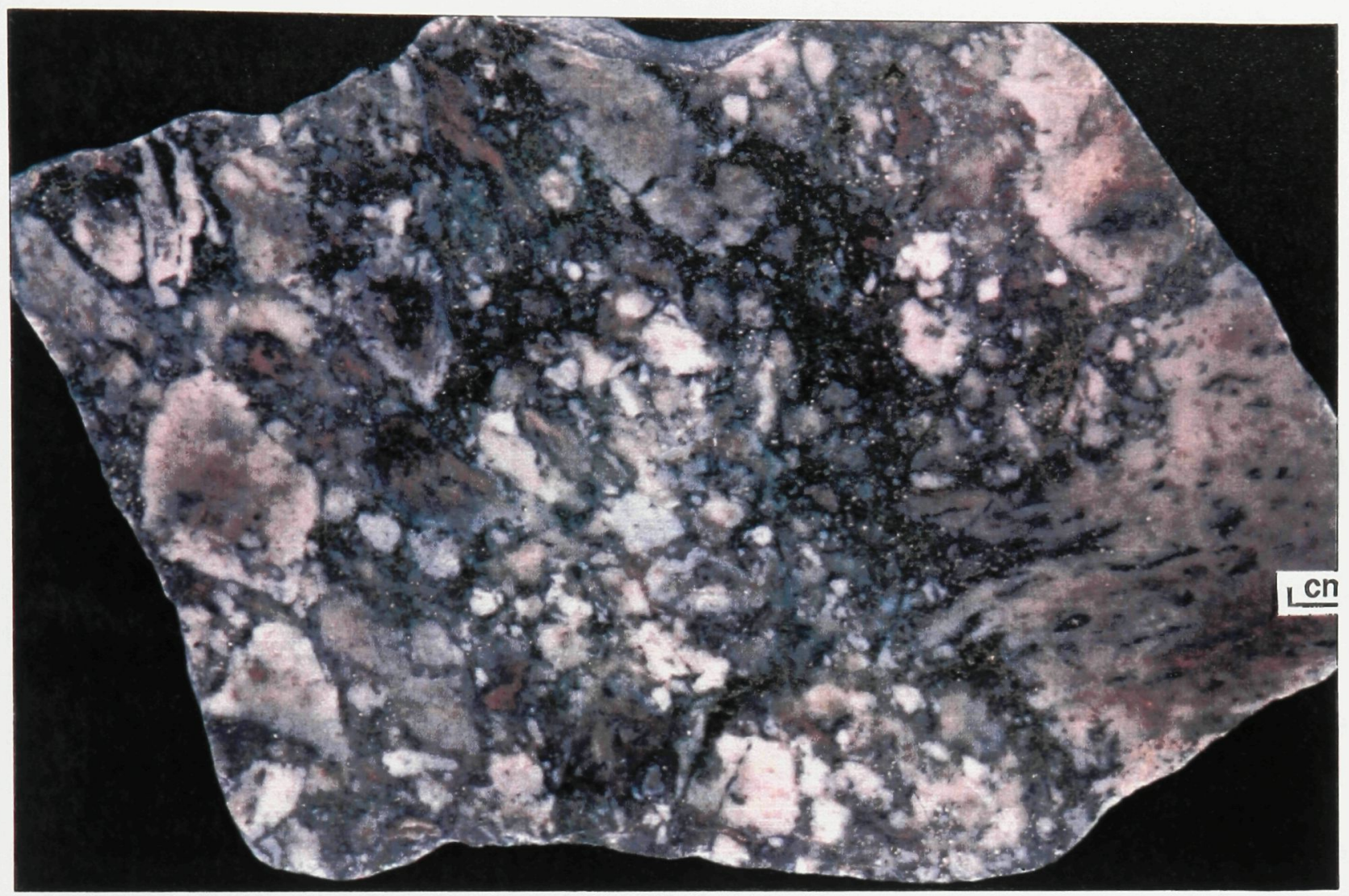

Figure 5.16 Polished slab showing a disrupted hydrothermal explosion breccia below the north flank of the orebody. Sample ANSL10-16. 


\section{Figure 5.17}

A. Backscatter image of delicately zoned pyrite crystal from sericite-quartz alteration facies. Crystal appears to be partially corroded, with rimming by pyrrhotite and chalcopryrite.

B. Backscatter image of rutile crystal partially altered to ilmenite with the chlorite-sulphide alteration facies.

C. Backscatter image of altered hangingwall andesite near the massive sulphide contact, with rutile altering to ilmenite in the presence of chalcopyrite.

D. Backscatter image showing complex intergrowth of allanite, apatite, titanite, rutile and xenotime within the chlorite-sulphide alteration facies.

E. Backscatter image of intergrown minnesotaite and chalcopyrite in Mg-rich chlorite groundmass within core of chlorite-sulphide alteration facies.

F. Backscatter image of stilpnomelane intergrown with chalcopyrite in massive sulphide lens. 

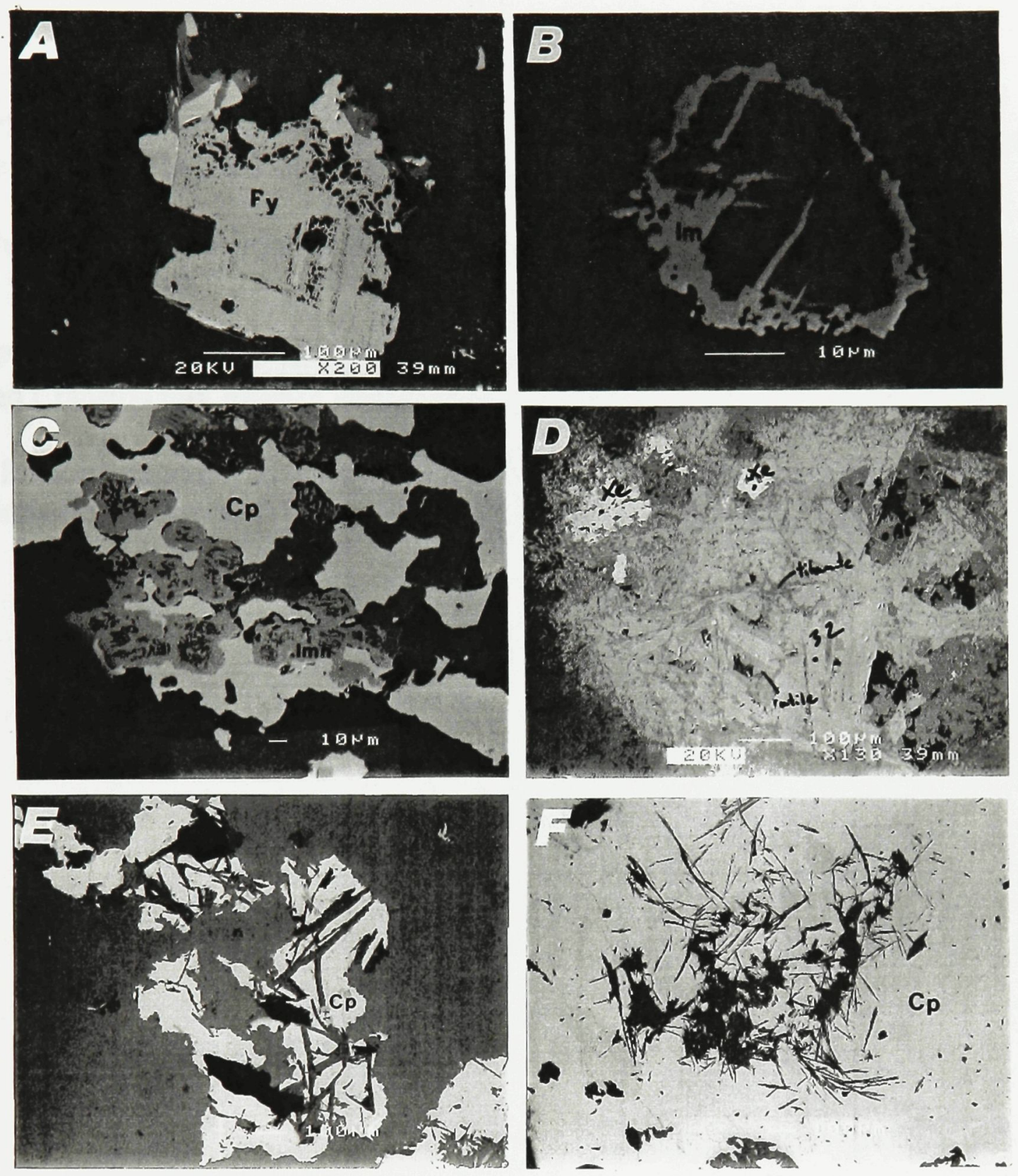


\section{Figure 5.18}

A. Photomicrograph of chlorite veinlet cross-cutting sericite-quartz altered Cranston tuff at the margin of the massive sulphide lens. Field of view $4 \mathrm{~mm}$.

B. Photomicrograph of weak chlorite spotting within sericite-quartz altered Cranston tuff. Field of view $4 \mathrm{~mm}$.

C. Photomicrograph of moderate chlorite mottling and replacement of sericite-quartzaltered Cranston tuff. Field of view $4 \mathrm{~mm}$.

D. Photomicrograph of hydrothermal albite crystal aggregate rimmed and infilled by chalcopyrite and pyrrhotite in altered andesitic flow. Field of view $2 \mathrm{~mm}$. 


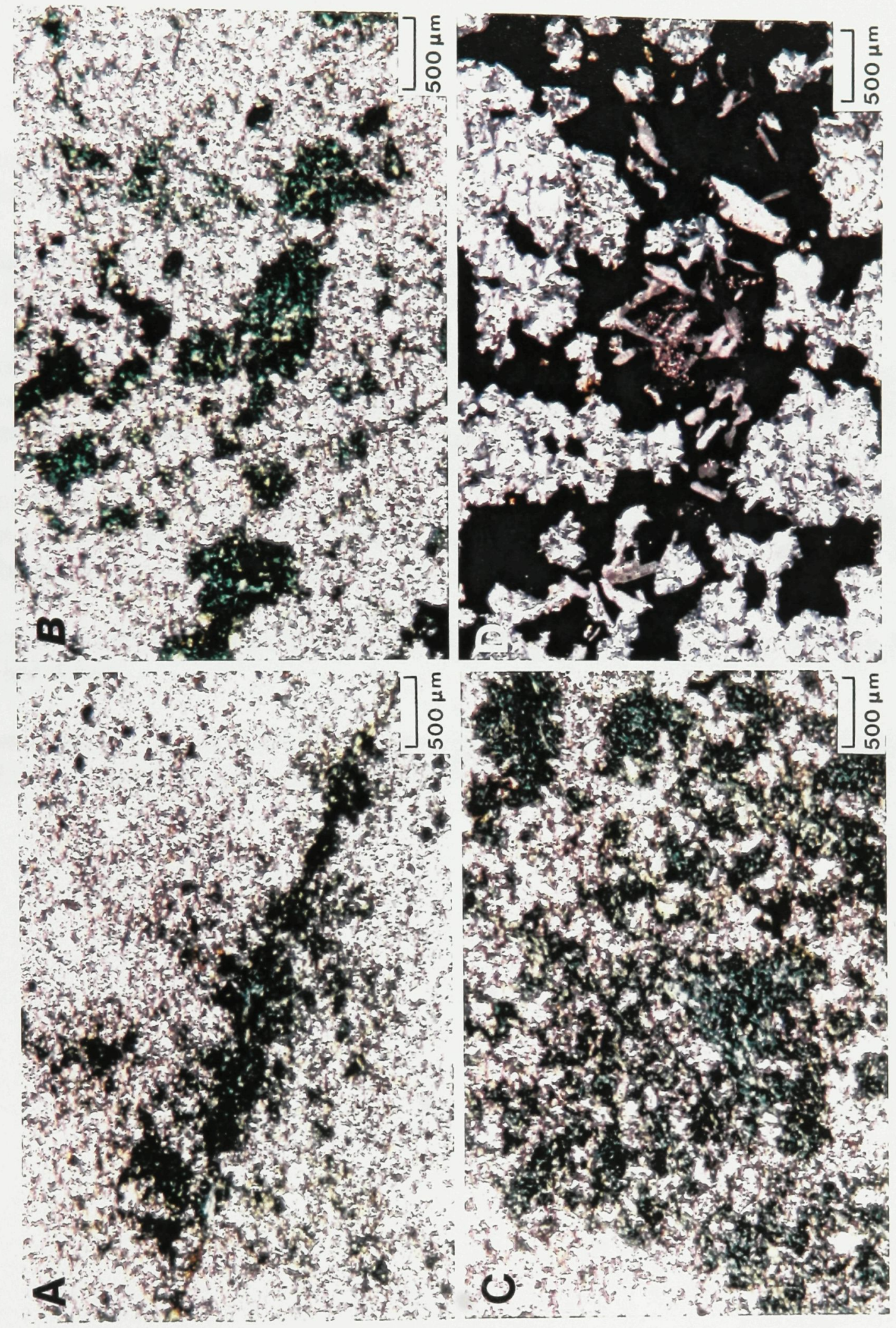


Figure 5.19

A. Photomicrograph of relatively unaltered Rusty Ridge andesite characterized by an albite-chlorite-actinolite-epidote-titanite mineral assemblage.

B. Photomicrograph of chlorite-quartz altered andesite in immediate hangingwall to Ansil orebody. Field of view $4 \mathrm{~mm}$.

C. Photomicrograph of partially ingested andesite along the hangingwall contact of the massive sulphide lens. Quartz-chlorite-chalcopyrite-stilpnomelane altered andesite is being overprinted by chalcopyrite-pyrrhotite-quartz-stilpnomelane. Field of view $4 \mathrm{~mm}$.

D. Photomicrograph of completely altered andesite, with patchy domains of quartzchlorite in coarser-grained quartz-stilpnomelane-pyrrhotite-chalcopyrite. Note albite laths replaced by quartz (arrow). Field of view $4 \mathrm{~mm}$.

E. Photomicrograph of remnant andesite domain within margin of massive sulphide lens. Field of view $4 \mathrm{~mm}$.

F. Photomicrograph of quartz domains within massive chalcopyrite-pyrrhotite, with albite porphyroblasts pseudomorphous to quartz. Field of view $4 \mathrm{~mm}$. 

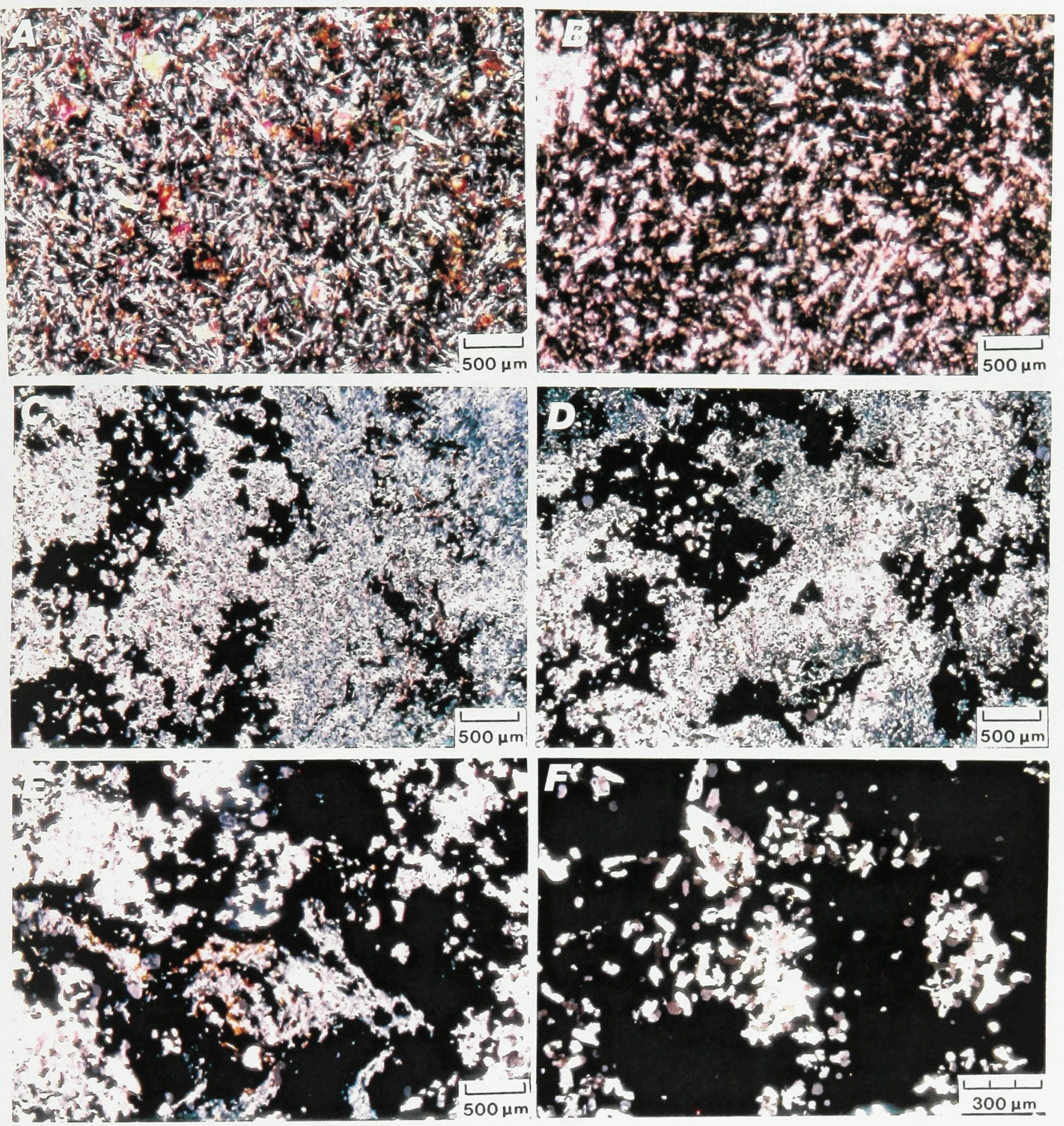


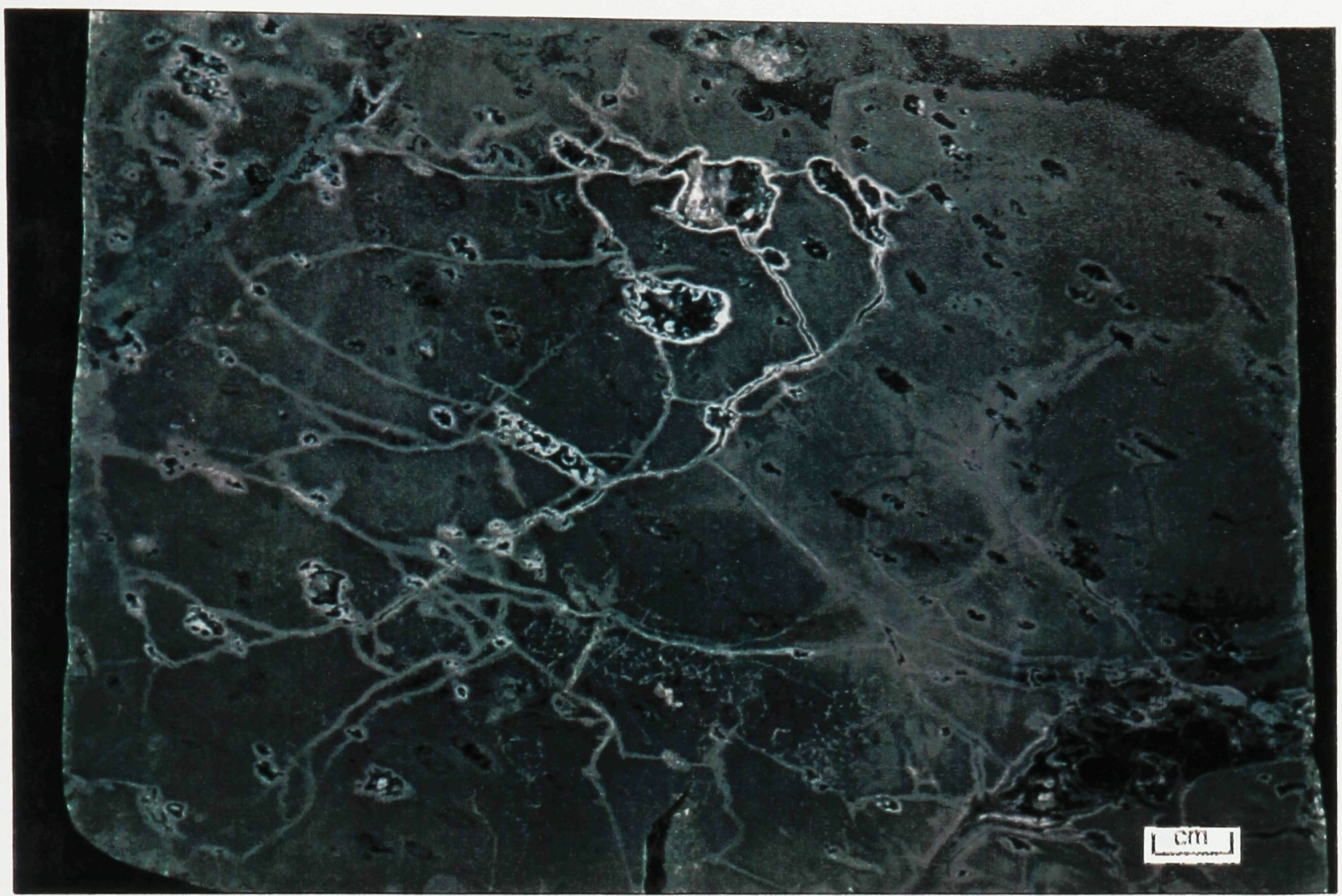

Figure 5.20 Polished slab showing weak quartz-chlorite alteration of hangingwall andesite, with chlorite-quartz filled amygdules connected by quartz veinlets with silicified margins. Sample ANSL6A-279. 


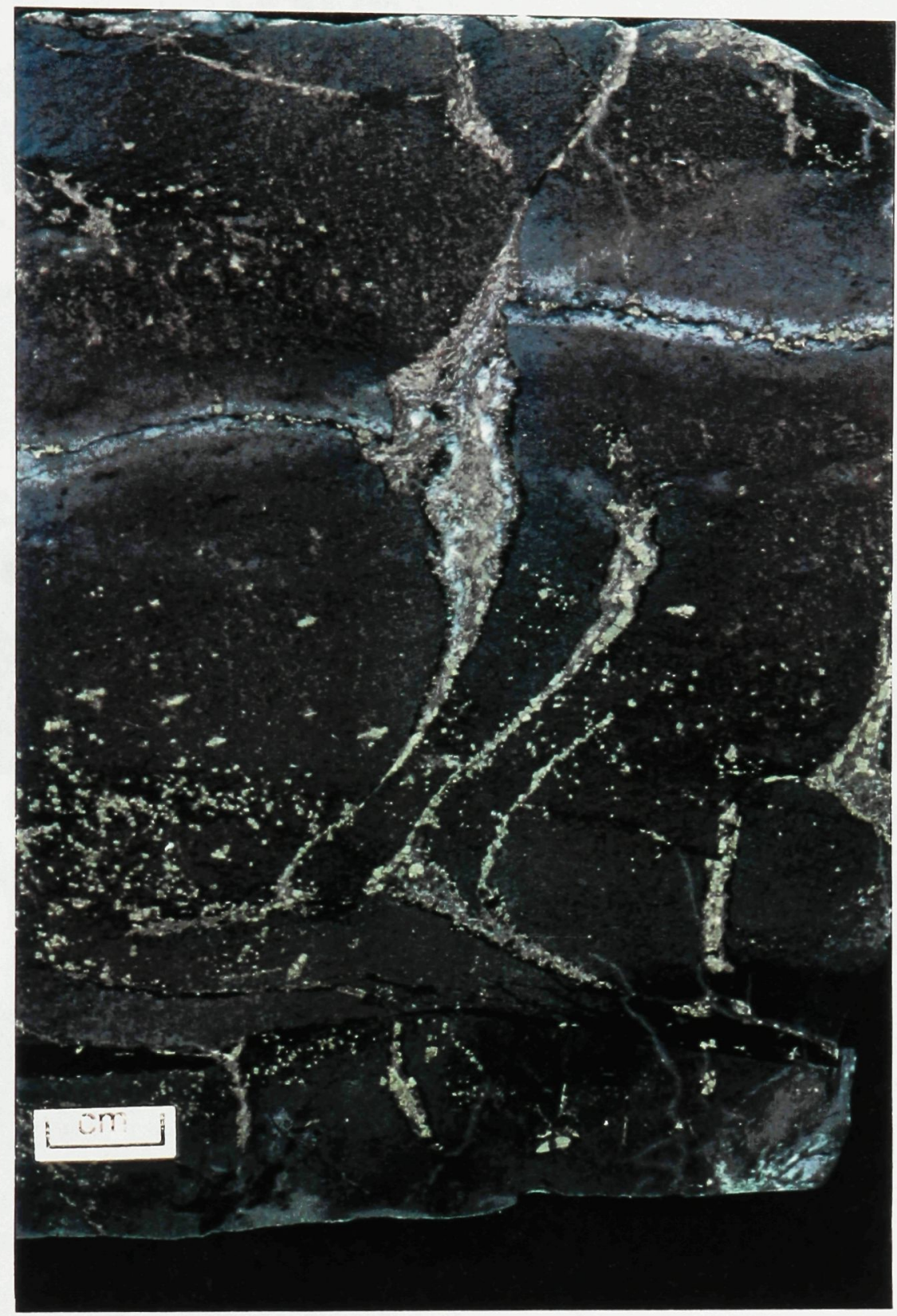

Figure 5.21 Sericite-quartz alteration of hangingwall andesite above the south flank of the orebody (Sublevel 7B). Sample ANSL7B-156. 


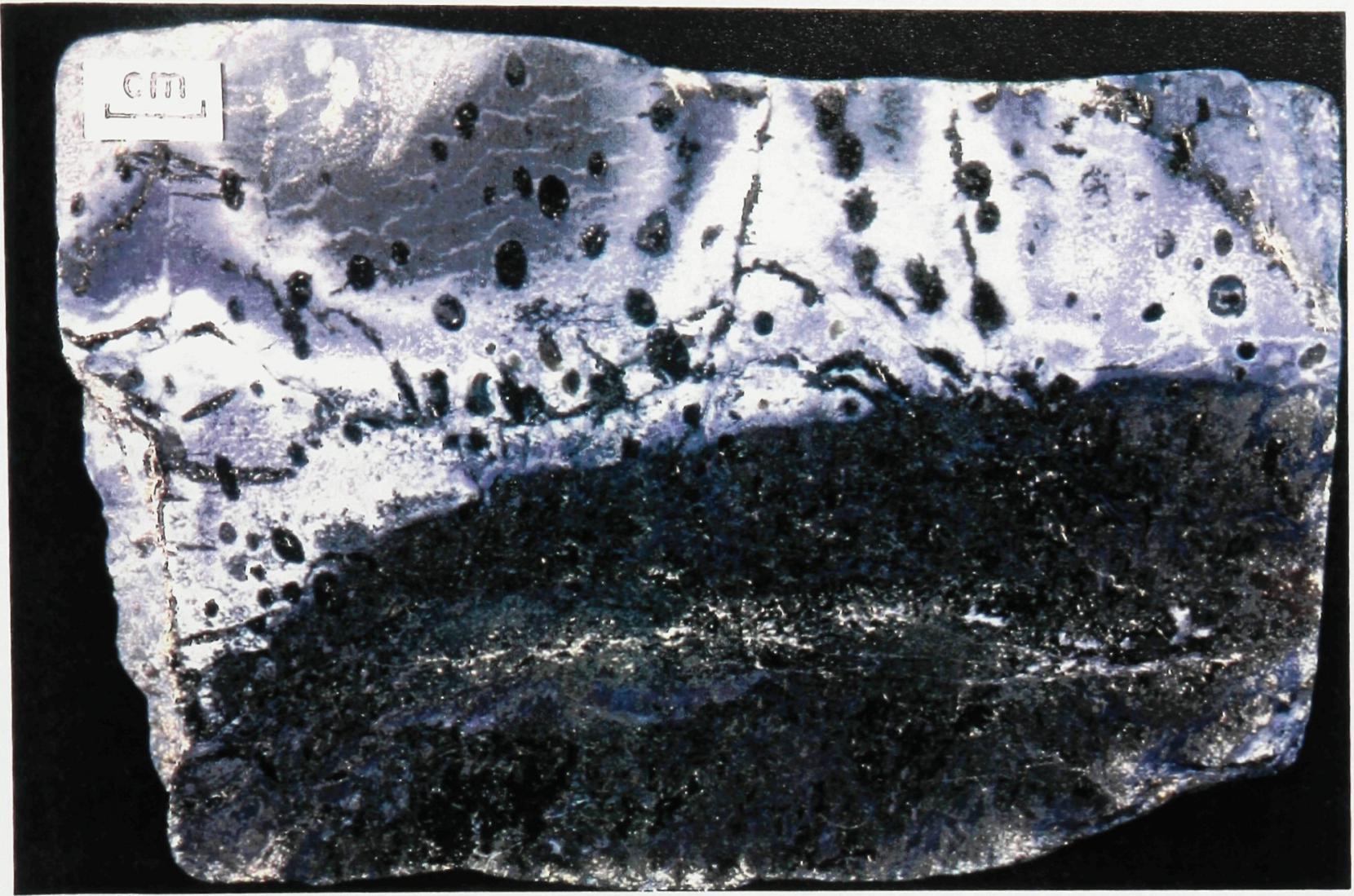

Figure 5.22 Polished slab showing sericite-quartz-chlorite-sulphide alteration of andesite pillow margin. Chlorite-rich alteration replaces interpillow hyaloclastite ANSL7R-36

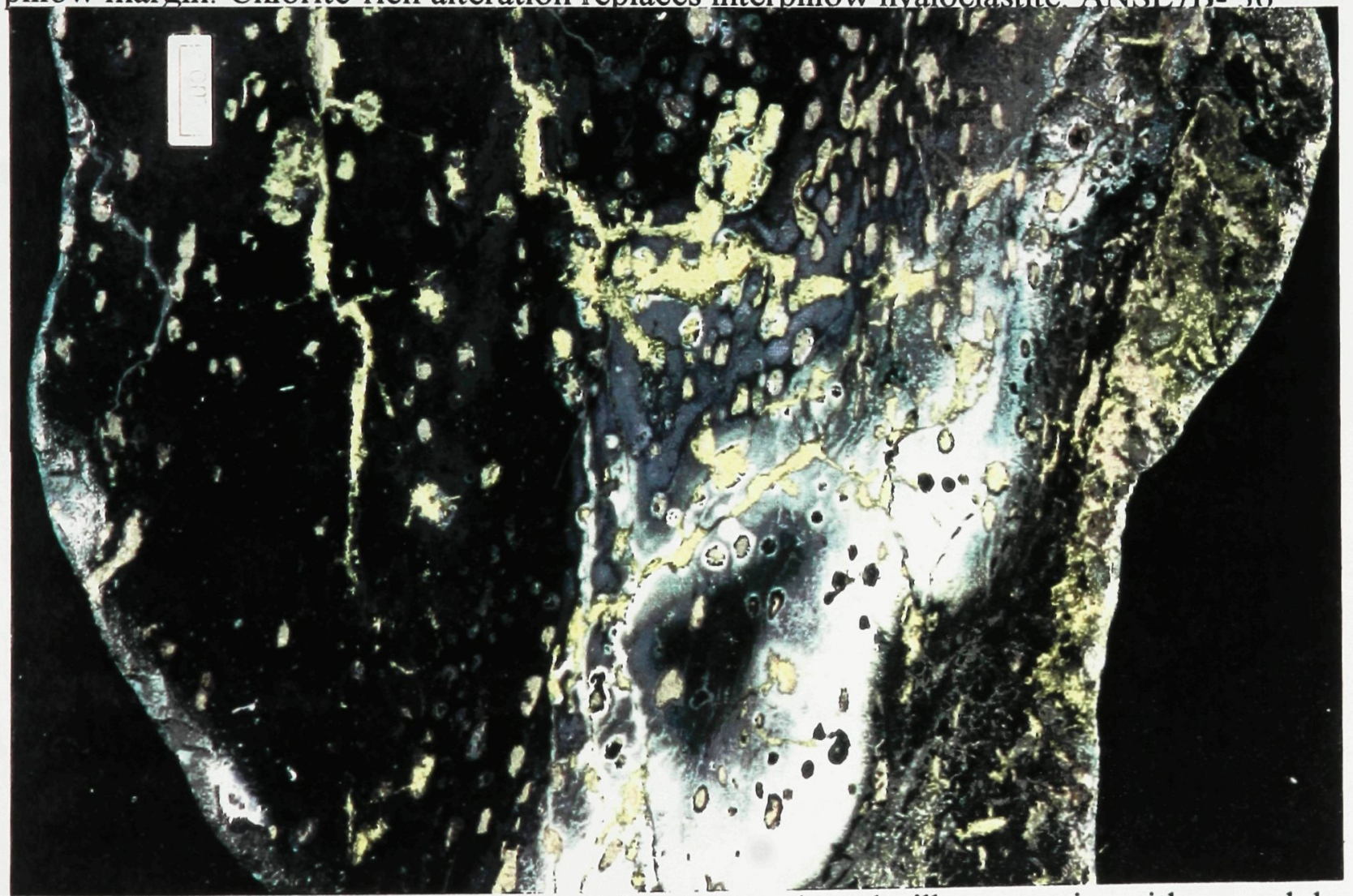

Figure 5.23 Polished slab showing sericite-quartz altered pillow margin, with amygdules infilled with sulphide, quartz and chlorite. Sample ANSL9-180. 


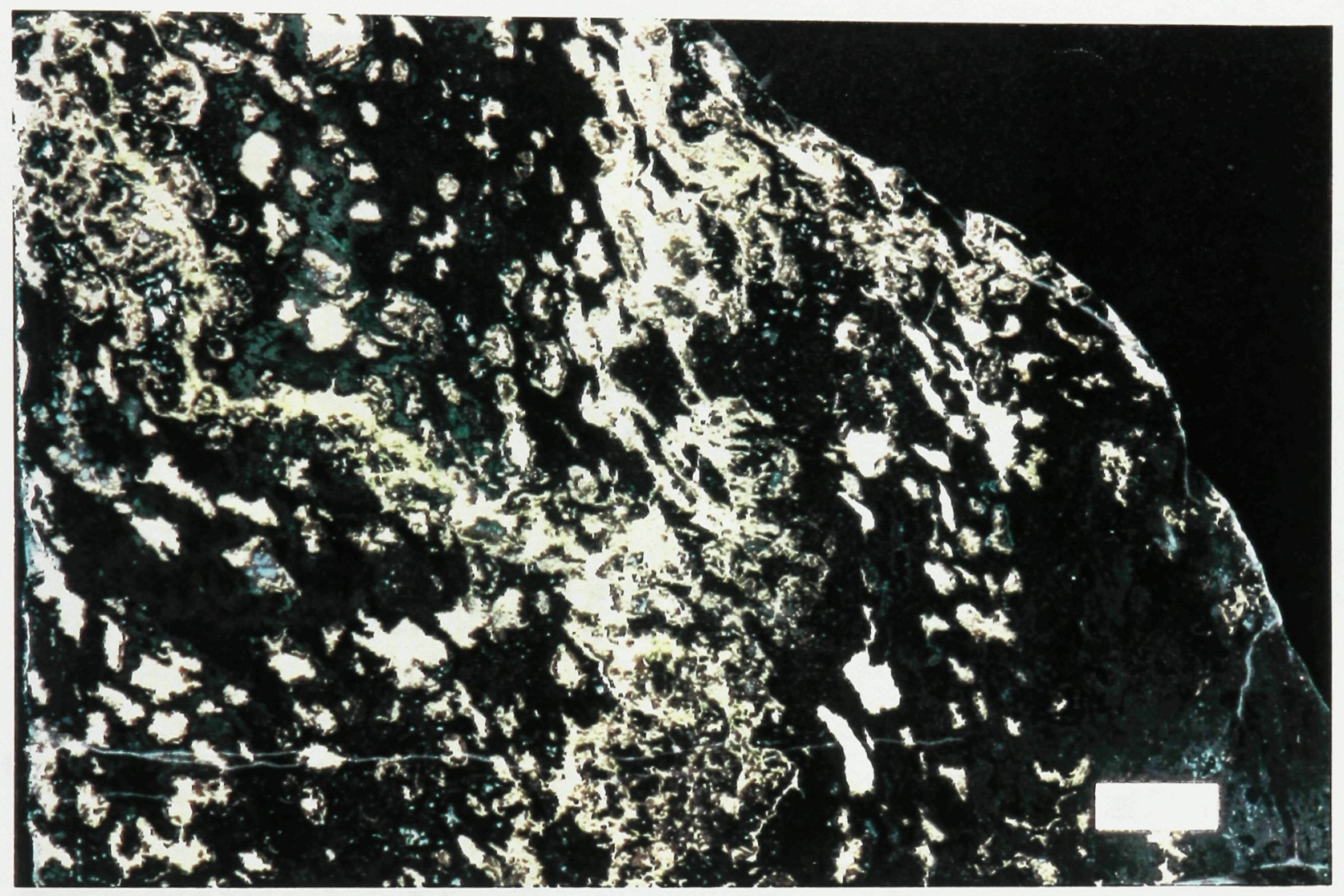

Figure 5.24. Chlorite-sulphide alteration of the hangingwall andesite along the margin of the pyrrhotite-chalcopyrite spine that is part of the western end of the massive sulphide lens. Sample ANSL7A-254. 


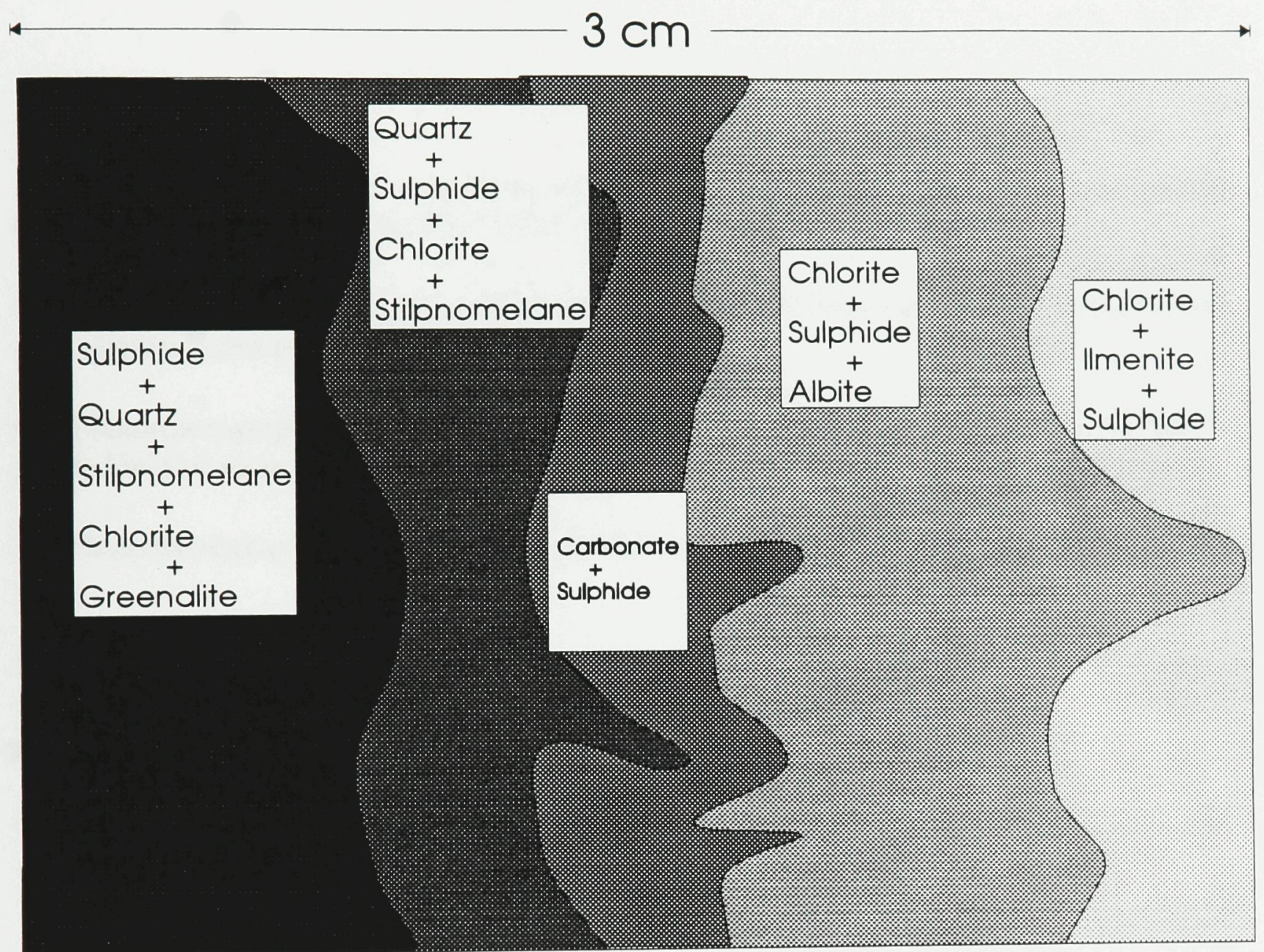

Massive sulphide $\longleftarrow$ Altered andesite

Flgure 5.25 Reaction zone along the contact of the massive sulphlde lens and overlying andesittic flows 
Figure 5.26

A. Photomicrograph of magnetite-chlorite-calcite alteration controlled by perlitic fracturing of massive rhyolite lobe. Field of view $4 \mathrm{~mm}$.

B. Photomicrograph of zoned epidote grains from the chlorite-magnetite alteration zone, with allanite cores and epidote rims. Field of view $1 \mathrm{~mm}$.

C. Photomicrograph of magnetite-chlorite-calcite alteration overprinting edge of epidote patch. Field of view $4 \mathrm{~mm}$.

D. Photomicrograph of epidote grain replaced along its margins by calcite. Field of view 2 $\mathrm{mm}$.

E.. Photomicrogaph of magnetite-rich domain within the chlorite-magnetite alteration zone. Atoll structure of magnetite idiomorphs cored by chlorite and rimmed by calcite. Field of view $2 \mathrm{~mm}$.

F. Photomicrograph of atoll-shaped magnetite crystals along the margin of a magnetite vein. Field of view $4 \mathrm{~mm}$. 


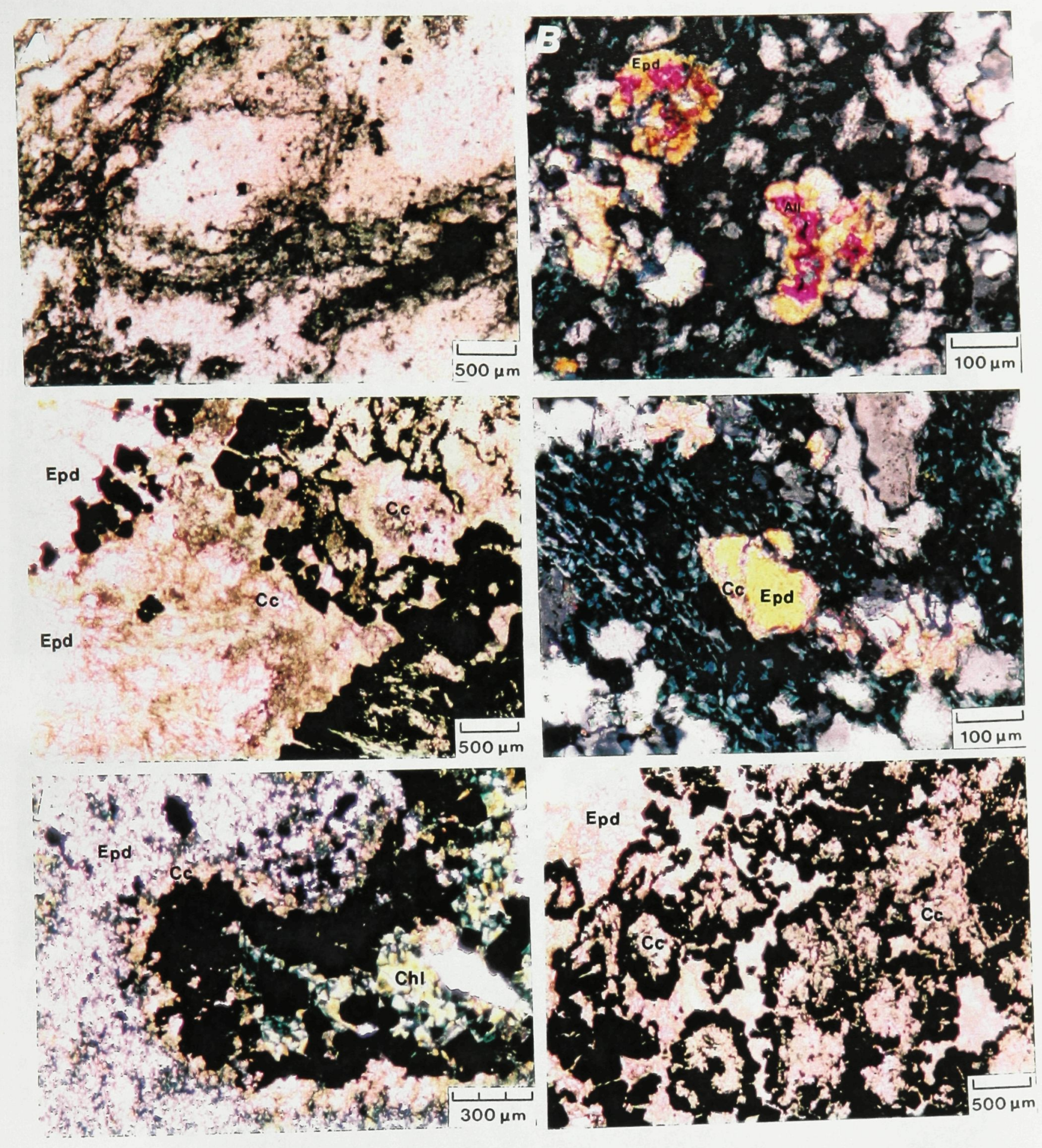




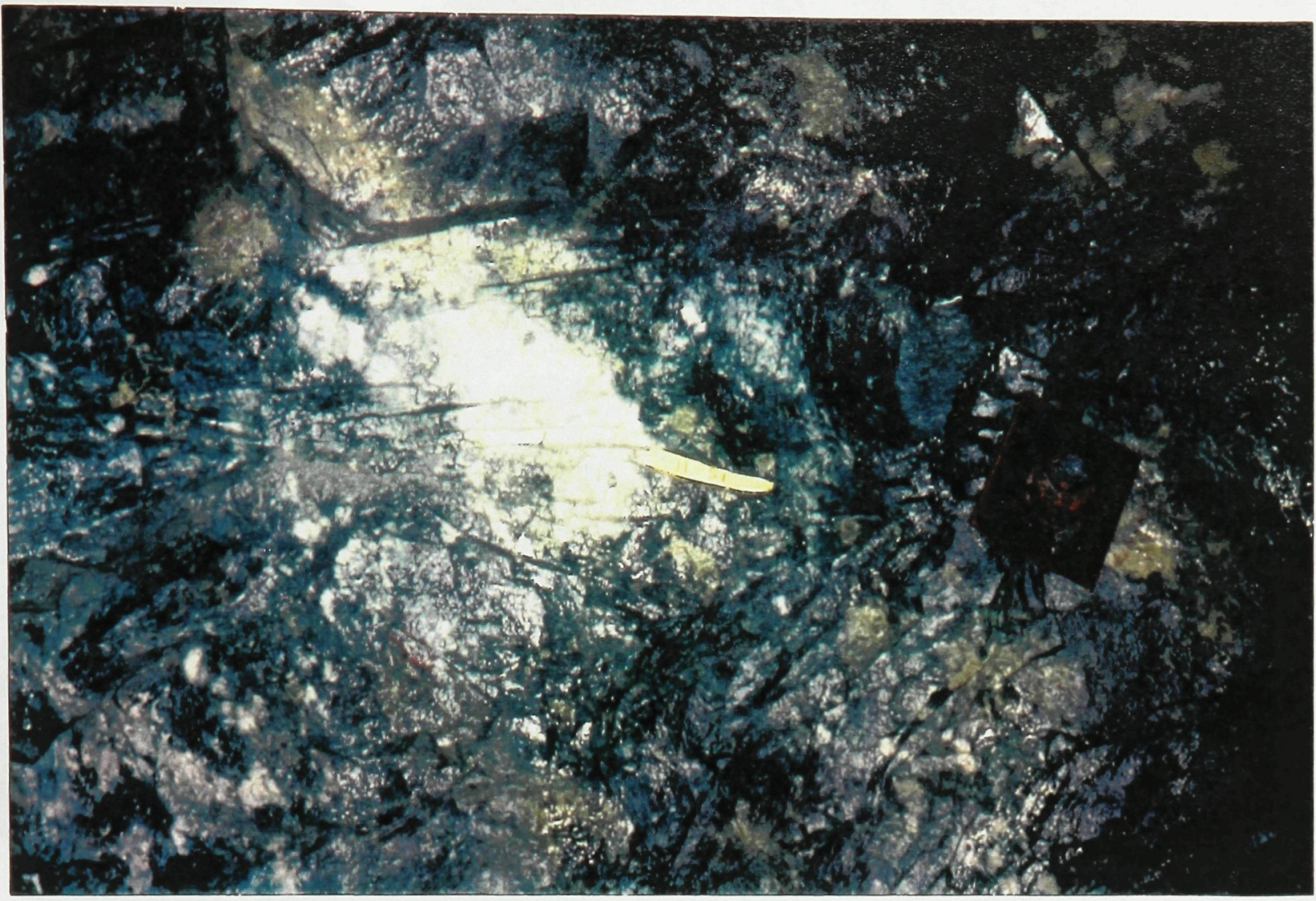

Figure 5.27 Large epidote patches within chlorite-magnetite alteration zone. 11-01 drift. Metal plates $15 \mathrm{~cm}$ across.

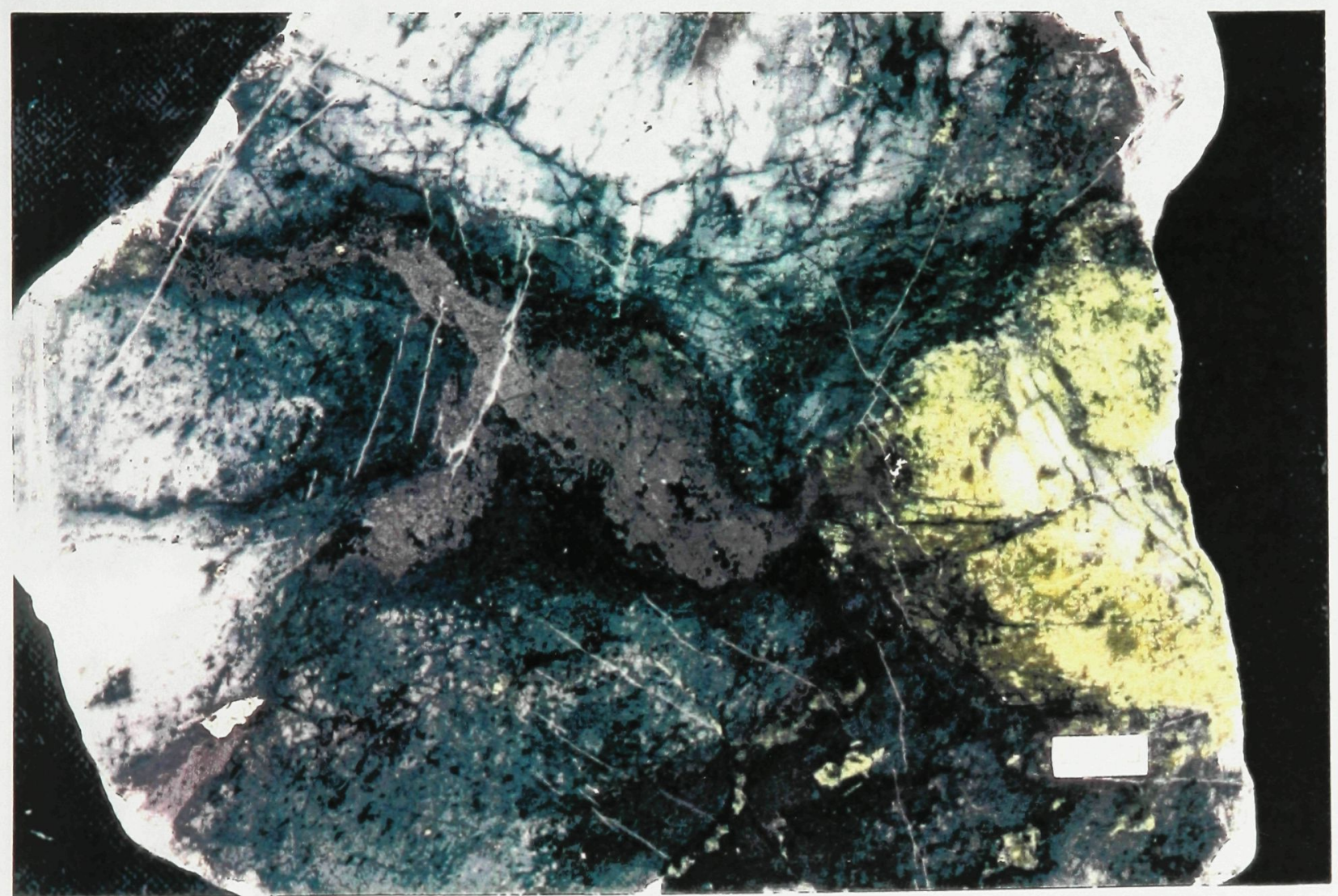

Figure 5.28 Polished slab showing a magnetite vein cross-cutting an epidote patch. 10A access drift. 


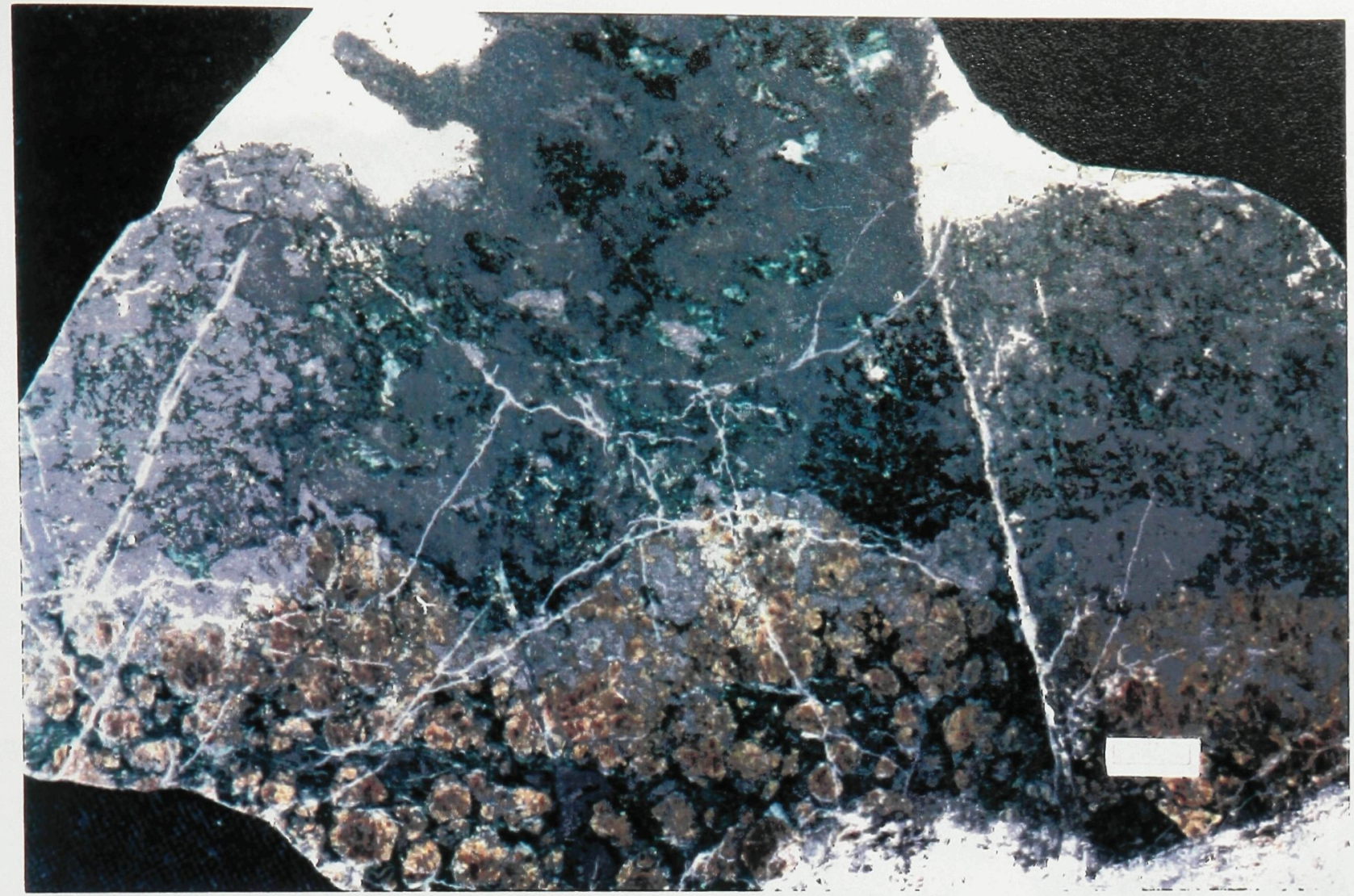

Figure 5.29 Polished slab showing semi-massive magnetite zone overprinting hedenbergite-andradite-ferroactinolite skarn. Level 10 hangingwall drift. Sample ANSL10A-198

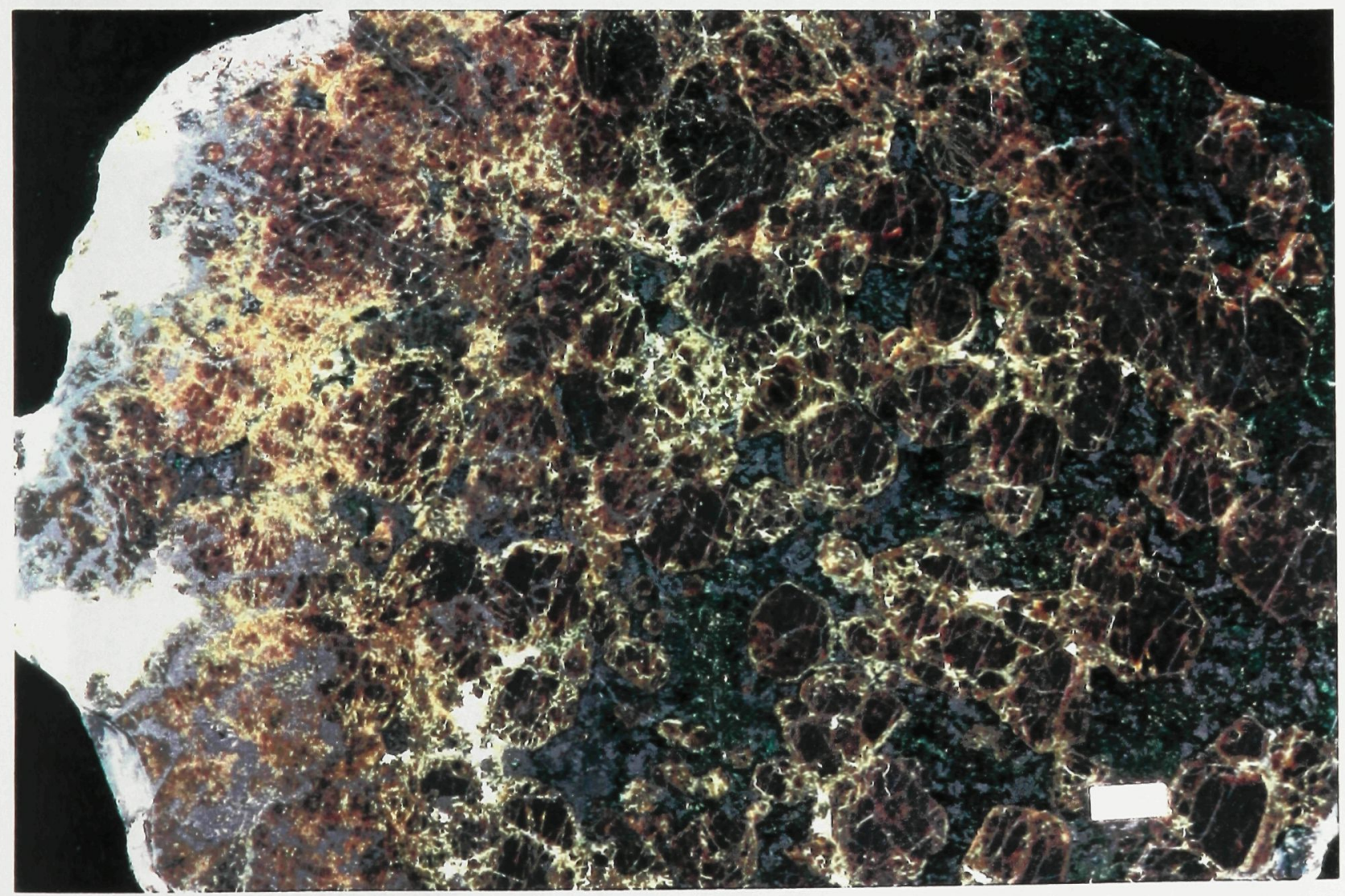

Figure 5.30 Polished slab of hedenbergite-andradite-ferroactinolite skarn. Level 10 hangingwall drift. Sample ANSL10-21. 


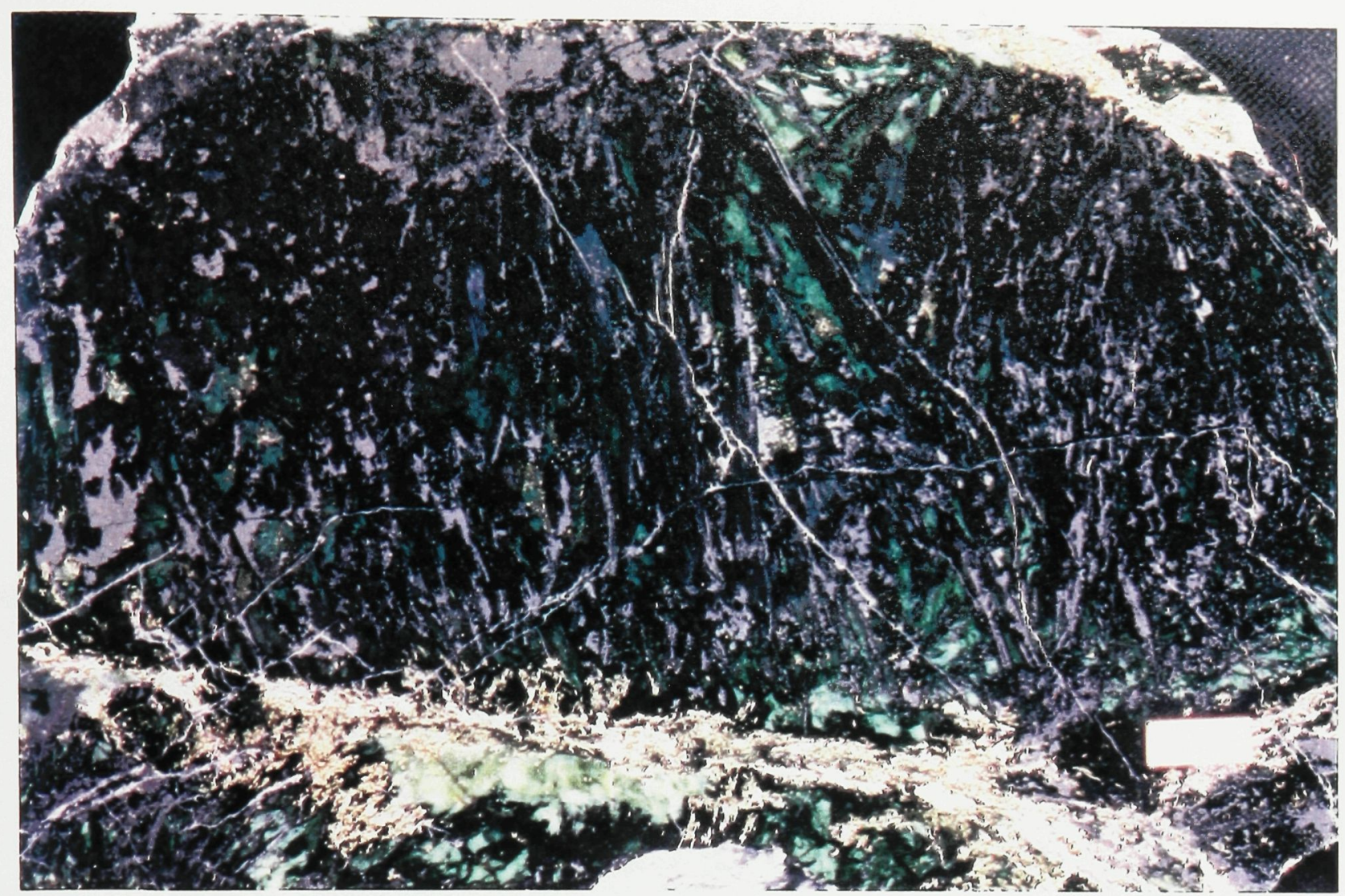

Flgure 5.31 Pollshed slab showing ferroactinollte skarn from the base of a massive magnetlte lens. Note magnetite overprinting margins of the amphlbole porphyroblasts. (Sublevel 9B). Sample ANSL9B-327.

$$
\longleftarrow-10 \mathrm{~cm} \rightarrow-2 \mathrm{~mm} \longrightarrow 20 \mathrm{~cm} \rightarrow
$$

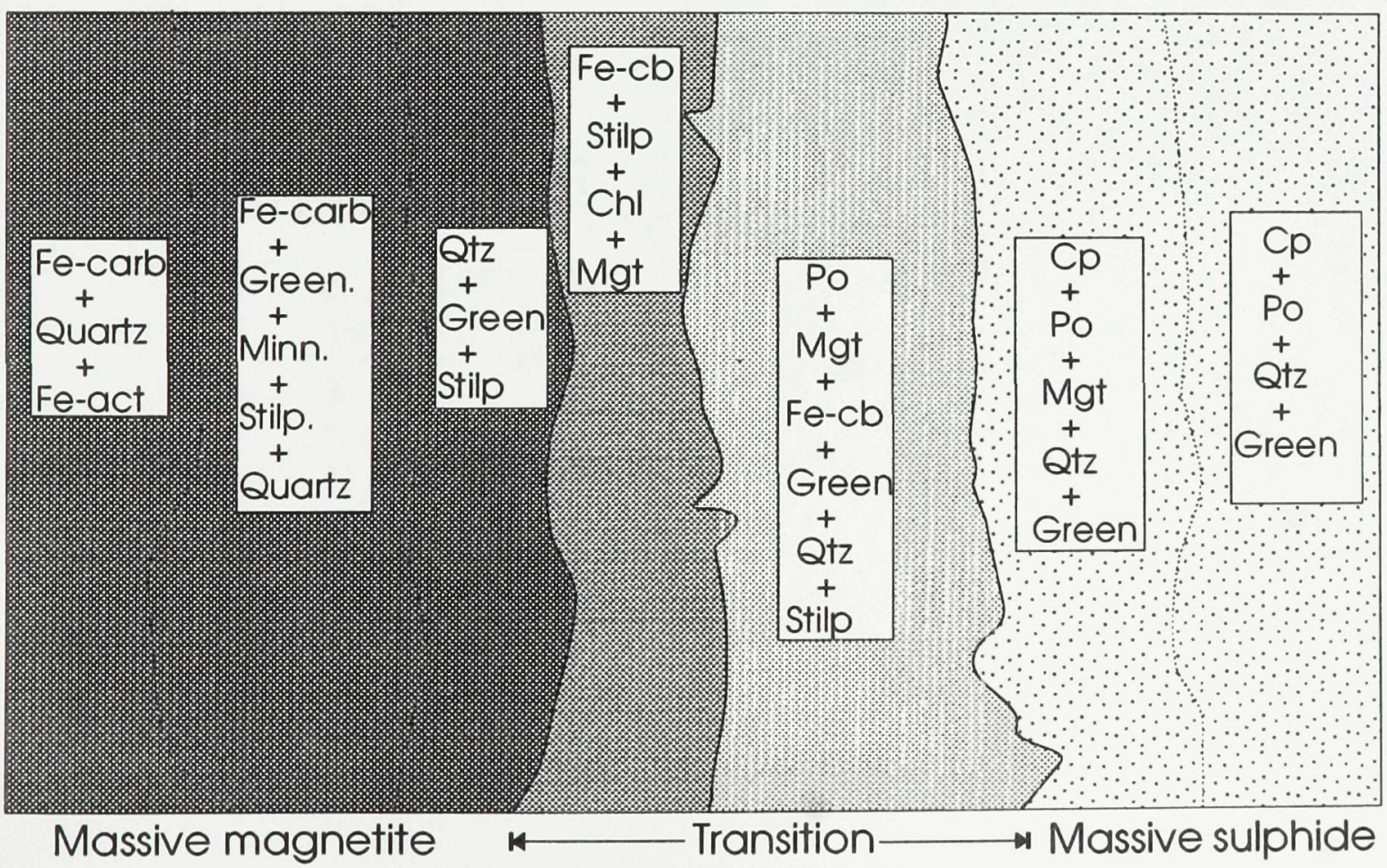

Flgure 5.32 Reaction zone at the contact of massive magnetite and massive sulphlde. 


\section{Figure 5.33}
A. Mineral assemblage within a massive magnetite zone, with ferroactinolite-quartz being replaced with Fe-carbonate and finely intergrown chlorite-greenalite-stilpnomelane. Field of view $4 \mathrm{~mm}$.
B. Near the contact between massive magnetite/sulphide the massive magnetite groundmass is composed of Fe-carbonate, greenalite and stilpnomelane and remnant patches of quartz. Field of view $4 \mathrm{~mm}$.
C. Contact between massive magnetite and sulphide, with mixed magnetite and pyrrhotite in a Fe-carbonate-greenalite groundmass. Field of view $4 \mathrm{~mm}$.
D. Chalcopyrite-pyrrhotite with disseminated magnetite grains. Field of view $4 \mathrm{~mm}$. 


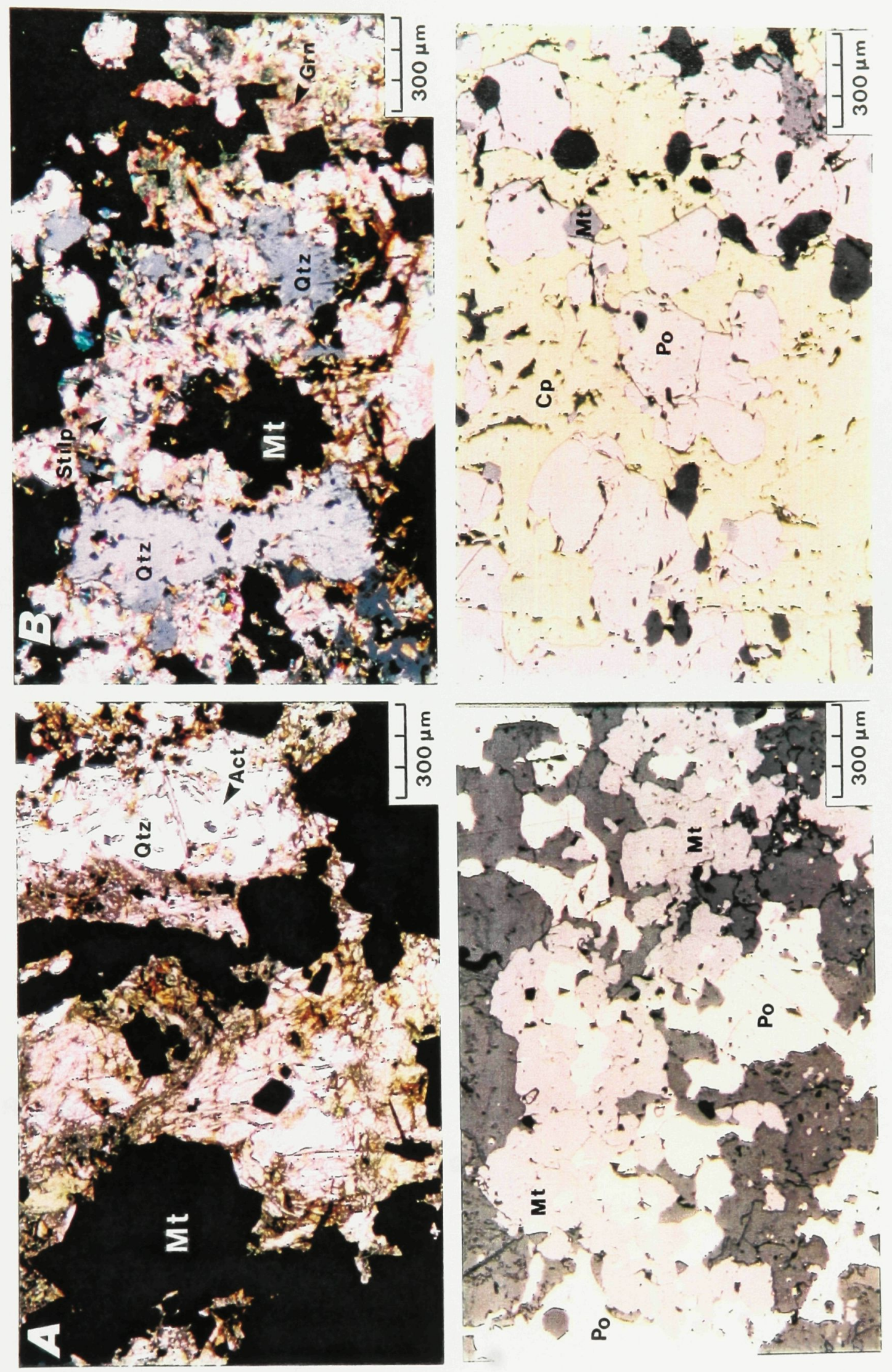



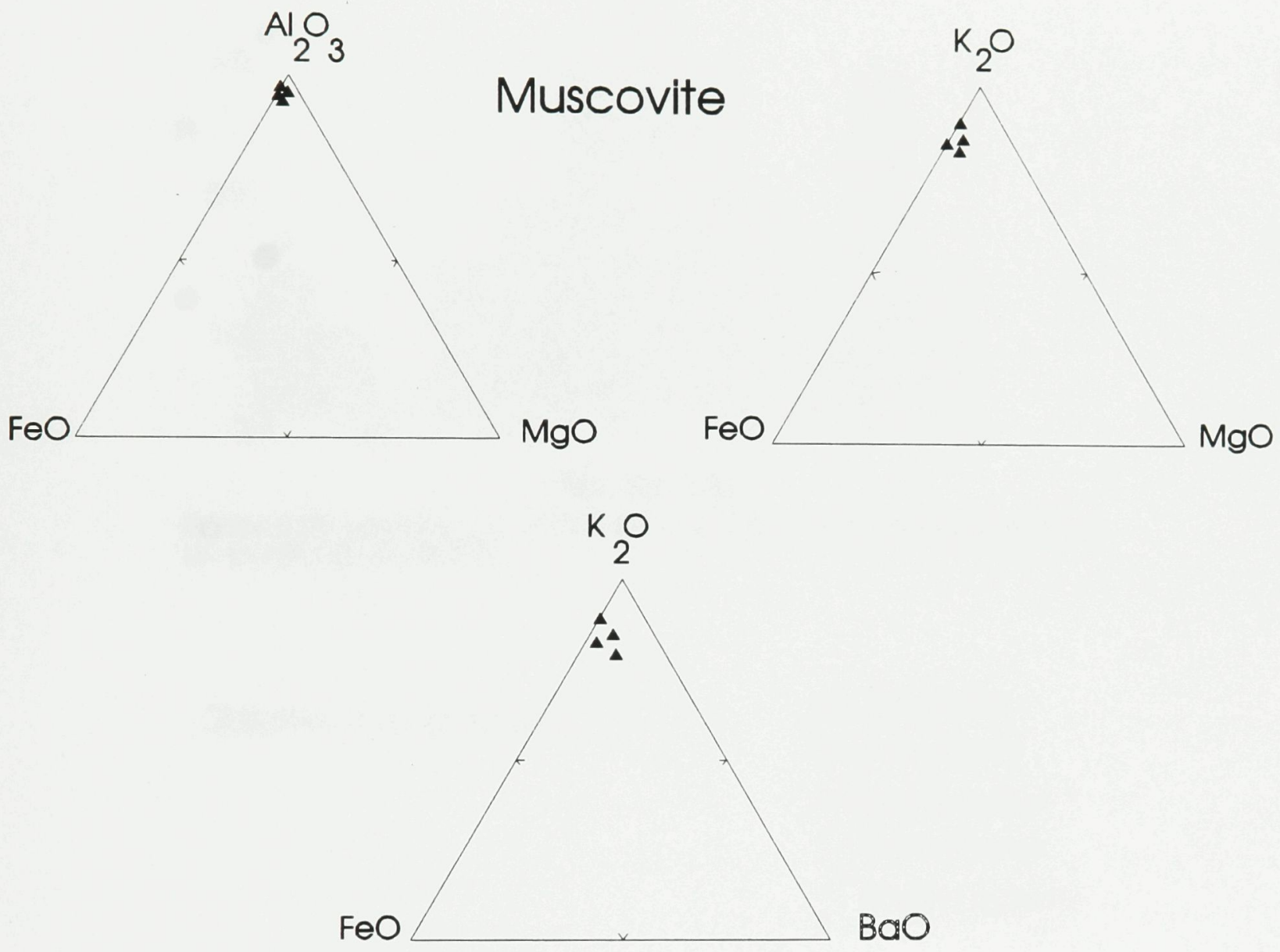

Flgure 5.34 Muscovite compositions from the serlclte-quartz alteration facles 


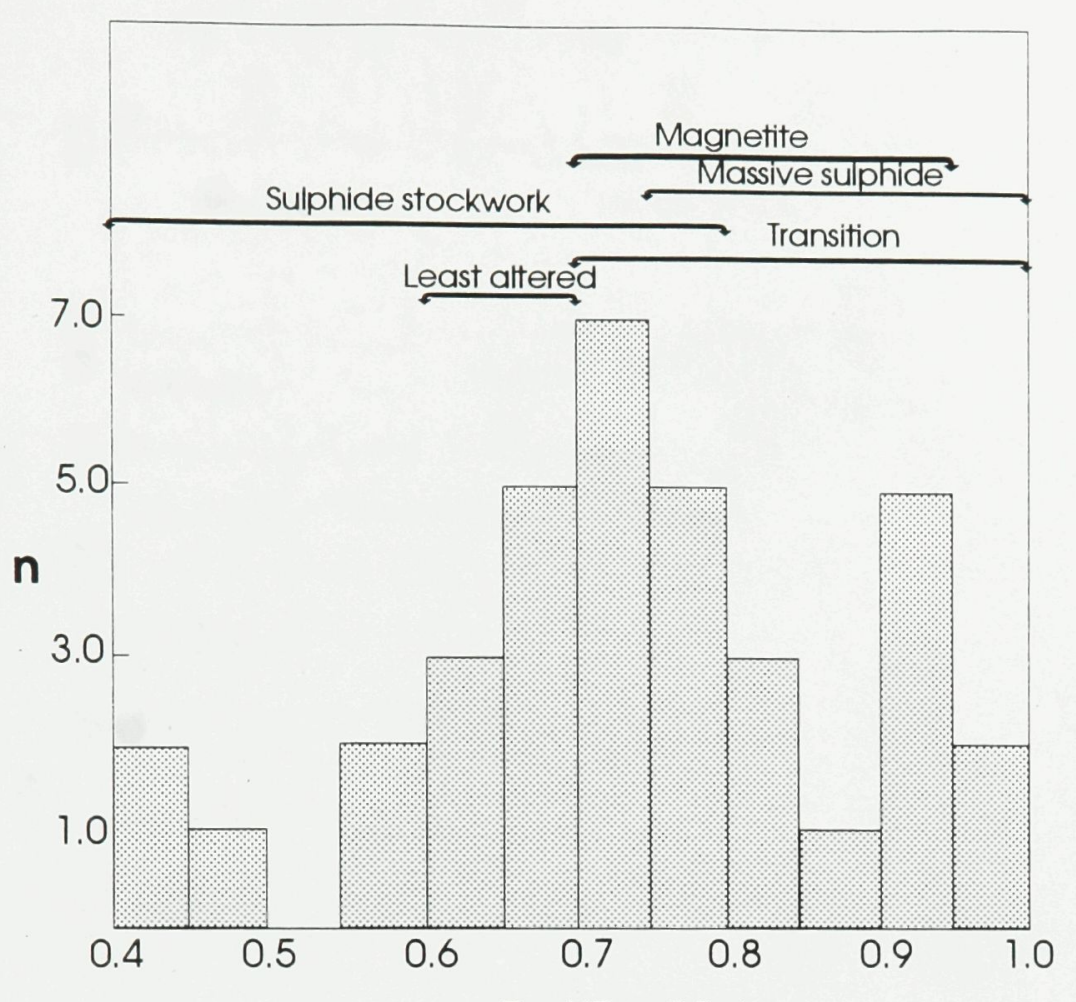

$\mathrm{Fe} /(\mathrm{Fe}+\mathrm{Mg})$

Figure 5.35 Variations in chlorite composition from the Ansil deposit as a ratio of $\mathrm{Fe}^{+2}$ to $\mathrm{Mg}$.

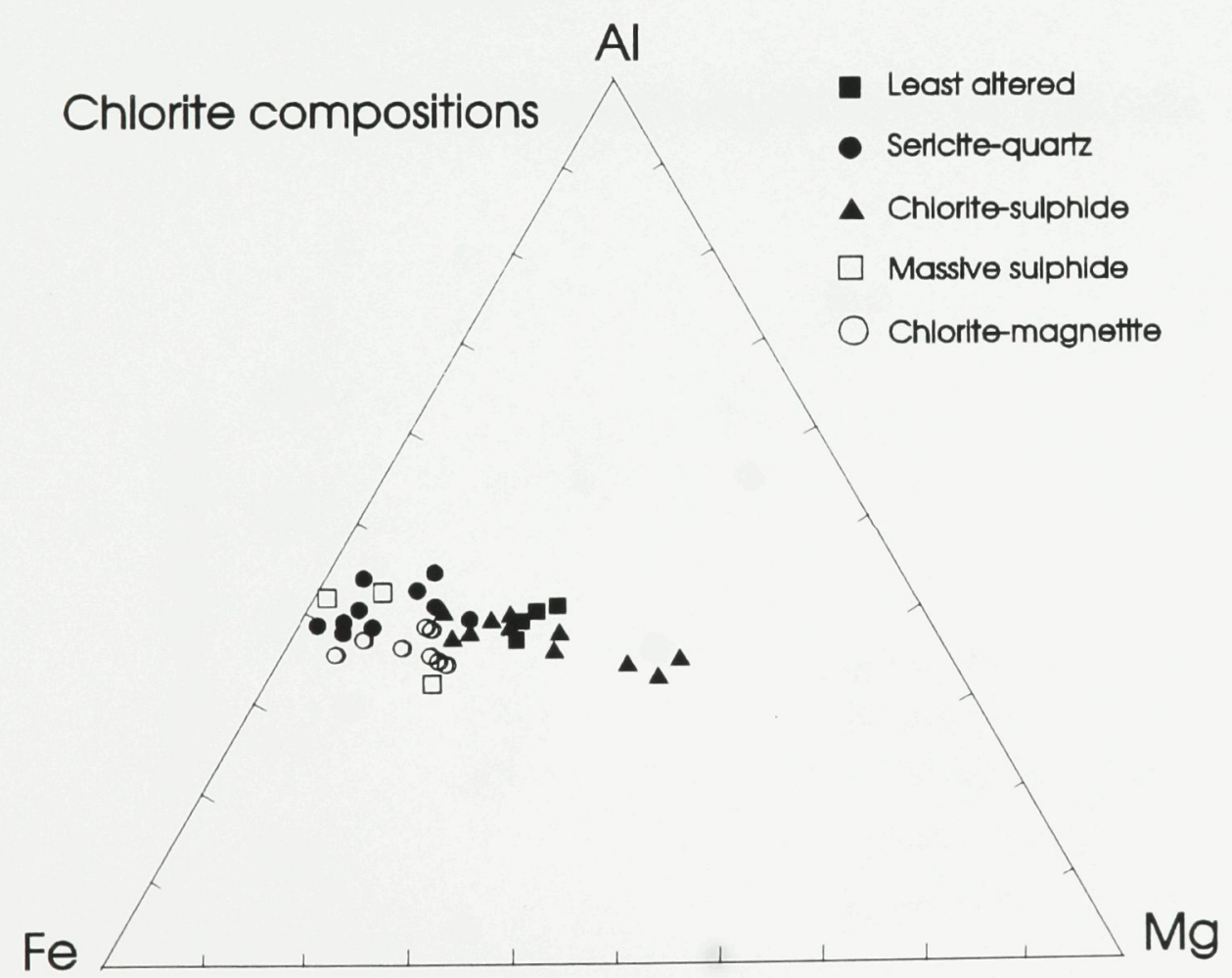

Figure 5.36 Fe-Al-Mg ternary diagram showing the range of chlorite compositions from the Ansil deposit 


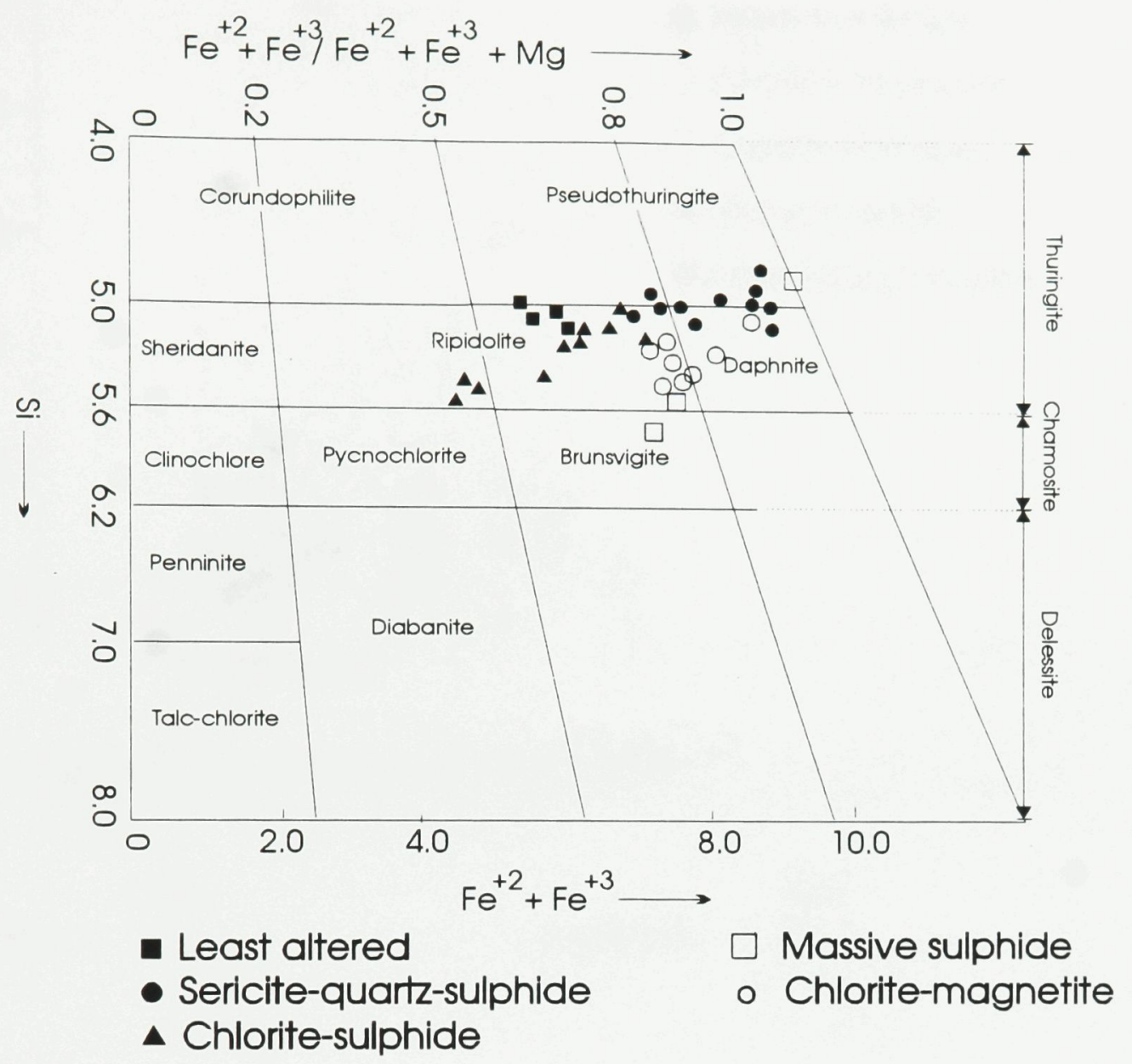

Figure 5.37 Heys (1954) chlorite classification with Ansil data

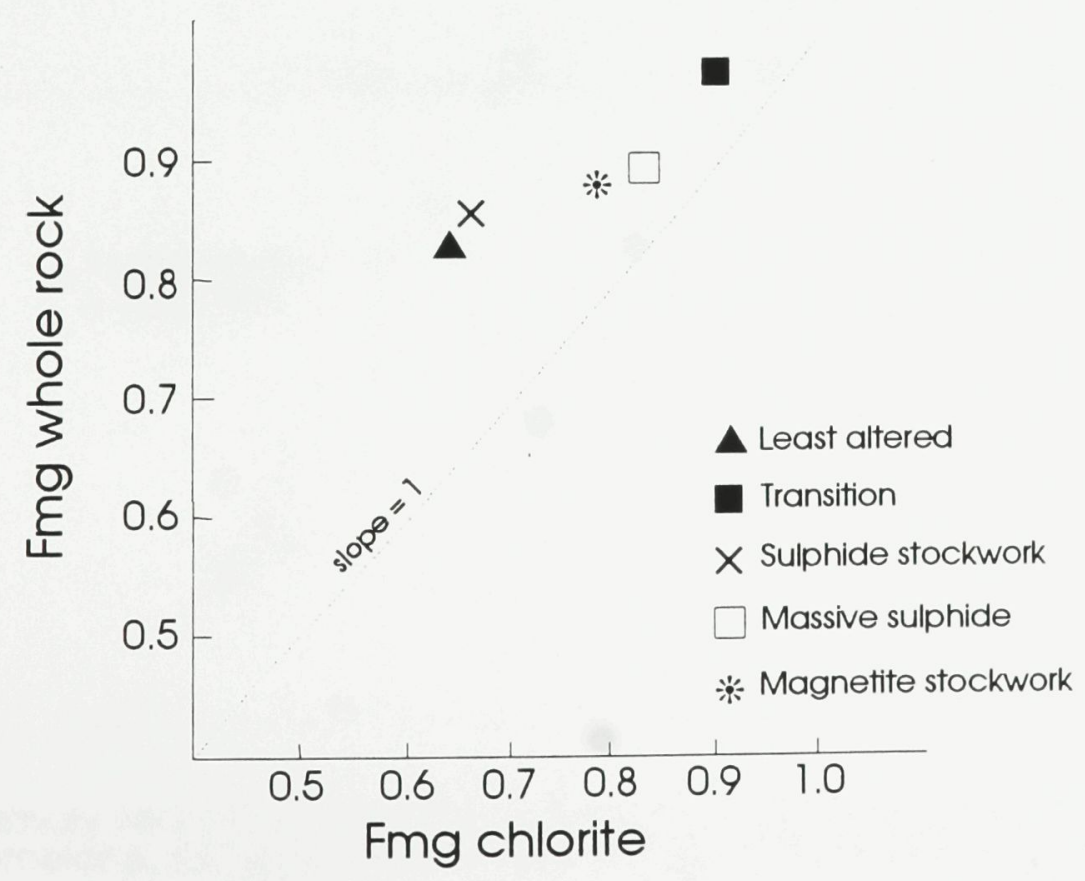

Flgure 5.38 Whole rock vs. chlorlte $\mathrm{Fe} /(\mathrm{Fe}+\mathrm{Mg})$ ratlos 


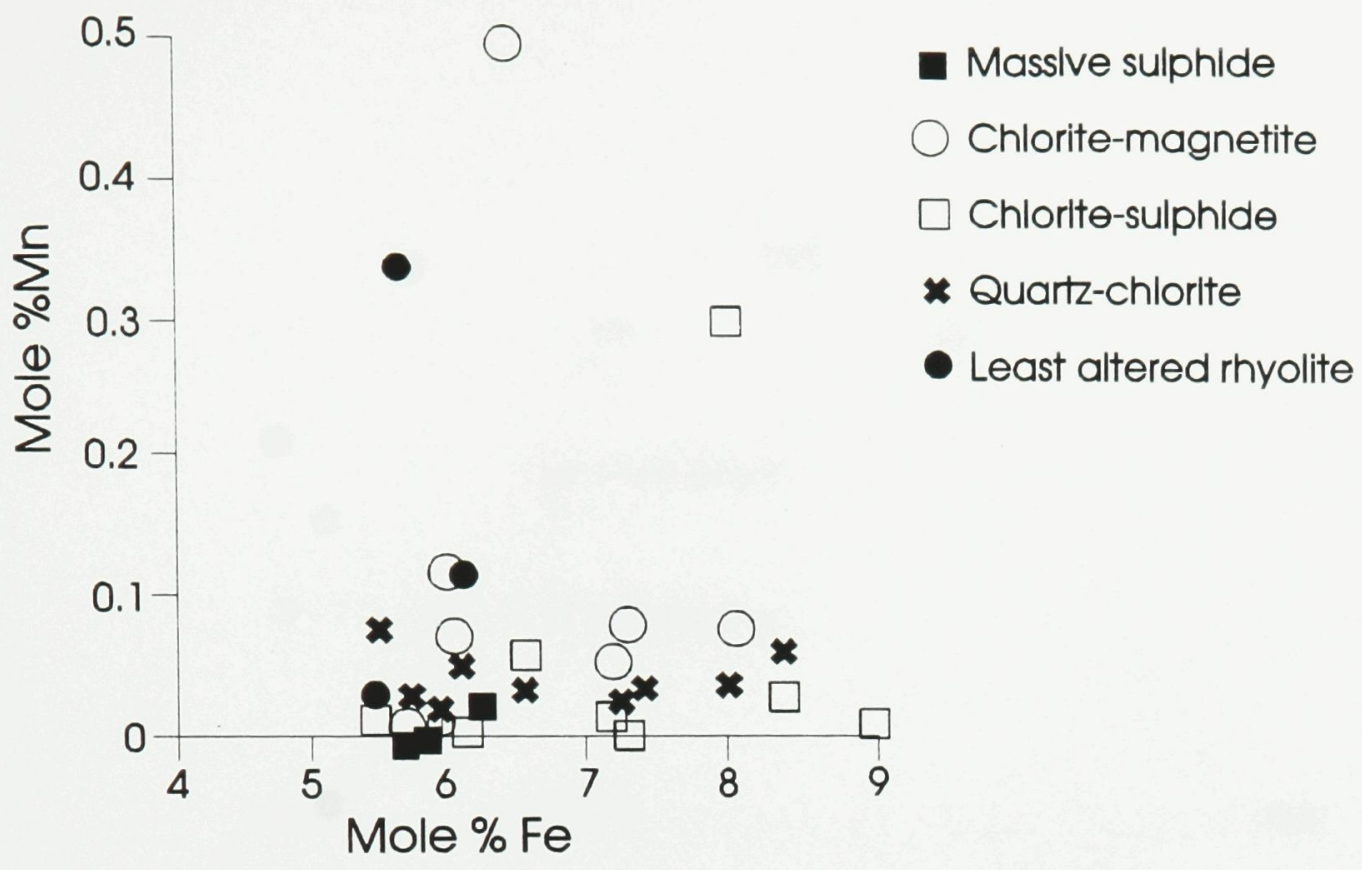

Figure 5.39 Mn vs. Fe for the Ansll chlorites
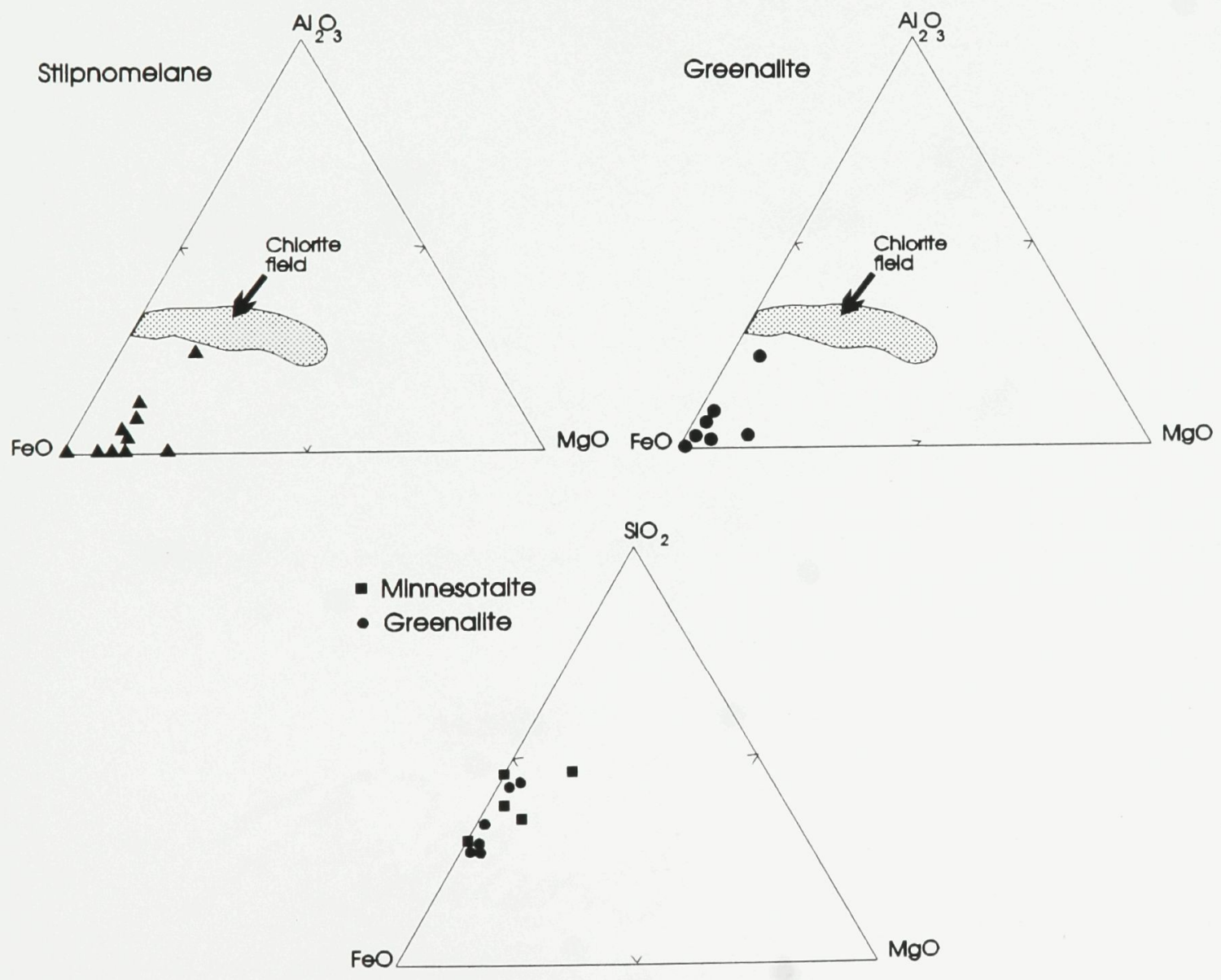

Figure 5.40 Ternary FeO-Al2O3-MgO plots showing compositional variations for (a) stilpnomelane, (b) greenallte, and (c) mlxed minnesotalte-greenallte 
$\mathrm{CaO}$

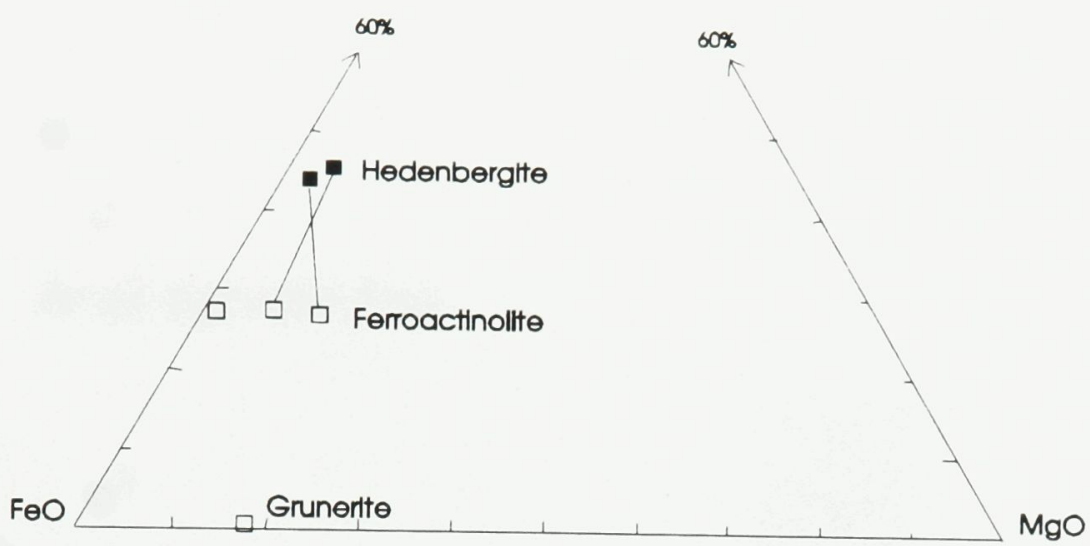

Flgure 5.41 Fe)-Ca)-MgO ternary plot of pyroxene and amphlbole compositions from the Ca-Fe skarn assemblage. Tle llnes Joln minerals from same sample.
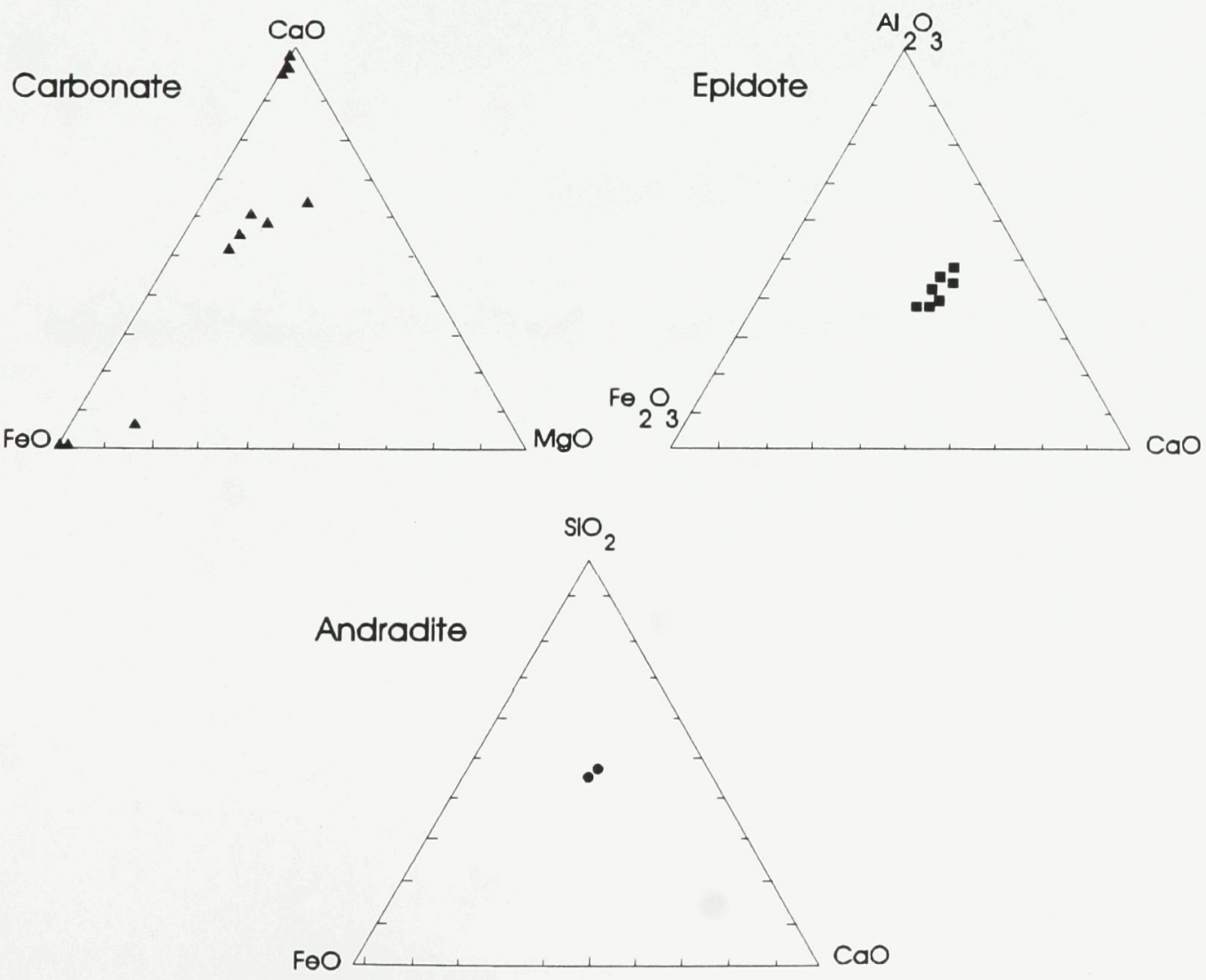

Flgure 5.42 FeO-CaO-MgO ternary plots with compositions of (a) epldotes, (b) andradites, and (c) carbonates from the calc-silicate alteration facies. 


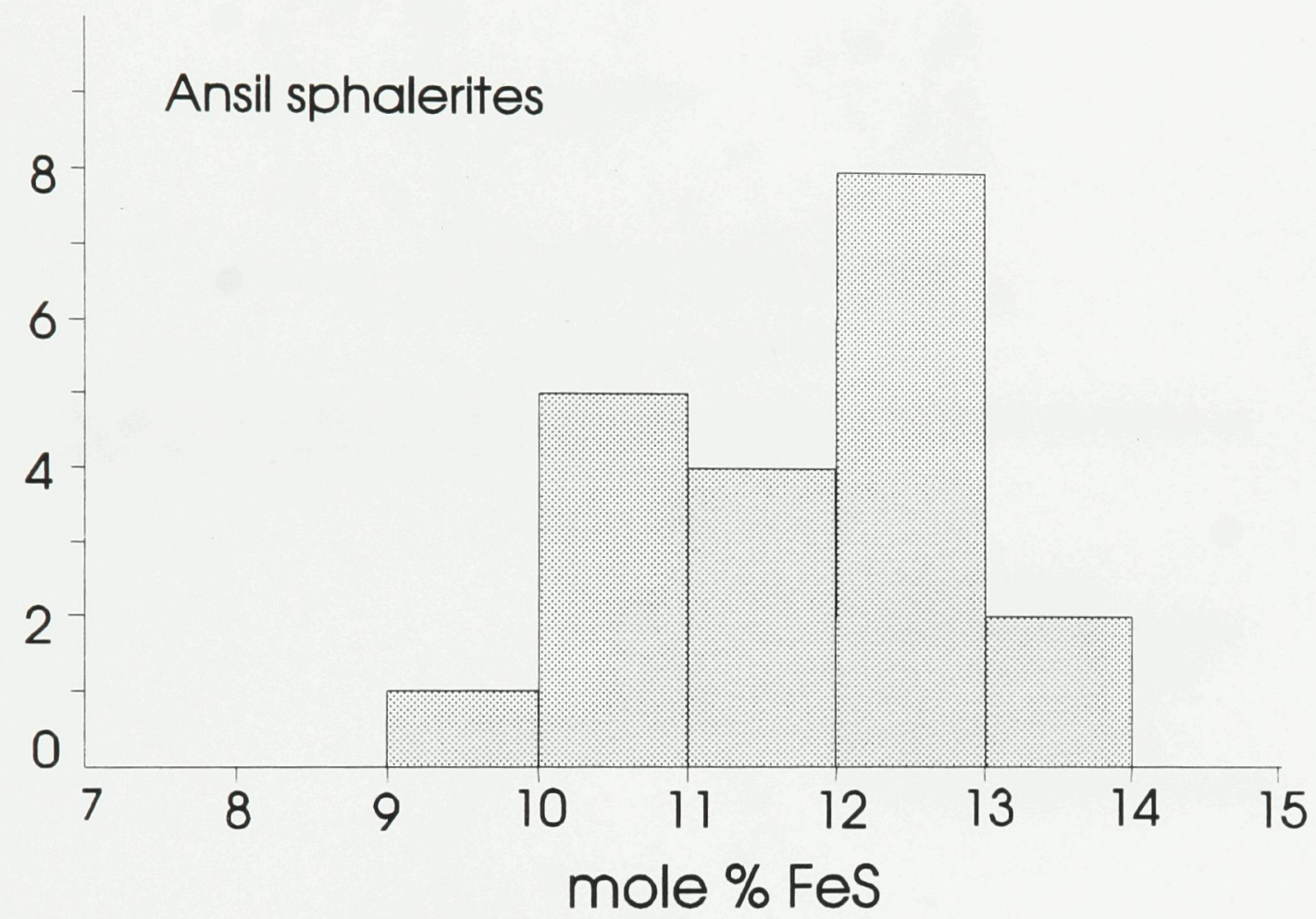

Figure 5.43 Range of mole \% FeS In Ansll sphalerltes. The average is $12 \%$. 


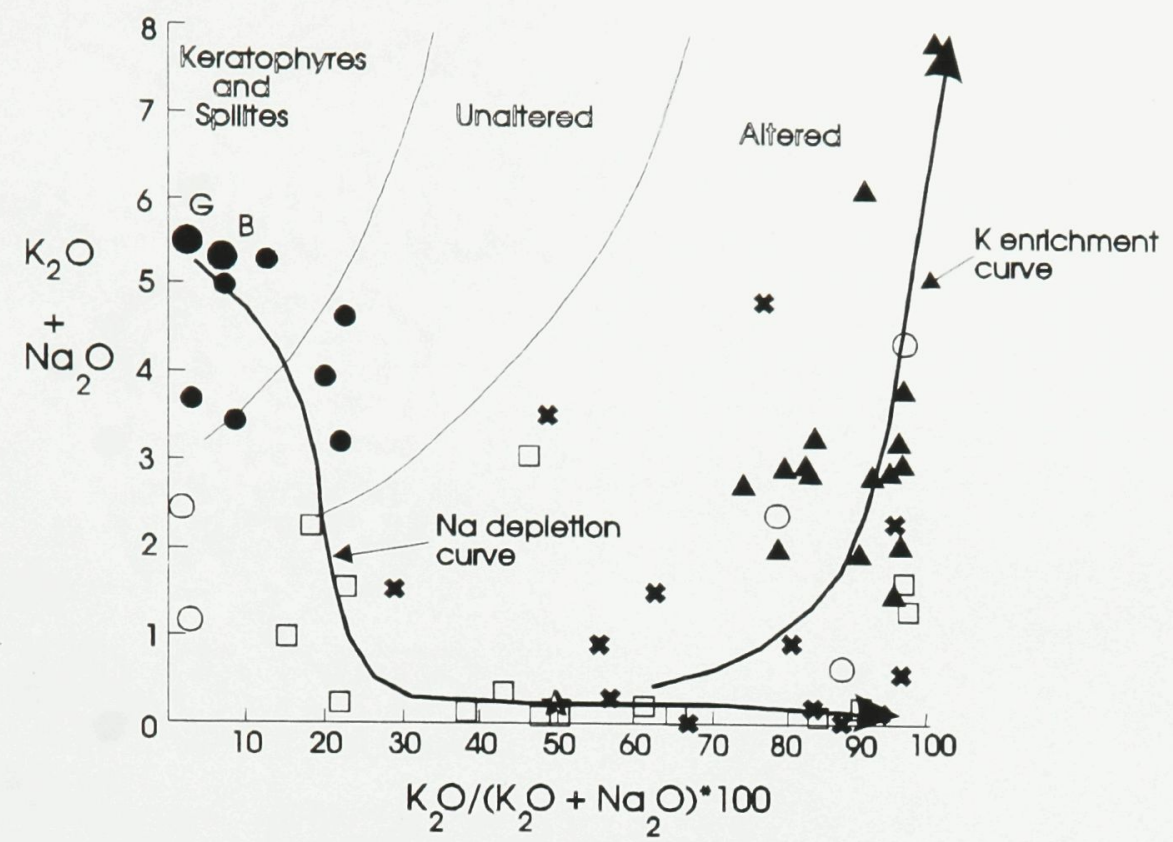

Flgure 5.44 Harker dlagram with the Glbson and Barrett standards as a starting point for $\mathrm{Na}$ and $\mathrm{K}$ enrlchment trends.

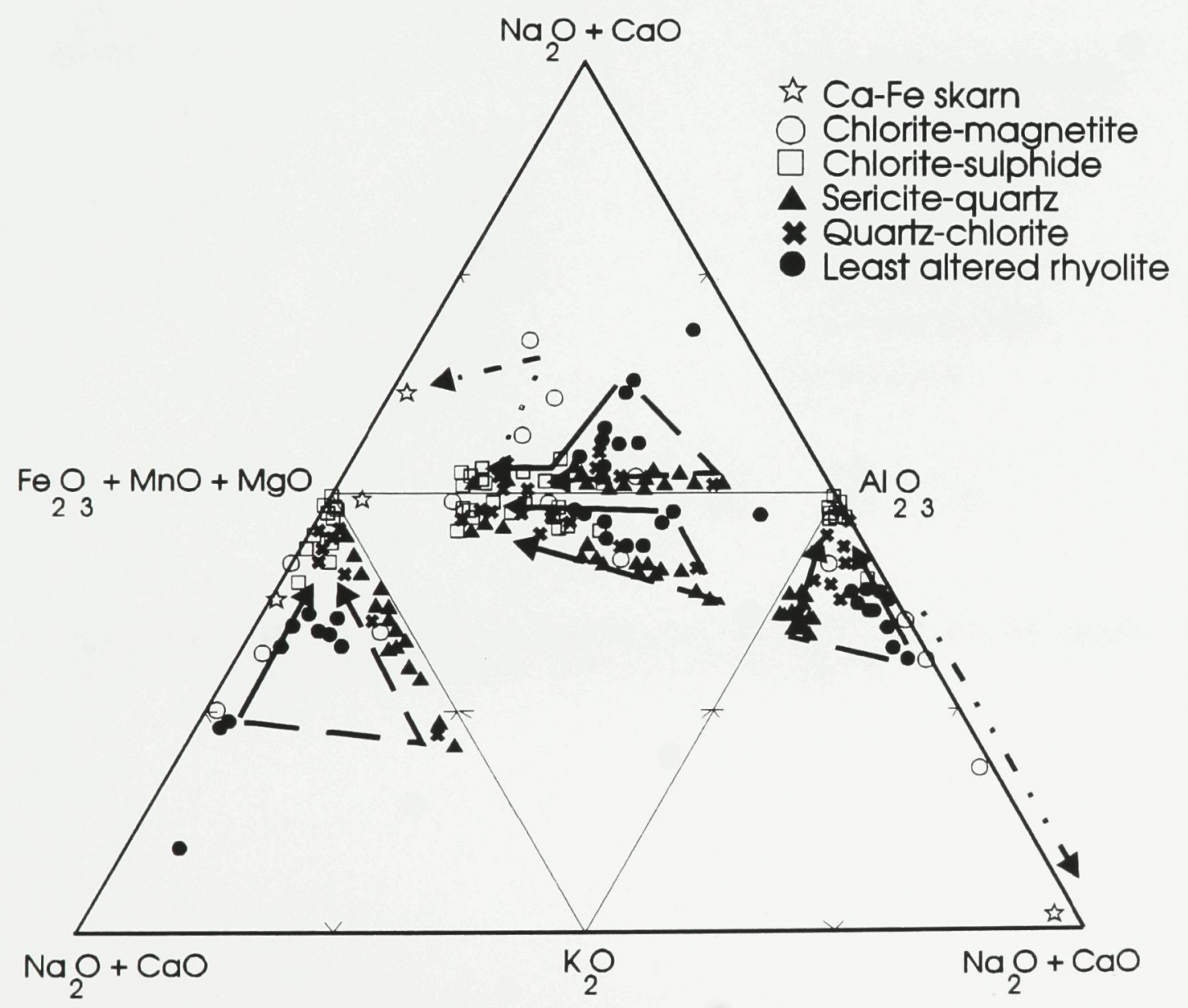

Flgure 5.45 Flattened tetrahedron (Rlverin and Hodgson, 1980) showing alteration trends. Dashed lines= serlcite-quartz alteration, solld lines chlorite-sulphide and dot-dashed lines chlorite-magnetite. 


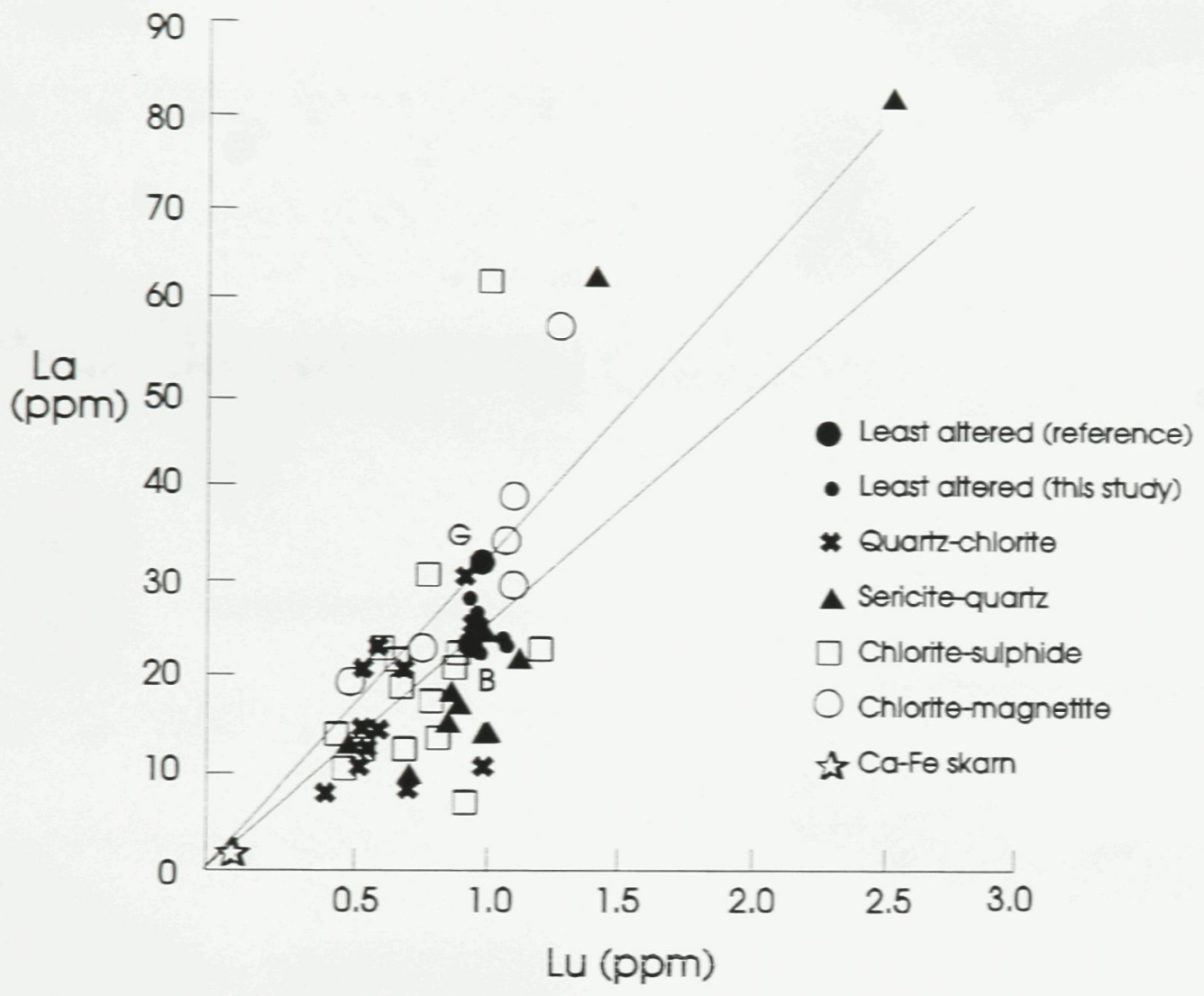

Figure 5.46 La/Lu ratios for the Ansil footwall alteration facies. The letters ' $G$ ' and 'B' Indlcate the Glbson and Barrett standards. 

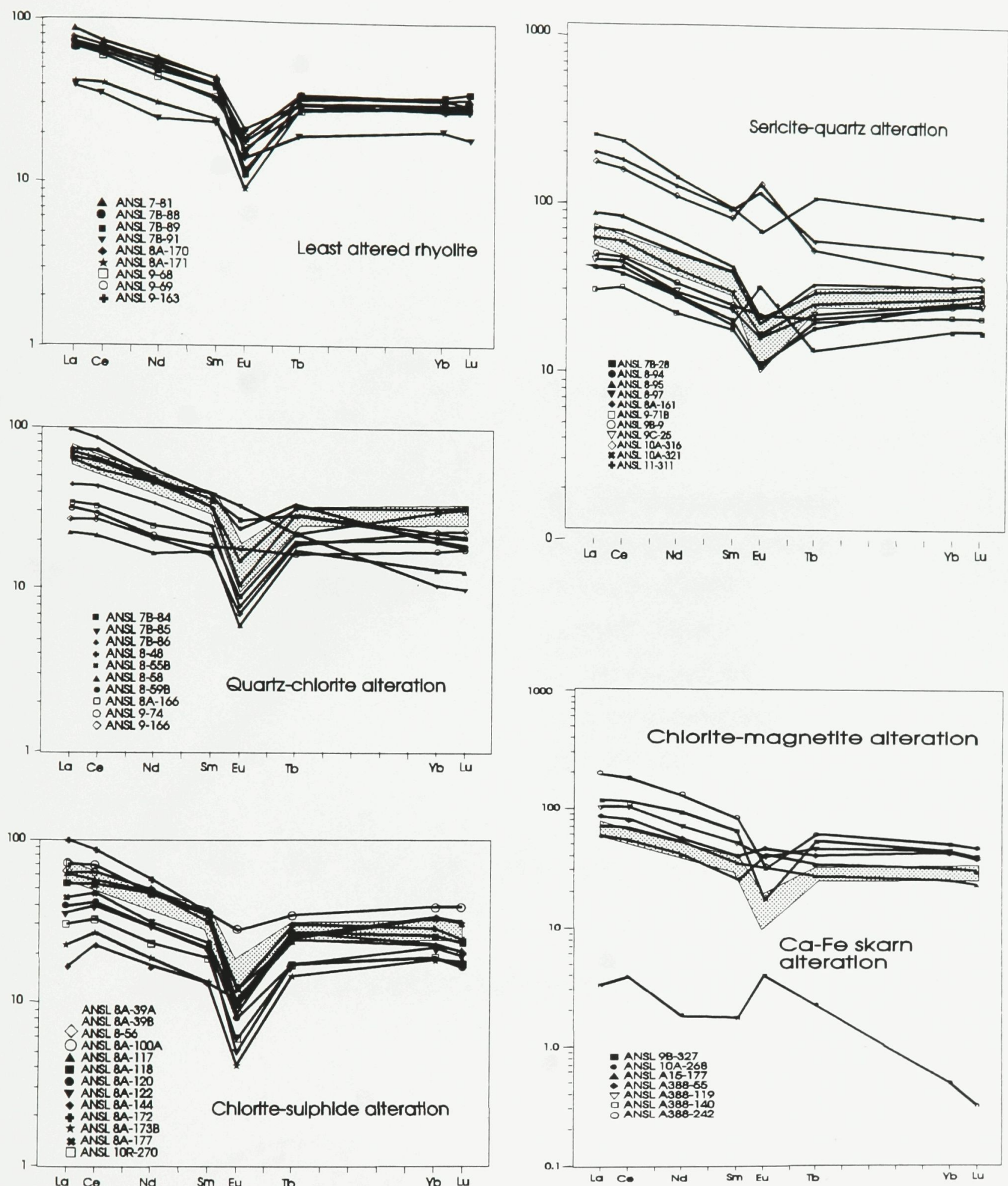

Flgure 5.47 Chondrite normallzed REE proflles for the Ansll alteration facles. Shaded areas represent the range of values for the least altered rhyollte 


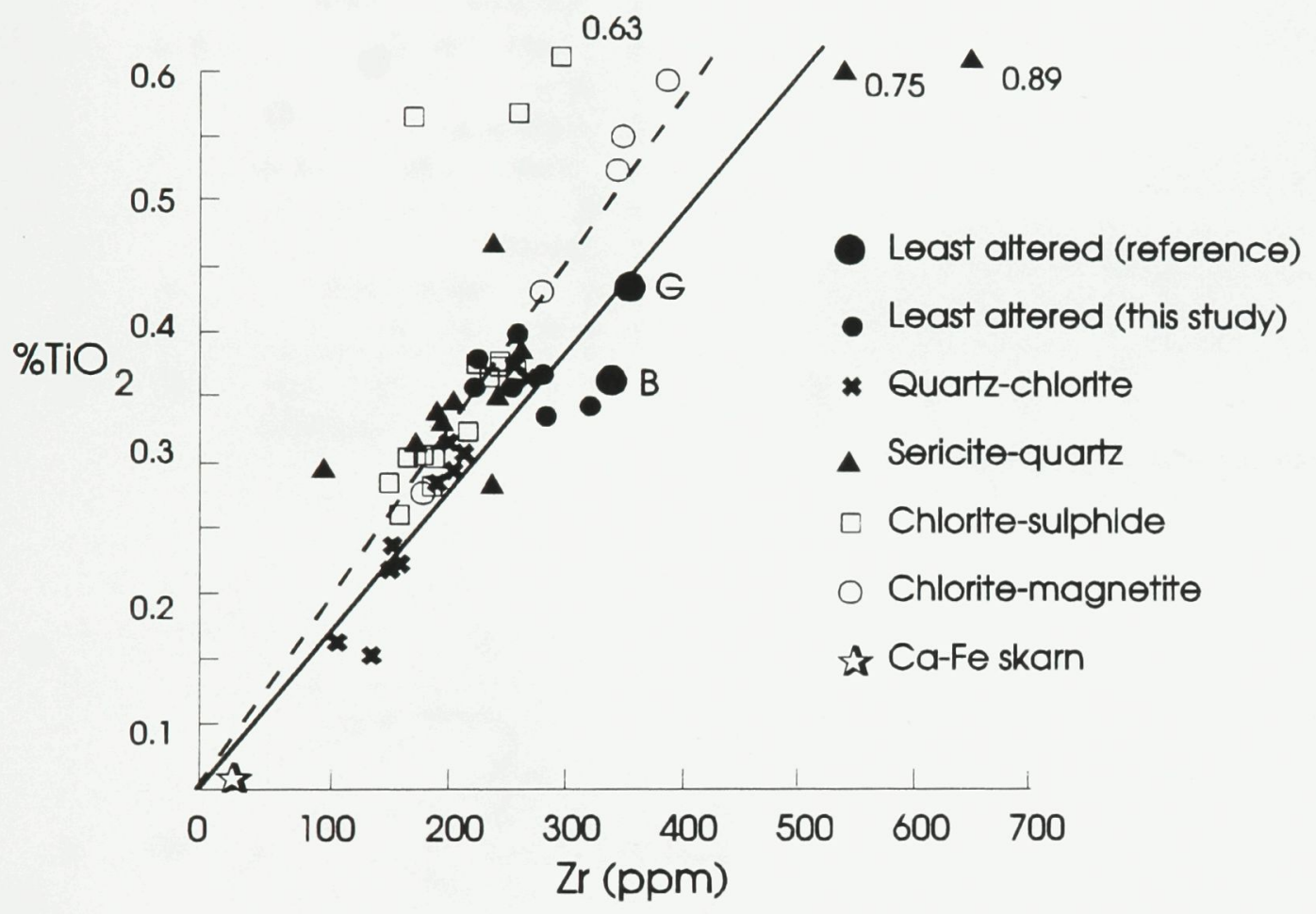

Figure 4.48 $\mathrm{TIO} 2$ vs. Zr plot for the Ansil alteration facles 

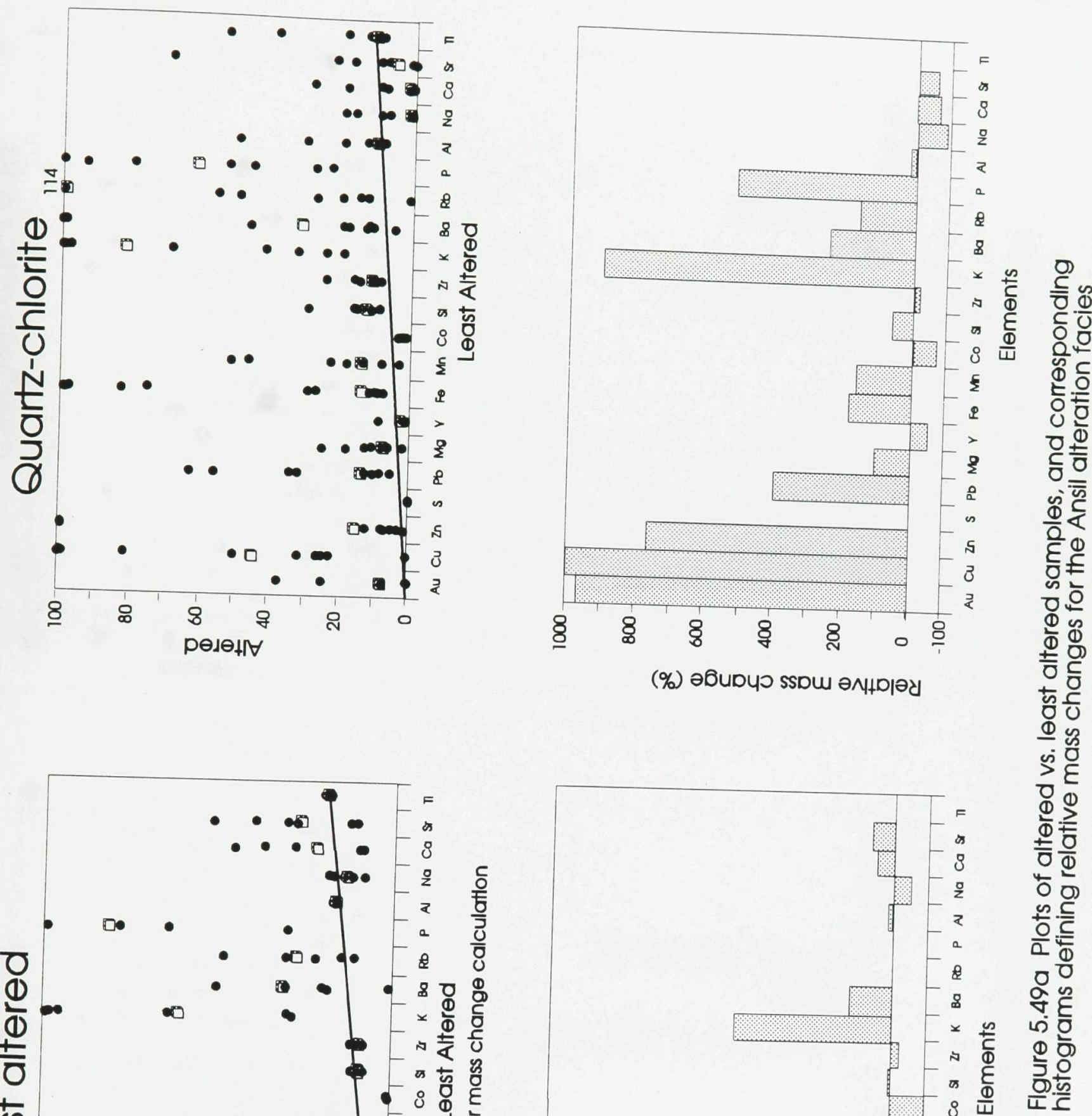

(\%) əठินDчว ssDu әмџроәу
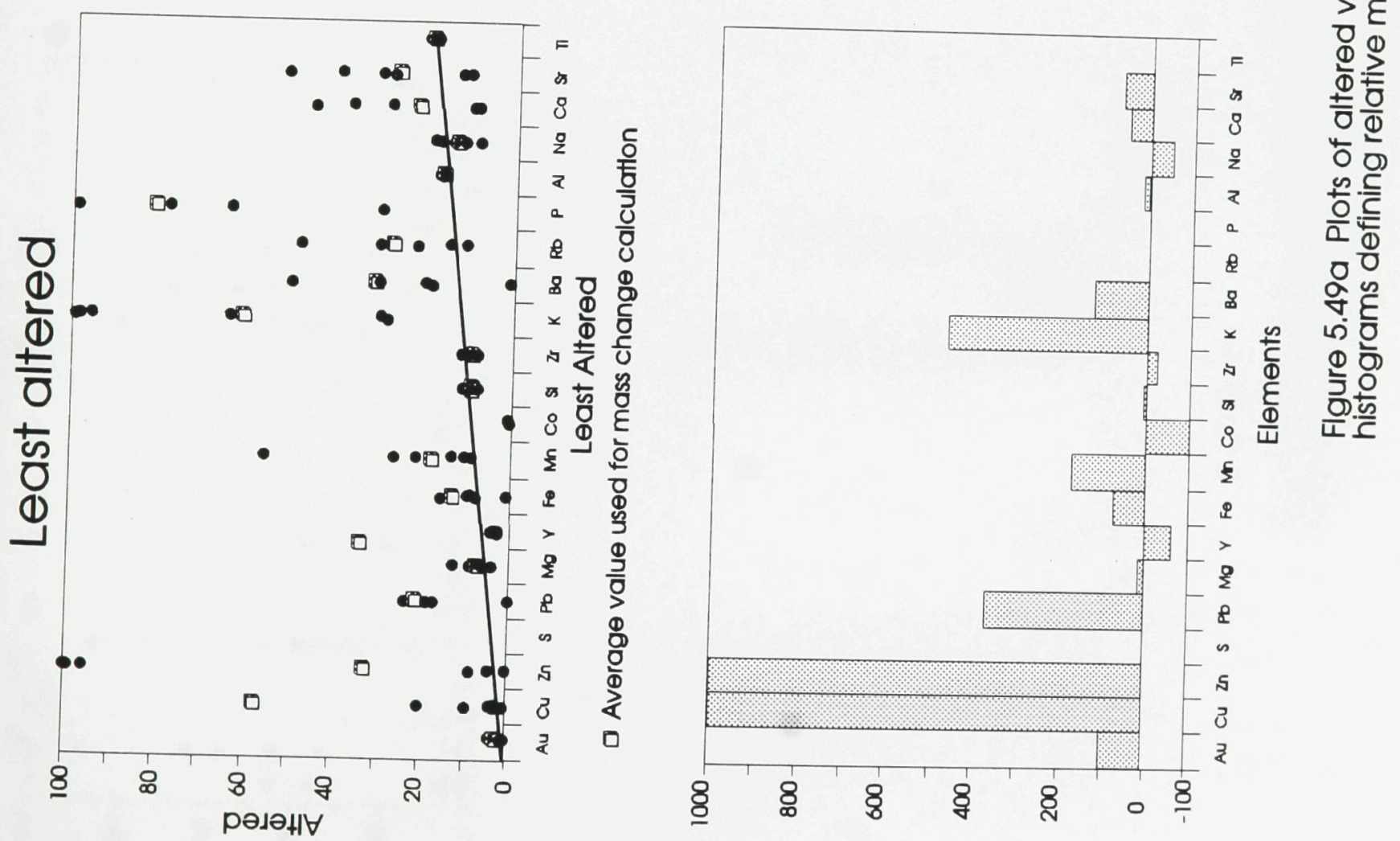

(\%) әбuрu० sspw әмฺฺр|әу 

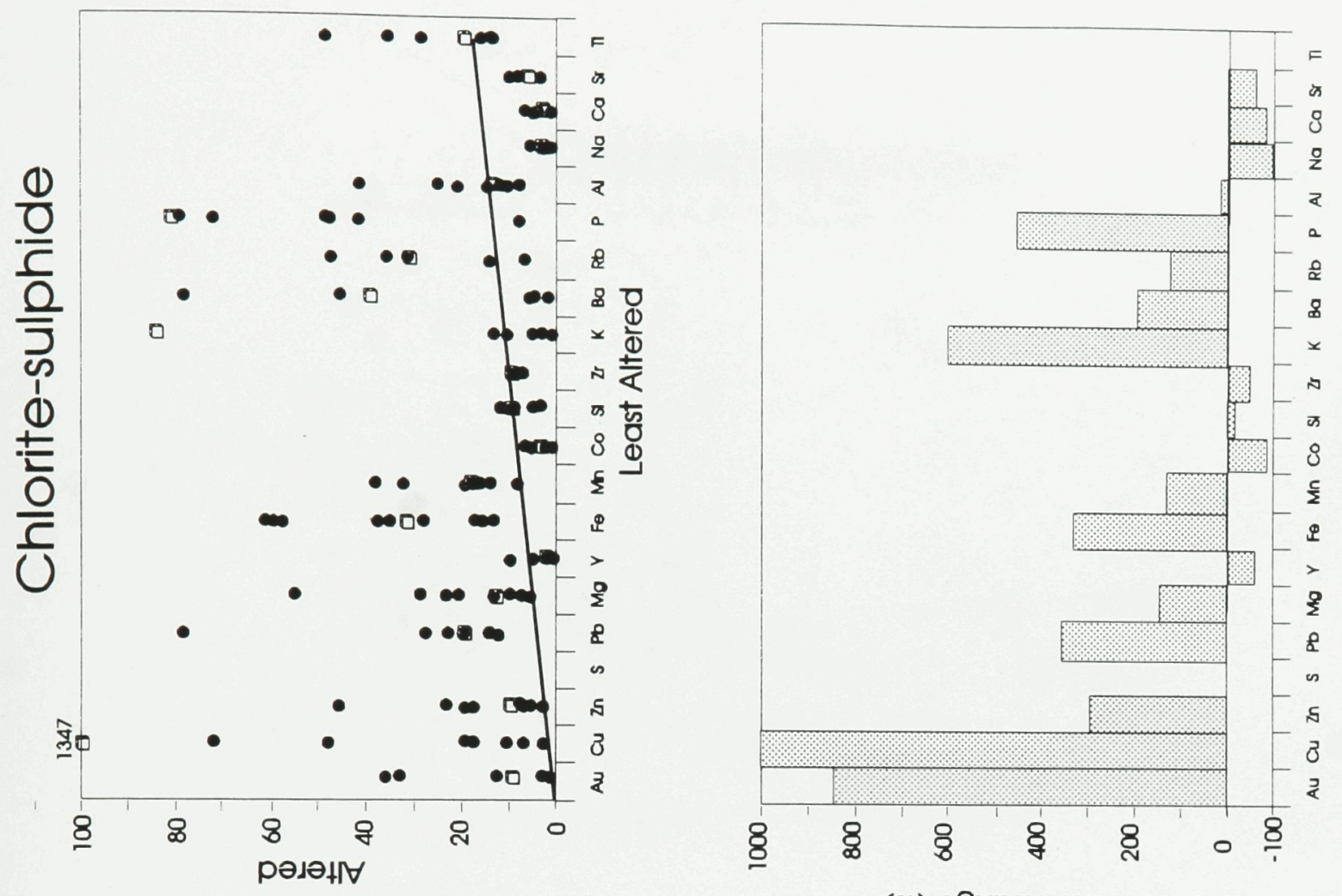

(\%) әठิUDบว ssDw ә^|†D|әу

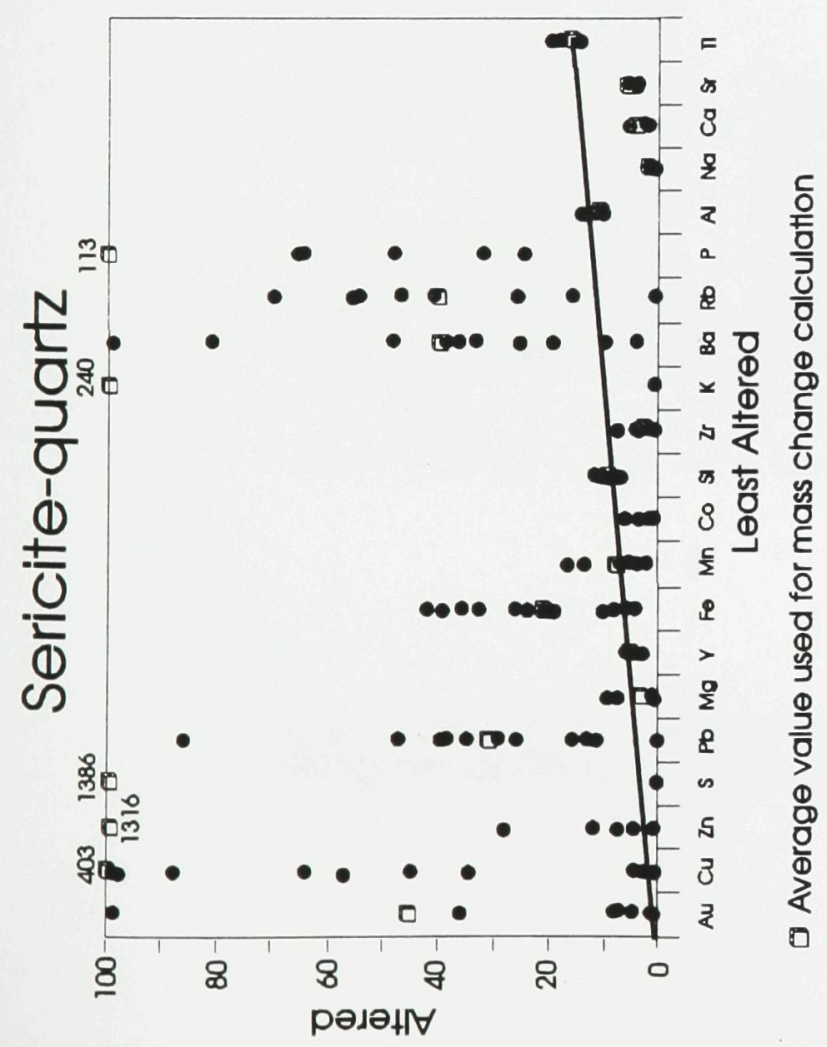

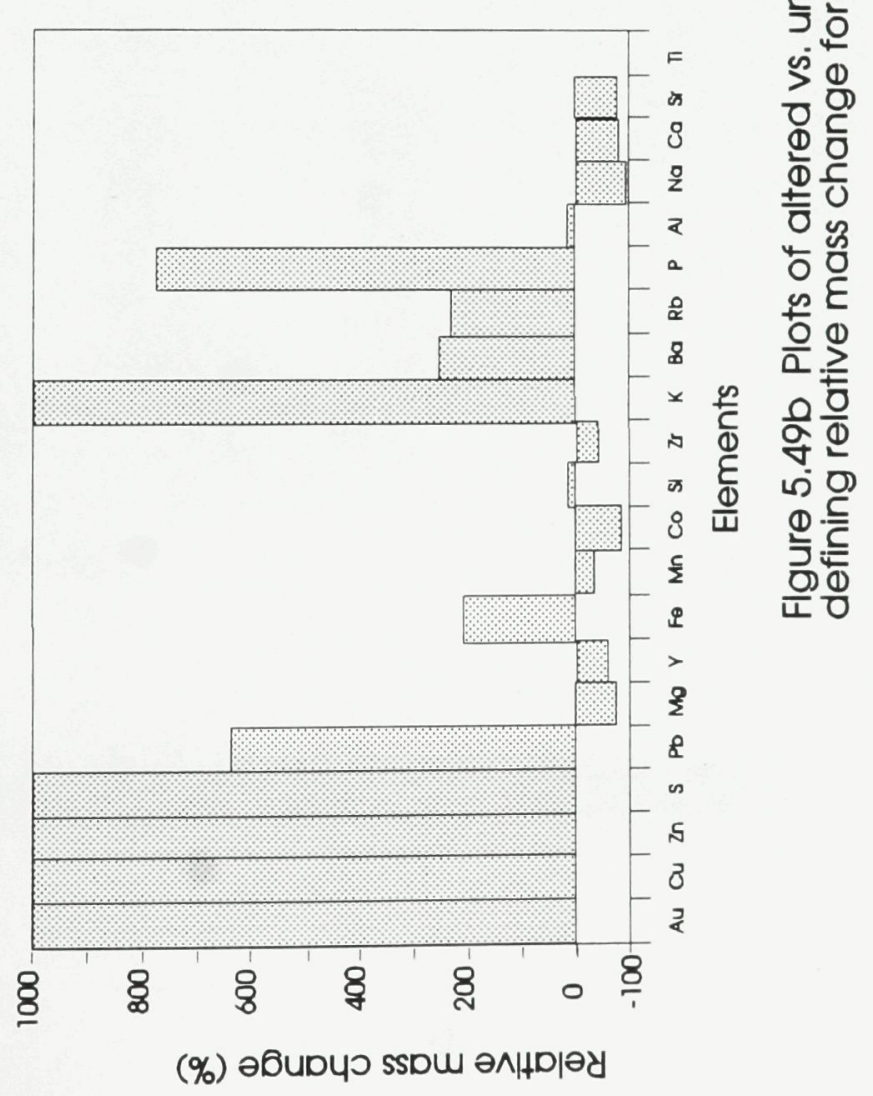




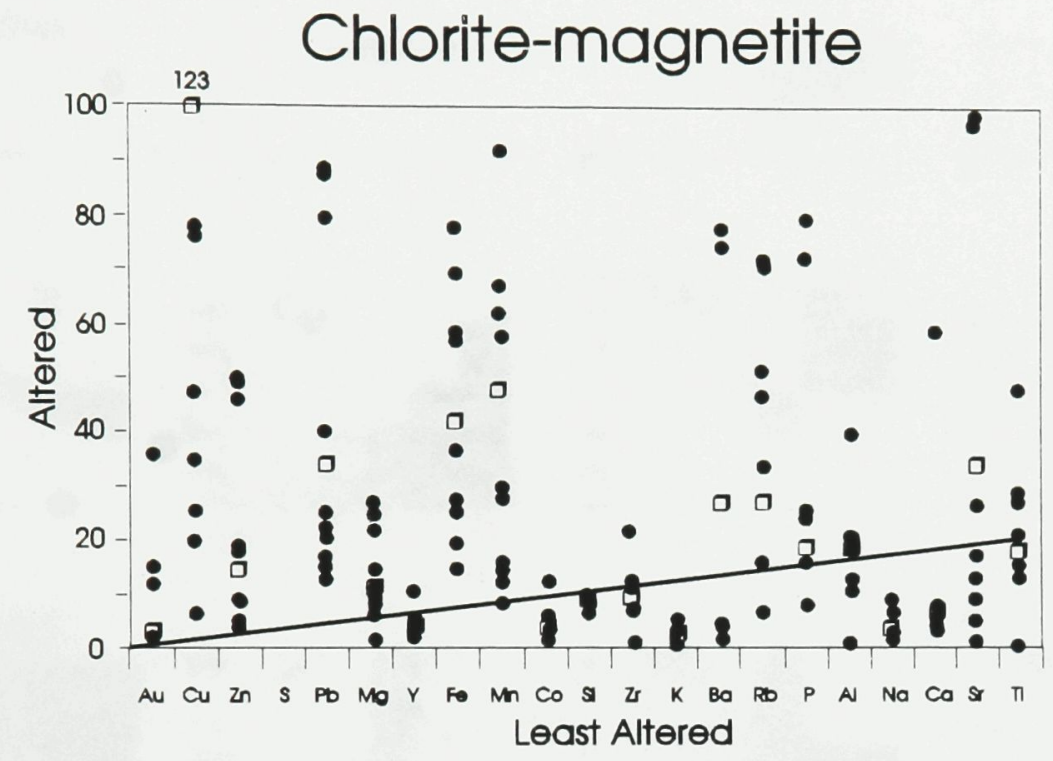

- Average value used for mass change calculation

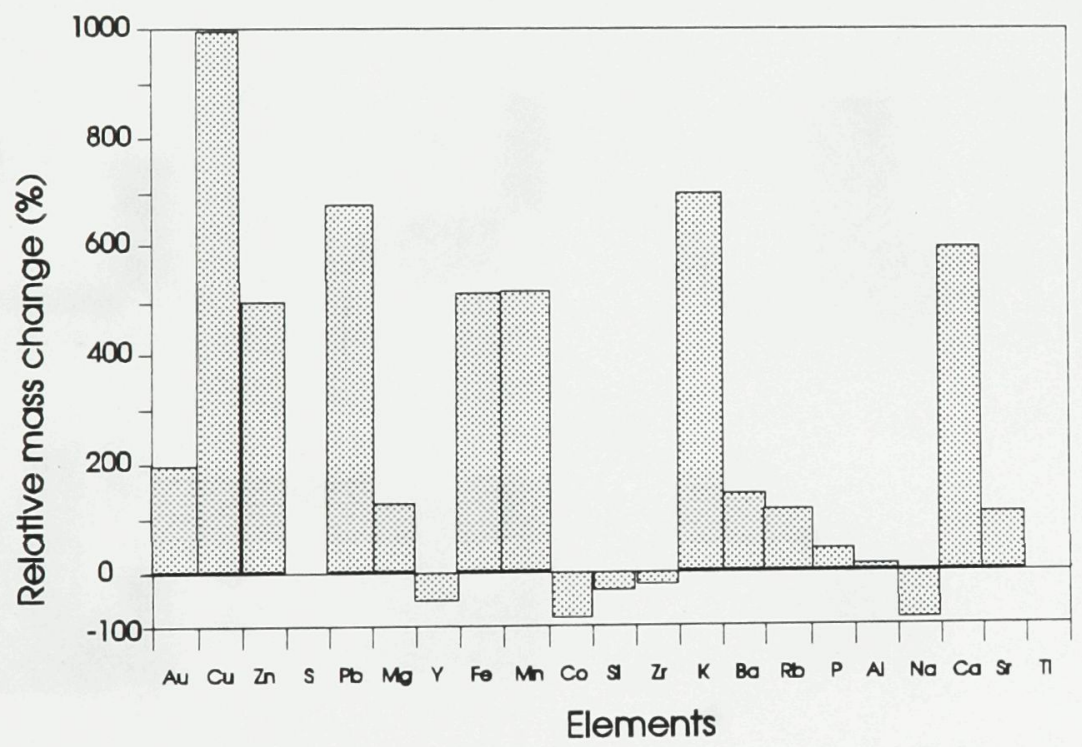

Flgure 5.49c Plot of altered vs. least altered samples, and corresponding histogram defining relative mass changes for the chlorite-magnetite zone. 

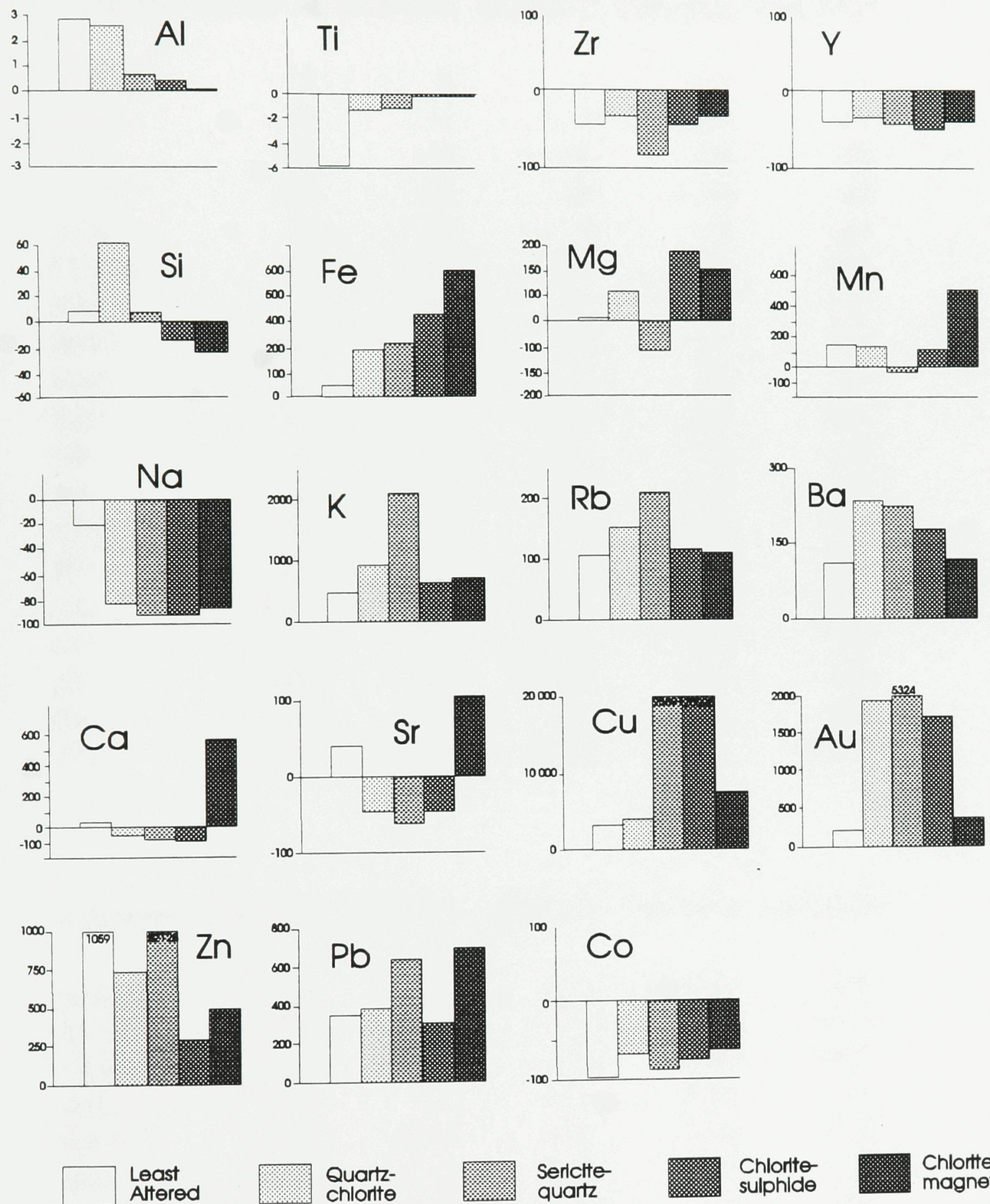

Figure 5.50 Bar graphs showing relative mass changes of the Ansil alteration facies grouped by element 
Table 5.1: Relative mass changes within the Ansil alteration system ELEMENT LEAST AL QTZ-CHL SER-QTZ CHL-SUL CHL-MGT

$\begin{array}{lrrrrr}\mathrm{AL2O} 3 & 3 & 3 & 1 & <1 & <1 \\ \mathrm{TIO} 2 & -6 & -1 & -1 & <1 & <1 \\ \mathrm{ZR} & -26 & -19 & -45 & -25 & -19 \\ \mathrm{Y} & -42 & -38 & -48 & -53 & -46 \\ \mathrm{SIO} 2 & 8 & 64 & 7 & -14 & -24 \\ \mathrm{FE2O3} & 49 & 198 & 220 & 321 & 503 \\ \mathrm{MGO} & 6 & 104 & -62 & 141 & 110 \\ \mathrm{MNO} & 155 & 147 & -29 & 121 & 504 \\ \mathrm{NAO} & -22 & -83 & -93 & -93 & -87 \\ \mathrm{~K} 2 \mathrm{O} & 444 & 915 & 2103 & 597 & 680 \\ \mathrm{RB} & 106 & 139 & 214 & 118 & 109 \\ \mathrm{BA} & 125 & 256 & 245 & 188 & 127 \\ \mathrm{CAO} & 36 & -55 & -72 & -80 & 577 \\ \mathrm{SR} & 40 & -49 & -67 & -63 & 102 \\ \mathrm{CU} & 3081 & 3509 & 23891 & 70097 & 6660 \\ \mathrm{AU} & 96 & 974 & 5324 & 844 & 190 \\ \mathrm{ZN} & 1059 & 745 & 52129 & 282 & 484 \\ \mathrm{~PB} & 347 & 395 & 637 & 330 & 661 \\ \mathrm{CO} & -91.1 & -67.75 & -81.36 & -71.97 & -63.61\end{array}$

ELEMENT LEAST AL QTZ-CHL SER-QTZ CHL-SUL CHL-MGT

$\begin{array}{lrrrrr}\mathrm{AL2O} 3 & 0.37 & 0.37 & 0.12 & 0.00 & 0.00 \\ \mathrm{SIO} 2 & 5.93 & 47.44 & 5.19 & -10.38 & -17.79 \\ \mathrm{FE2O3} & 1.96 & 7.90 & 8.78 & 12.81 & 20.07 \\ \mathrm{MGO} & 0.10 & 1.72 & -1.02 & 2.33 & 1.82 \\ \mathrm{MNO} & 0.06 & 0.06 & -0.01 & 0.05 & 0.20 \\ \mathrm{NAO} & -1.18 & -4.45 & -4.98 & -4.98 & -4.66 \\ \mathrm{~K} 2 \mathrm{O} & 0.62 & 1.28 & 2.94 & 0.84 & 0.95 \\ \mathrm{CAO} & 0.29 & -0.44 & -0.58 & -0.64 & 4.62\end{array}$

Table 5.2: Significant absolute mass changes ( $\mathrm{g} / 100 \mathrm{~g}$ ) 
TABLE 5.3: SUMMARY OF SIGNIFICANT MASS CHANGES IN THE ANSIL ALTERATION SYSTEM

$\begin{array}{lllll}\text { FACIES } & \text { MINOR GAINS } & \text { MAJOR GAINS } & \text { MINOR LOSS } & \text { MAJOR LOSS } \\ \text { Least altd } & \mathrm{Mn}, \mathrm{K}, \mathrm{Rb}, \mathrm{Ba} & & \mathrm{Na} & \mathrm{Al}, \mathrm{Ti}, \mathrm{Zr}, \mathrm{Y}, \mathrm{Si}, \mathrm{Mg} \\ \text { Qtz-chl } & \mathrm{Si} & \mathrm{Na}, \mathrm{Ca} & \mathrm{Sr} & \mathrm{Al}, \mathrm{Ti}, \mathrm{Zr}, \mathrm{Y} \\ \text { Ser-qtz } & \mathrm{Fe}, \mathrm{K}, \mathrm{Rb}, \mathrm{Ba} & \mathrm{Na}, \mathrm{Ca}, \mathrm{Mg} & \mathrm{Mn} & \mathrm{Al}, \mathrm{Ti}, \mathrm{Zr}, \mathrm{Y}, \mathrm{Si} \\ \text { Chl-sulf } & \begin{array}{l}\mathrm{Zn}, \mathrm{Cu}, \mathrm{Pb}, \mathrm{Au} \\ \mathrm{Fe}, \mathrm{Mg}, \mathrm{Mn}, \mathrm{Cu}\end{array} & \mathrm{Na}, \mathrm{Ca}, \mathrm{Sr} & \mathrm{Si} & \mathrm{Al}, \mathrm{Ti}, \mathrm{Zr}, \mathrm{Y} \\ & \mathrm{Au}, \mathrm{Zn}, \mathrm{Pb} & & \mathrm{Al}, \mathrm{Ti}, \mathrm{Zr}, \mathrm{Y}\end{array}$

TABLE 5.4: RELATIVE MASS GAINS IN REPLACED CRANSTON TUF Element 9B-TF1 9B-TF2 Least Ser-Qtz alt'd

SB-SP

to Chl-Sulf alt'd

$\begin{array}{lrrrrrr}\text { AL203 } & 18 & 17 & 19 & 18 & 1 & 5 \\ \text { TIO2 } & -20 & -16 & -17 & -17 & -1 & -4 \\ \text { Y } & -34 & -32 & -26 & -33 & -51 & -49 \\ \text { SIO2 } & 71 & 58 & 89 & 71 & -60 & 68 \\ \text { FE303(T) } & 359 & 302 & 56 & 36 & 446 & 1250 \\ \text { MGO } & 73 & 41 & -90 & -93 & 165 & -75 \\ \text { MNO } & 281 & 217 & -7 & -54 & 157 & 14 \\ \text { NA2O } & -88 & -81 & -92 & -90 & -100 & -95 \\ \text { K2O } & 1159 & 1351 & 2638 & 2493 & -89 & 2595 \\ \text { BA } & 182 & 397 & 209 & 406 & -73 & 279 \\ \text { CAO } & -64 & -64 & -44 & -10 & -80 & 5 \\ \text { SR } & -69 & -61 & -36 & -28 & -55 & -35 \\ \text { CR } & 1595 & 3075 & 2863 & 2493 & -26 & -100 \\ \text { P205 } & 408 & 456 & 5363 & 6011 & 488 & 5923 \\ \text { CO } & -29 & -21 & -38 & -36 & -75 & 225 \\ \text { AU } & 4985 & 4821 & 3326 & 50733 & 2510 & 46264 \\ \text { CU } & 39731 & 40376 & 8048 & 4993 & 15837 & 19218 \\ \text { ZN } & 3145 & 10331 & 35879 & 486672 & 490 & 486913 \\ \text { S } & 10239 & 11329 & 85456 & 117493 & -100 & 313536 \\ & & & & & & \end{array}$




\section{CHAPTER 6. DISCUSSION AND CONCLUSIONS}

\subsection{DEPOSITIONAL ENVIRONMENT}

The Ansil deposit formed during the initial phases of subsidence of the Noranda cauldron when the top of the Central Noranda Volcano was inundated with a succession of andesite and rhyolite flows originating from a high level intrusive complex (de Rosen-Spence, 1975). Although this first cauldron cycle is divided into four formations, in reality many of these fissure fed eruptions were contemporaneous, with elongate rhyolite flow ridges inundated by widespread andesite flows which flooded the rapidly subsiding cauldron floor (Gibson, 1989). There is little evidence within the first cauldron cycle of epiclastic or chemical sediments that would indicate periods of volcanic quiesence. This dynamic volcanic environment that characterizes the initial stages of cauldron subsidence is not the most favourable environment for developing and preserving large massive sulfide deposits, which may explain why only two small massive sulfide deposits (Ansil and Corbet) have been found to date within the first cauldron cycle. In spite of evidence for widespread hydrothermal activity during the formation of the Noranda Cauldron, all of the seventeen intracauldron massive sulfide deposits are less than 5 million tonnes (Kerr and Gibson, 1994). The dynamics of such an environment is comparable to modern oceanic fastspreading ridges (Kappel and Franklin, 1986) in which numerous small massive sulfide mounds develop, but are quickly inundated by successive eruptions within a rapidly developing axial graben. 
The immediate depositonal environment of the Ansil deposit was no less dynamic. The rhyolite ridge underlying the deposit was formed from an almost continuous eruption, with rapid extrusion of lobate rhyolite, followed by slower lava extrusion that developed into a lobe-breccia sequence. This was followed by discontinuous lava extrusion, with isolated flow lobes emplaced within a thick unit of hyaloclastite. In spite of the presence of a thin hyaloclastite layer above the basal massive lobate flow, there is no other evidence for any intervals in volcanic activity during the emplacement of the Northwest formation. The last phase of rhyolite activity was the formation of a dome (the Cranston QFP) along the southeast flank of the ridge $2000 \mathrm{~m}$ north of the future site of the Ansil deposit. The south face of the dome collapsed in a series of mass flows that inundated the southeast flank of the rhyolite ridge. In the vicinity of the Ansil deposit the basal flows of this volcanclastic unit are interlayered with intermediate lobe-hyaloclastite flows that form the base of the Rusty Ridge formation. The upper volcaniclastic flows (which host the east end of the Ansil massive sulfide lens) are overlain by massive andesite flows. Andesite flows continued to terminate against the side of the rhyolite ridge, finally inundating it, and burying it under 200 to $300 \mathrm{~m}$ of lava.

The water depth at which deposits such as Ansil formed would have a strong influence on the morphology and mineralogy of the deposit (Pisutha and Ohmoto, 1983; Large, 1992; Cas, 1992). Gibson (1989) gives evidence for phreatomagmatic and Strombolian eruptions during the emplacement of andesite flows of the Flavrian formation. Some of the upper flows contain more than $30 \%$ amygdules, from which he concludes that water depths were 
less than 300 m. Studies by Moore and Fiske (1969), Moore and Schilling (1973) and Allen (1980) suggest that basaltic pyroclastic eruptions have a limited water depth of 100 to $200 \mathrm{~m}$. The Ansil deposit is situated at least $200 \mathrm{~m}$ above the top of the Flavrian formation on the upper slope of the North Flow rhyolite ridge. Taking into account rapid subsidence of the cauldron floor, this would still place the deposit above a $500 \mathrm{~m}$ water depth. Underlying the deposit are highly vesiculated intermediate flows with gas cavities as large as $20 \mathrm{~mm}$ in diameter. The eastern half of the deposit is hosted by the Cranston tuff, a crystal-rich pyroturbidite unit. The finely layered volcaniclastic rock contains abundant broken phenocrysts and juvenile fragments that suggest that the mass flow may be in part pyroclastic. Felsic pyroclastic activity is usually restricted to depths of less than $1000 \mathrm{~m}$ ( Fisher and Schmincke, 1984). The tuff layers also contain cross-bedded ripple marks, structures usually formed by currents in shallow water (Figure 3.43).

Another indication of a shallow water environment is the presence of phreatic/hydrothermal breccia pipes below the flanks of the massive sulfide lens. Explosive brecciation, fragment ejection and formation of chaotic breccia piles on the seafloor are products of the rapid expansion of fluids as a result of boiling (Wohletz and Sheridan, 1983; Nelson and Giles, 1985). Depending on fluid composition (to be discussed later) and temperature, explosive activity would be restricted to water depths of less than $1000 \mathrm{~m}$ (Bischoff and Rosenbauer, 1984). This water depth appears to have been maintained during the emplacement of the first cauldron cycle, as phreatomagmatic explosion breccias are also present within the Amulet formation (Gibson et al., 1983). 


\subsection{STRUCTURAL CONTROLS ON DEPOSIT EMPLACEMENT}

The faults and fissures that developed during the early stages of cauldron subsidence controlled the formation of the Ansil hydrothermal system. Orthogonal sets of NNW- and ENE-trending synvolcanic faults were recognized by de Rosen-Spence (1976), Knuckey et al. (1980), Setterfield (1984) and Gibson (1989) to control locations of feeder dykes and hydrothermal activity south of Lac Duprat. These fault sets are postulated by Gibson (1989) to represent radial and ring faults that formed as a result of doming and subsequent collapse of the top of the volcanic edifice during emplacement and evacuation of a high level magma chamber now represented in part by the Flavrian intrusive complex.

In reality the pattern of faults and fissures within the Noranda Cauldron is more complex, with abundant variation on these two prominent orientations. This is to be expected, as most cauldron structures are centred on previously formed fault systems that are a result of the regional (tectonic) stress field which controlled the rise of magma and the distribution of volcanic edifices (Titley and Hiendrich, 1976; Hutton et al., 1990). This usually results in magma extrusion during the early phases of cauldron formation taking place along a central fissure-graben zone. When cyclic inflation and deflation of the magma chamber imposes a local stress field, related fault systems are controlled in part by the existing fault system. This is illustrated by such cauldron structures as Platoro (Lipman, 1975) and Valles-Toledo (Wohletz and Heiken, 1992). In the Noranda Cauldron a central, axial fissure-graben 
system (Old Waite Dyke Swarm) defines the main centre for andesite volcanism (Gibson 1989).

The location of massive sulfide deposits by synvolcanic faulting has been recorded for a number of deposits in the Noranda district. The Norbec, Vauze, East Waite and Old Waite deposits are located along the Old Waite Dyke Swarm and associated normal faults, whereas the Millenbach and D-68 deposits are located at the junction of northwest-trending Amulet-Millenbach structure and McDougall-Despina Fault and the northeast trending fissure over which the Millenbach rhyolite extruded (Gibson, 1989). The formation of massive sulfide deposits at the junction of faults is well documented in submarine axial rift environments such as Larnaca Graben, Cyprus (Lydon and Galley, 1986), northern Gorda Ridge (Rona and Clague, 1989), Endeavour Segment and Middle Valley, Juan de Fuca Ridge (Robigou et al., 1993; Goodfellow and Franklin, 1994) and the TAG Field, midAtlantic Ridge (Rona et al., 1994).

The Ansil deposit lies within an east-west trending graben that transects the northnortheast striking rhyolite ridge on which the massive sulfide lens is situated. The graben is part of a west-northwest striking lineament that is at least $2500 \mathrm{~m}$ long and is defined by a zone of Na-depletion of spilitized volcanic rocks (Figure 5.5). The Na-depletion defines a discordant zone that extends across four formations, indicating that this structure was hydrothermally active during all of the first cauldron cycle. Although there is no evidence that this lineament is a graben for its entire strike length, it does parallel the Dacite Fault, 
that defines the northern edge of the major graben-fissure system that controlled much of the andesite volcanism within the cauldron.

Graben structures are ideal loci for hydrothermal activity as their subsidence results commonly from magma chamber deflation in an extensional stress regime (Kappel and Franklin, 1989). Being the foci of magmatic activity the structures are characterized by high heat flux, which may generate convective hydrothermal systems between the magma chamber and the seafloor (Cathles, 1983). A product of such hydrothermal convection is the focused discharge of hydrothermal fluid and generation of massive sulfide deposits. Worley and Sleep (1975) postulated that only 10 to $20 \%$ of the total convective heat flux from mid-ocean ridges may be accounted for through focused fluid discharge. The remainder is diffuse, lower temperature discharge over the floor of the graben. This diffuse hydrothermal discharge would result in the widespread alteration of rocks within the structure, which may well result in the type of Na-depletion observed within the graben hosting the Ansil deposit.

Ansil is located within one of three discordant zones, $500 \mathrm{~m}$ apart, of strong Na-depletion within the larger alteration zone. The regularity of the separation suggests focused hydrothermal fluid discharge by a set of cross structures. The western-most zone lies above the intersection of the graben and the NNE-trending, Ansil QFP rhyolite ridge, and the Ansil deposit is situated at the intersection of the graben and the northeast-trending North Flow rhyolite ridge. The middle Na-depletion anomaly marks the intersection of trends of the WNW and NNE alteration zones. The NNE-trending alteration zone coincides with the 
eruption of the North Flow rhyolite along a fissure of similar orientation. There would appear to be some connection between focused hydrothermal discharge within the graben and eruption of rhyolite flows along intersecting structures.

The change in the orientation of the large Na-depletion zones with time from westnorthwest to north-northeast is related to the change in morphology between the $\mathrm{Zn}$ - and $\mathrm{Cu}$-rich stockwork vein systems underlying the Ansil massive sulfide lens. The earlier $\mathrm{Zn}$ rich stockwork is controlled largely by east-west trending lineaments that define the graben boundaries. The orientation of the overprinting $\mathrm{Cu}$-stockwork zone changes to north-south. This change in extensional direction at different scales and times suggests a cyclicity involving rapid changes in the orientation of principal stress axes during cauldron subsidence.

The fact that the Ansil deposit is the only massive sulfide accumulation found within the three zones of strong $\mathrm{Na}$ depletion suggests that unique conditions existed at that point along the graben. The Ansil alteration pipe is certainly the most long-lived, with the semicircular zone of Na-depletion penetrating over $500 \mathrm{~m}$ into the Amulet formation (Figure 5.5). The location of the deposit coincides with a rapid constriction in the graben width from greater than $500 \mathrm{~m}$ to less than $200 \mathrm{~m}$, and with a change in the orientation of the structure from WNW to east-west. This change in trend may be related to the intersection of the structure with another fault system, as observed just south of the deposit where the WNW-trending Dacite Fault intersects the east-west trending Des Fault (Figure 2.7). The 
fault intersection may have resulted in increased hydrothermal fluid flow through the creation of zone of intense cross-fracturing.

Plagioclase-glomeroporphyritic felsic dykes observed immediately below the Ansil massive sulfide lens are the loci for zones of silicification that pre-date the ore-forming event. The presence of the dykes may indicate that the part of the graben containing the deposit is a zone of anomalously high heat flow due to dyke injection. The presence of the dykes would tend to focus the upwelling of hydrothermal fluids. The focusing of seafloor hydrothermal activity above sill/dyke swarms is recorded by Gibson (1989) in the Old Waite Dyke Swarm, in the Early Proterozoic Snow Lake mining camp below the Chisel deposit (Skirrow, 1987; Galley and Scoates, 1991), in ophiolitic suites (Schiffman and Smith, 1988; Stakes and Taylor, 1992), and in modern oceanic ridge environments (Zierenberg et al., 1993; Goodfellow and Franklin, 1993).

\subsection{PERMEABILITY CONTROL ON DEPOSIT FORMATION}

The early structural history of the Noranda Cauldron was responsible for focusing hydrothermal activity along the flank of the rhyolite ridge where the Ansil orebody was formed, but it was a combination of fault geometry and permeability of the host strata that defined much of the morphology of the deposit and its associated stockwork vein system. The discordant parts of the vein systems are structurally controlled whereas the conformable parts are stratigraphically controlled. 
The alteration zone underlying the orebody extends upward $400 \mathrm{~m}$ from the contact with the Flavrian Pluton. Sulfide content is low and discontinuous through andesitic flows of the Flavrian formation and in the lower third of the Northwest rhyolite flow. This is due to the generally massive nature of the flow rocks. The andesite flows are either massive, or pillowed with little or no interpillow hyaloclastite. The base of the rhyolite flow consists of tightly packed flow lobes with a small percentage of autobreccia or hyaloclastite. This resulted in very little permeability for fluid flow, with patchy alteration and sulfides occurring as fine-grained disseminations and thin, discontinuous veinlets.

The first appearance of a substantial chalcopyrite-pyrrhotite stockwork vein system is at the transition between the massive rhyolite and overlying zone of mixed lobe-breccia and hyaloclastite (Figure 3.15). There is a widening of the vein system as the hydrothermal fluids flowed laterally and vertically around the fragmented rhyolite, infilling existing pore space and precipitating a semi-conformable zone of semi-massive to massive sulfide. Detailed mapping through the middle section of the alteration pipe revealed that, even in its core, strong chloritization and sulfide impregnation is restricted to the hyaloclastite facies, with little or no alteration of the flow lobes and associated breccia. Evidence for open space filling includes the rimming of rhyolite fragments by sulfide minerals followed by infilling by quartz, sulfide and phyllosilicates. Most of the sulfide veins within the massive flow lobes formed through the infilling of fractures previously generated through phreatic quenching and brecciation. The sulfide infilling of joints between cooling columns in the larger lobes is 
further evidence that hydrothermal fluids took advantage of the primary permeability of the volcanic pile, thereby reducing the necessity for hydraulically-induced fracturing.

Discordant, sharp-walled, breccia-filled, sulfide veins (denoting hydrothermal brecciation) comprise less than $20 \%$ of the main stockwork vein system. Most are restricted to a zone 20 to $40 \mathrm{~m}$ below the massive sulfide lens, where the rhyolite underwent early silicification (quartz-chlorite alteration), thereby forming a semi-impermeable cap to the hydrothermal system. This cap gave further impetus for lateral hydrothermal fluid flow within the underlying hyaloclastite. The primary dip of the rhyolite facies (5 to $\left.20^{\circ}\right)$ appeared to have some influence on lateral fluid flow, extending the semi-conformable stockwork zone westward (upslope). Hydraulic overpressuring permitted fluid to breach the silicified cap at two locations, from which fluid began to infill the hyaloclastite pile immediately underlying the graben floor. The two zones at which the silicified cap was breached appear to be controlled by the north-trending cross-faulting, intersecting the upper rhyolite surface where there are sudden slope changes (Riverin et al., 1990), and the stockwork vein concentrations within each zone are aligned north-south (Figure 4.3).

The footwall chalcopyrite-pyrrhotite stockwork vein system is restricted to the graben below the massive sulfide lens. This is partly structural, as the area under the graben defines a zone in which there is an intersection of east-west and north south faulting. It is also a function of the early development of sericite-quartz alteration zones along the grabenbounding faults. These discordant alteration zones formed permeability boundaries between which the later chalcopyrite-pyrrhotite alteration zone is restricted. 
The areal extent of the semi-conformable parts of the footwall stockwork system may also have been restricted by the interaction of the hydrothermal fluid with large volumes of seawater trapped within the hyaloclastite-rich flow facies. The interaction would mix and quickly cool the hydrothermal fluid, resulting in rapid precipitation of sulfide (Janecky and Seyfried, 1984).

The transition between the footwall chalcopyrite-pyrrhotite stockwork vein system and the massive sulfide lens takes place within the rhyolite lobe-hyaloclastite flow facies with the development of the semi-conformable fragmental sulfide ore. Between Levels $9 \mathrm{~B}$ and $10,30 \%$ of the orebody is located below the upper rhyolite contact, forming a large keel to the massive sulfide/magnetite lens. The ponding of the hydrothermal fluids immediately below the floor of the graben is due to the previous infilling of the eastern part of the structure by the Cranston tuff, and the western part by andesite flows. Both units were effective in temporarily capping the vertical movement of the hydrothermal fluids due to low, cross-stratal permeability. When the hydrothermal fluids began to infiltrate the flows and volcaniclastic rocks, their contrasting permeability dictated the difference in morphology between the two halves of the orebody (Figure 6.1).

Although the Cranston tuff was originally composed largely of quartz and feldspar, the finely laminated tops to the graded turbidite units appear to have been relatively impermeable. This is interpreted from the concentration of the early sphalerite and associated alteration along the coarser-grained bases of individual layers. The control of hydrothermal fluid flow by cross-stratal impermeability of unconsolidated sediment was 
concluded for some of the features observed within the presently active Middle Valley hydrothermal system (Goodfellow and Franklin, 1993; Franklin, pers comm.). The incursion of hydrothermal fluid into the Cranston tuff is likely the result of bedding dislocation along synvolcanic faults, and layer disruption through fluidization brought on by hydrothermal overpressure. The best example of fluid incursion along faults is seen at the contact of the Cranston tuff with the graben's north flanking fault (Figure 4.29), where layering is preferentially mineralized from the fault outwards. This mechanism of sulfide emplacement is observed in the Early Proterozoic Sullivan $\mathrm{Zn}-\mathrm{Pb}-\mathrm{Ag}$ massive sulfide deposit (Lydon et al., 1994; Leitch, 1994) and for massive sulfide deposits in the Escanaba Trough, a sediment-covered spreading centre along the southern Gorda Ridge (Zierenberg et al., 1993). Fluidization by the forceful channeling of hydrothermal fluid from the underlying stockwork zone would explain why macroscopic evidence for pre-existing tuff within the massive chalcopyrite-pyrrhotite lens is restricted to discontinuous rafts and segments far from its central core and underlying discordant stockwork pipe.

The margins of massive chalcopyrite-pyrrhotite lens may have been restricted for the same reason as the restriction on the size of the lower semi-conformable stockwork vein system within the lobe-hyaloclastite facies rhyolite: the Cranston tuff along the margins of the graben was already self-sealed by the early, sphalerite-rich, sericite-quartz-albite alteration event. This early alteration would have resulted in a reduction in permeability of the affected tuff layers, thereby sealing the margins of the graben from interaction with the potentially chlorite-chalcopyrite-pyrrhotite precipitating fluid. 
The pervasive degree of tuff replacement by massive chalcopyrite-pyrrhotite is due to the effective capping of the graben-infilling tuff unit by overlying massive andesite flows. The inability of the hydrothermal fluid to rise vertically would result in another lateral ponding and prolonged residence time. Evidence that some of the andesite flows were already emplaced before incursion of hydrothermal fluids into the Cranston tuff is: (1) the presence of $\mathrm{Zn}$-enriched, maroon-coloured chalcedony (part of the first mineralizing phase), infilling of basal andesite flow breccia above the south flank of the orebody and sericite-quartz altered breccia pipes crosscutting the base of the Rusty Ridge formation on Sublevel 11a, (2) the chlorite-alteration and sulfide emplacement along the base of the massive flows above the Cranston tuff, and (3) the lack of any textural evidence for seafloor precipitation of sulfides at the tuff-andesite contact. The chemical processes involved in the dissolution of the Cranston tuff will be discussed in the next section.

The development of the western half of the deposit as a steep-side dome along the rhyolite-andesite contact was either contemporaneous with the emplacement of massive chalcopyrite-pyrrhotite within the Cranston tuff, or was slightly younger. The reasoning for a model involving sequential development of the massive sulfide lens is that the formation of the western chalcopyrite-pyrrhotite stockwork zone may be due to the inability of the hydrothermal fluids to proceed upsection above the eastern pipe because of the massive andesite cap. The backpressure on the fluid system caused alternative fluid pathways to be found. The natural direction for lateral fluid flow would be updip: (1) along layering within 
the Cranston tuff, (2) along the rhyolite-Cranston tuff contact, and (3) along the base of the semi-impermeable quartz-chlorite alteration zone

The position of the massive sulfide mound was influenced both by the presence of a northtrending cross fault and by the permeability of the overlying andesite flow. The onlap of successive andesite flows against the side of the rhyolite ridge resulted in a shallow-dipping cross-section of the andesite strata along the rhyolite-andesite contact. The change upsection from massive to pillowed with abundant flow breccia and hyaloclastite resulted in an increase in permeability. Instead of damming up against the massive andesite flows (as occurred above the eastern discordant stockwork zone), hydrothermal fluids resumed vertical flow through interpillow hyaloclastite. Where flows are overlain by hyaloclastite, layered tuff and flow breccia, the vertical fluid flow was interrupted by lateral flow along the contacts. With reduction in permeability due to secondary mineral growth and sulfide precipitation, lateral fluid flow would be restricted, and vertical flow through the overlying pillowed flow could commence.

The result of this permeability-controlled channeling of hydrothermal fluid through the andesite pile was the development of small, massive chalcopyrite-pyrrhotite and magnetite lenses in the immediate hangingwall to the orebody, and thinner interflow zones of semimassive to disseminated sulfide further upsection. The inability of the hydrothermal system to maintain a strong upflow into the andesite pile resulted in a gradual shortening of these interflow sulfide zones, giving the hangingwall sulfide zone the appearance of a conifer. 
The vertical axis of the "conifer" developed from the longitudinal sulfide spine along the central axis of the western half of the deposit (Figure 4.2b). The formation of this spine may be due to the presence of a fissure within the andesite pile, as some of the spine has the appearance of a thick chalcopyrite-pyrrhotite vein infilling an open cavity. The underlying sulfide mound appears to have formed within a facies of andesite characterized by abundant amoeboid flow breccias and hyaloclastite. The presence of abundant, chloritealtered mafic xenoliths within the top of the dome would suggest that its growth involved envelopment and replacement of the volcaniclastic facies.

There is abundant evidence on a smaller scale of sulfide growth in hyaloclastite-rich interpillow areas through alteration and assimilation of glass shards. The feasibility of this process taking place on a larger scale may be a function of the amount of pore space present and the instability of the glassy flow material in the presence of hydrothermal fluids that are: (1) being constantly replenished, thereby minimizing the effect of the andesite as a buffer through high fluid-rock reaction ratios, and (2) being maintained at high temperature due to minimal interaction with seawater in a relatively deep, subseafloor environment. Much of the contact between the dome and surrounding andesite is tectonized, making primary contact relations difficult to discern. Microscopic evidence for andesite assimilation will be discussed in the next section.

The question also arises as to what depth in the constantly growing volcanic pile did the development of the massive sulfide lens take place. The presence of a conformable facies to the phreatomagmatic-hydrothermal breccias that host the discordant, Zn-rich deposit 
indicates that hydrothermal activity began near the seafloor. The continuation of the $\mathrm{Zn}$ mineralizing event into the overlying Cranston tuff suggests that the volcaniclastic unit was emplaced soon after explosive brecciation of the graben floor. The interlayering of the lower Cranston tuff with the first flows of the Rusty Ridge formation indicates that effusive flows began to cover the rhyolite ridge during emplacement of the Cranston mass flows. The character of the chalcopyrite-pyrrhotite deposit indicates that at least some andesite flows were in place during formation of the massive sulfide lens. The nature of the interflow sulfide mineralization within the andesite pile implies hydrothermal fluid flow along flow contacts rather than hydrothermal discharge at the seafloor. Hydrothermal activity, therefore, either evolved with the continued eruption of the andesite flows, or developed after emplacement of the Rusty Ridge formation (and the base of the Lower Amulet rhyolite). The most likely scenario is that the Ansil deposit began to form in the immediate subsurface ( 10 to $30 \mathrm{~m}$ ), and continued to evolve during the emplacement of the overlying $600 \mathrm{~m}$ of andesite and rhyolite flows. The continued evolution of the deposit in a relatively isolated environment would account for the high degree of zone refining it exhibits.

Ansil is not the only VMS deposit in the Noranda camp to contain more than one stratiform, semi-massive to massive sulfide lens. Corbet (Gibson et al., 1993), Amulet (Gibson, 1989) and Millenbach (Knuckey et al., 1982) deposits are composed of multiple sulfide lenses, some of which are vertically stacked, sharing the same stockwork vein system. There is no cited evidence that any one of these deposits formed in the subsurface, but they were certainly zone-refined after their burial (Knuckey et al., 1982, Kerr and 
Gibson, 1993). They are comparable to Ansil as examples of deposits in which sites of hydrothermal fluid discharge remained vigorous during periodic envelopment by rhyolite and/or andesite flows. Other examples of robust hydrothermal systems that have survived continued burial by extrusive and volcaniclastic flows to form deposits of vertically stacked, multiple massive sulfide lenses are the Australian deposits of Que River (Tasmania), Woodlawn (Victoria) and Thalanga (Queensland) (Large, 1992) and the Turner-Albright deposit in Oregon (Zierenberg et al., 1988).

The only other cited example in the Noranda of sulfide replacement of a volcaniclastic unit is at the Millenbach deposit. The discordant stockwork vein systems to several of the massive sulfide lenses at this deposit crosscut the $\mathrm{C}$ horizon and Lower $\mathrm{A}$ tuffite units that were deposited at approximately the same time the deposit was formed (Knuckey et al., 1982). Both volcaniclastic units have increased base metal concentrations in proximity to the alteration pipes. Samples of the tuff examined by the author clearly show signs of litpar-lit replacement of the andesite tuff by sulfides. It would appear that the formation of the stockwork vein systems was influenced by the primary permeability of the host units.

There are numerous examples involving varying degrees of massive sulfide emplacement in a subseafloor environment. The Kidd Creek and Horne deposits have both been cited as showing evidence for partial subseafloor emplacement. At Kidd Creek the North orebody is located at the contact between a footwall rhyolite and hangingwall, heterolithologic breccias. Along the 1420 Level the massive sulfide lens appears to be contained within rhyolite, and is charged with abundant rhyolite fragments. The sulfide mineralization 
continued into the overlying breccia pile, infilling the matrix between the larger fragments. At the Horne deposit the bowl-shaped morphology of the two main orebodies, and the occurrence of altered volcanic breccia within the massive sulfide lenses, allowed Kerr and Mason (1990) to conclude that the sulfide deposits formed through the replacement of rhyolite volcaniclastic rocks and pre-existing sulfide.

Other VMS deposits that may well have been emplaced in a shallow subseafloor environment include: (1) fault and intrusion-controlled sulfide emplacement within volcaniclastic piles, and (2) sulfide emplacement within previously-formed hydrothermal sediments.

(1) The Archean Mattabi deposit (Sturgeon Lake, Ontario) is hosted within a felsic tuff sequence believed to represent cauldron infill (Morton et al., 1990). The deposit consists of of lenses, of which two are within a unit of felsic volcaniclastic (Franklin et al., 1977). Examination of the core by the author showed that the tuff-hosted orebody had no welldefined contacts. Its margins are gradational, with a transformation over 10 to $15 \mathrm{~m}$ from disseminated to semi-massive to massive sulfide. Morton et al. (1990) concluded that the emplacement of the footwall stockwork vein system was controlled by a synvolcanic fault.

The Permian Tulsequah Chief deposit consists of massive sulfide lenses within felsic volcaniclastic units (Nelson and Payne, 1985). The units are cross-cut by a synvolcanic fault, along which vertically stacked massive sulfide lenses are situated. The lenses are thickest along the fault, thinning out into the volcaniclastic units. The location of the 
massive sulfide lenses within the volcaniclastic units led Thompson (1994) to conclude that they were emplaced in a subsurface environment.

The Cambrian Mount Lyell camp (Tasmania) includes eight deposits composed of chalcopyrite-pyrite stockworks surrounding central cores of stratiform, massive pyritechalcopyrite (Walshe and Solomon, 1981). In several cases the sulfide lenses are vertically stacked. The deposits appear to have formed by the lateral movement of hydrothermal fluids through permeable, felsic volcaniclastic horizons, or along contacts between andesite flows. The subseafloor formation of the deposits in a subseafloor environment may be in response to the emplacement of intrusive felsic domes (Large, 1994).

(2) The Cambrian Hercules and South Hercules deposits (Tasmania) are associated with a unit of fine-grained, tuffaceous shale within a thick sequence of felsic, pumice-rich volcaniclastic flows (Allen and Huns, 1990; Zaw and Large, 1992). Thin sphalerite-galenapyrite lenses are hosted within massive Fe-carbonate zones that have diffuse margins defined by layer-controlled nodular pods, spots and spheroids within the felsic tuff. The margins of the massive sulfide lenses are also diffuse, with their along-strike termination defined by apparent replacement of tuff layers by first massive, then spotted and disseminated sulfide. It is postulated that early hydrothermal alteration resulted in the subseafloor replacement of the felsic tuff by carbonate, and then by sulfide (Allen, pers comm., 1993).

Examples of very near-subseafloor massive sulfide formation are Early Proterozoic Chisel-North Chisel orebodies at Snow Lake, Manitoba . The $\mathrm{Zn}-\mathrm{Cu}-\mathrm{Pb}-\mathrm{Ag}-\mathrm{Au}$ massive 
sulfide deposits are at the contact between felsic and mafic volcaniclastic rocks, and spatially associated with a thin unit of rhyolite lobe-hyaloclastite flows (Bailes and Galley, 1990). The semi-massive to massive sulfide lenses were emplaced within a thin carbonate unit that formed on the seafloor as a result of early-stage, diffuse hydrothermal venting (Galley et al., 1993). Evidence for overprinting of the carbonate unit is the presence of hydrothermal skarn mineral assemblages. Other examples of this deposit type are the Early Proterozoic Vermillion and Errington deposits at Sudbury, Ontario (Paakki, 1992; Gray and Gibson, 1993) and Garpenberg deposit, Bergslagen District, Sweden (Vivallo, 1984).

There is obviously a large variation in the manner in which stratiform massive sulfide is formed in sub-seafloor and near-subseafloor environments. An end-member of this process is the evolution of massive sulfide mounds on the seafloor. It has long been recognized that the most likely mechanism for the formation and preservation of a massive sulfide deposit is to precipitate much of the sulfide and associated minerals within the mound. The continued maturation (zone refining) of a sulfide mound from within was first proposed by Large (1977) and Eldridge et al. (1983). Evidence from modern oceanic ridge-hosted deposits indicates that diffuse hydrothermal discharge through a mound of chimney talus would result in initial sulfide-silica precipitation in the outer part of the mound (Tivey and Delaney, 1986). This restricts subsequent fluid flow to within the mound, where it precipitates sulfide through mixing with seawater or conductive cooling (Goldfarb et al., 1983; Hekinian and Fouquet, 1985; Alt et al., 1987). Textural evidence for open-space infilling by sulfides 
within a sulfide mound is observed in such ancient deposits as Mathiati, Cyprus (Lydon and Galley, 1986) and Mine Gallen, Noranda (McEwen et al., 1990).

In summary, the Ansil orebody should not be thought of as the physical termination of a massive sulfide-producing hydrothermal system, but rather as the largest and most metalrich of several stratigraphically conformable sulfide zones. The reason it is the best developed stratiform sulfide zone is due to the primary permeability of its host rocks. The closest the system came to developing a seafloor vent field was where the $\mathrm{Zn}$-rich mineralization is associated with the phreatic-hydrothermal explosion breccias at the Ansil horizon. The remainder of the system's existence was spent trying to breach the seafloor. There is some evidence for weak hydrothermal activity within the Beecham breccias at the top of Rusty Ridge formation (Gibson, 1989) which may be evidence for seafloor hydrothermal activity from the Ansil system.

\subsection{HYDROTHERMAL EVOLUTION OF THE ANSIL DEPOSIT}

The alteration history of the Ansil host rocks may be divided into: (1) an early stage, involving devitrification, diagenesis and spilitization, (2) a middle stage during which focused hydrothermal activity along the deposit-hosting graben resulted in feldspar destruction and resultant Na-depletion, followed by the development of hydrothermal explosion breccias and $\mathrm{Zn}$-rich sericite-quartz alteration, and finally the formation of the $\mathrm{Cu}$-rich chlorite-sulfide alteration zone and the massive sulfide, and (3) a late stage during which the calc-silicate alteration assemblages formed and the massive sulfide lens was 
partially replaced by massive magnetite (Figure 6.2) The early stage alteration was a product of regional-scale convection of seawater into the cooling volcanic pile, and the middle and late stages represent the focused upwelling of hydrothermal fluid that define the ore-forming environment. In the Ansil area these stages should be viewed as a continuum that defines the progressive evolution of a hydrothermal system that was active during the time it took to emplace the first cycle of the Noranda Cauldron.

In drawing conclusions as to the hydrothermal history of the deposit it must be remembered that the rocks have undergone lower greenschist facies regional metamorphism. With the exception of discrete zones of high strain, most of the textures observed are interpreted to be primary or introduced during hydrothermal alteration. Low temperature mineral assemblages associated with devitrification and diagenesis are either replaced by, or pseudomorphed to higher temperature assemblages. This would also include the mineral assemblage in what is called the sericite-quartz zone, which was most likely illite-opal CT, or chalcedony. The higher temperature hydrothermal events are unlikely to be highly affected by regional metamorphism unless it was accompanied by a large volume of fluid passing through the crust, of which there is no evidence. In the case of the spilitized rocks, the albite-chlorite-actinolite-quartz-epidote-calcite-titanite assemblage of the mafic volcanic units and the quartz-albite-sericite-calcite assemblage of the felsic volcanic units are similar to a typical lower greenschist facies mineral assemblage. The $\mathrm{Cu}$ and magnetite hydrothermal assemblages were formed at high enough temperatures to be buffered against a prograde metamorphic recrystallization. In fact the magnetite $\mathrm{Ca}$-Fe skarn assemblage 
shows signs of retrograde overprinting to chlorite-calcite. The slight sericitization of the hydrothermal albite in the various zones is most likely a metamorphic overprinting.

\subsubsection{Early stage hydrothermal activity}

Evidence for devitrification, diagenesis and spilitization are observed within all volcanic units of the Noranda Cauldron (Gibson, 1989; Paradis, 1990). The first two processes could be considered to be independent of the third, as they are the natural products of cooling and burial metamorphism undergone to varying extents by volcanic rocks in all depositonal environments (Cas and Wright, 1988; Fisher and Schminke, 1984). The presence of widespread spilitization, and extensive zones of silicification (Gibson et al., 1983) and epidote-quartz alteration (Gibson, 1989) are evidence of a cauldron-scale hydrothermal system. In this context, the low temperature element mobility commonly associated with submarine devitrification and diagenesis may well represent the initiation of subseafloor seawater-rock interaction within the downwelling segment of a hydrothermal convection system. Unfortunately the mineralogical evidence for these two processes must be deduced from preserved textures, as they have been overprinted by successive phases of hydrothermal activity.

Devitrification, diagenesis and hydrothermal alteration all involve: (1) reduction of primary pore space, (2) dissolution of primary components, (3) cementation by precipitation of a secondary mineral assemblage, and (4) recrystallization of previously formed minerals (Fisher and Schmincke, 1984; Henley and Ellis, 1983). Devitrification is initiated at ambient 
seawater temperature, and diagenesis occurs at temperatures between $50^{\circ}$ and $200^{\circ} \mathrm{C}$. This is the temperature range in which zeolites are stable in modern geothermal fields, with the maximum marking the transition from smectite to a mixed layer clay, and the appearance of wairakite at the expense of laumonite (Tomasson and Kristmannsdottir, 1972; Franzson et al., 1974). Diagenesis of felsic volcanic rocks usually involves the formation of Mgsmectite and K-rich zeolites in the lower temperature range, changing to $\mathrm{Na}$-Ca-rich chabazite at higher temperatures (Henley and Ellis, 1983). Replacement by chalcedony of early-formed perlite (hydrated glass) along perlitic fractures, and the infilling of the fractures with silica indicate that the interacting seawater was saturated with respect to silica. This is most likely a result of devitrification during smectite formation.

Below the Ansil orebody there is evidence for enhanced diagenesis in the form of the quartz-chlorite alteration zone. The formation of this zone is believed to be part of the diagenetic alteration of the rhyolite because: (1) the mineral assemblage within the zone is identical to other diagenetically altered rhyolite, but with a much higher content of silica, (2) the mineral disposition and textures are identical to the diagenetically altered rhyolite, with the perlitic fractures controlling the distribution of silica, and (3) the alteration facies is devoid of sulfide or oxide minerals, suggesting a pre-hydrothermal origin.

The alteration zone is characterized by as much as $60 \%$ addition of silica, and moderate increases in $\mathrm{Ba}, \mathrm{K}, \mathrm{Rb}, \mathrm{Fe}, \mathrm{Mg}$ and $\mathrm{Mn}$. The increased concentrations of the first three elements is most likely resulted in zeolite growth, and the last three smectite formation. The spatial association of the most intense silica addition with some poorly defined, plagioclase 
glomeroporphyritic felsic dykes suggests that during the low temperature seawater-rock interaction that resulted in glass dissolution and smectite-zeolite growth the seawater within the porous lobe-hyaloclastite facies became saturated with respect to silica. A moderately saline solution becomes saturated with amorphous silica at approximately $100 \mathrm{oC}$ (at less than 100 bars pressure) (Kennedy, 1950). The moderate amounts of silica deposited along perlitic fractures during diagenesis would suggest that solution temperatures fluctuated about this temperature. The intrusion of the dykes caused this modified seawater to flash at approximately $300^{\circ} \mathrm{C}$, rapidly precipitating amorphous silica.

Enhancement of devitrification and diagenetic textures in the footwall to massive sulfide deposits has been recorded by Allen and McPhie (1994). This may be due to the fact that the focused upwelling of hydrothermal fluid responsible for the generation of a massive sulfide deposit requires a discrete area of sustained high heat flow. As the generation of the high heat flow zone would predate the hydrothermal activity, it could have some influence on the cooling rates of the host volcanic units. This in turn would influence the degree of local seawater-rock interaction that influences devitrification and diagenesis.

The timing of spilitization within the Noranda Cauldron has always been an enigma due to its pervasive distribution throughout the volcanic cycle (Gibson, 1989; Paradis, 1990). At the Ansil deposit its timing is constrained relative to the alteration facies below the Ansil deposit. Na enrichment had to have occurred after diagenesis, as it is a higher temperature phenomenon $\left(>200^{\circ} \mathrm{C}\right)$, with its minimum temperature constrained by the mineral assemblage albite-epidote-chlorite-quartz. It is overprinted by the envelope of $\mathrm{Na}$ depletion 
that surrounds the Ansil alteration system. As the Ansil alteration system was active to varying degrees up to the emplacement of the Lower Amulet rhyolite, it is possible that spilitization was contemporaneous with the formation of the Ansil deposit, and represented a higher temperature downwelling component of the regional hydrothermal system that superseded diagenesis. As the entire cauldron sequence is affected by spilitization, it is possible that with the extrusion of each successive volcanic unit the regional isotherms shifted upsection (Gibson, 1989). This would allow the incremental overprinting of lower temperature alteration zones.

Oxygen isotope data from the Noranda area (Cathles, 1993; Paradis et al., 1993; Hoy, 1993 ) is somewhat ambiguous with respect to the timing of the regional scale alteration system of which the spilitized strata are the most voluminous component. The consistent increase in whole rock and quartz-feldspar $\delta^{18} \mathrm{O}$ values upsection from the contact of the Flavrian Pluton is suggestive of a single, all encompassing hydrothermal system. This seems unlikely, as the distribution of intracauldron massive sulfide deposits indicates the presence of an active regional-scale alteration system at various stages of cauldron formation. The data of Paradis et al. (1993) shows that there is an internal $\delta{ }^{18} \mathrm{O}$ trend that varies within individual formations. This may well be correlated with the incremental spilitization of the sequence. 


\subsubsection{Middle stage hydrothermal activity}

The discordant zone of alteration and stockwork mineralization that underlies the Ansil deposit is unusual in that there is a temporal and spatial separation between the sphaleritesericite and chalcopyrite-chlorite parts of the system. The traditional model for the formation of a VHMS footwall alteration pipe is that the internal zonation is a result of hot, rising hydrothermal fluid mixing with cold seawater along the margins of the upflow system (Lydon, 1984). This results in an Fe-rich core, changing outwards to a Mg-Fe-rich margin and Mg-K-rich rim. Riverin and Hodgson (1980) noted the sericite rims on individual veins within the Millenbach footwall alteration pipe, and concluded that the hydrothermal fluids were responsible for all of the alteration, and the change from sericite to chlorite was a function of the hydrothermal fluid reacting with changing mineral assemblages at a constant temperature. The change from early, low-temperature sericite alteration to higher temperature chlorite alteration is more in agreement with the observations made at the Ansil deposit.

At Ansil the sericite-rich alteration facies is clearly associated with a sulfide-precipitating event that predates the chlorite-rich vein stockwork. The compositional and morphological differences between the two define an evolution from a subsurface fluid-rock interaction at shallow water depths to fluid-rock interactions taking place in the deep subsurface.

The middle stage hydrothermal activity began with sericite-quartz alteration and $\mathrm{Zn}$ mineralization that was centred on discordant breccia zones located along the east-west 
trending walls of the deposit-hosting graben. The breccias are rooted in the footwall rhyolite and dacite flows, and extend into the overlying Cranston tuff. The funnel-shaped morphology of many of the discordant breccia zones, the transition from in situ to disrupted breccia, and the presence of the overlying breccia apron is evidence for explosive brecciation that breached the seafloor. The formation of explosion breccias is due to rapid volume expansion of a subsurface fluid brought about by subcritical phase separation (Nelson and Giles, 1985). The funnel shape of the breccia conduit is a function of the increasing ability of the two phase system to expand upwards with decreasing

pressure. Boiling of subsurface fluids can be brought about by injecting magma into the reservoir (phreatomagmatic), or through the overpressuring of heated fluid (phreatic). If hydrothermal fluids is involved, these structures are called hydrothermal explosion breccias (Muffler et al., 1971), or hydrothermal eruption breccias (Lloyd, 1959).

The almost total lack of juvenile volcanic material restricts the origin of these breccias to either phreatic or hydrothermal (Fisher and Schmincke, 1984). The control on the distribution of these breccias by faults, the intense alteration of contained fragments and wallrocks, and the fracture infilling with hydrothermal minerals are all characteristics of hydrothermal explosion breccias (Sillitoe, 1985; Hedenquist and Henley, 1985; Porter and Ripley, 1985)

The $\mathrm{Zn}$ mineralized sericite-quartz alteration zones have many of the characteristics of some epithermal gold deposits. They are similar to bonanza-type adularia-sericite vein deposits (Heald et al., 1987) in that they are characterized by abundant silicification and 
silica precipitation in, and near, the vein stockwork, and strong sericite alteration of the wallrock. The veins contain finely banded microcrystalline quartz, or chalcedony, that is more massive near the tops of the vein system (Dowling and Morrison, 1988). Varying amounts of feldspar are present within the veins and disseminated in the immediate wallrock. Adularia-sericite systems are usually $\mathrm{Cu}$-poor and $\mathrm{Zn}$ - $\mathrm{Pb}$-rich, and are postulated to be dominated by neutral to weakly acidic, alkali chloride waters at emplacement temperatures between $200^{\circ}$ and $250^{\circ} \mathrm{C}$ (Henley and Ellis, 1983; Heald et al., 1987). Like adularia-sericite deposits, the sericite-quartz $-\mathrm{Zn}$ alteration at Ansil has a net mass gain in not only $\mathrm{Si}$ and $\mathrm{K}$, but also $\mathrm{Au}, \mathrm{As}, \mathrm{Sb}, \mathrm{Fe}, \mathrm{Zn}, \mathrm{Pb}$ and $\mathrm{Cu}$.

The Zn-rich sericite-quartz alteration zones at Ansil also have some of the characteristics of hot spring-precious metal deposits (Berger, 1985) in that the system breached the rock surface, and is associated with silica-infilled hydrothermal explosion breccias. The main difference is that alteration at hot spring deposits is dominated by advanced argillic alteration, of which there is no evidence at Ansil. Evidence from boiling submarine hydrothermal systems in the Lau Basin (Herzig and Hannington, 1994) indicates that acidsulphate alteration mineral assemblages can form under highly acid conditions where there is no mixing of the hydrothermal fluid with seawater. There is also no evidence for sinter formation at Ansil, but a large amount of silica was added to the conformable explosion breccia piles and to the sericite-quartz altered Cranston tuff.

The main difference between the sericite-quartz alteration zones and those of epithermal deposits is the predominance of base metal over precious metal concentrations, and the 
presence of albite instead of K-feldspar. Both of these differences may be attributed to a submarine versus subaerial environment, and a seawater versus magmatic-meteoric origin for the hydrothermal fluid. The dominance of base metals over precious metals indicates a sulfur-poor, chloride-rich fluid, in which abundant base metals may be maintained in solution as chloride complexes (Janecky and Seyfried, 1987). Precious metals may also form chloride complexes, but only in significantly high concentrations at high temperatures $>300^{\circ} \mathrm{C}$, Seward, 1982; Large et al., 1989) or under unusual high pH conditions (Fournier, 1985). Ligands are more commonly bisulfide or hydrogen sulfide complexes of Au under most hydrothermal conditions (Seward, 1982).

The absence of K-feldspar and predominance of sericite indicates that the hydrothermal fluid had a pH of between 5 and 6 in a temperature range of $200^{\circ}$ to $300^{\circ} \mathrm{C}$. At lower $\mathrm{pH}$ one could expect to find kaolinite or pyrophyllite. The presence of sphalerite-pyritepyrrhotite assemblages in the alteration zone in this $\mathrm{pH}$ range, and with an assumed low total $\mathrm{S}$ concentration $\left(10^{-3} \mathrm{M}\right)$ indicates that the hydrothermal fluid had a temperature between 210 and $230^{\circ} \mathrm{C}$ at $\log \mathrm{fo}_{2}$ between -40 and -45 . This is compatible with silica solubility studies by Fournier (1985) which suggest that fluids which precipitate large volumes of silica in a surface/near-surface environment were neutral to slightly alkaline, chloride-rich waters that flowed quickly to the surface from reservoirs with temperatures between $200^{\circ}-270^{\circ} \mathrm{C}$. Seyfried and Bischoff (1969) demonstrated that K will become fixed in an alteration assemblage as a result of fluid-rock interactions taking place at less than $150^{\circ} \mathrm{C}$. The amount of sericite present in the altered wallrock about the quartz-filled veins 
would suggests that a very steep temperature gradient was present between the fluid and the rhyolite/Cranston tuff. This could well be due to the presence of cooler seawater circulating within the volcaniclastic rocks .

If this was the temperature range, and if the hydrothermal fluid boiled to form the explosion breccias, then the combined lithostatic/hydrostatic pressures could not have been greater than 20 bars. This would place the graben floor in less than $200 \mathrm{~m}$ of water during the preliminary stages of deposit formation.

The restriction of the sericite-quartz alteration to near the upper contact of the footwall rhyolite, and to within the Cranston tuff and basal flows of the hangingwall flow sequence indicates a relatively restricted reaction zone. This provides little indication as to the location of the reservoir for the hydrothermal fluid. One piece of evidence suggesting a deep reservoir is remnant zones of quartz-sericite-sphalerite-rich rock within the chalcopyrite-pyrrhotite stockwork zone approximately $50 \mathrm{~m}$ below the massive sulfide lens on Sublevel 10A. This particular Cu-rich, discordant stockwork is the only one in which the company assay reports have significant ( $>500 \mathrm{ppm}$ ) amounts of $\mathrm{Zn}$. Analysis of the sphalerite indicated that it has the same FeS concentration ( 9 to 12 mole $\%$ ) as sphalerite within the sericite-quartz- $\mathrm{Zn}$ zones. The relatively low Fe content is unusual with respect to the Fe-rich content of the chlorite alteration zone. Combined with its association with the quartz-sericite rocks (which is unusual in the core of a chlorite-sulfide stockwork zone) it suggests that the sphalerite represents an earlier precipitation, perhaps representing a 
central upflow zone from which the early, Zn-rich hydrothermal fluids dispersed along the graben fault zones.

The middle stage hydrothermal activity terminated with the formation of the chloritesulfide alteration zone in the rhyolite, the emplacement of the massive chalcopyritepyrrhotite lens within the Cranston tuff, and the intitiation of the hangingwall alteration zone. The $\mathrm{Cu}$-rich footwall stockwork vein system and orebody indicate a high reservoir temperature for the hydrothermal fluid, and maintenance of temperatures above $250^{\circ} \mathrm{C}$ during the formation of the orebody, assuming a minimum required $\mathrm{Cu}$ concentration in solution of $10 \mathrm{ppm}$ (Lydon, 1984). The Au-Cu association at Ansil suggests gold transport as the $\mathrm{AuCl}_{2}{ }^{-}$complex by high temperature $\left(>300^{\circ} \mathrm{C}\right)$, low $\mathrm{pH}(<4.5)$, moderate to high $\mathrm{f}_{\mathrm{O}}$, and high salinity fluids (Large et al., 1989). Hoy (1993) used a comparison of bulk rock $\delta^{18} \mathrm{O}$ values against calculated $\delta^{18} \mathrm{O}$ values at a series of assumed temperatures to calculate a temperature at the core of the chlorite-sulfide alteration zone of between $335^{\circ}$ and $355^{\circ} \mathrm{C}$.

The chlorite-sulfide alteration process involved intense alteration of the host strata, followed by pyrrhotite-chalcopyrite deposition through replacement of the chlorite-altered lithologies. The process was initiated by the incipient destruction of hydrothermal albite and $\mathrm{Mg}$-smectite, and their replacement with chlorite:

1.

$$
3 \mathrm{Fe}^{+2}+2 \mathrm{Mg}^{+2}+2 \mathrm{alb}+8 \mathrm{H}_{2} \mathrm{O}->\mathrm{chl}+3 \mathrm{qtz}+2 \mathrm{Na}^{+}+8 \mathrm{H}^{+}
$$

$$
\text { smct }+4 \mathrm{H}_{2} \mathrm{O}+6 \mathrm{Fe}^{+2}->1.5 \mathrm{chl}+2 \mathrm{qtz}+8 \mathrm{H}^{+}+\mathrm{Si}^{+4}+0.7 \mathrm{Na}^{+}
$$


These are possible balanced reactions that were responsible for the halo of Na-depletion that surrounds both the footwall and hangingwall alteration. The Na-depletion zone formed as a moving front, behind which more concentrated hydrothermal fluid flow caused intense chloritization of the rhyolite, followed by the selective replacement of the fine-grained, chloritized shards within the hyaloclastite-rich areas of the rhyolite flow.

3.

$$
\mathrm{chl}+\mathrm{qtz}+4 \mathrm{H}^{+}+2 \mathrm{Fe}^{+2}->\mathrm{Fe}-\mathrm{chl}+\mathrm{H}_{4} \mathrm{SiO}_{4}+2 \mathrm{Mg}^{+2}
$$

4.

$$
\begin{gathered}
1.5 \mathrm{chl}+12 \mathrm{H}_{2} \mathrm{~S}+4 \mathrm{Cu}^{+2}+2 \mathrm{Fe}^{+2}->4 \mathrm{cp}+4 \mathrm{po}+4.5 \mathrm{SiO}_{2}+3 \mathrm{O}_{2}+3 \mathrm{Al}^{+3}+ \\
1.5 \mathrm{Mg}^{+2}+12 \mathrm{H}_{2} \mathrm{O}
\end{gathered}
$$

Small amounts of the $\mathrm{Al}$ and $\mathrm{Mg}$ released through the destruction of chlorite are accommodated in the precipitation of stilpnomelane, greenalite and minnesotaite, but most appears to have remained in solution to be carried further up-section, or possibly contributing along the margins of the fluid regime to additional chlorite formation. The hydrolysis reactions that accompanied sulfide precipitation (see last equation) would result in dissolved $\mathrm{Al}$ species such as $\mathrm{Al}(\mathrm{OH})_{2}{ }^{-}$or $\mathrm{Al}(\mathrm{OH})^{-2}$ (Zaleski, 1986). The above reactions account for the relative mass changes calculated for the chlorite-sulfide alteration zone (Figure 5.51), with extensive losses in $\mathrm{Na}, \mathrm{Ca}, \mathrm{Sr}$, and $\mathrm{Si}$, and gains in $\mathrm{Fe}, \mathrm{Mn}$ and $\mathrm{Cu}$.

The replacement of the Cranston tuff involved the alteration of the fine-grained matrix to chlorite, and partial dissolution of quartz and albite grains. Where the tuff was previously 
altered to sericite-quartz-albite, the sericite and albite were converted to chlorite, along with the partial dissolution of fine-grained quartz grains.

$$
\operatorname{musc}+6 \mathrm{H}_{2} \mathrm{O}+4 \mathrm{Fe}^{+2}+\mathrm{Mg}^{+2}->\mathrm{chl}+6 \mathrm{H}^{+}+\mathrm{Al}^{+3}+\mathrm{K}^{+}
$$

$$
2 \mathrm{alb}+8 \mathrm{H}_{2} \mathrm{O}+4 \mathrm{Fe}^{+2}+\mathrm{Mg}^{+2}->\mathrm{chl}+3 \mathrm{qtz}+2 \mathrm{Na}^{+}+8 \mathrm{H}^{+}
$$

This was followed by replacement of both chlorite and quartz by pyrrhotite, chalcopyrite, and minor stilpnomelane and minnesotaite-greenalite. The transition from chlorite-sulfide to sulfide-minnesotaite-greenalite involves a millimetre thick reaction front in which albite is stable. The appearance of a third generation of hydrothermal albite (the first formed during regional spilitization and second during sericite-quartz-albite alteration) is indicative of the abundance of $\mathrm{Na}$ in solution, but the conditions in which it forms a stable silicate must have been very transitory; it was probably resorbed due to a decrease in solution $\mathrm{pH}$.

From the reactions involved in the destruction of sericite and albite the resulting hydrothermal solution contained varying concentrations of $\mathrm{K}, \mathrm{Al}$ and $\mathrm{Na}$. The reactions involved in the destruction of chlorite and quartz, and formation of pyrrhotite and chalcopyrite added additional concentrations of $\mathrm{Al}$, and $\mathrm{Si}$. Some of the $\mathrm{K}, \mathrm{Al}$ and $\mathrm{Si}$ would have been taken out of solution during the formation of stilpnomelane and minnesotaitegreenalite, but the proportion of these minerals present in the massive sulfide lens would have been insufficient to account for all of the cation concentrations, particularly the large 
amount of silica that was taken into solution through the dissolution of the quartz-rich Cranston tuff.

The migration of the hydrothermal fluid into the hangingwall, and resultant fluid-rock interactions with the interflow, andesitic hyaloclastite could have absorbed the concentrations of $\mathrm{Si}, \mathrm{Al}$ and $\mathrm{K}$ dissolved from the replaced Cranston tuff. The sulfideenriched interflow volcaniclastics are chlorite-quartz-rich, with thin halos of quartz alteration and dumping, and broader halos of sericite quartz alteration. The process involved in the formation of the hangingwall alteration zone would be similar to that envisioned by Riverin and Hodgson (1980) for the formation of the footwall alteration zone at Millenbach. Ascending fluids first interacted with plagioclase to produce sericite and quartz.

7.

$$
2 \mathrm{plag}+\mathrm{Al}(\mathrm{OH})_{2}^{+}+\mathrm{K}^{+}->\text {musc }+3 \mathrm{qtz}+\mathrm{Na}^{+}+\mathrm{Ca}^{+2}
$$

Fresh, ascending hydrothermal fluids would then react with the sericite altered rocks to produce chlorite (Equation 5).

The questions arises as to whether the amount of hangingwall alteration can account for the amount of displaced material resulting from the replacement of the Cranston tuff. The massive sulfide/magnetite orebody has an approximate volume of $316,000 \mathrm{~m}^{3}$, which represents the replacement of Cranston tuff, andesite and connate seawater trapped within the rhyolite and andesite volcaniclastic rocks. If we assume $30 \%$ contained seawater within 
the replaced volume of volcaniclastic rocks, $221,200 \mathrm{~m}^{3}$ of rock had to be dissolved and transported. Evidence for remnant Cranston tuff and andesite fragments within the massive sulfide lens would conservatively account for $10 \%$ of the orebody's volume, bringing the amount of displaced rock down to $200,000 \mathrm{~m}^{3}$.

The hangingwall alteration and mineralization forms a dendritic zone with a central axis at least $400 \mathrm{~m}$ high from which "branches" emanated along hyaloclastite-rich andesite flow contact. The "trunk" of the alteration/mineralization system conservatively has a volume of $120,000 \mathrm{~m}^{3}$ ( $3 \mathrm{~m}$ by $100 \mathrm{~m}$ by $400 \mathrm{~m}$ ). The lowest "branches" extend out to the width of the orebody $(150 \mathrm{~m})$. Drill hole data define at least four "branches", each approximately half the length of the stratigraphically lower one. This could add another $100,000 \mathrm{~m}^{3}$ of altered and mineralized andesite.

With the volume of altered hangingwall andesite being the same order of magnitude as the displaced volume of the orebody, it would appear that formation of the Ansil orebody by subseafloor replacement is a feasible hypothesis if material from the replaced hangingwall strata was carried into the overlying watercolumn by venting fluids. It was therefore necessary that the hydrothermal system vented either periodically during andesite volcanism, or at the termination of eruption of the nadesite flows.

\subsubsection{Late stage hydrothermal activity}

The most unusual aspect of the Ansil deposit is the zoned, magnetite-rich, calc-silicate mineral assemblage that appears to have formed late in the hydrothermal history of the 
deposit. This includes the massive magnetite lenses, which, from textural relationships, are considered an end product of this alteration phase. Whereas most massive sulfide deposits show evidence along their margins of retrograde, Fe-Mg-K metasomatism due to mixing of seawater and hydrothermal fluid (Franklin et al., 1981; Large, 1992), the Ansil massive sulfide lens and underlying vein-stockwork zone is partially surrounded by calcic and Ferich calc-silicate assemblages.

The variations in mineral assemblages and overprinting relationships within the calcsilicate alteration facies indicate a complex, paragenetic sequence in which chloriteepidote-albite-pyrite formed in the rhyolite footwall and andradite-hedenbergite about the massive sulfide lens. The andradite-hedenbergite assemblage was then partly converted to ferroactinolite-ilvaite. The epidote- and amphibole-rich assemblages were then partly overprinted by a retrograde, magnetite-carbonate-rich phase in which epidote was altered to magnetite-chlorite-calcite, and amphibole-quartz to magnetite-Fe carbonate-talcserpentine-stilpnomelane. The latter phase was responsible for the replacement of massive pyrrhotite and chalcopyrite by massive magnetite.

This complex paragenesis involving overprinting anhydrous-hydrous reactions and late stage mineralization is more common to skarn than to VHMS deposits (Einaudi et al., 1981; Meinert, 1992). Although epidote is a common component in modern, geothermal systems (Henley and Ellis, 1977; Bird et al., 1984), it is usually within the lower, high temperature part of the hydrothermal system, and not closely associated with VHMS vein- 
stockwork zones. The discordant footwall alteration zones are commonly depleted in $\mathrm{Ca}$ (Franklin et al., 1981, Large, 1992), an environment not conducive to epidote growth.

Magnetite is a common, but minor, component of Cu-rich VHMS deposits, where it is associated with pyrrhotite-chalcopyrite rich zones near the base of the massive sulfide lens, or as disseminations in the footwall (Large, 1977; Franklin et al., 1981; Lydon, 1984). At the Chu Chua (Aggarwal and Nesbitt, 1984) and Mattagami Lake (Roberts and Reardon, 1978; Costa et al., 1983) deposits the magnetite is associated with talc, and at the Golden Grove deposit (Frater, 1983) the magnetite clearly replaces early hematite. None of the above deposits has the high oxide/sulfide ratio present at Ansil, or the magnetite-skarn association.

Coarse-grained, calc-silicate mineral assemblages (skarns) occur in a number of VHMS deposits (Hodgson, 1975; Vivallo, 1985; Johnson et al., 1990; Gemmel et al., 1992; Galley et al., 1993; Grey and Gibson, 1993), but in all cases they result from alteration of carbonate-rich sediments that were subsequently metamorphosed at high temperatures.

The magnetite-rich, coarse-grained calc-silicate assemblage that partially surrounds the massive sulfide lens has many similarities to two types of skarn deposits described by Einaudi et al. (1981) and Meinert (1992). Calcic-iron skarns occur in oceanic island arc regimes, are associated with primitive, Fe-rich intrusions, and occur either in limestone or volcanic rock (commonly andesite). They contain large quantities of magnetite associated with garnet and pyroxene, with lesser epidote, ilvaite and actinolite. At least one $\mathrm{Cu}$ skarn deposit of this type in Japan (Shiga, 1988) contains Si-rich magnetite similar to those 
analyzed from Ansil rocks by Westendorp et al. (1992). Copper skarns are also similar in that they associated with I-Type, magnetite-series, subvolcanic intrusions that are characterized by extensive hydrothermal alteration. The skarns commonly contain massive magnetite, with coarse-grained actinolite-chalcopyrite-magnetite ores, and minor garnet pyroxene assemblages. In both cases skarn alteration and mineralization take place at shallow depths, and at temperatures between $300^{\circ}$ and $600^{\circ} \mathrm{C}$ in relatively oxidizing environments.

The distinct nature of the calc-silicate-magnetite alteration in relation to known VHMSforming processes, its overprinting of the other alteration mineral assemblages, and its similarity to calcic-iron skarns would suggest a late, high temperature overprinting of the massive sulfide by $\mathrm{Ca}-\mathrm{Fe}-\mathrm{CO}_{2}$-rich fluids after deep burial and nearby emplacement of late volcanic to syn-kinematic intrusions. Textural evidence appears to refute this hypothesis; magnetite veins in the footwall rhyolite are sometimes transitional through pyrrhotite to pyrrhotite-chalcopyrite veins, and Cranston tuff layers and andesite interflow hyaloclastite replaced lit-par-lit by magnetite. Circumstantial evidence defining the calc-silicate alteration as synvolcanic is the presence of similar epidote-carbonate-magnetite alteration in the tonalite phase of the underlying, subvolcanic Flavrian Pluton. The restriction of the alteration to one particular phase of the intrusive complex would suggest that the responsible hydrothermal activity was temporally restricted.

The lack of fluid inclusion data on the Ansil calc-silicate mineral assemblage makes it necessary to use mineral associations and compositions, and bulk chemical mass balance to 
estimate conditions of formation and possible fluid sources. Oxygen isotope data from chlorite, magnetite and quartz separates (Barrett et al., 1990) indicate a temperature range for the chlorite-magnetite zone of between $210^{\circ}$ and $270^{\circ} \mathrm{C}$ (chlorite-magnetite pairs) and $280^{\circ}$ to $500^{\circ} \mathrm{C}$ for from quartz-magnetite pairs. Other temperature calculations from ferroactinolite-magnetite and quartz-magnetite pairs range up to $570^{\circ} \mathrm{C}$ (Watkinson, unpublished data).

Two problems must be addressed before evaluating these data: (1) magnetite compositions, and (2) mineral paragenesis within the calc-silicate alteration facies. Westendorp et al. (1991) presented data to show that magnetite at Ansil can contain up to $3.5 \mathrm{wt} \% \mathrm{Si}$. Whether the $\mathrm{Si}$ is part of the magnetite structure is problematic, but its presence at such a fine scale makes it difficult to separate from the magnetite. Concentration of $\mathrm{Si}$ in the magnetite might tend to affect its ${ }^{18} \mathrm{O}$ concentration, which would make calculated temperatures of formation unreliable (Watkinson and Fouillac, pers comm.).

The calc-silicate mineral paragenesis is complex, defining anhydrous and hydrous mineral growth, and prograde and retrograde conditions of formation. For this reason, any two mineral pairs within the zone are not necessarily in equilibrium, making temperature calculations from these pairs unreliable. Textural relationships suggest that the chloriteepidote-albite-pyrite alteration assemblage was imposed on the margin of the chloritepyrrhotite-chalcopyrite footwall alteration zone. Although the rocks were previously chloritized, the general Fe-Si-enrichment of this chlorite indicates that it is part of the calc- 
silicate alteration facies. The epidote patches are then overprinted by veins and disseminations of magnetite accompanied by retrograde alteration to chlorite and calcite. It is apparent that although the magnetite is Si-rich, it is not commonly in contact with quartz, making quartz-magnetite pair ${ }^{18} \mathrm{O}$ temperature calculations unreliable. The presence of two or more generations of hydrothermal chlorite would also make chlorite-magnetite pairs unreliable for accurate temperature calculations.

The formation of the epidote-rich footwall mineral assemblage involved the reaction of a Ca-Na-rich fluid with a quartz-chlorite-sulfide dominated assemblage to produce Fechlorite, epidote, albite and pyrite.

8. $2 \mathrm{chl}+5 \mathrm{qtz}+2 \mathrm{po}+2 \mathrm{Ca}^{+2}+\mathrm{Na}^{+}+7 \mathrm{H}^{+}->\mathrm{chl}+\mathrm{epd}+\mathrm{alb}+\mathrm{py}+7 \mathrm{H}_{2} \mathrm{O}+3 \mathrm{Si}^{+4}+\mathrm{Mg}^{+2}$

The reaction requires a fluid with relatively low $\mathrm{pH}$ (4 to 5) and low $\mathrm{X}_{\mathrm{CO}_{2}}(<<0.01)$. The presence of epidote and albite in apparent equilibrium would restrict temperatures of formation to above $250^{\circ} \mathrm{C}$ (Bird et al., 1984). At a $\mathrm{pH}$ range of 4 to 5 , the formation of pyrite from a fluid with relatively low total $\mathrm{S}$ concentration $\left(<10^{-3} \mathrm{M}\right)$ indicates a $\log \mathrm{fo}_{2}$ between -33 and -38 , with a temperature of formation between $250^{\circ}$ and $270^{\circ} \mathrm{C}$ (Large, 1977).

The overprinting of epidote by magnetite-chlorite-calcite involved fluids rich in $\mathrm{Fe}^{+2}$, $\mathrm{H}_{2} \mathrm{O}$ and $\mathrm{CO}_{2}$. 
9.

$$
\text { epd }+7 \mathrm{H}_{2} \mathrm{O}+5 \mathrm{Fe}^{+2}+\mathrm{CO}_{2}->\mathrm{mgt}+\mathrm{chl}+2 \mathrm{cc}+7 \mathrm{H}^{+}
$$

The veins about which these reactions take place are usually infilled with varying proportions of magnetite, quartz and epidote. This indicates that preliminary fluid-rock interaction through which Fe-chlorite and calcite formed changed the remaining fluid composition from neutral and $\mathrm{CO}_{2}$ saturated, to acid and $\mathrm{Si}-\mathrm{Ca}-\mathrm{Fe}$ oversaturated. The degree to which wallrock-fluid interaction took place dictated the vein fluid composition. The marked change in fluid composition also indicates a rock-dominated system with a low fluid/rock ratio. The rhombic, annular morphology of many of the magnetite grains suggests that zoned carbonate crystals could have been partially replaced by sequential formation of magnetite.

The mass balance calculations for the chlorite-magnetite zone support the cumulative net mass element gains and losses indicated by the mineral paragenesis. Si and $\mathrm{Mg}$ are lost and $\mathrm{Ca}, \mathrm{Sr}$ and $\mathrm{Na}$ are added during the epidote-forming phase, whereas magnetite formation corresponds to the addition of $\mathrm{Fe}$ and Mn. The REE profiles for this alteration phase show erratic increases in Eu relative to the chlorite-sulfide alteration (Figure 5.47). This may be due to the substitution of $\mathrm{Eu}^{+2}$ for $\mathrm{Ca}^{+2}$ during epidote precipitation.

The paragenesis of the Ansil Ca-Fe-rich skarns is similar to that described for both calcic-iron and copper skarns. The pods and layers of semi-massive to massive andradite in an hedenbergite groundmass is also observed at the post-Hercynian Cala magnetite deposit 
in Huelva, Spain (Velasco and Amigó, 1981). A more distinct early paragenesis at Cala shows that the hedenbergite formed before the massive andradite. For the same sequence to occur at Ansil, the preliminary formation of hedenbergite would take place through the reaction of chlorite and quartz with a low $\mathrm{pH}, \mathrm{Ca}$-rich fluid:

10.

$$
\mathrm{chl}+\mathrm{qtz}+\mathrm{Ca}^{+2}+8 \mathrm{H}^{+}->\text {hed }+\mathrm{mt}+2 \mathrm{Mg}^{+2}+2 \mathrm{Al}^{+3}+8 \mathrm{H}_{2} \mathrm{O}
$$

This is not an unreasonable assumption, as the rocks surrounding the massive sulfide lens were strongly chloritized during the chalcopyrite-pyrrhotite emplacement. Evidence for the formation of early magnetite may be the zonation of the magnetite crystal described by Westendorp et al. (1991). The corroded, pure magnetite cores to these grains may represent the first formation of magnetite by the above reaction. The low $\mathrm{pH}$ of the fluid would also be an ideal environment for the liberation of $\mathrm{Al}$ from the chlorite structure, and its retention in solution (Gamo et al., 1993).

The formation of andradite from hedenbergite could have been controlled by both oxidation and sulfidation reactions (Gamble, 1982)

$$
9 \text { hed }+6.5 \mathrm{O}_{2}->3 \text { and }+9 \mathrm{qtz}+\mathrm{mt} \quad \text { (Velasco and Amigó, 1981) }
$$

$$
\text { hed }+\mathrm{S}_{2}->\text { and }+\mathrm{qtz}+\text { po } \quad(\text { Gamble, 1982) }
$$


Sulfidation reactions may have been of most importance as the skarns formed along the margins of the massive sulfide lens from chlorite-altered precursors rich in chalcopyrite and pyrrhotite. The presence of chalcopyrite and pyrrhotite within the massive andradite lenses may be evidence for this reaction, but their presence in fractures within the garnet could be related to either local remobilization or tectonic injection, making the timing of sulfide emplacement problematic. Almost all experimental studies on the hedenbergite-andradite system have been carried out at $2 \mathrm{~kb}$ pressures over a range of temperatures (Gustafson, 1972; Taylor and Liou, 1978; Gamble, 1982). Andradite formation controlled by the magnetite-pyrrhotite buffer at $300^{\circ} \mathrm{C}$ at $2 \mathrm{~kb}$ requires a $\log \mathrm{f}_{\mathrm{S} 2}$ of approximately -11 and a $\log f_{\mathrm{O} 2}$ of between -33 and -34 . This is the minimum temperature at which garnet and pyroxene are found co-existing in modern geothermal fields (Bird et al., 1984; Gianelli and Teklemarian, 1993). At lower pressures one can assume that the reaction temperatures would be higher. As the temperature of formation for the underlying epidote-rich calcsilicate assemblage probably lies between $250^{\circ}$ and $300^{\circ} \mathrm{C}$, it would be unreasonable to expect an inverse temperature gradient in the absence of any related dykes or sills. It may be possible that the massive sulfide orebody acted as a temporary heat sink, allowing higher temperature reactions to take place along its margins. With the orebody retaining a quartzstilpnomelane-greenalite-chlorite mineral assemblage, temperatures could not have been higher than approximately $400^{\circ} \mathrm{C}$ (Winkler, 1974).

The formation of the hedenbergite-andradite skarn was followed by a series of retrograde reactions involving the formation of amphibole- and then magnetite-rich mineral 
assemblages. The formation of ferroactinolite involved the replacement of hedenbergite through the addition of $\mathrm{Si}, \mathrm{Fe}^{+2}$ and $\mathrm{H}_{2} \mathrm{O}$. A high $\mathrm{Fe}$ activity is required in order to form amphibole and not epidote (Bird et al., 1984):

$$
\text { 4hed }+\mathrm{H}_{2} \mathrm{O}+\mathrm{Fe}^{+2}+\mathrm{Si}^{+4}->\mathrm{act}+\mathrm{qtz}+2 \mathrm{Ca}^{+2}+2 \mathrm{H}^{+}
$$

The formation of the magnetite-rich mineral assemblage involved the replacement of up to $17 \%$ the massive sulfide lens, and 10 to $15 \%$ of the $\mathrm{Ca}-\mathrm{Fe}$ skarn. The replacement reactions were focused at the top of the magnetite vein stockwork zones at the base of the massive sulfide lens, with alteration of the skarn being synchronous with the replacement of the massive sulfide. The formation of carbonate, stilpnomelane and talc/serpentine along with magnetite requires a decrease in $\mathrm{Ca}$ activity at a relatively high $\mathrm{Fe}$ activity in oxidizing conditions (Bird et al., 1984):

14.

$$
2 \mathrm{act}+\mathrm{qtz}+3 \mathrm{CO}_{2}+2 \mathrm{O}_{2}->\mathrm{mt}+3 \mathrm{sid}+\text { stilp }
$$

The alteration of massive pyrrhotite-chalcopyrite to magnetite would involve similar fluid compositions:

15.

$$
\mathrm{cp}+5 \mathrm{po}+4 \mathrm{O}_{2}+\mathrm{CO}_{2}+\mathrm{Ca}^{+2}->2 \mathrm{mt}+\mathrm{CaCO}_{3}+\mathrm{Cu}^{+2}+3.3 \mathrm{~S}_{2}
$$


Where the fluid reacts with pyrrhotite-chalcopyrite in the presence of hedenbergite the following reactions also takes place:

16.

$$
\text { hed }+\mathrm{mt}+\mathrm{H}_{2} \mathrm{O}->\text { ilv }
$$

This results in a distinctive zonation about sulfide patches within the $\mathrm{Ca}-\mathrm{Fe}$ skarn from pyrrhotite-chalcopyrite through massive magnetite to ilvaite and finally hedenbergite. The presence of ilvaite limits maximum reaction temperatures to below $500^{\circ} \mathrm{C}$ (Gustafson, 1972). Ilvaite is also only stable at high fluid pressures, indicating a high fluid/rock ratio during the magnetite-forming reactions. Considering the high potential for the massive chalcopyrite-pyrrhotite lens to buffer reactions, a high fluid pressure must have been present in order to maintain a stable fluid composition long enough to replace about 300,000 tonnes of sulfide.

The replacement of parts of the massive sulfide lens by magnetite involved migration of $\mathrm{Cu}, \mathrm{Au}$ and $\mathrm{S}$. The occurrence of high grade $\mathrm{Cu}-\mathrm{Au}$ zones along the massive magnetitesulfide contacts indicates that these elements reacted locally with minerals present in the massive sulfide lens:

$$
\mathrm{po}+\mathrm{Cu}+\mathrm{S}->\mathrm{cp}
$$


Microprobe analyses of the chalcopyrite from these high grade zones indicates that the $\mathrm{Au}$ occurs within the chalcopyrite. Replacement of the massive sulfide by magnetite along the orebody's hangingwall contact, and along interflow boundaries within the andesite, would have released $\mathrm{Cu}, \mathrm{Zn}, \mathrm{Pb}, \mathrm{Au}$ and $\mathrm{S}$ into solution. As these zones of replacement are commonly located about the discordant hangingwall alteration zone it is plausible that these elements were carried up further into the hangingwall andesite to react with the glass-rich interflow volcaniclastics to form sulfide minerals. The excess $\mathrm{Al}$ present in solution from the formation of the Al-poor skarn assemblages may have also been transported into the hangingwall to form chlorite. The formation of the massive magnetite and associated $\mathrm{Ca}-\mathrm{Fe}$ skarns therefore played a significant role in enhancing the grade and magnitude of the hangingwall alteration zone

The formation of the calc-silicate mineral assemblages and associated magnetite mineralization must have involved highly oxidized (relative to the sulfide-producing fluids) fluids that were rich in $\mathrm{Ca}, \mathrm{Fe}, \mathrm{Si}$ and $\mathrm{CO}_{2}$. These fluids passed up along the margins of the previously formed chlorite-sulfide through a series of fractures that appear to widen in proximity to the orebody. The fluid-rich reactions along the margins of the fractures took place at moderate $\mathrm{Ca}-\mathrm{Fe}$ activity, first producing epidote-albite, and then calcite-chloritemagnetite. The formation of carbonate-rich reaction rims about the fluid conduits effectively isolated the ascending fluids from further wallrock interaction until the base of the massive sulfide lens was reached. Ponding of the fluids increased the fluid-rock ratios at which reactions took place, and the time in which the fluids could interact with the 
wallrocks. This appears to have increased the $\mathrm{Ca}$ and $\mathrm{Fe}$ activity of the fluid significantly, allowing for the formation of hedenbergite and andradite. Formation of these coarsegrained skarns required temperatures between $300^{\circ}$ and $400^{\circ} \mathrm{C}$, which is higher than the temperatures assumed from the underlying, epidote-rich mineral assemblage. It would appear that an inverse temperature gradient was present about the massive sulfide lens, resulting in the formation of the high temperature calc-silicate skarn. Continued fluid-rock reactions resulted in the formation of a series of retrograde reactions under lowering conditions of decreasing $\mathrm{Ca}$ activity and higher $\mathrm{XCO}_{2}$. This resulted in the hydrolysis of the hedenbergite-andradite assemblage, and formation of massive magnetite by replacement of the parts of the top of the sulfide vein stockwork and the base of the massive sulfide lens.

\subsection{SUMMARY AND CONCLUSIONS}

The Ansil deposit is the stratigraphically second-lowest-known massive sulfide deposit within the Mine Sequence. The bimodal basaltic andesite-rhyolite Mine Sequence represents the third of five cycles of volcanism within the Blake River Group of the Archean Abitibi greenstone belt. It infills the Noranda Cauldron, a $30 \mathrm{~km}$ wide subsidence structure situated on top of a large shield volcano. Rocks comprising the floor of the cauldron were intruded by the subvolcanic Flavrian Pluton, which is interpreted to have been the heat engine for the

regional-scale hydrothermal system responsible for the formation of the Noranda VHMS deposits. 
The Ansil deposit formed in a small graben along the southeast flank of a fissure-fed rhyolite lava flow of the Northwest formation, the lowermost formation of felsic volcanic rocks in the Noranda Cauldron. The graben was infilled with quartz-phyric mass flows, and covered over by $500 \mathrm{~m}$ of fissure-fed andesitic flows of the Rusty Ridge formation. The graben is an expression of a long-lived structural weakness over $2000 \mathrm{~m}$ long and as wide as $500 \mathrm{~m}$ that became the focus of hydrothermal activity during the formation of andesite of the Flavrian formation (which underlies the footwall rhyolite), and continued during the emplacement of the Rusty Ridge formation. This extensive zone of hydrothermal fluid upflow is marked by a zone of feldspar destruction and Na-depletion.

The hydrothermal fluid upflow zone in which the Ansil deposit formed appears to have first breached the seafloor after cessation of the Flavrian volcanism. This seafloor hydrothermal event is marked by a zone of $\mathrm{Zn}$-enriched, silicified andesitic flow, and occurred at the same time as formation of the Corbet deposit (the lowest deposit in the Mine Sequence). Seafloor hydrothermal activity was terminated by the extrusion of the Northwest formation lobe-hyaloclastite flow. Synvolcanic faults propagated up through the rhyolite flow to form the Ansil graben (Figure 6.3). These faults were the foci for continued hydrothermal fluid flow up from the Flavrian formation.

The first indication that the graben represented a zone of high heat flow was during the intrusion of several plagioclase glomeroporphyritic felsic dykes below the graben floor, and the resultant silicification of the dykes and surrounding hyaloclastite. This indicated that early diagenesis/hydrothermal activity had resulted in the release of $\mathrm{Si}$ into solution. The 
partial silicification of the rhyolite below the graben floor reduced permeability and resulted in hydraulic overpressuring from the rising hydrothermal fluids. The pressure release caused phase separation and rapid expansion of the fluids and formation of hydrothermal explosion breccia pipes along the base of the graben walls. Breaching of the seafloor by the hydrothermal explosions resulted in conformable breccia aprons above the pipes. The pipes were rapidly flooded with Si-Na-Fe-Zn-rich hydrothermal fluid, resulting in the precipitation of finely laminated quartz, probably chalcedony, with albite, Fe-sulfides and sphalerite. Wallrock interaction with downward-percolating seawater resulted in abundant sericite-quartz alteration, with addition of $\mathrm{K}, \mathrm{Ba}, \mathrm{Rb}, \mathrm{Fe}, \mathrm{Zn}, \mathrm{Cu}, \mathrm{Pb}$ and $\mathrm{Au}$, and removal of $\mathrm{Na}, \mathrm{Ca}, \mathrm{Mg}$ and $\mathrm{Sr}$.. The similarity of the explosion breccias to both bonanza-type, adularia-sericite and hot-spring sinter deposits indicates that this early hydrothermal activity involved sulfur-poor, slightly alkaline, chloride-rich waters that carried moderate concentrations of $\mathrm{Fe}$ and $\mathrm{Zn}$, but only small amounts of $\mathrm{Au}$ or $\mathrm{Ag}$. The presence of albite instead of adularia, and the abundance of chloride ligands was a result of the source of the fluid being sulphate depleted seawater rather than meteoric/magmatic water. Fluid temperatures ranged between $200^{\circ}$ and $230^{\circ} \mathrm{C}$.

The breccia pipes transect both the footwall rhyolite and Ansil dacite flows, indicating that formation of the Ansil deposit did not represent a time of volcanic quiesence, but rather took place during the continual build-up of the cauldron floor. The interlayering of the basal beds of the Cranston quartz-phyric mass flow with Ansil dacite flows indicates that the graben was already being infilled during the hydrothermal brecciation of its floor. The $\mathrm{Zn}$ - 
rich fluids continued to discharge into the rapidly deposited Cranston tuff, displacing trapped seawater along the coarse-grained bases of the tuff layers and depositing sphalerite, Fe-sulfides, quartz, sericite and albite. Most of the alteration/mineralization of the tuff was centred along the graben walls, although there is some evidence for fluid flow up through the middle of the graben floor.

The shallow $\mathrm{Zn}$-rich alteration/mineralization event was overprinted by higher temperature fluid upflow along the central axis of the graben. The resultant discordant alteration zone transects the entire footwall rhyolite, with its roots merging with the earlier Flavrian alteration zone. The rising fluids were $\mathrm{Fe}-\mathrm{Mn}-\mathrm{Cu}-\mathrm{Au}-\mathrm{Zn}-\mathrm{Pb}-\mathrm{rich}$, and undersaturated with respect to Si. Reservoir temperatures ranged from $330^{\circ}$ to $350^{\circ} \mathrm{C}$. The upward fluid flow was controlled by an overall structural weakness, but up to $80 \%$ of the alteration and sulfide deposition was controlled within the discordant zone by the primary permeability of the lobe-hyaloclastite rhyolite flow. This resulted in the formation of semiconformable alteration/mineralization zones along hyaloclastite-rich sections of the rhyolite flow. Fluid-rock interaction resulted in the formation of a broad halo of Nadepletion in which smectite and albite were altered to quartz and chlorite. The central zone of more intense fluid-rock interaction resulted in chlorite-quartz alteration, followed by chlorite-pyrrhotite-chalcopyrite and then pyrrhotite-chalcopyrite-quartz-minnesotaitegreenalite. Alteration, therefore, involved the progressive depletion in the rocks of $\mathrm{Na}, \mathrm{Ca}$, $\mathrm{Si}$ and finally $\mathrm{Al}$ and $\mathrm{Ti}$. 
The infiltration of the Cranston tuff by this hydrothermal fluid phase resulted in the emplacement of chlorite-pyrrhotite-chalcopyrite through the displacement of trapped seawater and replacement of the fine-grained matrix. This was followed by replacement of all but the largest quartz phenoclasts by first chlorite-pyrrhotite-chalcopyrite, and the pyrrhotite-chalcopyrite-stilpnomelane-minnesotaite-greenalite. The chlorite-producing reactions within the underlying rhyolite resulted in a low $\mathrm{pH}$ fluid capable of dissolving quartz and Al-containing silicates. The maintenance of high fluid temperatures $\left(>300^{\circ} \mathrm{C}\right)$ allowed both $\mathrm{Si}$ and $\mathrm{Al}$ to remain in solution and to be carried up-section to take part in further fluid-rock reactions. The fact that the hydrothermal fluid had high $\mathrm{Cu}$ concentrations to form the chalcopyrite-rich orebody within the Cranston tuff is also evidence that the fluid maintained its high temperatures during the alteration and replacement process.

The formation of the Ansil orebody through high temperature fluid-rock interaction took place because the sediment-filled graben was already being covered over by andesitic flows of the Rusty Ridge formation, thereby isolating the hydrothermal fluids from dilution by infiltrating seawater. Evidence that these flows were being emplaced during formation of the orebody includes the formation of the massive sulfide mound at the west end of the deposit through sulfide precipitation in, and replacement of, volcaniclastic-rich parts of the hangingwall sequence. The position of the hangingwall replacement was restricted by the presence of a facies change within the andesitic flow sequence from massive to pillowed, volcaniclastic-rich. Under the massive flows the orebody formed through replacement of 
the Cranston tuff, and above the facies change the deposit formed through replacement of the andesite.

The massive sulfide spine that formed through the replacement of the base of the hangingwall flows formed the root to a more extensive hangingwall alteration zone as the hydrothermal fluids continued up-section for over $400 \mathrm{~m}$. The system either periodically breached the seafloor during emplacement of the nadesite flows, or vented on the seafloor after cessation of andesite volcanism. The fluids cross-cut the flows along a discordant zone, from which the fluids spread out along hyaloclastite-flow breccia-rich flow contacts. Sulfides were precipitated in open spaces and the glass-rich volcaniclastic rocks were altered first to sericite-quartz-sphalerite, and then to chlorite-quartz-pyrrhotite-chalcopyrite. The end-product was a "classic" alteration pipe, with a sericite-rich margin and a chloriterich core. Much of the $\mathrm{Si}$ and $\mathrm{Al}$ (and $\mathrm{K}$ picked up through the overprinting of early stage sericite-quartz alteration) that went into solution during the replacement of the Cranston tuff was used to form the hangingwall sericite zones.

The final stage of hydrothermal alteration involved the overprinting of all previous alteration phases by a $\mathrm{Ca}-\mathrm{Na}-\mathrm{Fe}-\mathrm{CO}_{2}$ rich fluid phase. This resulted in the formation of calc-silicate-rich alteration assemblages within the footwall to, and around the margins of, the orebody, accompanied by a magnetite-rich vein stockwork and magnetite replacement of parts of the massive sulfide lens. The footwall chlorite-sulfide alteration zone was first overprinted by an chlorite-epidote-albite-pyrite assemblage, which in turn was overprinted by vein-controlled Fe-chlorite-magnetite-calcite alteration. The magnetite-quartz-epidote- 
rich veins merge at the base of the massive sulfide lens with massive magnetite. Coarsegrained, hedenbergite-andradite skarn formed around the margins of the massive sulfide lens. This was then altered to ferroactinolite and quartz, which in turn was altered to magnetite-Fe-carbonate-stilpnomelane-minnesotaite-greenalite assemblages. The massive sulfide lens was also affected by the $\mathrm{CO}_{2}$-rich fluid phase, altering to magnetite-Fecarbonate-stilpnomelane-minnesotaite-greenalite assemblages. These fluids replaced $15 \%$ of the massive sulfide lens. The remobilized $\mathrm{Cu}, \mathrm{Au}$ and $\mathrm{S}$ enriched the remaining parts of the pyrrhotite-chalcopyrite orebody. Element remobilization during this hydrothermal phase also enhanced the hangingwall alteration/mineralization.

The footwall, epidote-rich calc-silicate assemblage formed at temperatures between $250^{\circ}$ and $270^{\circ} \mathrm{C}$, whereas the $\mathrm{Ca}-\mathrm{Fe}$ skarns formed between $300^{\circ}$ and $400^{\circ} \mathrm{C}$. The overprinting of both assemblages by the magnetite-carbonate-rich assemblage is typical of retrograde alteration that takes place in the late phase formation of calcic-iron skarns. The change in calc-silicate assemblages may be due to the presence of an inverted thermal gradient centred on the massive sulfide lens, possibly due to the capacity of the massive sulfide to retain high temperatures for a longer period than the surrounding volcanic rocks.

In conclusion:

(1) The formation of the Ansil deposit was the product of a long-lived, evolving hydrothermal system that was initiated near the beginning of cauldron volcanism, and continued up to the end of the first period of subsidence. 
(2) Hydrothermal activity occurred along a $+2000 \mathrm{~m}$ long fault system that remained active during the first cauldron cycle as a fluid upflow zone. The graben hosting the deposit is part of the fault system.

(3) The deposit is a product of shallow subseafloor replacement, with the morphology of the orebody and associated vein stockworks controlled by the primary permeability of the host rocks. The deposit began to form in shallow water (200 to $300 \mathrm{~m}$ ) on the floor of a graben that transected the top of a ridge composed of a lobe-hyaloclastite rhyolite flow. The deposit continued to evolve during infilling of the graben by fine-grained, mass flow deposits, and burial of the rhyolite ridge by a thick sequence of andesitic flows. The late stage development of the deposit most likely took place under a $500 \mathrm{~m}$ thickness of volcanic flows at some unknown water depth.

(3) Three compositionally distinct fluid phases were responsible for the development of the Ansil deposit, with a lower temperature, Si-K-Zn-rich fluid associated with hydrothermal brecciation of the graben floor, and sphalerite formation within the quartz-phyric mass flow, a higher temperature $\mathrm{Fe}-\mathrm{Cu}-\mathrm{Au}-\mathrm{Ag}$-rich fluid formed extensive, footwall and hangingwall alteration zones, and was responsible for the formation of the pyrrhotite, and finally a $\mathrm{Ca}-$ $\mathrm{Fe}-\mathrm{CO}_{2}$-rich fluid that was responsible for partial replacement of the sulfide orebody by massive magnetite.

(4) Fluid compositions changed from a neutral $\mathrm{pH}$, chloride-rich, sulfur poor, $200^{\circ}$ to $230^{\circ} \mathrm{C}$ fluid through to highly reduced, low $\mathrm{pH}$, chloride and sulfur-rich, $330^{\circ}$ to $355^{\circ} \mathrm{C}$ fluid to 
highly oxidized, low $\mathrm{pH}$, sulfur-poor and $\mathrm{CO}_{2}$-rich fluid that had a temperature range of between $250^{\circ}$ to $400^{\circ} \mathrm{C}$.

(5) The presence of a high temperature $\mathrm{Ca}-\mathrm{Fe}$ skarn about the margins of the massive sulfide/magnetite lens indicates a heat flow inversion about the deposit, possibly due to the massive sulfide lens acting as a heat sink during late-stage hydrothermal activity. 

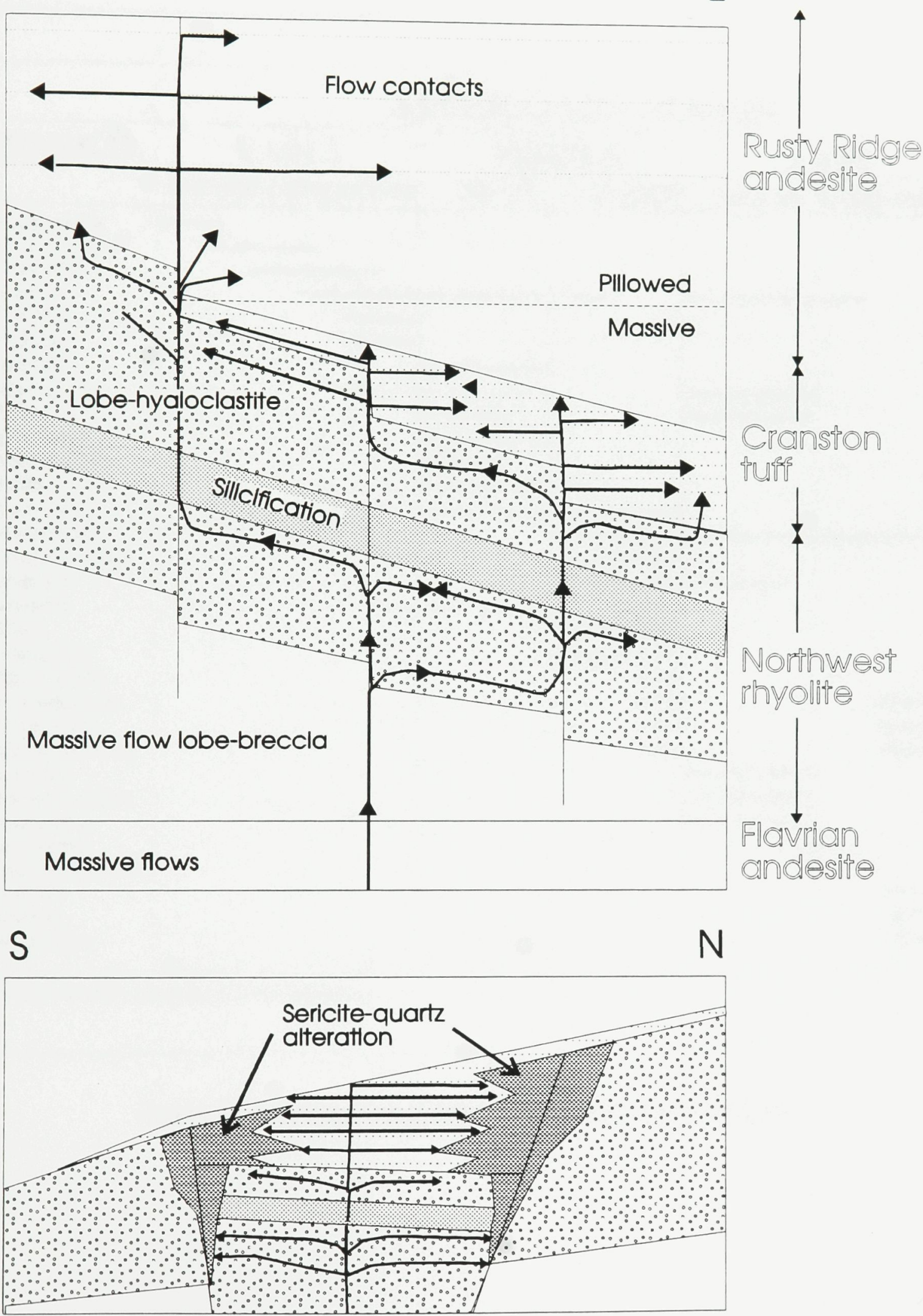

Figure 6.1 Probable pathways for circulating hydrothermal fluid during the formation of the Ansil deposit. 


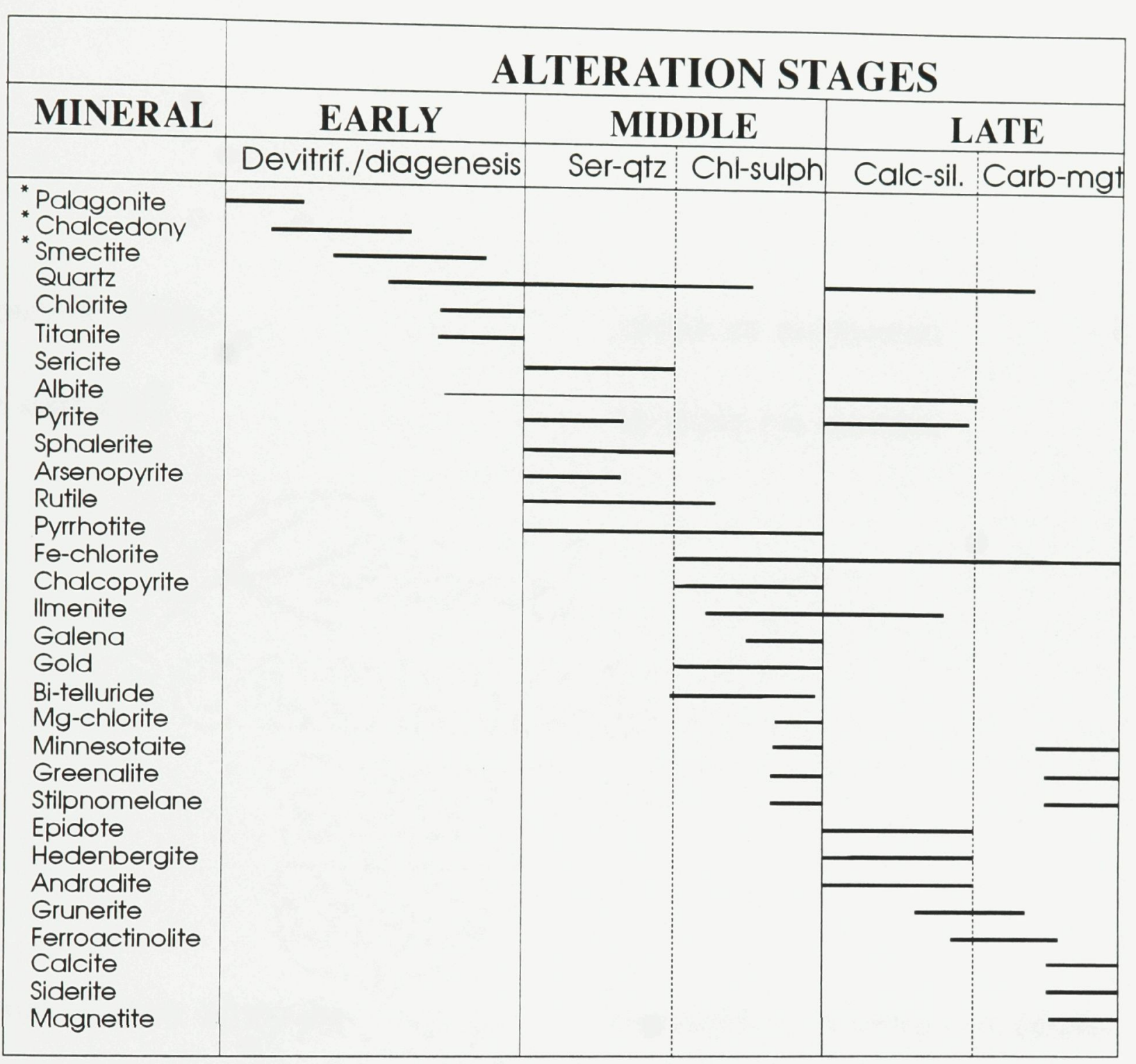

* Mineral formation assumed but not observed

Figure 6.2 Mineral paragenesis for the Ansill alteration system. 
PAGINATION ERROR.

TEXT COMPLETE.

NATIONAL LIBRARY OF CANADA.

CANADIAN THESES SERVICE.
ERREUR DE PAGINATION.

LE TEXTE EST COMPLET.

BIBLIOTHEQUE NATIONALE DO CANADA. SERVICE DES THESES CANADIENNES. 


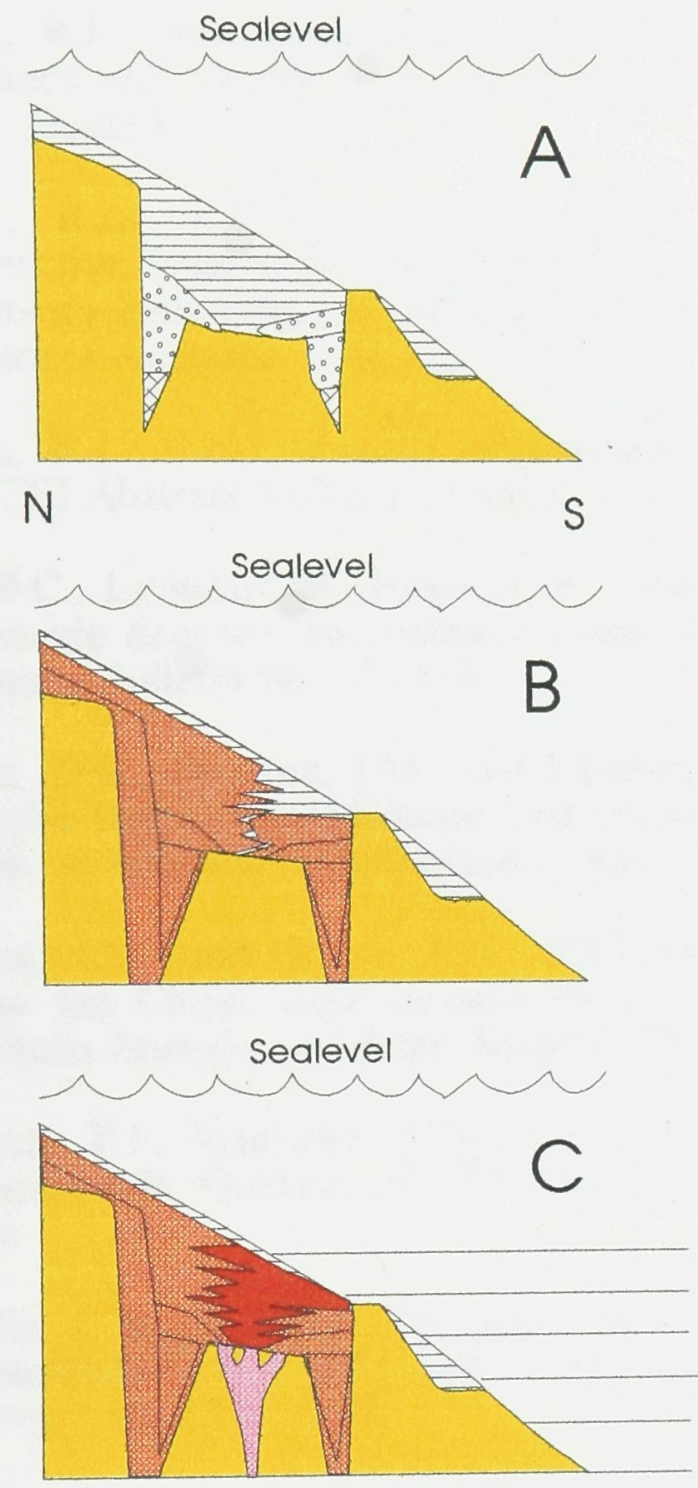

Northwest rhyolite

\section{Explosion breccia}

Cranston tuff
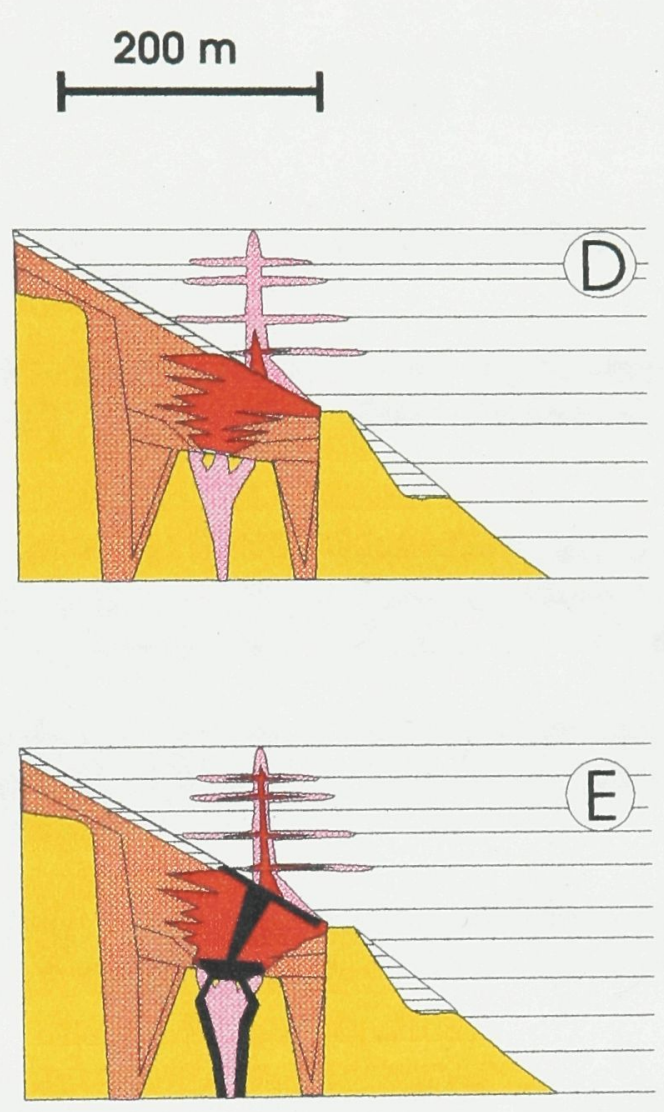

Rusty Ridge andesite

Sphalerite-pyrite

Chalcopyrite-pyrrhotite

Magnetite

Figure 6.3 Stages in the formation of the Ansil orebody 


\section{REFERENCES}

Aggarwal, P.K., and Debit, Nesbitt, 1984. Geology and Geochemistry of the Cu Chua massive sulfide deposit, British Columbia. Economic Geology, 79, 815-825

Allen, R.L., and Huns, S.R., 1990. Hercules excursion stops. In: The Mount Read volcanics and related ore deposits, Australian Geological Society Convention, Hobart, 1990, Guide E1, 22-27.

Allen, R.L., and Cas, R.A.F., 1990. The Roseberry controversy: Distinguishing prospective submarine ignimbrite-like units from true subaerial ignimbrites in the Roseberry-Hercules $\mathrm{ZnCu}-\mathrm{Pb}$ massive sulfide district, Tasmania. Abstract, Geological Society of Australia Abstracts, 25, 31-32

Allen, R.L., 1993. Pseudo-volcaniclastic textures below massive sulfide deposits. In IAVCEI Abstract Volume, General Assembly, Canberra, 1993.

Alt, J.C., Lonsdale, P., Haymon, R., and Muehlenbachs, K., 1987. Hydrothermal sulfide and oxide deposits on seamounts near 210 , East Pacific Rise. Geological Society of America, Bulletin 98, 157-168.

Ames, D.E., Franklin, J.M., and Hannington, M.D., 1993. Mineralogy and geochemistry of active and inactive chimneys and massive sulfide, Middle Valley, northern Juan de Fuca Ridge: an evolving hydrothermal system. The Canadian Mineralogist, 31, 997-1024.

Bailes, A.H., and Galley, A.G., 1989. Geological setting of the hydrothermal alteration below the Chisel Lake massive $\mathrm{Zn}-\mathrm{Cu}$ sulfide deposit. In: Report of Activities 1989, Manitoba Energy and Mines, Minerals Division, 31-37.

Barrett, T.J., MacLean, W.H., and Cattalani, S., 1991. Massive sulfide deposits of the Noranda area, Quebec. III. The Ansil Mine. Canadian Journal of Earth Science, 28, 16991730.

Barrie, C.T., Ludden, J.N., and Green, A.H., 1993. Geochemistry of Volcanic Rocks Associated with $\mathrm{Cu}-\mathrm{Zn}$ and $\mathrm{Ni}-\mathrm{Cu}$ deposits in the Abitibi Subprovince. Economic Geology, 88. 1341-1358.

Berger, B.R., 1985. Geologic-geochemical features of hot-spring precious-metal deposits. in E.W. Tooker edt., Geologic characteristics of sediment- and volcanic-hosted disseminated gold deposits - search for an occurrence model, United States Geological Survey Bulletin 1646, 47-54.

Bird, D.K., Schiffman, P., Elders, W.A., Williams, A.E., and McDowell, D.E., 1984. Calcsilicate mineralization in active geothermal systems. Economic Geology, 79, 671-695.

Bischoff, J.L., and Rosenbauer, R.J., 1984. The critical point and two-phase boundary of seawater, $200-500^{\circ} \mathrm{C}$. Earth and Planetary Science Letters, 68, 173-189.

Card, K.D., 1990. A review of the Superior Province of the Canadian Shield, a product of Archean accretion. Precambrian Research, 48. 99-156.

Cas, R.A.F., and Wright, J.V., 1987. Volcanic successions: Modern and Ancient. Allen and Unwin, London, 528p. 
Cas, R.A.F., 1992. Submarine volcanism: eruption styles, products and relevance to understanding the host-rock successions to volcanic-hosted massive sulfide deposits Economic Geology, 84, 511-541

Cathles, L.M., 1983. An analysis of the hydrothermal system responsible for massive sulfide deposition in the Hukoroko Basin of Japan. In: H. Ohmoto and B.J. Skinner edts, Kuroko and Related Volcnaogenic Massive Sulfide Deposits, Economic Geology, Monograph 5, 439-487

Cathles, L.M., 1993. Oxygen Isotope Alteration in the Noranda Mining District, Abitibi Greenstone Belt, Quebec. Economic Geology, 88, 1483-1511.

Comba, C.D.A., 1975. Copper-Zinc zonation in tuffaceous exhalites, Millenbach Mine, Noranda, Quebec. Msc. thesis, Queen's University, Kingston, Ontario (unpubl).

Comba, C.D.A, and Gibson, H.L., 1983. Geology of the Millenbach Rhyolite Volcano, Noranda, Quebec. In Program with. Abstracts, vol. 8, Geological Association of Canada Mineralogical Association of Canada.

Corfu, F., Jackson, S.L., and Sutcliffe, R.H., 1991. U-Pb ages and tectonic significance of late alkalic magmatism and non-marine sedimentation: Timiskaming Group, southern Abitibi belt, Ontario. Canadian Journal of Earth Sciences, 26. 2141-2149.

Corfu., F., 1993. The Evolution of the Southern Abitibi Greenstone Belt in Light of Precise U-Pb Geochronology. Economic Geology, 88, 1323-1340.

Costa, U.R., Barnett, R.L. and Kerrich, R., 1983. The Mattagami Lake Mine Archean Zn$\mathrm{Cu}$ sulfide deposit, Quebec: Hydrothermal coprecipitation of talc and sulfides in a seafloor brine pool - evidence from geochemistry, ${ }^{18} \mathrm{O} /{ }^{16} \mathrm{O}$ and Mineral Chemistry. Economic Geology, 78, 1144-1203.

Cousineau, P.A., and Dimroth, E., 1982. Interpretation of the relations between massive, pillowed and brecciated facies in an Archean submarine volcano - Amulet Andesite, Rouyn Noranda, Canada. Journal of Volcanology and Geothermal Research, 13, 83-102.

Daigneault, R., and Archambault, G., 1990. Les grands couloirs de déformation de la sous-province de l'Abitibi. In The Northwestern Québec Polymetallic Belt. Edited by M.Rive, P. Verplaelst, Y. Gagnon, J.M. Lulin, G. Riverin and A. Simard. The Canadian Institute of Mining and Metallurgy, Special Volume 43. 43-64.

de Rosen-Spence, A.P., 1976. Stratigraphy, development and petrogenesis of the central Noranda volcanic pile, Noranda, Quebec. Ph.D. thesis, University of Toronto, Toronto, Ontario (unpubl).

Desrochers, J-P., Hubert,. C., Ludden, J.N., and Pilote, P., 1993. Accretion of Archean oceanic plateau fragments in the Abitibi greenstone belt, Canada. Geology, 21. 451-454.

Dimroth, E., Imreth, L., Goulet, N., and Roucheleau, M., 1983. Evolution of the southcentral segment of the Abitibi Belt, Quebec. Part 3: Plutonic and metamorphic evolution and geotectonic model. Canadian Journal of Erath Science, 20. 1374-1388. 
Einaudi, M.T., Meinert, L.D., and Newberry, R.J., 1981. Skarn deposits. Economic Geology, $75^{\text {th }}$ Anniversary Volume, 317-391.

Eldridge, C.S., Barton, P.B., Jr. and Ohmoto, H., 1083. Mineral textures and their bearing on formation of the Kuriko orebodies. In: H. Ohmoto and B.J. Skinner edts, Kuroko and Related Volcnaogenic Massive Sulfide Deposits, Economic Geology, Monograph 5, 241281 .

Escher, B.G., 1933. On a classification of central eruptions according to gas pressure of the magma and viscosity of the lavas. Leids. Geol. Meded., Decl. VI, Afl. I, 50-58.

Fournier, R.O., 1985. Silica mineral as indicators of conditions during gold deposition. in E.W. Tooker edt., Geologic characteristics of sediment- and volcanic-hosted disseminated gold deposits - search for an occurrence model, United States Geological Survey Bulletin $1646,15-26$

Fisher, R.V., and Schminke, H.-U., 1984. Pyroclastic rocks. Springer Verlag, 472 p

Franklin, J.M., Lydon, J.W., and Sangster, D.F., 1981. Volcanic-Associated Massive Sulfide Deposits., Economic Geology, $75^{\text {th }}$ Anniversary Volume, 485-627.

Frater, K.M., 1983. Geology of the Golden Grove Prospect, Western Australia: a volcanogenic massive sulfide-magnetite deposit. Economic Geology, 78, 875-919.

Galley, A.G., Salmon, B., and Jonasson, I.R., 1991. Sphalerite-rich breccias in the footwall to the Ansil copper deposit, Noranda, Quebec. In Current Research Part C, Paper 91-1C, Geological Survey of Canada, 35-42.

Galley, A.G., and Scoates, J.S., 1990. Relationship of synvolcanic dykes to hydrothermal alteration in the Edwards Lake formation, Chisel Lake area (NTS 63K/16). in Report of Activities 1990, Manitoba Energy and Mines, Minerals Division, 170-177.

Galley. A.G., 1993. Characteristics of semi-conformable alteration zones associated with volcanogenic massive sulfide deposits. Journal of Geochemical Exploration, 48, 175-200.

Galley, A.G., Bailes, A.H., and Kitzler, G., 1993. Geological setting and hydrothermal evolution of the Chisel Lake and North Chisel $\mathrm{Zn}-\mathrm{Pb}-\mathrm{Cu}$-Ag-Au massive sulfide deposits, Snow Lake, Manitoba. Exploration and Mining Journal, 2, 271-295.

Galley, A.G., and Watkinson, D.H., 1994. The subseafloor formation of volcanic-hosted massive sulfide: evidence from the Ansil deposit, Noranda, Quèbec. In Program with Abstracts, Waterloo'94, Geological Association of Canada/Mineralogical Association of Canada, 19, A39.

Gamble, R.P., 1982. An experimental study of sulfidation reactions involving andradite and hedenbergite. Economic Geology, 784-797.

Gamo, T., Sakai, H., Ishibashi, J., Nakayama, Isshiki, K., Matsuura, H., Shitashima, K., Takeuchi, K., and Ohta, S., 1993. Hydrothermal plumes in the eastern Manus Basin, Bismark Sea: $\mathrm{CH}_{4}, \mathrm{Mn}, \mathrm{Al}$, and $\mathrm{pH}$ anomalies. Deep-Sea Research. 
Gemmel, J.B., and Large, R.R., 1992. Stringer system and alteration zones underlying the Hellyer volcanic-hosted massive sulfide deposit, Tasmania, Australia. Economic Geology, $84,620-649$

Gemmel, J.B., Zantop, H., and Meinert, L.D., 1992. Genesis of the Aguilar zinc-leadsilver deposit, Argentina: contact metamorphism vs. sedimentary exhalative. Economic Geology, 87, 2085-2112.

Gibson, H.L., and Watkinson, D.H., 1979. Silicification in the Amulet "Rhyolite" formation, Turcotte Lake section, Noranda area, Quebec. Geological Survey of Canada, Paper 79-18, 111-120.

Gibson, H.L., Watkinson, D.H., and Comba, C.D.A., 1983. Silicification: Hydrothermal alteration in an Archean geothermal system within the Amulet Rhyolite formation, Noranda, Quebec. Economic Geology, 78, 954-971.

Gibson, H.L., 1989. The Mine Sequence of the Central Noranda Volcanic Complex: Geology, Alteration, Massive Sulfide Deposits and Volcanological Reconstruction. Ph.D. thesis, Carleton University, Ottawa, Ontario, Canada, (unpubl), 715 p.

Gibson, H.L., and Watkinson, D.H., 1990. Volcanogenic massive sulfide deposits of the Noranda Cauldron and Shield Volcano, Quèbec. In The Northwestern Québec Polymetallic Belt. Edited by M.Rive, P. Verplaelst, Y. Gagnon, J.M. Lulin, G. Riverin and A. Simard. The Canadian Institute of Mining and Metallurgy, Special Volume 43. 119132.

Gibson, H.L., Watkinson, D.H., and Comba, C.D.A., 1983. Silicification: hydrothermal alteration in an Archean geothermal system within the Amulet Rhyolite Formation Economic Geology, 78, 954-971.

Goldfarb, M.S., Converse, D.R., Holland, H.D., and Edmond, J.M., 1983. The genesis of hot spring deposits on the East Pacific Rise, $21^{\circ}$ N. In : H. Ohmoto and B.J. Skinner edts, Kuroko and Related Volcnaogenic Massive Sulfide Deposits, Economic Geology, Monograph 5, 184-197.

Goldie, R.J., 1976. The Flavrian and Powell Plutons, Nornada area, Quebec. Ph.D. thesis (unpubl.), Queen's University, Kingston, Ontartio,

Goodfellow, W.D., and Franklin, J.M., 1993. Geology, Mineralogy, and chemistry of sediment-hosted clastic massive sulfides in shallow cores, Middle Valley, northern Juan de Fuca Ridge.. Economic Geology, 88, 2037-2068.

Goodwin, A.M., 1982. Archean volcanoes in southwestern Abitibi belt, Ontario and Quebec: Form, composition, and development. Canadian Journal of Earth Sciences, 19, 1140-1155. 
Grant, J.A., 1986. The isocon diagram-A simple solution to Gresen's equation for metasomatic alteration. Economic Geology, 81, 1976-1982.

Gray, M.J., and Gibson, H.L., 1993. Geological setting of the Vermillion Cu-Zn-Pb-AuAg massive sulfide deposit, Sudbury Basin. In Geological Association of Canada/Mineralogical Association of Canada, Annual Meeting, Program with Abstracts, A37

Gresens, R.L., 1967. Composition-volume relationships of metasomatism. Chemical Geology, 2, 47-65.

Gustafson, W.I., 1974. The stability of andradite, hedenbergite, and related minerals in the system Ca-Fe-Si-O-H. Journal of Petrology, 15, 455-496.

Heald, P, Foley, N.K., and Hayba, D.O., 1987. Comparative anatomy of volcanic-hosted epithermal deposits: acid-sulphate and adularia-sericite types. Economic Geology, 82, 123.

Hedenquist, J.W., and Henley, R.W., 1985. Hydrothermal eruption in the Waiotapu geothermal system, New Zealand: their origin, associated breccias and relation to precious metal mineralization. Economic Geology, 80, 1640-1668.

Heiken, G.H., 1972. Morphology and petrography of volcanic ashes. Geological Society of America, Bulletin 83, 1961-1968.

Hekinian, R., and Fouquet, Y., 1985. Volcanism and metallogenesis of axial and off-axial structures on the East Pacific Rise near $13^{\circ} \mathrm{N}$. Economic Geology, 80, 221-249.

Henderson, P., 1984. General geochemical properties and abundances of the rare earth elements. In: P. Henderson (edt), Rare Earth Element Geochemistry, Developments in Geochemistry 2, Elsevier, Amsterdam, 1-32.

Henley, R.W., and Thornley, P., 1979. Some geothermal aspects of polymetallic massive sulfide formation. Economic Geology, 74, 1600-1612.

Henley, R.W., and Ellis, A.J., 1983. Geothermal systems, ancient and modern. Earth Science Reviews, 19, 1-50

Herzig, P.M., Hannington, M.D., Scott, S.D., Maliotis, G., Rona, P.A., and Thompson, G., 1991. Gold-rich sea-floor gossans in the Troodos ophiolite and on the Mid-Atlantic Ridge. Economic Geology, 86, 1747-1755.

Herzig, P.M., Hannington, M.D., Fouquet, Y., von Stackelberg, U., and Peterson, S., 1993. Gold-rich polymetallic sulfides from the Lau back arc and implications for the geochemistry of gold in sea-floor hydrothermal systems of the southwest Pacific. Economic Geology, 88, 2182-2209.

Hey, M.H., 1954. A new review of the chlorites. Mineralogical Magazine, 30, 277. 
Hodgson, C.J., Hamilton, J.V., and Piroshco, D.W., 1990. Structural setting of gold deposits and the tectonic evolution of the Timmins-Kirkland Lake area, southwestern Abibiti greenstone belt. University of Western Australia Geology Department, External Publication 24. 101-120.

Hopf, S., 1993. Behaviour of rare earth elements in geothermal systems of New Zealand Journal of Geochemical Exploration, 47, 333-357.

Hoy, L.D., 1993. Regional evolution of hydrothermal fluids in the Noranda District, Quebec: evidence from $\delta^{18} \mathrm{O}$ values from volcanogenic massive sulfide deposits. Economic Geology, 88, 1526-1541.

Huston, D.L., 1993. The effect of alteration and metamorphism on wall rocks to the Balcooma and Dry River South volcanic-hosted massive sulfide deposits, Queensland, Australia. Journal of Geochemical Exploration, 48, 277-307.

Iijima, A, and Harada, K., 1969. Authigenic zeolites in zeolitic palagonite tuffs on Oahu, Hawaii. The American Mineralogist, 54, 182-197.

Jackson, S.L., and Fyon, J.A., 1991. The Western Abitibi Subprovince in Ontario. In: Geology of Ontario. Edited by P.C. Thurston, H.R. Williams, R.H. Sutcliffe and G.M. Stotts. Ontario Geological Survey, Special Volume 4-1. 405-484.

Janecky, D.R., and Seyfried, W.E., Jr., 1984. Formation of massive sulfide deposits on oceanic ridge crests: Incremental reaction models for mixing between hydrothermal solutions and seawater. Geochemica Cosmochimica Acta, 48, 2723-2738.

Jensen, L.S., 1985. Stratigraphy and petrogenesis of Archean metavolcanic sequences, southwestern Abitibi Subprovince, Ontario. In: Evolution of Archean Supracrustal Sequences. Edited by L.D. Ayres, P.C. Thurston, K.D. Card, and W. Weber, Geological Association of Canada, Special Paper 28, 65-87.

Jolly, W.T., 1980. Development and degradation of Archean lavas, Abitibi area, Canada, in light of major element geochemistry. Journal of petrology, 21, 323-363.

Kabamoto, J., 1990.

Kalogeropoulos, S.I., and Scott, S.D., 1989. Mineralogy and geochemistry of an Archean tuffaceous exhalite: the Main Contact Tuff, Millenbach Mine area, Noranda, Quebec. Canadian Journal of Earth Science, 26, 88-105.

Kennedy, G.C., 1950. A portion of the system silica-water. Economic Geology, 45, 629653.

Kennedy, L.P., 1984. The geology and geochemistry of the Archean Flavrian Pluton, Noranda, Quebec. PhD. thesis (unpublished), University of Western Ontario, London, Ontario, 469p.

Kerr, D.J., and Gibson, H.L., 1993. A comparison of the Horne Volcanogenic Massive Sulfide Deposit and Intracauldron Deposits of the Mine Sequence, Noranda, Quebec. Economic Geology, 88. 1419-1442. 
Klein, C., 1964. Cummingtonite-grunerite series: a chemical, optical and x-ray study American Mineralogist, 49, 963

Knuckey, M.S., and Watkins, J.J., 1982. The geology of the Corbet massive sulpfide deposit, Noranda District, Quebec, Canada. Geological Association of Canada, Special paper $25,255-295$

Knuckey, M.S., Comba, C.D.A., and Riverin, G., 1982. The Millenbach deposit, Nornada District, Quebec - an update on structure, metal zoning and wall rock alteration: Geological Association of Canada, Special Paper 25, 297-318.

Kristmansdottir, H., 1983. Chemical evidence from Icelandic geothermal systems as compared to submarine geothermal systems. In: P.A. Rona, K. Bostrom, L. Laubier and K.L. Smith edts, Hydrothermal Processes at Seafloor Spreading Centres, NATO Conference Series IV, Marine Sciences, Plenum Press, New York, 12, 291-320.

Laflêche, M.R., Dupuy, C., and Bougault, H., 1992. Geochemistry and petrogenesis of Archean mafic volcanic rocks of the southern Abitibi Belt, Quebec. Precambrian Research, 57, 207-241

Large, R.R., 1977. Chemical evolution and zonation of massive sulfide deposits in volcanic terrains. Economic Geology, 72, 549-572

Large, R.R., Huston, D.L., McGoldrick, P.J. and Ruxton, P.A., 1989. Gold distribution and genesis in Australian volcanogenic massive sulfide deposits and their significance for gold transport models. Economic Geology, 40, 520-535.

Large, R.R., 1992. Australian volcanic-hosted massive sulfide deposits: features, styles and genetic models. Economic Geology, 87, 471-510.

Lesher, C.M., Gibson, H.L. and Campbell, I.H., 1986. Composition volume changes during hydrothermal alteration of andesite at Buttercup Hill, Noranda District, Quebec Geochimica Cosmochimica Acta, 50, 2693-2705.

Lichtblau, A.P., and Dimroth, E., 1980. Stratigraphy and facies at the south margin of the Archean Noranda caldera, Noranda, Quebec. Geological Survey of Canada, Current Research, Paper 80-1A, 756.

Lipman, P.W., 1975. Evolution of the Paltoro caldera complex and related volcanic rocks, southeastern San Juan Mountains, Colorado. United States Geological Survey, Professional Paper 852, 128p.

Lister, C.R.B., 1972. On the thermal balance of a mid-ocean ridge. Royal Astronomical Society, Geophysical Journal, 26, 515-535

Lofgren, G., 1971. Spherulitic textures in glassy and crystalline rocks. Geophysical Research, 76, 5635-5648

Lottermoser, B.G., 1992. Rare earth elements and hydrothermal ore formation processes. Ore Geology Reviews, 7, 25-41.

Ludden, J., and Hubert, C., 1986. The geological evolution of the Late Archean Abitibi greenstone belt of Canada. Geology, 14, 707-711. 
Lydon, J.W., 1984. Ore Deposit Models \#14: Volcanogenic Massive Sulfide Deposits Part 2: Genetic Models. Geoscience Canada, 15, 43-65.

Lydon, J.W., and Galley, A., 1986. The chemical and mineralogical zonation of the Mathiati alteration pipe, Cyprus, and its genetic significance. in M.J. Gallagher, R.A. Ixer, C.R Neary and H.M. Prichard, edts, Metallogeny of basic and ultrabasic rocks, Institute of Mining and Metallurgy, 49-68.

MacDonald, G.A., 1972. Volcanoes. Prentice-Hall, New Jersey.

Meinert, L.D., 1984. Skarns and skarn deposits. Geoscience Canada, 19, 145-162.

Moore, J.G., 1966. Rate of palagonization of submarine basalt adjacent to Hawaii. United States Geological Survey, Professional paper 550D, 163-171.

Moore, J.G., and Schilling, J.G., 1973. Vesicles, water and sulfur in Rekyjanes Ridge basalts. Contributions to Mineralogy and Petrology, 41, 105-118.

Mortensen, J.K., 1987. Preliminary U-Pb zircon ages for volcanic and plutonic rocks of the Noranda-Lac Abitibi area, Abitibi Subprovince, Quebec. Geological Survey of Canada, Paper 87-1A., 581-590

1993. U-Pb geochronology of the eastern Abitibi subprovince, Part 2 Noranda-Kirkland Lake area. Canadian Journal of Earth Science, 30, 29-41.

Morton, M.L., Hudak, G.J., Walker, J.S., and Franklin, J.M., 1990. Physical volanology and hydrothermal alteration of the Sturgeon Lake caldera complex. In: J.M. Franklin, B.R. Schnieders and E.R Koopman edts, Geological Survey of Canada, Open File 2164, Mineral Deposits in the Western Superior Province, Ontario, 74-94.

Muffler, L.J.P., White, D.F. and Truesdell, A.H., 1971. Hydrothermal explosion craters in Yellowstone National park. Geological Society of America Bulletin, 82, 723-740.

Munha, J., and Kerrich, R., 1980. Sea water basalt interaction in spilites from the Iberian Pyrite Belt. Contributions to Mineralogy and Petrology, 73, 191-200.

Nelson, C.E. and Giles, D.L., 1985. Hydrothermal eruption mechanisms and hot spring gold deposits. Economic Geology, 80, 1633-1639.

Nelson, J., and Payne, J., 1985. Upper Paleozoic volcanogenic massive sulfide deposits near Tulsequah, B.C., Canadian Institute of Mining and Metallurgy, Abstract Volume, $87^{\text {th }}$ Annual General Meeting, 92-93.

Ojakangas, R.W., 1985. Review of Archean clastic sedimentation, Canadian Shield: major felsic volcanic contributions to turbidite and alluvial fan-fluvial associations. In: Evolution of Archean Supracrustal Sequences. Edited by L.D. Ayres, P.C. Thurston, K.D. Card, and W. Weber, Geological Association of Canada, Special Paper 28, 23-48.

Paradis, S., 1990. Stratigraphy, volcanology, and geochemistry of the New Vauze-Norbec area, central Noranda volcanic complex, Quebec, Canada. Ph.D. thesis (unpubl), Carleton University, Ottawa Ontario, Canada, 453 p. 
Paradis, S., Ludden, J., and Gelinas, L., 1988. Evidence for contrasting compositional spectra in comagmatic intrusive and extrusive rocks of the late Archean Blake River Group, Abitibi, Quebec. Canadian Journal of Earth Sciences, 25, 134-144.

Paradis, S., Taylor, B.E., Watkinson, D.H., and Jonasson, I.R., 1993. Oxygen isotope zonation and alteration in volcanic crusts of the Noranda district, Quebec: evidence from hydrothermal fluid flow. Economic Geology,

Peacock, M.A., 1926. The volcano-glacial palagonite formation of Iceland. Geology Magazine, 63, 385-399

Pelltier, C., and Jebrak, M., 1994. Au-(cu-Mo) porphyries in the Noranda area, Blake River Group, South Abitibi greenstone belt, Quebec. In Geological Association of Canada/Mineralogical Association of Canada, Program with Abstracts, A87.

Péloquin, S., Potvin, R., Paradis, S., Laflèche, M.R., Verplaelst, P., and Gibson H.L., 1990. The Blake River Group, Rouyn-Nornada Area, Quèbec: A stratigraphic synthesis. In The Northwestern Québec Polymetallic Belt. Edited by M.Rive, P. Verplaelst, Y. Gagnon, J.M. Lulin, G. Riverin and A. Simard. The Canadian Institute of Mining and Metallurgy, Special Volume 43. 107-118.

Péloquin S., Ludden, J.N., and Hubert, C., 1994. Magmatic systems in Late Archean volcanic basins: implications for Noranda-type VMS. In Program with Abstracts, Waterloo'94, Geological Association of Canada/Mineralogical Association of Canada, 19, A87.

Perret, F.A., 1937. The eruption of Mt. Pelee 1929-1932. Carnegie Institute of Washington, Publication 458, 1-126.

Percival, J.A., 1986. A possible exposed Conrad discontinuity in the Kapuskasing uplift, Ontario. In: Reflection Seismology: The Continental Crust. Geodynamics Series 14, American Geophysical Union, Washington D.C., 135-141.

Percival, J.B., and Ames, D.E., 1993. Clay mineralogy of active hydrothermal chimneys and an associated mound, Middle Valley, northern Juan de Fuca Ridge. The Canadian Mineralogist, 31, 957-971.

Pisutha-Arnond, V., and Ohmoto, H., 1983. Thermal history, and chemical and isotopic compositions of the ore-forming fluids responsible for the Kuroko massive sulfide deposits in the Hukoroko District of Japan. In: H. Ohmoto and B.J. Skinner edts, Kuroko and Related Volcnaogenic Massive Sulfide Deposits, Economic Geology, Monograph 5, 523558.

Porter, E., W., and Ripley, E., 1985. Petrologic and stable isotope study of the goldbearing breccia pipe at the Golden Sunlight deposit, Montana. Economic Geology, 80, 1689-1706. 
Rive, M., Hillar, P., and Ludden, J.N., 1990. Characterisitics of late archean plutonic rocks from the Abitibi and Pontiac subprovinces, Superior province, Canada. In: The Northwestern Québec Polymetallic Belt. Edited by M.Rive, P. Verplaelst, Y. Gagnon, J.M. Lulin, G. Riverin and A. Simard. The Canadian Institute of Mining and Metallurgy, Special Volume 43. 65-76

Riverin, G., and Hodgson, C.J., 1980. Wall-rock alteration at the Millenbach Cu-Zn Mine, Noranda, Quebec. Economic Geology, 75, 424-444.

Riverin, G., LaBrie, M., Salmon, B., Cazavant, A., Asselin, R., and Gagnon, M., 1990 The Geology of the Ansil Deposit, Rouyn-Noranda, Québec. In: The Northwestern Québec Polymetallic Belt. Edited by M.Rive, P. Verplaelst, Y. Gagnon, J.M. Lulin, G. Riverin and A. Simard. The Canadian Institute of Mining and Metallurgy, Special Volume 43. $143-152$.

Roberts, R.G., and Reardon, E.J., 1978. Alteration and ore-forming processes at Mattagami Lake Mine, Quebec. Canadian Journal of Earth Sciences, 15, 1-21.

Robigou, V., and Delaney, J.R., 1988. Large massive sulfide deposits in a newly discovered active hydrothermal system, the High-Rise Field, Endeavour Segment, Juan de Fuca Ridge. Geophysical Research Letters, 20, 1887-1890.

Rona, P.A., and Clague, D.A., 1989. Geologic controls of hydrothermal discharge on the northern Gorda Ridge. Geology, 17, 1097-1101.

Rona, P.A., Hannington, M.D., Raman, C.V., Thompson, G., Tivey, M.K., Humphris, S.E., Lalou, C. and Peterson, S., 1993. Active and relict sea-floor hydrothermal mineralization at the TAG hydrothermal field, Mid-Atlantic Ridge. Economic Geology, 88, 1989-2017.

Salmon, B., 1991. Etude de la distribution de l'or dans le sulfure massif du gîtes d'Ansil au $1^{\text {er }}$ septembre $1991.73 p$.

Schiffman, P., and Smith, B.M., 1988. Petrology and O-isotope geochemistry of a fossil seawter hydrothermal system within the Solea graben, northern Troodos Ophiolite, Cyprus. Journal of Geophysical Research, 93, 4612-4625.

Setterfield, T., 1984. Nature and significance of the McDougall-Despina fault set, Noranda, Quebec. Msc. thesis (unpubl.), University of Western Ontario, London, Ontario.

Seyfried, W., and Bischoff, J.L., 1979. Low temperature basalt alteration by seawter: an experimental study at $70^{\circ} \mathrm{C}$ and $150^{\circ} \mathrm{C}$. Geochemica et Cosmochimica Acta, 43, 19371947. 
Seyfried, W., E., Jr., Berndt, M.E., and Seewald, J.S., 1988. Hydrothermal alteration processes at mid-ocean ridges: constraints from diabase alteration experiments, hot-spring fluids and composition of the oceanic crust. Canadian Mineralogist, 26, 787-804

Seward, T.M., 1982. The transport and deposition of gold in hydrothermal systems. In R.P. Foster, edt, Gold'82, Rotterdam, 165-181.

Sheridan, M.F., and Wohletz, K.C., 1983. Hydrovolcanism: Basic considerations and review. Journal of Volcanology and Geothermal Research, 17, 1-30.

Shiga, Y., 1988. Silician magnetite from the Kamaishi Mine, Japan. Mining Geology, 38, 437-440.

Sillitoe, R.H., 1985. Ore-related breccias in volcanoplutonic arcs. Economic Geology, 80, 1467-1514.

Spence, C.D., 1967. The Noranda area. Canadian Institute of Mining and Metallurgy, Centennial Field Excursion Guidebook, 36-39.

Stakes, D.S., and Taylor, H.P., 1992. The northern Samail Ophiolite: an oxygen, microprobe and field study. Journal of Geophysical Research, 97-B, 7043-7080.

Taylor, B.E., and Liou, J.G., 1978. The low-temperature stability of andradite in C-O-H fluids. American Mineralogist, 63, 378-393.

Tivey, M.K. and Delaney, J.R., 1986. Growth of large sulfide structures on the Endeavour Segment of the Juan de Fuca Ridge. Earth and Planetary Science Letters, 77, 303-317.

Tomasson, J., and Kristmannsdottir, H., 1972. High temperature alteration minerals and thermal brines, Rekyjanes, Iceland. Contributions to Mineralogy and Petrology, 36, 123134.

Ujike, O., 1985. Geochemistry of Archean alkalic volcanic rocks from the Crystal Lake area, east of Kirkland Lake, Ontario, Canada. Earth and Planetary Science Letters, 73. $333-344$.

Velasco, F., and Amigó, J.M., 1981. Mineralogy and origin of the skarn from Cala (Huelva, Spain). Economic Geology, 76, 719-726.

Vivallo, W., 1985. The geology and genesis of the Proterozoic massive sulfide deposit at Garpenberg, central Sweden. Economic Geology, 80, 17-32.

Von Damm, K.L., and Bischoff, J.L., 1987. Chemistry of hydrothermal solutions from the southern Juan de Fuca Ridge. Journal of Geophysical Research, B1 1, 11334-11346. 
Walshe, J.L., and Solomon, M., 1981. An investigation into the environment of formation of the volcanic-hosted Mount Lyell copper deposits using geology, mineralogy, stable isotopes and a six-component chlorite solid solution model. Economic Geology, 76, 246284

Westendorp, R., W., 1991. Hydrothermal magnetite at the Ansil Cu-Zn mine, RouynNoranda, Quebec. Msc. thesis (unpubl), Ottawa, Ontario, Carleton University, 91p.

Westendorp, R.W., Watkinson, D.H., and Jonasson, I.R., 1991. Silicon-bearing zoned magnetite crystals and the evolution of hydrothermal fluids at the Ansil $\mathrm{Cu}-\mathrm{Zn} \mathrm{Mine}$, Rouyn-Noranda, Quebec. Economic Geology, 86, 1110-1114.

Winkler, H.G.F., 1974. Petrogenesis of Metamorphic Rocks. E. Froese edt, SringerVerlag, New York, 74-80.

Wohletz, K., and Heiken, G., 1992. Volcanology and Geothermal Energy, University of California Press, Berkely, 146-156.

Wolery, T.J., and Sleep, N.H., 1976. Hydrothermal circulation and geochemical flux at mid-ocean ridges. Journal of Geology, 84, 249-275.

Zaleski, E., 1986. The speciation of aluminum under hydrothermal conditions. Unpublished paper, University of Manitoba, 37p.

Zaw, K., and Large, R.R., 1992. The precious metal-rich South Hercules mineralization, western Tasmania: a possible sub-seafloor replacement volcanic-hosted massive sulfide $\mathrm{d}$ deposit. Economic Geology, 84, 931-952.

Zierenberg, R.A., Shanks III, W.A., Seyfried, W.E. Jr., Koski, R.A. and Strickler, M.D., 1988. Mineralization, alteration, and hydrothermal metamorphism of the ophiolite-hosted Turner Albright sulfide deposit, southwestern Oregon. Journal of Geophysical Research, 93-B5, 4657-4674. 
APPENDIX III

SAMPLE LOCATION MAPS 


\section{LEGEND}

Feldspar porphyry dyke

Felsic dyke

Mafic dyke

Dacite

Andesite

Cranston Tuff

Rhyolite

Hydrothermal explosion breccia

Massive sulphide

Stockwork chalcopyrite-pyrrhotite

Massive magnetite

Stockwork magnetite

Quartz-chlorite alteration

Chlorite sulphide stringers

Quartz-sericite stringers 

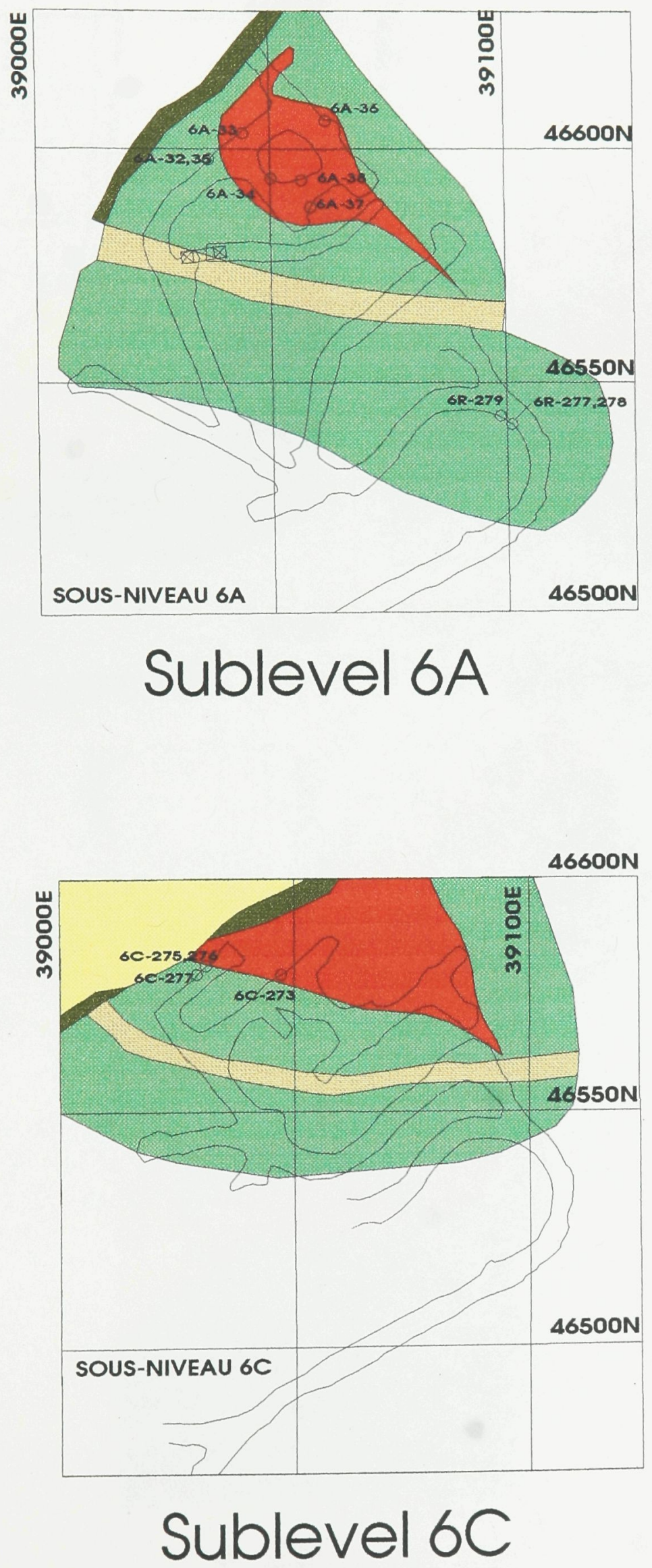

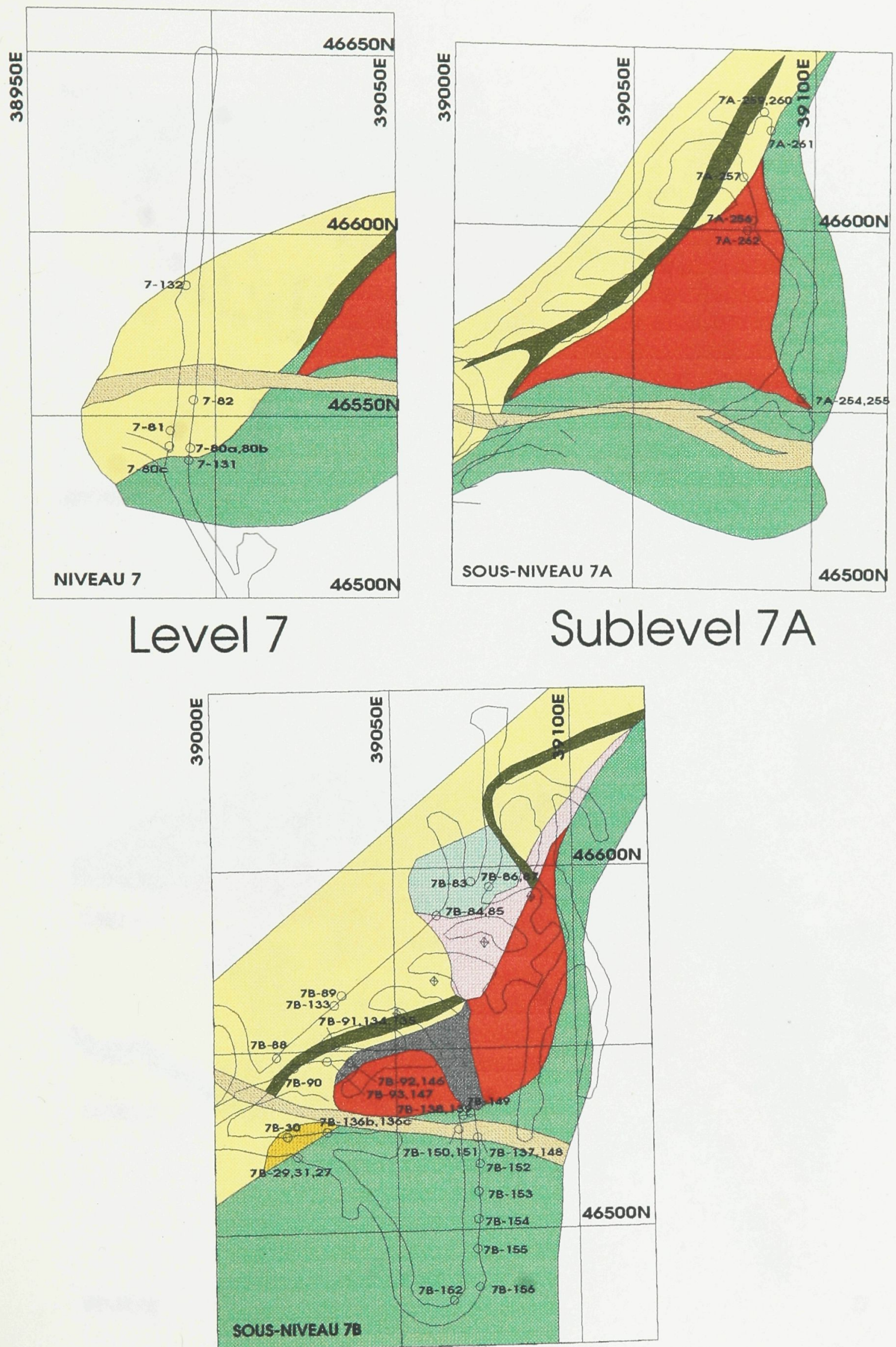

Sublevel 7B 

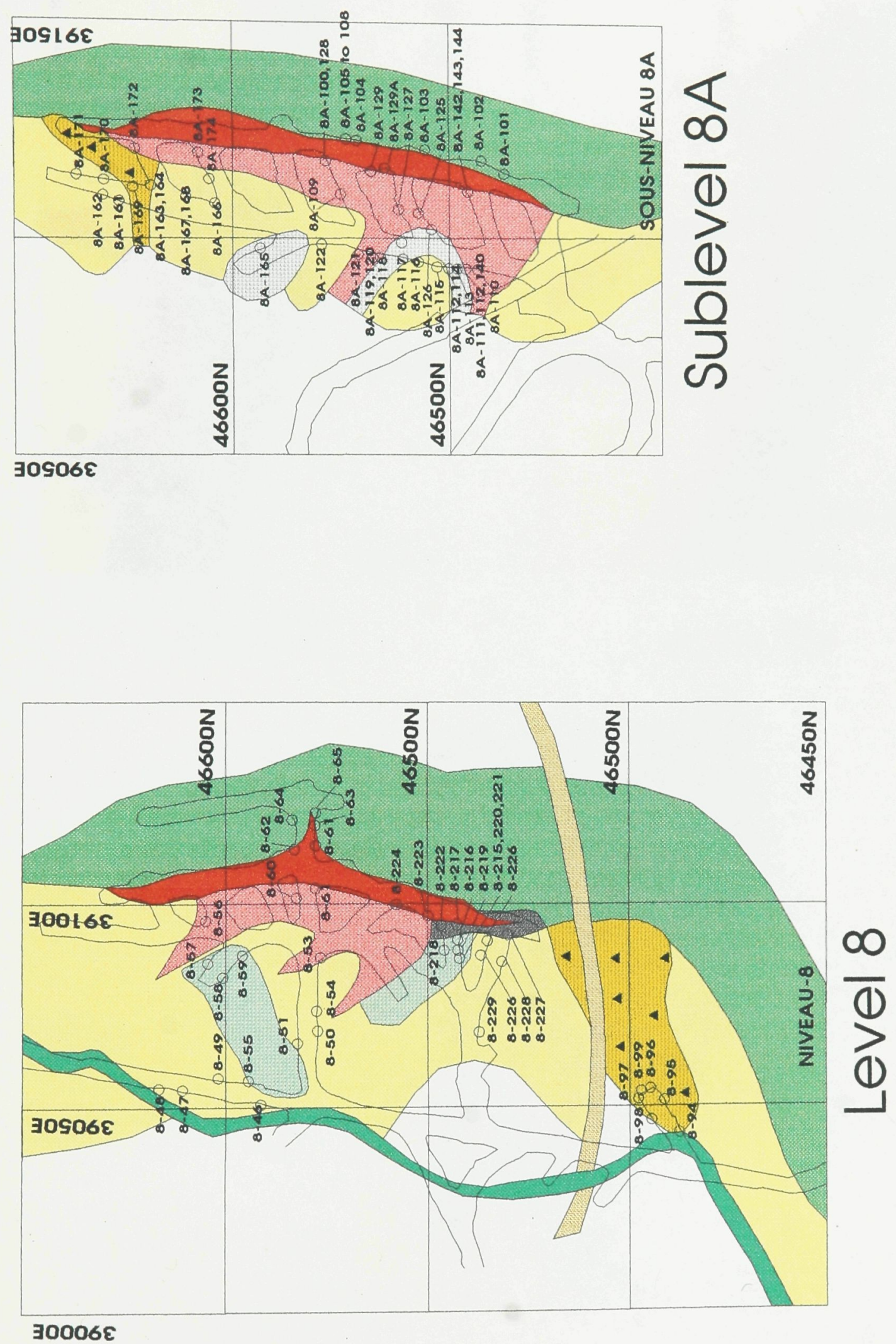

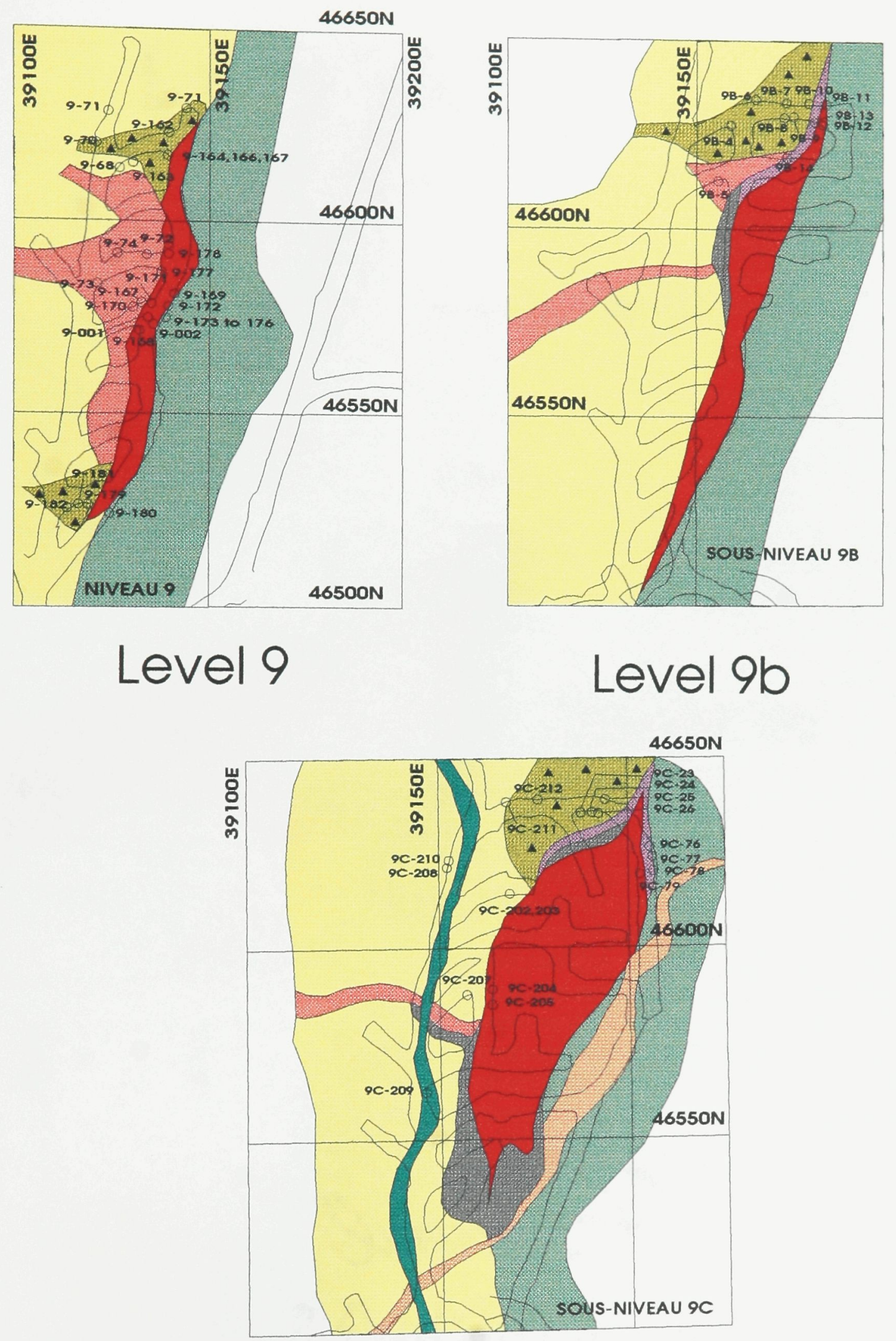

Level 9c 

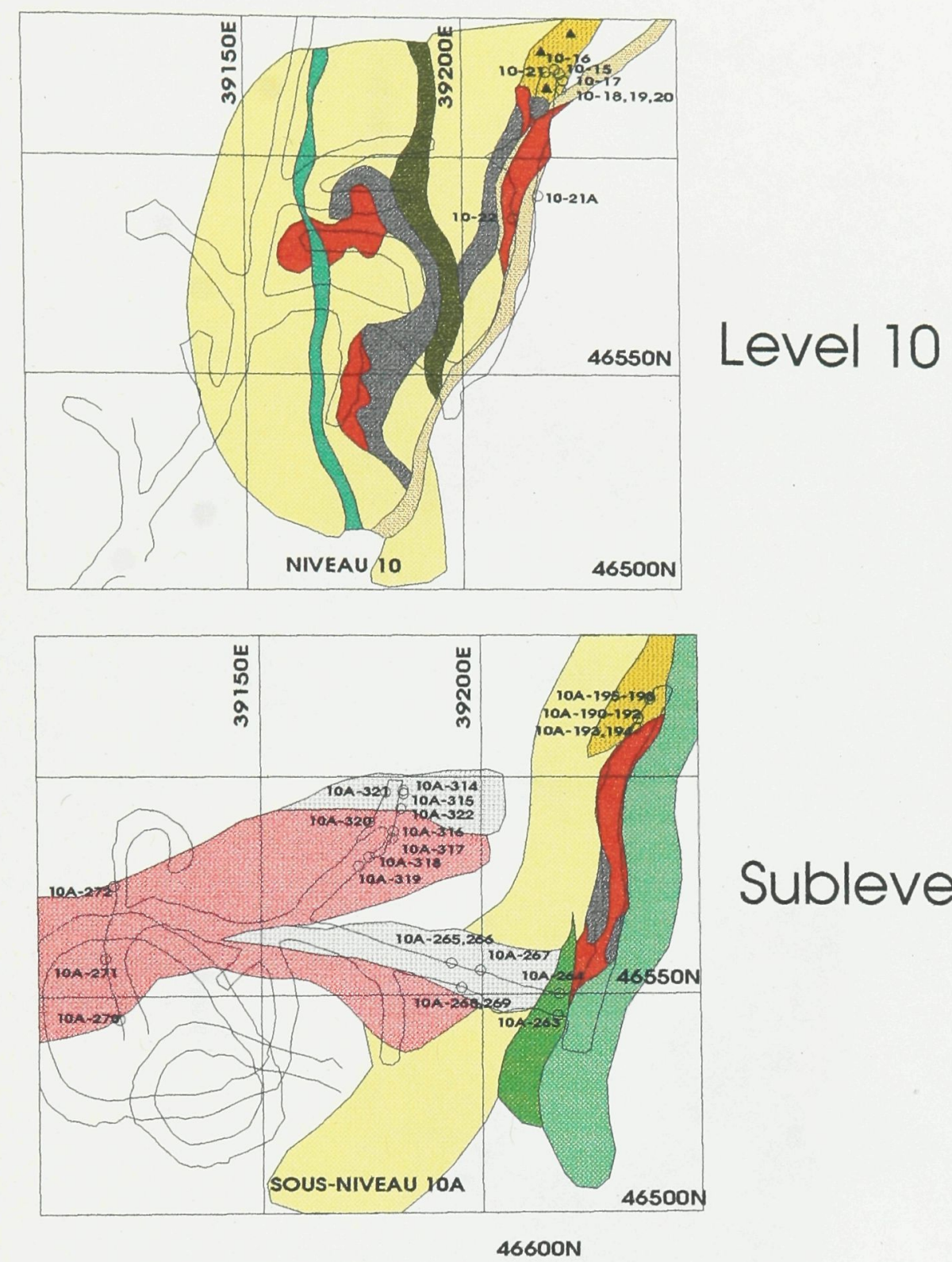

\section{Sublevel 10a}

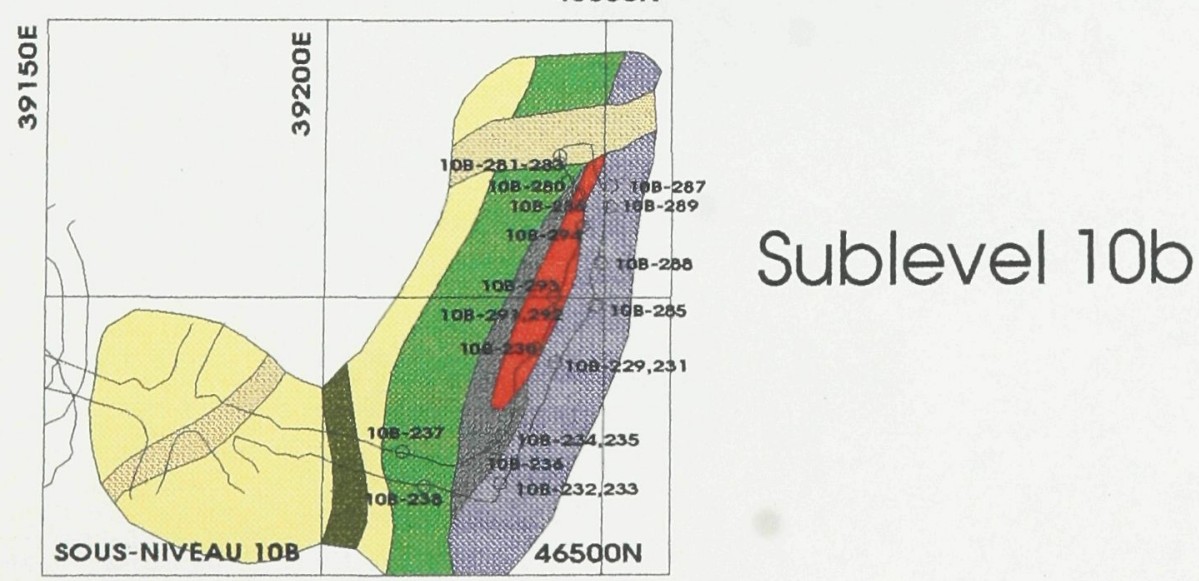




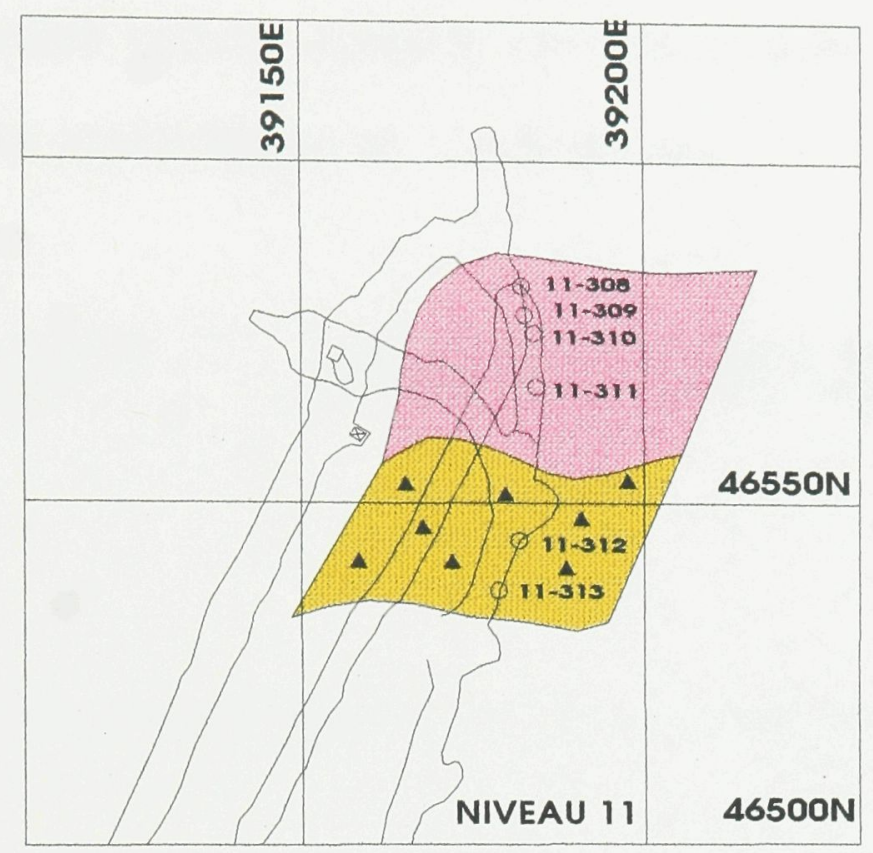

\section{Level 11}

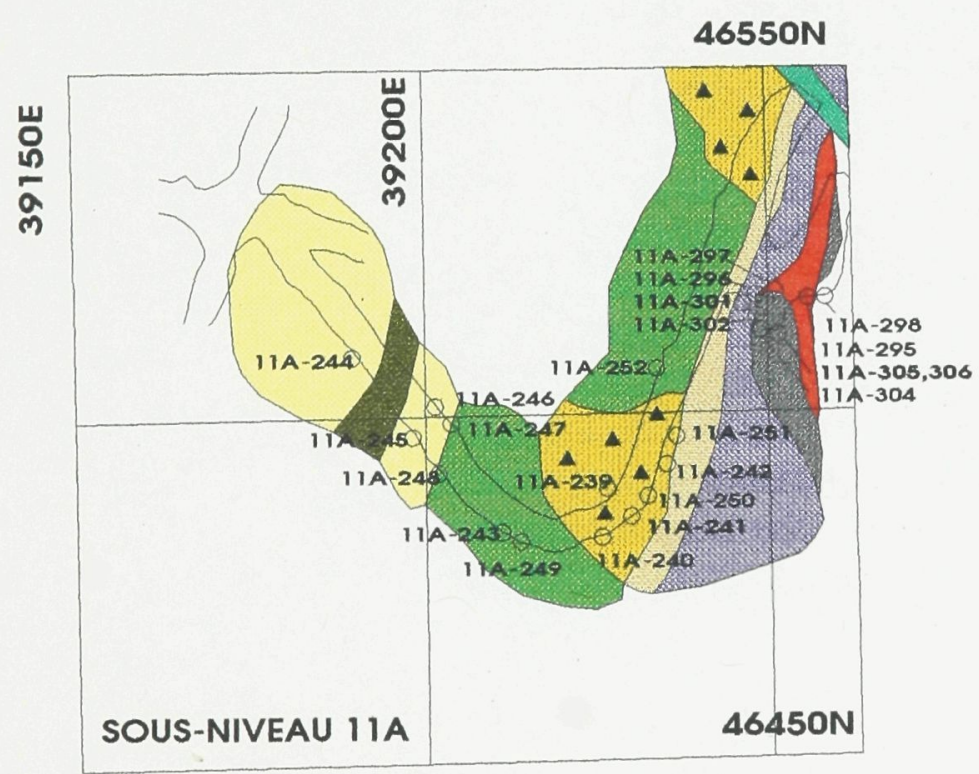

\section{Sublevel 11a}


Appendix I 1:150 scale geology maps (7 in a11) of the Ansil deposit. 


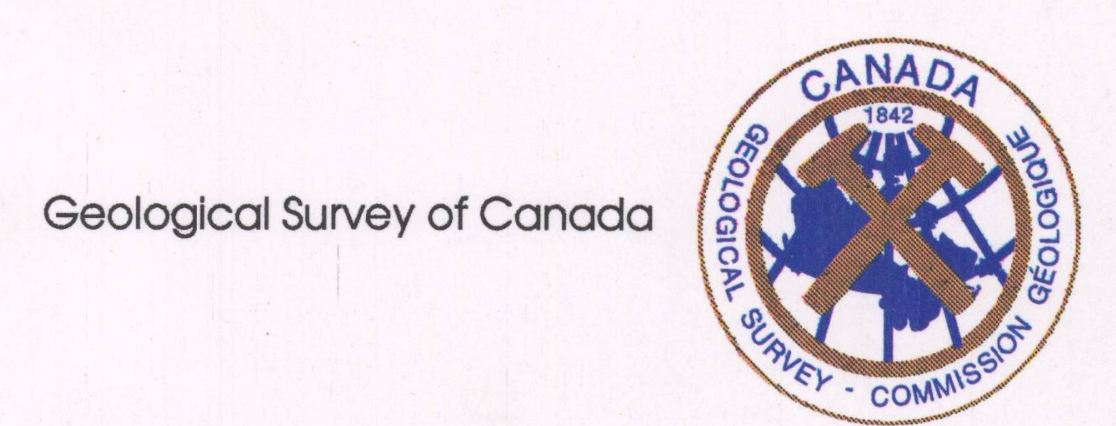

OPEN FLE 2681/DOSSIER PUBLC 2681

GEOLOGY OF THE ANSIL MINE CU-Zn MASSIVE SULPHIDE DEPOSIT, ROUYN-NORANDA, QUEBEC (sheet 1 of 7 )

Mapping and compilation by A.G. Galley
Mineral Resources Division
Geological Survey of Canada

Recommended citation Galley, A. G., Jonasson, I.R., Salmon, B., Asselin, R., Gagnon, M.,
1994: Geology of the Ansil Cu-Zn Massive Sulphide Deposit, Gouyn-Noranda, Québec;

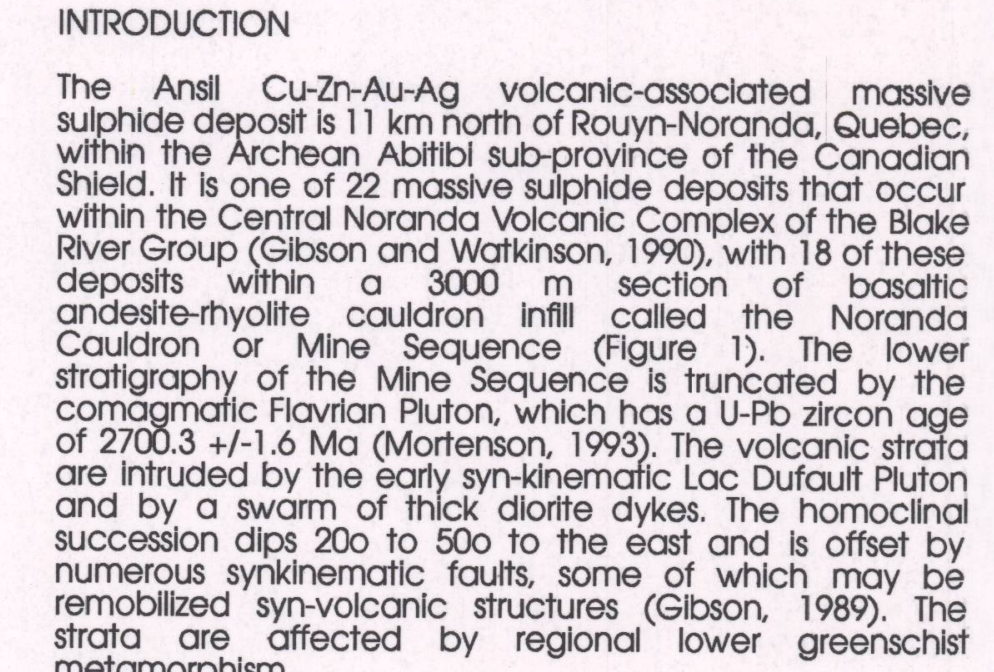

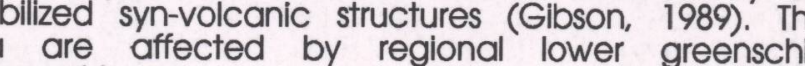

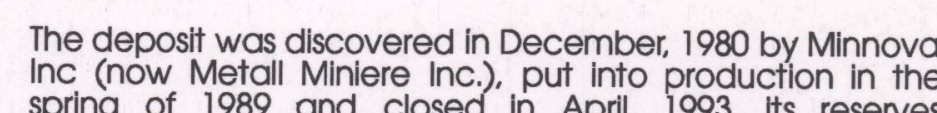

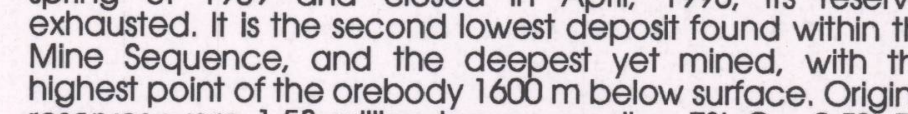

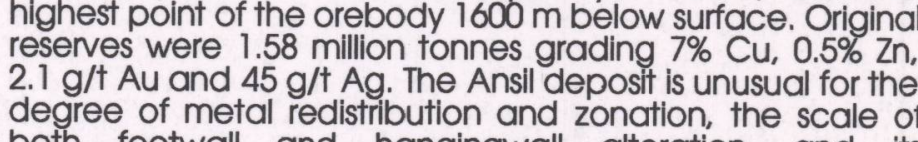

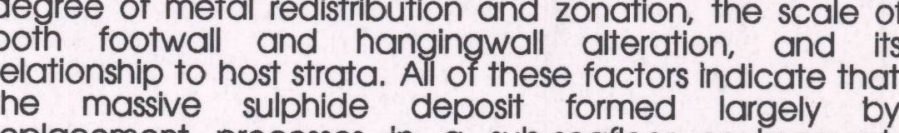

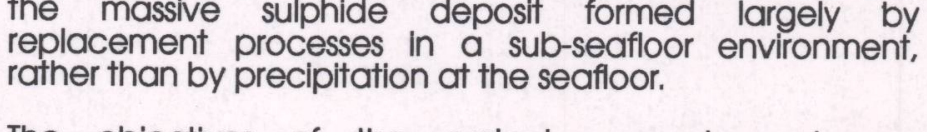

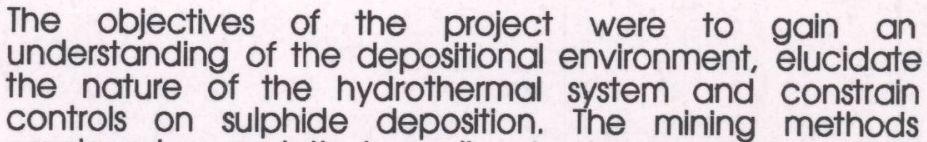

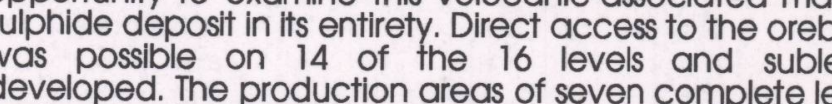

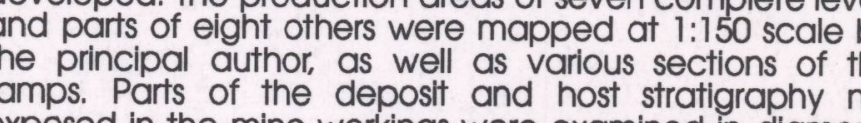

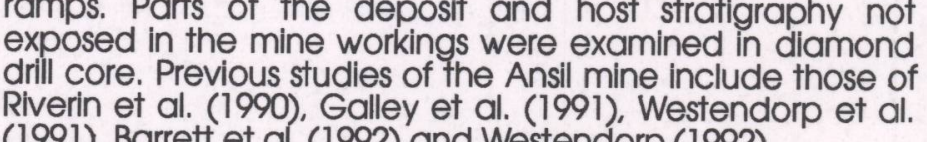

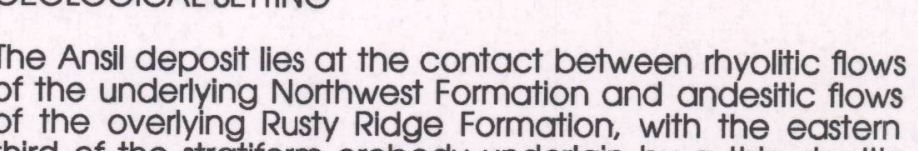

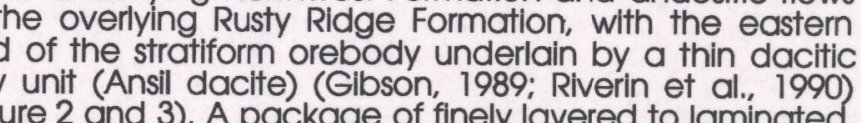

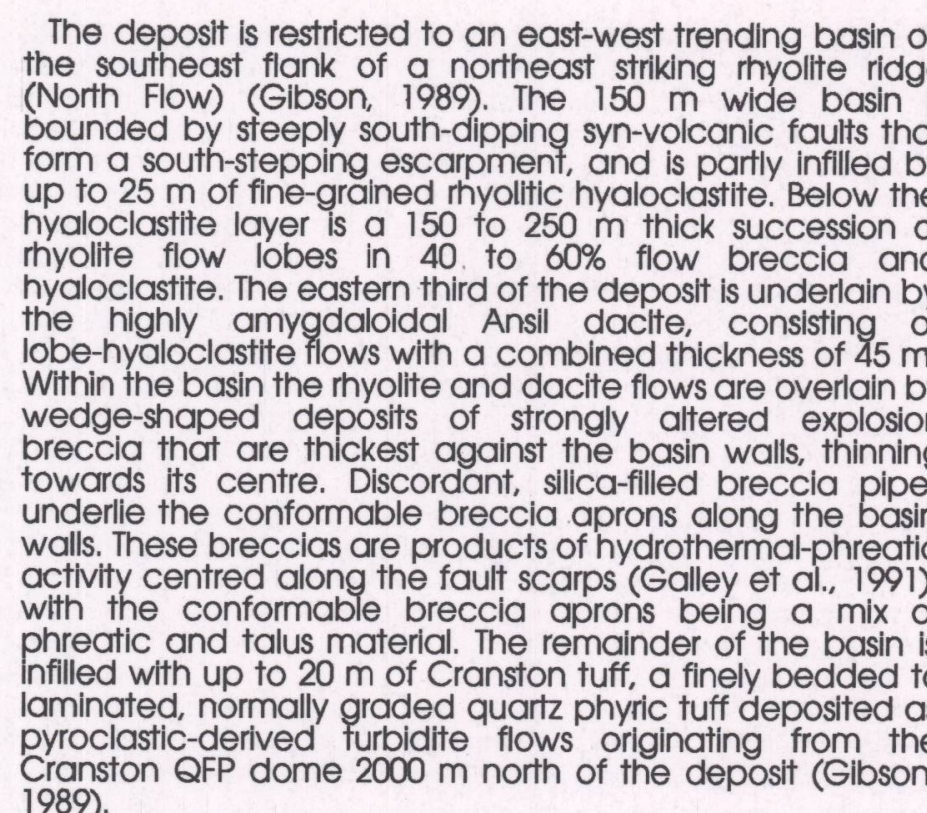

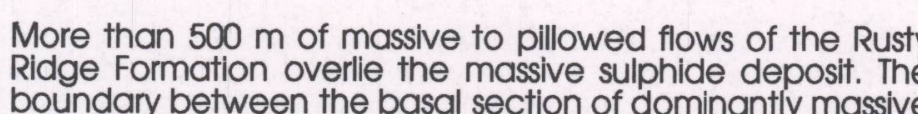

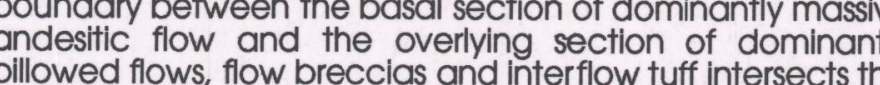

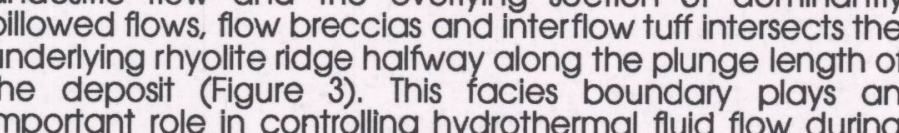

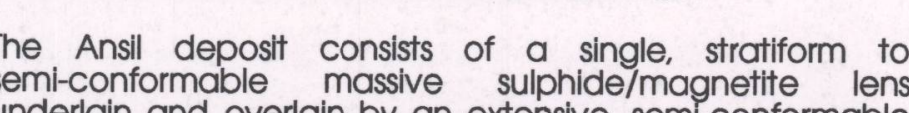

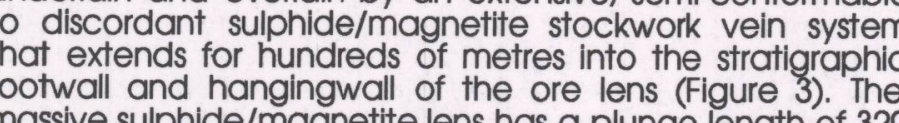

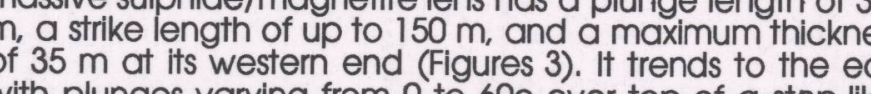

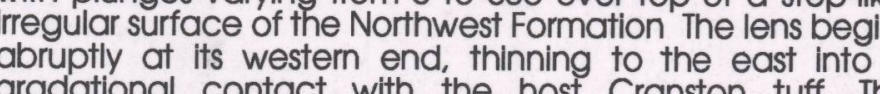

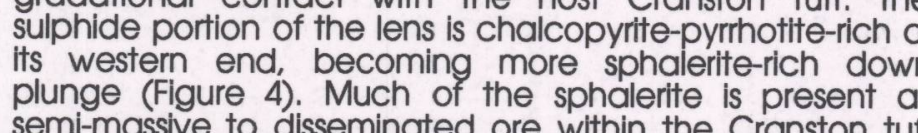

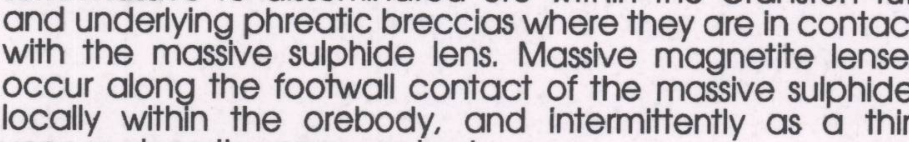

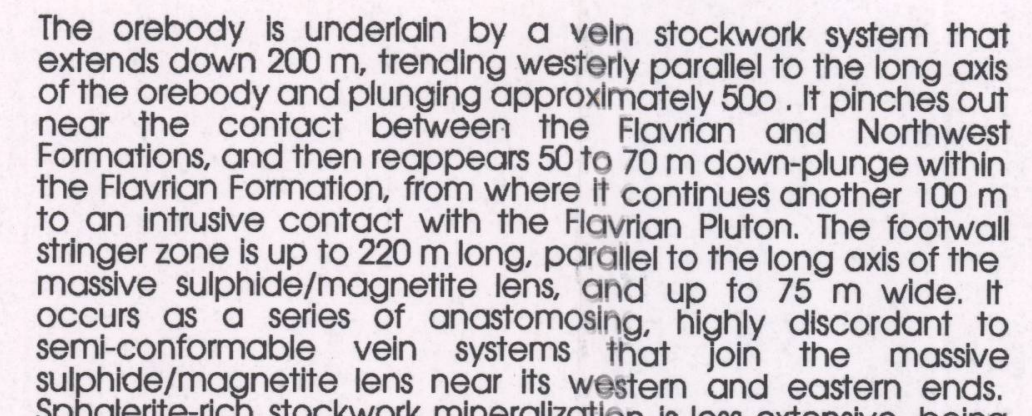

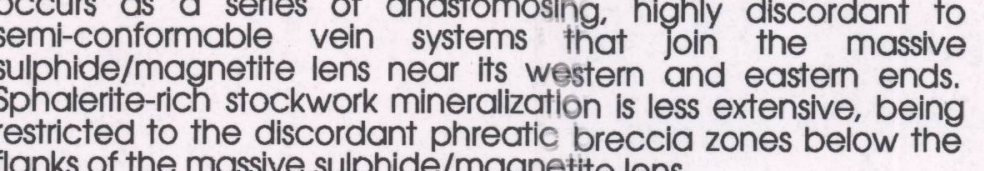

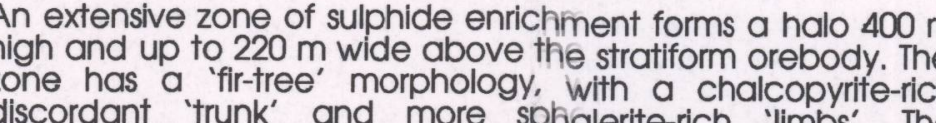

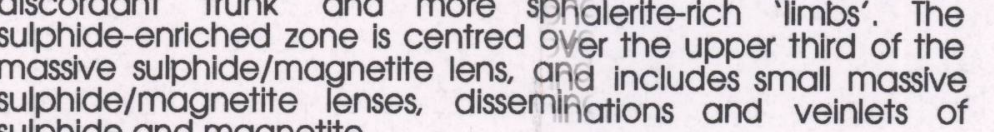
suphice and
ALIERATION

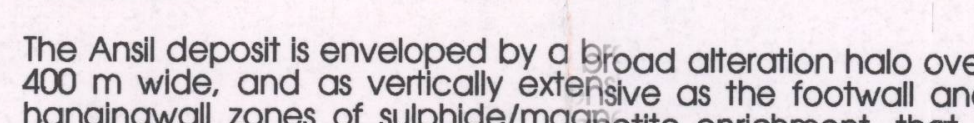

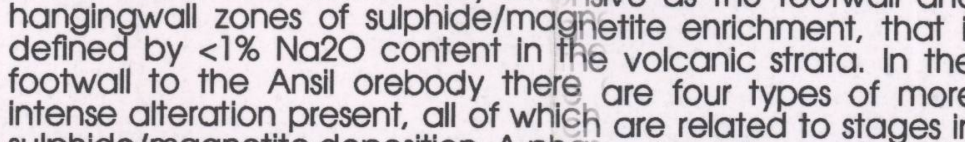

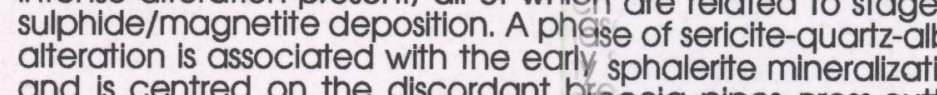

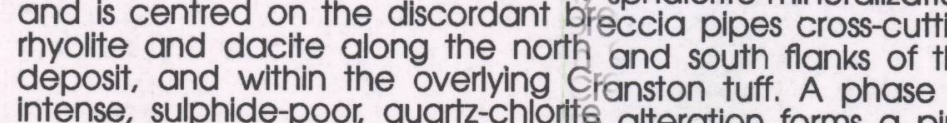

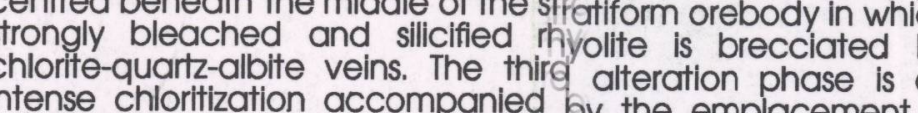

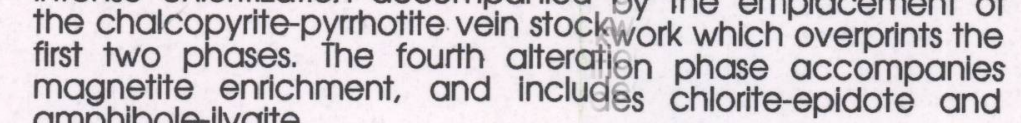

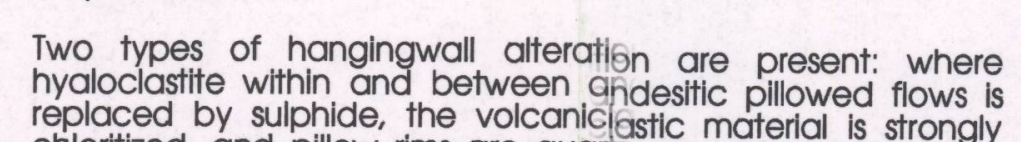

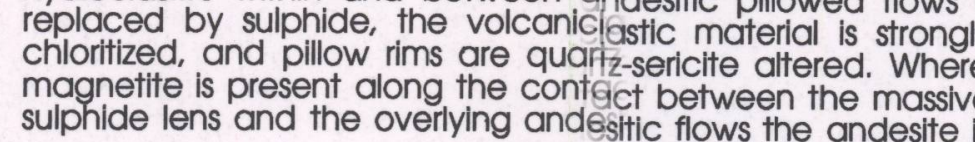

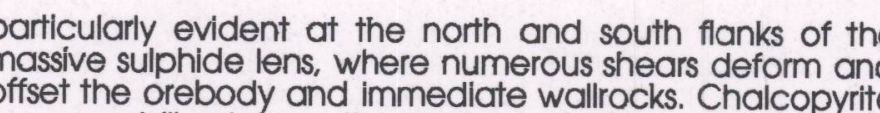

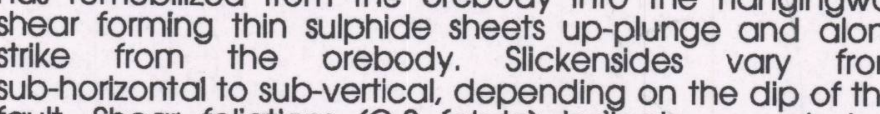

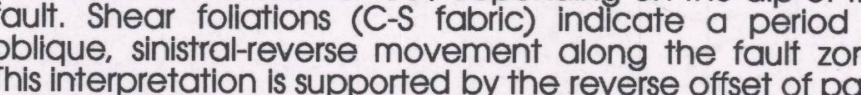

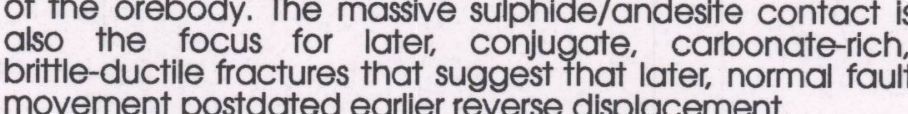

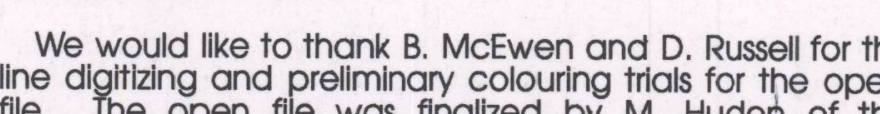

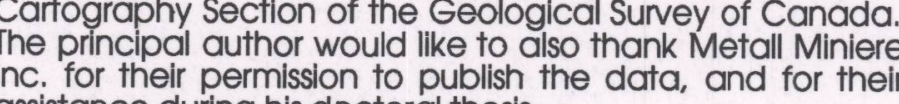

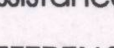

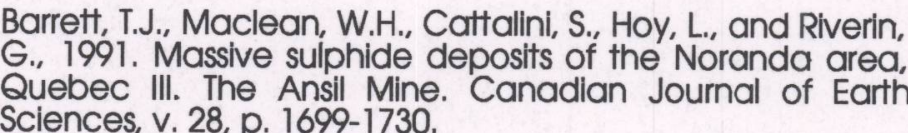

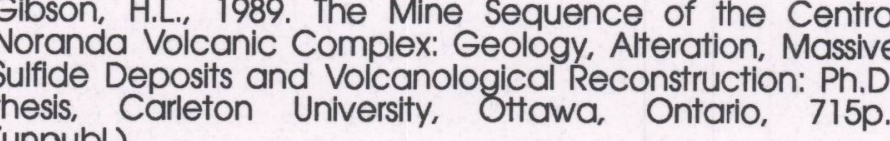

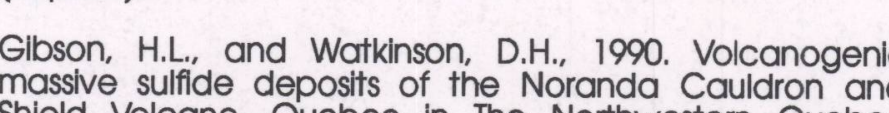

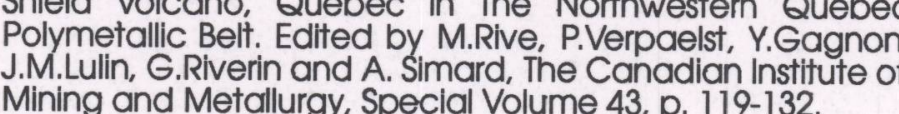

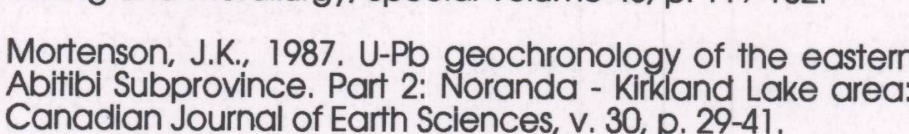

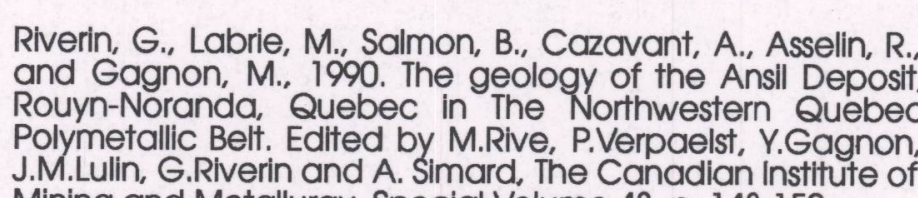

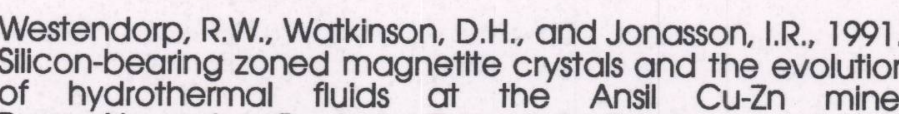
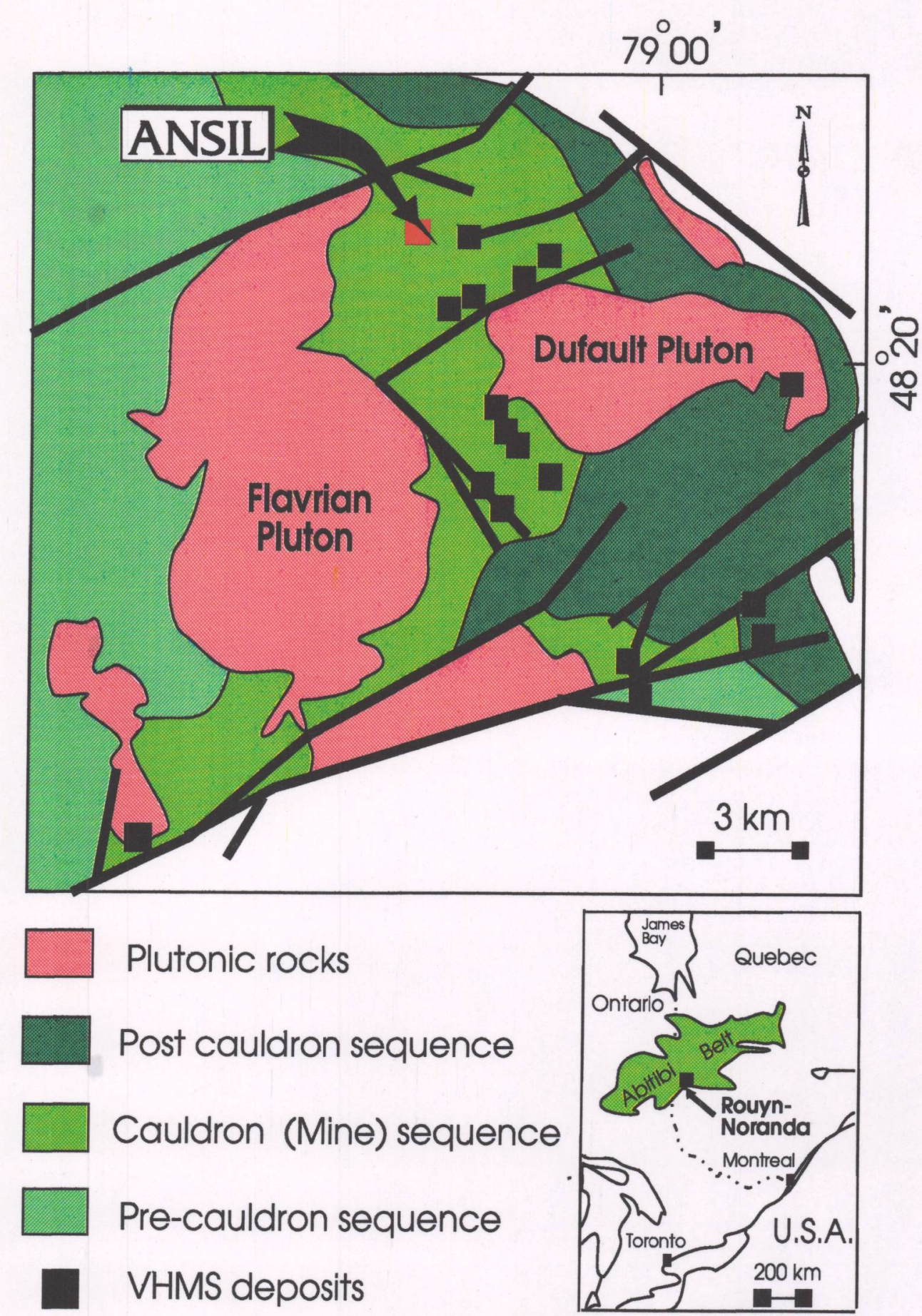

Figure 1:

Location of Ansil deposit

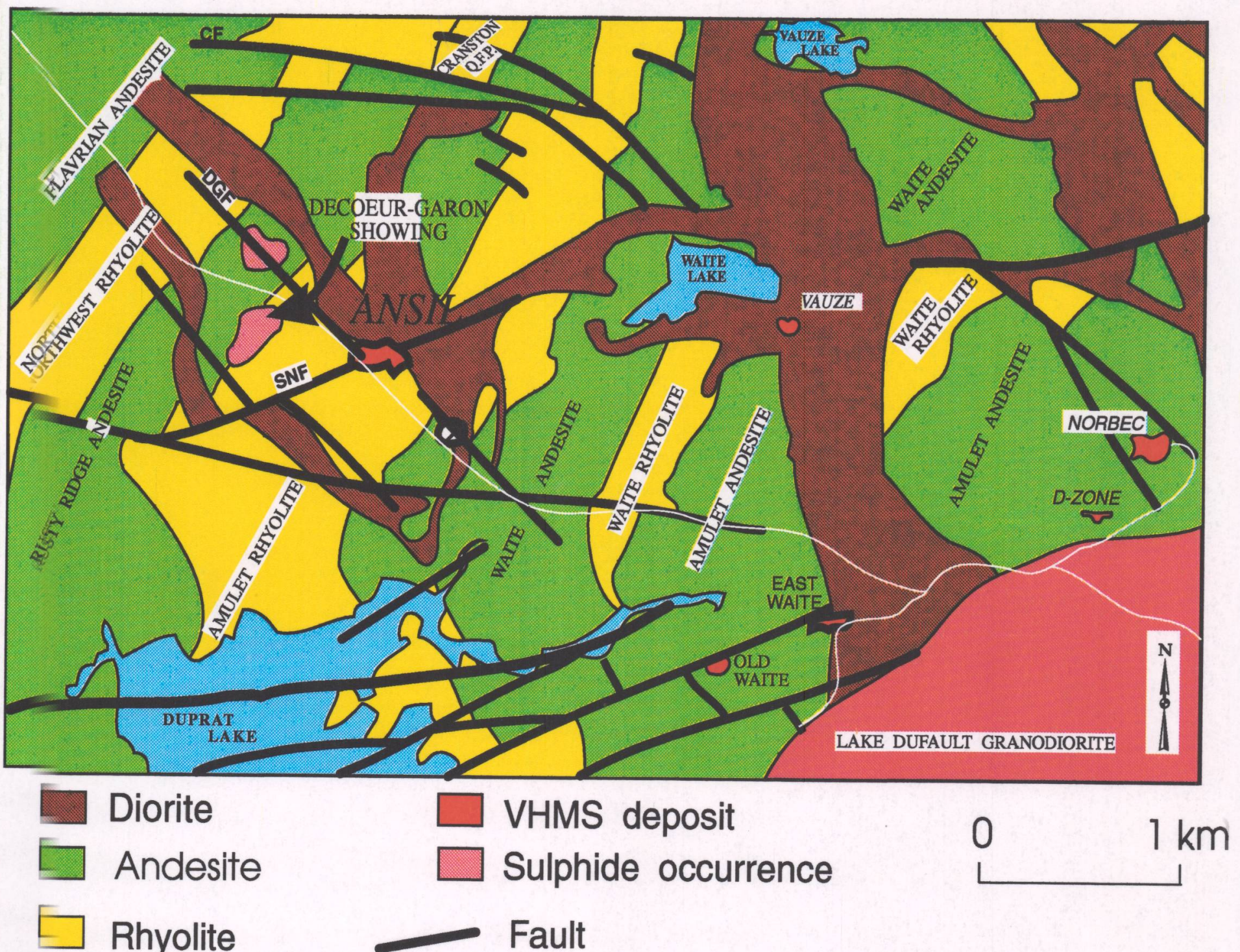

Figure 2:

Geologic setting of the Ansil deposit

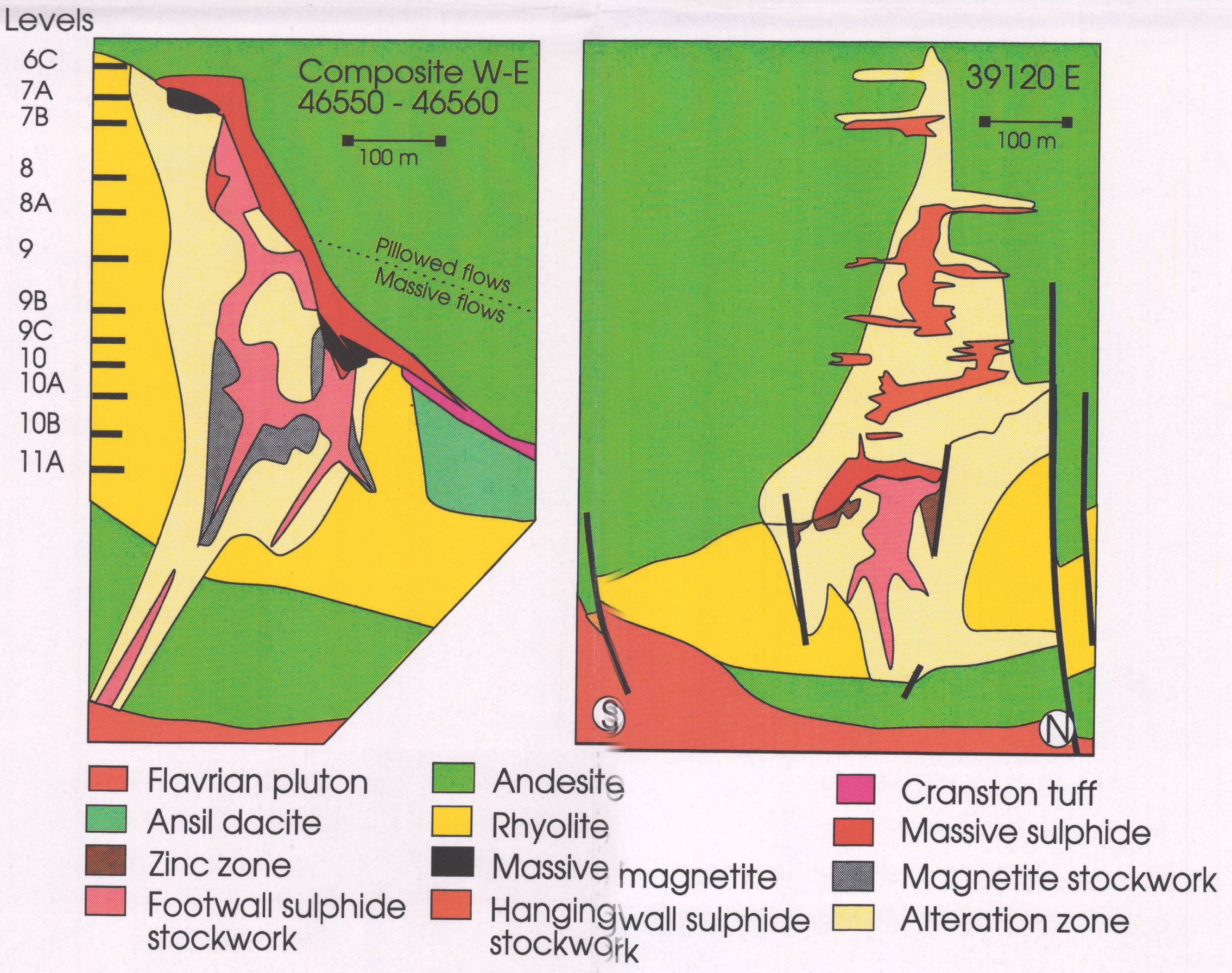

Figure 3:

West to east and south to north composite sections through the Ansil deposit

Figure 4:Composite plan of the mine geology at the mining levels in the Ansil deposit. Dykes are removed to better illustrate original deposit morphology.

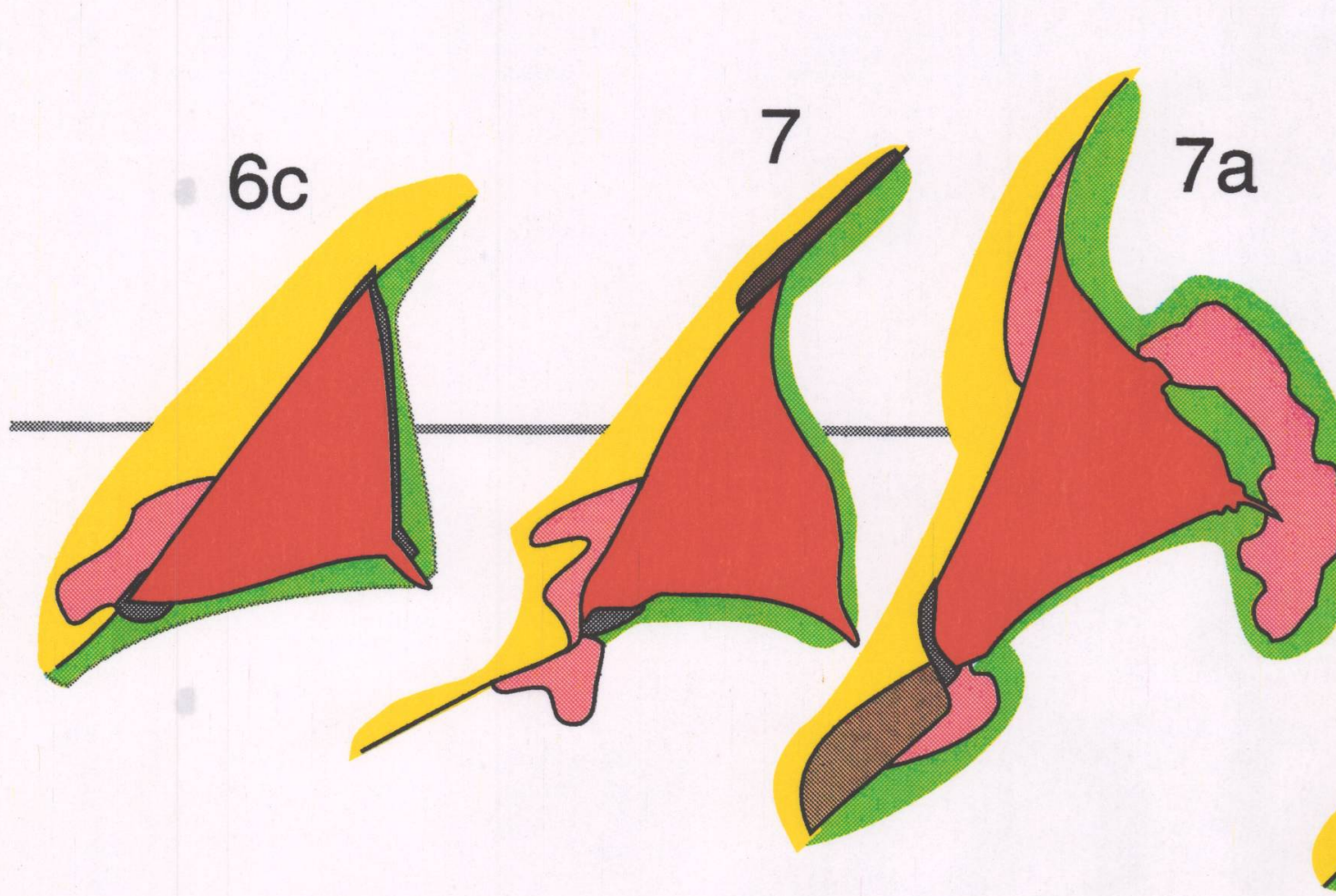

Andesite

QP Tuff
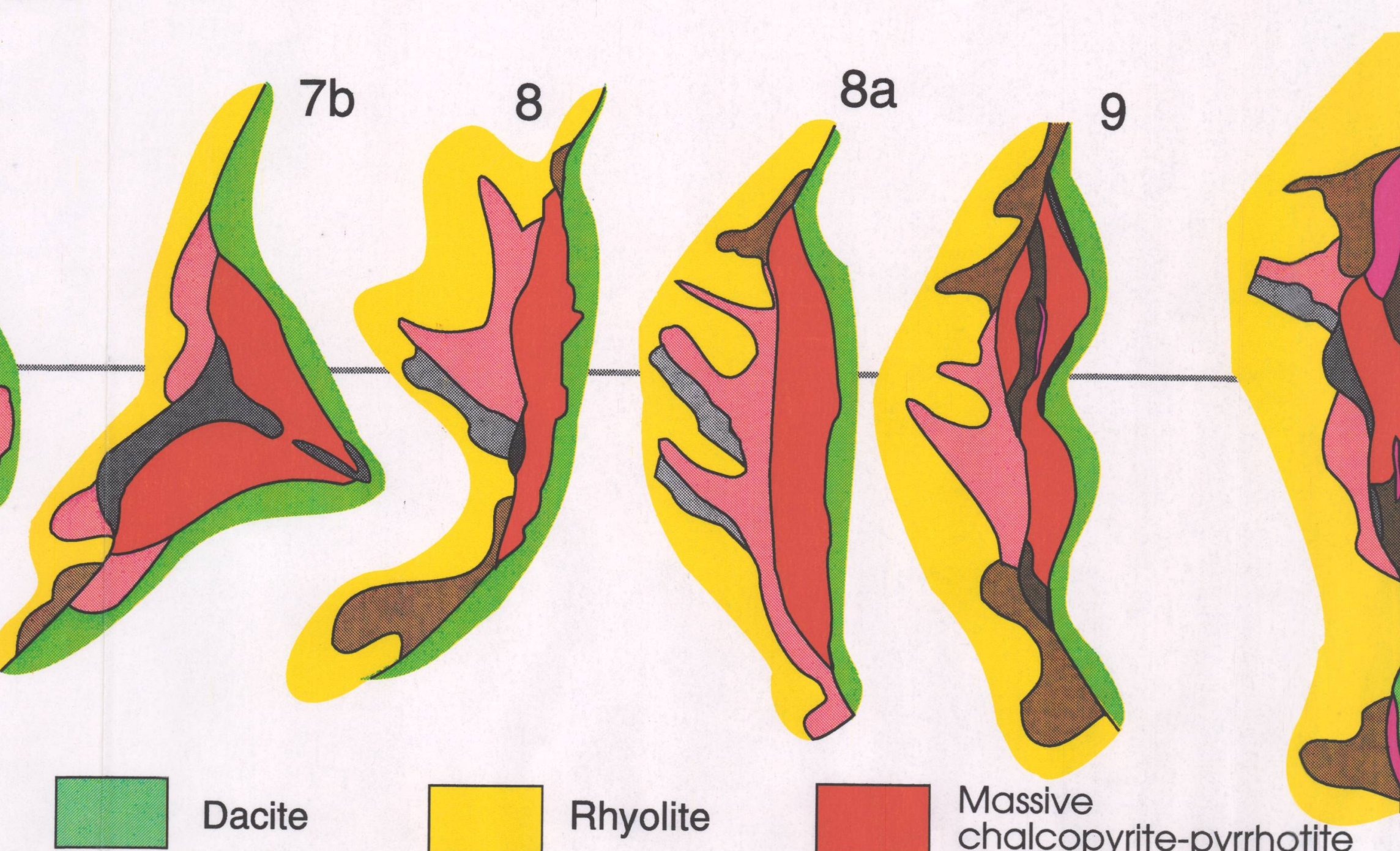

Massive
chalcopyrite-pyrrhotite

Massive chalcopyriteSphalerite Massive

Chalcopyrite-pyrrhotite stockwork zone

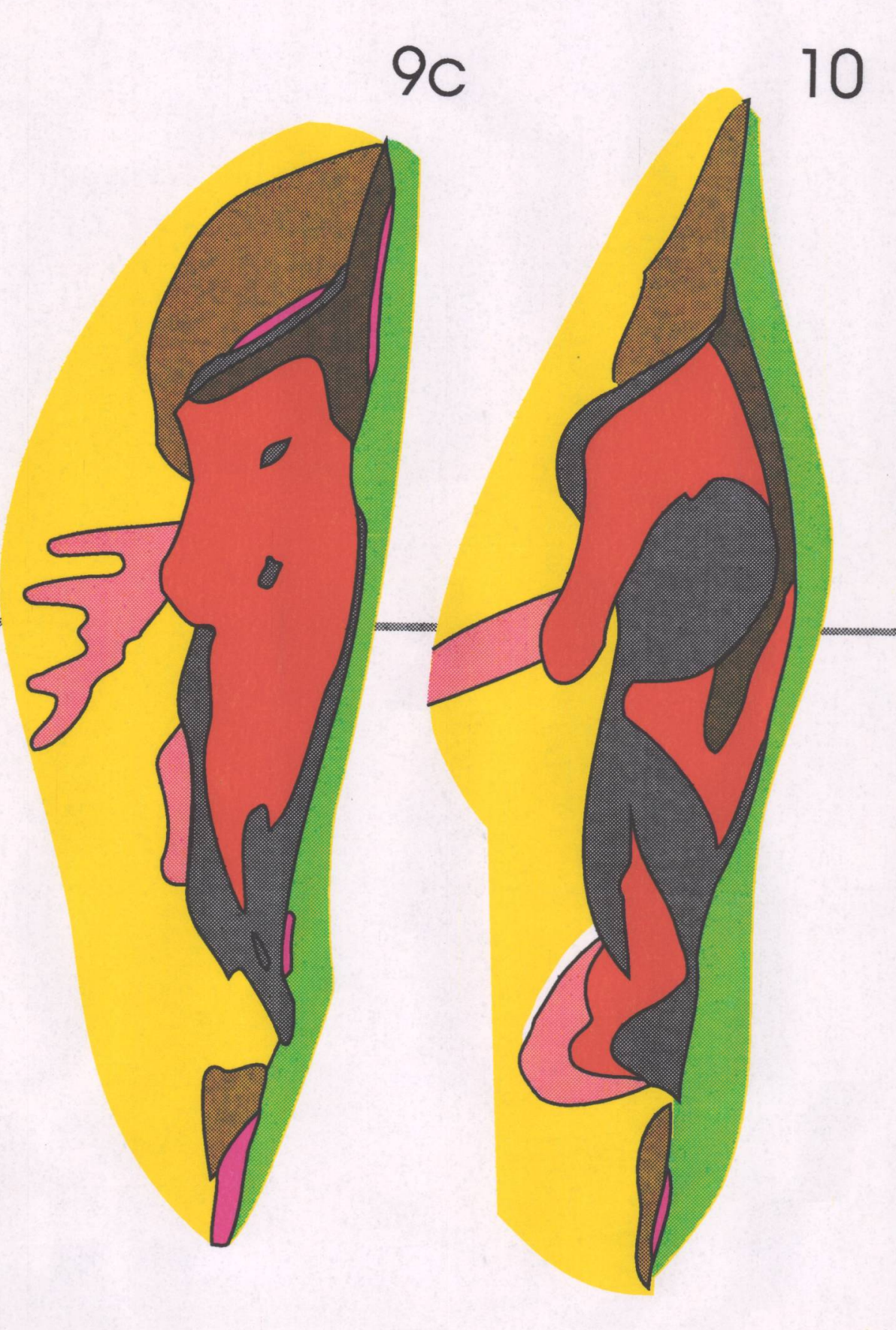

10

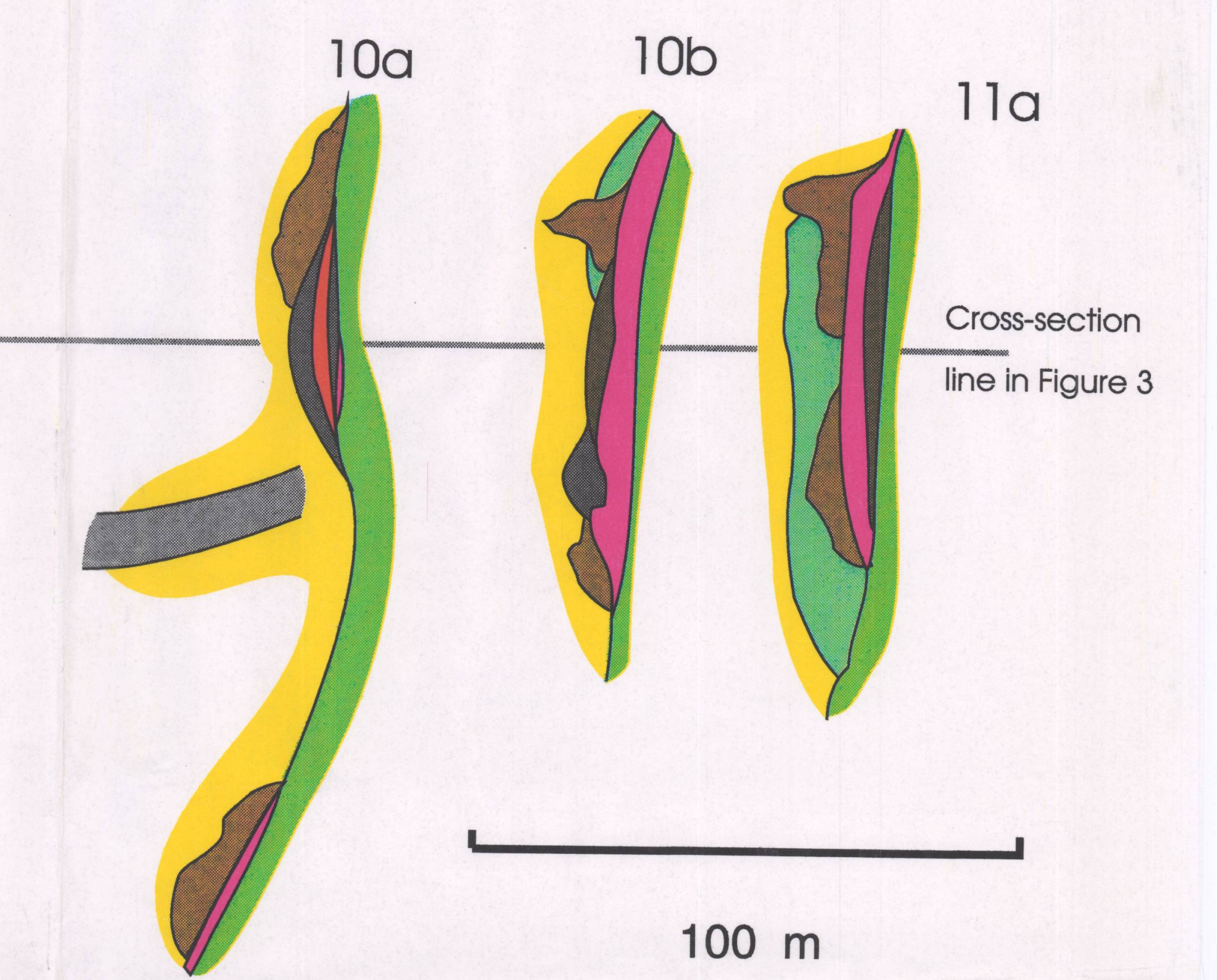














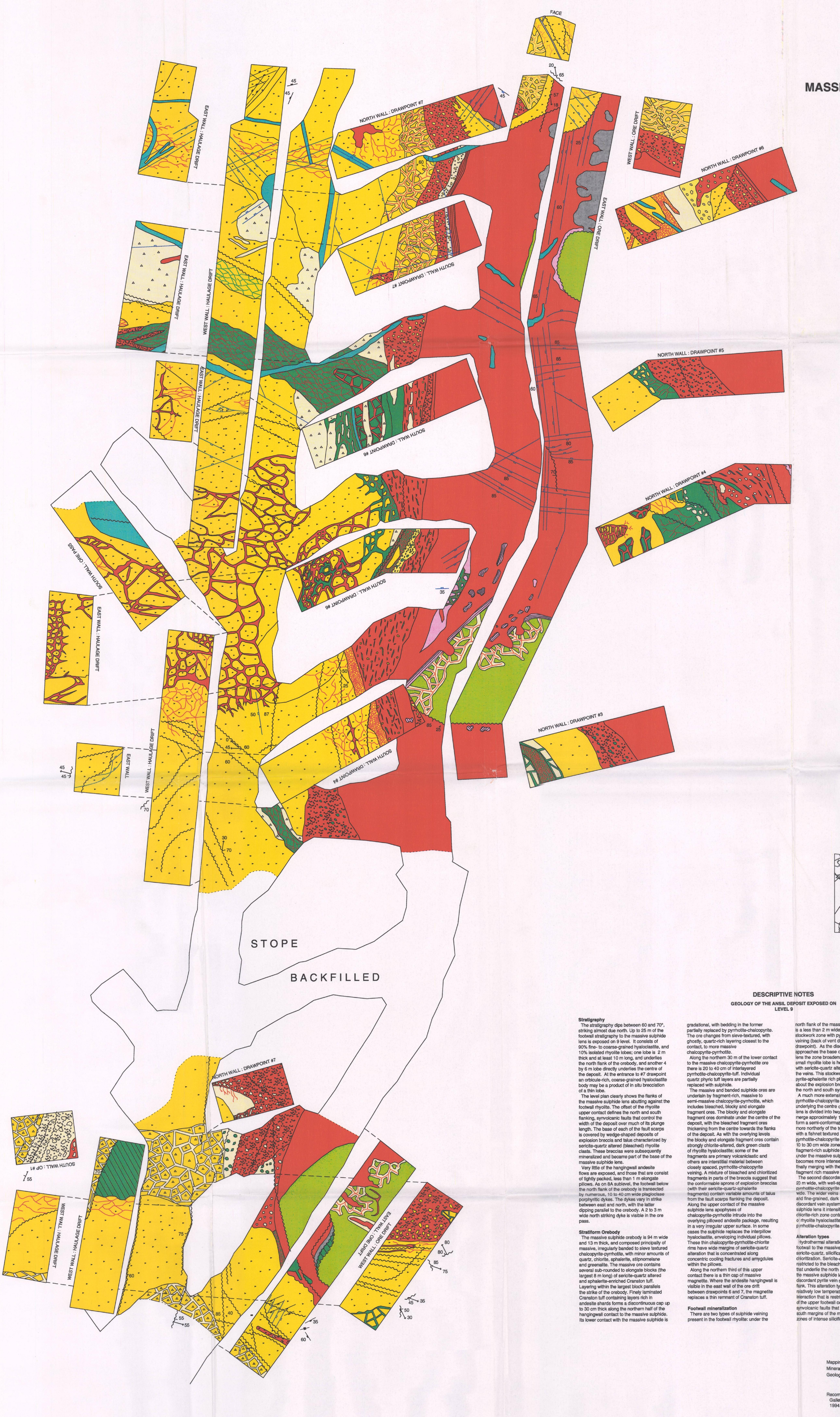

(2)

Canad'à' 


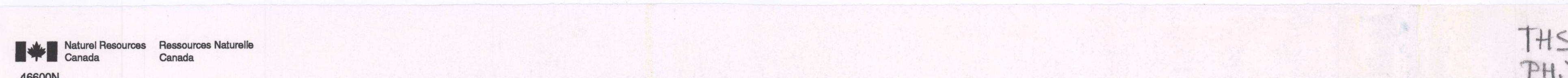



Canadä 




